\author{
UNIVERSIDADE DE SÃO PAULO \\ FACULDADE DE FILOSOFIA, LETRAS E CIÊNCIAS HUMANAS \\ DEPARTAMENTO DE HISTÓRIA \\ PROGRAMA DE PÓS-GRADUAÇÃO EM HISTÓRIA SOCIAL
}

ISMARA IZEPE DE SOUZA

\title{
Caminhos que se cruzam: relações históricas entre Brasil e Espanha (1936-1960)
}

São Paulo 2009 


\author{
UNIVERSIDADE DE SÃO PAULO \\ FACULDADE DE FILOSOFIA, LETRAS E CIÊNCIAS HUMANAS \\ DEPARTAMENTO DE HISTÓRIA \\ PROGRAMA DE PÓS-GRADUAÇÃO EM HISTÓRIA SOCIAL
}

\title{
Caminhos que se cruzam: relações históricas entre Brasil e Espanha (1936-1960)
}

Ismara Izepe de Souza

Tese apresentada ao Programa de PósGraduação em História Social do Departamento de História da Faculdade de Filosofia, Letras e Ciências Humanas da Universidade de São Paulo para a obtenção do título de Doutor em História.

Orientadora: Profa. Dra. Maria Luiza Tucci Carneiro

São Paulo

2009 


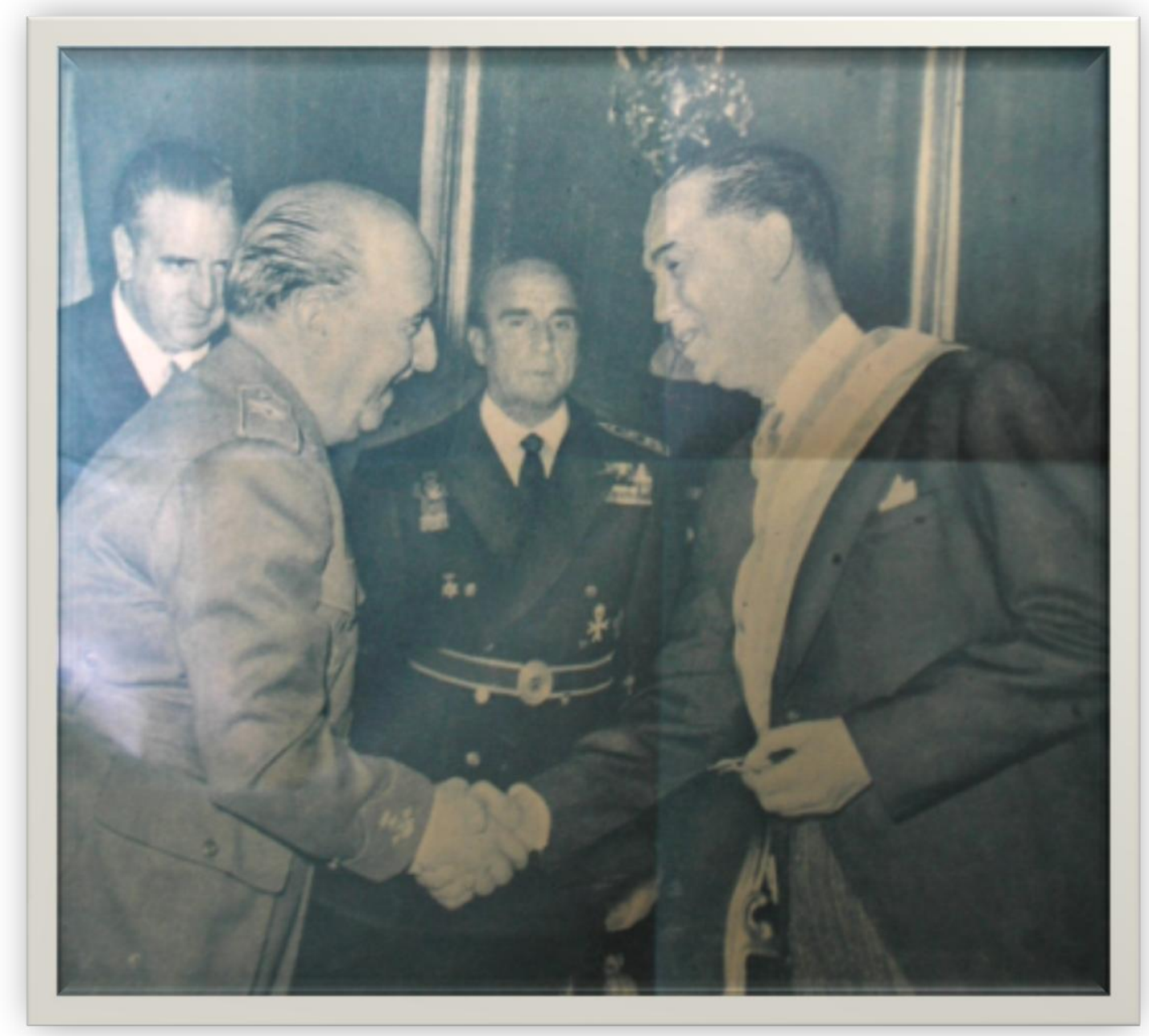


Para Luiza e Marcelo com todo o meu amor... 


\section{Resumo}

Este estudo analisa as relações diplomáticas entre o Brasil e a Espanha sob a ótica da política externa brasileira entre 1936 a 1960, tendo como referências para reflexão: as tensões político-ideológicas geradas pela Guerra Civil Espanhola e pelo alinhamento brasileiro aos Aliados durante a Segunda Guerra Mundial; o anticomunismo como fator de aproximação entre os dois países; a intensificação das ações de intercâmbio cultural e comercial verificada a partir da década de 1950; o fluxo imigratório de espanhóis para o Brasil como um elemento central das relações hispano-brasileiras. Tendo como principal fonte os documentos do Ministério das Relações Exteriores do Brasil, sob a guarda do Arquivo Histórico do Itamaraty/RJ e da Coordenação de Documentação Diplomática em Brasília, procuramos avaliar a posição da diplomacia brasileira frente à Espanha e os interesses que permearam a configuração das relações históricas construídas com esse país. Considerando os momentos de ruptura e permanência, demonstramos que os compromissos firmados no cenário internacional pautaram as atitudes do governo brasileiro frente à Espanha, especialmente entre 1936-1939 e na década de 1940.

Palavras-chaves: Relações diplomáticas; Guerra Civil Espanhola; Franquismo; Itamaraty; Imigração Espanhola; Ministério das Relações Exteriores. 


\section{Abstract}

This study analyzes the diplomatic relationships between Brazil and Spain from the point of view of the Brazilian foreign policy between 1930 and 1960, using as references for the analysis: the political-ideological tensions generated by the Spanish Civil War and by the Brazilian alignment with the Allies during to Second World War; the anticommunism as an approaching factor between the two countries; the intensification of the cultural and commercial exchanges verified in 1950's; the emigration current of Spaniards to Brazil as a central element of the Spanish-Brazilian relationship. Using, as the main source for this study, the documents of Foreign Relations State Department of Brazil, under the guard of the Itamaraty Historical File/RJ and of the Coordination of Diplomatic Documentation in Brasilia, we tried to evaluate the position of the Brazilian Diplomacy regarding Spain and the interests that permeated the configuration of the historical relationships built with that country. Taking into account the moments of rupture and permanence, we demonstrated that the commitments in the international scenery ruled the attitudes of the Brazilian government concerning Spain, especially between 1936-1939 and in the 1940's.

Key Words: Diplomatic relationships; Spanish Civil War; Itamaraty; Spanish emigration; Foreign Relations State Department of Brazil. 


\section{Agradecimentos}

Primeiramente agradeço à professora Maria Luiza Tucci Carneiro, por todo o apoio e pela oportunidade de aprender com ela a função de historiadora. Pela orientação segura que, desde a época de Iniciação Científica, me possibilitou seguir os caminhos da História. Seus trabalhos foram fontes de constante estímulo e inspiração, especialmente em sua maneira de trabalhar com os documentos diplomáticos. Admiração sempre.

Registro aqui meus agradecimentos à FAPESP - Fundação de Amparo à Pesquisa do Estado de São Paulo - que me concedeu uma bolsa, sem a qual minhas pesquisas nos acervos de Brasília, Rio de Janeiro e Madri, se tornariam inviáveis.

Aos funcionários dos arquivos consultados, por toda a atenção e apoio, especialmente à Rosiane Graça Rigas Martins e ao Sr. José Luis Miranda, do Arquivo Histórico do Itamaraty. Também à Andressa Ravanello da Costa, Antonio Celso Xavier de Oliveira, André Vicente Lino de Souza e à Lúcia Naomi Iwakiri, da Coordenação de Documentação Diplomática do Ministério das Relações Exteriores. Às senhoras Pilar Casado Liso e Cristina González Martin, do Arquivo do Ministério de Asuntos Exteriores y Cooperación da Espanha que, solucionando os entraves burocráticos, enviaram-me as fotocópias dos documentos pesquisados.

Aos professores Marcos Napolitano e Antonio Pedro Tota, por suas importantes considerações quando do Exame de Qualificação.

Ao pesquisador Bruno Ayllón Pino pelas valiosas dicas e sugestões bibliográficas. Também pela acolhida quando de minha primeira visita à Espanha.

À professora Sandra Maria Lubisco Brancato, da PUC do Rio Grande do Sul, ao professor Lorenzo Delgado Gomes Escalonilla, do Consejo Superior de Investigaciones Científicas de Madri e ao professor Paul Preston, do Cañada Blanch Centre for Contemporany Spanish Studies da London School of Economics, por terem gentilmente me enviado suas produções acadêmicas. À professora Beatriz Las Heras, por sua acolhida afetuosa e por suas explicações sobre o funcionamento da Biblioteca Nacional da Espanha. 
Aos professores do Departamento de História da USP, Maria Helena Capelato e Angelo Segrillo, ao professor Paulo Fagundes Vizentini, da Universidade Federal do Rio Grande do Sul e ao professor Clodoaldo Bueno, da UNESP, por aceitarem integrar a banca de defesa desta tese.

Às amigas Marcia Yumi Takeuchi e Mariana Cardoso dos Santos Ribeiro, por compartilharem das minhas inquietações pessoais e daquelas próprias da "vida acadêmica". E também por tornarem as viagens ao Rio de Janeiro muito mais agradáveis. Aos amigos Gláucia Castellán, Taciana Wiazovski, Wagner Pinheiro Pereira e Priscila Ferreira Perazzo, pela troca de idéias e pelos momentos de descontração.

Um agradecimento especial aos amigos Elena Pájaro Peres e Nelson Aprobato Filho que, mesmo longe, não deixaram de oferecer um estímulo determinante para a execução deste trabalho. Por terem localizado e fotocopiado um importante material só encontrado nas bibliotecas da Universidade de Harvard. Tenho grande admiração pela forma séria e competente com que se dedicam ao ofício de historiador.

À Aline Machado Lopes por todo o apoio. Seu humor inteligente e suas observações me ajudaram a refletir sobre o que realmente importa na vida.

À família Balbino, especialmente à minha sogra Maria Aparecida, por ter sempre uma palavra positiva e por suas impressões sobre o cinema espanhol no Brasil dos anos 50.

À Maria das Graças Marques da Silva, pela dedicação com que cuidou da Luiza enquanto eu trabalhava.

Qualquer agradecimento aos meus pais Alzira e Edvar resulta insuficiente. Por terem me oferecido um lar afetuoso e seguro, decisivo para que eu corresse atrás dos meus sonhos. Ao cuidarem da Luiza com tanto carinho durante minha ausência, me proporcionaram a tranqüilidade necessária para a realização da pesquisa de campo. À minha irmã Deise pela disposição em me ajudar e por the "roubar" horas de dedicação aos estudos, quando fatalmente a Luiza preferia ficar em seu quarto. Ao Denis Eduardo Malta por ajudar a todos nos cuidados com a minha pequena.

Por fim, às duas pessoas que conviveram com o árduo processo de produção deste trabalho. Ao meu marido Marcelo Balbino, por todo o amor e 
por todo o carinho, expressos até nas falas do "Bizú". Por acreditar em mim e por me incentivar a ir mais além. Sua trajetória de vida e seu crescimento profissional, frutos de muito trabalho e dedicação, são motivos da minha mais profunda admiração.

À minha filha Luiza, que foi gerada e cresceu simultaneamente a esta tese. Mesmo sem ter consciência, ela foi responsável por me estimular nos momentos de cansaço, tornando os meus dias mais "bagunçados", porém muito mais felizes. 


\section{SUMÁRIO}

Siglas e abreviaturas

Introdução

I - O Brasil na trama da Guerra Civil Espanhola

32

1.1 - O Itamaraty diante da República espanhola

33

1.2 - Asilo e repatriação: O Brasil como salvação

74

1.3 - O reconhecimento da Espanha franquista

II - Época de incertezas: as relações entre Brasil e Espanha nos conturbados anos 40

2.1 - Conflitos e desconfianças em tempos de guerra

2.2 - A "euforia democrática": o Brasil e a questão espanhola

na ONU (1946-1949)

III-Rumo à parceria: os anos dourados

193

3.1 - O discurso da cordialidade

3.2 - Momento de confluências: a política cultural entre Brasil e Espanha

223

3.3 - O Itamaraty diante da imigração

254

Considerações Finais

268

Acervos e Fontes

271

Bibliografia

292

Notas biográficas

304

Anexos 


\section{Siglas e abreviaturas}

$\mathrm{ABI}$ - Associação Brasileira de Imprensa

ABAPE - Associação Brasileira dos Amigos do Povo Espanhol

AESP - Arquivo do Estado de São Paulo

$\mathrm{AHI} / \mathrm{RJ}$ - Arquivo Histórico do Itamaraty / Rio de Janeiro

AMAE - Arquivo do Ministério de Asuntos Exteriores de España

BN - Biblioteca Nacional

CDO - Coordenação de Documentação do Ministério das Relações Exteriores

CIC - Conselho de Imigração e Colonização

CPDOC/FGV - Centro de Pesquisa e Documentação de História Contemporânea do Brasil/ Fundação Getúlio Vargas

DEOPS - Departamento de Ordem Política e Social

$\mathrm{ICH}$ - Instituto de Cultura Hispânica

INIC - Instituto Nacional de Imigração e Colonização

MAE - Ministério de Asuntos Exteriores (Espanha)

MRE - Ministério das Relações Exteriores do Brasil

MDB - Missões Diplomáticas Brasileiras

SERE - Secretaria de Estado das Relações Exteriores do Brasil 


\section{Introdução}

Nestes últimos anos temos presenciado o aprofundamento das relações econômicas entre o Brasil e a Espanha, decorrente dos investimentos maciços de empresas espanholas em vários setores da economia brasileira. Hoje, a Espanha é o segundo maior investidor estrangeiro no Brasil, perdendo apenas para os EUA. Graças a esse processo e ao fato de tornar-se um importante parceiro do ponto de vista das nossas exportações, a Espanha passou a ser um alvo privilegiado para a agenda da política externa brasileira.

O estreitamento das relações entre os dois países deu-se recentemente, especialmente após a inserção do Brasil numa economia globalizada. Diante desta constatação, cabe ressaltar as potencialidades e os problemas que envolvem as relações diplomáticas com esse país. Observamos que há uma lacuna, no âmbito da historiografia brasileira contemporânea, de estudos que abordem, sob uma perspectiva histórica, as relações hispanobrasileiras.

Existem trabalhos historiográficos que tratam indiretamente do assunto, como aqueles que analisam a imigração espanhola. As análises acadêmicas - dissertações e teses em sua maioria - sobre a questão imigratória, nos interessam na medida em que trazem contribuições para a compreensão de um dos fenômenos determinantes nas relações entre Brasil e Espanha. Seja no século XIX ou XX, a imigração de hispânicos para o Brasil manteve-se como uma das prioridades eleitas pelo Itamaraty na agenda da política externa para a Espanha. Nenhum desses trabalhos, no entanto, teve como objeto principal de análise a política externa brasileira com relação à imigração espanhola. Esses propõem, em sua maioria, a análise de um aspecto específico da presença espanhola em solo brasileiro, seja sua atuação política ou sua experiência cultural num período delimitado. A raridade de tais obras, se comparada à quantidade de publicações acerca das experiências italiana e japonesa, expressa as dificuldades de acesso às fontes documentais. Alguns dos trabalhos que tem a imigração como foco afirmam que, por terem uma raiz cultural muito próxima ao Brasil, os espanhóis não deixaram marcas 
em nossa sociedade. ${ }^{1}$ Em apenas um artigo, desenvolvido a partir da documentação do Arquivo do Ministério de Asuntos Exteriores da Espanha, encontramos referências sobre as relações diplomáticas entre os dois países nos anos $30 .^{2}$

Essa lacuna na historiografia foi parcialmente preenchida por uma tese de doutorado defendida em 2004 na Universidade Complutense de Madri, sobre as relações entre Brasil e Espanha no período de 1979 - 2000. ${ }^{3}$ Este trabalho, desenvolvido na perspectiva da área de relações internacionais, foi de fundamental importância para a elaboração do nosso estudo por trazer uma cronologia dos principais fatos que condicionaram a política externa brasileira para a Espanha no século XX. O autor, Bruno Ayllón Pino, afirma que até 1979, as relações entre Brasil e Espanha foram marcadas pela mútua irrelevância e pela ausência de eixo instrumental. A data escolhida como ponto de partida da pesquisa é justificada como sendo o ano em que as relações hispanobrasileiras começam a se consolidar, substituindo o "eixo da sentimentalidade" pelo "eixo da instrumentalidade".

\footnotetext{
${ }^{1}$ Essa é a justificativa utilizada por Avelina Martinez Gallego. Os espanhóis em São Paulo: presença e invisibilidade. São Paulo, 1993. Dissertação (Mestrado em Ciências Sociais) PUC. Cumpre mencionar outros trabalhos que se relacionam à imigração espanhola para 0 Brasil: Ester Gambi Gimenez. La guerra en la distancia. Los inmigrantes españoles en el Brasil de los anos 30. Salamanca, 2005. Dissertação (Mestrado) - Centro de Estudos Brasileiros, Universidade de Salamanca; Herbert S. Klein. A Imigração Espanhola no Brasil. São Paulo: Sumaré; FAPESP, 1994. Série Imigração; Laura Antunes Maciel; Maria Antonieta Martinez Antonacci. Espanhóis em São Paulo: modos de vida e experiências de associação. Revista do programa de estudos pós-graduados em História. São Paulo, PUC, n 12, p.173-192, 1995; José de Souza Martins. A imigração espanhola no Brasil e a formação da força de trabalho na economia cafeeira: 1880-1930. Revista de História. São Paulo: ago-dez, 1989; Elena Pájaro Peres. A inexistência da terra firme: a imigração galega em São Paulo (1946 - 1964). São Paulo: Edusp; Fapesp; Imprensa Oficial, 2003; Ismara Izepe de Souza. Solidariedade Internacional. A comunidade espanhola do Estado de São Paulo e a polícia política diante da Guerra Civil da Espanha (1936-1946). São Paulo: Humanitas; FAPESP, 2005. Coleção Histórias da Intolerância,5; Ismara Izepe de Souza. Espanhóis: história e engajamento. São Paulo: Lazuli; Companhia Editora Nacional, 2006. Coleção Imigrantes no Brasil; Ismara Izepe de Souza. República Espanhola: um modelo a ser evitado. São Paulo: Arquivo do Estado; Imprensa Oficial, 2001. Inventário DEOPS, Módulo IV - Espanhóis; Ismara Izepe de Souza. Adiós Compañeros: os espanhóis expulsos na Era Vargas. Revista Histórica. São Paulo: Arquivo do Estado; Imprensa Oficial, ano 3, n० 4, p.35-39, 2001; Marília Dalva Klaumann Cánovas. Imigrantes espanhóis na Paulicéia: trabalho e sociabilidade urbana, 1890-1922. São Paulo, 2007. Tese (Doutorado em História) - FFLCH, USP.

2 Sandra Maria Lubisco Brancato. As relações Brasil/Espanha na transição para o Estado Novo. Revista de Estudos Ibero-Americanos. Porto Alegre, Pontifícia Universidade Católica, vol. XIII, n², p.151-160, dez. 1987.

${ }^{3}$ Bruno Ayllón Pino. Las relaciones entre Brasil y España ponderadas desde la perspectiva de la politica exterior brasileña (1970-2000). Madri, 2004. Tese (Doutorado) - Universidad Complutense de Madrid.
} 
Para Ayllón Pino, o relacionamento entre os dois países durante a maior parte do século XX, se insere dentro do "eixo da sentimentalidade." Essa perspectiva explicaria a política externa do Brasil face àqueles países europeus com os quais o país tinha laços históricos, culturais e/ou linguísticos, mas não compartilhava interesses econômicos ou de ordem estratégia no cenário mundial. Em oposição ao "eixo da sentimentalidade" estaria o "eixo da instrumentalidade", caracterizando as relações do Brasil com países como Itália e Alemanha, por exemplo, com quem se compartilhava interesses econômicos mútuos e que acenavam com a possibilidade de nos trazer benefícios concretos. $^{4}$

Apesar de não serem prioridade para a política externa brasileira, as relações históricas construídas com a Espanha foram caracterizadas durante a maior parte do século XX como cordiais. Essa histórica cordialidade, declarada pela diplomacia brasileira como uma marca das relações com esse país, viu-se seriamente ameaçada pelos episódios recentes de recusa à entrada de brasileiros na Espanha. Fatos como esses nos levam a pensar que a cordialidade não é um traço constante nas relações hispano-brasileiras, apesar de constar historicamente como elemento central dos discursos diplomáticos em ambos os casos. ${ }^{5}$

Analisando a documentação do Arquivo Histórico do Itamaraty, pudemos reiterar a idéia de que Espanha e Brasil não se constituíram como parceiros efetivos do ponto de vista comercial. No entanto, nos chama a

\footnotetext{
${ }^{4}$ Idem, p. 69.

${ }^{5}$ Entre 2008 e 2009, cercou-se de incertezas o futuro das relações diplomáticas entre Brasil e Espanha, dados os casos recorrentes de deportação de brasileiros impedidos no aeroporto de Barajas em Madri. Em março de 2008, o chanceler brasileiro Celso Amorin chegou a declarar que a atitude do governo espanhol de reter brasileiros era "desagradável e incompatível com a posição de segundo investidor do Brasil". (Cf. artigo "Casos de brasileiros barrados na Espanha causa indignação nas autoridades do Brasil", de 13/03/2008. Disponível em http://noticias.uol.com.br/midiaglobal/elpais/2008/03/13/. Acesso em 13 mar. 2008). Nos dias subseqüentes, a fiscalização da Polícia Federal passou a ser maior com relação à entrada de espanhóis no Brasil, culminando com vários casos de deportação. O Presidente Luis Inácio Lula da Silva e o Ministro das Relações Exteriores Celso Amorin, pronunciaram-se sobre o caso evidenciando que as ações do Brasil deveriam obedecer ao princípio da reciprocidade. A cobertura dos diversos casos de deportação de brasileiros da Espanha pela mídia teve seu auge na primeira semana de março de 2008. Tanto os especialistas em relações internacionais, quanto as autoridades brasileiras, associaram o aumento do número de cidadãos impedidos de entrar na Espanha às eleições que se realizariam naquele país. $A$ alegação seria a de que o governo de José Luis Zapatero, do PSOE, estaria aumentando a fiscalização da entrada de imigrantes, devido às acusações do PP, partido de oposição, de que o governo espanhol não estaria agindo adequadamente no combate à imigração ilegal.
} 
atenção que, em alguns momentos, como o da Guerra Civil Espanhola, e em alguns períodos da década de 50 , as relações entre os dois países não foram irrelevantes para a configuração de seus respectivos projetos de relações internacionais.

Durante a Guerra Civil Espanhola, a incompatibilidade de diretrizes político-ideológicas entre o governo de Getúlio Vargas no Brasil e a República Espanhola, levou a um posicionamento duplo por parte do governo brasileiro: reconhecimento diplomático do governo de Frente Popular espanhol, e declaração de apoio moral aos rebeldes nacionalistas. Convém lembrar que a polícia política brasileira coibia qualquer manifestação a favor da República espanhola, taxada genericamente de comunista e interpretada como um modelo a ser evitado. ${ }^{6}$

Diante disso, este estudo tem como proposta analisar as relações históricas entre Brasil e Espanha sob a ótica da política externa brasileira no período de 1936 a 1960. O interesse por esse tema foi despertado durante o desenvolvimento da minha pesquisa de mestrado que analisou a mobilização de imigrantes espanhóis e brasileiros frente à Guerra Civil Espanhola, a partir da documentação do acervo DEOPS e subsidiariamente, de documentos do Arquivo Histórico do Itamaraty. ${ }^{7}$

A inexistência de trabalhos acadêmicos sobre as relações diplomáticas entre Brasil e Espanha no século XX, com exceção do trabalho de Bruno Ayllón Pino, nos confirma a originalidade do tema proposto para esta tese. $^{8}$ A análise do discurso sustentado pelo Ministério das Relações Exteriores, constitui-se no eixo de nosso trabalho. Temos o intuito de analisar a atuação da diplomacia brasileira frente à Espanha e os interesses que permearam a configuração das relações históricas construídas com esse país.

\footnotetext{
${ }^{6}$ Ismara Izepe de Souza. República Espanhola, op. cit.

7 Ismara Izepe de Souza. Solidariedade Internacional, op. cit.

${ }^{8}$ Bruno Ayllón Pino, que realizou suas pesquisas com base na documentação do Ministério das Relações Exteriores do Brasil, ao reiterar a ausência de trabalhos e projetos que tenham como eixo as relações entre o Brasil e a Espanha, faz menção ao único Centro Universitário na Espanha dedicado à análise da realidade brasileira: o Centro de Estudos Brasileiros, na Universidade de Salamanca. Afirma, no entanto, que o centro possui recursos limitados e poucos especialistas brasileiros. (Bruno Ayllon Pino. Las relaciones entre Brasil y España ponderadas desde la perspectiva de la politica exterior brasileña, op. cit, p.42.) $O$ trabalho de Ayllón Pino será citado como uma das nossas mais importantes referências bibliográficas. Nossa proposta se distancia cronologicamente do trabalho deste pesquisador, mas devemos a formulação de muitas de nossas hipóteses às reflexões propostas em seus diversos trabalhos.
} 
Pretendemos avaliar de que forma o posicionamento do Itamaraty frente aos acontecimentos políticos e sociais espanhóis serviu às relações internacionais do Brasil.

A opção em priorizar as fontes do Arquivo Histórico do Itamaraty, justifica-se pela vastidão e riqueza da documentação diplomática. Através desses documentos é possível verificar os acontecimentos que foram significativos para as relações hispano-brasileiras. A troca de informações estabelecida entre os Ministérios das Relações Exteriores, brasileiro e espanhol, assim como desses com a Embaixada do Brasil e com os consulados brasileiros na Espanha, pode ser verificada nos milhares de documentos e notas presentes no referido Arquivo Histórico. Localizado no elegante Palácio Itamaraty, na cidade do Rio de Janeiro, o AHI concentra a documentação diplomática, desde a criação do Ministério de Negócios Estrangeiros e da Guerra, até o final da década de 1950. Com a mudança da capital em 1960, a documentação gerada a partir dessa data passou a se concentrar no Palácio Itamaraty em Brasília. Atualmente, a Coordenação de Documentação Diplomática (CDO), reúne uma valiosa documentação que se divide em três setores: Arquivo Histórico; Setor de Correspondência Especial e Setor de Antecedentes. ${ }^{9}$

O Arquivo Histórico no Rio de Janeiro mantém a documentação catalogada a partir de tipologias documentais organizadas por ordem cronológica. Assim, consultamos ofícios, notas, telegramas, e despachos trocados entre o MRE e as representações presentes na Espanha, assim como a documentação trocada com outras esferas do governo brasileiro como, por exemplo, o Instituto Nacional de Imigração e Colonização.

\footnotetext{
${ }^{9}$ O Arquivo Histórico da CDO concentra a documentação ostensiva e reservada arquivada cronologicamente a partir de séries tipológicas, critério semelhante a dos documentos anteriores à década de 1960, presentes no AHI Rio de Janeiro. Algumas séries de ofícios e telegramas trocados com a Embaixada brasileira em Madri, a partir de 1956, estão sob a guarda do Arquivo Histórico em Brasília. A presença desse material junto à documentação dos anos 60 era de desconhecimento dos próprios responsáveis e funcionários do Arquivo Histórico de Brasília, que à princípio defenderam a idéia de que esses documentos estariam no Rio de Janeiro por serem anteriores a 1960. Como essas séries não foram localizadas no Rio de Janeiro, solicitamos verificar se essa documentação estava acondicionada junto às séries a partir de 1960, resultando correta nossa hipótese. O Setor de Correspondência Especial, guarda a documentação confidencial e secreta, e pelo que constatamos, o arquivo conta com documentos a partir da década de 1940. Já o Setor de Antecedentes, conta com os documentos organizados por temas e assuntos, ou seja, os maços temáticos. CDO/MRE.
} 
A documentação não está organizada de forma temática, o que nos fez realizar uma exaustiva pesquisa, tipologia a tipologia, mês a mês dos 30 anos propostos para este estudo. Os ofícios trocados entre o MRE e a representação brasileira em Madri e os principais consulados, especialmente os de Barcelona e Vigo, foram o principal alvo de nossas atenções, uma vez que essa tipologia nos possibilita identificar os problemas cotidianos enfrentados por nossos representantes na Espanha, assim como obter informações sobre o contexto político-cultural espanhol. Freqüentemente, os ofícios eram acompanhados de anexos, como recortes de periódicos. Esses se apresentam como um valioso material para a compreensão de como as questões concernentes ao Brasil eram noticiadas pela imprensa espanhola. Os despachos do MRE para as representações na Espanha nos possibilitaram verificar como este Ministério determinava as diretrizes que deveriam nortear a ação dos diplomatas.

Junto aos ofícios eram enviados relatórios mensais acerca da situação política, econômica e cultural da Espanha. Em alguns momentos, esses aspectos da realidade espanhola foram analisados em um único relatório. A partir do término da Segunda Guerra Mundial, tais relatórios foram subdivididos em Mês político, Mês cultural e Mês econômico. O Mês político geralmente era elaborado pelo chefe da representação, seja o embaixador ou 0 encarregado de negócios. Os relatórios do Mês cultural e econômico, a depender do momento, eram elaborados pelos adidos à Embaixada brasileira responsáveis pelo setor. Através desses registros é possível perceber a visão que os diplomatas tinham dos aspectos políticos e econômicos da Espanha.

Tais relatórios apresentavam um panorama da situação interna e externa do país em questão, sendo um documento formal e que se pretendia "objetivo". O que observamos, no entanto, é que geralmente as análises detalhadas de um determinado assunto vinham acompanhadas e mesclavamse com considerações que denotavam as posições políticas e ideológicas de seus autores. A leitura de tais documentos possibilitou-nos conhecer a visão que os diplomatas brasileiros tinham de assuntos diversos como, por exemplo, a respeito da democracia e do fascismo. A formalidade da linguagem diplomática não impediu a defesa de alguma ideologia ou postura política, e não ocultou, muitas vezes, interesses pessoais. 
No corpus documental consultado encontramos quatro tipos de classificação para a correspondência oficial: ostensiva; reservada; confidencial e secreta. ${ }^{10}$ As séries documentais do $\mathrm{AHI}$, em sua maioria, são compostas de documentos ostensivos e reservados. Documentos confidenciais e secretos foram comuns na década de 1930, mas a partir dos anos 40, estes foram arquivados no "Arquivo de Correspondência Especial" que atualmente está sob a guarda da Coordenação de Documentação do Ministério das Relações Exteriores, em Brasília. Após o cumprimento dos trâmites burocráticos, conseguimos a autorização para consultá-lo, o que foi de fundamental importância para preencher as lacunas da nossa compreensão sobre muitos aspectos das relações hispano-brasileiras. Os documentos secretos, por sua vez, não apresentaram informações inovadoras, tratando essencialmente de questões administrativas internas, como a remessa de códigos telegráficos.

A nossa metodologia de pesquisa, no que concerne à sistematização das fontes, orientou-se a partir dos próprios critérios de arquivamento adotados pelo Ministério das Relações Exteriores. Ao contrário de outros arquivos, como o do Ministério de Asuntos Exteriores da Espanha (MAE), a documentação do Itamaraty está disposta de forma cronológica. Uma prática burocrática comum era a de reproduzir os documentos, arquivando-os também em maços temáticos. Alguns maços de nosso interesse, no entanto, não puderam ser localizados sob a alegação de que foram "perdidos" durante 0 processo de transferência para o Palácio Itamaraty em Brasília.

Analisamos também os documentos pesquisados no Centro de Pesquisa e Documentação de História Contemporânea do Brasil da Fundação Getúlio Vargas (CPDOC), no Rio de Janeiro, que reúne os arquivos pessoais de figuras proeminentes da história política do Brasil, como os de Getúlio Vargas e de Oswaldo Aranha. Na correspondência trocada entre eles, pudemos verificar como os temas de política externa eram tratados no âmbito

\footnotetext{
${ }^{10}$ A classe de correspondência secreta foi criada na gestão de José Carlos de Macedo Soares, "destinada exclusivamente para documentos, ou informações, que exigissem absoluto sigilo e cuja divulgação pudesse comprometer a segurança, a integridade do estado ou as suas relações internacionais". Foi o decreto n. 1081 de 03 de setembro de 1936 que "determinou para a correspondência oficial os seguintes tipos de classificação: a)secreta; b) confidencial; c)reservada; d)ostensiva ou ordinária." (Cf Flávio M. de Oliveira Castro. História da Organização do Ministério das Relações Exteriores. Brasília: Editora UNB, 1983, p.323).
} 
particular. A postura do governo brasileiro diante do conflito civil espanhol (1936-1939) pôde ser melhor compreendida a partir da pesquisa neste acervo.

Recorremos também aos relatórios anuais encaminhados pelo Ministério das Relações Exteriores ao presidente da República do Brasil, disponibilizados online no site do MRE. ${ }^{11}$ Esses tinham por função relatar ao Chefe do Executivo as ações do Itamaraty frente aos principais problemas internacionais. Constatamos que durante a Segunda Guerra Mundial e no pósguerra, os relatórios deram maior ênfase à situação européia e ao papel que o Brasil posteriormente passou a exercer nos foros multilaterais como a ONU. As referências à Espanha são muito raras, sendo indicações de recebimento de espanhóis ilustres recepcionados oficialmente pelo Itamaraty, menção às nomeações ou falecimentos de diplomatas em missão no Brasil e resumos dos acordos comerciais entre Brasil e Espanha.

Consultamos o Arquivo do Ministério de Asuntos Exteriores da Espanha, o que nos ofereceu uma visão mais abrangente das relações entre os dois países, avaliada sob o viés da Espanha. A correspondência entre a diplomacia espanhola em missão no Brasil e o Ministério espanhol está organizada em pastas temáticas, o que nos permitiu, por exemplo, avaliar o posicionamento da diplomacia espanhola frente à mobilização dos imigrantes espanhóis durante e após a Guerra Civil Espanhola. Também foram essenciais para compreensão das relações entre os dois países, o acesso aos documentos que abordam as negociações que culminaram com a efetivação de acordos nas áreas de cultura e imigração.

Este estudo extrapola as fronteiras de uma história meramente diplomática das relações entre o Brasil e a Espanha, apesar da base documental ter sido concebida por uma Instituição governamental. Os milhares de documentos analisados nos deram condições de, a partir da leitura das "entrelinhas", entrever outros aspectos das relações históricas construídas com a Espanha. A política cultural sustentada pelos dois países, assim como a imagem de povo e nação são alguns dos aspectos considerados neste estudo. A construção de nossa identidade internacional através das relações multilaterais constitui-se em tema de suma importância, haja vista que, especialmente após a Segunda Guerra Mundial, as relações bilaterais com

\footnotetext{
${ }^{11}$ Site: www.mre.gov.br
} 
qualquer país não podem ser explicadas sem levar em consideração os interesses e compromissos brasileiros assumidos junto aos organismos multilaterais.

Com relação ao referencial teórico-metodológico que orientou a interpretação das fontes selecionadas neste trabalho, caberia citar os estudos desenvolvidos por Pierre Renouvin e seus seguidores, que trazem novos postulados para a história das Relações Internacionais. Renouvin e Jean Baptiste Durosselle promoveram uma verdadeira renovação metodológica e teórica no que diz respeito à compreensão da história diplomática tradicional. Defendendo a importância dos processos de natureza estrutural para a compreensão das relações internacionais, esses autores adotam o conceito de "forças profundas". Essas forças estão relacionadas às influências que orientam o curso das relações internacionais, tais como as de ordem econômica, as financeiras, as demográficas, psicológicas ou sentimentais, além do papel da vontade dos homens de governo. ${ }^{12}$

O conceito de "forças profundas" nos auxiliou na análise da documentação diplomática, interpretada sob a perspectiva das ações geradas pelo Estado. Mas isso não significa explicar as relações internacionais como sendo motivadas pela vontade específica de um único agente, como por exemplo, a vontade dos líderes de governo. Entendemos que as ações do Estado devem ser pensadas na perspectiva de interação de vários fatores, ainda que a força maior venha dos aparatos institucionais à serviço do poder.

As análises teóricas produzidas por Hannah Arendt acerca do fenômeno totalitário nos permitiram refletir sobre as experiências do Estado

\footnotetext{
12 "Na verdade, as diversas influências que orientam a evolução das relações internacionais, papel das influências econômicas, financeiras, demográficas, psicológicas ou sentimentais, e papel da impulsão exercida pela vontade dos homens de governo, se contrariam ou se associam, segundo as modalidades, diferentes, sem cessar, no tempo e no espaço. $O$ historiador, quando procura os elementos de explicação, deve, pois, examinar, em cada caso, a título de hipóteses de trabalho, o jogo de cada uma dessas influências. Ele é levado, ora a constatar a influência dominante das forças econômicas ou demográficas (é o caso que freqüentemente ocorre, no estudo das mudanças de longa duração), ora a enfatizar as forças sentimentais ou espirituais, cuja ação é sensível, sobretudo nas crises internacionais em que intervêm as paixões, ora a concluir pelo papel determinante das iniciativas individuais. Reservar, de antemão, a uma de tais explicações, uma parte preponderante, e estabelecer, em princípio, que uma dessas forças teve, permanentemente, papel determinante - seria falsear o sentido da pesquisa histórica. (...) No estudo das relações internacionais, o único meio de evitar erros importantes consiste, para o historiador, em conservar uma constante disponibilidade de espírito." (Pierre Renouvin; Jean Baptiste Duroselle. Introdução à História das Relações Internacionais. São Paulo: Difusão Européia do Livro, 1967, p.480.)
} 
Novo brasileiro e do franquismo na Espanha. Considerando o contexto histórico de ambos os países, adotamos o conceito de autoritarismo para designar os movimentos onde o grau de controle político e policial existem, mas sempre em menor escala do que nos regimes totalitários. ${ }^{13}$ Lembramos aqui que uma das polêmicas que persistem nos trabalhos acadêmicos sobre 0 autoritarismo, diz respeito ao emprego do termo fascismo, inicialmente utilizado em referência ao movimento liderado por Mussolini na Itália. Hoje, este conceito foi suplantado por um significado muito mais amplo, prestandose como definição para outros movimentos e partidos nacionalistas de extrema direita. Assim, em muitos momentos, a palavra fascismo foi empregada genericamente para todos os movimentos caracterizados por uma forte hierarquia centrada na liderança de um chefe, cuja essência é autoritária, antidemocrática e anticomunista.

De acordo com Francisco Calazans Falcon, em seu artigo "Fascismo: Autoritarismo e Totalitarismo", as generalizações desse tipo não são de grande valia para o trabalho do historiador, uma vez que não levam em conta as especificidades dos modelos políticos autoritários: "Consideramos de antemão fadada ao fracasso qualquer tentativa de análise teórico-explicativa que se revele incapaz de levar, na devida conta, a realidade multifacetada do fenômeno fascista". ${ }^{14}$ Sendo assim, suas discussões nos despertam para 0 cuidado que se deve ter nas análises sobre o fenômeno do nacionalismo, manifesto como característica tanto do governo franquista como do governo Vargas. Embora tenham características bastante semelhantes, não se pode deixar de considerar as particularidades específicas desses regimes.

Em seu livro Los Fascismo Europeos, Elena Hernández Sandoica analisa os movimentos autoritários europeus surgidos após a década de 1920 . ${ }^{15}$ Embora concentre suas atenções na questão do fascismo italiano e do nazismo, traz referências ao caso espanhol e brasileiro. Analisando como vários autores abordam a questão dos "fascismos", Sandoica expressa

\footnotetext{
${ }^{13}$ Hannah Arendt. Origens do totalitarismo. São Paulo: Companhia das Letras, 1998.

${ }^{14}$ Francisco José Calazans Falcon. "Fascismo: Autoritarismo e Totalitarismo". In: José Luis Werneck Silva (org.). O Feixe. O autoritarismo como questão teórica e historiográfica. Rio de Janeiro: Jorge Zahar, 1989, p. 29.

${ }_{15}$ Elena Hernández Sandoica. Los Fascismos Europeos. Madrid: Ediciones Istmo, 1992. Colección La Historia en sus textos.
} 
algumas das idéias sustentadas por autores que destacam as especificidades do fenômeno fascista. Para aqueles que são contrários à generalização do termo fascismo, o regime de Vargas no Brasil e o de Franco na Espanha, podem ser excluídos dos "sistemas fascistas". Esses, em lugar de fascistas, "vendrian a considerarse como clásicos regímenes conservadores y autoritarios, salpicados de características fascistoides." ${ }^{16}$

Estas questões atentam para a persistência do debate historiográfico sobre as particularidades dos regimes ditatoriais espanhol e brasileiro. No que diz respeito ao franquismo e às discussões sobre a aplicabilidade do termo fascista para designá-lo, compartilhamos com as afirmações de Stanley Payne, que considera a Falange como a instituição que, ao longo da história espanhola, mais se aproximou do ideário fascista. ${ }^{17}$

Payne afirma que uma das características do franquismo que o diferencia do fascismo italiano e do nazismo na Alemanha, diz respeito as suas relações com a Igreja Católica. O governo do General Franco adquiriu uma peculiaridade especial: a de se manter vinculado aos valores católicos e defender a posição privilegiada da Igreja. Entendido como incorporador da tradição dos espanhóis, o catolicismo significava para os espanhóis guardadas as devidas especificidades - o mesmo que o sangue ariano para Hitler. $^{18}$

Da mesma forma como o conceito de fascismo permeia o conteúdo da correspondência oficial trocada entre os diplomatas brasileiros e o MRE, também o nacionalismo emerge como expressão característica dos anos de 1930 e 1940. As análises de Benedict Anderson e Montserrat Guiberneau nos instigam a avaliar as dimensões desse nacionalismo, que se configurou como elemento presente nos discursos oficiais. Ambos os autores procuram explicar o Estado Nacional como uma instituição voltada à criação de uma cultura, símbolo e valores comuns a um país. Segundo Anderson, o nacionalismo é um artefato cultural peculiar e a nação uma "comunidade política imaginada", uma comunidade fraterna, na qual um companheirismo profundo e horizontal é o sentimento que prevalece entre seus membros. Essa

\footnotetext{
${ }^{16}$ Idem, p.22.

17 Stanley G. Payne. El fascismo. Madrid: Alianza Editorial, 1980, p.152.

18 Idem.
} 
fraternidade é o que torna possível a desconsideração da profunda desigualdade e exploração que marcam as sociedades, e é o que explica porque no século $\mathrm{XX}$, milhões de pessoas morreram e mataram por essa "comunidade imaginada". ${ }^{19}$

Para Montserrat Guiberneau o nacionalismo, denominado de "religião civil", configura a "sacralização de certos aspectos da vida em comunidade, por meio de ritos públicos, liturgias políticas ou civis e devoções populares, elaboradas para conferir poder e fortalecer a identidade e a ordem em sociedades heterogêneas". ${ }^{20}$

Considerando que os ofícios e relatórios eram produzidos por representantes de um segmento intelectual do país, devemos avaliá-los enquanto agentes produtores de conhecimentos, ou seja, de um saber que tem força junto às esferas de poder. A fluidez dos relatos, bem como a erudição lingüística desses autores, nos permite entrever uma elite que muito se distanciava do perfil social, econômico e cultural da maior parte da população brasileira. Essa diminuta parcela de brasileiros mantinha estreita vinculação com o poder instituído, relação que pode ser definida pela concepção "englobante" de elites, de Guy Chaussinand-Nogaret. Esse pensador, de acordo com Jean Duma, define a elite como um conjunto de grupos sociais que devido a seu estatuto jurídico, sua riqueza, ou seus talentos se isolam do resto da sociedade, mantendo relações privilegiadas com o poder. ${ }^{21}$

Esta definição nos permite elaborar um perfil da "elite Rio Branco" em missão na Espanha, bem como reconstituir elementos expressivos da sua visão de mundo e de política externa. Sempre se fizeram presentes nos quadros do Itamaraty expoentes da cultura brasileira, como grandes poetas e escritores. A escolha dos representantes do Brasil no exterior, sempre obedeceu a uma rigorosa seleção, na qual se sobressaíam aqueles com uma formação sólida e domínio de língua estrangeira. Nesse contexto, muitos

\footnotetext{
${ }^{19}$ Benedict Anderson. Nação e Consciência Nacional. São Paulo: Ática, 1989, p.16.

${ }^{20}$ Montserrat Guiberneau. Nacionalismos: o Estado Nacional e o nacionalismo no século XX. Rio de Janeiro: Jorge Zahar Editor, 1997, p.55.

${ }^{21}$ Jean Duma. Sobre as elites: abordagem historiográfica. Revista História Unisinos. São Leopoldo: UNISINOS, vol. $7^{\circ}$ (8), p. 89-103, 2003.
} 
seguiam a tradição familiar encontrando facilidades para adentrar a vida diplomática. $^{22}$

Ao chefiar as missões diplomáticas sediadas em diferentes países, essa elite era responsável por executar os objetivos de política externa pretendidos pelo Estado estando assim, subordinada ao presidente da República. ${ }^{23}$ A historiografia que analisa a atuação do Itamaraty ao longo da História do Brasil, costuma ressaltar que, a despeito das diferentes diretrizes políticas desenvolvidas pelos governos republicanos, este Ministério sempre procurou seguir uma linha de continuidade, especialmente em seu respeito ao juridicismo. $^{24}$ Tal constatação é perceptível durante os quase trinta anos que propusemos como balizamento para este estudo, dada a continuidade de certos traços de nossa política externa, apesar das alterações de cunho político-ideológico do Executivo.

A definição do diplomata como executor de um pensamento formulado por outras instâncias de poder foi desenvolvida por Jean Baptiste Duroselle em sua obra Todo Império Perecerá. Duroselle faz referências aos diplomatas como sendo os táticos que executam as estratégias dos que detêm o poder de decisão. ${ }^{25}$ Tais considerações podem ser aplicadas para o caso brasileiro, ainda que o Itamaraty e seu quadro de funcionários, por vezes, tivessem autonomia suficiente na ação decisória frente à questões importantes.

Os chefes de missões diplomáticas do Brasil no exterior detinham certa autonomia para resolver questões rotineiras no que se refere ao intercâmbio comercial e cultural. Eram incumbidos de prestar assistência aos brasileiros, velar pela fiel observância dos tratados, refutar notícias tendenciosas sobre o Brasil, incentivar o intercâmbio cultural, expedir e visar

\footnotetext{
${ }^{22}$ Datam de 1944 e 1946, respectivamente, a criação de cursos preparatórios para a carreira diplomática na Espanha e no Brasil. O Instituto Rio Branco foi fundado no Brasil em um momento no qual a política externa brasileira passou a contar com maiores desafios, haja vista a importância das relações multilaterais a partir da criação da ONU e dos órgãos a ela vinculados. Tal Instituto, ainda hoje é responsável pela seleção e treinamento dos diplomatas brasileiros. Para maiores informações sobre a carreira diplomática e o Instituto Rio Branco ver http://www.irbr.mre.gov.br/instituto/instituto.html. Acesso em 22 abr. 2008.

${ }^{23}$ Anualmente, o Ministro das Relações Exteriores encaminhava um relatório ao presidente da República, no qual eram resumidas as suas principais ações frente ao exterior. Os relatórios dos anos que balizam nossa pesquisa, com exceção dos anos de 1945, 1948, 1953 e 1954, estão disponibilizados no site do Ministério das Relações Exteriores (www.mre.gov.br).

${ }^{24}$ Amado Luiz Cervo (Org.). O desafio internacional: a política exterior do Brasil de 1930 a nossos dias. Brasília: Editora UNB, 1994, p.27.

${ }^{25}$ Jean Baptiste Duroselle. Todo Império perecerá. Trad. de Ane Lize Spaltemberg de Seiqueira Magalhães. Brasília: UNB; São Paulo: Imprensa Oficial, 2000, p.101.
} 
passaportes, promover a concessão de exeqüator, além de remeter relatórios sobre a situação econômico- financeira, a vida intelectual, científica e artística do país onde se achassem acreditados. ${ }^{26}$

Caberia ressaltar a ausência de mulheres na carreira diplomática brasileira, tradição que marca a história do Itamaraty. ${ }^{27}$ No entanto, na Espanha, a Embaixada do Brasil costumava contratar espanholas para executar alguns serviços tais como a organização dos arquivos, e a datilografia e tradução de correspondência para o francês e o espanhol. No setor consular há casos de mulheres contratadas para atuar junto ao financeiro, cuidando da transferência e da contabilidade da renda consular. Também fazia parte de suas obrigações visar as faturas comerciais. Em 1958, na Embaixada brasileira na Espanha, dos sete funcionários que desempenhavam atividades rotineiras, cinco eram mulheres. ${ }^{28}$

Junto à documentação consultada são raras as referências à presença de mulheres diplomatas na Espanha. Dentre os registros identificamos que, em dezembro de 1950, a Embaixada do Brasil na Espanha enviou a carta-patente de Marina Moscoso ao Ministério de Assuntos Exteriores da Espanha, solicitando o exeqüator para que ela pudesse assumir

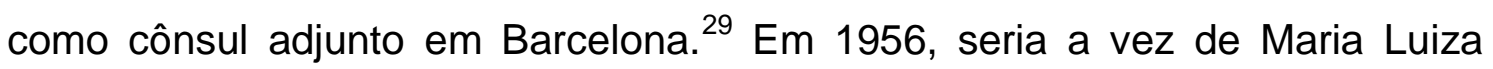
Fialho de Castro e Silva assumir a mesma função. ${ }^{30}$

\footnotetext{
${ }^{26}$ Flávio Mendes de Oliveira Castro, op. cit., p. 307.

${ }^{27} \mathrm{Se}$ atualmente as mulheres ocupam cerca de $20 \%$ das vagas para diplomatas, podemos imaginar a ínfima quantidade de mulheres que integravam a Casa Rio Branco na primeira metade do século XX. Em 1918, Maria José de Castro galgou o primeiro lugar no concurso do MRE. Sua admissão foi contestada pelas autoridades de então, mas a defesa de Rui Barbosa garantiu seu direito. Em 1938, um decreto presidencial vetou novamente o acesso das mulheres à carreira, sendo de 1954 a decisão de abrir o concurso para todos os brasileiros, sem distinção de gênero. Informações disponíveis em: http://www.irbr.mre.gov.br/contato/perg resp frequentes.htm\#embaixadora. Acesso em 19 abr. 2008.

28 "Descrição das tarefas atribuídas a cada um dos auxiliares contratados na Embaixada do Brasil em Madri". Anexo ao ofício reservado n.1078 da Embaixada do Brasil na Espanha (s/assin.) para Francisco Negrão de Lima, ministro das Relações Exteriores. Madri, 09 dez. 1958. Missões Diplomáticas Brasileiras. Ofícios recebidos de Madri (novembro a dezembro de 1958). AHI/RJ.

${ }^{29}$ Nota (cópia) da Embaixada do Brasil na Espanha para Ministério de Assuntos Exteriores da Espanha. Madri, 27 dez. 1950. Missões Diplomáticas Brasileiras. Ofícios recebidos de Madri (janeiro a março de 1951). AHI/RJ.

30 Despacho da Secretaria de Estado das Relações Exteriores para Embaixada do Brasil na Espanha. Rio de Janeiro, 14 jan. 1956. Missões Diplomáticas Brasileiras. Despachos para Madri (1954-1959). AHI/RJ.
} 
Estiveram à frente de nossa representação diplomática na Espanha entre 1930 e 1960, Luiz Guimarães Filho (1931-1933), Luis Guimarães Fernandes Pinheiro (1933 - 1935), Alcebíades Peçanha (19351938), Carlos da Silveira Martins Ramos (1938-1939), Abelardo Roças (19391943), Roberto Mendes Gonçalves (1943-1944), Mario de Pimentel Brandão (1944-1945), Antonio Mendes Viana (1945-1946), Vasco Tristão Leitão da Cunha (1946-1950), Rubens Ferreira de Mello (1950-1956) e João Gabizo Coelho Lisboa (1956-1959). ${ }^{31}$ Outros diplomatas atuaram na Espanha em períodos curtos, seja como encarregados de negócios, como secretários à espera de nomeação, ou em substituição durante as férias do titular do posto. Não realizaremos aqui uma explanação da biografia e da carreira diplomática de cada um desses, mas se faz necessário discorrer sobre alguns elementos importantes para compreendermos suas posturas frente à realidade política da Espanha.

Ao contrário de outros postos, para a Espanha, entre 1930 e 1960, foram nomeados diplomatas de carreira que levavam a experiência de anos ou décadas como chefes de missão em outros países. Entre esses, citamos Mario de Pimentel Brandão e Vasco Leitão da Cunha que, antes ou após assumirem o posto em Madri, exerceram a função de ministro das Relações Exteriores. ${ }^{32}$

Chefiaram o Consulado brasileiro em Barcelona dois expoentes da cultura brasileira: Raul Bopp e João Cabral de Melo Neto. Escritores conceituados, Bopp e Cabral de Melo fizeram parte dos quadros do Itamaraty, servindo na Espanha na década de 1950. Fragmentos dessa experiência foram registrados por ambos. Bopp em seu livro Memórias de um embaixador tece interessantes considerações sobre a Espanha, dando destaque à descoberta que fez acerca de um grave caso de irregularidades praticadas por funcionários do Consulado, assunto esse que retomaremos adiante. ${ }^{33}$ João Cabral de Melo,

\footnotetext{
${ }^{31}$ Informações detalhadas sobre a carreira desses diplomatas podem ser consultadas nas notas biográficas.

32 Mario de Pimentel Brandão foi ministro das Relações Exteriores entre agosto de 1937 e março de 1938. Vasco Tristão Leitão da Cunha foi nomeado para assumir a pasta das Relações Exteriores logo após o golpe militar de 1964, tendo deixado o cargo em janeiro de 1966.

${ }^{33}$ Raul Bopp. Memórias de um embaixador. Rio de Janeiro: Gráfica Record, 1968. Bopp assumiu o Consulado-Geral em Barcelona em 1951, sendo removido para a Guatemala em 1953.
} 
por sua vez, reconhece a influência que sua obra recebeu da vivência no país ibérico e dos autores espanhóis. ${ }^{34}$

Apesar das distintas trajetórias pessoais e profissionais dos diplomatas que atuaram junto à Embaixada brasileira, uma característica comum se faz perceptível em seus discursos: o anticomunismo. A despeito das transformações políticas ocorridas no Brasil ao longo das décadas de 1930 e 1960, o discurso anticomunista persiste enquanto elemento expressivo da postura do governo brasileiro. O combate ao comunismo em escala internacional se fazia através de uma eficiente rede de informações, manifestando-se como uma das principais preocupações das missões diplomáticas brasileiras. Principalmente nos anos 30 e 40 , os registros comprovam o intuito de se formar uma rede de comunicação para vigiar as atividades de brasileiros comunistas na Espanha. Ao governo espanhol também interessava o conhecimento de atividades de "subversivos" espanhóis em território brasileiro, como forma de precaver-se contra a possível entrada desses na Espanha.

As considerações acima não nos possibilitam, no entanto, realizar afirmações generalizantes acerca do perfil político-ideológico da diplomacia brasileira. Não nos causou surpresa o teor das opiniões emitidas pelos diplomatas brasileiros acerca de questões políticas da Espanha. No entanto, muitas das afirmações de nossos representantes sobre o governo desse país constituíam-se em críticas exacerbadas. Muitas dessas incidiam sobre qualquer alteração que pudesse significar reformas estruturais do país. As mudanças de cunho liberal na Espanha republicana eram muitas vezes mencionadas como fruto da presença do "perigo vermelho" nesse país.

Outro fator que permeia a documentação do MRE diz respeito às divergências entre os diplomatas atuantes num mesmo posto ou em um mesmo país. Conflitos de interesses, divergências com relação a assuntos de trabalho ou rotineiros, ou até mesmo de caráter pessoal, são ocorrências que não devem ser negligenciadas, pois muitas vezes interferiam nas decisões que deveriam seguir a política oficial.

\footnotetext{
${ }^{34}$ Ivan Junqueira. João Cabral, um mestre sem herdeiros. In: Alberto da Costa Silva (Org.). $O$ Itamaraty na cultura brasileira. Brasília: Instituto Rio Branco, 2001, p.346. João Cabral de Mello foi nomeado cônsul adjunto em Barcelona em maio de 1956.
} 
No que tange ao papel do Itamaraty frente às trocas comerciais entre os dois países cabe observar que, entre 1930 e 1960, a balança comercial foi favorável ao Brasil, sendo o café o "carro chefe" de nossas exportações. A atuação do Itamaraty frente às questões econômicas, especialmente na formulação de acordos comerciais com a Espanha, constituise em um assunto recorrente na documentação diplomática. Ao longo desses anos, triunfou entre os nossos representantes uma visão afirmativa da vocação agro-exportadora brasileira. Poucos foram os momentos em que houve a promoção de atitudes inovadoras visando o crescimento e a diversificação do intercâmbio comercial entre os dois países. O discurso diplomático defendia que as trocas comerciais deveriam ser fortalecidas por uma política cultural que beneficiasse a imagem brasileira na Espanha. No entanto, as medidas concretizadas nesse sentido foram incipientes.

Considerando o conjunto das fontes consultadas e nossas hipóteses direcionadas para o estudo das relações diplomáticas, optamos por dividir o trabalho em três capítulos, obedecendo a uma ordem cronológica. Tal opção se fez necessária diante do reconhecimento de certos recortes políticos para a compreensão dos momentos de rupturas e mudanças de postura do Brasil frente à Espanha.

A postura do governo brasileiro e da diplomacia brasileira diante da Guerra Civil Espanhola é analisada no primeiro capítulo. Durante os três anos de conflito, o Ministério das Relações Exteriores centrou maiores preocupações na política que vinha realizando frente ao governo republicano espanhol. A postura anticomunista diante dos acontecimentos naquele país é facilmente identificada em centenas de relatórios, ofícios e telegramas. Nesse capítulo, apresentamos a difícil situação vivenciada pelos diplomatas brasileiros que sofreram as conseqüências de uma guerra fratricida, além de analisar o processo de reconhecimento do governo nacionalista pelo Brasil. A leitura dos documentos diplomáticos nos permite afirmar que, embora ainda não fosse ministro, as opiniões de Oswaldo Aranha determinaram as diretrizes dadas por Vargas para a questão.

No segundo capítulo, abordamos dois momentos cruciais para a redefinição da política externa do Brasil frente à Espanha: o período que 
compreende a participação brasileira no conflito mundial e os quatro anos imediatos ao pós-guerra. Entre 1942 e 1945, o relacionamento oficial entre os dois países alterou-se em função do rompimento brasileiro com os países do Eixo. A partir de 1942, devido à identificação do governo franquista com a Alemanha nazista, a Embaixada da Espanha passou a representar os interesses alemães no Brasil. A atuação da Falange Espanhola no Brasil, que antes desse ano não preocupava as autoridades brasileiras, passou a ser alvo da repressão policial, devido ao seu comprometimento com as idéias nazifascistas. Diante desta realidade, as relações hispano-brasileiras tornaram-se tensas.

Em 1946, após acalorados debates, o regime franquista foi condenado pela ONU. A polêmica em torno da Espanha, acusada pelos países socialistas de constituir-se em um perigo à paz internacional, ficou conhecida como o "caso espanhol". O Brasil como país fundador da Organização acatou a determinação da Resolução 39/I da Assembléia das Nações Unidas de 1946, rompendo as relações em mais alto nível com a Espanha e deixando a sua representação sob responsabilidade de um encarregado de negócios. A postura do Brasil na ONU com relação ao "caso espanhol" está diretamente relacionada com o seu contexto político interno, assim como à redefinição de sua atuação externa que, nesse momento, caracterizou-se por um alinhamento quase incondicional aos EUA.

As relações bilaterais permaneceram quatro anos marcadas pela ambigüidade. Em 1949, no relatório do Ministério das Relações Exteriores para a Presidência da República, o ministro defendeu que o Brasil desejava manter o relacionamento diplomático com a Espanha, só acatando a decisão da ONU "para que não vencesse a ala de países liderados pela Polônia que propunha total ruptura diplomática." ${ }^{35}$ Nesse mesmo ano, o Brasil alterou esse posicionamento defendendo o fim do embargo à Espanha. A decisão do Brasil de enviar um embaixador a Madri foi anterior à resolução da ONU de 1950, que autorizou a nomeação de representantes diplomáticos para esse país.

Outro aspecto que deve ser observado refere-se à importância, cada vez maior, a partir do pós-guerra, da atuação brasileira nos foros multilaterais, participação essa que incide na compreensão das relações

\footnotetext{
${ }^{35}$ Elena Pájaro Peres. A inexistência da terra firme, op. cit., p.134.
} 
bilaterais do Brasil com a Espanha e outros países. Consideramos que, a partir do alinhamento brasileiro aos Estados Unidos durante a Segunda Guerra Mundial, as relações entre Brasil e Espanha não devem mais ser analisadas somente no âmbito bilateral. A participação do Brasil no conflito mundial e sua atuação na ONU frente ao "caso espanhol" demonstram que a política externa brasileira para a Espanha estava condicionada aos compromissos assumidos com os EUA.

No terceiro capítulo, analisaremos o período entre 1951 e 1960. No Brasil, o projeto nacional-desenvolvimentista criou uma expectativa de crescimento e modernização, que sensibilizou grande parte da sociedade brasileira. $\mathrm{Na}$ Espanha, os anos 50 - apesar de fragilizados pelas dificuldades geradas pela herança social e econômica da guerra civil e da Segunda Guerra Mundial - marcam o início da recuperação econômica do governo franquista. Em 1953, a Espanha realizou acordos com os EUA, permitindo a instalação de bases militares norte-americanas em seu território, em troca de auxílio econômico, técnico e militar. ${ }^{36}$

$\mathrm{Na}$ década de 1950, as relações hispano-brasileiras foram marcadas por um esforço de aproximação. Em 1956, Juscelino Kubitschek visitou a Espanha, sendo recebido com pompa por Francisco Franco. Para além das simpatias mútuas entre Kubitschek e Franco, existiam interesses estratégicos de ambos os países nessa aproximação. A viagem do presidente brasileiro, segundo Bruno Ayllón, se inseria dentro de uma estratégia relacionada ao Plano de Metas. Por outro lado, para o governo de Franco era uma oportunidade de mostrar à opinião pública que a fase de exílio havia sido superada. ${ }^{37}$ Assim, podemos afirmar que as relações com a Espanha na década de 1950 foram de grande relevância para a concretização do projeto desenvolvimentista que marca os "anos dourados" no Brasil.

Neste terceiro e último capítulo analisaremos temas que, a despeito dos momentos de ruptura política decorrentes das mudanças de regimes políticos no Brasil e na Espanha, perpassam com maior ou menor

\footnotetext{
${ }^{36}$ Idem.

${ }^{37}$ A visita de Juscelino, segundo Bruno Ayllón Pino "se enmarcaba en el contexto más amplio del caráter instrumental de la politica exterior del Brasil en relación con el Programa de Metas de Desarrollo." Por outro lado, para o governo de Franco "se trataba de instrumentalizar la visita y demonstrar a la opinión pública española que se superaba la fase del aislamiento." (Las relaciones culturales en la agenda bilateral hisp ano-brasileña, op. cit., p.40).
} 
destaque todo o período de nosso estudo: a questão imigratória e as relações culturais. Constatamos que, na década de 50, o Itamaraty preocupou-se em desenvolver uma política cultural para a Espanha. Os acordos culturais, a participação de cidadãos e artistas de ambos os países em congressos e exposições, além da presença de estudantes brasileiros na Espanha, foram aspectos importantes para as relações entre esses países. Optamos por analisar esse aspecto somente no terceiro capítulo porque a profusão de aspectos culturais nas relações entre Brasil e Espanha na década de 1950, confronta-se com a ausência de uma política cultural formulada pelo Itamaraty para esse país nas décadas anteriores.

Um dos pontos nevrálgicos nas relações hispano-brasileiras diz respeito à imigração. Cabe analisar a postura do Itamaraty frente ao segundo surto imigratório espanhol para o Brasil, ocorrido especialmente nos anos 50 do século XX. À representação brasileira na Espanha coube tomar iniciativas no sentido de orientar e sistematizar o movimento imigratório que, à princípio, apresentava-se desordenado. Veremos que em coordenação com o INIC, Instituto Nacional de Imigração e Colonização, a diplomacia brasileira colocou em prática uma política restritiva à entrada de alguns imigrantes espanhóis, evidenciando o preconceito e a intolerância que se faziam presentes na mentalidade de parte da elite brasileira.

Em síntese: pretendemos identificar as continuidades e rupturas que caracterizam as relações entre Brasil e Espanha, com o objetivo de compreender as causas de eventuais tensões e conflitos, assim como os interesses nacionais que estiveram em jogo nas relações construídas com esse país. 
I - O Brasil na trama da Guerra Civil Espanhola (1936-1939) 


\title{
1.1 - O Itamaraty diante da República espanhola
}

\author{
O Governo Vargas e a Il República espanhola (1931-1936)
}

As relações internacionais do Brasil devem ser analisadas levando-se em conta as transformações políticas ocorridas após a Revolução de 1930. A definição desse episódio como um marco significativo na história política gera debates e polêmicas acerca de suas repercussões na política externa brasileira.

O governo provisório que assumiu o poder em 1930 esforçou-se em afirmar que a condução da política externa brasileira, apesar da ruptura política, mantinha-se contínua. ${ }^{38} \mathrm{~A}$ despeito dos debates acerca da natureza conservadora ou reformista dos novos equilíbrios de poder, é inegável que a política externa brasileira do primeiro governo Vargas (1930-1945) obteve ampla projeção no cenário internacional. Gerson Moura, em suas análises sobre este período, afirma que não se trata nem de continuidade nem de ruptura com o momento anterior, e sim de uma redefinição da política externa a partir da Revolução de $30 .{ }^{39}$ Segundo este autor, a redefinição foi decorrente da conjugação do reordenamento do poder mundial e das transformações econômicas, políticas e sociais de ordem interna. O confronto entre os dois sistemas de poder - o alemão e o norte-americano - deu condições ao Brasil de explorar as "possibilidades oferecidas por ambos os centros, sem se definir por qualquer um deles". No plano interno ocorria também uma divisão completa das opiniões sobre qual seria a melhor aliança para o país. Esse traço da política externa brasileira, o autor nomeou de "eqüidistância pragmática". ${ }^{40}$

A eqüidistância pragmática é um conceito que, em nossa concepção, explica os traços principais da política externa brasileira dos anos 30. O fato do Brasil não alinhar-se automaticamente a nenhum desses sistemas de poder, trouxe uma margem de autonomia no gerenciamento de sua política externa. Consideramos que as relações com a Espanha nesse período, beneficiaram-se dessa autonomia. Apesar de não configurar-se como

\footnotetext{
${ }^{38}$ Gerson Moura. A Revolução de 1930 e a política externa brasileira: ruptura ou continuidade? Seminário Internacional. Brasília: Editora da UNB, 1983, p.575.

${ }^{39}$ Idem, p.576.

${ }^{40}$ Idem, p.580.
} 
estratégico do ponto de vista político, a Espanha apresentava-se como um país com o qual o Brasil compartilhava interesses de ordem econômica, sendo as exportações de produtos primários muito maiores do que as importações recebidas desse país.

Do ponto de vista político, as relações com a Espanha nos primeiros anos da década de 1930 mantiveram-se cordiais, culminando com a elevação de ambas as representações para Embaixadas. Em 1931, o governo brasileiro, atendendo ao pedido encaminhado por Alejandro Lerroux, primeiroministro da República espanhola, ordenou que o representante brasileiro em Madri reconhecesse o governo republicano espanhol "dándole la bienvenida a la familia de las democracias" ${ }^{41}$ Apesar do reconhecimento, a diplomacia brasileira via com ressalvas a nova situação política desse país. A queda da monarquia de Alfonso XIII e a proclamação da Segunda República trouxeram como conseqüência um governo de tendências socialistas que foi considerado uma ameaça para os setores mais privilegiados da sociedade espanhola.

Durante os dois anos em que os socialistas estiveram no poder (1931-1933), o encarregado de negócios do Brasil na Espanha, Luis Guimarães Filho, acompanhou com atenção as reformas sociais e econômicas empreendidas pela República. Apesar de não suprir as expectativas de todos os setores trabalhistas, o governo espanhol promoveu medidas que suscitaram acalorados debates sobre qual o "conteúdo" que deveria revestir as reformas sociais e econômicas. ${ }^{42}$

A maioria dos relatórios produzidos pela Embaixada do Brasil na Espanha acerca da situação política daquele país revestia-se de críticas às reformas sociais, e em especial à reforma agrária proposta pelo governo republicano espanhol. Um ofício encaminhado por Guimarães Filho em 13 de fevereiro de 1933 informava o MRE acerca do embate entre a direita e a esquerda no espectro político espanhol, evidenciando o impacto negativo que certas reformas como a religiosa e a agrária tiveram sobre o "povo". Em suas observações, Guimarães Filho exemplificou tais medidas: confisco de bens dos "grandes da Espanha", o desterro de centenas de militares e aristocratas sem

${ }^{41}$ Bruno Ayllón Pino. Cronología de las relaciones hispano-brasileñas, 1931. Disponível em: www.brasilespanha.com.br. Acesso em 21 ago. 2006.

${ }^{42}$ Paul Preston. A Guerra Civil de Espanha. Lisboa: Edições 70, 2006, p. 39. 
culpa formada, entre outras. ${ }^{43}$ Utilizando-se da expressão "povo" como denominação para a minoria daqueles que efetivamente perderam seus privilégios - aristocratas, militares e setores da lgreja - o representante brasileiro tendia a enfatizar o "descontentamento" reinante diante daquele governo.

O governo brasileiro suprimiu o Consulado brasileiro em Madri em 1931, criando um setor consular dentro da representação diplomática brasileira. Diversos consulados brasileiros na Espanha também foram extintos sob a justificativa de "contenção de custos". Os consulados honorários eram geralmente criados em lugares de diminuta colônia de brasileiros ou de ínfimo intercâmbio comercial com o Brasil. Segundo Flávio Mendes de Oliveira Castro essas repartições honorárias não demandavam muitos custos ao Itamaraty, uma vez que "a remuneração de seus titulares era tirada de parte da arrecadação dos emolumentos consulares". ${ }^{4}$

Nos anos 30 , muitos parlamentares brasileiros pressionaram 0 governo no sentido de extinguir as legações brasileiras nos países com os quais o Brasil não possuía expressivos contatos comerciais. A justificativa era limitar os gastos, o que segundo Amado Cervo, demonstra uma visão diminuta de relações externas, pois desprezava-se "as possibilidades que a diplomacia ensejava de servir aos interesses do país ao buscar a ampliação de mercados, o favorecimento da imigração e a atração de capitais." ${ }^{45}$

O MRE não justificava a supressão dessas repartições apenas pelos custos. Em 1930, foi realizado um estudo baseado em dados estatísticos sobre o montante da renda consular e o valor do intercâmbio comercial com o Brasil, que forneceu subsídios para a decisão de extinguir algumas repartições. Segundo Oliveira Castro, por outro lado, "vários Consulados Honorários, com boa arrecadação, foram transformados em repartições de carreira" ${ }^{46}$

A extinção do Consulado brasileiro em Sevilha, em 1931, gerou protestos por parte dos comerciantes dessa cidade, que apresentaram à

\footnotetext{
${ }^{43}$ Ofício n. 17 de Luis Guimarães Filho, encarregado de negócios na Espanha para Afrânio de Mello Franco, ministro das Relações Exteriores do Brasil. Madri, 13 fev. 1933. Missões Diplomáticas Brasileiras. Ofícios recebidos de Madri (abril de 1932 a junho de 1933). AHI/RJ.

${ }^{44}$ Flávio Mendes de Oliveira Castro, op. cit., p.389.

${ }^{45}$ Amado Luiz Cervo; Clodoaldo Bueno. História da política externa. São Paulo: Ática, 1992, p. 145 .

${ }^{46}$ Idem, p.285.
} 
Legação do Brasil em Madri um abaixo-assinado pedindo 0 seu restabelecimento. Os comerciantes sentiam-se prejudicados financeiramente, pois as importações do Brasil encontravam melhores facilidades com uma representação institucional na cidade. ${ }^{47}$ Protestos sob a mesma justificativa também foram realizados por espanhóis da cidade de San Sebastián, diante da supressão da repartição consular brasileira nessa cidade. ${ }^{48}$ Foi também determinado pelo MRE a supressão dos vice-consulados honorários nas seguintes cidades espanholas: Ferrol, Cartagena, Granada, Jerez de la Frontera, Santander, Tarragona, Torrevieja e Valencia. Os arquivos dessas repartições foram transferidos para o Consulado Geral de Barcelona. ${ }^{49}$ Todas essas extinções estavam relacionadas às profundas mudanças administrativas e burocráticas levadas a cabo pelo chanceler Afrânio de Mello Franco, ministro das Relações Exteriores do Brasil entre 1930 e 1933.

Uma injeção de ânimo nas relações entre os dois países ocorreu a partir do novo governo espanhol formado ao final de 1933. O chamado Biênio Negro (1934-1936) teve início quando as eleições de novembro de 1933 conferiram o poder novamente à direita que, segundo Paul Preston, estava "determinada a vingar as injúrias e indignidades" que considerava ter sofrido durante os anos anteriores de maioria de esquerda. ${ }^{50}$ Esta aproximação é bastante sintomática, se considerarmos que a elite política que assumiu 0 poder no Brasil após 1930 não escondia suas simpatias pelas idéias conservadoras e autoritárias.

Luis Guimarães Filho foi o nosso primeiro embaixador na Espanha. Em 1934, o Brasil elevou sua representação para a categoria de Embaixada. Tal decisão parecia dar-se mais em sinal de agradecimento à

\footnotetext{
${ }^{47}$ Ofício de Luis Guimarães Filho, ministro plenipotenciário do Brasil na Espanha para Afrânio de Mello Franco, ministro das Relações Exteriores do Brasil. Madri, 30 jul. 1932. Missões Diplomáticas Brasileiras. Ofícios recebidos de Madri (abril de 1932 a janeiro de 1933). AHI/RJ.

${ }_{48}$ Carta (assinada por diversos comerciantes) para ministro do Brasil na Espanha. San Sebastián, 09 ago 1932. Missões Diplomáticas Brasileiras. Ofícios recebidos de Madri (abril de 1932 a janeiro de 1933). AHI/RJ.

49 Ofício n. 38 de Moniz Gordilho para Afrânio de Mello Franco, ministro das Relações Exteriores do Brasil. Madri, 28 mar. 1931. Missões Diplomáticas Brasileiras. Ofícios recebidos de Madri (1931 a março de 1932). AHI/RJ.

${ }^{50}$ Paul Preston. A Guerra Civil de España, op. cit., p. 57. Em 1931, após a fuga do rei Alfonso XIII, foi proclamada a República espanhola, elegendo-se um governo de tendências esquerdistas, realizador de várias reformas sociais e políticas, como a implementação do divórcio e a secularização dos cemitérios. Nas eleições de novembro de 1933, a direita voltou ao poder.
} 
decisão do governo da Espanha em elevar sua missão no Brasil à Embaixada - o que ocorreu em setembro de 1933 - do que reforçar as relações entre os dois países. Essa iniciativa provavelmente era uma forma de tentar uma aproximação com o governo Vargas que, nitidamente, não coadunava das mesmas opções políticas da República da Espanha, o que dificultava o relacionamento entre os dois países no aspecto comercial e cultural.

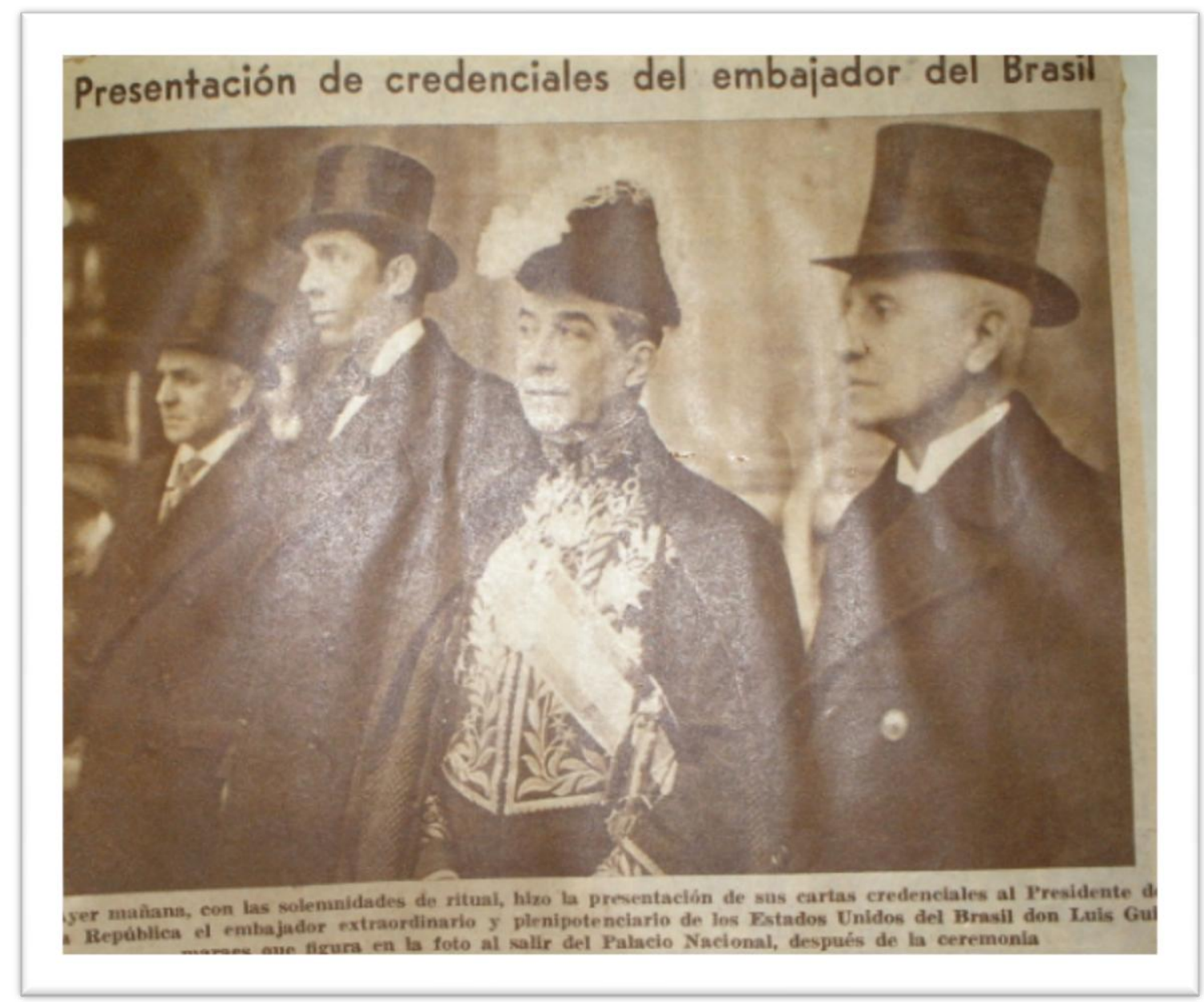

1 - Entrega de credenciais de Luis Guimarães Filho, embaixador do Brasil na Espanha ao presidente da República espanhola. Foto reproduzida em jornal (sem identificação). Recorte anexado ao ofício n. 23 de Luis Guimarães Filho para F. de Cavalcanti de Lacerda, ministro interino das Relações Exteriores do Brasil. Madri, 8 fev. 1934. Missões Diplomáticas Brasileiras. Ofícios recebidos de Madri (julho de 1933 a março de 1934). AHI/RJ. 


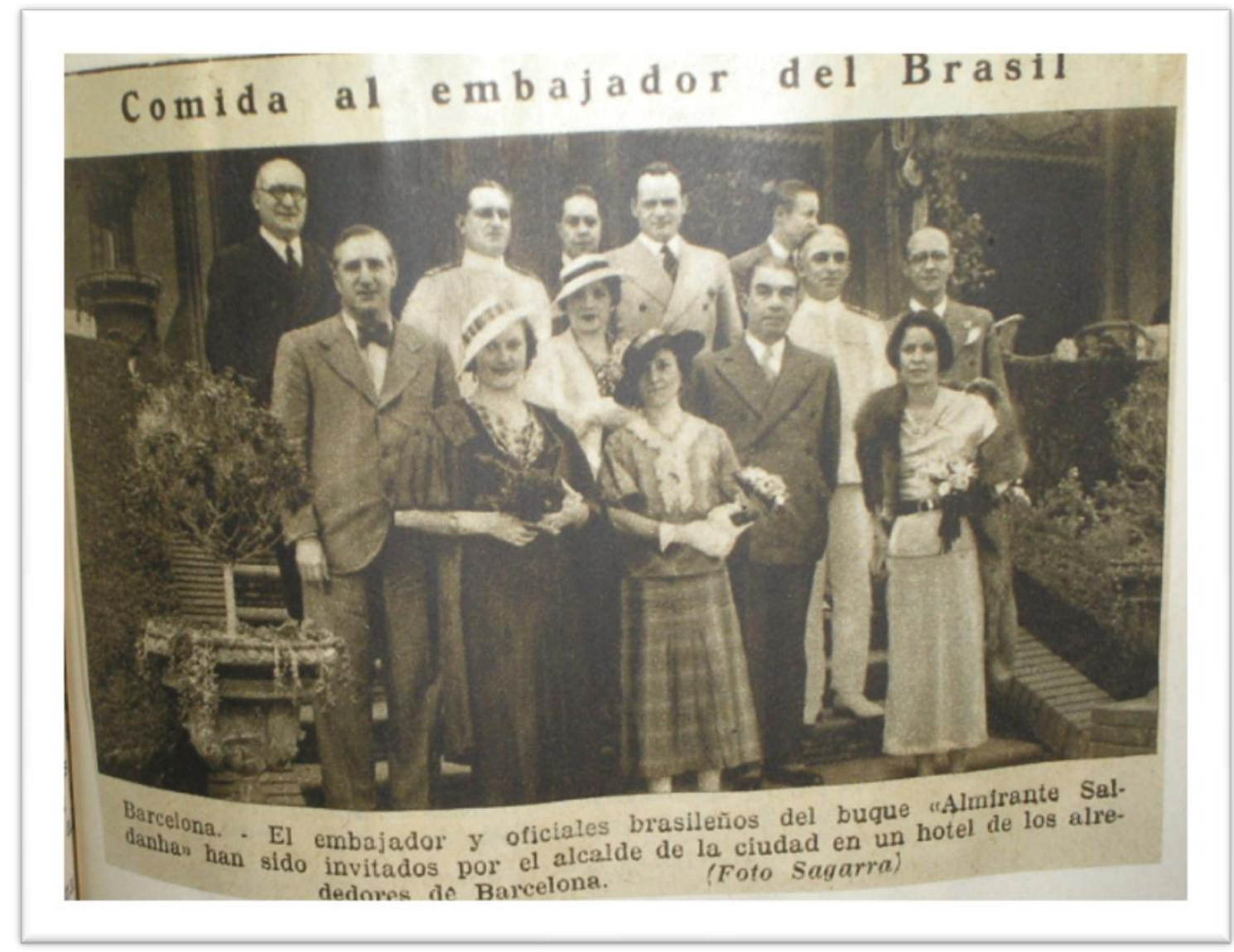

2 - Recepção oferecida pelo alcaide de Barcelona ao embaixador brasileiro e à comitiva de oficiais do navio "Almirante Saldanha". Fotografia reproduzida em jornal (s/ident. e s.d). Recorte anexado ao ofício n. 106 de Luis Guimarães Filho para José Carlos de Macedo Soares. Madri, 24 set. 1934. MDB. Ofícios recebidos de Madri (abril de 1934 a fevereiro de 1935). AHI/RJ.

A política exterior espanhola durante a Segunda República expressa a preocupação com a manutenção de relações amistosas com os países hispano-americanos. Embora as atenções estivessem mais concentradas em países como México e Argentina, ambos com grandes contingentes de imigrantes espanhóis, a elevação da representação espanhola deixa entrever uma preocupação em manter boas relações com o Brasil. Essa atitude, no entanto, contrastava com as contenções de despesas que 0 governo espanhol levou a cabo ao extinguir diversos consulados pelo mundo, afetando alguns no Brasil. O caso brasileiro corrobora com as afirmações da historiadora Nuria Tabanera de que nesse período, o governo espanhol seguiu um antigo critério: de que o prestígio político (sinônimo de representações diplomáticas em mais alto nível) era mais benéfico do que o cuidado com os 
resultados obtidos pelos consulados na proteção e assistência às colônias espanholas. $^{51}$

A elevação de Legação da Espanha para Embaixada no Rio de Janeiro pode ser vista como o início de um processo de modernização e alteração nos quadros diplomáticos e consulares, expressivo das ações que o novo governo espanhol tentou realizar a partir de janeiro de 1934. Nesse mês, a Legação brasileira na Espanha enviou ao Ministério das Relações Exteriores do Brasil, um ofício produzido pela República sobre as novas regras e diretrizes a serem cumpridas pelo quadro diplomático e consular da Espanha em outros países. O conteúdo nos permite afirmar que o governo de Manuel Azaña desejava uma representação diplomática no exterior pautada mais pelo profissionalismo do que pelos laços de tradição e amizade. ${ }^{52}$

No início da década de 1930, alguns episódios foram responsáveis por criar certa tensão nas relações bilaterais entre os dois países. Desencontros que se tornariam freqüentes e que caracterizariam as relações entre o primeiro governo Vargas e a República da Espanha. A representação brasileira na Espanha nutria um sentimento de descontentamento para com o governo republicano espanhol, por este não censurar os periódicos locais que divulgavam notícias consideradas ofensivas ao Brasil.

$\mathrm{Na}$ visão dos diplomatas brasileiros, a imagem veiculada sobre 0 Brasil na imprensa espanhola era, muitas vezes, prejudicada por cidadãos que apregoavam a idéia de que esse era um país que "facilitava as liberdades sexuais". Em 1933, foi publicado um livro sobre o título Temas sexuales, no qual o autor Martin de Lucenay afirmava ser formado em "Sexologia" pela Universidade do Rio de Janeiro. Lucenay, chamado à Legação brasileira, não temeu as conseqüências de seu ato alegando que havia inserido aquela referência por acreditar que dessa forma conseguiria vender mais livros. ${ }^{53}$

\footnotetext{
${ }^{51}$ Nuria Tabanera. Las dotaciones presupuestarias de la Segunda República española para el servicio diplomático en Hispanoamerica, 1931-1936: embajadas, legaciones y consulados, p. 14. Disponível em: www.ucm.es/BUCM/revistas/ghi/02116111/articulos. Acesso em 31 maio 2007.

${ }^{52}$ Ofício n. 11 de Luis Guimarães Filho, ministro plenipotenciário do Brasil na Espanha para F. de B. Cavalcante de Lacerda, secretário geral do Ministério das Relações Exteriores do Brasil. Madri, 09 jan. 1934. Missões Diplomáticas Brasileiras. Ofícios recebidos de Madri (julho de 1933 a março de 1934). AHI/RJ.

${ }^{53}$ Ofício n. 07 de Luis Guimarães Filho, ministro plenipotenciário do Brasil na Espanha para Afrânio de Mello Franco, ministro das Relações Exteriores do Brasil. Madri, 03 fev. 1933.
} 
A orientação do Itamaraty para esse caso foi a de pedir que a Legação do Brasil em Madri providenciasse a retirada de circulação dos referidos exemplares. A Secretaria de Estado das Relações Exteriores solicitou que houvesse rapidez na resolução do ocorrido e deu a anuência para que, caso fosse necessário, se contratasse um advogado para processar o autor. As medidas só não deveriam ser mais austeras para evitar um escândalo envolvendo o nome do Brasil. ${ }^{54}$

Deturpar a imagem do Brasil nos jornais espanhóis era segundo Luis Guimarães Filho, a intenção do embaixador espanhol no Chile, Ricardo Baezza. Em ofício ao MRE, Guimarães transcreveu as frases que o embaixador chileno utilizou para referir-se ao Brasil: "Um país de negros, onde impera a ausência de inteligência e a sexualidade". ${ }^{55}$

Interessante observar que, por diversas vezes, referências à composição étnica da população brasileira pelos periódicos espanhóis foram consideradas desabonadoras à imagem do Brasil. É evidente que a maior parte da diplomacia brasileira em missão na Espanha desejava transmitir uma imagem idealizada da nação e do povo brasileiro, realidade nem sempre condizente com o perfil de um país multirracial e multicultural. Era comum enfatizar a nossa origem européia, menosprezando a importância da influência africana na composição da sociedade brasileira. Em 1945, por exemplo, encontramos a reincidência desse discurso quando Roberto Mendes Gonçalves, cônsul brasileiro em Barcelona, relatou ao Itamaraty as atitudes que tomou em sinal de protesto contra as notícias que afirmavam que a maioria da população brasileira era composta de "negros e analfabetos". O cônsul afirmou ao MRE que solicitou ao jornal que corrigisse tais informações,

Missões Diplomáticas Brasileiras. Ofícios recebidos de Madri (abril de 1932 a junho de 1933). $\mathrm{AHI} / \mathrm{RJ}$.

54 Despacho n. 08 da Secretaria de Estado das Relações Exteriores do Brasil para Luis Guimarães Filho, ministro plenipotenciário do Brasil na Espanha. Madri, 08 mar. 1933. Missões Diplomáticas Brasileiras. Despachos expedidos a Madri $(1931$ - 1945). AHI/RJ.

${ }^{55}$ Ofício n. 65 de Luis Guimarães Filho, ministro plenipotenciário do Brasil na Espanha para Afrânio de Mello Franco, ministro das Relações Exteriores do Brasil. Madri, 13 jun. 1933. Missões Diplomáticas Brasileiras. Ofícios recebidos de Madri (abril de 1932 a junho de 1933). AHI/RJ. 
"esclarecendo" a esse "não exceder de $10 \%$ a população negra no Brasil, porcentagem mais ou menos igual a dos Estados Unidos". 56

As considerações de Mendes Gonçalves expressam a persistência de um pensamento racista entre as elites políticas brasileiras que, em diferentes momentos, se pronunciaram à respeito do "caráter mestiço" do povo brasileiro, interpretado como um "problema" a ser esmiuçado. Ao negarem que o Brasil era um país onde ainda predominava o analfabetismo, os diplomatas compartilhavam da omissão oficial à realidade nacional. As elites políticas e intelectuais brasileiras deparavam-se com a seguinte questão: como formar um Estado Nacional - cujo modelo era evidentemente a Europa - num país de mestiços? Este questionamento explica, até certo ponto, o sucesso alcançado pelo livro Casa Grande e Senzala, de Gilberto Freyre, que encontrou na mestiçagem a solução para os problemas nacionais. Através deste processo "integrador das raças" diluíam-se as acusações de que o Brasil era um país racista. $^{57}$

A obra de Gilberto Freyre encontrou terreno fértil entre aqueles que pensavam a brasilidade sob a ótica da valorização dos "nossos" traços mestiços. O pensamento que ganhou espaço a partir de Freyre foi o de que a mestiçagem deveria ser preservada como garantia de nossa especificidade. ${ }^{58}$ Casa Grande e Senzala, apresentou-se como uma obra em sintonia com os novos tempos, e sua publicação foi recebida como um acontecimento de suma importância no universo intelectual dos anos 30. No entanto, alguns diplomatas apoiavam as teorias que responsabilizavam a herança africana e a mestiçagem pelo atraso brasileiro, simpatizando com o ideal de branqueamento da população.

O governo republicano espanhol, ao atender aos pedidos do governo brasileiro de censura à imprensa, também sentia - se à vontade para exigir reciprocidade. Em 1935, o governo de maioria de direita na Espanha solicitou ao Itamaraty, através de sua Embaixada no Brasil, a proibição da exibição nos cinemas do filme The Devil is a woman. José Carlos de Macedo

\footnotetext{
${ }^{56}$ Ofício n. 153 de Roberto Mendes Gonçalves, cônsul do Brasil em Barcelona para Pedro Leão Velloso, ministro das Relações Exteriores do Brasil. Barcelona, 06 dez. 1945. Consulados Brasileiros. Ofícios recebidos de Barcelona (1944). AHI/RJ.

57 Sobre esse assunto ver: Silvia Cortez Silva. Tempos de Casa Grande (1930-1940). São Paulo, 1995. Tese (Doutorado em História Social) - FFLCH, USP.

${ }^{58}$ Hermano Vianna. O Mistério do Samba. Rio de Janeiro: Jorge Zahar/UFRJ, 1995, p.63.
} 
Soares considerou justa a solicitação, encaminhando o pedido para Vicente Rao, ministro da Justiça. A alegação era a de que o filme possuía "inumerosas inexactidões altamente offensivas a Espanha". ${ }^{59}$ No mesmo dia, Mario de Pimentel Brandão, em nome do ministro de Estado, comunicou a Embaixada da Espanha que estavam sendo tomadas as "providências necessárias a fim de ser satisfeito o referido pedido." ${ }^{60}$ Não sabemos qual fora a decisão do Ministério da Justiça.

A produção norte-americana estrelada por Marlene Dietrich em 1935, não trazia referências diretas à sociedade e à política espanhola. Tratase de uma história fictícia desenvolvida em torno da personagem principal, uma mulher bonita e sedutora chamada Concha Pérez que, por interesses financeiros, atraía os homens, sugava suas riquezas e depois os descartava. Apesar do filme não fazer alusão ou críticas às características sociais e políticas da Espanha, o fato da personagem ser espanhola constituía-se em elemento passível de críticas, tendo em vista as forças dos símbolos de representação. ${ }^{61}$ Importante lembrar, que a imagem da mulher "honesta" na Espanha estava atrelada aos valores morais propagados pela Igreja Católica. Assim, o fato de um filme sugerir a nacionalidade hispânica de uma mulher com tal comportamento, tornou-se motivo para considerá-lo ofensivo ao país.

Outra questão recorrente na correspondência diplomática diz respeito ao intercâmbio comercial entre Brasil e Espanha. Nos anos 30 ocorreram muitos embates sobre essa questão, principalmente no que tange à exportação de café, principal produto brasileiro destinado àquele país. As estatísticas demonstram que entre 1930 e 1960, salvo raros momentos, a balança comercial foi favorável ao Brasil. Se no plano cultural a postura do Itamaraty e da Embaixada do Brasil na Espanha foi sempre a de tentar uma aproximação baseada na cordialidade, no aspecto comercial houve uma atitude muito mais ativa, e em muitos momentos, de conflito declarado com os institutos governamentais responsáveis pelo comércio da Espanha. Isso porque

\footnotetext{
${ }^{59}$ Nota de José Carlos de Macedo Soares, ministro das Relações Exteriores do Brasil para Vicente Rao, ministro da Justiça. Rio de Janeiro, 11 nov. 1935. Lata 1030 maço 17657. AHI/RJ. ${ }^{60}$ Nota de Mario de Pimentel Brandão, em nome do Ministro de Estado para Vicente Sales, embaixador da Espanha no Brasil. Rio de Janeiro, 11 nov. 1935. Lata 1030 maço 17657. AHI/RJ.

${ }^{61}$ The devil is a woman (Mulher satânica), 1935. Direção: Josef Von Sternberg, 79 min, preto e branco. Silver Screen Collection.
} 
à missão diplomática cabia proteger os interesses das exportações brasileiras para esse país.

Segundo Ayllón Pino, os conflitos comerciais em torno do café implicavam "questões de caráter simbólico, ao ser este pequeno grão um estandarte nacional que representava a qualidade dos produtos brasileiros no mundo" ${ }^{62}$ Tal afirmação reitera uma das principais funções dos consulados brasileiros na Espanha: a de valorizar o café nacional. Quando, em 1942, Eduardo P. Osorio Bordini providenciou sua defesa no processo administrativo em que esteve envolvido, apresentou ao Itamaraty diversas fotos dos stands brasileiros de café como "prova" de seus bons ofícios enquanto defensor do comércio brasileiro. Bordini foi acusado de facilitar a vinda de judeus ao Brasil, sem a autorização do MRE. ${ }^{63}$

Um dos primeiros embates nos anos 30 no aspecto comercial diz respeito ao nome "Café Brasil" que, em Barcelona, passou a ser de uso exclusivo de um comerciante espanhol. A Embaixada brasileira encaminhou uma reclamação formal ao governo da Espanha, solicitando que o emblema brasileiro fosse retirado dos produtos comercializados por aquele estabelecimento. $^{64}$ Não parece que o governo espanhol tenha dado um desfecho favorável ao Brasil, pois em abril de 1932, Luis Guimarães Filho afirmou que o caso estava ainda em julgamento na segunda instância dos órgãos competentes. ${ }^{65}$

Questões como essas devem ser avaliadas em um contexto mais amplo, que implica na afirmação da política externa efetivada pelo primeiro chanceler do Governo Provisório de Vargas, Afrânio de Mello Franco, que negociou acordos bilaterais com mais de trinta países. ${ }^{66}$ Segundo Clodoaldo

\footnotetext{
${ }^{62}$ Bruno Ayllón Pino. As relações Brasil - Espanha na perspectiva da política externa brasileira (1945-2005), op. cit., p.129.

${ }^{63}$ São quatro fotos anexadas às "Conclusões do processo administrativo sobre concessão de vistos em passaportes". Do chefe do Departamento Administrativo do Serviço Público (ass. ileg.) para Presidente da República. Rio de Janeiro, 11 ago. 1942. Lata 1587, maço 34502. AHI/RJ.

${ }^{64}$ Ofício n. 16 de Luis Guimarães Filho, ministro plenipotenciário do Brasil na Espanha para Afrânio de Mello Franco, ministro das Relações Exteriores do Brasil. Madri, 16 fev. 1932. Missões Diplomáticas Brasileiras. Ofícios recebidos de Madri (1931 a março de 1932). AHI/RJ.

${ }^{65}$ Ofício n. 32 de Luis Guimarães Filho, ministro plenipotenciário do Brasil na Espanha para Afrânio de Mello Franco, ministro das Relações Exteriores do Brasil. Madri, 27 abr. 1932. Missões Diplomáticas Brasileiras. Ofícios recebidos de Madri (1931 a março de 1932). AHI/RJ.

${ }_{66}$ Monica Hirst. Política Interna e Política Externa. A Era Vargas, História da Diplomacia Brasileira. Disponível em : www.mre.gov.br. Acesso em 22 abr. 2006.
} 
Bueno, em 1932 o Brasil estudou as condições para assinar um acordo comercial com a Espanha. ${ }^{67}$ Tal intenção culminou com a inauguração, em 1934, da Câmara Hispano-Brasileira de Comércio, Indústria e Navegação, sediada em Madri. ${ }^{68}$ Essa instituição tinha por missão incrementar 0 intercâmbio comercial hispano-brasileiro. O café, até 1960, liderou as exportações brasileiras para a Espanha, seguido de produtos como a carne congelada, o tabaco, o fumo e o algodão. O Brasil, em contrapartida, comprava desse país principalmente azeite e armamentos como fuzis e baionetas.

Se no aspecto comercial havia uma tentativa de intensificar as relações com a Espanha, no âmbito político predominava desconfianças. Isso porque a experiência republicana na Espanha recuperou para o vocabulário brasileiro a conotação esquerdista do conceito de República que, no Brasil, sempre foi pensado nos moldes conservadores. ${ }^{69}$ Desde 1931 e especialmente após a vitória da Frente Popular no início de 1936, os diplomatas brasileiros demonstraram estar apreensivos com as agitações políticas que tomavam conta da Espanha.

Os antecedentes e a deflagração do conflito

A polarização das opiniões políticas na Espanha após a vitória do governo de Frente Popular prenunciava que uma tentativa de golpe, por parte dos setores de direita, não tardaria a ocorrer. Os setores da sociedade espanhola partidários do governo de Frente Popular acompanhavam com interesse a situação política do Brasil e a repressão a todas as frentes de resistência ao governo Vargas.

A atuação do governo Vargas na repressão ao comunismo recebia elogios dos setores conservadores da sociedade espanhola. No entanto, os ataques provenientes da esquerda se faziam sentir com muito mais intensidade na imprensa da capital espanhola. Segundo Alcebíades

\footnotetext{
${ }^{67}$ Amado Luis Cervo; Clodoaldo Bueno. História da Política Exterior do Brasil, op. cit., p.217.

${ }^{68}$ Ofício n. 52 da Embaixada do Brasil na Espanha para Secretaria de Estado das Relações Exteriores do Brasil. Madri, 20 abr. 1934. Missões Diplomáticas Brasileiras. Ofícios recebidos de Madri (abril de 1934 a fevereiro de 1935). AHI/RJ.

${ }^{69}$ Gisálio Cerqueira Filho; Gizlene Neder. Ecos da $2^{a}$ República e da Guerra Civil Espanhola no Brasil. Disponível em: www.gladiator.historia.uff.br/tempo/textos/art8-5.pdf. Acesso em 20 maio 2006.
} 
Peçanha, que esteve à frente da missão diplomática em Madri a partir de 1935, havia entre os políticos espanhóis uma completa ignorância quanto às leis brasileiras que proibiam a "propaganda subversiva". ${ }^{70}$

Reverenciado como símbolo da luta pela liberdade e justiça social, Luis Carlos Prestes era um político conhecido e admirado na Espanha. Sua prisão após o movimento comunista de 1935 causou indignação em agremiações trabalhistas, sindicais e estudantis espanholas. Alcebíades Peçanha relatava em ofícios quase que diários e em relatórios mensais, a delicada situação da sede da Embaixada, que sofria constantes ameaças de "extremistas" que protestavam contra a conduta do governo Vargas em reprimir os comunistas brasileiros. Segundo Peçanha, tais ameaças confirmavam as informações sobre o entusiasmo que as primeiras notícias do levante de Natal, Recife e Rio de Janeiro despertaram entre os "subversivos" espanhóis. ${ }^{71}$ Temendo que atos de violência contra a representação brasileira se efetivassem, o embaixador brasileiro solicitou à República espanhola que reforçasse a segurança em frente da Embaixada no que, segundo ele, foi prontamente atendido. ${ }^{72}$

Entre abril e maio de 1936, Leocádia Prestes liderou na Espanha uma intensa campanha em prol da libertação de seu filho, Luis Carlos Prestes, sendo bem recebida, juntamente com sua filha Lygia, por vários setores da sociedade desse país. A preocupação do representante brasileiro em Madri com a repercussão internacional que esse movimento chegou a alcançar é evidente nos diversos ofícios enviados ao Itamaraty. Nesse período, a Embaixada brasileira foi alvo de tiros que deixaram perfuradas as paredes de sua sede. Atingido por estilhaços, o embaixador Alcebíades Peçanha remeteu uma nota ao governo espanhol solicitando providências e, mais uma vez, reforços na segurança do prédio. Sua preocupação não era somente com a

\footnotetext{
${ }^{70}$ Ofício n. 36 de Alcebíades Peçanha, embaixador do Brasil na Espanha para José Carlos de Macedo Soares, ministro das Relações Exteriores do Brasil. Madri, 25 mar. 1936. Missões Diplomáticas Brasileiras. Ofícios recebidos de Madri (1936 a junho de 1937). AHI/RJ.

${ }^{71}$ Ofício n. 191 (reservado) de Alcebíades Peçanha, embaixador do Brasil na Espanha para José Carlos de Macedo Soares, ministro das Relações Exteriores do Brasil. Madri, 26 dez. 1935. Missões Diplomáticas Brasileiras. Ofícios recebidos de Madri (março a dezembro de 1935). AHI/RJ.

${ }^{72}$ Ofício n. 10 de Alcebíades Peçanha, embaixador do Brasil na Espanha para José Carlos de Macedo Soares, ministro das Relações Exteriores do Brasil. Madri, 19 jan. 1936. Missões Diplomáticas Brasileiras. Ofícios recebidos de Madri (1936 a junho de 1937). AHI/RJ.
} 
sua própria segurança e a dos funcionários, mas também com a sua valiosa coleção pessoal de objetos de arte que poderia ser atingida nessas ofensivas. $^{73}$

Receoso de que esses incidentes prejudicassem as relações diplomáticas entre os dois países, o governo espanhol atendeu as solicitações da Embaixada brasileira, enviando mais de vinte seguranças que se estabeleceram em frente ao seu edifício. Segundo informações enviadas ao Itamaraty, a situação vinha piorando a cada dia, estando a Embaixada brasileira, no dizer de muitos, ameaçada de incêndio. ${ }^{74} \mathrm{Na}$ visão do embaixador brasileiro, as manifestações populares e as investidas contra a Embaixada do Brasil estavam diretamente relacionadas à presença da mãe e da irmã de Prestes na Espanha, e da campanha que essas estavam empreendendo junto aos segmentos de esquerda. D. Leocádia e Lygia estariam realizando apelos não só ao povo espanhol, mas também ao Congresso e aos líderes políticos daquele país.

Alcebíades Peçanha atribuiu os atos contra a Embaixada às "influências de Moscou", trazendo à tona um tipo de discurso que exemplifica o pensamento que grande parte dos políticos brasileiros tinha da Espanha republicana: a de que suas diretrizes estavam ligadas às decisões advindas da União Soviética. ${ }^{75}$ A idéia de que haveria uma conspiração comunista de caráter internacional agindo não só na Espanha, mas também no Brasil, povoava o imaginário de muitos brasileiros partidários do governo Vargas e dos conservadores espanhóis. ${ }^{76}$

A amplitude que o movimento a favor da libertação de Luis Carlos Prestes alcançou numa Espanha de intensas agitações políticas, pode ser comprovada pelo apoio que recebeu de alguns dos mais importantes políticos

\footnotetext{
${ }^{73}$ Nota (cópia) de Alcebíades Peçanha, embaixador do Brasil na Espanha para governo espanhol (documento sem identificação de destinatário), Madri, 17 abr. 1936. Missões Diplomáticas Brasileiras. Ofícios recebidos de Madri (1936 a junho de 1937). AHI/RJ.

74 Ofício n. 55 de Alcebíades Peçanha, embaixador do Brasil na Espanha para José Carlos de Macedo Soares, ministro das Relações Exteriores do Brasil. Madri, 06 maio 1936. Missões Diplomáticas Brasileiras. Ofícios recebidos de Madri (1936 a junho de 1937). AHI/RJ.

${ }^{75}$ Ofício n. 65 de Alcebíades Peçanha, embaixador do Brasil na Espanha para José Carlos de Macedo Soares, ministro das Relações Exteriores do Brasil. Madri, 25 maio 1936. Missões Diplomáticas Brasileiras. Ofícios recebidos de Madri (1936 a junho de 1937). AHI/RJ.

${ }^{76}$ Sobre o mito da conspiração comunista internacional ver: Raoul Girardet. Mitos e mitologias políticas. São Paulo: Companhia das Letras, 1987.
} 
ligados à República espanhola. Em um dos comícios realizados em prol de Prestes estiveram presentes Juan Casanovas, presidente do Parlamento Catalão e Dolores Ibárruri, na época deputada do Partido Comunista. Essa, também chamada de La Pasionaria, ficou conhecida mundialmente por sua atuação a favor da República da Espanha e por seus discursos memoráveis em defesa das Brigadas Internacionais durante a Guerra Civil. Nas palavras de Paul Preston: "Para sus admiradores, sobre todo entre los comunistas, Dolores Ibárruri fue tanto la heroína, la inspiradora y la alentadora de la guerra civil española como una especie de madre universal." ${ }^{37}$ La Pasionaria era identificada no Brasil como o símbolo da mulher revolucionária, modelo que não se coadunava com o perfil da mulher "do lar" endossado pelos segmentos mais conservadores da sociedade brasileira.

Durante os dois meses em que Leocádia e Lygia Prestes estiveram na Espanha, intensificou-se o envio de ofícios acompanhados de recortes de jornais remetidos da Embaixada brasileira em Madri ao Ministério das Relações Exteriores. As matérias detalhavam a receptividade do povo espanhol aos apelos feitos a favor do "Cavaleiro da Esperança".

77 Paul Preston. Dolores Ibárruri, pasionaria de acero. In: Las tres españas del 36. Madrid: Debolsillo, 2006, p.369. 


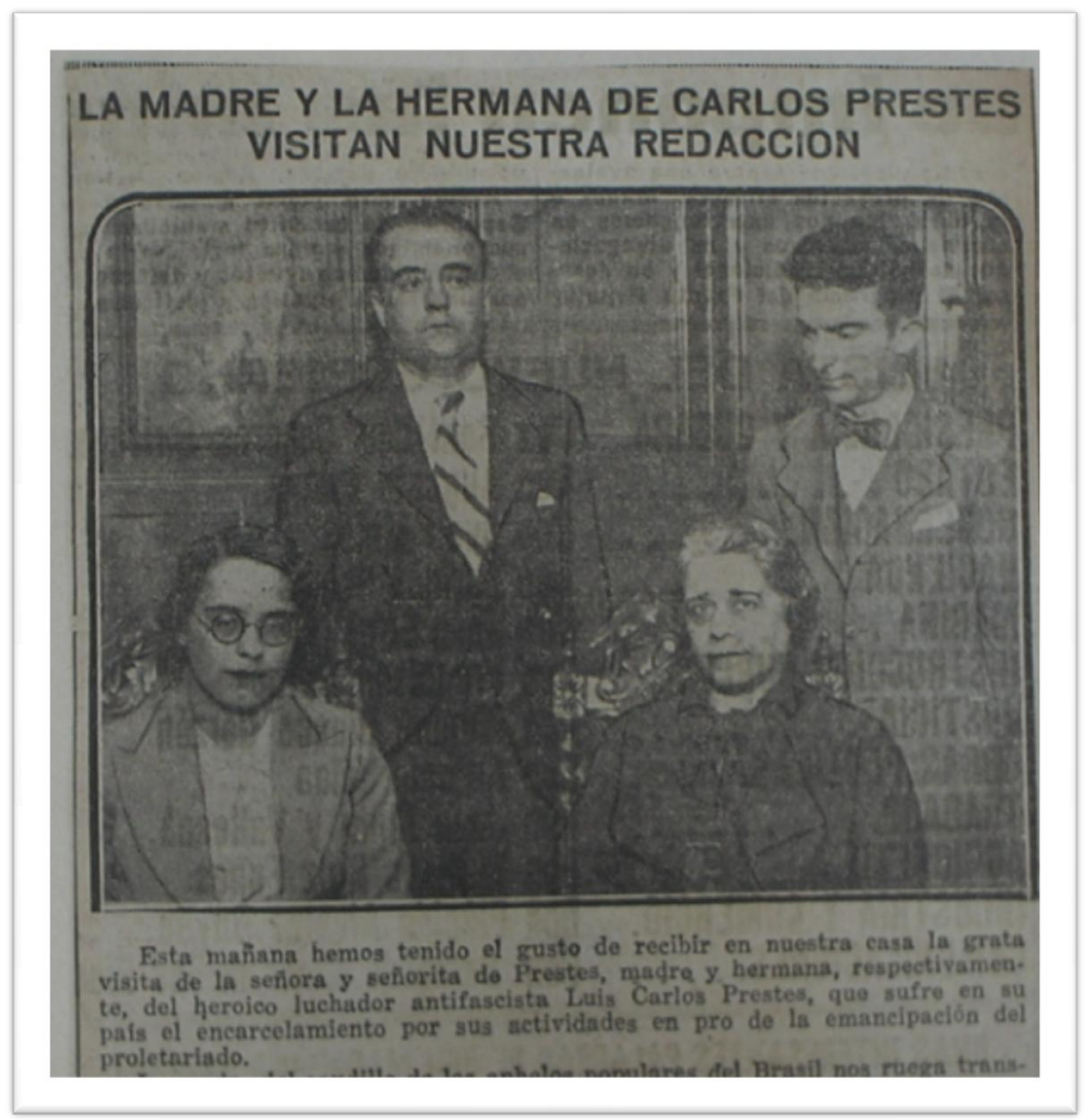

3 - D. Leocádia e Lígia Prestes em campanha pela libertação de Luis Carlos Prestes na Espanha. Fotografia reproduzida no jornal Heraldo de Madrid. Madri, 13 de maio de 1936. Recorte anexado ao ofício n. 61 de Alcebíades Peçanha, embaixador do Brasil na Espanha para José Carlos de Macedo Soares, ministro das Relações Exteriores do Brasil. Madri, 25 maio 1936. Missões Diplomáticas Brasileiras. Ofícios recebidos de Madri (1936 a junho de 1937). AHI/RJ. 
Os laços de solidariedade existentes entre os comunistas brasileiros e espanhóis devem ser entendidos como o principal motivo que levou a diplomacia brasileira a desconfiar das verdadeiras intenções da expedição científica liderada por um espanhol na Amazônia. Em 1931, Luis Guimarães Filho foi procurado pelo Capitão Francisco Iglesias, oficial da aeronáutica espanhola, que expôs os interesses científicos que motivavam o desejo de realizar uma expedição ao Amazonas. ${ }^{78}$

Em 1934, a expedição prosseguia no país, tendo o Itamaraty recebido cópia da revista mensal ilustrada Crónica de la Expedición Iglesias al Alto Amazonas. ${ }^{79}$ No entanto, constatou-se que entre os equipamentos da expedição constava um armamento que não poderia ser o de uma expedição científica. Como afirma Ferreira Reis no artigo "A que vinha a expedição Iglesias": "Não se tratava de armamento natural, defensivo ou para caça e pesca na região". ${ }^{80}$ A polêmica em torno da descoberta desse material levantou a desconfiança de que o mesmo poderia estar destinado aos "subversivos" brasileiros. Tais suspeitas não puderam ser confirmadas, mas com certeza contribuíram para que a expedição fracassasse.

Outro fato que contribuiu para demonstrar ao Itamaraty que as relações entre os partidários da República espanhola e o governo brasileiro não eram amistosas, foi o envio de um telegrama assinado por Largo Caballero - que viria a tornar-se Primeiro Ministro da Espanha logo no início da guerra civil - e por vários deputados espanhóis a Getúlio Vargas. Nessa correspondência os remetentes pediram a libertação do "Cavaleiro da Esperança", gesto considerado pelo governo brasileiro como uma tentativa da Espanha em interferir nos assuntos de política interna do Brasil.

Martínez Barrio, presidente da Câmara dos deputados da República espanhola, desaprovou a iniciativa de Largo Caballero. Referindo-se ao ato como um "gesto inqualificável", Martínez Barrio deixou claro que

${ }^{78}$ Ofício n. 48 de Luis Guimarães Filho, chefe da Legação brasileira na Espanha para Afrânio de Mello Franco, ministro das Relações Exteriores do Brasil. Madri, 21 abr. 1931. Missões Diplomáticas Brasileiras. Ofícios recebidos de Madri (1931 a março de 1932). AHI/RJ.

79 Anexo ao ofício n. 2 da Legação do Brasil na Espanha para Secretaria de Estado das Relações Exteriores do Brasil. Madri, 02 jan. 1934. Missões Diplomáticas Brasileiras. Ofícios recebidos de Madri (julho de 1933 a março de 1934). AHI/RJ

${ }^{80}$ Arthur C. Ferreira Reis. "A que vinha a Expedição Iglesias". In: A Amazônia e a cobiça internacional. São Paulo: Companhia Editora Nacional, 1960, p.200. 
discordava dessa atitude que, no Brasil, foi tomada como ofensa pessoal ao Presidente Vargas. ${ }^{81}$ A postura do referido líder político demonstra uma tentativa de evitar que o episódio se projetasse como um entrave nas relações diplomáticas entre Brasil e Espanha, mas acima de tudo, expõe as divergências entre os vários partidos e ideologias que compunham a República espanhola. As discordâncias sobre qual a postura que o governo deveria manter diante de países que mantinham regimes não democráticos é apenas um, entre os inúmeros exemplos, que demonstram que as divergências interferiam na condução das decisões importantes do governo espanhol. Vale lembrar que o leque de tendências político-ideológicas reunidas em defesa da República espanhola era amplo, abrigando anarquistas, socialistas, comunistas e liberais. Os desentendimentos e a falta de coesão entre eles são interpretados por muitos historiadores como um dos fatores que levaram os republicanos à derrota na Guerra Civil Espanhola.

Essa correspondência destinada a Vargas teve ampla repercussão na imprensa brasileira e internacional. Oswaldo Aranha, então embaixador do Brasil nos Estados Unidos, escreveu uma carta pessoal a Vargas na qual expôs a forma pela qual os jornais norte-americanos noticiaram essa questão. Afirmou que sua convicção era a de que na Espanha as manifestações contrárias ao governo brasileiro e a favor de Prestes eram provocados por agentes comunistas "disfarçados e ostensivos". Também mencionou saber que os brasileiros Octávio Brandão e Fernando Lacerda estavam nesse país, escrevendo diariamente "infâmias e mentiras sobre a situação do Brasil". 82

Oswaldo Aranha possuía grande influência sobre a condução da política externa brasileira. No seu próprio entendimento e no de Getúlio Vargas, sua função ia muito além de conduzir as relações bilaterais com os Estados Unidos. Aranha era um observador e um conselheiro de Vargas nos assuntos internacionais tendo, por vezes, maior poder de influência sobre 0 presidente da República do que o próprio chefe do Itamaraty.

\footnotetext{
${ }^{81}$ Ofício n. 75 de Alcebíades Peçanha, embaixador do Brasil na Espanha para José Carlos de Macedo Soares, ministro das Relações Exteriores do Brasil. Madri, 15 jun. 1936. Missões Diplomáticas Brasileiras. Ofícios recebidos de Madri (1936 a junho de 1937). AHI/RJ.

${ }_{82}$ Telegrama de Oswaldo Aranha para Getúlio Vargas (s/d). Arquivo Getúlio Vargas (GVc, 1936.05.00 / XXII - 54). CPDOC/FGV.
} 
Dias antes do levante militar que deu início ao conflito civil espanhol em julho de 1936, aumentou significativamente o volume de ofícios enviados pelos consulados brasileiros à Embaixada do Brasil, dando conta da situação de instabilidade política nas principais cidades da Espanha. Na visão desses diplomatas, um levante militar era previsto, e a reação dos setores de esquerda já deixava entrever um conflito civil.

O prenúncio de um conflito civil era a percepção dos representantes brasileiros na Espanha. No entanto, tal opinião não era compactuada pelos setores mais conservadores da sociedade espanhola que, juntamente com os militares, esperavam que o levante fosse caracterizado como mais um golpe na história da Espanha, acionado com a intenção de manter o poder nas mãos das classes privilegiadas. Segundo Herbert Matthews, a intenção dos militares era organizar um pronunciamiento e não um conflito de tempo indeterminado. ${ }^{83} \mathrm{~A}$ guerra civil, no entanto, não pode ser evitada uma vez que houve a reação de diversos grupos políticos organizados e de milícias populares que saíram em defesa da República. A guerra duraria três anos.

As relações diplomáticas entre Brasil e Espanha durante o conflito permaneceram em curso normal, apesar dos insistentes apelos do Ministro das Relações Exteriores, José Carlos de Macedo Soares, para que Vargas o autorizasse a tomar decisões no sentido de definir-se a favor dos rebeldes espanhóis. Embora não houvesse rompimentos oficiais, as diretrizes políticas do Governo Vargas deixavam evidente sua incompatibilidade com o governo legalmente constituído da Espanha.

Assim como em vários países americanos, a Guerra Civil Espanhola despertou as atenções de milhares de cidadãos que, no Brasil, entendiam o conflito como uma luta de duas ideologias antagônicas. A imprensa brasileira, responsável por informar sobre o cotidiano do conflito, dotou-se em grande parte de uma polarização que pouco refletia a complexidade do jogo de forças políticas presentes na Espanha. Como lembra Pierre Vilar, a divisão em dois campos ideológicos e a passionalidade

\footnotetext{
${ }^{83}$ Herbert Matthews. Metade da Espanha morreu: uma reavaliação da Guerra Civil Espanhola. Rio de Janeiro: Civilização Brasileira, 1975, p.75.
} 
com que se defendia a um ou outro lado parece ter sido mais simplista no mundo do que na própria Espanha. ${ }^{84}$

Poucos acontecimentos internacionais despertaram no Brasil debates acalorados sobre ideologias políticas quanto o conflito espanhol. Renomados artistas, intelectuais e personalidades políticas brasileiras não se furtaram a expor a sua percepção do conflito, fazendo analogias e comparações com a situação política interna brasileira. Poesias de Carlos Drummond de Andrade e de Manuel Bandeira expressaram, de certa forma, como a República espanhola foi defendida por aqueles setores da sociedade brasileira identificados com o antifascismo e com as idéias de esquerda. Já os defensores dos nacionalistas espanhóis, identificados com as idéias de direita, viam o conflito como um exemplo dos perigos que o "comunismo internacional" representava no mundo.

A imagem da República espanhola como representativa dos ideais comunistas configurou-se em vários segmentos do governo brasileiro, estendendo-se também para a prática da polícia política. A atuação ostensiva do DEOPS - Departamento de Ordem Política e Social - é sintomática da eficiência nas relações entre polícia e Estado durante a Era Vargas. ${ }^{85}$ Houve, especialmente no período da Guerra Civil Espanhola, uma ampla repressão às associações e aos imigrantes espanhóis que se mobilizaram na tentativa de auxiliar, material ou moralmente, os republicanos na Espanha. ${ }^{86}$

Grande parte da elite política brasileira defendia princípios políticos que iam ao encontro ao que os rebeldes liderados por Francisco Franco representavam. Os órgãos de censura e de repressão política instruíam a imprensa brasileira no sentido de evitar referências a União Soviética e aos países simpáticos ao comunismo, incluindo nessa categoria o governo republicano espanhol. Em despacho ao Ministério de Estado espanhol, Fernando Morales Llamas, encarregado de negócios da Espanha, transcreveu as orientações do governo brasileiro para que a imprensa evitasse divulgar as

\footnotetext{
${ }^{84}$ Pierre Vilar. A Guerra da Espanha. São Paulo: Paz e Terra, 1991, p. 46.

${ }^{85}$ Sobre as relações entre polícia e Estado no governo Vargas ver: Elisabeth Cancelli. $O$ mundo da violência: a polícia da Era Vargas. Brasília: UNB, 1994.

${ }^{86}$ Sobre a mobilização dos imigrantes espanhóis diante da Guerra Civil Espanhola ver: Ismara Izepe de Souza. Solidariedade Internacional, op.cit.
} 
vitórias militares dos republicanos espanhóis. Levando o caso ao Itamaraty, Llamas afirmou que era injusto qualificar o governo republicano de "bolchevique", lembrando que o Brasil reconhecia diplomaticamente a República da Espanha. ${ }^{87}$

Dos Estados Unidos, Oswaldo Aranha teceu considerações sobre o significado do conflito civil espanhol. Diversas foram as correspondências pessoais trocadas entre o embaixador e Getúlio Vargas, mencionando a situação espanhola e o contexto internacional. Aranha considerava preocupante o apoio do México aos republicanos, efetivado através do envio de armas e munições. Valendo-se de um discurso maniqueísta considerava que:

... se vencerem as esquerdas espanholas, a offensiva communista e a bolchevisação dos países indo-espanhóis é uma ameaça a temer. Tenho razões para crer que já, agora, essas republicas estão soffrendo graves repercussões da lucta na Hespanha em sua vida interna e que a própria Argentina está sentindo esses effeitos. ${ }^{88}$

Apesar de analisar o conflito espanhol sob esta ótica, Oswaldo Aranha não coadunava com as mesmas opiniões de Macedo Soares, que pretendia oferecer o apoio oficial brasileiro aos rebeldes espanhóis. Ao assumir a chefia do Itamaraty em 1937, Aranha promoveu uma política cautelosa com relação a Espanha, transmitindo oficialmente seu apoio ao governo legalmente constituído naquele país. Manuel Garcia Miranda, encarregado de negócios da Espanha no Brasil informou ao seu Ministério de Estado que o novo ministro mostrava-se generoso com a causa republicana. ${ }^{89}$

No diário pessoal de Getúlio Vargas encontram-se alguns apontamentos que, cruzados com a documentação diplomática e com a sua correspondência com Oswaldo Aranha, nos permitiram conhecer melhor o processo de definição da postura brasileira diante dos acontecimentos

\footnotetext{
${ }^{87}$ Despacho n. 92 de Fernando Morales Llamas, encarregado de negócios da Espanha no Brasil para ministro de Assuntos Exteriores da Espanha. Rio de Janeiro, 29 out. 1936. R999, expt. 12. AMAE.

${ }^{88}$ Carta de Oswaldo Aranha para Getúlio Vargas. Washington, 26 ago. 1936. Arquivo Getúlio Vargas (GV c, 1936.08.26). CPDOC/FGV.

${ }^{89}$ Despacho n. 223 (confidencial e reservado) de Manuel Garcia Miranda, encarregado de negócios da Espanha no Brasil para ministro de Assuntos Exteriores da Espanha. Rio de Janeiro, 23 jun. 1938. R999, expt. 12. AMAE.
} 
espanhóis. Vargas, em 10 de agosto de 1936, registrou que o ministro das Relações Exteriores o havia procurado:

... com um pesado cartapácio de informações sobre a Espanha, propondo uma manifestação do Brasil no sentido de definir-se a favor dos rebeldes, ou pelo reconhecimento da beligerância destes, ou por outro ato qualquer que tenha por objetivo uma quebra de neutralidade. Indago-lhe sobre a pressa do embaixador italiano em falar-me e guardo os papéis sobre a Espanha." ${ }^{\prime 0}$

Ansioso por uma autorização para apoiar os nacionalistas espanhóis, apenas três dias depois da entrega da pasta com os documentos sobre a Espanha, Macedo Soares interpelou novamente o chefe do Executivo:

No Guanabara, recebi os ministros da Fazenda e do Exterior. Vieram tratar do convênio comercial com a Itália. Depois de assentada a solução, o Ministro do exterior insistiu, apresentado-me o esboço de um decreto, pela declaração de neutralidade do Brasil na Guerra Civil Espanhola. Novamente recusei-me em concordar com tal atitude. É uma questão de política interna da Espanha que só a este cabe intervir, não nos competindo opinar no assunto sobre o qual ninguém nos consultou. ${ }^{91}$

Em 17 de agosto, entre outros assuntos, Getúlio Vargas comentou com Oswaldo Aranha a insistência de Macedo Soares na questão espanhola, mas afirmou que resistiu, pois necessitava saber sobre a possível atitude do governo dos EUA. ${ }^{92}$ Isso demonstra a preocupação do governo brasileiro em praticar nos assuntos europeus, uma política que estivesse afinada com os interesses norte-americanos. É perceptível uma tentativa de direcionar a política externa brasileira para uma ação coordenada com a dos demais países americanos, sob a liderança dos EUA. Nesse contexto, a atuação de Aranha à frente da Embaixada em Washington extrapolava os limites de defesa das relações bilaterais entre Brasil e EUA.

A influência de Oswaldo Aranha na condução da política externa brasileira acarretou freqüentes embates com o ministro Macedo Soares. Em seus registros referentes aos anos de 1936 e 1937, Vargas faz diversas

\footnotetext{
${ }^{90}$ Getúlio Vargas. Diário. São Paulo: Siciliano; Rio de Janeiro: FGV, 1995, p.531.

${ }^{91}$ Idem, p.534.

${ }^{92}$ Carta de Getúlio Vargas a Oswaldo Aranha. Rio de Janeiro, 17 ago. 1936. Arquivo Oswaldo Aranha (OA cp 1936.08.17/1). CPDOC/FGV.
} 
menções às divergências entre esses dois ministros, o que muitas vezes se configurava em queixas de ordem pessoal. ${ }^{93}$ Parece-nos que esse caso ilustra uma das estratégias de Vargas para manter-se no poder: a de compor sua base política mantendo em seu entorno lideranças que possuíam visões distintas sobre a condução dos rumos do país. Como afirma Gerson Moura, ao lembrar as ambigüidades do governo brasileiro, Vargas “...tornou-se árbitro das decisões que emanavam das instâncias secundárias e mesmo das que ocorriam nas instâncias centrais de decisão."94

O desejo de Macedo Soares em romper com o governo legal da Espanha persistiu durante todo o ano de 1937. Em dezembro desse ano, Aranha voltou a alertar Vargas sobre a importância de se manter uma atitude reservada diante do reconhecimento do estado de beligerância na Espanha. Enfatizou que tal ato era desnecessário e só traria conseqüências desagradáveis ao Brasil. ${ }^{95}$

A "neutralidade" brasileira não se consubstanciaria em atitudes louváveis, como veremos. Em muitos momentos, a ação do Itamaraty pautouse pelas desconfianças das diretrizes ideológicas que norteavam o governo republicano. Uma carta presente no arquivo pessoal de Getúlio Vargas demonstra que o governo brasileiro realizou, sob sigilo, a doação de alimentos à zona nacionalista, poucos meses após a deflagração da guerra civil da Espanha. Em 29 de outubro de 1936, Francisco Franco escreveu a Getúlio Vargas agradecendo a doação de importantes quantidades de açúcar e café:

En nombre de la España Nacional, tan estrechamente ligada por vínculos espirituales y afectivos a esa Gran República que V.E. tan digna y acertadamente preside, le doy las mas rendidas gracias, esperando poder en su dia tributar publicamente al Brasil y a V.E. el homenaje de gratitud y admiración que tan hidalgo proceder merece.

Por el momento y cumpliendo los deseos de V.E, tan importante donativo será mantenido dentro de la mas estricta reserva hasta que las

\footnotetext{
93 "Dia 17 de março de 1936: despachei com os ministros do Exterior e Agricultura. O primeiro estava amargo, cheio de queixas pessoais, de melindres pessoais contra seus antecessores no ministério, contra o embaixador Osvaldo Aranha, a importunar-me com vários casinhos, onde havia em tudo sua vaidade ferida de gerador do mundo e centro do universo." (Getúlio Vargas, op. cit. p. 487)

${ }^{94}$ Gerson Moura. A Revolução de 30, op. cit., p.582.

95 Telegrama de Oswaldo Aranha para Getúlio Vargas. Washington, 12 jul. 1937. Arquivo

Getúlio Vargas (GVc 1937.07.12). CPDOC/FGV.
} 
circunstancias permitan darlo a la publicidad y entonces todo el pueblo español pueda agradecerlo. ${ }^{96}$

$\mathrm{Na}$ documentação diplomática não encontramos menção alguma sobre a intenção e a efetivação dessa medida, mas as referências ao pedido de Vargas para que se mantivesse em sigilo tal doação nos levam a pensar que ela realmente tenha acontecido.

Os diplomatas brasileiros diante do conflito.

Com o desencadear do conflito, as missões diplomáticas na Espanha mantiveram-se em estado de constante alerta diante da onda de violência que tomava conta do país. A Secretaria de Estado do Ministério das Relações Exteriores do Brasil informou à Embaixada em Madri que o cônsul da cidade de Almeria teria comunicado que "o estado de anarchia" naquela cidade era completo e que receava ser assassinado de acordo com as ameaças dos comunistas. O MRE pediu que a representação brasileira tomasse providências no sentido de manter um diálogo com o governo republicano espanhol, na tentativa de resolver a questão. ${ }^{97}$ Preocupado com o futuro político da Espanha, que poderia ser dominado pelos grupos de esquerda, o Itamaraty solicitou relatórios detalhados sobre o que ocorria neste país.

Os diplomatas brasileiros em Barcelona testemunharam uma verdadeira revolução social. Nessa cidade, associações de trabalhadores chegaram a tomar propriedades privadas, fábricas e estabelecimentos comerciais, gerenciando-os sob os princípios socialistas. Cooperativas obreiras comandavam restaurantes e empresas, demonstrando aos olhos do mundo que a utopia de um mundo controlado pelo povo estava se tornando realidade. Para o historiador Paul Preston, "poucas outras cidades sentiram o fervor revolucionário que se viveu em Barcelona". 98

\footnotetext{
${ }^{96}$ Carta de Francisco Franco, "El jefe del Estado y general em jefe del Ejercito Nacional" para Getúlio Vargas. Salamanca, 29 out. 1936. Arquivo Getúlio Vargas (GV 36.10/1 XXIV - 44). CPDOC/FGV.

97 Telegrama da Secretaria de Estado das Relações Exteriores para Embaixada do Brasil em Madri. Rio de Janeiro, 14 ago. 1936. Missões Diplomáticas Brasileiras. Telegramas expedidos a Madri (1931-1937). AHI/RJ.

${ }_{98}$ Paul Preston. A Guerra Civil de Espanha. Trad. Antonio Belo. Lisboa: Edições 70, 2005, p.166.
} 
É evidente que o que ocorreu nos primeiros meses em Barcelona não deve ser interpretado como representativo das diretrizes da República espanhola. O governo de Frente Popular vivenciou momentos dramáticos, decorrentes da coexistência das instituições tradicionais do Estado com as comissões revolucionárias. A opção do governo republicano foi, à luz da impossibilidade de obter o apoio soviético à causa revolucionária, de priorizar o fortalecimento das instituições de Estado para vencer a guerra, combatendo assim os esforços revolucionários. ${ }^{99}$

Na capital catalã, a organização das massas em torno do ideal de revolução e a formação de comissões espontâneas, assustavam a opinião pública internacional e o corpo diplomático estabelecido naquela cidade. $O$ cônsul brasileiro em Barcelona, após fechar a sede da representação do Brasil, descreveu ao Itamaraty as dificuldades e os perigos pelos quais ele e outros funcionários haviam passado até chegarem em Marselha. Relatou que cidadãos embriagados haviam tomado seu automóvel, desconsiderando o fato de ser ele um representante diplomático. Estava certo de que teria sido assassinado caso estivesse em sua residência no dia da referida apropriação, uma vez que ninguém possuía garantias. Citou o episódio vivenciado pelo vicecônsul Sr. Couceiro, que havia abrigado um religioso em sua residência na condição de refugiado, haja vista o risco de assassinato que todos os clérigos corriam naquele momento. ${ }^{100}$

Este comentário tem fundamento se considerarmos que os sentimentos de ira e ódio popular contra a Igreja Católica eram conseqüência da sua tradicional associação com a elite conservadora espanhola. Estudos mais confiáveis sobre a perseguição aos religiosos durante a guerra civil estimam que foram assassinados ou executados 6.832 membros do clero ou de ordens religiosas. Com o esforço do governo republicano, especialmente do Partido Comunista, a ordem acabou por ser reposta. Paul Preston afirma que "após o outono de 1936, o terror em território republicano seria dirigido não contra os de direita, mas contra os de esquerda". ${ }^{101}$

\footnotetext{
${ }^{99}$ Idem, p.178.

100 Ofício (reservado) do cônsul em Barcelona (ass. ilegível) para José Carlos de Macedo Soares, ministro das Relações Exteriores do Brasil. Marselha, 22 ago. 1936. Consulados Brasileiros. Ofícios recebidos de Barcelona (maio de 1936 a setembro de 1938). AHI/RJ.

${ }^{101}$ Paul Preston. A Guerra Civil de Espanha, op. cit., p. 161.
} 
Da mesma forma como a diplomacia, os empresários também foram alvo da revolução espanhola. Em setembro de 1936, a Embaixada do Brasil tentou defender junto ao governo espanhol os interesses da empresa brasileira Junqueira $Y$ Meirelles que teve mais de 600 sacos de café apreendidos por uma associação obreira de Valencia. Alcebíades Peçanha, embaixador em Madri, solicitou junto ao governo espanhol a devolução ou a restituição do valor correspondente à mercadoria que teria sido transportada para os Almacenes de Abastos de las Organizaciones Obreras del Puerto. ${ }^{102}$

Madri e Barcelona vivenciaram distintas ações em defesa do governo legalmente constituído. Na capital do país, o ambiente era muito mais bélico e, por estar sob controle direto das instâncias de poder, Madri presenciou muito menos o fervor revolucionário se comparado à capital catalã. ${ }^{103}$ Mesmo assim, na visão do embaixador brasileiro Alcebíades Peçanha, a segurança pessoal do corpo diplomático era um motivo de constante preocupação.

O temor dos representantes brasileiros era reforçado pelas notícias sobre 0 assassinato de estrangeiros de outras nacionalidades. Em agosto de 1936, por exemplo, sete padres colombianos foram assassinados quando se deslocavam de Madri para Barcelona. $O$ fato de viajarem com o amparo da documentação expedida pela Legação de seu país não impediu a tragédia, que se constituiu como o fator primordial na deterioração das relações hispano-colombianas. Agressões como essas partiam de grupos que fugiam ao controle do governo que, preocupado em preservar a sua imagem no exterior, procurava evitar incidentes contra os diplomatas acreditados na Espanha.

Na visão de Alcebíades Peçanha, a chancelaria da Embaixada do Brasil deveria ser rapidamente trasladada para Barcelona devido à ausência de condições materiais em Madri. Em ofício ao Itamaraty, o embaixador brasileiro descreveu com detalhes a situação precária em que se encontrava a capital espanhola. Ausência de alimentos e deficiência nas comunicações telefônicas eram os principais motivos mencionados para transferir a sede da Embaixada

\footnotetext{
${ }^{102}$ Nota n. 46 da Embaixada do Brasil na Espanha para o governo republicano espanhol (cópia). Madri,1ํㅗㅇ. 1936. Missões Diplomáticas Brasileiras. Ofícios recebidos de Madri (1936 a junho de 1937). AHI/RJ.

${ }_{103}$ Javier Rubio. Asilos y canjes durante la guerra civil española: aspectos humanitários de uma contienda fratricida. Barcelona: Editorial Planeta, 1979, p.119.
} 
para a capital da Catalunha. ${ }^{104}$ Vale lembrar que no primeiro semestre de 1938 , Madri já estava cercada pelas tropas nacionalistas e as frentes de combate não se distanciavam mais de cinco kilômetros do centro da cidade.

Durante a maior parte de 1938, a representação diplomática permaneceu em Barcelona, sede do governo republicano espanhol desde outubro de 1937. A transferência da missão diplomática brasileira foi feita a pedido do próprio governo espanhol. ${ }^{105} \mathrm{Em}$ fevereiro de 1938, Alcebíades Peçanha foi aposentado e substituído por Carlos da Silveira Martins Ramos, que responderia em Barcelona na qualidade de encarregado de negócios. ${ }^{106}$. Martins Ramos chegou a Madri em dezembro de 1937, momento crítico para a defesa da cidade, tendo realizado um trajeto arriscado. Peçanha informou ao Itamaraty das dificuldades da viagem e do apoio da República espanhola para que seu substituto chegasse em segurança a Madri. ${ }^{107}$ Dias depois, Ramos partiu para Barcelona como observador político. Consideramos esse diplomata uma figura emblemática nos quadros do Itamaraty, pois foi o único que, em suas análises sobre a questão espanhola, demonstrou certa simpatia ao governo legalmente constituído da Espanha. Tal postura pode ser constatada em diversos documentos nos quais afirmava que os atos de crueldade advindos de cidadãos que combatiam no lado legalista, não deveriam servir para rotular genericamente o governo espanhol de comunista.

Ao expor a complexa situação da Espanha em meio ao sangrento conflito, Martins Ramos teceu considerações que demonstram a sua preocupação em defender muitas das atitudes do governo legalista. Sua postura de defesa dos princípios liberais e de crítica ao autoritarismo levou muitos de seus companheiros de carreira a acusá-lo de ser partidário do comunismo.

\footnotetext{
${ }^{104}$ Ofício de Alcebíades Peçanha, embaixador do Brasil na Espanha para Mario de Pimentel Brandão, ministro das Relações Exteriores do Brasil. Madri, 10 fev. 1938. Missões Diplomáticas Brasileiras. Ofícios recebidos de Madri (julho de 1937 a 1938). AHI/RJ.

${ }_{105}$ Idem. Em 31 de outubro, Juan Negrín anunciou a transferência do governo central para Barcelona. Hugh Thomas. A Guerra Civil Espanhola. $2^{\circ}$ vol. Rio de Janeiro: Civilização Brasileira, 1964, p.206.

${ }^{106}$ Telegrama do Ministério das Relações Exteriores para Consulado do Brasil em Barcelona. Rio de Janeiro, 05 fev. 1938. Lata 998, maço 16237. AHI/RJ.

107 Ofício n. 64 de Alcebíades Peçanha, embaixador do Brasil na Espanha para Mario de Pimentel Brandão, ministro das Relações Exteriores do Brasil. Madri, 11 dez. 1937. Missões Diplomáticas Brasileiras. Ofícios recebidos de Madri (julho de 1937 a 1938). AHI/RJ.
} 
Em suas memórias, Vasco Leitão da Cunha, que entre 1946 e 1949 esteve à frente da Embaixada do Brasil em Madri, faz referências a Carlos da Silveira Martins Ramos como um diplomata que se envolveu em conflitos com 0 próprio Itamaraty ao defender governos considerados comunistas. Anos após sua experiência na Espanha, Martins Ramos foi embaixador em Quito e, quando em 1953 o governo de tendências nacionalistas e esquerdistas da Guatemala foi ameaçado, consta que enviou um telegrama ao presidente Arbenz dando irrestrito apoio brasileiro ao governo guatemalteco. Vasco Leitão da Cunha assim comenta o episódio: "Isso foi noticiado pela imprensa da Guatemala e Vicente Rao chamou a atenção do Silveira Martins. E ele respondeu dizendo que mantinha a sua posição e que esperava que o ministério o apoiasse, já que era um grande democrata". ${ }^{108}$

Vasco Leitão da Cunha definiu a postura de Martins Ramos nos seguintes termos: "Era teoricamente a favor do comunismo. Não praticamente, mas teoricamente. Achava muito bonito tudo o que o comunismo ia fazer (...) Acho que sua opinião sobre a Guatemala era isolada. Ele sempre disse o que pensava, e em termos decifráveis." ${ }^{109}$

A análise dos ofícios e relatórios produzidos por Carlos da Silveira Martins Ramos nos permite afirmar que não apenas sua opinião sobre a situação política da Guatemala nos anos 50 era isolada. Suas considerações acerca da Espanha em pleno conflito destoavam do teor dos documentos escritos por outros diplomatas, cujas críticas ao governo republicano eram exacerbadas e, por vezes, incompatíveis com a realidade. Tal constatação nos permite afirmar que, embora houvesse uma diretriz determinada pelo Itamaraty no que diz respeito às prioridades de ação da nossa diplomacia, algumas questões eram tratadas a partir da compreensão pessoal de cada diplomata.

Martins Ramos comoveu-se frente à situação das vítimas civis do conflito. Em novembro de 1938, esse diplomata relatou ao Itamaraty que vinha auxiliando, em caráter particular, crianças da cidade de Arenys del Mar. ${ }^{110}$.Nos jardins de sua residência, nesta mesma cidade, próxima a Barcelona, eram

\footnotetext{
${ }^{108}$ Vasco Leitão da Cunha. Diplomacia em alto-mar, depoimento ao CPDOC. Rio de Janeiro: Fundação Getúlio Vargas, 1994, p.190.

${ }^{109}$ Idem.

${ }^{110}$ Referências ao auxílio oferecido por esse diplomata às crianças de Arenys del Mar podem ser encontradas em: Jacint Aixer Bussalleu; Estanislau Torres. La guerra civil a Arenys del Mar. Publicacions de L'abadia de Montserrat, 1999, p.87.
} 
oferecidos, duas vezes na semana, almoço e merenda para cerca de 100 crianças selecionadas por sua esposa nas escolas públicas do local. Esse seu gestou humanitário teve grande repercussão, mas infelizmente ele e sua mulher não conseguiam atender aos pedidos que chegavam diariamente dos pais desejosos de verem seus filhos inseridos no grupo. ${ }^{111}$

Ao informar o Itamaraty sobre seu gesto de solidariedade, Martins Ramos sugeriu que tal auxílio deixasse de ser particular para se tornar uma ação da representação brasileira. Argumentava que o Brasil poderia criar um "hogar brasileño" que estenderia o mesmo auxílio para 200 crianças, a exemplo do que fazia a Suécia, mantenedora de um Instituto que abrigava mais de 500 delas. Martins Ramos enviou ao Itamaraty uma fotografia das crianças beneficiárias desses encontros, assim como o projeto que propunha a criação oficial do referido espaço. ${ }^{112}$

111 Ofício n. 110 de Carlos da Silveira Martins Ramos, encarregado de negócios do Brasil na Espanha para Oswaldo Aranha, Ministro das Relações Exteriores. Barcelona, 01 nov. 1938. Lata 716, maço 10364. AHI/RJ.

${ }^{112}$ Idem. Foto anexa. 


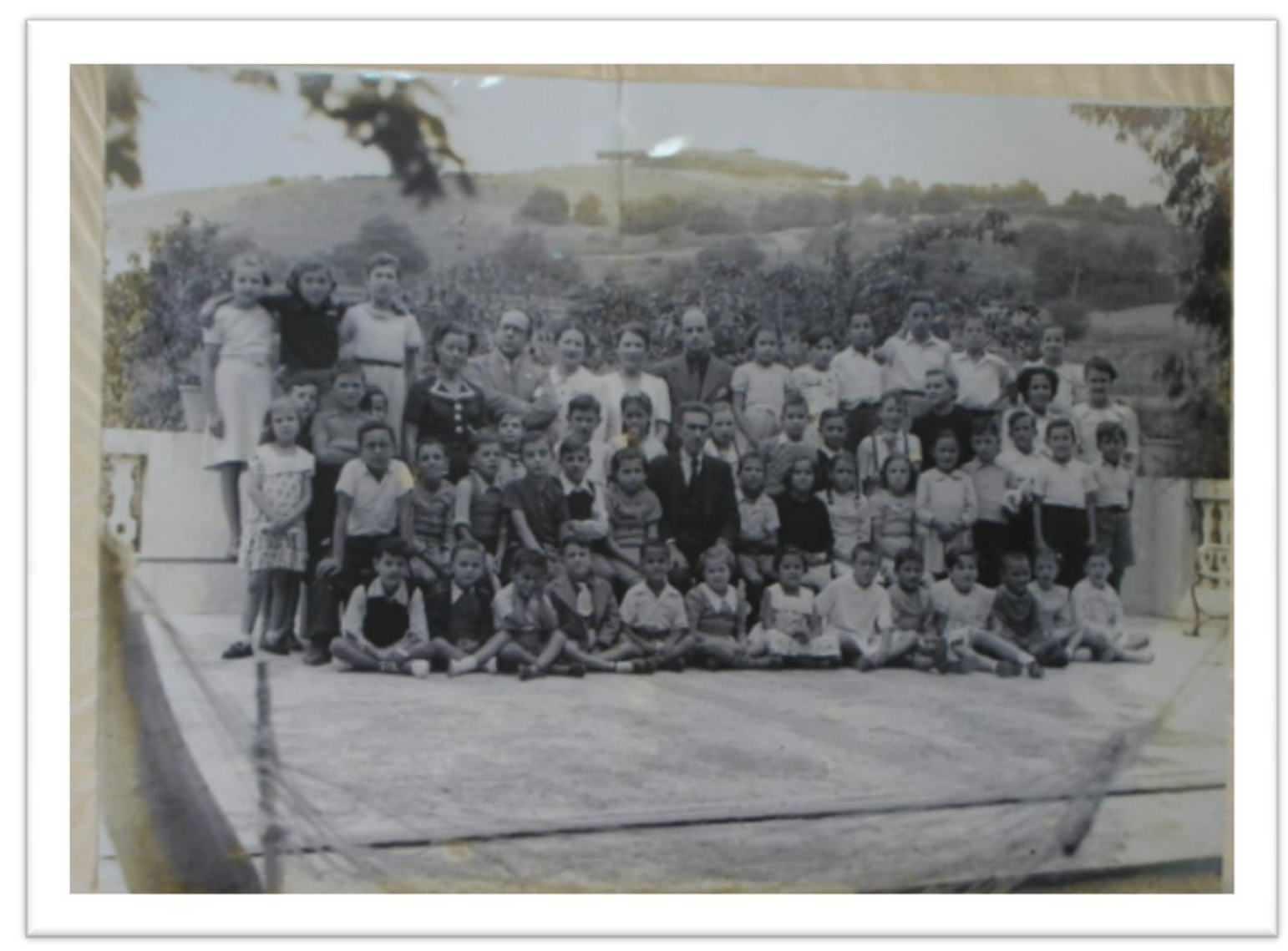

4 - Grupo de crianças espanholas auxiliadas por Carlos da Silveira Martins Ramos. Fotografia anexada ao ofício n.110 de Carlos da Silveira Martins Ramos, encarregado de negócios do Brasil para Oswaldo Aranha, Ministro das Relações Exteriores. Barcelona, 01 nov. 1936. Lata 716, maço 10364. AHI/RJ.

Não encontramos junto aos despachos e telegramas do Itamaraty a resposta ao pedido de Martins Ramos. Não nos parece plausível a hipótese de que houve a anuência do governo brasileiro a essa proposta, dada à sua postura dúbia diante da República espanhola. O não rompimento com os republicanos servia de estratégia política para o governo Vargas, mas de forma alguma significava simpatias ou apoio aos legalistas. Sendo assim, acrescido o fato de tradicionalmente a Secretaria de Estado das Relações Exteriores alegar falta de verbas para solicitações que denotavam gastos extraordinários, era de se esperar a negativa do governo brasileiro para tal proposta. O problema certamente não era apenas por exceder os gastos previstos, mas por consubstanciar o apoio brasileiro a um governo considerado de "tendências esquerdistas". Tanto as ações como os pedidos de Martins Ramos ao Itamaraty podem, a princípio, ser entendidos como um gesto de ingenuidade ou de desconsideração para com as diretrizes do Itamaraty frente à Guerra Civil 
Espanhola. No entanto, podemos analisar esse pedido como uma tentativa de estender a sua comoção frente às vítimas civis do conflito para o dirigente do Ministério, Oswaldo Aranha. Vale lembrar, que havia importantes divergências entre Macedo Soares (que deixou de ser ministro ao final de 1936) e Aranha no que concerne à postura brasileira diante da situação daquele país ibérico.

Pelo menos dois agentes consulares a serviço do governo brasileiro praticaram atividades relacionadas à defesa dos nacionalistas espanhóis: Adrian de Burgos e Julio Morin. O primeiro, vice-cônsul na cidade de Almeria, envolveu-se com a Falange e o movimento rebelde espanhol. ${ }^{113}$ Segundo a Embaixada do Brasil em Madri, as autoridades dessa cidade durante o governo de Manuel Azaña, recebiam freqüentes queixas do comportamento hostil de Adrian que, mal visto pelos elementos da Frente Popular, foi detido logo no início do conflito. A situação desse agente consular complicou-se após o governo republicano espanhol ter Ihe retirado o exeqüator, ficando o mesmo sem imunidades diplomáticas. Alcebíades Peçanha informou ao Itamaraty que havia se esforçado nas negociações junto ao governo espanhol para amenizar a situação do referido agente, conseguindo que the fosse dado tratamento com "atenções especiaes" enquanto esteve detido. ${ }^{114}$

Adrian de Burgos faleceu em maio de 1937, conforme

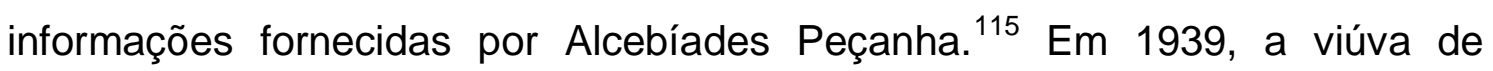
Burgos escreveu uma carta a Oswaldo Aranha, na qual enfatizava a generosidade do governo brasileiro em ter-lhe dado o cargo de datilógrafa no Consulado de Cádiz. Pedia também um adiantamento de seus proventos para pagar o dote necessário ao ingresso na vida religiosa, afirmando que seu marido foi sacrificado "Por Cristo, pela Espanha e por Vosso grande paiz...". ${ }^{116}$ Os documentos analisados não nos permitem descobrir as circunstâncias

\footnotetext{
${ }^{113}$ De acordo com a nota (cópia) do governador civil de Almeria para Embaixada do Brasil na Espanha. Madri, 16 out. 1936. Missões Diplomáticas Brasileiras. Ofícios recebidos de Madri (janeiro de 1936 a julho de 1937). AHI/RJ.

${ }_{114}$ Ofício n. 112 de Alcebíades Peçanha, embaixador do Brasil na Espanha para Mario de Pimentel Brandão, ministro interino das Relações Exteriores do Brasil. Madri, 31 dez. 1936. Missões Diplomáticas Brasileiras. Ofícios recebidos de Madri (1936 a junho de 1937). AHI/RJ.

115 Ofício de Alcebíades Peçanha, embaixador do Brasil na Espanha para Mario de Pimentel Brandão, ministro das Relações Exteriores do Brasil. Madri, 10 maio 1937. Missões Diplomáticas Brasileiras. Ofícios recebidos de Madri (1936 a junho de 1937). AHI/RJ.

${ }_{116}$ Carta de Dolores de Burgos para Oswaldo Aranha, ministro das Relações Exteriores. Cádiz, 21 nov. 1939. Lata 1756, maço 35635. AHI/RJ.
} 
exatas da morte de Burgos, mas as afirmações de sua mulher atestam que essas circunstâncias estão relacionadas à sua prisão e ao contexto da guerra. É provável que tenha sido executado ou morrido em decorrência dos maustratos ou das condições precárias de carceragem.

Em fevereiro de 1938, Alcebíades Peçanha observou que Julio Morin, outro agente consular preso pelos republicanos espanhóis, poderia ter um destino "tão trágico" quanto o de Burgos. Isso nos leva a reforçar a hipótese de que Burgos tenha morrido devido ao seu envolvimento com os revoltosos espanhóis. ${ }^{117}$

Julio Morin dirigiu o Consulado Geral brasileiro na cidade de Barcelona e foi acusado de realizar espionagem e comércio ilegal com os nacionalistas. Morin foi detido em 1937 e, segundo Martins Ramos, o alcance da atuação da Embaixada do Brasil nessa questão era limitado, uma vez que o referido funcionário diplomático não possuía o exeqüator do governo espanhol. Martins Ramos avaliou a condição do referido diplomata como desanimadora, já que teria sido transferido para um "campo de concentração" próximo à cidade de Valência. ${ }^{118}$ Sugeriu ao Itamaraty que solicitasse a intervenção da representação diplomática da Espanha no Brasil junto à República espanhola. Para Martins Ramos a melhor solução seria conseguir para Julio Morin uma autorização de saída da zona republicana espanhola. Em seu ofício sobre o "caso Morin", Ramos teceu inúmeras críticas ao governo republicano, que acabava por ferir as normas de direito ao enviar, sem julgamento, um agente consular para um campo de concentração. ${ }^{119}$

O auxílio a Julio Morin e Adrian de Burgos não se repetiu com relação à brasileira Dolores Valls Lucas, acusada de prestar serviços de espionagem aos nacionalistas espanhóis. Martins Ramos afirmava que Valls Lucas tinha exercido espionagem, observando que não merecia maiores

\footnotetext{
117 Ofício n. 08 (secreto) de Alcebíades Peçanha, embaixador do Brasil na Espanha para Mario de Pimentel Brandão, ministro das Relações Exteriores do Brasil. Madri, 11 fev. 1938. Missões Diplomáticas Brasileiras. Ofícios recebidos de Madri (julho de 1937 a 1938). AHI/RJ.

${ }_{118}$ Idem.

${ }^{119}$ Idem.
} 
cuidados da representação brasileira, uma vez que não corria risco de morte, sendo provavelmente expulsa como indesejável. ${ }^{120}$

Um dos casos mais emblemáticos com os quais nos deparamos é o do embaixador Alcebíades Peçanha, aposentado em fevereiro de $1938 .^{121}$ Peçanha entregou suas credenciais à República Espanhola em março de 1935. Os recortes de jornais do período demonstram que o governo da Espanha o recebeu com toda a pompa e cerimonial reservado aos grandes diplomatas. Sua última experiência na carreira, no entanto, ficou marcada por acontecimentos conturbados.

Em 1936, o embaixador sofreu agressões físicas dos partidários da República, que o consideravam um inimigo dos ideais defendidos pelo governo espanhol. Em 1938, logo após receber a notícia de sua aposentadoria, foi ferido em um bombardeio que fez desabar sobre ele o teto do restaurante onde almoçava em Barcelona. Segundo o cônsul brasileiro nessa cidade, Aluízio de Magalhães, Peçanha havia permanecido na Espanha para tratar da remoção de seus objetos, que haviam permanecido na sede da Embaixada do Brasil em Madri. Magalhães relatou os riscos a que todo o corpo diplomático estava exposto, lembrando o caso do falecimento do cônsul e do vice-cônsul francês nessa cidade em decorrência da guerra. ${ }^{122}$

Nesse mesmo ano a Comissão do Thesouro Artístico apreendeu quarenta e sete peças de obras de arte que estavam na residência de Alcebíades Peçanha em Madri. ${ }^{123}$ Em julho de 1939, alguns espanhóis o agrediram fisicamente, sob a justificativa de terem sido mal-tratados quando se

${ }^{120}$ Ofício n. 12 do encarregado de negócios na Espanha, Carlos da Silveira Martins Ramos, para Oswaldo Aranha, ministro das Relações Exteriores do Brasil. Barcelona, 23 abr. 1938. Missões Diplomáticas Brasileiras. Ofícios recebidos de Madri (julho de 1937 a 1938). AHI/RJ.

${ }^{121}$ Segundo Flávio M. de O. Castro, em 1931 "Para maior rejuvenescimento dos quadros, determinou-se que seriam aposentados todos os funcionários do Corpo Diplomático ou Consular que contassem mais de 35 anos de efetivo exercício e também aqueles que atingissem os limites de idade determinados pelo Decreto n. 19592 de 15 de janeiro de 1931 (68 anos para Embaixadores, 65 anos para Env. Extraord e Ministros Plenip.; 55 anos para 1 os Secretários e 50 anos para $2^{\circ}$ Secretários." (História da Organização do Ministério das Relações Exteriores, op. cit., p.303).

122 Ofício n. 17 de Aluízio de Magalhães, cônsul adjunto em Barcelona para Oswaldo Aranha, ministro das Relações Exteriores do Brasil. Barcelona, 24 mar. 1938. Consulados Brasileiros. Ofícios recebidos de Barcelona (maio de 1936 a setembro de 1938). AHI/RJ.

${ }^{123}$ Ofício n. 91 de Carlos da Silveira Martins Ramos, encarregado de negócios do Brasil em Barcelona para Osvaldo Aranha, ministro das Relações Exteriores do Brasil. Barcelona, 23 set. 1938. Missões Diplomáticas Brasileiras. Ofícios recebidos de Madri (julho de 1937 a 1938). AHI/RJ. 
refugiaram na sede da Embaixada do Brasil, assunto esse que retomaremos adiante. Segundo a descrição de Argeu Guimarães, Peçanha foi violentamente atacado na rua por cinco indivíduos que o deixaram ensangüentado e sem algumas peças de seu vestuário. Os agressores eram partidários da Falange e, apesar do pedido de desculpas do governador civil de Madri, não foram punidos pelas autoridades policiais franquistas. Poucos meses após o término do conflito civil, Guimarães relatou que atitudes de violência para com os diplomatas em missão na Espanha estavam se tornando freqüentes, e eram especialmente destinadas àqueles que haviam tido contatos com as autoridades republicanas. ${ }^{124}$

Após o término do conflito civil, o Ministério das Relações Exteriores ordenou a Argeu Guimarães - chefe da missão diplomática brasileira estabelecida na cidade de San Sebastián, provisoriamente sede do governo franquista - que tomasse providências junto ao governo da Espanha no sentido de exigir a punição dos culpados pelas agressões a Alcebíades. ${ }^{125}$ Tais agressões são sintomáticas da violência perpetrada por ambos os lados durante o conflito. Paul Preston, que escreveu várias obras sobre a Guerra Civil Espanhola, lembra que a violência no lado republicano foi executada, na maioria das vezes, por pessoas que ficaram fora do controle do governo, enquanto as cometidas pelos nacionalistas foram oficialmente conduzidas por aqueles que combatiam em nome da ordem e da religião cristã. ${ }^{126}$

Durante o conflito civil da Espanha, os representantes diplomáticos espanhóis no Brasil também chegaram a sofrer as conseqüências do maniqueísmo das elites políticas brasileiras, que entendiam aquela guerra como uma luta do comunismo contra os que queriam "restaurar" a ordem no país. No Brasil os consulados da Espanha, de forma geral, encontravam-se até o momento do desencadeamento do referido conflito, sob a liderança de indivíduos que não manifestavam simpatias à causa republicana. A maioria

${ }^{124}$ Ofício n. 84 (confidencial) de Argeu Guimarães, encarregado de negócios do Brasil na Espanha para Oswaldo Aranha, ministro das Relações Exteriores do Brasil. San Sebastián, 10 jul. 1939. Missões Diplomáticas Brasileiras. Ofícios recebidos de Madri (abril a dezembro de 1939). AHI/RJ

${ }^{125}$ Telegrama da Secretaria de Relações Exteriores para Embaixada do Brasil na Espanha. Rio de Janeiro, 01 jul. 1939. Missões Diplomáticas Brasileiras. Telegramas expedidos a Madri (1938-1942). AHI/RJ.

${ }^{126}$ Paul Preston. A Guerra Civil de Espanha, op. cit, p.95. 
dos consulados eram honorários, com funcionários externos à carreira diplomática, portanto, não nomeados pelo governo espanhol. Nesses casos os cargos eram ocupados por pessoas da comunidade espanhola, influentes por sua posição social. Os diplomatas de carreira, nomeados para chefiar os postos mais significativos também optaram, em sua grande maioria, por apoiar o movimento nacionalista espanhol, como é o caso de Fernando Carlos de Navarro y Jordan, cônsul espanhol na cidade de Santos.

Em muitas cidades brasileiras, as representações oficiais da República espanhola passaram a conviver com representações oficiosas, que dirigiam-se ao Itamaraty como representantes do governo nacionalista. A aceitação e a passividade do governo brasileiro diante dessa bicefalia diplomática se constituíram em uma amostra do duplo jogo de Vargas com relação aos acontecimentos na Espanha. Mantinha-se relações oficiais com a República, mas simultaneamente dava-se brechas para que os representantes oficiosos tomassem a liberdade de enviar ao Itamaraty constantes pedidos de regalias, como por exemplo, o de colocarem placas diplomáticas em seus carros. $^{127}$

Em novembro de 1936, por exemplo, Jose de Cárcer y Lassance entregou ao Itamaraty sua carta credencial como encarregado de negócios do governo nacionalista espanhol. ${ }^{128}$ Tal documento, assinado pelo secretário de Relações Exteriores do governo de Burgos, demonstra que os espanhóis partidários de Franco acreditavam na possibilidade de serem reconhecidos pelo governo Vargas, como representantes da "verdadeira" Espanha. ${ }^{129}$

\footnotetext{
${ }^{127}$ Os Estados Unidos também contaram com o equivalente a dois embaixadores espanhóis em Washington: um legítimo e um pseudo. Herbert Matthews afirma que à medida que a guerra favorecia os nacionalistas, a posição do enviado de Franco, Juan F. de Cárdenas, ia tornandose a de um enviado especial. "Em teoria, era ele apenas um agente nacionalista em Washington, mas era recebido regularmente no Departamento de Estado pelo subsecretário pró-Franco, católico, James C. Dunn" (Herbert Matthews, op.cit., p.184).

${ }^{128}$ Carta credencial de José de Cárcer y Lassance. Burgos, 09 nov. 1936. Notas de governo a governo recebidas (1931-1950). AHI/RJ. O fato do documento estar arquivado na pasta referente às notas trocadas entre governos é sintomática da postura dúbia do Itamaraty com relação à Guerra Civil Espanhola.

129 José Cárcer y Lassance figura na lista de funcionários diplomáticos declarados "admitidos" pelo decreto-Ley de 11 de janeiro de 1937 que "reorganizou" a carreira diplomática franquista (Marina Casanovas. La diplomacia española durante la Guerra Civil. Madrid: Ministerio de Asuntos Exteriores, 1996, p.226. Biblioteca Diplomática Española, Estudios 13).
} 
Segundo a historiadora Marina Casanovas, muitos diplomatas desertados da República que permaneceram residindo no exterior participaram dos serviços de informação franquistas. ${ }^{130}$ Esse parece ter sido o caso de alguns diplomatas espanhóis no Brasil, que atuaram em prol dos nacionalistas espanhóis e que se dedicavam à delação das atividades lideradas pelos imigrantes simpatizantes do governo republicano de seu país. ${ }^{131}$

Além do embaixador espanhol no Rio de Janeiro, Teodomiro de Aguilar Salas, quase todos os diplomatas de carreira que atuavam no Brasil foram "separados" do corpo diplomático republicano em 1936. Muitos desses foram incorporados à lista de representantes do governo de Burgos e após o conflito continuaram a liderar postos importantes como representantes oficiais da Espanha franquista no Brasil. ${ }^{132}$

Após a deflagração do conflito civil, houve uma considerável rotatividade no cargo de representante do governo republicano espanhol no Brasil. Nos países latino-americanos, a maioria desses diplomatas não permaneceu fiel à República, que teve que nomear pessoas alheias à carreira para substituir os diplomatas que optaram pelo lado rebelde. ${ }^{133}$

Fernando Morales Llamas, encarregado de negócios da Espanha, deparou-se com a difícil missão de tentar convencer o governo Vargas de que as atividades em prol dos republicanos praticadas no Brasil, não significavam ingerência nos assuntos de política interna do país. As ações em solidariedade ás vítimas civis do conflito, lideradas pelos centros republicanos espanhóis espalhados pelo Brasil, foram duramente reprimidas pela Polícia Política. Uma Comissão de apoio ao governo espanhol foi criada em São Paulo, pelos imigrantes espanhóis, com o objetivo de arrecadar fundos a serem enviados a

\footnotetext{
${ }^{130}$ Idem, p.25.

${ }^{131}$ Ismara Izepe de Souza. Solidariedade Internacional, op. cit, p.81.

${ }^{132}$ Após o conflito civil espanhol, a administração franquista criou um "tribunal de depuración de funcionários diplomáticos", que certamente incorporou àqueles que haviam sido demitidos do corpo diplomático republicano. (Marina Casanovas, op. cit, p.37). Dentre os diplomatas separados do corpo diplomático da República atuantes no Brasil estão: Teodomiro de Aguilar Salas, embaixador no Rio de Janeiro; Fernando Carlos de Navarro y Jordan, cônsul de segunda classe em Santos; Miguel Cordomi Escorihuela, cônsul de terceira classe em São Paulo; José de Cárcer y Lassance, secretário de primeira classe no Rio de Janeiro; Fulgêncio Vidal y Saura, cônsul de segunda classe em Porto Alegre; Eduardo Danis Navarro, cônsul de primeira no Rio de Janeiro (Relación de funcionários diplomáticos separados del cuerpo por el gobierno de la República, apêndice 1. Marina Casanovas, op. cit, p.209-224).

${ }^{133}$ Marina Casanovas, op. cit., p.28.
} 
Espanha. A Comisión Central de Propaganda de España Republicana, no entanto, teve poucos meses de existência, sendo fechada pelo DEOPS de São Paulo, que apreendeu seus arquivos como "prova da subversão de suas atividades". ${ }^{134}$ Segundo a historiadora Sandra Maria Lubisco Brancato, que analisou parte da correspondência trocada entre a Embaixada da Espanha e o Ministério de Estado espanhol, Morales Llamas vivenciou momentos difíceis por tentar intervir, junto ao MRE, a favor das atividades republicanas no Brasil. 135 O representante espanhol no Brasil mostrava-se desanimado com a constatação das atitudes do governo Vargas. ${ }^{136}$

As atividades da comunidade espanhola radicada no Brasil em prol dos republicanos intensificaram-se com a chegada de Andres Rodriguez Barbeito, nomeado vice-cônsul em São Paulo pelo ministro de Estado Julio Alvarez del Vayo. Barbeito assumiu o Consulado espanhol em Santos, tornando-se um dos principais mentores da campanha pró - República espanhola no Brasil. ${ }^{137} \mathrm{O}$ vice-cônsul era jornalista e pertencia ao grupo de defensores do governo identificados com segmentos da intelectualidade espanhola. Diante da evasão dos diplomatas de carreira, vários desses cidadãos foram convocados às pressas para representar a República no exterior.

O histórico político de Barbeito era exemplar de um republicano influente, tendo ocupado a função de secretário particular de Largo Caballero, que assumiu o governo espanhol em setembro de 1936. Havia anteriormente trabalhado como jornalista no periódico Claridad, jornal vinculado a UGT, principal central sindical socialista da Espanha. ${ }^{138}$ Afirmara à polícia que apesar de poder optar por cargos de maior relevância, preferiu vir para São Paulo para exercer um trabalho mais produtivo, evidenciando sua intenção de

${ }^{134}$ Graças ao vasto material apreendido, que se encontra anexado aos prontuários policiais do DEOPS de São Paulo, pudemos analisar as atividades realizadas por esse comitê. Sobre a mobilização dos imigrantes a favor da República Espanhola ver: Ismara Izepe de Souza. Solidariedade Internacional, op. cit.

${ }_{135}$ Sandra Maria Lubisco Brancato. As relações Brasil/Espanha na transição para o Estado Novo, op. cit. p.151-160.

${ }^{136}$ Despacho n. 121 do encarregado de negócios da Espanha no Brasil para Ministro de Assuntos Exteriores. Rio de Janeiro, 27 nov. 1937. R999, expt. 13. AMAE.

${ }_{137}$ Sobre essa questão ver: Ismara Izepe de Souza. Solidariedade Internacional, op. cit.

${ }^{138}$ Sobre o jornal Claridad ver: Hugh Thomas. A Guerra Civil Espanhola, $1^{\circ}$ vol. Rio de Janeiro:

Civilização Brasileira, 1964, p. 126. 
não acomodar-se num cargo consular apenas para exercer atividades burocráticas. Sua atuação no Brasil visava despertar as atenções dos imigrantes espanhóis para o que estava ocorrendo na Espanha. ${ }^{139}$

As atividades de Barbeito em apoio à República extrapolavam suas funções consulares, dando margem à críticas por parte de membros da comunidade espanhola, além de chamar a atenção dos agentes da Polícia Política de São Paulo. Sua pretensa imunidade diplomática não evitou que fosse obrigado a deixar o Brasil no ano de 1937. Barbeito não possuía o exeqüator - documento que demonstrava a anuência do governo brasileiro em recebê-lo - podendo assim, ser processado e tratado como um estrangeiro comum. Além disso, sua pretensa imunidade - conforme as regras que regem o serviço diplomático e consular - estava restrita aos atos de ofício e aos processos de caráter cível e penal. ${ }^{140}$ A polícia considerava que seu engajamento na propaganda pró- República espanhola extrapolava suas funções oficiais, o que possibilitava um ato administrativo como o processo de expulsão. Segundo o encarregado policial José Gomes, Rodriguez Barbeito teria sido expulso, embarcando no navio Alsina com destino a Marselha, juntamente com sua esposa e filhos, em 5 de dezembro de $1937 .{ }^{141}$

Era de se esperar que ao manter relações diplomáticas com o regime republicano espanhol, o governo brasileiro tivesse dado um encaminhamento diferente ao caso de Barbeito, evitando assim sua expulsão do país. Por ações como esta, fica comprovado que o governo Vargas não ocultava a aversão aos ideais políticos que sustentavam a República espanhola.

\footnotetext{
${ }^{139}$ Termo de Declarações de Andres Rodriguez Barbeito à Guilherme Pires de Albuquerque. Delegacia de Ordem Social. São Paulo, 23 nov. 1937. Prontuário 80136 - Comité Central de Propaganda de España Republicana. DEOPS-SP/AESP.

${ }^{140}$ De acordo com o código do Direito Internacional Público, os privilégios consulares "... se assemelham àqueles que cobrem o pessoal de serviços da missão diplomática. Com efeito, os cônsules e funcionários consulares gozam de inviolabilidade física e de imunidade ao processo - penal ou cível - apenas no tocante aos atos de ofício." (José Francisco Rezek. Direito Internacional Público: Curso Elementar. São Paulo: Saraiva, 1995, p. 172).

${ }_{141}$ Informe (cópia) de José Gomes para delegado adido à Seção de Investigações. São Paulo, 06 dez. 1937, doc. 18, fl 26. Prontuário 3817 - Andres Rodriguez Barbeito. DEOPS-SP/AESP. Segundo a pesquisadora Mariana Cardoso dos Santos Ribeiro, no Arquivo Nacional consta o processo de expulsão do referido diplomata. Ver: Mariana Cardoso dos Santos Ribeiro. Venha o decreto de expulsão. A legitimação da ordem autoritária no Governo Vargas (1930-1945). São Paulo, 2003. Dissertação (Mestrado em História Social) - FFLCH,USP.
} 
Referências à atuação de Rodriguez Barbeito na Espanha, após a sua breve estadia no Brasil, podem ser verificadas em um ofício no qual Carlos da Silveira Martins Ramos mencionou o diálogo amistoso que teve, em 1938, com esse representante diplomático espanhol. Martins Ramos teceu diversos elogios a Barbeito afirmando que o mesmo, apesar de acusado de atividades comunistas pelo governo brasileiro, fazia com freqüência considerações positivas do Brasil junto à imprensa da Espanha. Numa atitude de ingenuidade ou de provocação, Martins Ramos chegou a sugerir que fosse outorgada a ele a condecoração da Ordem Nacional do Cruzeiro do Sul. ${ }^{142}$ Tal sugestão pode ser interpretada como uma maneira de tentar transmitir ao Itamaraty que nem todos os partidários da República espanhola eram adeptos do radicalismo de esquerda e consideravam-se inimigos do Brasil. Martins Ramos procurou, em diferentes momentos, minimizar a imagem negativa que a República da Espanha vinha adquirindo na visão da elite política brasileira, especialmente do Ministério das Relações Exteriores.

A situação dos agentes consulares espanhóis em missão no Brasil também foi motivo de preocupação e de troca de correspondências entre a Embaixada do Brasil na Espanha e o Ministério das Relações Exteriores. Se na Espanha, os agentes consulares à serviço do governo brasileiro foram detidos por não coadunarem com os ideais da República espanhola, no Brasil, os representantes diplomáticos e consulares espanhóis leais ao governo republicano de seu país, ficaram sob a vigilância sistemática da Polícia Política, como bem elucida o caso de Andres Rodriguez Barbeito.

A imprensa no Brasil, sob rígido controle do governo, tendia a noticiar os acontecimentos na Espanha como sendo fruto das "forças demolidoras do comunismo internacional". ${ }^{143}$ Representativo dessa tendência dos órgãos de imprensa é o caso de Francisco Valdés Casas, cônsul espanhol

\footnotetext{
142 Ofício n. 30 do encarregado de negócios na Espanha, Carlos da Silveira Martins Ramos para Oswaldo Aranha, ministro das Relações Exteriores do Brasil. Barcelona, 22 jun. 1938. Missões Diplomáticas Brasileiras. Ofícios recebidos de Madri (julho de 1937 a 1938). AHI/RJ.

${ }^{143}$ Sobre a censura à imprensa ver: Maria Luiza Tucci Carneiro (Org.). Minorias silenciadas. História da censura no Brasil. São Paulo: Edusp; Fapesp, 2002. Sobre a forma pela qual a Guerra Civil da Espanha foi interpretada pelas revistas brasileiras ver da mesma autora: La Guerra Civil Espanõla através de las revistas ilustradas brasileñas: imagenes y simbolismos. Estudios Interdisciplinares da América Latina y el Caribe. Jerusalém, Universidade Hebraica de Jerusalém, v.2, n², p.39-50, 1991.
} 
na Bahia, acusado pelo jornal $A$ Pátria de ser o assassino do líder falangista Jose Antonio Primo de Rivera. O jornal mencionava que em 1936, quando o referido líder falangista foi fuzilado na cidade de Alicante, Valdés Casas teria ocupado o cargo de governador civil dessa cidade.

Preocupado com a repercussão de tais notícias sobre o cônsul republicano, o encarregado de negócios da Espanha no Brasil enviou ao ministro de Estado espanhol um recorte do jornal que, segundo ele, era um órgão fascista financiado pela Alemanha. Os termos utilizados eram agressivos, despertando a reação da representação espanhola no Rio de Janeiro. Mesmo tratando-se de um diplomata, o governo brasileiro não interferiu no caso, o que demonstra mais uma vez sua tendência em incentivar uma imagem negativa dos republicanos espanhóis como agentes do comunismo internacional. ${ }^{144}$ Como lembra Raoul Girardet, no imaginário da sociedade o "perigo vermelho" estaria além das fronteiras nacionais, sendo seus adeptos "agentes de um poderio de caráter supra-estatal e de dimensão universal". ${ }^{145}$ A idéia de que os "agentes de Madri" se constituíam em ameaça à nação fica evidenciada em um fragmento do artigo contra Valdés Casas. A metáfora de uma "Hespanha vermelha" e o perfil de "agitador perigoso" internacional atribuído ao cônsul, configura o processo de construção de inimigo-objetivo proposto por Hannah Arendt em sua clássica obra Origens do Totalitarismo. ${ }^{146}$

Disfarçado em "cônsul" da Hespanha vermelha vem ahi um perigoso agitador internacional.

O Sr. Valdes Casas arrumou então, as malas de caixeiro viajante e vem agora para o Brasil. Vem para agitar, para fazer conferencias, para escrever nos jornais e, em última análise, para ligar-se com os seus companheiros marxistas, fazendo a "ligação" entre o Partido Communista Brasileiro e o Secretariado Internacional do Komintern para a América do Sul, recentemente creado e já em franca actividade. A chegada do Sr. Valdes é um caso de polícia. É preciso que esse aventureiro bolchevista fique sabendo que não encontrará aqui o

\footnotetext{
${ }^{144}$ Sobre como o jornal O Estado de S. Paulo noticiou a Guerra Civil Espanhola ver: João Henrique Botteri Negrão. Selvagens e Incendiários: o discurso anti-comunista e as notícias da Guerra Civil Espanhola. São Paulo: Humanitas;Fapesp, 2005.

${ }_{145}^{145}$ Raoul Girardet, op. cit., p.43.

${ }^{146}$ Hanna Arendt afirma que a idéia de "oponente objetivo" é central no sistema totalitário. Origens do Totalitarismo, op. cit., p.475.
} 
terreno propício a sua pregação e que a "capa" em que se envolve de "cônsul" do Sr. del Vayo não enganará a ninguém. ${ }^{147}$

As referências ao ministro Julio Alvarez del Vayo serviam para dar ênfase à idéia de que tratava-se de um enviado do comunismo internacional que tinha a intenção de provocar o caos e a desordem no Brasil. As manifestações a favor do comunismo, interpretado como o responsável pelo conflito civil espanhol, deveriam ser coibidas. A guerra na Espanha servia assim, como parâmetro para justificar o Estado autoritário no Brasil.

A situação mencionada acima foi o assunto principal da entrevista que o chanceler espanhol del Vayo concedeu a Martins Ramos. O ministro espanhol procurou demonstrar que Valdés Casas não tinha ligações com o comunismo, sendo apenas um fiel partidário da República espanhola convidado para assumir como agente diplomático na América. ${ }^{148}$ Tal acusação não tinha qualquer ligação com a realidade, pois o fuzilamento de Primo de Rivera foi decidido pelos tribunais militares. Além disso, segundo o historiador Paul Preston, o governador civil de Alicante era Jesús Mónzon, um comunista que tentara retardar a execução do chefe e fundador da Falange. ${ }^{149}$

As acusações contra Valdés Casas serviram para reforçar a idéia de que ele era um político proeminente na política interna da Espanha, e que sendo responsável por uma decisão tão importante quanto a de determinar o extermínio de Primo de Rivera, não teria vindo ao Brasil apenas para exercer atividades burocráticas. Assim como no caso de Andres Rodriguez Barbeito, a imprensa utilizava-se de uma argumentação que justificava a periculosidade dos diplomatas espanhóis a serviço da Espanha republicana.

\footnotetext{
147 "Transigir com os communistas é nos condemnarmos ao suicídio" (autor não identificado), jornal A Pátria de 21 out. 1938. Recorte anexado ao despacho n. 375 de (ass. ileg.), encarregado de negócios da Espanha no Brasil para Ministro de Estado. Rio de Janeiro, 22 out. 1938. R999, expt. 12. AMAE. Grifo nosso.

${ }^{148}$ Ofício n. 118 do encarregado de negócios na Espanha, Carlos da Silveira Martins Ramos, para Oswaldo Aranha, ministro das Relações Exteriores do Brasil. Barcelona, 08 nov. 1938. Missões Diplomáticas Brasileiras. Ofícios recebidos de Madri (julho de 1937 a 1938). AHI/RJ.

${ }^{149}$ Paul Preston. Jose Antonio Primo de Rivera, el heroe ausente. Las tres españas del 36, op. cit., p.149.
} 


\title{
1.2 - Asilo e repatriação: o Brasil como salvação
}

\author{
Os asilados na Embaixada do Brasil
}

O golpe militar que deflagrou o conflito civil espanhol em julho de 1936, tinha como um de seus alvos principais a conquista rápida de Madri. A articulação de uma eficiente defesa republicana, na qual muito contribuiu a população civil, impossibilitou a tomada da capital espanhola pelas tropas rebeldes nos primeiros dias de conflito. Em novembro de 1936, os nacionalistas e os legalistas travaram duros embates na Cidade Universitária, às portas da capital. Sua ocupação seria, no entanto, adiada por mais de dois anos. ${ }^{150}$ As faixas que divulgavam No pasarán, a frase célebre atribuída à comunista espanhola Dolores Ibárruri marcaram os atos de resistência da cidade às investidas nacionalistas.

Nesse contexto, muitos cidadãos que de alguma forma pudessem ser identificados com a defesa de um golpe contra a República, consideraram que suas vidas corriam perigo. Clérigos, simpatizantes declarados da monarquia, assim como pessoas pertencentes à elite financeira, eram vistos como cidadãos que tinham reais interesses em contribuir para a vitória dos rebeldes.

Diversas missões diplomáticas se dispuseram a dar asilo político àqueles que consideravam estar a sua segurança pessoal ameaçada pelos republicanos espanhóis. A amplitude do asilo diplomático durante a contenda espanhola foi um ato, até então, sem precedentes na história das relações internacionais. $O$ asilo territorial e diplomático não foi praticado por todas as representações estrangeiras na Espanha. Países como Estados Unidos e União Soviética, esse último por razões óbvias, optaram por não conceder refúgio aos que se julgavam ameaçados. No entanto, a maior parte das

${ }^{150}$ Javier Rubio, op. cit., p.142. 
representações, mais de trinta, praticaram o asilo concedendo, segundo as estatísticas oficiais, refúgio a cerca de onze mil pessoas. ${ }^{151}$

Além daquelas que nitidamente mantinham simpatias aos rebeldes espanhóis como as missões do Chile, Cuba e Peru, também recorreu ao direito de oferecer asilo o México, cuja simpatia de seu governo à República não impediu que aproximadamente oitocentas pessoas se abrigassem em sua Embaixada. Como afirma Esther Gambi Giménez,

El derecho de asilo contaba con una larga tradición en Iberoamerica y había dado lugar a una importante legislación suscrita en diversos acuerdos y tratados. Sin embargo, en España como en la mayoría de los países europeus, el derecho de asilo no pasaba de ser una postura meramente humanitaria.(...). ${ }^{152}$

O asilo gerou tensões entre muitos países e o governo republicano espanhol, que interpretava a prática desse ato como uma forma de dar proteção a desertores do exército, inimigos políticos e espiões. A Legação peruana, por exemplo, foi invadida quando abrigava 400 pessoas. No local, os policiais encontraram documentos comprovando, segundo sua lógica, que muitos asilados transmitiam informações secretas ao bando inimigo. ${ }^{153}$

Dos países latino-americanos, dois se destacaram pela amplitude na concessão de asilo: Chile e Argentina, onde a mobilização em defesa de ambos os lados conflitantes na Espanha partia não apenas dos imigrantes espanhóis, mas de amplos setores da sociedade civil. Os debates e rivalidades suscitaram uma polarização ideológica, que logo repercutiu na imprensa chilena e argentina. No Brasil, as sociedades de imigrantes em defesa da República espanhola e as atividades de arrecadação de fundos e de propaganda seguiam o exemplo daqueles dois países. ${ }^{154}$

\footnotetext{
${ }^{151}$ Idem, p.31-38.

${ }^{152}$ Esther Gambi Giménez, op. cit, p.66.

153 Idem, p.68.

${ }^{154}$ Sobre a influência da Guerra Civil Espanhola na sociedade argentina e chilena ver: Enrique Pereira. La Guerra Civil Española en Argentina. Buenos Aires, (s.n), 1976. Colección Todo es Historia, n. 110; Ernesto Goldar. Los Argentinos y La Guerra Civil Española. Buenos Aires: Plus Ultra,1996; Pablo Sapag Muñoz de La Peña. Propaganda republicana y franquista em Chile durante la Guerra Civil Española. Madri, 1996. Tese (Doutorado) - Universidad Complutense.
} 
Ao final de 1939 a representação chilena e seus anexos abrigavam cerca de 1200 pessoas. O embaixador chileno Nunez Morgado, segundo Rubio, foi o "coordinador eficaz y el vigoroso impulsor, de la política de asilo diplomático entre todos los jefes de misión, titulares o interinos, que quedaban en la capital."155 O Chile merece destaque na história do asilo diplomático não apenas pela quantidade de pessoas acolhidas, mas também porque permaneceu defendendo o direito de asilo após o fim do conflito, abrigando até 1940 os partidários da República espanhola.

O governo republicano espanhol, mesmo sabendo das possibilidades de desenvolvimento de atividades do "quinta-colunismo" nas sedes das representações estrangeiras, respeitou 0 direito de asilo. A República espanhola preocupava-se com sua imagem frente aos países que o concediam, receando que incidentes envolvendo os asilados pudessem servir de justificativa para a determinação desses em romperem com o governo legalmente constituído. O asilo diplomático teve, a princípio, uma dimensão fundamentalmente humanitária, mas acabou se transformando, no decorrer da guerra, em um tema de interesse político. ${ }^{156}$

No segundo semestre de 1936, a posição do governo brasileiro com relação ao asilo nas missões estrangeiras em Madri era ainda muito cautelosa e se direcionava no sentido de não defender o "direito de asilo", mas somente a ação de asilar como um ato temporário de fins humanitários. O Itamaraty reprovou a atuação do governo argentino que enviou, em nome das nações americanas, um telegrama ao governo espanhol defendendo tal direito. $^{157}$

A permanência em Madri de cerca de dois mil asilados desafetos do regime era fonte de contínuos aborrecimentos ao governo da Espanha. Muitos dos asilados eram homens em idade militar e para o governo republicano a evacuação dessas pessoas - através de troca por prisioneiros do

\footnotetext{
155 Javier Rubio, op. cit., p.46.

156 Idem, p.149.

157 Telegrama (confidencial) da Secretaria de Estado das Relações Exteriores do Brasil para Embaixada do Brasil em Buenos Aires. Rio de Janeiro, 31 out. 1936. Lata 711, maço 10326. $\mathrm{AHI} / \mathrm{RJ}$.
} 
campo nacionalista - implicava em aceitar a possibilidade de enviar ao bando inimigo mais soldados.

Em abril de 1937, tendo o então embaixador do Chile se ausentado de Madri, coube a Alcebíades Peçanha assumir como decano do corpo diplomático, incumbindo-se de tentar resolver a questão dos asilados. ${ }^{158}$ A evacuação dos asilados para a zona nacionalista dependia das negociações do governo republicano com os chefes das missões diplomáticas. Peçanha solicitou da Cruz Vermelha Internacional um parecer técnico sobre o assunto, visto que a situação dos asilados era prejudicada pela proximidade do verão que ameaçava o estado sanitário dos respectivos refúgios. ${ }^{159}$ A Cruz Vermelha intermediou as negociações junto ao governo de Valência, que aceitou permutar alguns dos asilados nas missões diplomáticas por prisioneiros de guerra no campo nacionalista. ${ }^{160}$

Durante os três anos de conflito civil, cerca de sessenta pessoas buscaram refúgio junto à representação brasileira que, devido a esse grande contingente de pessoas, foi obrigada a alugar uma casa adjacente à sua sede em Madri. ${ }^{161}$ A concessão massiva de asilo por diversas representações gerou um problema físico de alojamento, implicando no surgimento dos famosos "anexos" às embaixadas e legações. A aceitação por parte do governo espanhol constitui, sem dúvida, um dos fatos que singularizam a concessão de asilo durante a Guerra Civil Espanhola. ${ }^{162}$

Entre 1937 e 1938, o número de asilados cresceu e revelou-se como um assunto complexo por comprometer a reputação da representação brasileira junto ao governo republicano espanhol. Em setembro de 1937, Alcebíades Peçanha informou ao ministro Macedo Soares, à época chanceler,

\footnotetext{
${ }^{158}$ As tensões entre o governo do Chile e a República espanhola decorrentes da questão dos asilados levaram à saída do embaixador chileno Nuñez Morgado em abril de 1937. Javier Rubio, op. cit., p.48.

159 Ofício de Alcebíades Peçanha, embaixador do Brasil em Madri para José F. de Barros Pimentel, ministro interino das Relações Exteriores do Brasil. Madri, 28 abr. 1937. Missões Diplomáticas Brasileiras. Ofícios recebidos de Madri (1936 a julho de 1937). AHI/RJ.

${ }_{160}$ Ofício de Alcebíades Peçanha, embaixador do Brasil na Espanha para José Carlos de Macedo Soares, ministro das Relações Exteriores. Madri, 03 jul. 1937. Missões Diplomáticas Brasileiras. Ofícios recebidos de Madri (julho de 1937 a 1938). AHI/RJ.

${ }_{161}$ Despacho de Cyro de Freitas Valle em nome do ministro de Estado para Argeu Guimarães, encarregado de negócios em Madri. Rio de Janeiro, 01 abr. 1939. Missões Diplomáticas Brasileiras. Despachos expedidos a Madri (1935-1941). AHI/RJ.

162 Javier Rubio, op. cit., p.35.
} 
que não havia comunicado oficialmente o governo espanhol da existência de "refugiados" na sede da Embaixada. Peçanha explicou que os refugiados eram filhos de espanhóis nascidos no Brasil que, devido ao conflito, haviam perdido suas moradias. Alegava que os asilados, de acordo com a legislação espanhola, também eram considerados espanhóis, uma vez que prevalecia naquele país o jus sanguinis, princípio pelo qual a nacionalidade é reconhecida aos indivíduos de acordo com sua ascendência. Estando em idade militar, esses cidadãos não estavam autorizados a sair da zona republicana, tendo que se incorporar ao exército. ${ }^{163}$

É provável que o ministro Macedo Soares não tenha repreendido Peçanha por tal omissão, pois somente em março de 1938 é que Oswaldo Aranha ordenou que fosse feita a comunicação oficial da existência de asilados na Embaixada brasileira. A complacência de Macedo Soares para com essa questão pode ser explicada pelo anticomunismo por ele professado. Proteger pessoas que estariam sob ameaça de um "governo comunista" significava contribuir, ainda que indiretamente, para a causa dos nacionalistas espanhóis. O que estava em jogo não era apenas a proteção de cidadãos e sim a defesa de uma ideologia.

O fato de Peçanha não ter tornado público a existência de asilados nos permite pensar na existência de interesses pessoais nesse gesto. Essa atitude pode estar relacionada à proteção de sua secretária particular Nelly Vidal, acusada de envolver-se juntamente com a família Selgas, na adulteração e venda de passaportes brasileiros para aqueles que desejavam sair do território espanhol. A menção às irregularidades cometidas pela secretária de Peçanha é recorrente na documentação trocada entre o Itamaraty e Martins Ramos.

Segundo Javier Rubio, Nelly Vidal submetia a "continuas vejaciones y amenazas a los desvalidos asilados que tampoco encontraron ninguna comprensión en el embajador..." 164 Rubio, autor de um estudo específico sobre o asilo diplomático ocorrido durante o conflito civil espanhol,

163 Ofício n. 48 de Alcebíades Peçanha, embaixador do Brasil na Espanha para José Carlos de Macedo Soares, ministro das Relações Exteriores. Madri, 25 set. 1937. Lata 711, maço 10326. AHI/RJ.

${ }^{164}$ Javier Rubio, op. cit., p.180. 
analisa a atuação da Embaixada brasileira frente à questão. Em uma passagem de seu livro Asilos y canjes durante la guerra civil española, não se furtou em tecer severas críticas ao que considerou uma "modesta e censurável" política de asilo. Segundo o historiador, as circunstâncias indicavam que a Embaixada do Brasil seria uma "de las que más ampliamente concediera el asilo y en cualquier caso, una de las que mejores relaciones habrían de mantener con el Ministerio de Estado español y que más eficaces negociaciones para la evacuación de sus refugiados habría de desarrollar." Isso porque o Brasil havia ratificado as convenções de Havana de 1928 e de Montevidéu de 1933, praticando com freqüência o direito de asilo. Alegou que o Brasil, além do mais, tinha um dos mais eficientes ministérios das Relações Exteriores da América. ${ }^{165}$

A documentação produzida pela Embaixada do Brasil na Espanha, pelo Itamaraty e pelo Ministério espanhol, cruzada com as informações obtidas no livro mencionado acima, nos leva a concluir que a representação diplomática do Brasil desenvolveu uma atuação inexpressiva e incompetente na resolução do caso. A ocultação das listas de asilados pelo embaixador Peçanha é um dos fatores que contribuíram para as tensões entre a Embaixada brasileira e o Ministério de Estado espanhol.

Em diversos momentos, Martins Ramos fez questão de evidenciar que considerava que o silêncio mantido acerca da existência de asilados na missão brasileira era um erro. Ao não enviar a lista de refugiados para o governo republicano espanhol, o Brasil foi excluído das negociações que possibilitaram a evacuação de asilados de outras embaixadas.

Através de um extenso ofício datado de 25 de março de 1938, Ramos resumiu a situação dos asilados, expondo os motivos que o levavam a defender a necessidade do fim do asilo na Embaixada e no "anexo" brasileiro. Afirmava que Peçanha havia mandado instalar uma faixa com os dizeres "Residência de brasileiros" no referido anexo, mas que aos poucos esse local passou a dar guarida a muitos espanhóis. Informou que havia até mesmo asilados que reclamavam criados para a limpeza dos quartos que habitavam. Em sua opinião, não havia razão para continuar dando abrigo à "milionária

${ }^{165}$ Idem, p. 73 
família Selgas", proprietária do palacete alugado para servir como anexo ao prédio da Embaixada. Tais fatos, segundo Ramos, sujavam o nome de nossa representação, nivelando-o com o de outras embaixadas como as de Cuba e Chile, cujos titulares conseguiram "fazer fortuna" com tais negócios. ${ }^{166}$

A República espanhola sabia que o asilo em algumas embaixadas era decorrente do interesse de muitos diplomatas em conseguir benefícios financeiros. Muitos cidadãos só obtiveram o asilo mediante o pagamento de um "oneroso portazgo, un portazgo en general de tipo económico, pero otras veces de uma naturaleza aún más abusiva e indigna” 167

No caso brasileiro, nenhum documento nos possibilita levantar a hipótese de que Alcebíades Peçanha tivesse recebido benefícios financeiros para manter pessoas asiladas na Embaixada. No entanto, não deixa de causar estranhamento o fato de que, na posição de decano do corpo diplomático, não tenha fornecido as listas ao governo republicano espanhol.

A situação ficou ainda mais complexa quando Martins Ramos descobriu que junto ao "anexo" não havia somente "brasileiros", como a princípio havia indicado Peçanha, mas também militares e religiosos. Com a presença desses últimos, dificilmente o governo espanhol autorizaria a evacuação de todos os asilados para a França. As observações realizadas por Ramos indicam que Oswaldo Aranha o orientou a negociar a evacuação desses asilados até a França e seu internamento no Brasil. A República certamente não aceitaria negociar tal proposta, haja vista o ocorrido com os refugiados em outras embaixadas que, ao serem autorizados a se dirigirem ao país vizinho, fugiram para as regiões sob poder dos rebeldes.

Pelo tom do discurso, percebe-se que o encarregado de negócios estava apreensivo e indignado com os rumos que o caso havia tomado, solicitando que, diante de seu relato minucioso, Oswaldo Aranha o orientasse quanto aos procedimentos cabíveis. Sugeria que deveria se providenciar a retirada dos brasileiros filhos de espanhóis e outros cidadãos que, segundo ele, não corriam risco de vida. Por ter recebido anteriormente instruções para

${ }^{166}$ Ofício de Carlos da Silveira Martins Ramos, encarregado de negócios em Barcelona para para Oswaldo Aranha, ministro das Relações Exteriores do Brasil. Barcelona, 25 mar. 1938. Lata 711, maço 10326. AHI/RJ.

167 Javier Rubio, op. cit., p.156. 
manter os asilados, Martins Ramos afirmou que só pretendia agir "à luz da jurisprudência brasileira sobre a matéria, da Convenção de Havana e do próprio regulamento do corpo diplomático brasileiro". ${ }^{168}$

Em muitos momentos, Martins Ramos demonstrou que a questão dos asilados prejudicava a imagem do Brasil que, corroborando com muitas irregularidades, acabava por desrespeitar o governo legalmente constituído da Espanha. Afirmava que desconhecia completamente a existência de religiosos e militares na sede da Embaixada e que isso significava ingerência nos assuntos internos espanhóis. Demonstrando coragem em defender seu ponto de vista, o diplomata escreveu:

Mas nesse caso não me parece lícito que a Embaixada do Brasil
continuasse mantendo um procedimento que implicava em ingerência
nos assumptos internos espanhóes. No Brasil, aliás, acredito poder
affirmar que esse systema não medraria. E pensava que para sermos
respeitados, devíamos respeitar o Governo perante o qual
representamos o nosso paiz, observando estrictamente suas leis sem
cogitar de sympatias por este ou aquelle grupo em armas. ${ }^{169}$

Tal postura constitui-se em uma demonstração de ousadia de Carlos da Silveira Martins Ramos, que não furtou-se em criticar o Itamaraty na condução da política externa brasileira diante da República espanhola. Para ele, o Brasil deveria agir de forma coerente com sua posição de país que mantinha relações diplomáticas com aquele governo.

A resposta pronta e enfática do Ministério das Relações Exteriores trouxe, além de orientações que contrariavam o desejo de Martins Ramos, um alerta para que esse diplomata compreendesse que havia se excedido na defesa de suas opiniões. Através de um telegrama, a Secretaria de Estado das Relações Exteriores informava que o asilamento era um procedimento tradicional do Brasil e que, independentemente de comunicação oficial, o dever de Ramos era o de "proteger e salvar vidas", afirmando que isso era "o que seu antecessor soube fazer". Esta última menção provavelmente

\footnotetext{
${ }^{168}$ Ofício de Carlos da Silveira Martins Ramos, encarregado de negócios em Barcelona para Oswaldo Aranha, ministro das Relações Exteriores do Brasil. Barcelona, 25 mar. 1938. Lata 711, maço 10326. AHI/RJ.

169 Idem.
} 
rebatia a crítica que Ramos teceu à atitude de Peçanha de ter omitido do governo espanhol a presença de asilados na representação brasileira. ${ }^{170}$

A opinião de Martins Ramos divergia das orientações do Itamaraty com relação aos asilados. Percebendo que suas divergências com Oswaldo Aranha certamente iriam prejudicá-lo, Ramos afirmou que, em reunião com o ministro das Relações Exteriores da Espanha, teria defendido o ponto de vista do Itamaraty na questão como se fosse o seu próprio, e que suas ações se pautavam exclusivamente pelas orientações advindas do ministro Oswaldo Aranha. ${ }^{171}$

O encarregado de negócios fazia questão de demonstrar que cumpria as determinações do MRE sem, entretanto, conter suas críticas às atitudes dúbias, e em sua concepção, incoerentes do governo brasileiro. Se levarmos em consideração as afirmações do diplomata Heitor Lyra acerca da postura de Aranha diante das posições divergentes dentro do MRE, o gesto de Martins Ramos torna-se ainda mais surpreendente. Lyra, numa clara demonstração de antipatia ao ministro Aranha, opina que "não houve ali ministro de Estado que se mostrasse tão truculento e tão despótico, tão violento em seus atos, tão indiferente aos direitos ou privilégios dos funcionários do Ministério do Exterior. (...) Ninguém, durante sua gestão, se sentia garantido". ${ }^{172}$

Carlos da Silveira Martins Ramos defendia o fim do asilo àqueles cidadãos que não corriam risco. Alegava que devido ao seu bom relacionamento com os líderes republicanos espanhóis, teria garantias de que os "jovens insubmissos" - ou seja, aqueles que se refugiaram para fugir do alistamento - e os brasileiros que ali estavam nada sofreriam. ${ }^{173}$ Junto ao ofício encaminhado ao chanceler Aranha, anexou a lista dos asilados onde constavam 34 homens, dos quais 09 se declaravam militares, totalizando 43 pessoas. Grande parte desse contingente entrou no anexo ainda no ano de

170 Telegrama da Secretaria de Relações Exteriores do Brasil para Embaixada do Brasil em Barcelona. Rio de Janeiro, 25 mar. 1938. Missões Diplomáticas Brasileiras. Telegramas expedidos a Madri (1938-1942). AHI/RJ.

${ }^{171}$ Telegrama de Carlos da Silveira Martins Ramos, encarregado de negócios em Barcelona para Oswaldo Aranha, ministro das Relações Exteriores do Brasil. Barcelona, 29 mar. 1938. Lata 711, maço 10326. AHI/RJ.

172 Heitor Lyra. Minha vida diplomática. Brasília: Editora UNB, 1972, p.669.

173 Ofício de Carlos da Silveira Martins Ramos, encarregado de negócios em Barcelona para Oswaldo Aranha, ministro das Relações Exteriores do Brasil. Barcelona, 05 mai. 1938. Lata 711, maço 10326. AHI/RJ. 
1936. Os asilados declaravam-se proprietários, industriais, e religiosos, além de "estudantes". ${ }^{174}$

Martins Ramos procurava sempre ressaltar que mantinha boas relações com os políticos republicanos e que, graças a sua amizade com o ministro de Gobernación, teria conseguido que a lista referida fosse analisada no prazo de uma semana, quando que os casos de asilados de outras legações demoravam em média três meses para serem analisados.

A documentação do arquivo do Ministério de Asuntos Exteriores da Espanha reforça a idéia de que Martins Ramos era bem quisto pelo governo republicano. Em uma das notas enviadas do Rio de Janeiro, o representante espanhol no Brasil afirmava que o encarregado de negócios do Brasil "nos es altamente afecto" e que de maneira confidencial, Mario de Pimentel Brandão teria the mostrado despachos em que Ramos tecia elogios ao presidente e à República espanhola. ${ }^{175}$

O governo republicano, a partir das informações detalhadas sobre os asilados, deu garantias para que os brasileiros pudessem deixar a Embaixada, exceto os militares e homens em idade militar que teriam que aguardar. Três outras pessoas, por sua importância social, deveriam ali permanecer para futuras trocas por prisioneiros de guerra republicanos no campo nacionalista: Francisco Reina Framis e Pedro Zuazo Ugalde da Ação Popular (AP) e Luisa Prado Lisboa, viúva de um militar, que havia sido dama da corte da rainha Vitória. A senhora Lisboa, que ostentava o título de Marquesa de Guad el Jelú, era neta do Barão de Japurá, nobre e diplomata brasileiro que, à época do Império, serviu como ministro em Lisboa. ${ }^{176}$

Aproveitando-se da sua condição de nobreza a Marquesa enviou, através da Secretaria de Relações Exteriores, um telegrama à Getúlio Vargas solicitando que fosse dada autorização a Martins Ramos para manter os refugiados espanhóis na sede da Embaixada na condição de asilados até o

\footnotetext{
$\overline{174}$ Anexo 1 "Asylados no annexo da antiga sede da Embaixada do Brasil em Madrid." Idem à nota anterior.

${ }^{175}$ Nota da Embaixada da Espanha no Brasil para Ministério de Assuntos Exteriores da Espanha. Rio de Janeiro, 27 fev. 1938. R1070, exp.57. AMAE.

${ }_{176}$ Ofício de Carlos da Silveira Martins Ramos, encarregado de negócios em Barcelona para Oswaldo Aranha, ministro das Relações Exteriores do Brasil. Barcelona, 05 mai. 1938. Lata 711, maço 10326. AHI/RJ.
} 
final da contenda. Provavelmente o encarregado de negócios do Brasil já havia informado os asilados que deveriam deixar a Embaixada e seu anexo. ${ }^{177}$

Em março de 1938, o ministro de Estado espanhol autorizou a saída do país dos asilados que fossem mulheres, crianças e homens acima de 45 anos. A intenção do governo republicano era de manter nas embaixadas as pessoas que tivessem alguma importância política e social e que poderiam despertar no lado nacionalista, a disposição em negociar a "libertação" dessas pessoas em troca de presos republicanos.

A existência de asilados na sede da Embaixada brasileira foi motivo de desconfianças do governo republicano para com a sinceridade das intenções do governo brasileiro de "proteger cidadãos". Ao final de março de 1938, o Ministério de Estado espanhol manifestou surpresa diante da existência de asilados na missão diplomática brasileira. O governo espanhol também demonstrou estranhamento pelo fato de Alcebíades Peçanha ter informações minuciosas sobre as negociações envolvendo os asilados de outras missões diplomáticas quando assumiu como decano do corpo diplomático. ${ }^{178}$

Luis de Soroa Garcia Goyena, secretário da Embaixada responsável pelos asilados quando Martins Ramos transferiu-se para Barcelona, expunha com freqüência as constantes atitudes abusivas e desrespeitosas das pessoas que ali estavam. A correspondência analisada nos deixa entrever uma situação que fugia àquela imaginada para pessoas na condição de asilados. Em agosto de 1938, por exemplo, Soroa relatou a Martins Ramos que muitos cidadãos comportavam-se de forma a estar "num balneário ou numa colônia de férias", tomando banhos de sol e promovendo jogatinas em plena luz do dia. Informou também que muitos possuíam armas e munições e se expunham diariamente nas janelas do "anexo", dando vivas às evoluções dos aviões nacionalistas. Soroa explicou que teria solicitado, sem sucesso, a mudança de postura de um cidadão que diariamente se expunha

\footnotetext{
177 Telegrama de Luiza Prado Lisboa para Getúlio Vargas remetido através de Telegrama das Relações Exteriores para Luis Vergara, secretário da Presidência da República. 19 mar. 1938. Lata 711, maço 10326. AHI/RJ.

${ }_{178}$ Ofício (cópia) do Ministério de Estado Español para Carlos da Silveira Martins Ramos, encarregado de negócios na Espanha. Barcelona, 30 mar. 1938. Lata 711, maço 10326. $\mathrm{AHI} / \mathrm{RJ}$.
} 
aos transeuntes da rua "ao jogar xadrez de pijamas no jardim do palácio" que funcionava como anexo da Embaixada. ${ }^{179}$

Atitudes como essas eram freqüentemente apontadas pelos jornais republicanos como provas das intenções das embaixadas estrangeiras em abrigar "fascistas", como indica o título de um artigo do jornal Castilla Libre: "!Basta ya de complascencias peligrosas". 180

Em agosto de 1938, Martins Ramos sugeriu enfaticamente o fim do direito de asilo na Embaixada brasileira. Os argumentos apresentados reforçavam a não adequação da categoria de asilo para definir a situação daqueles que estavam no anexo da representação brasileira. Segundo Martins Ramos, os cidadãos ali estabelecidos não corriam risco de morte, sendo que dois deles teriam saído espontaneamente desse refúgio, apresentando-se à polícia madrilenha e sendo colocados em liberdade. Defendia, no entanto, a permanência do asilo somente para os refugiados militares, tendo em vista as regras severas para os desertores. ${ }^{181}$

A posição do Itamaraty, em todo o período do conflito, foi de extrema cautela, sempre ressaltando que o governo brasileiro não poderia tomar medidas que contrariassem o que havia sido ratificado nas conferências de Havana e Montevidéu sobre o direito de asilo. ${ }^{182}$ Ramos enfatizava que o caso espanhol não se ajustava minimamente aos princípios estabelecidos em tais conferências, lembrando que o asilo só era admissível para fornecer proteção temporária a indivíduos ameaçados de iminente perigo de vida. A aplicação ao caso em discussão não se justificava, uma vez que haviam sido dadas garantias de segurança aos que deixassem o anexo. ${ }^{183}$

\footnotetext{
179 Ofício de Luis de Soroa Garcia Goyena para Carlos da Silveira Martins Ramos, encarregado de negócios do Brasil em Barcelona. Madri, 22 ago. 1938. Lata 711, maço 10326. AHI/RJ.

180 "IBasta ya de complascencias peligrosas" (autor desconhecido), jornal Castilla Libre, de 16 ago. 1938. Anexo ao ofício de Luis de Soroa Garcia Goyena para encarregado de negócios, Carlos da Silveira Martins Ramos. Madri, 22 ago. 1938. Lata 711, maço 10326. AHI/RJ.

${ }_{181}$ Ofício de Carlos da Silveira Martins Ramos, encarregado de negócios do Brasil na Espanha para Oswaldo Aranha, ministro das Relações Exteriores do Brasil. Barcelona, 23 ago. 1938. Lata 711, maço 10326. AHI/RJ.

${ }_{182}$ Referências à Convenção sobre Asilo assinada na VI Conferência Pan-americana de Havana, em 1928, e à Convenção sobre asilo político, assinada na VII Conferência Internacional Americana de Montevidéu, em 1933. Sobre esse assunto ver: Luiz Paulo Teles F. Barreto. Das diferenças entre os institutos jurídicos do asilo e do refúgio. Disponível em: http://www.mi.gov.br/sni/artigo refugio.htm. Acesso em 31 mar. 2007.

${ }^{183}$ Ofício de Carlos da Silveira Martins Ramos, encarregado de negócios do Brasil na Espanha para Oswaldo Aranha, ministro das Relações Exteriores do Brasil. Barcelona, 23 ago. 1938. Lata 711, maço 10326. AHI/RJ.
} 
Além do comportamento hostil e provocativo de alguns dos asilados, Luis de Soroa teve de enfrentar outra situação difícil. $O$ fato se resumia a uma briga que resultou no ferimento de um dos asilados, que corria risco de morte. A situação da Embaixada mais uma vez apresenta-se delicada, uma vez que poderia ser acusada de ocultar das autoridades um crime comum. ${ }^{184}$ Segundo Javier Rubio, tais conflitos eram freqüentes, dada a intensa vida comunitária a que os asilados eram submetidos. ${ }^{185}$

Em novembro de 1938, a situação dos asilados ainda era alvo de intensa troca de correspondência entre o Itamaraty e a Embaixada do Brasil sediada em Barcelona. Martins Ramos parecia disposto a resolver a questão, fornecendo a lista brasileira de refugiados para a Comissão Internacional de Troca de Prisioneiros. Segundo Ramos, a morosidade também se devia ao fato de que a Junta Revolucionária de Burgos tinha notório desinteresse pelo assunto, demorando em fornecer a lista com o nome das pessoas que poderiam ser trocadas pelos refugiados na zona republicana. ${ }^{186}$

Mesmo não tendo certeza do tempo que levaria para o início da evacuação dos asilados, mas prevendo a demora de pelo menos dois meses, Martins Ramos solicitou do Ministério das Relações Exteriores orientações quanto às providências que deveriam ser tomadas caso houvesse a negação, por parte dos próprios asilados na Embaixada brasileira, de efetivarem a saída da capital espanhola. Os motivos de tal negação eram variados, mas a maioria previa a proximidade do fim do conflito. Caberia observar que muitos espanhóis procuraram refúgio apenas para fugirem à luta fratricida, não desejando a transferência ao campo nacionalista, onde provavelmente seriam incorporados às fileiras do exército rebelde. ${ }^{187}$

Houve grande morosidade nas negociações já que em março de 1939, nos momentos finais do conflito, a questão dos asilados na Embaixada brasileira ainda não havia sido resolvida. Martins Ramos defendia o fim do

\footnotetext{
${ }^{184}$ Ofício de Carlos da Silveira Martins Ramos, encarregado de negócios do Brasil na Espanha para Oswaldo Aranha, ministro das Relações Exteriores do Brasil. Barcelona, 29 nov. 1938. Lata 711, maço 10326. AHI/RJ.

185 Javier Rubio, op. cit, p. 175.

186 Ofício de Carlos da Silveira Martins Ramos, encarregado de negócios em Barcelona para Oswaldo Aranha, ministro das Relações Exteriores do Brasil. Barcelona, 28 nov. 1938. Missões Diplomáticas Brasileiras. Ofícios recebidos de Madri (julho de 1937 a 1938). AHI/RJ.

${ }^{187}$ Idem.
} 
direito de asilo, procurando demonstrar que muitos estavam se aproveitando dessa condição para fugirem de suas obrigações ou para manter uma vida cômoda e, na medida do possível, confortável, diante das privações a que estava submetida a população civil de Madri.

No entanto, esse representante preocupou-se em resguardar a vida dos asilados quando considerou que essas estavam realmente ameaçadas. Em março de 1939, o governo brasileiro reconheceu o governo de Francisco Franco. Ramos alertou o Itamaraty que essa medida poderia ocasionar uma situação trágica, uma vez que devido ao reconhecimento, os republicanos poderiam não mais considerar o direito de asilo na representação brasileira. ${ }^{188}$ Vale lembrar que muitos eram militares que professavam simpatias aos nacionalistas. Se o governo republicano ordenasse a desocupação da missão brasileira, esses provavelmente seriam executados por serem considerados desertores.

A atitude do governo brasileiro mediante a eminência do derramamento de sangue dos asilados foi enviar à Legação brasileira em Berna uma ordem para solicitar junto ao governo suíço o auxílio da Cruz Vermelha. ${ }^{189}$ Provavelmente tal solicitação não foi atendida por falta de tempo, uma vez que o conflito terminou poucos dias depois.

Assim, podemos concluir que Martins Ramos empreendeu esforços para normalizar a situação e obter a evacuação dos asilados brasileiros. No entanto, o momento oportuno havia passado. Antes do término da guerra três dezenas de asilados abandonaram a Embaixada brasileira. ${ }^{190} \mathrm{E}$ provável que os militares e religiosos tenham deixado a Embaixada do Brasil somente após os nacionalistas entrarem em Madri, fato que culminou com o fim do conflito.

\footnotetext{
188 Telegrama de Carlos da Silveira Martins Ramos, encarregado de negócios do Brasil na Espanha para Ministério das Relações Exteriores. Perpignan, 03 mar. 1939. Lata 293, maço 10326. AHI/RJ.

${ }^{189}$ Telegrama da Secretaria das Relações Exteriores para Legação do Brasil em Berna. Rio de Janeiro, 06 mar. 1939. Lata 293, maço 10326. AHI/RJ.

190 Javier Rubio, op. cit., p.76.
} 
A repatriação de cidadãos brasileiros residentes na Espanha é um assunto que perpassa a documentação diplomática em todo o período proposto para esse estudo. Os consulados tinham autonomia para decidir sobre a procedência ou não da necessidade de repatriação. No entanto, em alguns casos cabia à Secretaria de Estado das Relações Exteriores fornecer aos consulados o parecer e a eventual autorização para a repatriação. Como o governo brasileiro arcava com as despesas de transporte e de trâmites de documentação, a orientação do Itamaraty se fazia no sentido de somente conceder o "benefício" àqueles que comprovassem verdadeiramente estarem em total estado de penúria ou miséria.

Tal política também pode ser atestada no caso dos imigrantes espanhóis que desejavam deixar o Brasil, cuja maioria contava com o auxílio das Sociedades mutualistas criadas para esse fim. As Sociedades Mútuas de Repatriação de espanhóis existiram em várias cidades brasileiras e se constituíram em uma alternativa diante da omissão do governo espanhol em auxiliar os seus compatriotas. ${ }^{191}$

A maioria dos brasileiros que solicitava junto aos consulados a repatriação possuía dupla cidadania. Eram em geral filhos de espanhóis nascidos no Brasil e que, juntamente com a família, haviam retornado à Espanha. A condição de "dupla cidadania" desses indivíduos era estabelecida pelo fato de Brasil e Espanha concederem a nacionalidade aos seus baseando-se em princípios distintos. No Brasil, há prevalência do reconhecimento da nacionalidade pelo local de nascimento, o jus solis cuja palavra indica o direito de solo. ${ }^{192}$ Os filhos de imigrantes espanhóis nascidos no Brasil além de brasileiros por esse princípio, também eram considerados cidadãos da Espanha uma vez que esse país segue o jus sangüinis, reconhecendo a nacionalidade daqueles que tem ascendência espanhola.

191 Sobre as sociedades espanholas de repatriação ver: Ismara Izepe de Souza. Espanhóis: história e engajamento, op. cit.

${ }^{192}$ Francisco Rezek. Direito Internacional Público, op. cit., p.185-190. 
Essa diferença de modelos no reconhecimento da nacionalidade gerou inúmeros casos curiosos de filhos de espanhóis que obtiveram auxílio do governo espanhol e das sociedades de repatriação para se repatriarem à Espanha e que, anos depois, solicitavam junto aos consulados brasileiros auxílio para, na condição de brasileiros, serem novamente repatriados ao Brasil. No período que antecede o conflito civil da Espanha, a maioria dos casos apresentados ao Itamaraty dizia respeito aos cidadãos que viviam em total estado de miséria, ou seja, como "indigentes", expressão comumente empregada para qualificá-los. Em junho de 1936, o cônsul brasileiro em Barcelona expôs ao ministro Macedo Soares detalhes da penosa situação de três famílias que haviam sido repatriadas pelo Consulado espanhol em São Paulo após terem vivido no Brasil. Como todos os filhos dessas famílias numerosas haviam nascido no Estado de São Paulo, o cônsul opinou que fossem também concedidas aos pais espanhóis as passagens para retornarem ao Brasil. Argumentava ainda, que a privação e fome a que estavam submetidas essas pessoas decorria da situação de desemprego e carestia da Espanha. ${ }^{193}$

Durante a Guerra Civil Espanhola cresceu vertiginosamente o número de pessoas que buscaram os consulados brasileiros e a Embaixada em Madri para solicitar repatriação. Os espanhóis que possuíam dupla cidadania podiam com maiores facilidades pleitear o asilo nas missões diplomáticas dos países que adotavam o jus solis, assim como garantir passaporte estrangeiro para a saída do território espanhol. No contexto da guerra, essa era uma das melhores condições que alguém podia aspirar. Esse assunto foi alvo de dezenas de relatórios e correspondências trocadas especialmente entre Oswaldo Aranha, ministro das Relações Exteriores e Martins Ramos, encarregado de negócios em Barcelona.

O volume de requerimentos de repatriação chegou a preocupar o MRE, que solicitou parecer de consultores na área de direito. Em um memorandum interno do Itamaraty, destinado ao chefe da divisão política e diplomática, o relator sugeriu que o Ministério da Justiça revisse a legislação

${ }^{193}$ Ofício n. 48 do cônsul (ass. ileg.) em Barcelona para José Carlos de Macedo Soares, ministro das Relações Exteriores do Brasil. Barcelona, 19 jun. 1936. Consulados Brasileiros. Ofícios recebidos de Barcelona (maio de 1936 a setembro de 1938). AHI/RJ. 
sobre esses casos, para evitar que o Brasil desse guarida a "oportunistas" interessados em ser repatriados para fugir ao alistamento militar. ${ }^{194} \mathrm{O}$ autor do memorandum demonstrava sua indignação diante do que considerava "complascência" das leis brasileiras frente aos abusos cometidos por esses cidadãos. Evocando o Decreto-Lei n. 389 de abril de 1938, demonstrou estar coadunado com os ideais nacionalistas do governo Vargas:

É o caso freqüente dos indivíduos que, sem qualquer sentimento de amizade ou de patriotismo para com o Brasil, só se lembram de invocar a qualidade de cidadão brasileiro e pedir a proteção dos nossos representantes no exterior, quando se encontram em conjucturas difíceis, nas quais, geralmente nada é possível fazer... (...)Com a guerra civil espanhola recrudesceram esses pedidos, e indivíduos que sempre, pode-se dizer, viveram na Espanha, pelo simples fato de terem nascido no Brasil, passaram a assediar direta e indiretamente, as nossas autoridades diplomáticas e consulares, ora solicitando-lhes repatriação, ora pedindo-lhes desmobilização das fileiras em que haviam sido incorporados. ${ }^{195}$

O parecer reafirmava a necessidade "premente" de serem tomadas medidas uniformes e gerais para facilitar 0 trabalho dos representantes brasileiros no exterior, além de evitar os abusos dos "oportunistas":

... reprimir os abusos por parte daqueles que só se lembram de que são brasileiros quando desejam usufruir uma vantagem imerecida, ou quando pretendem furtar-se ao cumprimento de seu dever na pátria onde há muito se integram. ${ }^{196}$

De acordo com essa visão, os jovens que solicitavam repatriação ou simplesmente documentos que pudessem livrá-los das fileiras do exército não atendiam a um requisito determinante para o Estado brasileiro: o sentimento de amor à pátria. As qualificações dadas a esses indivíduos e as adjetivações empregadas demonstram que havia, por parte de alguns

\footnotetext{
${ }^{194}$ Memorandum (ass. llegível) para o chefe da divisão política e diplomática. Ministério das Relações Exteriores. Rio de Janeiro, 16 jan. 1939. Lata 716, maço 10364. AHI/RJ.

${ }^{195}$ Idem.

${ }^{196}$ Idem.
} 
membros do Itamaraty, um descontentamento com o fato de esses cidadãos possuírem pelas leis, os mesmos direitos que os nacionais.

Outros argumentos reforçavam a premissa de que muitos cidadãos não mereciam obter o direito de entrada no Brasil devido à sua pouca familiaridade e seu pouco conhecimento do país. Essa argumentação também foi utilizada pelos diplomatas que defendiam as determinações do Itamaraty em limitar a entrada de judeus no Brasil. Tucci Carneiro afirma que o diplomata Ouro Preto enfatizou a Oswaldo Aranha que o judeu "só se lembrava de nós quando necessita e quando todas as portas lhe estão fechadas". ${ }^{197}$

Durante o ano de 1938 o cônsul brasileiro em Barcelona, Aluízio de Magalhães, expôs à Secretaria de Estado das Relações Exteriores a situação penosa de muitas famílias espanholas, agravada pelo contexto da guerra civil. Especialmente no caso de mulheres e crianças o cônsul opinou favoravelmente à repatriação. $\mathrm{Na}$ impossibilidade de providenciar a saída dos repatriados pelo porto de Barcelona, Magalhães solicitou do Consulado brasileiro em Marselha que tomasse as medidas necessárias para que esses cidadãos pudessem embarcar nos navios atracados naquele porto francês.

${ }^{197}$ Relatório de atividades da Legação de Bucarest durante o ano de 1939, pelo ministro C. de Ouro Preto para Oswaldo Aranha, ministro das Relações Exteriores. Bucarest, 1939. Lata 650, maço 9797, p. 1 AHI/RH Apud Maria Luiza Tucci Carneiro. Cidadão do mundo. Brasil e a questão dos refugiados judeus (1933-1948). São Paulo, 2001. Tese (Livre-Docência) - FFLCH,USP, p.272. 


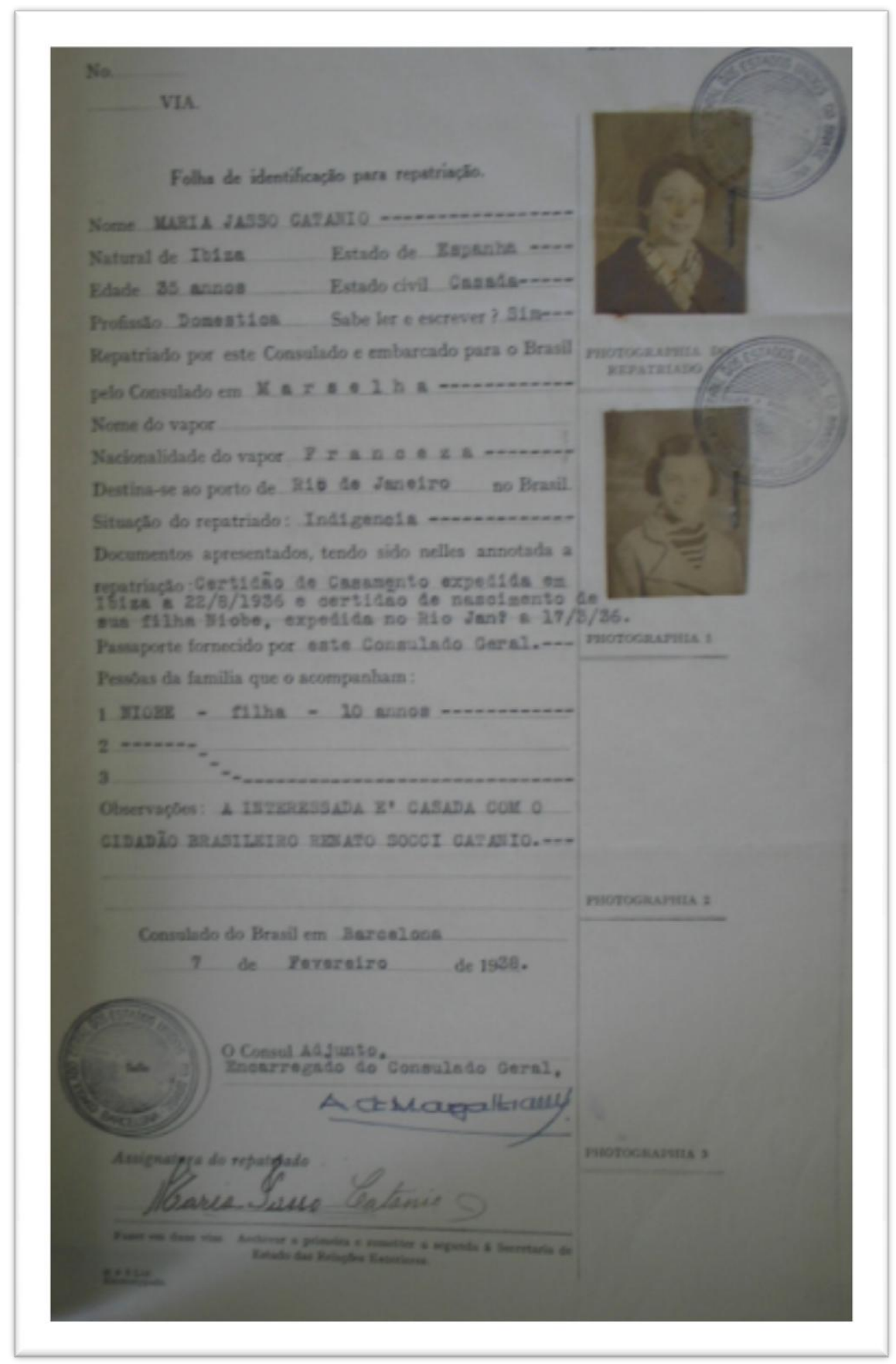

5 - Folha de identificação para repatriação de Maria Jasso Catanio e Niobe Catanio anexada ao ofício n.7 de Aluisio de Magalhães, cônsul do Brasil em Barcelona para Murillo Martins Sousa, cônsul do Brasil em Marselha. Lata 630, maço 9696. AHI/RJ. 
No caso da repatriação de homens, percebemos uma postura distinta. Magalhães demonstrava sua indignação frente à repatriação de cidadãos nascidos no Brasil, tecendo elogios ao Decreto-Lei de 1938. Em ofício a Oswaldo Aranha, antes de apresentar sua "Solução ao problema da dupla nacionalidade", Magalhães teceu considerações expressivas de seu pensamento nacionalista, afirmando que sua posição se assemelhava as de outros diplomatas frente à questão. Em sua opinião, os cidadãos que solicitaram repatriação durante o conflito militar eram "falsos compatriotas" pois:

... apenas se recordavam do lugar onde haviam nascido na hora em que as autoridades espanholas Ihes exigiam o cumprimento de suas obrigações militares. Lembravam-se que eram brasileiros porque Ihes batiam à porta as patrulhas de recrutamento. ${ }^{198}$

Magalhães menciona também que a concessão da repatriação ou de documentos que comprovassem a condição de brasileiros possibilitou o salvamento de muitas vidas. Havia o reconhecimento do sentido humanitário da repatriação naquele contexto histórico. Mesmo assim, o diplomata emitiu seu parecer sobre a necessidade de alterar as leis sobre a dupla cidadania, demonstrando seus sentimentos com relação aos cidadãos nessas condições:

Não me arrependo de os haver ajudado, mas cumpro um dever patriótico ao assinalar a Vossa Excelência a necessidade iniludível de ser resolvida, uma vez por todas, a situação desses indivíduos que não merecem, em sua grande maioria, os desvelos com que os tratei. (...) A atual legislação brasileira já se encaminhou para uma valorização mais extensa da nossa cidadania. O Brasil já não é mais um país deserto, disposto a acolher quem quer que seja e a ter como brasileiros todos aqueles que desejarem sê-lo quando a tanto 0 impelirem as conveniências do momento. O decreto-Lei 389, de 25 de abril de 1938, considera como havendo renunciado tácitamente a nacionalidade brasileira aos naturalizados que voltarem a residir por dois anos seguidos no seu país de origem ou que morarem fora do Brasil pelo

\footnotetext{
198 Ofício n.25 de Aluísio de Magalhães, cônsul em Barcelona para Oswaldo Aranha, ministro das Relações Exteriores do Brasil. Barcelona, 25 mar. 1939. Consulados Brasileiros. Ofícios recebidos de Barcelona (outubro de 1938 a junho de 1939). AHI/RJ.
} 
espaço de cinco anos consecutivos. Semelhante dispositivo, que revela a sabedoria dos nossos legisladores aplicada à defesa daquilo que possuímos de mais sagrado - a nacionalidade - poderá ser utilmente estendido a todos os indivíduos que de uma ou de outra forma gozem do privilégio da dupla nacionalidade e o queiram manter, considerando que esses semi-brasileiros em nada contribuem para a grandeza e o progresso da pátria, antes pelo contrário constituem um motivo de perene conflito com outras nações amigas.

Magalhães sugeria a seguinte alteração na lei sobre a dupla cidadania: os cidadãos nascidos no Brasil que por mais de 5 anos residissem no país de origem de seu país, perderiam a nacionalidade brasileira. Também propunha que esses indivíduos, ainda na condição de "brasileiros", não tivessem direito à proteção consular brasileira caso residissem no país de cuja cidadania também usufruísse. Tal discurso é revelador do sentimento nacionalista. A nacionalidade, vista como um valor "sagrado" não poderia ser atribuída àqueles que não estivessem integrados à sociedade brasileira.

Carlos da Silveira Martins Ramos sugeriu ao Itamaraty que o cônsul Aluísio de Magalhães fosse alertado da inconveniência de suas atitudes. Numa carta pessoal destinada a Hildebrando Accioly - naquele momento à frente da Secretaria de Relações Exteriores - Martins Ramos solicitou que o "amigo" dedicasse atenções ao ofício reservado enviado ao ministro Aranha no dia anterior, no qual expunha as atitudes empreendidas por Magalhães na qualidade de decano do corpo diplomático consular sediado em Barcelona. Afirmou que o cônsul havia se envolvido num "balaio de gatos" e devido a sua pouca experiência estava levando a representação brasileira a uma "empresa cheia de riscos." Magalhães teria enviado ao Ministério espanhol, sem conhecimento da Embaixada do Brasil, uma carta na qual pedia a mudança no regime de dupla nacionalidade. Manifestava também a intenção de, como decano do corpo consular em Barcelona, assumir a representação de interesses de mais de dez países "inimigos da República". 199

${ }^{199}$ Carta (cópia) de Carlos da Silveira Martins Ramos para Hildebrando Accioly. Barcelona, 14 out. 1938. Lata 710, maço 10325. AHI/RJ. Ofício (reservado) n. 100 de Carlos da Silveira Martins Ramos, encarregado de negócios na Espanha para Oswaldo Aranha, ministro das Relações Exteriores. 14 out. 1938. Lata 710, maço 10325. AHI/RJ. 
A carta, assim como o ofício enviado a Aranha em março de 1938, demonstram que Martins Ramos sentiu-se desrespeitado na qualidade de representante brasileiro na Espanha, ao não ter sido convidado a emitir sua opinião sobre a iniciativa de enviar ao governo espanhol uma proposta de tamanha importância. Martins Ramos provavelmente desejava que Accioly reforçasse junto a Oswaldo Aranha a necessidade de punir ou ao menos advertir o "jovem cônsul". Assim terminava sua exposição: "É mister recomendar-Ihe mais prudência e talvez menos assanhamento." 200

Mais uma vez, estamos diante de uma situação difícil se ser delimitada tendo em vista os conflitos entre os diplomatas brasileiros em missão na Espanha. Fica evidente que tais tensões eram, muitas vezes, fruto de discordâncias profissionais ou de rivalidades de caráter pessoal. $O$ fato da representação brasileira estar sediada em Barcelona gerava dificuldades em delinear os limites de ação do consulado e da Embaixada. Martins Ramos considerava que muitas das atitudes tomadas por Aluísio de Magalhães extrapolavam os limites de ação de um Consulado, resvalando em questões de sua alçada.

As sugestões de Aluisio de Magalhães para alterar as normas de preservação da nacionalidade parecem ter merecido as atenções do Itamaraty, que submeteu ao Ministério da Justiça a apreciação da questão. ${ }^{201}$ Após o conflito civil, a Embaixada e os consulados espanhóis continuaram a receber centenas de pedidos de repatriação, de matrícula e de requerimentos que comprovassem a condição de dupla nacionalidade de muitos cidadãos.

Quando havia a disposição do interessado em arcar com os custos do transporte, a repatriação era autorizada sem maiores complicações. Esse foi o caso do comerciante Bernardo Wull, que se encontrava em Barcelona a negócios quando o conflito espanhol foi deflagrado. Wull conseguiu ser repatriado pelo Consulado da Antuérpia sob alegação de estar

\footnotetext{
${ }^{200}$ Carta (cópia) de Carlos da Silveira Martins Ramos para Hildebrando Accioly ... (idem à nota anterior).

${ }^{201}$ Ofício n.72 de Matheus de Albuquerque, cônsul do Brasil em Barcelona para Oswaldo Aranha, ministro das Relações Exteriores do Brasil. Barcelona, 30 ago.1939. Consulados Brasileiros. Ofícios recebidos de Barcelona (julho de 1939 a abril de 1940). AHI/RJ.
} 
em condição de "indigência". No entanto, segundo o cônsul nessa cidade o repatriado teria se comprometido a indenizar o Tesouro Nacional, assumindo as despesas referentes à passagem de terceira classe. ${ }^{202}$

A inércia ou a impossibilidade da Embaixada e dos consulados em resolver alguns pedidos de repatriação, mesmo após o término do conflito, levou a situações curiosas, como a da espanhola Agustina Romo y Mayo. Residente em Havana, capital cubana, Agustina resolveu escrever diretamente a Getúlio Vargas, solicitando providências para a libertação e a repatriação de seu irmão, prisioneiro em Salamanca. Nesta carta, de 24 de novembro de 1939, a espanhola explicava que seu irmão não havia cometido delitos graves e que, informada sobre o indulto que o governo franquista daria para esses casos, solicitava a intervenção para sua soltura e repatriação, uma vez que o prisioneiro não havia renunciado à sua nacionalidade brasileira. ${ }^{203}$ É provável que a secretaria da Presidência da República não tenha dado maiores atenções ao relato, encaminhando ao Itamaraty a referida carta.

Em março de 1938, Aluísio de Magalhães explicou ao Itamaraty que Martin Barrazal Fernandez, que possuía a cidadania brasileira, teria sido incorporado forçosamente às fileiras nacionalistas e preso pelas tropas republicanas. O cônsul informou que conseguira negociar com a República espanhola a troca da condenação de Fernandez por sua expulsão para o Brasil. Informava que o referido cidadão teria sido encaminhado à fronteira francesa e entregue ao Consulado brasileiro em Marselha, que se encarregaria de enviá-lo ao Brasil. ${ }^{204}$ Esse caso é sintomático de quanto a dupla cidadania se constituía numa "faca de dois gumes" para os que a possuíam. Barrazal, mesmo comprovando sua condição de brasileiro foi integrado às tropas lideradas por Franco. Não só de benefícios revestia-se a dupla cidadania, como opinaram muitos diplomatas brasileiros.

\footnotetext{
202 Ofício n. 5 (cópia) de Octaviano Machado para Mario de Pimentel Brandão, ministro Interino das Relações Exteriores. Antuérpia, 11 fev. 1937. Lata 630, maço 9696. AHI/RJ.

${ }^{203}$ Carta (cópia) de Agustina Romo y Mayo para o presidente Getúlio Vargas. Havana, 24 nov. 1939. Lata 630, maço 9696. AHI/RJ.

204 Ofício n. 20 de Aluisio de Magalhães, cônsul do Brasil em Barcelona para Oswaldo Aranha, ministro das Relações Exteriores do Brasil. Barcelona, 28 mar. 1938. Consulados Brasileiros. Ofícios recebidos de Barcelona (maio de 1936 a setembro de 1938). AHI/RJ.
} 
Durante o conflito civil, foram registrados outros casos semelhantes aos descritos acima, ou seja, de cidadãos que diante de uma situação mais grave, como a prisão ou a condenação, recorriam à Embaixada do Brasil na Espanha. A pesquisadora Esther Gambi Gimenez afirma que o cidadão brasileiro Patrocinio Rubio Sauce, trabalhador residente em Madri, foi detido e após breve julgamento fuzilado. Sua viúva teria recorrido à Embaixada em busca de ajuda. Ao pedir explicações ao governo espanhol, a representação brasileira teria recebido somente as condolências, ficando 0 caso sem solução. ${ }^{205}$

Outro caso que gerou intensa troca de correspondência entre a Embaixada, o Consulado em Barcelona e o Itamaraty foi o de Emilio Castrillo. O relatório policial de Venacio Ayres, delegado de Ordem Política e Social, sugeria, em novembro de 1937, sua expulsão do Brasil. Para Ayres, Castrillo era um elemento indesejável por defender em rodas de amigos o governo "comunista" da Espanha, além de criticar as idéias fascistas e integralistas. ${ }^{206}$ Apesar de não declarar-se comunista, Castrillo foi expulso do Brasil em 1937, configurando as práticas autoritárias do governo Vargas contra os defensores das ideologias de esquerda.

\footnotetext{
${ }^{205}$ Esther Gambi Giménez, op. cit, p.69.

${ }^{206}$ Parecer de Venâncio Ayres, delegado de Ordem Social. Delegacia de Ordem Social. São Paulo, 9 nov. 1937. Prontuário 4872 - Emilio Castrilho Rodrigues. DEOPS/SP, AESP.
} 


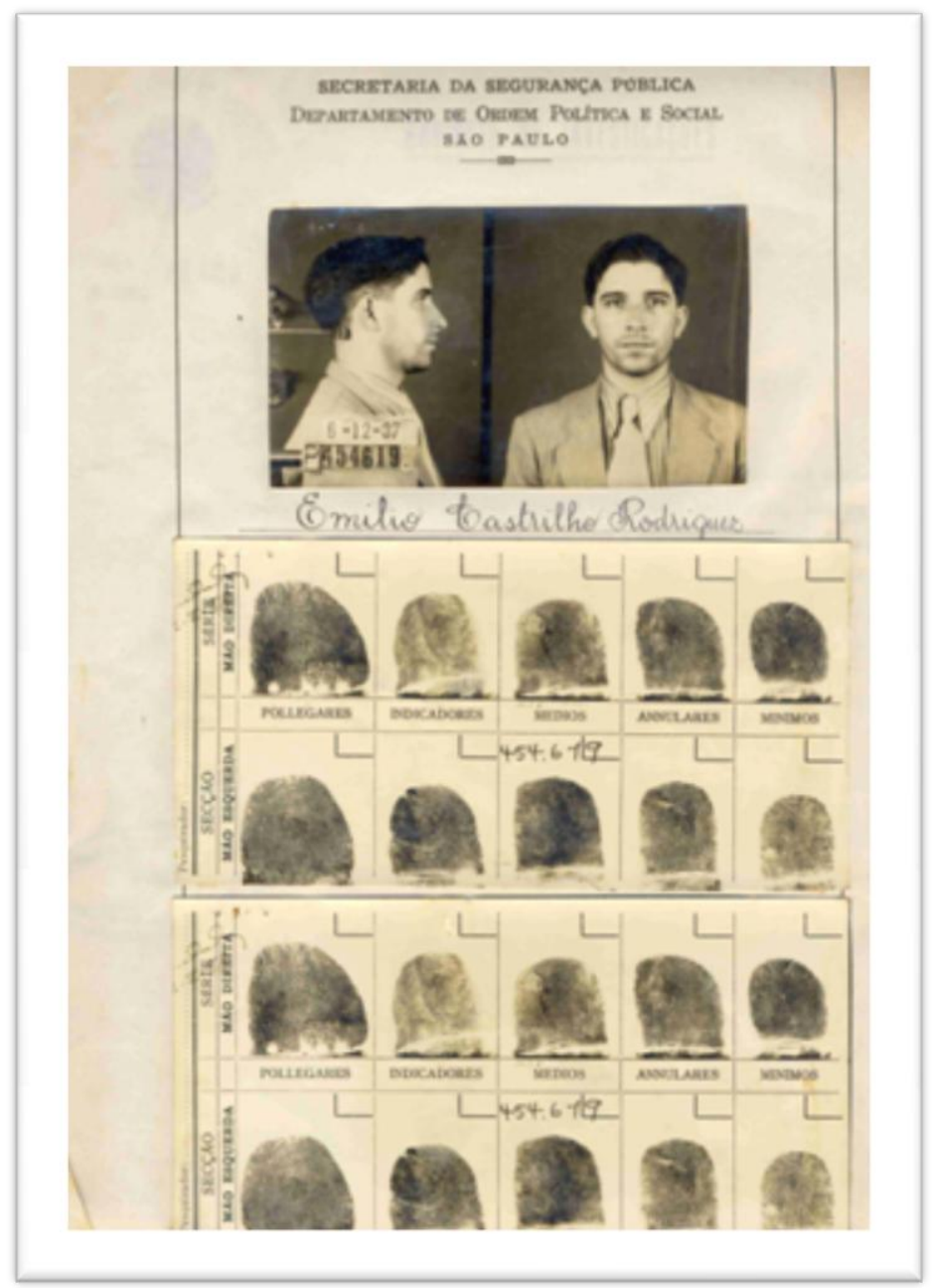

6 - Fotografia (frente e perfil) e ficha dactiloscópica e de identificação de Emilio Castrilho Rodrigues. Departamento de Ordem Política e Social. São Paulo, 06 de dezembro de 1937. Prontuário 4872 - Emílio Castrilho Rodrigues. DEOPS/SP, AESP.

O fator decisivo para a efetivação ou não da repatriação era a forma como os diplomatas brasileiros conduziam a questão junto ao Itamaraty e ao governo espanhol. Em julho de 1938 Martins Ramos, enquanto encarregado de negócios do Brasil em Barcelona, intermediou o pedido de Emilio Castrillo de que the fosse concedido o direito de regressar ao Brasil. Ficou evidenciado que esse cidadão fora vítima das arbitrariedades cometidas pelas instituições do governo Vargas responsáveis pela expulsão de estrangeiros do Brasil. ${ }^{207}$

Martins Ramos defendeu junto a Oswaldo Aranha o Estado de Direito e o pronto cumprimento das leis brasileiras no que tange aos direitos e 207 Sobre a expulsão de estrangeiros no Brasil ver: Mariana Cardoso dos Santos Ribeiro. Expulsão de estrangeiros: o mito da nocividade no Brasil (1937-1945). São Paulo, 2008. Tese (Doutorado em História Social) - FFLCH, USP. 
deveres dos estrangeiros. Afirmava que Castrillo Rodriguez havia the dito ter sido injustamente expulso do Brasil por conta das denúncias de comunismo, motivadas por questões de ordem pessoal. Segundo Martins Ramos a expulsão havia sido efetiva em contrariedade com as leis brasileiras, pois se tratava de um cidadão casado com mulher brasileira e pai de seis filhos nascidos no Brasil. ${ }^{208}$

Como em outros momentos, Martins Ramos não se furtou em defender, com firmeza, seu posicionamento contrário às medidas de caráter arbitrário e autoritário do governo Vargas para com os taxados genericamente de "comunistas". Ramos provavelmente conhecia os meandros do processo que levava os cidadãos estrangeiros a serem expulsos por crime político, ou seja, a necessidade de confirmação da decisão pelo Ministério da Justiça e a ratificação pelo Presidente da República. No entanto, sabia que naquele momento político brasileiro deveria minimizar suas críticas, atribuindo a expulsão arbitrária de Castrillo à falta de preparo das polícias brasileiras: "Da falta de escrúpulos de um agente policial, que a educação moral deficiente não soube preparar para funções de tão graves responsabilidades, quantos crimes não se comettem diariamente em nome da Justiça?". Também afirmava tratarse de um cidadão de bem que parecia sofrer com a falta dos filhos e da mulher. ${ }^{209}$

Sem condições para expor suas verdadeiras opiniões acerca do encaminhamento dado pelo governo Vargas para casos semelhantes, Ramos não perdeu a oportunidade de solicitar a Aranha que o caso fosse revisto pela justiça brasileira:

Vossa Excellencia, cujo espírito de justiça e equidade ninguém ignora, encaminhará seguramente a quem de direito a carta inclusa, encarecendo se assim for o caso, a necessidade de revisão do processo de expulsão de Emilio Castrillo Rodriguez. ${ }^{210}$

\footnotetext{
208 Ofício n.54 de Carlos da Silveira Martins Ramos, encarregado de negócios em Barcelona para Oswaldo Aranha, ministro das Relações Exteriores do Brasil. Barcelona, 16 jul. 1938. Missões Diplomáticas Brasileiras. Ofícios recebidos de Madri (julho de 1937 a 1938). AHI/RJ. ${ }^{209}$ Idem.

${ }^{210}$ Idem.
} 
Oswaldo Aranha encaminhou o caso ao Ministério da Justiça que revogou a decisão de expulsão. Três meses depois, Castrillo Rodriguez apresentou-se ao Consulado em Barcelona alegando a sua condição de brasileiro e portando um documento que afirmava ser a revogação da expulsão. Aluisio de Magalhães informou que Castrillo havia lutado nas fileiras republicanas através das Brigadas Internacionais, pedindo que diante de tais informações, a Secretaria de Estado das Relações Exteriores the orientasse se devia ou não facilitar a sua repatriação ao Brasil. ${ }^{211}$

Em dezembro de 1938, o Itamaraty autorizou o Consulado a providenciar a repatriação de Castrillo Rodriguez, o que foi efetivado por intermédio do Consulado de Marselha. ${ }^{212} \mathrm{O}$ posicionamento firme de Martins Ramos em denunciar ao Itamaraty a situação de Castrillo como irregular, certamente contribuiu para que o desfecho da situação fosse favorável ao espanhol. Vítima das arbitrariedades cometidas pelo governo Vargas, Castrillo foi um dos raros e poucos estrangeiros a terem sua situação revista pela justiça brasileira.

\section{O caso "Ameletto Branda"}

Dos casos de repatriação que pudemos analisar junto à documentação diplomática, nenhum é mais curioso e intrigante que o de Ameletto Branda. O desenrolar dessa história constituiu-se num verdadeiro "quebra-cabeças", dadas as referências dispersas que nos confirmam que na representação diplomática brasileira foram cometidas sérias irregularidades relacionadas à emissão de passaportes.

Em julho de 1938, Carlos da Silveira Martins Ramos relatou a Oswaldo Aranha que Nelly Vidal, secretária particular de Alcebíades Peçanha,

\footnotetext{
${ }^{211}$ Ofício n. 87 de Aluisio de Magalhães, cônsul do Brasil em Barcelona para Oswaldo Aranha, ministro das Relações Exteriores do Brasil. Barcelona, 28 out.. 1938. Consulados Brasileiros. Ofícios recebidos de Barcelona (outubro de 1938 a junho de 1939). AHI/RJ.

${ }^{212}$ Ofício n. 48 de Matheus de Albuquerque, do Consulado Geral de Barcelona para Oswaldo Aranha, ministro das Relações Exteriores do Brasil. Barcelona, 27 mai. 1939. Consulados Brasileiros. Ofícios recebidos de Barcelona (outubro de 1938 a junho de 1939). AHI/RJ.
} 
havia praticado um sério delito. Explicou que de acordo com suas investigações, descobriu que o Sr. Real Crespo, pertencente à uma família abastada de Madri, obteve da referida secretária um passaporte e uma certidão de nascimento brasileiros em nome de Ameletto Branda. Ao tentar deixar o território republicano utilizando-se dessa documentação, teria sido reconhecido por um de seus ex-funcionários, que relatou às autoridades competentes a farsa. $^{213}$

A situação tornara-se complexa, uma vez que Ramos tinha sob seu poder a cópia de uma carta enviada a Julio Alvarez del Vayo, ministro de Estado espanhol, na qual o suposto Branda solicitava ajuda por não conseguir obter junto à Embaixada sua certidão de nascimento, requerida há mais de dez meses. Tal carta foi enviada para Martins Ramos por Andrés Rodriguez Barbeito, ex-cônsul em São Paulo que, naquele momento, trabalhava como secretário particular de Alvarez del Vayo. ${ }^{214}$ Diante dessas circunstâncias a Embaixada do Brasil ficava exposta a uma situação que, a qualquer momento, poderia transformar-se num escândalo. Ramos não poderia fornecer a certidão ao requerente - supostamente o verdadeiro Branda - porque essa teria sido apreendida pela Polícia de Madri quando da prisão de Real Crespo.

Não foi possível conhecer a forma pela qual a questão foi resolvida. O fato é que em dezembro de 1938, Ameletto Branda foi repatriado ao Brasil após a autorização do Itamaraty, tendo embarcado em Marselha em direção ao porto de Santos. ${ }^{215}$

De acordo com Martins Ramos, a secretária Nelly Vidal teria sido presa diante das evidências de irregularidades na emissão de passaporte falso. Outros fatos também podem estar relacionados à sua prisão, como o envolvimento com o caso dos asilados, mencionado anteriormente. Ramos

${ }^{213}$ Ofício n. 56 (reservado) de Carlos da Silveira Martins Ramos, encarregado de negócios em Barcelona para Oswaldo Aranha, ministro das Relações Exteriores do Brasil. Barcelona, 24 jul. 1938. Lata 630, maço 9696. AHI/RJ.

${ }^{214}$ Ofício (cópia) de Andres Rodriguez Barbeito, secretário do ministro de Estado Julio Alvarez del Vayo para Carlos da Silveira Martins Ramos, encarregado de negócios do Brasil na Espanha. Barcelona, 20 jun. 1938. Carta (cópia) de Ameletto Branda para Julio Alvarez del Vayo, Ministro de Estado. Valencia, 11 jun. 1938. Anexos ao ofício mencionado na nota anterior. Tais documentos nos possibilitou conhecer o destino de Andres Rodriguez Barbeito, que após ter sido expulso do Brasil por liderar as atividades em prol da propaganda republicana em São Paulo, obteve, na Espanha, o cargo de secretário de Alvarez del Vayo.

${ }^{215}$ Ofício n. 3 de Aluisio de Magalhães, cônsul do Brasil em Barcelona para Oswaldo Aranha, ministro das Relações Exteriores do Brasil. Barcelona, 07 jan. 1939. Lata 630, maço 9696. $\mathrm{AHI} / \mathrm{RJ}$. 
enviou ao Itamaraty a cópia da carta em que Peçanha, entre outras coisas, tratava do caso "Ameletto Branda".

Referindo-se a esse último aspecto e à atuação de sua secretária, Peçanha concluía sua carta:

Sobre a queixa enviada ao Ministro de Estado pelo "brasileiro", não me lembro do caso, mas quando me lembrasse não me abrandaria a repulsa que sinto por essas brasilidades forçadas pela lei, ou melhor, pelo acto do Ministerio de "Gobernación" não reconhecendo a nacionalidade estrangeira dos filhos de espanhóes que residem em Espanha comprehendendo-os portanto no serviço militar. Branda porém não quer saber disto. A Senhorita Vidal, nesse caso como em outros, agiu com a doença que os médicos lhe reconhecem, sobretudo que sabem que ella havendo sido operada em Vienna, há alguns annos, por uma celebridade mundial d'alli, ficou, não obstante com a circulação alterada, o que coincidindo com a edade, produziu-lhe phenomenos nervosos taes como o delírio do prestigio e o automatismo carmínico que lhe fez tanto mal. Enfim, esse lamentável caso de minha secretaria (aqui não tenho outra) só pode ser devidamente examinado mais tarde. $^{216}$

Segundo a interpretação de Martins Ramos, Peçanha teria se referido com seus trocadilhos e suas pilhérias, à influência que Carmen Selgas, asilada na Embaixada em Madri, teria tido sobre as atitudes de Nelly Vidal. A rica família Selgas era proprietária do anexo à Embaixada, tendo seus membros permanecidos ali na condição de asilados. Martins Ramos, ao enviar ao Itamaraty a cópia da carta de Peçanha, alegou que não havia "intenção em desrespeitar a pessoa daquele embaixador", mas pedia a atenção de Oswaldo Aranha para os termos inseridos na correspondência que, segundo ele, traduziam "um estado mental positivamente enfermiço". ${ }^{217}$

A carta escrita pelo ex-embaixador, então aposentado e residindo próximo a Perpignan, ainda que confusa, nos permite verificar que, assim como outros colegas do Itamaraty, o diplomata via nas solicitações de repatriação um aviltamento à nação brasileira.

No segundo semestre de 1939, o caso Ameletto Branda (ou Brandi), aparentemente resolvido no ano anterior com a repatriação do

${ }^{216}$ Carta (cópia) de Alcebíades Peçanha para Carlos da Silveira Martins Ramos. Villa la Pommerais, 22 jul. 1938. Anexo n. 1 ao ofício n. 60 (reservado) de Carlos da Silveira Martins Ramos, encarregado de negócios em Barcelona para Oswaldo Aranha, ministro das Relações Exteriores do Brasil. Barcelona, 02 ago. 1938. Lata 630, maço 9696. AHI/RJ.

${ }^{217}$ Idem. 
"verdadeiro" cidadão, voltou a intrigar o Itamaraty. Oswaldo Aranha encaminhou a Francisco Campos, ministro da Justiça, uma carta na qual Andres Rodriguez Marin confessou que no ano anterior havia conseguido ser repatriado pelo Consulado de Barcelona com o nome de "Ameletto Brandi". Marin justificou o ato ilícito como uma tentativa de fugir dos "rojos" de seu país, detalhando também a situação de seu irmão que estava internado no Juqueri e que o teria auxiliado na documentação falsa para conseguir deixar a Espanha. $^{218}$

Demonstrando ingenuidade ou falta de consciência da gravidade do que havia exposto, Marin solicitava que o governo brasileiro lhe concedesse a "deportação", assim como a de seu irmão, uma vez que as circunstâncias políticas da Espanha já Ihe permitiam o regresso.

Junto ao processo de repatriamento aberto pelo Ministério da Justiça em nome de Ameletto Branda Luzzi, encontramos a carta assinada por Oswaldo Aranha, mencionada acima, e um documento no qual há o parecer manuscrito de Luis Bordini, sugerindo a necessidade de levar o caso até o Interventor Federal de São Paulo. ${ }^{219}$ Referências à efetivação ou não da deportação de Rodriguez Marin não estão anexas ao processo, que finaliza com a cópia do ofício enviado ao Interventor Federal de São Paulo, Adhemar de Barros, pelo Ministério da Justiça encaminhando o caso. ${ }^{220}$

Através deste rol de documentos é possível conhecer os meandros que permitiram a repatriação de Rodriguez Marins com a falsa identidade de Ameletto Branda. O "quebra-cabeça" em que este caso se constitui não pode ser totalmente montado. No entanto, nos colocou diante de uma situação que pôs à prova a capacidade da representação brasileira em impedir atos ilegais relacionados à repatriação de "brasileiros".

\footnotetext{
${ }^{218}$ Carta (cópia) de Andres Rodriguez Marin para Oswaldo Aranha. São Paulo, 27 jun. 1939. Anexo ao ofício (cópia) de Oswaldo Aranha, ministro das Relações Exteriores para Francisco Campos, ministro da Justiça. Rio de Janeiro, 02 set. 1939. Lata 630, maço 9696. AHI/RJ.

${ }^{219}$ Parecer de Luis Bordini, diretor de Seção interna. Rio de Janeiro, 19 set. 1939. Ministério da Justiça, Subsérie Repatriamento, Processo n. 9774/39. Arquivo Nacional/RJ.

220 Ofício (cópia) do Ministério da Justiça para Adhemar de Barros, interventor federal do Estado de São Paulo. Rio de Janeiro, 12 out. 1939. Ministério da Justiça, Subsérie Repatriamento, Processo n. 9774/39. Arquivo Nacional/RJ.
} 


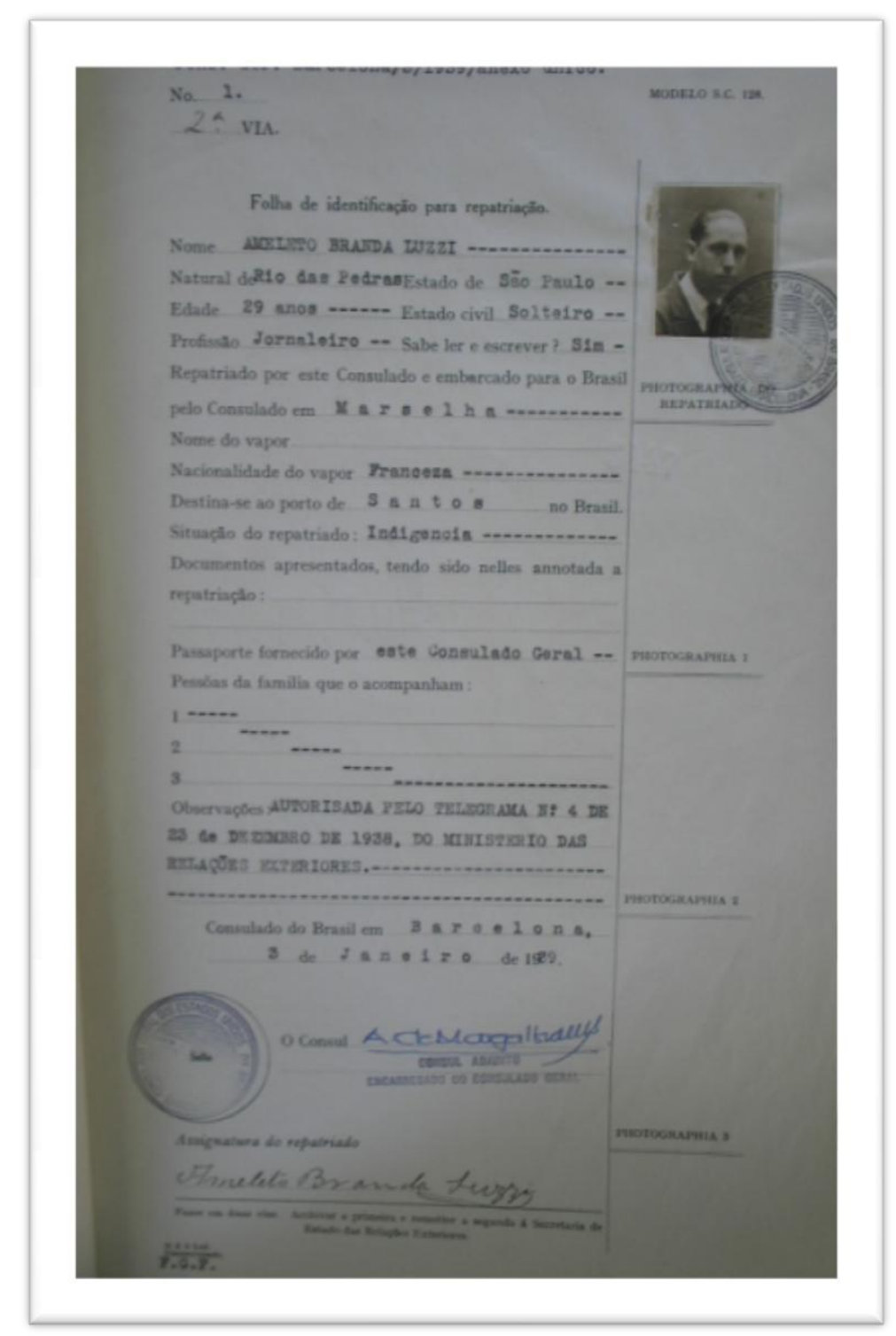

7 - Folha de identificação para repatriação de Ameletto Branda Luzzi anexada ao ofício n. 3 de Aluisio de Magalhães, cônsul do Brasil em Barcelona para Oswaldo Aranha, Ministro das Relações Exteriores do Brasil. Barcelona, 07 jan. 1939. Lata 630, maço 9696. AHI/RJ.

\section{Repatriar os indesejáveis?}

Para milhares de espanhóis, o término das operações militares em abril de 1939 não significou o fim da guerra. O que poderia ser o começo da paz ou da reconciliação entre espanhóis significou nas palavras de Paul Preston, "el anuncio de la institucionalización de la venganza a gran escala 
contra la izquierda derrotada."221 A bibliografia referente ao assunto, assim como os inúmeros relatórios da missão diplomática brasileira sobre a situação política da Espanha nos meses subseqüentes ao conflito, nos permitem entrever que as atrocidades da guerra, como os fuzilamentos, continuaram a ocorrer. Os derrotados no conflito foram tratados com severidade, tendo Franco se esforçado para manter abertas as feridas do conflito. A ditadura franquista procurou extirpar do seio da sociedade os republicanos, considerados como um exército de estrangeiros. Estima-se que $70 \%$ dos quartéis foram transformados em prisões e de acordo com o relato do Conde Ciano, em Madri eram efetivadas de 200 a 250 execuções diárias. ${ }^{222}$ Os prisioneiros, centenas de milhares, eram utilizados como força de trabalho em obras de barragens, estradas, pontes e canais de irrigação. Vinte mil trabalharam na construção do Valle de los Caídos, um gigantesco monumento dedicado a todos que tombaram em nome da causa nacionalista e que serviria de mausoléu, préconcebido pelo próprio Franco.

Diante dessa realidade, entre 1939 e 1940, a quantidade de pedidos de repatriação junto às representações brasileiras continuou a se elevar. A proteção consular do Brasil era a saída encontrada por centenas de espanhóis que haviam lutado em defesa do regime republicano e que agora temiam as represálias do governo franquista.

Por também serem considerados espanhóis, de acordo com jus sanguinis, muitos cidadãos nascidos no Brasil foram involuntariamente incorporados às fileiras do Exército, defendendo a República espanhola. Em agosto de 1939, Matheus de Albuquerque, cônsul brasileiro em Barcelona, informou Oswaldo Aranha que, para esses casos, continuava a negar matrícula, alegando aos solicitantes que o assunto era "pendente de solução superior". ${ }^{223}$ As instruções do Itamaraty provavelmente foram dadas, no sentido de dificultar a matrícula e o reconhecimento da condição de nacionais desses

\footnotetext{
${ }^{221}$ Paul Preston. La Guerra Civil. Las fotos que hicieron historia. Esfera de los libros: $\mathrm{J}$ de J Editores, 2005, p.9.

${ }_{222}$ Paul Preston. A Guerra Civil de Espanha, op. cit. p.202.

${ }^{223}$ Ofício n.72 de Matheus de Albuquerque, cônsul do Brasil em Barcelona para Oswaldo Aranha, ministro das Relações Exteriores do Brasil. Barcelona, 30 ago.1939. Consulados Brasileiros. Ofícios recebidos de Barcelona (julho de 1939 a abril de 1940). AHI/RJ.
} 
indivíduos. É o que se pode deduzir das afirmações de Albuquerque de que assim continuaria a proceder até que a questão fosse resolvida em definitivo.

A resposta do Consulado brasileiro a esses cidadãos estava de acordo com a política do governo Vargas de evitar a entrada no Brasil de elementos que estavam identificados com a República espanhola. Ao MRE não interessava averiguar se esses eram efetivamente partidários dos ideais de esquerda ou se haviam defendido o governo por terem sido incorporados involuntariamente ao exército nacional. Constatamos que não havia interesse em fazer essa "triagem" para receber os elementos desejados do ponto de vista ideológico. No caso desses cidadãos, o fato de terem lutado ao lado da República já era suficiente para considerá-los indesejáveis e "subversivos" em potencial.

No entanto, as arbitrariedades do governo franquista para com os brasileiros que possuíam dupla cidadania chegaram a sensibilizar àqueles diplomatas que, mesmo avessos ao comunismo, tentaram defender os direitos desses cidadãos. Segundo Argeu Guimarães, os pedidos de repatriação ou de documentos que comprovassem a nacionalidade brasileira eram motivados pela prisão por suspeita de extremismo, incorporação forçada ao exército e o impedimento de deixar o país. Guimarães informou a Aranha que suas solicitações junto ao governo espanhol para que cessassem os "constrangimentos" contra esses cidadãos não obtiveram êxito. ${ }^{224}$

A atuação do Itamaraty nesse aspecto apresentou-se dúbia. Em alguns momentos permitia-se o auxílio a esses cidadãos, mas ao mesmo tempo, havia uma política de contenção do repatriamento dos mesmos. Em 1940, uma carta de Oswaldo Aranha a Francisco Campos evidenciou sua preocupação em coibir a entrada de espanhóis republicanos no Brasil. Nela, o chefe do Ministério das Relações Exteriores explicava que um grupo de espanhóis residentes no Brasil havia solicitado ao presidente Getúlio Vargas que o Brasil acolhesse os refugiados espanhóis.

${ }^{224}$ Ofício n. 87 de Argeu Guimarães, encarregado dos negócios do Brasil na Espanha para Oswaldo Aranha, ministro das Relações Exteriores do Brasil. San Sebastián, 12 jul. 1939. Missões Diplomáticas Brasileiras. Ofícios recebidos de Madri (abril a dezembro de 1939). AHI/RJ. 
Aranha solicitou providências ao ministro da Justiça, referindo-se aos refugiados genericamente como "comunistas". 225 Tais providências foram tomadas dias depois, quando Campos enviou para Adhemar de Barros, interventor federal de São Paulo, uma petição para que impedisse essa iniciativa que "colide com os altos interesses da defesa do país contra a propagação de ideologias extremistas..."226

Entre 1938 e o início de 1939, outro assunto passou a ser alvo das preocupações do Itamaraty: a repatriação dos brasileiros que lutaram a favor dos republicanos como voluntários através das Brigadas Internacionais. $O$ caráter internacional da guerra na Espanha tornou-se evidente na formação das Brigadas Internacionais que, organizadas e dirigidas pela III Internacional Comunista, mobilizou cerca de sessenta mil voluntários do mundo inteiro para lutar pelos ideais da República espanhola. Milhares destes cidadãos foram motivados pela idéia de que naquele país se desencadeava uma luta contra um inimigo mundial: o fascismo.

O Comitê de Não Intervenção criado para assegurar que os países europeus e a União Soviética não auxiliariam com tropas e armas ambos os lados em luta na Espanha, nunca foi respeitado, tendo atuação praticamente nula. Ao final de 1937, a Liga das Nações chamou para si as negociações de não intervenção, na tentativa de diminuir o auxílio alemão e italiano ao campo nacionalista. O governo republicano aceitou a decisão da referida organização de retirar os estrangeiros que lutavam pelas Brigadas Internacionais. ${ }^{227}$ Essa medida não impediu que Itália e Alemanha - que nunca haviam se submetido ao controle do Comitê de Não Intervenção continuassem auxiliando Franco na tarefa de derrotar os republicanos. ${ }^{228}$

\footnotetext{
${ }^{225}$ Informe reservado (cópia) de Osvaldo Aranha para Francisco Campos, ministro de Estado da Justiça e Negócios Interiores. Ministério das Relações Exteriores. Rio de Janeiro, 7 jun. 1940. Prontuário 3817 - Andres Rodrigues Barbeito. DEOPS-SP/AESP.

${ }^{226}$ Informe reservado (cópia) de Francisco Campos para Adhemar de Barros, interventor federal de São Paulo em 03 jul. 1940, fl 58-59. Prontuário 3817 - Andres Rodrigues Barbeito. DEOPS-SP/AESP.

${ }^{227}$ José Carlos Sebe Bom Meihy; Claudio Bertolli Filho. A Guerra Civil Espanhola. São Paulo: Ática, 1996, p.30. Coleção História em movimento.

${ }^{228}$ Paulo Roberto de Almeida. O Brasil e a Guerra Civil Espanhola: participação de brasileiros no conflito. Artigo on-line, p. 16. Disponível em:

http://www.hispanista.com.br/revista/artigo37esp.htm. Acesso em 15 out. 2007.
} 
O desmantelamento das Brigadas Internacionais chamou a atenção do governo Vargas, pois cerca de quarenta brasileiros lutaram como brigadistas. Grande parte desse grupo esteve envolvida no levante comunista de 1935. Fracassada a rebelião, muitos foram processados pelo Tribunal de Segurança Nacional. ${ }^{229}$

Para os voluntários brasileiros, assim como para outros estrangeiros que ofereciam suas vidas pela causa espanhola, o que ocorria em território espanhol detinha um significado universal, uma vez que os rebeldes espanhóis eram identificados e tratados genericamente de "fascistas". Se por um lado, a presença de voluntários brasileiros na Espanha representava uma escolha internacional, por outro, tal atitude reforçava um forte sentimento de comprometimento com causas nacionais. Nesse sentido, apoiar a República espanhola não se constituía apenas em um ato de solidariedade, pois como afirma Eric Hobsbawn "questões que eram essencialmente domésticas em cada país foram trazidas a luta em campos de batalha de um país tão distante e desconhecido pela maioria dos trabalhadores". ${ }^{230}$

O receio de que esses indivíduos retornassem ao Brasil clandestinamente fez com que a Polícia Política do Rio de Janeiro enviasse ao DEOPS de São Paulo, em março de 1939, uma relação nominal dos "brigadistas brasileiros", juntamente com a solicitação de vigilância nos pontos de desembarque. ${ }^{231}$ É possível que essa lista tenha sido elaborada graças às informações enviadas ao Itamaraty pela Embaixada do Brasil em Barcelona

\footnotetext{
${ }^{229}$ Ismara Izepe de Souza. República Espanhola, op. cit., p. 28. Neste livro, que integra a Série Inventário DEOPS, foram publicadas as considerações parciais da pesquisa de Iniciação Científica que teve apoio da FAPESP - Fundação de Amparo a Pesquisa do Estado de São Paulo. Tivemos como objetivo verificar o discurso policial veiculado sobre a Guerra Civil da Espanha baseando-se na vasta documentação do acervo DEOPS-SP. Analisamos entre outros temas, os prontuários policiais dos brasileiros e estrangeiros que foram à Espanha lutar pela República Espanhola. Outros trabalhos que têm como tema a participação de brasileiros na Guerra Civil Espanhola: Thaís Battibugli. A militância antifascista: comunistas espanhóis na Guerra Civil Espanhola (19361939). São Paulo, 2000. Dissertação (Mestrado em História Social) - FFLCH, USP; Paulo Roberto de Almeida. "O Brasil e a Guerra Civil Espanhola: participação de brasileiros no conflito". Artigo online, op. cit. Apolônio de Carvalho. Vale a Pena Sonhar. Rio de Janeiro: Rocco, 1997; José Gay da Cunha. Um brasileiro na Guerra Civil Espanhola. São Paulo: Alfa-Ômega, 1986.

${ }_{230}$ Eric J.Hobsbawn. Nações e Nacionalismo desde 1780. Trad. Maria Célia Paoli e Ana Maria Quirino. Rio de Janeiro: Paz e Terra, 1990, p. 175.

231 "Relação dos Brigadistas Brasileiros", (s/d); Ofício do delegado especial de Segurança Política e Social, Batista Teixeira ao delegado de Segurança Política e Social de São Paulo, Carneiro da Fonte. Delegacia Especializada de Segurança Política e Social. Rio de Janeiro, 17 mar. 1939. Prontuário 5290 - Carlos da Costa Leite. DEOPS-SP/AESP.
} 
que, durante meses, esteve empenhada em resolver a questão dos brasileiros que foram internados em campos de concentração na França. A maioria dos voluntários na Espanha partiu de barco e de trem para este país, encontrando opressões e sofrimentos piores do que os da Guerra Civil. ${ }^{232}$

Como encarregado de negócios do Brasil na Espanha, Carlos da Silveira Martins Ramos solicitou ao Ministério das Relações Exteriores, instruções de como proceder no caso dos voluntários brasileiros que se encontravam na fronteira com a França. ${ }^{233}$ Durante todo o ano de 1938 essa questão não pode ser definida, apesar da boa vontade do encarregado de negócios. Expondo a situação dos ex-voluntários de várias nacionalidades que encontravam dificuldades em atravessar a fronteira da Espanha com a França, Martins Ramos explicou que ao governo republicano espanhol interessava a evacuação desses combatentes para os seus países de origem. Dessa forma, se evitaria um conflito com o governo francês. Martins Ramos também expôs o perfil político dos cerca de quarenta voluntários brasileiros, afirmando que se existiam aqueles que não desejavam ser repatriados por estarem condenados no Brasil, havia também aqueles que não tinham envolvimento algum com a política brasileira, desejando o auxílio da representação diplomática brasileira para regressarem a seu país. As orientações solicitadas ao Itamaraty referiamse especialmente a esses últimos.

Em resposta às indagações de Martins Ramos, a Secretaria de Estado das Relações Exteriores determinou o envio de uma lista completa dos brasileiros que combateram pela República. Solicitava também que fosse feita a sugestão de quais deveriam realmente ser repatriados. ${ }^{234} \mathrm{Em}$ dezembro de 1939, o Ministério das Relações Exteriores orientou a Embaixada do Brasil a agir com cautela, já que entre esses brasileiros poderiam estar cidadãos condenados pelo Tribunal de Segurança Nacional. Alertava também para o fato

\footnotetext{
${ }^{232}$ Hugh Thomas, op. cit., p.287.

${ }^{233}$ Ofício de Carlos da Silveira Martins Ramos, encarregado de negócios do Brasil na Espanha para Oswaldo Aranha, ministro das Relações Exteriores do Brasil. Barcelona, 29 dez. 1938. Missões Diplomáticas Brasileiras. Ofícios recebidos de Madri (julho de 1937 a 1938). AHI/RJ.

${ }^{234}$ Despacho de C. de Ouro Preto em nome do ministro de Estado para Carlos da Silveira Martins Ramos, encarregado de negócios do Brasil na Espanha. Rio de Janeiro, 05 jan. 1939. Missões Diplomáticas Brasileiras. Despachos enviados a Madri (1935-1941). AHI/RJ.
} 
de que muitos teriam nacionalidade duvidosa, sendo necessárias apurações sobre esses casos. ${ }^{235}$

A documentação consultada não nos permite afirmar em quais circunstâncias esses brasileiros retornaram ao Brasil. Sabemos, no entanto, que a maioria dos voluntários brasileiros que combateram na Espanha estava condenada por atividades comunistas, portanto, impossibilitada de retornar ao Brasil. Em abril de 1940 Luis Martins de Souza Dantas, embaixador do Brasil em Paris, solicitou ao Itamaraty a autorização para o Consulado de Marselha fornecer um atestado de nacionalidade para os brasileiros Hermenegildo de Assis Brasil, Costa Leite, Dinarco Reis e Apolônio de Carvalho, internados em um campo de concentração nos Pirineus. Explicava que se fazia necessário essa documentação, tendo em vista que esses haviam sido avisados que seguiriam para a linha de frente..$^{236}$

A tentativa de Souza Dantas auxiliar os brigadistas brasileiros malogrou. O setor consular lembrou a SERE de que a solicitação era improcedente e que já havia avisado a Embaixada de que tais brasileiros haviam perdido a nacionalidade brasileira, de acordo com o artigo 2 do Decreto-Lei n. 389 de abril de $1938 .{ }^{237}$ Tal artigo previa que perderia a nacionalidade o brasileiro que "sem licença do presidente da República, aceitar comissão ou emprego remunerado de governo estrangeiro, como tal considera a prestação voluntária do serviço militar." 238

Sob a mesma alegação, foi retirada a cidadania brasileira de Manuel Serrano Manzano, cidadão nascido em Paranapiacaba e que, segundo o Consulado brasileiro em Barcelona, havia servido o exército espanhol. Nesse caso em específico, diante do contexto de guerra, torna-se difícil crer que se tratava de um caso de prestação "voluntária" de serviços militares. ${ }^{239}$

\footnotetext{
235 Telegrama da Secretaria de Relações Exteriores para Embaixada do Brasil em Madri. Rio de Janeiro, 20 dez. 1939. Missões Diplomáticas Brasileiras. Telegramas expedidos a Madri (1938-1942). AHI/RJ.

${ }^{236}$ Ofício confidencial (cópia) de Luis Martins de Sousa Dantas para Ministério das Relações Exteriores. Paris, 05 abr. 1940. Lata 1756, maço 35635. AHI/RJ.

${ }^{237}$ Memorandum do chefe da divisão consular (ass. ileg.) para secretário-geral das Relações Exteriores. Rio de Janeiro, 06 abr. 1940. Lata 1756, maço 35635. AHI/RJ.

${ }^{238}$ Artigo 2, letra b do Decreto-Lei n. 389 de 25 de abril de 1938.

${ }^{239}$ Ofício n. 40 de Matheus de Albuquerque, cônsul em Barcelona para Oswaldo Aranha, ministro das Relações Exteriores do Brasil. Barcelona, 18 mai. 1940. Consulados Brasileiros. Ofícios recebidos de Barcelona (maio de 1940 a dezembro de 1941). AHI/RJ.
} 
A legislação de caráter nacionalista possibilitou uma interpretação deturpada da condição dos voluntários brasileiros, pois era de conhecimento público que as Brigadas Internacionais constituíram-se como um corpo independente da organização do Exército republicano espanhol. Ao se incorporarem a essa Organização, os estrangeiros não estavam servindo militarmente ao governo de outro país. Segundo Herbert Matthews, "o governo republicano raramente interferia nos assuntos das Brigadas Internacionais, nem mesmo procurando manter-se inteiramente informado sobre elas" ${ }^{240} \mathrm{~A}$ perda de nacionalidade respaldada pelo artigo do decreto mencionado não foi sustentada, mas tal alegação demonstra o quanto se tornava difícil, naquele contexto, a autorização para que os brigadistas pudessem retornar ao Brasil.

A trajetória de alguns desses voluntários é conhecida, como a de Apolônio de Carvalho que, estando na França quando da eclosão da Segunda Guerra Mundial, participou ativamente da resistência francesa. Também podemos mencionar o caso do capitão do exército brasileiro Carlos da Costa Leite, que permaneceu em Montevidéu até 1942, ano em que retornou ao Brasil, sendo preso por determinação da Superintendência de Ordem Política e Social. ${ }^{241}$

Apolônio de Carvalho e Dinarco Reis, na década de 1960, participaram ativamente da resistência à ditadura militar no Brasil, sofrendo novamente represálias por defenderem suas convicções político-ideológicas.

\footnotetext{
${ }^{240}$ Herbert Matthews, op. cit., p.197.

241 Ismara Izepe de Souza. República Espanhola, op. cit, p.99.
} 


\section{3 - O reconhecimento da Espanha franquista}

Em novembro de 1936 os governos da Alemanha e da Itália reconheceram diplomaticamente o governo nacionalista espanhol sediado em Burgos, oferecendo-lhe um importante auxílio em termos de tropas e armas. Ao final desse ano, os nacionalistas haviam sido reconhecidos também pelos governos da Guatemala, El Salvador e Portugal. ${ }^{242}$

Apesar das afinidades ideológicas de muitos países com os rebeldes espanhóis, a maioria dos países europeus e ibero-americanos preferiu aguardar e acompanhar o desenvolvimento dos resultados militares para definir um posicionamento oficial com relação à Espanha. Mas ao final do ano de 1938, a situação de desvantagem territorial dos republicanos e as imensas dificuldades enfrentadas pelos mesmos, evidenciavam que os nacionalistas tinham mais chances de vencer a guerra civil. Alguns países passaram a nomear agentes oficiais junto ao governo de Burgos, dando os primeiros passos para o reconhecimento oficial do General Franco como chefe político da Espanha. Na América Latina, o Peru, por exemplo, já havia rompido relações diplomáticas com o governo de Barcelona desde o início de $1938 .{ }^{243}$ Como vimos, o Brasil realizou uma política dúbia ao manter as relações diplomáticas com o governo espanhol e simultaneamente incentivar a promoção de uma imagem negativa dos republicanos.

O governo republicano espanhol conhecia a orientação brasileira de atrelar a sua posição à política norte-americana. Em 1937, o encarregado de negócios da Espanha no Rio de Janeiro interpretava essa linha de atuação como algo positivo, afirmando que a declaração de Vargas de que aguardaria as orientações do Gabinete de Washington teria desanimado os espanhóis que, no Brasil, aguardavam o rompimento brasileiro com os legalistas espanhóis. $^{244}$

\footnotetext{
${ }^{242}$ Javier Rubio, op. cit., p.78.

243 Segundo o artigo "O Peru rompeu as relações diplomáticas com o governo de Barcelona". Jornal Acção. São Paulo, 22 mar. 1938, n 439, p. 1. AESP.

${ }_{244}$ Despacho n. 115 do encarregado de negócios da Espanha no Brasil para ministro de Assuntos Exteriores. Rio de Janeiro, 20 nov. 1937. R999, expt. 13. AMAE.
} 
A República espanhola sabia da fragilidade das relações mantidas com o governo Vargas. Os incidentes envolvendo a apreensão das obras de arte e do veículo de Alcebíades Peçanha em Madri, serviram como justificativa para que o Itamaraty defendesse a permanência de um encarregado de negócios da Espanha no Brasil, não aceitando a proposta de envio de um Ministro plenipotenciário espanhol ao Rio de Janeiro. Dessa forma, a categoria de representação espanhola no Brasil durante a guerra civil acabou por ser rebaixada. $^{245}$

Em 1938, um artigo considerado grosseiro e ofensivo a Vargas publicado pelo jornal socialista Solidariedad Obrera foi lamentado pelo governo espanhol. Com receio de que o episódio contribuísse para o rompimento brasileiro com a República - num momento em que vários governos já o haviam feito, abrindo margem para o reconhecimento dos rebeldes chefiados por Francisco Franco - o ministro Julio Alvarez del Vayo prometeu coibir os excessos da imprensa de esquerda, criando assim um serviço de imprensa junto à Chancelaria espanhola. ${ }^{246}$

A política externa brasileira para a Espanha estava de acordo com a política pan-americanista de Oswaldo Aranha na condução das questões referentes à Europa. O Estado-Novo, cujos princípios flertavam com os governos nazi-fascistas, manteve na chefia do Ministério das Relações Exteriores um defensor da solidariedade pan-americana. Essa solidariedade, no entanto, não dependia, como afirma Gerson Moura "da adesão aos princípios democráticos ou mesmo à aceitação de um regime político (a liberaldemocracia), mas somente da adesão e fidelidade a um centro hegemônico". 247

O controvertido auxílio de café enviado à zona republicana pelo governo Vargas é exemplar dessa política, que procurava caminhar paralela à resolução norte-americana. Em agosto de 1938, Carlos da Silveira Martins Ramos, apelando para a generosidade do povo e do governo brasileiro,

${ }^{245}$ Ofício n. 73 (reservado) de Carlos da Silveira Martins Ramos, encarregado de negócios do Brasil na Espanha para Oswaldo Aranha, ministro das Relações Exteriores do Brasil. Barcelona, 30 ago. 1938. Lata 713, maço 10343. AHI/RJ.

${ }^{246}$ Ofício n. 33 da Embaixada do Brasil na Espanha para o Ministério das Relações Exteriores do Brasil. Barcelona, 27 jun. 1938. Missões Diplomáticas Brasileiras. Ofícios recebidos de Madri (julho de 1937 a 1938). AHI/RJ.

${ }^{247}$ Gerson Moura, op. cit., p. 585. 
solicitou a Oswaldo Aranha que o Brasil contribuísse para amenizar o flagelo da população civil na zona legalista espanhola. Em um extenso ofício que demonstra as boas relações desse diplomata com os líderes da República espanhola, Ramos expôs o teor da audiência que teve com o Ministro Julio Alvarez del Vayo, na qual mais uma vez o assunto dos atos ilegais de Nelly Vidal vieram à tona. Sobre as considerações do ministro espanhol acerca dos atos ilegais praticados pelas representações estrangeiras em nome do "direito de asilo", Ramos ponderava:

Senti-me coberto de vergonha, ferido no meu amor próprio de brasileiro digno, de não poder vir em público desmentir aquellas accusações, no tocante à Missão diplomática do Brasil na Espanha, porquanto infelizmente também nessa Missão também se verificaram, na gestão de meu antecessor, ocorrências degradantes. ${ }^{248}$

Na tentativa de convencer Oswaldo Aranha a realizar donativos de café e outros gêneros alimentícios à Espanha legalista, Martins Ramos utilizou-se de um argumento que sabia estar coadunado com as posições políticas do chanceler brasileiro. Aranha foi informado de que o governo republicano esperava a doação de excedentes do trigo norte-americano e que isso não tardaria a ocorrer, uma vez que o filho do presidente Roosevelt teria estado na retaguarda republicana, acompanhando de perto as necessidades do povo espanhol. ${ }^{249}$

Martins Ramos mencionava a necessidade da doação brasileira, já solicitada em meses anteriores, para auxiliar o grave problema de abastecimento na zona legalista. A fome era uma realidade em Madri que, no inverno de 1938 e 1939, contava com mais de meio milhão de pessoas sobrevivendo com uma ração individual em torno de 100 gramas diários de lentilhas, arroz ou feijão. ${ }^{250}$

\footnotetext{
${ }^{248}$ Ofício n. 73 (reservado) de Carlos da Silveira Martins Ramos, encarregado de negócios do Brasil na Espanha para Oswaldo Aranha, ministro das Relações Exteriores do Brasil. Barcelona, 30 ago. 1938. Lata 713, maço 10343. AHI/RJ.

${ }^{249}$ Embora tivesse auxiliado a população civil da zona republicana com o envio de alimentos, os EUA prestaram um grande serviço ao General Franco ao impor e manter com rigor o embargo de armas. Em nome da "neutralidade", o governo legal da Espanha foi impedido de comprar dos EUA o armamento de que tanto necessitava. Cf. Herbert Matthews, op. cit., p.182. ${ }^{250}$ Hugh Thomas, op. cit., p.295.
} 
Nessa época, a Embaixada dos EUA no Rio de Janeiro remeteu a Oswaldo Aranha a cópia de um telegrama no qual Cordell Hull pedia que o Brasil realizasse uma doação de café aos flagelados da guerra da Espanha. Para garantir o transporte e a distribuição desse produto pela população, Hull afirmava que "o Departamento de Estado teria muito prazer em pôr a Embaixada do Brasil em Washington em contacto com a Cruz Vermelha Americana". ${ }^{251} \mathrm{O}$ sentido humanitário do oferecimento era evidenciado pelo secretário de Estado que, durante o conflito civil espanhol, determinou uma política de neutralidade que se converteu em medida intervencionista a favor dos rebeldes. Segundo Herbert Matthews, o presidente Roosevelt permitiu que Cordell Hull decidisse a política a seguir no caso da Espanha. ${ }^{252}$

Em outubro de 1938, o cônsul Aluísio Azevedo informou o Itamaraty que a imprensa espanhola havia noticiado a doação de 300 mil kilos de café brasileiro e que o encarregado de negócios do Brasil havia feito uma comunicação oficial à República da Espanha nessa direção. ${ }^{253}$ Procurando seguir uma orientação dos EUA, o Brasil enviou à Espanha legalista, segundo informações da diplomacia espanhola, dez mil sacos de café que saíram do porto de Santos no dia 30 de novembro de $1938 .^{254}$

Embora a ação externa do Itamaraty para a Espanha estivesse respaldada pelas diretrizes de Oswaldo Aranha, havia uma corrente dentro dos círculos de poder brasileiros que desejavam o reconhecimento dos nacionalistas espanhóis ainda em 1938. Ao final desse ano, o Ministério das Relações Exteriores comunicou à Embaixada brasileira em Barcelona a intenção de acreditar junto ao governo de Franco um agente oficial, a exemplo do que realizavam outros países. ${ }^{255}$ Martins Ramos pediu a Oswaldo Aranha permissão para expor minuciosamente as desvantagens desta intenção.

251 Telegrama (cópia) traduzido do secretário de Estado norte-americano Cordell Hull para a Embaixada dos EUA no Rio de Janeiro. Washington, 21 set. 1938. Lata 713, maço 10343. AHI/RJ.

${ }^{252}$ Herbert Matthews, op. cit., p.182.

${ }^{253}$ Ofício n. 85 de Aluízio de Magalhães, cônsul do Brasil em Barcelona para Oswaldo Aranha, ministro das Relações Exteriores do Brasil. Barcelona, 26 out. 1938. Consulados Brasileiros. Ofícios recebidos de Barcelona (outubro de 1938 a junho de 1939). AHI/RJ.

${ }^{254}$ Despacho n. 438 de Jose Prieto del Rio, encarregado de negócios para ministro de Assuntos Exteriores da Espanha. RJ, 02 dez. 1938. R999 Expt. 12. AMAE.

${ }^{255}$ Telegrama da Secretaria de Estado das Relações Exteriores para a Embaixada do Brasil em Barcelona. Rio de Janeiro, 10 dez. 1938. Missões Diplomáticas Brasileiras. Telegramas expedidos a Madri (1938-1942). AHI/RJ. 
Procurava demonstrar que seria precipitado colocar-se ao lado de um governo que se inspirava "nos methodos brutaes do hitlerismo allemão e do fascismo italiano". Ramos apelou para um discurso humanitário em prol das vítimas da guerra:

O desrespeito flagrante às leis de guerra, com a violação de todos os princípios de humanidade, como os bombardeios de cidades abertas, que recrudesceram criminosamente nestes últimos tempos, victimando mulheres, anciãos e criancinhas innocentes, constitue objeção fundamental para desaconselhar-nos qualquer passo no sentido de iniciar relações com um Governo que pauta sua conducta na guerra por princípios tão cruéis. ${ }^{256}$

Ramos considerava também que os interesses econômicos do Brasil nas regiões controladas pelos nacionalistas espanhóis eram mínimos e que a capacidade de resistência republicana vislumbrava um prolongamento indefinido da luta na Espanha. ${ }^{257}$ Terminava seu relato manifestando seu desejo de que os argumentos arrolados tivessem força para demover Aranha do propósito de nomear o referido agente especial para o governo rebelde, visto como um primeiro passo no reconhecimento do General Franco.

O encarregado de negócios omitiu a realidade da luta naquele território quando afirmou que a situação dos dois lados em conflito estava "empatada" no que tange às condições militares. Ao final de 1938, a República da Espanha já havia perdido importantes territórios. Barcelona sofria com ataques aéreos regulares, e abrigava um contingente de cerca de um milhão de refugiados que se originavam de todo o país. Os socialistas e anarquistas pensavam em uma maneira de escapar para a França e a cidade já "respirava um ar de derrota". ${ }^{258}$

A situação de Barcelona foi se tornando mais complexa a cada dia. Ao final de janeiro de 1939 começaram as investidas do exército nacionalista para tomar a cidade. $O$ cenário era tão desolador e desfavorável

\footnotetext{
${ }^{256}$ Ofício n. 138 de Carlos da Silveira Martins Ramos, encarregado de negócios do Brasil na Espanha para Osvaldo Aranha, ministro das Relações Exteriores do Brasil. Barcelona, 27 dez. 1938. Missões Diplomáticas Brasileiras. Ofícios recebidos de Madri (julho de 1937 a 1938). AHI/RJ.

${ }^{257}$ Idem.

${ }^{258}$ Hugh Thomas, op. cit., p.301.
} 
aos republicanos que permitiu que o encarregado de negócios brasileiro alterasse a sua opinião em pouco mais de um mês. De otimista defensor da possibilidade da vitória republicana, Martins Ramos passou a "reconhecer" a morte daquele governo. Em 10 de fevereiro de 1939, já estabelecido na cidade francesa de Perpignan, Ramos escreveu uma carta pessoal destinada a "Cyro" - que presumimos ser Cyro de Freitas Valle - tecendo um interessante panorama da situação em que se encontrava a capital catalã em fins de janeiro. Afirmou que teria sido o último diplomata a deixar a capital, enfrentando um trajeto arriscado. A situação dos refugiados era assim descrita

O governo republicano está a braços com mil e um problemas além do da guerra. A questão dos refugiados - militares e civis em número approximado ao meio milhão - tem dado trabalho a todos e despezas avaliadas em cerca de 3 milhões de francos, por dia, ao Governo francez. Não poderia, si eu quisesse, descrever o que tem sido o êxodo da população espanhola das cidades recentemente conquistadas pelos nacionalistas! Panorama immensamente trágico! No meio de um gentio heterogêneo, fiz minha viagem de Barcelona a Figueras levando cerca de 12 horas!!! $!^{259}$

A fuga em massa da Catalunha em direção à fronteira francesa pela "estrada do sofrimento", ${ }^{260}$ constitui-se em um dos relatos mais comoventes da guerra. O movimento em direção ao território francês fazia-se sob um clima de pânico e as cidades na rota para esse país fervilhavam. $O$ governo francês recusara-se, por motivos financeiros, a permitir a entrada dos refugiados. Depois, permitiu relutantemente a abertura da fronteira, embora, a princípio, somente para os civis e feridos. ${ }^{261}$

A fome e a fadiga atingiam a todos indistintamente. Meses depois do término do conflito a fronteira era o cenário de uma tragédia consumada. Milhares de cidadãos foram colocados nos campos de refugiados como o de Argèles-sur-Mer, que careciam de condições sanitárias e de abastecimento.

\footnotetext{
${ }^{259}$ Carta (cópia) de Carlos da Silveira Martins Ramos para “Cyro”. Perpignan, 10 fev. 1939. Lata 716, maço 10364. AHI/RJ.

${ }^{260}$ Expressão utilizada por Hugh Thomas, op. cit., p.304.

${ }^{261}$ Idem.
} 
As dificuldades do governo francês para abrigar cerca de quatrocentos mil refugiados eram "hercúleas". 262

Martins Ramos demonstrou que possuía uma relação de amizade com Cyro de Freitas Valle. Em uma carta, o encarregado de negócios ficou à vontade para expor sua opinião sobre os acontecimentos espanhóis e sobre assuntos que careciam de pendência. $O$ que mais chama a atenção nesse documento é o desencanto de Martins Ramos para com as autoridades republicanas que, segundo ele, teriam abandonado os representantes diplomáticos à sua própria sorte. Opinava assim, que a República estava morta e se questionava se valeria a pena continuar "velando um defunto". ${ }^{263}$

O reconhecimento do governo nacionalista da Espanha pelo governo Vargas foi efetivado em março de 1939, após o reconhecimento dos demais países europeus e dos Estados Unidos. Tal decisão - tomada somente a partir da certeza de que a vitória nacionalista seria efetiva em pouco tempo nos leva a refletir sobre as relações entre a nossa política externa e os interesses da política externa norte-americana.

A neutralidade adotada pelo governo Vargas diante da guerra civil da Espanha pode ser interpretada como uma medida de alinhamento à política externa norte-americana, que neste momento, pregava a não intervenção nos assuntos exteriores. Segundo Eliane Silveira, desde o início do conflito, Oswaldo Aranha vinha atuando junto a Getúlio Vargas, com vistas a impedir que o Brasil se envolvesse com os problemas políticos europeus. Colocando o presidente da República a par da situação política européia, Aranha argumentava que o reconhecimento do governo de Franco implicaria numa aproximação estreita com a Alemanha nazista. ${ }^{264}$

A questão do donativo de café brasileiro aos republicanos evidencia essa tentativa de seguir as diretrizes norte-americanas: manutenção da neutralidade e efetivação de uma tímida política de fins humanitários. No entanto, nos parece perigoso atribuir o posicionamento de neutralidade

\footnotetext{
${ }^{262}$ Idem, p. 306. Sobre o exílio espanhol ver Julio Martin Casas. El exílio español, 1936-1939. 5 a ed. Barcelona: Planeta, 2002.

${ }^{263}$ Carta (cópia) de Carlos da Silveira Martins Ramos para "Cyro". Perpignan, 10 fev. 1939. Lata 716, maço 10364. AHI/RJ.

${ }^{264}$ Eliane Ávila Silveira. A Guerra Civil Espanhola e as elites políticas brasileiras: 1936-1939. Porto Alegre, 1991. Dissertação (Mestrado em História) - PUC, p. 147.
} 
adotado por Vargas somente a essa tentativa de acompanhar as determinações da política externa norte-americana.

A opção em manter uma política de neutralidade, não pode ser vista apenas como reflexo automático das decisões do centro hegemônico norte-americano, uma vez que nesse período, o Brasil habilmente começava a ampliar sua margem de autonomia, ao explorar "as indefinições do jogo hegemônico mundial entre Alemanha e Estados Unidos". ${ }^{265}$ Getúlio Vargas e Oswaldo Aranha optaram por promover a manutenção de uma neutralidade descomprometida com a coerência de evitar uma imagem negativa da República Espanhola em âmbito interno. A pseudo neutralidade era uma forma de não comprometer-se com uma guerra que, em suas primeiras fases, não vislumbrava vencedor.

${ }^{265}$ Gerson Moura. Autonomia na dependência, op. cit., p.14. 
II - Época de incertezas: as relações entre Brasil e Espanha nos conturbados anos 40 


\title{
2.1 - Conflitos e desconfianças em tempos de guerra
}

\author{
Afinidades entre Franco e Vargas
}

Após a vitória nacionalista ser concretizada, as relações diplomáticas entre Brasil e Espanha entraram numa fase de aproximação, dadas as simpatias do governo brasileiro às idéias defendidas pelo novo regime espanhol. $\mathrm{O}$ anticomunismo professado pelos diplomatas brasileiros $\mathrm{e}$ suas opiniões acerca da República espanhola podiam, nesse contexto, ser expressos abertamente.

Em junho de 1939, ao expor a Oswaldo Aranha a difícil situação de uma cidade convalescente da guerra, Matheus de Albuquerque teceu considerações que nos permitem entrever sua aversão aos republicanos espanhóis. O comunismo era apresentado como uma ideologia que fomentava o caos e a desordem e seus partidários os únicos responsáveis pela guerra na Espanha ${ }^{266}$ Atribuindo a culpa do conflito aos "vermelhos", o cônsul descrevia Barcelona - um dos mais importantes focos de resistência civil às investidas nacionalistas - através de metáforas apropriadas para uma Espanha "doente":

\begin{abstract}
Sente-se que este grande corpo urbano, outrora palpitante de vida e de alegria, ainda padece os efeitos desastrosos da longa e cruel dominação marxista. Dir-se-ia que uma peste inexorável devastara, física e moralmente, os lares da Catalunha, onde dificilmente se reconheceria, agora, a alma deste povo laborioso, que só a muito custo vae despertando de seu extenuante pesadelo. ${ }^{267}$
\end{abstract}

Dias após o término do conflito, o governo de Francisco Franco passou a receber as credenciais de embaixadores de vários países. Em 10 de abril de 1939, Argeu Guimarães Filho apresentou suas credenciais como embaixador brasileiro ao Conde Jordana, ministro de Assuntos Exteriores da

\footnotetext{
${ }^{266}$ Sobre o discurso anticomunista na sociedade brasileira ver: Rodrigo Patto Sá Motta. Em guarda contra o perigo vermelho. O anticomunismo no Brasil (1917-1964). São Paulo: Perpectiva; Fapesp, 2002.

${ }^{267}$ Ofício n. 57 de Matheus de Albuquerque, cônsul brasileiro para Oswaldo Aranha, ministro das Relações Exteriores do Brasil. Barcelona, 15 jun. 1939. Consulados brasileiros. Ofícios recebidos de Barcelona (outubro de 1938 a junho de 1939). AHI/RJ. Grifo nosso.
} 
Espanha. ${ }^{268} \mathrm{O}$ novo embaixador teceu elogios ao Caudillo, muitos dos quais ultrapassavam a dimensão política. A admiração que Guimarães nutria ao ditador espanhol alcançava o âmbito pessoal:

Franco tem por hábito pesar longamente as suas resoluções antes de divulgá-las e pô-las em execução. É tanto mais sereno e ponderado quanto mais enérgico e firme. Jamais pronuncia uma palavra ou toma uma atitude antes de maduro e demorado exame. E como conhece profundamente os homens que o cercam e as pretensões que 0 assediam, a sua vontade se exterioriza, afinal, inapelável, com a só consideração do bem coletivo. Assim foi durante a guerra civil, assim continua a ser na presente fase de reconstrução pacífica da Espanha.

Os seus subordinados, os seus comandados no Exército, habituaram-se a confiar cegamente no chefe que jamais os precipitou numa empreza imprudente ou insegura e que ademais, não perde a serenidade de ânimo, o calmo julgamento, a isenção do espírito, ainda nos embates mais eriçados de dificuldades. (...)

Exemplar chefe de família, cidadão virtuoso (que nunca fumou um cigarro, nem bebeu um copo de vinho), cheio de afeto pelo seu lar, ele não hesita, entretanto em sacrificar os impulsos do coração aos imperativos do dever, tal a retidão do seu caráter. Nos inícios da Revolução, confirmou a sentença de morte contra um dos chefes da base aérea de Tetuan, que era nada menos que o seu cunhado Bahamonde. Com o pai, seu homônimo, coronel do Exército, cortou virtualmente as relações, por não aceitar-lhe o feitio moral pouco severo". 269

Argeu Guimarães oferecia uma definição de "caráter" que desconsiderava o significado humanitário do gesto de condenar o próprio cunhado à morte. As biografias do Generalísimo estiveram permeadas por um pensamento semelhante, repletas de fatos idealizados com o intuito de reforçar a imagem de um líder forte, sem máculas em sua vida pessoal. ${ }^{270}$

As considerações elogiosas ao chefe político da Espanha são expressivas de um pensamento conservador que valorizava a moral e a retidão de costumes como alicerces da sociedade cristã. Cabe observar que as

\footnotetext{
268 Ofício n. 26 (reservado) de Argeu Guimarães, embaixador do Brasil na Espanha para Oswaldo Aranha, ministro das Relações Exteriores do Brasil. Burgos, 10 abr. 1939. Missões Diplomáticas Brasileiras. Ofícios recebidos de Madri (abril a dezembro de 1939). AHI/RJ.

${ }^{269}$ Ofício n. 69 (confidencial) de Argeu Guimarães Filho, encarregado de negócios do Brasil na Espanha para Oswaldo Aranha, ministro das Relações Exteriores do Brasil San Sebastián, 10 jun. 1939. Missões Diplomáticas Brasileiras. Ofícios recebidos de Madri. (abril a dezembro de 1939). AHI/RJ. Grifo nosso.

${ }^{270}$ Paul Preston afirma que Francisco Franco é o menos conhecido dos grandes ditadores do século XX e que, "esto se debe em parte a la cortina de humo creada por sus hageógrafos y propagandistas. Em vida se le comparo com el Arcángel Gabriel, Alejandro Magno, Julio César... Felipe II, Napoleón y uma hueste de heróes reales e imaginários." (Paul Preston. Franco: Caudillo de España. Barcelona: Grijalbo Mandadori, 1999, p.13. Colección Mitos Bolsillo).
} 
representações que compõe o imaginário anticomunista também resgataram a temática moral. As ações comunistas, nos discursos de Franco, ameaçavam a manutenção dos valores da Igreja Católica. ${ }^{271}$

Em outubro de 1939, Getúlio Vargas felicitou o chefe político da Espanha e comunicou a nomeação de Abelardo Roças como embaixador brasileiro. Vargas demonstrava toda a sua simpatia a Franco ao começar a carta chamando-o por "grande e bom amigo". ${ }^{272}$ Em dezembro do mesmo ano, Roças assumiu a Embaixada do Brasil na Espanha, entregando suas credenciais diretamente ao Caudillo, numa solenidade que contou com grande suntuosidade. A recepção do Generalísimo teve um significado político interno, já que foi a sua primeira aparição pública na capital espanhola. Segundo Roças, o esplendor dessa recepção diplomática extrapolou àquelas realizadas nos tempos de Alfonso XIII, consideradas as mais "brilhantes" da Europa. ${ }^{273}$

Após o término do conflito civil, as relações de cordialidade entre os dois chefes políticos ficaram ainda mais evidenciadas com a doação de café que o governo brasileiro fez ao povo espanhol. Aluísio de Magalhães, cônsul brasileiro em Barcelona, informou o Itamaraty que o recém prefeito de Barcelona teria feito um pedido de doação do referido produto. Magalhães mostrou-se favorável à doação, argumentando que essa deveria fazer-se não apenas por motivos humanitários, mas também para assegurar a preferência do café brasileiro entre os barceloneses. ${ }^{274}$

Caberia observar que a exportação de café durante o período da Guerra Civil Espanhola praticamente cessou, tendo o Itamaraty e a Embaixada brasileira na Espanha trocado poucos documentos sobre essa questão. Com o fim da guerra, no entanto, o embaixador brasileiro Argeu Guimarães sugeriu ao Itamaraty que era chegado o momento de reatar nossas relações comerciais. Expondo a situação caótica em que se encontrava a Espanha, Guimarães atentou para o fato de que o governo franquista tinha alterado o rol de seus

\footnotetext{
${ }^{271}$ Sobre a temática moral no discurso anticomunista ver: Rodrigo Patto Sá Mota, op. cit., p.6263.

${ }^{272}$ Carta (cópia) de Getúlio Vargas e Oswaldo Aranha para Francisco Franco. Palácio da Presidência. Rio de Janeiro, 17 out. 1939. Lata 998, maço 16237. AHI/RJ.

${ }^{273}$ Ofício n. 168 de Abelardo Roças, embaixador do Brasil na Espanha para Oswaldo Aranha, ministro das Relações Exteriores do Brasil. Madri, 01 dez. 1939. Missões Diplomáticas Brasileiras. Ofícios recebidos de Madri (abril a dezembro de 1939). AHI/RJ.

${ }_{274}$ Ofício n. 14 de Aluísio de Magalhães, cônsul do Brasil em Barcelona para Oswaldo Aranha, ministro das Relações Exteriores do Brasil. Barcelona, 04 mar. 1939. Consulados Brasileiros. Ofícios recebidos de Barcelona (outubro de 1938 a junho de 1939). AHI/RJ.
} 
principais parceiros comerciais, e que não havia melhor momento para o Brasil reiniciar o comércio com esse país. ${ }^{275}$

Vários comerciantes espanhóis fizeram contato com a Embaixada do Brasil, manifestando seu interesse em estabelecer relações com importadores brasileiros de vinhos, e também a intenção de importar produtos brasileiros sob o regime de compensação. A Embaixada do Brasil na Espanha preparou uma lista com os nomes de comerciantes que, ansiosamente, propunham vender produtos para o Brasil em troca do café brasileiro. ${ }^{276}$ Esse contato direto, sem a intermediação do governo espanhol, expressa a necessidade urgente de recuperar a economia de um país destroçado pela guerra civil.

Em julho de 1939 chegaram a Vigo, na Galícia, cerca de 4 mil sacas de café doadas pelo governo brasileiro ao governo da Espanha. ${ }^{277} \mathrm{O}$ fato serviu como instrumento de propaganda para a ditadura franquista, uma vez que a imprensa noticiou o gesto como um "regalo" do Brasil ao Generalísimo. ${ }^{278}$ Os pedidos para que o Brasil contribuísse para amenizar o sofrimento e a situação de miséria da população espanhola foram feitos não apenas pelo governador de Barcelona, mas também pela International Comision for the Assistance of Child Refugees in Spain, uma organização de auxílio humanitário sediada em Paris. ${ }^{279}$

\footnotetext{
${ }^{275}$ Ofício n. 71 de Argeu Guimarães, embaixador do Brasil na Espanha para Oswaldo Aranha, ministro das Relações Exteriores do Brasil. San Sebastián, 15 jun. 1939. Missões Diplomáticas Brasileiras. Ofícios recebidos de Madri (abril a dezembro de 1939). AHI/RJ.

${ }^{276}$ Ofício de Argeu Guimarães, embaixador do Brasil na Espanha para Oswaldo Aranha, ministro das Relações Exteriores do Brasil. San Sebastián, 10 jul. 1939. Missões Diplomáticas Brasileiras. Ofícios recebidos de Madri (abril a dezembro de 1939). AHI/RJ.

277 Ofício n. 65 de Matheus de Albuquerque, cônsul em Barcelona para Oswaldo Aranha, ministro das Relações Exteriores do Brasil. Barcelona, 06 jul. 1939. Lata 713, maço 10343. AHI/RJ.

278 "El Brasil regala al Generalísimo 240.000 Kilos de café". Jornal La Vanguardia Española. Pontevedra, 06 jul. 1939. Anexo 1 ao ofício acima citado.

${ }^{279}$ Carta (cópia) de Howard E. Kerahner (em nome da International Comission for the Assistance of Child Refugees in Spain) para Oswaldo Aranha. Paris, 07 abr. 1939. Lata 713, maço 10343. AHI/RJ.
} 


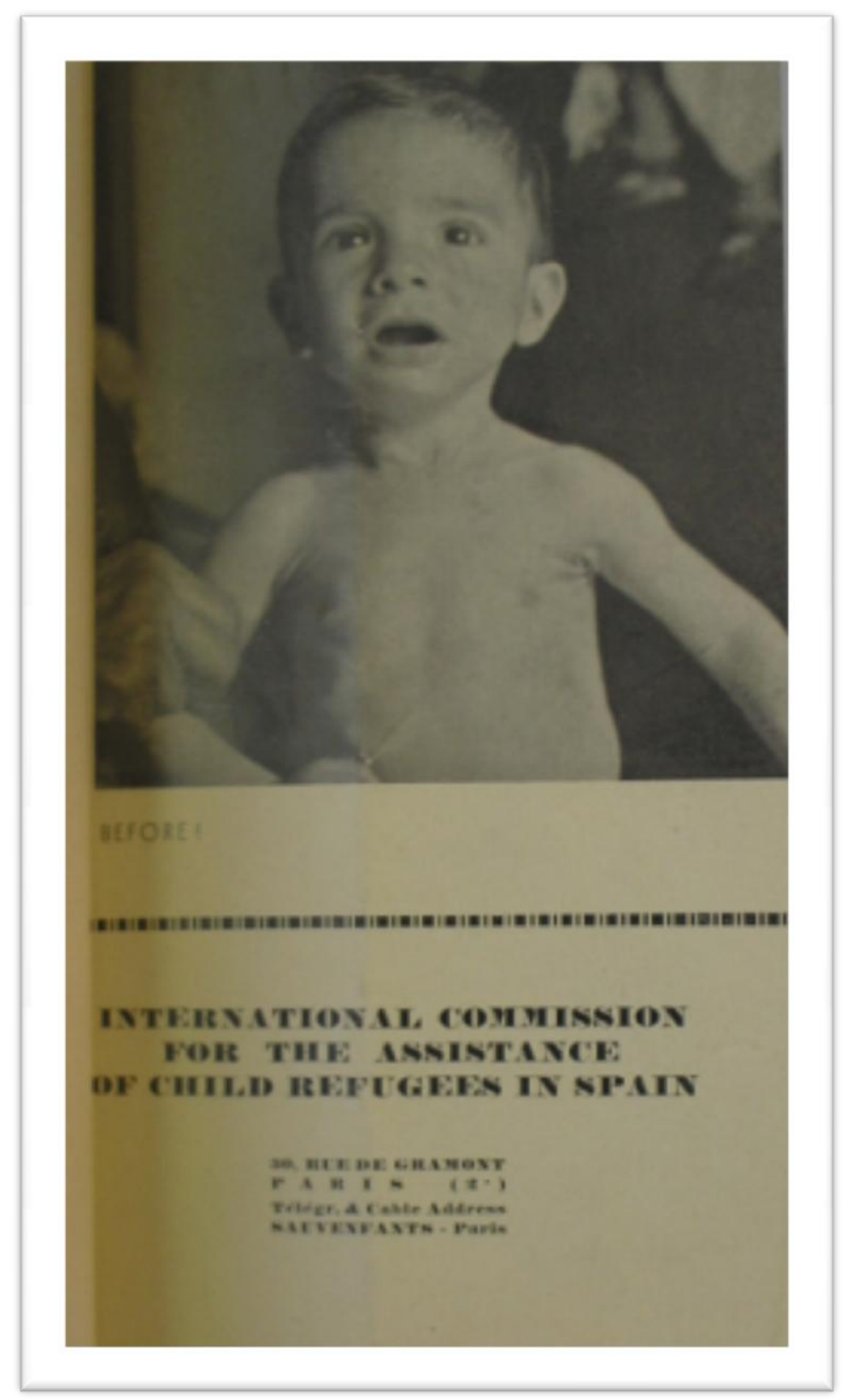

8 - Panfleto da International Comission for the assistance of child refugees in Spain. Anexo à carta (cópia) de Howard E. Kerahner para Oswaldo Aranha. Paris, 07 abr. 1939. Lata 713, maço 10343. AHI/RJ. 
Durante o ano de 1940, a Embaixada do Brasil na Espanha procurou reforçar as afinidades ideológicas entre o governo brasileiro e 0 espanhol. A entrevista dada por Abelardo Roças ao jornal $A B C$, um dos principais periódicos da Espanha, é sintomática do posicionamento de apoio que o Brasil ofereceu ao governo de Francisco Franco. Na referida entrevista, o representante brasileiro salientou as semelhanças entre o regime político brasileiro e as "potências totalitárias" da Europa, tecendo elogios pessoais ao Caudilho. $\mathrm{O}$ artigo foi publicado na primeira página do jornal, demonstrando que a Franco também interessava reforçar os laços de amizade e de identidade política entre os dois países. ${ }^{280}$

A simpatia mútua entre o Brasil e a Espanha se fazia respaldada principalmente na aversão ao comunismo e na defesa da necessidade de um regime autoritário. O nacionalismo e a utilização da educação como um instrumento de propaganda de governo, também podem ser considerados traços comuns entre os dois países.

O governo brasileiro, nesse momento, não permitiu que a produção cultural ficasse à mercê de iniciativas dispersas, tomando para si a função de dirigi-la. Por intermédio do DIP (Departamento de Imprensa e Propaganda), e de outras organizações, o governo penetrou em todas as atividades culturais, tais como o cinema, teatro e literatura, tendo 0 nacionalismo como um elemento central da cultura brasileira.

A vinculação ao Estado como forma de garantir a divulgação de seus projetos de cultura envolveu Mário de Andrade e Heitor Villa Lobos, apenas para citar os mais conhecidos intelectuais e artistas. ${ }^{281} \mathrm{~A}$ música erudita, por exemplo, atuou como elemento propagandístico do regime de Vargas. Villa Lobos implementou o Canto Orfeônico nas escolas, produzindo espetáculos nos quais as canções executadas continham um forte teor ufanista de exaltação à nação. ${ }^{282}$

\footnotetext{
${ }^{280}$ Ofício n. 81 de Abelardo Roças, embaixador do Brasil na Espanha para Oswaldo Aranha, ministro das Relações Exteriores do Brasil. Madri, 04 abr. 1940. Missões Diplomáticas Brasileiras. Ofícios recebidos de Madri. (1940 a março de 1941). AHI/RJ.

${ }^{281}$ Sobre a participação dos intelectuais no projeto cultural do Estado-Novo ver: Daniel Pecaut. Os intelectuais e a política no Brasil: entre o povo e a nação. São Paulo: Ática, 1990.

${ }_{282}$ Sobre os projetos de difusão do Canto Orfeônico organizados por Villa Lobos durante a Era Vargas ver Arnaldo D. Contier. Passarinhada do Brasil: canto orfeônico, educação e getulismo. Bauru, SP: EDUSC, 1998, p.20.
} 
$\mathrm{Na}$ Espanha, a educação também foi acionada pelo governo franquista para promover a unidade nacional. $\mathrm{O}$ ensino do castelhano como a única língua espanhola tornou-se uma medida eficiente para sufocar os regionalismos. A fixação de uma "identidade nacional", como afirma Elena Pájaro Peres, procurou "insidiosamente excluir e exterminar a divergência, elegendo alguns elementos de cultura e projetando-os como definidores de um suposto caráter nacional." ${ }^{283}$

As afinidades ideológicas entre Franco e Vargas constituíram-se em peça fundamental no discurso daqueles que pretendiam realizar uma efetiva aproximação comercial entre os dois países. Em uma carta particular endereçada ao embaixador brasileiro Abelardo Roças, em que o trata por "amigo", Juan Beigbeder, ministro de Assuntos Exteriores espanhol, fez sugestões para facilitar a exportação de algodão brasileiro para a Espanha, mencionando a necessidade de reatarem os laços comerciais pela proximidade de ideais políticos que uniam os dois países. ${ }^{284}$

Entre 1940 e 1941, o Itamaraty empreendeu esforços no sentido de reativar o comércio hispano-brasileiro através da exportação de algodão. Apesar da iniciativa, o comércio desse produto não se realizou de forma eficaz, pois mesmo com a abertura da concorrência para o produto brasileiro, os problemas com a liberação de créditos espanhóis dificultaram a realização dos trâmites comerciais. Abelardo Roças informou ao Itamaraty, em agosto de 1941, que a corrupção nos setores espanhóis responsáveis pelo comércio era um dos grandes entraves à efetivação das relações comerciais entre os dois países. ${ }^{285}$ Mesmo assim a importação de produtos brasileiros - especialmente algodão e gêneros alimentícios - foi muito superior às exportações espanholas, ficando a balança comercial favorável ao Brasil.

Fazendo previsões sombrias sobre a falta de alimentos para os espanhóis, Roças elaborou relatórios que se constituem em interessantes testemunhos sobre a situação não só econômica, mas também política da Espanha no pós-guerra civil. O caos econômico foi parcialmente solucionado

\footnotetext{
${ }^{283}$ Elena Pájaro Peres. A inexistência da terra firme, op. cit., p.332.

${ }^{284}$ Carta (particular) de Juan Beigbeder para Abelardo Roças. Madrid, 31 ago. 1940. Missões Diplomáticas Brasileiras. Ofícios recebidos de Madri (1940 a março de 1941). AHI/RJ.

285 Relatório "mês econômico" de Abelardo Roças, embaixador do Brasil na Espanha para Oswaldo Aranha, ministro das Relações Exteriores do Brasil. Madri, 01 ago. 1941. Missões Diplomáticas Brasileiras. Ofícios recebidos de Madri (abril a dezembro de 1941). AHI/RJ.
} 
com o auxílio oferecido pela Argentina que, em 1941, enviou toneladas de trigo à Espanha. ${ }^{286}$ Segundo Ranaan Rein, a ditadura de Franco no período posterior à guerra mundial, só sobreviveu graças ao auxílio oferecido pelo governo argentino que, com essa atitude, tentava praticar uma política externa contrária as diretrizes ditadas pelos EUA. ${ }^{287}$ Por outro lado, Perón ao ajudar a Espanha, agradava setores da direita apegados ao "hispanismo", ou seja, ligados à idéia de que os laços históricos com a pátria-mãe deveriam ser mantidos e estreitados. ${ }^{288}$

As opiniões pessoais dos representantes diplomáticos brasileiros são perceptíveis, especialmente nos relatórios mensais que a Embaixada brasileira enviava ao MRE. A partir de 1940, esses relatórios passaram a se dedicar quase que exclusivamente à inserção da Espanha no contexto da Segunda Guerra Mundial elucidando, com riqueza de detalhes, os embates políticos internos que ocorriam no governo franquista, no que tange à definição de seu posicionamento no conflito.

Apesar de manifestar sua admiração pelos países do Eixo, o embaixador Abelardo Roças não prenunciava uma rápida vitória dos alemães, afirmando, em 1941, que na França ocupada, os soldados nazistas já demonstravam cansaço e desânimo. Roças provavelmente mantinha contato com as lideranças nazistas, pois afirmou em relatório que, graças à gentileza dos alemães presentes na zona de ocupação, conseguia trasladar-se quase que diariamente de San Sebastián, onde passava férias, à cidade de Biarritz, para a realização de tratamento médico. ${ }^{289}$

Abelardo Roças deixou registrada, em muitos documentos, a sua admiração a figuras proeminentes da política espanhola. A correspondência enviada ao MRE demonstra que Roças nutria uma relação de proximidade e

\footnotetext{
${ }^{286}$ Ofício n. 227 de Abelardo Roças, embaixador do Brasil na Espanha para Oswaldo Aranha, ministro das Relações Exteriores do Brasil. Madri, 08 dez. 1941. Missões Diplomáticas Brasileiras. Ofícios recebidos de Madri (abril a dezembro de 1941). AHI/RJ.

${ }_{287}$ Ranaan Rein. La salvación de una dictadura. Alianza Franco-Perón, 1936-1955. Madrid: Consejo Superior de Investigaciones Científicas; Instituto de Cooperación para el desarollo, 1995.

${ }^{288}$ luri Cavlak. A política externa brasileira e a argentina peronista (1946/1955). Assis, 2005. Dissertação (Mestrado em História) - UNESP, p.96.

${ }_{289}$ Relatório (reservado) do "mês político" de Abelardo Roças, embaixador do Brasil na Espanha para Oswaldo Aranha, ministro das Relações Exteriores do Brasil. Madri, 30 abr. 1941. Missões Diplomáticas Brasileiras. Ofícios recebidos de Madri (abril a dezembro de 1941). $\mathrm{AHI} / \mathrm{RJ}$.
} 
amizade com o braço direito de Franco e principal articulador da política pró germânica da Espanha no início da Segunda Guerra Mundial: Serrano Suñer. O Cunhadíssimo - como ficaria conhecido por seus laços de parentesco com Franco - compartilhava com o ditador espanhol o entusiasmo pelos triunfos alemães e em 1940, tinha grande desejo de tomar para si as rédeas da política exterior espanhola. Segundo Paul Preston, em uma recepção oferecida pela Embaixada brasileira, Suñer convidou os presentes para uma festa em comemoração à derrota de Londres. ${ }^{290}$

Tais afirmações, constantes numa das mais completas biografias do Caudillo, complementam as informações dos relatórios enviados ao Itamaraty, que indicam um bom relacionamento entre o embaixador brasileiro e Serrano Suñer. No relatório confidencial de julho de 1941, Roças afirmou que Suñer o havia confidenciado algumas das estratégias utilizadas para que a Espanha não se envolvesse diretamente na guerra. Suñer teria pedido que o embaixador brasileiro oferecesse as suas impressões sobre como o corpo diplomático havia recebido as declarações de Franco acerca de sua política externa. Roças teria respondido que os ataques da Espanha às nações com os quais se mantinham relações amistosas (EUA e Inglaterra) causavam estranheza. Roças seguia transcrevendo as confidências de Serrano Suñer:

"Em termos de realidade, prego uma política de guerra para poder realisar uma política de paz. As minhas viagens a Berlim sempre foram a de um paraquedista. Sem esta minha atuação, há muito que estaríamos na guerra. Parece que os Aliados atribuem uma grande importância à neutralidade da Espanha. Assim, pois, me deveriam antes estar mui reconhecidos." 291

Essas considerações foram realizadas por ocasião de um jantar oferecido pela Embaixada brasileira aos políticos da Espanha. A data desse jantar, comentada em outros documentos diplomáticos, é distinta daquela mencionada por Paul Preston anteriormente. Assim, parece-nos que sob o comando de Roças, a Embaixada do Brasil ofereceu diversas recepções às lideranças políticas espanholas. Roças afirmou que em outra ocasião, num

\footnotetext{
${ }^{290}$ Paul Preston. Franco: Caudillo de España, op. cit., p.448.

291 Relatório do mês político (confidencial) de julho de 1941, de Abelardo Roças, embaixador do Brasil na Espanha para MRE. Madri, 31 jul. 1941. Lata 1373, maço 31856. AHI/RJ.
} 
jantar reservado somente a Suñer, esse teria feito severas críticas ao Caudilho, confidenciando suas reais opiniões sobre o exército espanhol.

Num momento de expansão nazista pelo continente europeu, o governo espanhol levantou a possibilidade de apoiar militarmente as potências totalitárias. Havia, no entanto, abismos que separavam os interesses de Franco e Hitler, no que se refere à participação da Espanha na guerra. ${ }^{292}$ Isso permitiu a Franco ganhar tempo, apoiando o Eixo somente nos bastidores.

A posição defendida pelo embaixador brasileiro diante das autoridades franquistas, no tocante ao conflito mundial, foi norteada pelo Itamaraty e pela política de neutralidade que o Brasil manteve durante o ano de 1940. Em outubro desse ano, através de um telegrama confidencial, o Itamaraty autorizou o embaixador em Madri a manifestar

que deante da situação atual, o povo e o governo brasileiro fazem votos para que a Espanha não seja arrastada à guerra, e ao mesmo tempo, a declarar a esse Govêrno que para esse fim pode contar com a colaboração nossa no que for possível. ${ }^{293}$

A postura dúbia e não definida, tanto do Brasil quanto da Espanha diante do conflito que se desenrolava em território europeu, contribuiu para que as relações entre os dois países permanecessem permeadas, como vimos, por discursos de cordialidade. O bom relacionamento entre o governo de Vargas e o de Franco fez com que a Embaixada do Brasil se responsabilizasse por intermediar o reatamento das relações diplomáticas entre Espanha e Chile. O rompimento foi o ponto culminante de um lento processo de agravamento das relações hispano-chilenas que se iniciaram com a vitória dos franquistas em abril de 1939.

Quando as autoridades nacionalistas entraram em Madri, vários partidários republicanos dirigiram-se à Embaixada do Chile para pedir asilo. Essa representação diplomática, que havia abrigado asilados suspeitos de coadunarem com os nacionalistas durante o conflito civil, aceitou prontamente acolher dezessete refugiados republicanos. O governo chileno de Frente

\footnotetext{
292 Paul Preston. Franco: Caudillo de España, op. cit., p.473.

293 Telegrama (confidencial) do Ministério das Relações Exteriores para a Embaixada do Brasil na Espanha. Rio de Janeiro, 29 out. 1940. Missões Diplomáticas Brasileiras. Telegramas expedidos a Madri (1938/1942). AHI/RJ.
} 
Popular, eleito em 1938, manteve uma altiva posição de defesa da vida desse pequeno grupo, composto principalmente por jornalistas e escritores.

Em fins de 1939, quando as negociações acerca dos asilados já perduravam por nove meses sem êxito, o governo chileno resolveu solicitar a mediação brasileira. ${ }^{294} \mathrm{Em}$ janeiro de 1940, Abelardo Roças colocou Oswaldo Aranha a par da questão, explicando que o governo chileno teria considerado insuficiente a proposta do governo espanhol de garantir que, uma vez libertados os asilados, os que viessem a ser julgados não seriam condenados à morte pelos tribunais militares. ${ }^{295}$

O governo brasileiro, depois de haver aceitado realizar a mediação, estudou as divergências hispano-chilenas propondo uma solução. Abelardo Roças escreveu ao Chefe de Estado espanhol articulando sua proposta em duas frentes. O Brasil mostrou os pontos débeis da argumentação jurídica espanhola e expôs as motivações políticas que aconselhavam o governo espanhol a autorizar a saída dos asilados do território espanhol. ${ }^{296}$

A questão estaria a caminho da solução se não fosse um incidente que culminou com o rompimento de relações entre os dois países. Em um comício no qual estavam presentes o presidente Aguirre Cerda e vários ministros chilenos, alguns oradores realizaram alusões consideradas ofensivas às novas instituições espanholas e ao Chefe de Estado. Essa foi a justificativa para o governo de Madri tomar a iniciativa do rompimento. ${ }^{297}$

Em nota dirigida ao embaixador brasileiro, o ministro de Assuntos Exteriores da Espanha, Juan Beigbeder, afirmou que a ruptura de relações com o Chile fora a decisão do General Franco, diante da atitude do governo desse país em não proibir as manifestações de rádio e imprensa contra o regime político espanhol. Nessa mesma nota, o ministro espanhol afirmou que não tomaria medidas contra os asilados na Embaixada chilena somente em consideração pessoal a Abelardo Roças e ao governo brasileiro. ${ }^{298}$

\footnotetext{
294 Javier Rubio, op. cit., p.333.

295 Ofício n. 41(reservado) de Abelardo Roças, embaixador do Brasil na Espanha para Oswaldo Aranha, ministro das Relações Exteriores do Brasil. Madri, 12 fev. 1940. Missões Diplomáticas Brasileiras. Ofícios recebidos de Madri. (1940 a março de 1941). AHI/RJ.

296 Javier Rubio, op. cit., p.334.

297 Idem, p.337.

${ }^{298}$ Nota (cópia) de Juan Beigbeder, ministro de Assuntos Exteriores da Espanha para Abelardo Roças, embaixador do Brasil na Espanha. Ministério de Asuntos Exteriores da Espanha. Madri,
} 
Observamos, tanto no discurso do embaixador brasileiro quanto no de Juan Beigbeder, uma defesa da aplicação da censura que, na opinião de ambos, deveria nortear as atitudes do governo chileno face às manifestações populares em seu país. Para ambos, a liberdade de imprensa, cara ao governo de Frente Popular chileno, deveria ser coibida como forma de manter o bom relacionamento entre a Espanha e aquele país.

Em setembro de 1940, o governo brasileiro deu instruções para que Abelardo Roças notificasse ao MAE a intenção do Chile em reatar as relações com o governo franquista. Em seu discurso conciliatório, Roças afirmou a Juan Beigbeder que a ruptura teria ocorrido devido a um "mal entendimento", fruto do retardo nas comunicações entre os dois países, justificável em tempos de guerra. ${ }^{299}$ Ainda nesse mês, o governo espanhol autorizou a saída dos asilados que, acompanhados pelo embaixador brasileiro até Lisboa, embarcaram em direção ao Brasil, de onde a maioria seguiu para o Chile. Em 11 de outubro os cinco asilados restantes seguiram rumo a Portugal. ${ }^{300}$

Javier Rubio, que abordou o tema dos asilados e do rompimento hispano-chileno, faz menções elogiosas à atuação mediadora do Brasil. Comparando com a atuação do embaixador Alcebíades Peçanha - no caso dos asilados na representação brasileira durante a Guerra Civil Espanhola considerou tal intervenção como "inteligente e oportuna", garantindo à diplomacia brasileira uma mediação a "altura de su fama - que no va a resultar estéril." 301

A atuação brasileira nesse episódio é um tema recorrente nos documentos pessoais de Oswaldo Aranha. Luis Hermosilla, um dos asilados na representação chilena, pediu a intervenção de Aranha para que seu pai, Antonio Hermosilla Rodriguez, pudesse deixar a Espanha. Agradecia a intervenção do ministro que, segundo ele, teria salvado a vida de treze asilados. Aranha informou que havia dado instruções à Embaixada do Brasil

16 jul. 1940. Missões Diplomáticas Brasileiras. Ofícios recebidos de Madri (1940 a março de 1941). AHI/RJ.

${ }^{299}$ Nota confidencial (cópia) de Abelardo Roças, embaixador do Brasil na Espanha para Juan Beigbeder, ministro de Assuntos Exteriores da Espanha. Madri, 16 set. 1940. Missões Diplomáticas Brasileiras. Ofícios recebidos de Madri. (1940 a março de 1941). AHI/RJ.

${ }_{300}$ Javier Rubio, op. cit., p.338.

${ }^{301}$ Idem, p.336. 
em Madri, no sentido de solicitar do governo espanhol a transferência de seu pai para um sanatório em Portugal. ${ }^{302}$

A mediação brasileira nos permite avaliar 0 discurso anticomunista do embaixador brasileiro Abelardo Roças, que teceu críticas ao governo de Frente Popular do Chile e à atuação do poeta Pablo Neruda como cônsul em Madri à época da Guerra Civil Espanhola. Segundo Roças, o governo daquele país manifestava simpatias às idéias marxistas, deixando surgir diversos incidentes como aqueles relacionados às ofensas ao General Franco realizados pela imprensa.

As considerações emitidas pelo embaixador Roças acerca do poeta chileno trouxeram à tona informações interessantes que, no entanto, não podem ser comprovadas. De acordo com Roças, Neruda teria vendido asilo a muitos aristocratas espanhóis que, ao chegarem à Embaixada do Chile, eram entregues aos republicanos para serem fuzilados nos arredores de Madri. Segundo o embaixador brasileiro, após ser destituído do posto, Neruda teria assumido o Consulado em Paris, dedicando-se à "lucrativa" atividade de vender passaportes aos israelitas perseguidos pelo III Reich. ${ }^{303}$ Em suas memórias, Neruda registrou sua atuação em defesa dos republicanos espanhóis, o que lhe custou o afastamento do cargo de cônsul. O poeta relembra que em 1940, enviado pelo Governo de Frente Popular à Europa, liderou as negociações para a ida de refugiados espanhóis ao seu país. ${ }^{304}$

Os documentos diplomáticos, assim como as referências presentes no livro de Javier Rubio sobre o asilo diplomático, nos permitem afirmar que Abelardo Roças empenhou-se em obter êxito na solução da questão chilena. Provavelmente sua motivação não se respaldava na simpatia pessoal que nutria aos asilados "republicanos", mas no status que o sucesso das negociações traria ao Brasil e a ele na qualidade de diplomata. Com a intermediação brasileira, as relações entre Espanha e Chile foram oficialmente reatadas em 12 de outubro - Dia de la Raza, data na Espanha de grandes comemorações em lembrança à "descoberta da América".

\footnotetext{
${ }^{302}$ Carta de Oswaldo Aranha para Antonio Hermosilla. Rio de Janeiro, 05 set. 1940. Em anexo carta (manuscrita) de Luis Hermosilla para Oswaldo Aranha. Santiago do Chile, 19 ago. 1940. Arquivo Oswaldo Aranha. CPDOC/FGV.

303 Idem.

${ }^{304}$ Pablo Neruda. Confesso que vivi. Rio de Janeiro: Difel, 1977, p.124.
} 
As festividades em torno do Dia de La Raza ganharam um significado especial no governo franquista, pois esse era um momento utilizado para reforçar a idéia de que o Caudillo resgataria para a Espanha a posição hegemônica no cenário europeu, tal qual nos séculos XVII e XVIII. O ideal de Hispanidade foi uma característica marcante do governo de Franco no início dos anos 40. O programa da Falange, por exemplo, fazia menção ao resgate do poder espanhol através de sua expansão pelo mar, enfatizando a ligação entre a Espanha e os países da América Latina, reservando à primeira o papel de protetora e mentora dos rumos americanos. ${ }^{305}$

O governo do General Franco apregoava que a função da Espanha deveria ser a de defender "povos dispersos geograficamente, mas unidos por uma vontade comum oriunda da mesma origem". ${ }^{306} \mathrm{Em}$ um ensaio escrito no Brasil em 1966, Paulo Henrique Bahiana exaltou a Espanha franquista, tecendo considerações sobre a política externa adotada por Franco para os países hispano-americanos. O governo espanhol assim entendia a missão de seu país: "Por desígnio da Providência, pertence-lhe um título precioso: o de fiel guardiã, na família dos povos hispânicos, dos tesouros da tradição". 307

A presença da Falange Espanhola nos países americanos constituiu-se como elemento central da política externa de Franco. Nos anos da guerra civil, as organizações falangistas foram as responsáveis por irradiar na América a propaganda franquista, expressa nos ideais de Hispanidade e Império. $^{308}$ Isso era feito através de seu Servicio Exterior que organizava

\footnotetext{
305 "Documento 21: Programas de la Falange". Thierry Buron; Pascal Gauchon. Los Fascismos. México: Fondo de Cultura Económica, 1983, p. 157-172.

${ }_{306}^{306}$ Paulo Henrique Bahiana. A Espanha e o mundo. Rio de Janeiro: Tupy, 1966, p.18.

307 Idem, p.20.

${ }^{308}$ Lorenzo Delgado Gomez-Escalonilla. Império de papel. Acción cultural y política exterior durante El primer franquismo. Madrid: Consejo Superior de Investigaciones Científicas, 1992, p.130.
} 
concentrações e desfiles uniformizados dentre os emigrantes espanhóis. ${ }^{309}$ Entre 1940 e 1941, a Falange procurou manter suas bases nos países hispanoamericanos, incutindo nos mesmos um projeto de supra-nacionalidade hispânica, que defendia a língua castelhana como o "sangre del espirito".

No México, país que enfaticamente condenou o movimento nacionalista, a Falange não conseguiu se estabelecer. O governo de Lázaro Cárdenas, após o triunfo de Franco, expulsou do país o inspetor da Falange na América, dissolvendo definitivamente suas atividades. ${ }^{311}$

A disposição do governo espanhol em elaborar uma política hispanista na América Latina foi tema de muitos dos documentos trocados entre o Itamaraty e a Embaixada do Brasil na Espanha, uma vez que havia a intenção de estender tal política aos imigrantes espanhóis estabelecidos no Brasil. Apesar das relações cordiais e da afirmação dos laços de identidade política, o governo Vargas passou a ver com certa desconfiança a atuação da Falange Espanhola no Brasil. A Polícia Política manteve-se em alerta, mas sem reprimir as atividades falangistas até 1941. Essa postura policial pode ser compreendida se levarmos em conta que o governo Vargas, em sua essência, identificava-se com os princípios do ideário falangista.

A criação de um "Patronato de emigrados espanhóis" pelo governo franquista foi realizada, segundo informou Abelardo Roças ao MRE, com o intuito de submeter os espanhóis residentes na América à disciplina do partido nacional falangista. ${ }^{312}$ As constantes informações enviadas ao Itamaraty sobre essa questão, indicam que o governo espanhol intencionava criar um desses patronatos no Brasil. Se por um lado, o Brasil não podia ser incluído no rol de países hispano-americanos, por outro, abrigava uma considerável comunidade espanhola que deveria ser cooptada pelos ideais da Falange.

\footnotetext{
309 Jose Luis Abellán; Antonio Monclús (Coord.). El pensamiento español contemporâneo y la Idea de América, vol. 1: El pensamiento en España desde 1939. Barcelona: Anthropos, 1989, p.126.

${ }^{310}$ Idem, p.21.

${ }^{311}$ Resenha do livro: Clara E. Lida (Coord.). México y España en el primer franquismo, 19391950: rupturas formales, relaciones oficiosas. México: El Colegio de México, 2001. In: Reynaldo Yunuen Ortega-Ortiz. Nuevo Mundo, Mundos Nuevos, número 2 - 2002, disponível em : http://nuevomundo.revues.org/document390.html. Acesso em ago. de 2007.

${ }^{312}$ Ofício n. 115 de Abelardo Roças, embaixador do Brasil na Espanha para Oswaldo Aranha, ministro das Relações Exteriores do Brasil. San Sebastián, 9 ago. 1939. Missões Diplomáticas Brasileiras. Ofícios recebidos de Madri (abril a dezembro de 1939). AHI/RJ.
} 
O governo franquista não reconhecia ou não fazia questão de salientar a especificidade do Brasil enquanto país latino-americano. Segundo o cônsul Matheus de Albuquerque, a Falange em suas publicações mencionava - Brasil como um país de língua hispânica, não fazendo referência alguma à colonização portuguesa. O cônsul argumentava que essa pretensa unidade lingüística era irreal, uma vez que ela não havia sido alcançada nem no solo ibérico, onde persistiam os separatismos. ${ }^{313}$

Em fevereiro de 1940, Oswaldo Aranha foi informado por Abelardo Roças que a seção feminina da Falange teria enviado à Embaixada da Espanha no Rio de Janeiro um caixote contendo livros de propaganda e vinte mil medalhas comemorativas do movimento nacional, para serem distribuídas entre a comunidade espanhola no Brasil. Informou também que Gregorio Miranda Minguela teria sido nomeado chefe da Falange espanhola no Brasil. ${ }^{314}$ Alarmado pela notícia, o Ministério das Relações Exteriores solicitou à Embaixada do Brasil em Madri que comunicasse ao governo espanhol o caráter ilegal de tal nomeação, lembrando os decretos que proibiam a existência de partidos políticos e de atividades políticas de estrangeiros no Brasil. $^{315}$

A atitude do Ministério das Relações Exteriores demonstra que a simpatia do governo brasileiro a Franco não significava permissão para que um partido político estrangeiro viesse a ser propagado entre os espanhóis no Brasil. O projeto de valorização do nacional e a vigilância aos estrangeiros já impunham limites às atividades falangistas no país.

A definição brasileira em apoiar os Aliados durante a Segunda Guerra Mundial foi responsável por abalar novamente as relações entre Brasil e Espanha. $O$ alinhamento com os EUA foi recebido com pesar pelos países

313 Ofício n. 52 de Matheus de Albuquerque, cônsul do Brasil em Barcelona para Oswaldo Aranha, ministro das Relações Exteriores do Brasil. Barcelona, 22 jul. 1940. Consulados Brasileiros. Ofícios recebidos de Barcelona (maio de 1940 a dezembro de 1941). AHI/RJ.

314 Ofício n. 48 de Abelardo Roças, embaixador do Brasil na Espanha para Oswaldo Aranha, ministro das Relações Exteriores do Brasil. Madri, 24 fev. 1940. Missões Diplomáticas Brasileiras. Ofícios recebidos de Madri (1940 a março de 1941). AHI/RJ.

${ }_{315}$ Telegrama (cópia) da Secretaria de Estado das Relações Exteriores para a Embaixada do Brasil na Espanha. Rio de Janeiro, 27 fev. 1940. Missões Diplomáticas Brasileiras. Telegramas expedidos a Madri (1938-1942). AHI/RJ. 
nazi-fascistas. ${ }^{316}$ Segundo o historiador Ricardo Seitenfuss, os embaixadores dos países do Eixo atuaram em 1942 junto ao governo brasileiro, na tentativa de impedir o comprometimento do Brasil com os Aliados. Espanha e Portugal teriam sido incumbidos pela Alemanha de convencer a América Latina a manter a neutralidade diante do conflito. No entanto, tais tentativas malograram, tendo o Brasil declarado guerra às potências do Eixo em 22 de agosto desse mesmo ano. ${ }^{317}$

Em 1942 acentuou-se a preocupação do Ministério das Relações Exteriores com as atividades desenvolvidas pela Embaixada espanhola no Brasil. Havia fortes indícios de que ali eram planejadas ações em apoio ao nazifascismo, especialmente no que diz respeito à propaganda e à espionagem na América Latina. Esse receio se justificava pelo auxílio que a Espanha ofereceu a Alemanha até 1943, permitindo-Ihe instalar bases militares em seus territórios, além de facilitar os serviços de espionagem nazista. Sabe-se que Franco foi cauteloso em manter uma posição oficial de neutralidade frente à guerra mundial, porém, é provável que tenha apoiado, ou pelo menos permitido a utilização da Falange como intermediária das atividades nazistas na América. $^{318}$

Em 1939 o Itamaraty recebeu com preocupação a informação de que Raimundo Fernandez Cuesta havia sido nomeado embaixador no Rio de Janeiro, solicitando à Embaixada do Brasil em Madri informações detalhadas

\footnotetext{
${ }^{316}$ Com relação ao alinhamento brasileiro com os Aliados Gerson Moura afirma: "Dada uma certa capacidade acumulada de barganha, a política externa brasileira aceita o alinhamento aos Estados Unidos mediante a obtenção de certos benefícios políticos e econômicos de porte. Estes não se devem portanto à "boa vontade norte-americana", mas a uma capacidade real, embora limitada, de negociação por parte do governo brasileiro." (Gerson Moura. A Revolução de 1930, op. cit., p.594).

317 Ricardo Seitenfus. O Brasil de Getúlio Vargas e a formação dos blocos (1930-1942). São Paulo: Editora Nacional, 1985, p. 370-372.

${ }^{318}$ Allan Chase. Falange: o Exército Secreto do Eixo na América. Rio de Janeiro: Vitória, 1944. Esse livro constituiu-se em uma referência fundamental para o conhecimento da atuação da Falange Espanhola e de suas relações com as atividades do Partido Nazista na América. A obra, através de um discurso emotivo e de exaltação aos países Aliados, descreve minuciosamente as atividades da Falange nos países latino-americanos como uma organização secreta à serviço do nazifascismo. $\mathrm{O}$ autor atenta para o caráter periculoso dessa organização que, financiada pelos alemães, tentaria impor o domínio nazista sob o Novo Mundo. É provável que Allan Chase tenha superestimado a influência que a Falange exerceu como braço secreto do Eixo, uma vez que sua obra tinha como objetivo "alarmar" os leitores para as formas pouco conhecidas de domínio nazista fora da Europa. No entanto, as informações contidas nesse livro nos levam a crer que a vinda de Fernandez Cuesta para o Brasil implicava em interesses que extrapolavam a rotina de trocas diplomáticas.
} 
sobre o mesmo. ${ }^{319}$ Fernandez Cuesta foi um dos líderes falangistas "presenteados" com cargos de destaque no governo de Franco, após o final da Guerra Civil Espanhola. A decisão de enviá-lo ao Brasil como embaixador, demonstra o interesse de Franco em atender as demandas da Falange que, neste período, objetivava cooptar membros entre os espanhóis residentes na América. No entanto, outra hipótese não deve ser descartada: a de que esse diplomata pretendia, com a anuência do ditador espanhol, promover atividades em prol do Eixo.

Com o rompimento das relações diplomáticas do Brasil com os países do Eixo, a Embaixada da Espanha passou a representar os interesses alemães e japoneses no país. As afinidades ideológicas entre Franco e Hitler determinaram a escolha da Espanha como "potência protetora" dos interesses alemães no Brasil, encarregada, a partir de 1942, de proteger juridicamente os bens e interesses daqueles que seriam considerados "súditos do Eixo". A partir desse momento, a Embaixada espanhola passou a ser freqüentada por elementos nazistas como Von Cossel e Gustav Glock. A Polícia Política do Rio de Janeiro atentou para a condição "duvidosa" de alguns alemães que freqüentavam a referida representação diplomática, entre eles Von Cossel e Evan Kurt Paul. ${ }^{320}$ Segundo Priscila Perazzo, a representação dos alemães pela Embaixada da Espanha foi enfática, estando atenta à preservação das propriedades alemãs e denunciando "veementemente os maus tratos e torturas praticadas no interior dos cárceres". 321

A Espanha aceitou assumir tal função no mesmo momento em que Franco alterava sua política abertamente pró-Eixo. Contudo, mesmo a conjuntura interna espanhola não permitindo a definição de beligerância, a compatibilidade política entre Hitler e Franco tornava natural o comprometimento do último em nome da Alemanha nazista.

É possível que a Embaixada espanhola tenha facilitado e auxiliado os serviços de espionagem alemã. Porém, esse auxílio se

\footnotetext{
${ }^{319}$ Telegrama (cópia) da Secretaria de Estado das Relações Exteriores à Embaixada do Brasil na Espanha. Rio de Janeiro, 16 nov. 1939. Missões Diplomáticas Brasileiras. Telegramas expedidos a Madri (1938-1942). AHI/RJ.

${ }^{320}$ Informe em 03 jul. 1942. Dossiê Embaixada da Espanha. Setor espanhol, pasta 1. DOPSRJ/APERJ.

${ }^{321}$ Priscila Ferreira Perazzo. Prisioneiros de guerra: os cidadãos do Eixo nos campos de concentração brasileiros (1942-1945). São Paulo, 2002. Tese (Doutorado em História Social) FFLCH-USP, p.391.
} 
configurava como interesse secundário a um objetivo maior que era ampliar a importância da Falange na América do Sul. Em fevereiro de 1942, a Falange emitiu um boletim com instruções sobre como deveriam se direcionar as atividades de seus membros no Brasil. Naquela conjuntura de alinhamento brasileiro com os Aliados, se instruía para que os falangistas recuassem, suspendendo temporariamente suas ações. Algumas orientações práticas eram fornecidas, como a de evitar visitar a Embaixada, manter reserva com elementos do país que não eram alvo de confiança absoluta; evitar o termo hispanismo para não ferir a suscetibilidade "de estas gentes". Chama a atenção o fato de o boletim afirmar que o lema "agredir para vencer" deveria ser substituído por "discreción para vencer."322

Ao final do ano de 1942, Fernandez Cuesta foi nomeado embaixador na Itália, deixando a direção da Embaixada do Brasil. Considerado pela polícia como um grande articulador das atividades nazistas no Brasil, o diplomata espanhol se apresentava, no contexto de guerra, como um potencial inimigo.

O embaixador brasileiro em Madri também estava atento à possível participação espanhola no conflito mundial. Detalhes da política dúbia da Espanha com relação ao nazifascismo foram descritos em relatórios enviados mensalmente ao Itamaraty. Em fevereiro de 1943, Roças teceu considerações sobre o jogo de cintura do chefe espanhol, que flertava com ambos os lados em conflito: "Neste momento, por exemplo, ele queima todo o seu incenso verbal em louvor do Eixo, enquanto que na sombra vem procurando atender às petições dos Aliados, com a consigna de que o que vale são os actos e não as palavras." Roças também informava sobre as disputas internas entre os falangistas mais exaltados, que defendiam uma postura próEixo e Conde Jordana, ministro de Assuntos Exteriores, preferido dos Aliados. $^{323}$

A preocupação com a imagem brasileira na imprensa hispânica se mantinha, mas naquela conjuntura, as atenções do embaixador se

\footnotetext{
322 "Boletin extraordinario de instrucciones". Falange Española. Arquivo Getúlio Vargas (GVc. 1942.02.00 XXXVIII - 3). CPDOC/FGV.

${ }^{323}$ Relatório (reservado) do mês político de Abelardo Roças, embaixador do Brasil na Espanha para Oswaldo Aranha, ministro das Relações Exteriores do Brasil. Madri, 28 fev. 1943. Missões Diplomáticas Brasileiras. Ofícios recebidos de Madri (janeiro a junho de 1942). AHI/RJ.
} 
concentraram nas matérias sobre a participação do Brasil no conflito mundial. Segundo Roças, grande parte do que se publicava sobre o Brasil era fornecido pelo ministério da propaganda alemão, responsável pelas notícias que chegavam à Espanha. Em uma dessas reportagens podia-se ver o mapa do país no qual a legenda "Brasil Branco" foi utilizada para especificar as regiões habitadas por pessoas de origem alemã. ${ }^{324}$ Sob esse aspecto, convém observar que não encontramos referências acerca da tentativa da Embaixada do Brasil em impedir ou amenizar o teor dessas notícias. Iniciativas nesse sentido só foram verificadas após 1944, quando Mario de Pimentel Brandão assumiu a representação brasileira em Madri.

No que tange às relações culturais, cumpre mencionar que no período de participação no conflito mundial, o Brasil não firmou nenhum convênio cultural com o governo do General Franco. Certamente a Argentina foi o país da América que mais promoveu o intercâmbio cultural com a Espanha. Em setembro de 1943, os dois países firmaram um acordo cultural visando incrementar medidas para diminuir o custo de passagens e hotéis e incentivar o turismo. ${ }^{325}$

Diante da situação internacional, a Embaixada do Brasil já não podia manifestar sua intenção de reiterar os laços e afinidades políticas com a Espanha. A maioria dos documentos que aborda as relações culturais entre os dois países, refere-se ao intercâmbio de professores espanhóis que foram convidados a assumir cátedras nas universidades brasileiras.

Um caso digno de nota é o do Professor Damaso Alonso, que em 1943 foi convidado pelo Interventor de São Paulo a reger a cátedra de Língua e Literatura Espanhola na Universidade de São Paulo. A Embaixada brasileira remeteu nota ao Conde Jordana, pedindo autorização para que o professor pudesse aceitar o convite. Esse Ministério, por sua vez, respondeu que a presença do professor era necessária em Madri. ${ }^{326}$

\footnotetext{
${ }^{324}$ Ofício n.60 (reservado) de Abelardo Roças, embaixador do Brasil na Espanha para Oswaldo Aranha, ministro das Relações Exteriores do Brasil. Madri, 22 abr. 1942. Missões Diplomáticas Brasileiras. Ofícios recebidos de Madri (janeiro a junho de 1942). AHI/RJ.

325 Ofício n. 153 de Abelardo Roças, embaixador do Brasil na Espanha para Oswaldo Aranha, ministro das Relações Exteriores do Brasil. Madri, 09 set. 1943. Missões Diplomáticas Brasileiras. Ofícios recebidos de Madri. (julho a dezembro de 1943). AHI/RJ.

${ }^{326}$ Nota (cópia) da Embaixada do Brasil na Espanha para Conde Jordana, ministro de Assuntos Exteriores da Espanha. Madri, 01 jun. 1943. Missões Diplomáticas Brasileiras. Ofícios recebidos de Madri (1943). AHI/RJ.
} 
Nesse período persistiram as disputas e rivalidades entre os diplomatas brasileiros atuantes na Espanha. Abelardo Roças enfrentou sérias desavenças com o primeiro-secretário da Embaixada, Octavio de Sá Neves da Rocha. $O$ embaixador determinou o afastamento desse funcionário por um mês, relatando minuciosamente em que consistia a sua "conduta altamente indisciplinar". Além de mencionar a recusa de Neves da Rocha em executar os serviços solicitados, ressaltou que esse chegava a chamar para a "luta corporal" alguns funcionários da representação brasileira. $O$ embaixador expediu portaria de punição ao referido funcionário, explicando que ele teria trazido à Embaixada um desafeto seu, conhecido por ser "germanófilo" e "atacar a posição do governo brasileiro". ${ }^{327}$

Vale observar que, naquele momento de configuração do alinhamento brasileiro aos Aliados, trazer à Embaixada brasileira um cidadão que possivelmente expressava suas simpatias ao Eixo constituía-se em prova do descomprometimento do funcionário com as diretrizes políticas do Brasil. Neves da Rocha foi chamado imediatamente à Secretaria de Estado. ${ }^{328}$ Esta aliás, manifestou concordância com a punição, lembrando que de acordo com o artigo 242 do estatuto do funcionário, tal decisão era de exclusiva competência do embaixador. ${ }^{329}$

Era também função do embaixador apreciar positivamente o empenho daqueles funcionários considerados exemplares solicitando, quando julgasse conveniente, o aumento de salário para os mesmos. Em julho de 1943, Roças pediu a Pedro Leão Velloso, secretário-geral do Itamaraty, que o funcionário Luís de Soroa Filho - que havia permanecido na sede da Embaixada em Madri durante a Guerra Civil Espanhola - fosse agraciado com a majoração de salário, dado o seu desempenho e dedicação aos serviços de chancelaria. $O$ pedido provavelmente não obedecia às regras para a alteração de salários de funcionários, uma vez que foi feito através de uma carta

327 Portaria assinada por Abelardo Roças, embaixador do Brasil na Espanha. Madri, 05 out. 1942. Missões Diplomáticas Brasileiras. Ofícios recebidos de Madri (julho a dezembro de 1942). AHI/RJ.

328 Telegrama n. 95 da Secretaria de Estado das Relações Exteriores para Embaixada em Madri. Rio de Janeiro, 09 out. 1942. Missões Diplomáticas Brasileiras. Telegramas expedidos a Madri (1938 a 1942). AHI/RJ.

${ }_{329}$ Telegrama confidencial n. 93 da Secretaria de Estado das Relações Exteriores para Embaixada em Madri. Rio de Janeiro, 07 out. 1942. Missões Diplomáticas Brasileiras. Telegramas expedidos a Madri (1938 a 1942). AHI/RJ. 
pessoal. $^{330}$ A análise que o Itamaraty fazia do desempenho de seus funcionários no exterior muito dependia da opinião do chefe da missão, único responsável por fornecer um parecer sobre a atuação dos auxiliares contratados, como era o caso de Soroa Filho.

Algumas considerações devem ser feitas com relação à concessão de vistos aos israelitas. Este assunto foi abordado com grande freqüência nas correspondências trocadas entre a Embaixada do Brasil na Espanha e o Itamaraty, durante a Segunda Guerra Mundial.

Segundo Maria Luiza Tucci Carneiro, o anti-semitismo na Era Vargas encontrou condições para fluir enquanto fenômeno político através do quadro de diplomatas do Itamaraty. ${ }^{331}$ Analisando como a questão dos judeus perseguidos pela Alemanha Nazista foi interpretada pela "Elite Rio Branco", Tucci Carneiro demonstra que os diplomatas brasileiros incorporaram uma doutrina racista que foi muito além da simples negação de vistos para emigrar. ${ }^{332}$

A análise dos ofícios, telegramas e despachos trocados com a Embaixada do Brasil na Espanha nos permitiu avaliar a preocupação que o Itamaraty nutria com relação à entrada de judeus em território brasileiro. Um despacho de junho de 1941 vem ao encontro das análises que Tucci Carneiro realizou acerca do posicionamento intolerante que o Ministério das Relações Exteriores adotou diante da questão dos refugiados judeus. Tal despacho alertava para as irregularidades cometidas no visto fornecido pelo serviço consular da Embaixada em Madri no passaporte de George Stranski. Lembrando os dispositivos e decretos que tinham sido desrespeitados, Oswaldo Aranha utilizou-se de um discurso de censura, afirmando que a não rigidez no cumprimento das normas que regulavam a concessão de vistos aos

\footnotetext{
330 Carta de Abelardo Roças para Pedro Leão Velloso, secretário-geral das Relações Exteriores. Madri, 19 jul. 1943. Missões Diplomáticas Brasileiras. Ofícios recebidos de Madri (1943). AHI/RJ.

${ }^{331}$ Maria Luiza Tucci Carneiro. O anti-semitismo na Era Vargas: fantasmas de uma geração (1930-1945). São Paulo: Brasiliense, 1995, p.295.

${ }^{332}$ Idem, p.298.
} 
passaportes de estrangeiros, expunha todo o Ministério das Relações Exteriores às "mais severas e justas críticas". ${ }^{333}$

Essa rigidez na concessão dos vistos refletia o novo decreto de abril de 1941 que, segundo Amado Cervo, veio acrescentar mais dificuldades ao de 20 de agosto de 1938. As instituições do Governo Vargas, "alegando minúcias da lei sustaram a concessão de vistos que as representações diplomáticas no exterior pretendiam ceder com generosidade." 334

Diversos documentos emitidos pelo Itamaraty alertavam a Embaixada do Brasil e os consulados na Espanha, para as irregularidades observadas quanto à concessão de vistos em passaportes de judeus. Esses documentos nos levam a considerar que, assim como na Embaixada do Brasil em Paris, na representação brasileira em Madri também houve a tentativa de auxiliar os judeus que procuravam desesperadamente refúgio na América. Parece-nos pouco provável que essa atitude tenha se dado exclusivamente pelo desejo do embaixador Abelardo Roças em auxiliar as vítimas do nazismo. A admiração que Roças nutria aos países do Eixo não nos permite colocá-lo em situação de igualdade com Luis Martins de Souza Dantas, embaixador brasileiro em Paris que, visando passaportes de judeus e desacatando as resoluções do Itamaraty, salvou inúmeras pessoas dos campos de concentração. ${ }^{335}$

Alguns diplomatas brasileiros estiveram envolvidos na concessão ilegal de vistos para aqueles que tentavam fugir das perseguições nazistas. $O$ escritor Guimarães Rosa, que fez parte dos quadros do Itamaraty e durante a guerra atuava em Hamburgo, ajudou judeus emitindo mais vistos do que a cota estipulava. $^{336}$

Souza Dantas, reconhecido como um dos "Justos entre as Nações" pelo Yad Vashen de Israel, solidarizou-se com os judeus visando

\footnotetext{
${ }^{333}$ Despacho de Oswaldo Aranha, ministro de Estado para Abelardo Roças, embaixador do Brasil na Espanha. Rio de Janeiro, 02 jun. 1941. Missões Diplomáticas Brasileiras. Despachos enviados a Madri (1935-1941). AHI/RJ.

${ }^{334}$ Amado Cervo. As relações históricas entre o Brasil e a Itália: o papel da diplomacia. Brasília: Editora UNB; SP: Instituto Italiano di Cultura, 1992, p. 160.

${ }^{335}$ Sobre essa questão ver: Maria Luiza Tucci Carneiro. Cidadão do mundo, op. cit.

${ }^{336}$ Felipe Fortuna. Guimarães Rosa, viajante. In: Alberto Silva (Org.) O Itamaraty na cultura brasileira. Brasília: Instituto Rio Branco, 2001, p.270.
} 
dezenas de passaportes, a despeito das determinações do governo Vargas. ${ }^{337}$ $\mathrm{O}$ acervo do Itamaraty nos possibilitou conhecer casos de outros diplomatas que também foram punidos, sob a alegação de facilitarem a concessão de vistos para as vítimas do nazismo. O processo administrativo instaurado para averiguar a situação de Souza Dantas também incluía outros dois diplomatas: Antônio Porciúncula, cônsul em Casablanca e Eduardo Porto Osorio Bordini, cônsul na cidade espanhola de Cádiz. O relatório da comissão formada para investigar as irregularidades na concessão de vistos, explicava ao presidente Getúlio Vargas que Bordini teria concedido 10 vistos permanentes e temporários aos passageiros do navio Cabo de Buena Esperanza:

Da letra d do parágrafo 26 ressaltam a leviandade com que agiu o ex cônsul em Cádiz, Senhor Eduardo Porto Osório Bordini, que fundamentou sua concessão de novos vistos na autorização que o consulado honorário em Casablanca dizia possuir da Secretaria de Estado ou da Embaixada em Vichy, para revalidar vistos caducos (sem ter procurado confirmação dessa autorização) - e a boa fé com que, em ofício assinado, avisou a Inspetoria da Polícia Marítima e Aérea do Distrito Federal sobre a situação dos dez passageiros em questão. ${ }^{338}$

Assim como Souza Dantas, Bordini foi aposentado do serviço público, medida essa caracterizada como penalidade. Meses depois desse parecer interno do Itamaraty, o Departamento Administrativo do Serviço Público enviou a Getúlio Vargas as conclusões do processo. O relator concluía que as declarações de Eduardo Bordini convenciam e o isentavam de qualquer responsabilidade, sugerindo que sua aposentadoria fosse revista. ${ }^{339}$

Não sabemos se a aposentadoria de Eduardo Bordini foi reconsiderada, mas é inegável que o episódio representou um grande problema na vida desse diplomata. Durante o período em que esteve afastado, Bordini preparou a sua defesa respaldada em documentos que tentavam comprovar a sua eficiência e dedicação na representação dos interesses brasileiros. Anexadas junto às conclusões, encontramos diversas fotografias

\footnotetext{
${ }^{337}$ Sobre a biografia de Souza Dantas ver: Fabio Koifman. Quixote nas trevas: o embaixador Souza Dantas e os refugiados do nazismo. Rio de Janeiro: Record, 2002.

${ }^{338}$ Relatório de Maurício de Nabuco, presidente da Comissão de Inquérito para Getúlio Vargas, Presidente da República. Rio de Janeiro, 25 fev. 1942. Maço 20778, lata 1096. AHI/RJ.

${ }^{339}$ Relatório de (ass. ileg.) para Getúlio Vargas, Presidente da República do Brasil. Distrito Federal, 11 ago. 1942. Departamento Administrativo do Serviço Público. Maço 34502, lata 1587. AHI/RJ.
} 
que procuravam demonstrar seu envolvimento na organização e apoio às exposições de café brasileiro no exterior. As fotos mostram o cônsul ao lado de stands brasileiros de café e uma particularmente curiosa, tenta "comprovar" seu empenho e prestígio diante das autoridades políticas de Cardiff. Nesta cidade durante a "semana brasileira", a bandeira do Brasil foi hasteada junto à prefeitura.

Os documentos arrolados para a defesa de Bordini nos demonstram que o Ministério das Relações Exteriores desejava que seus representantes promovessem uma imagem do país que beneficiasse as exportações brasileiras. O café, no período proposto nesse trabalho, constituiuse como símbolo do que o Brasil tinha de melhor para vender ao mundo.

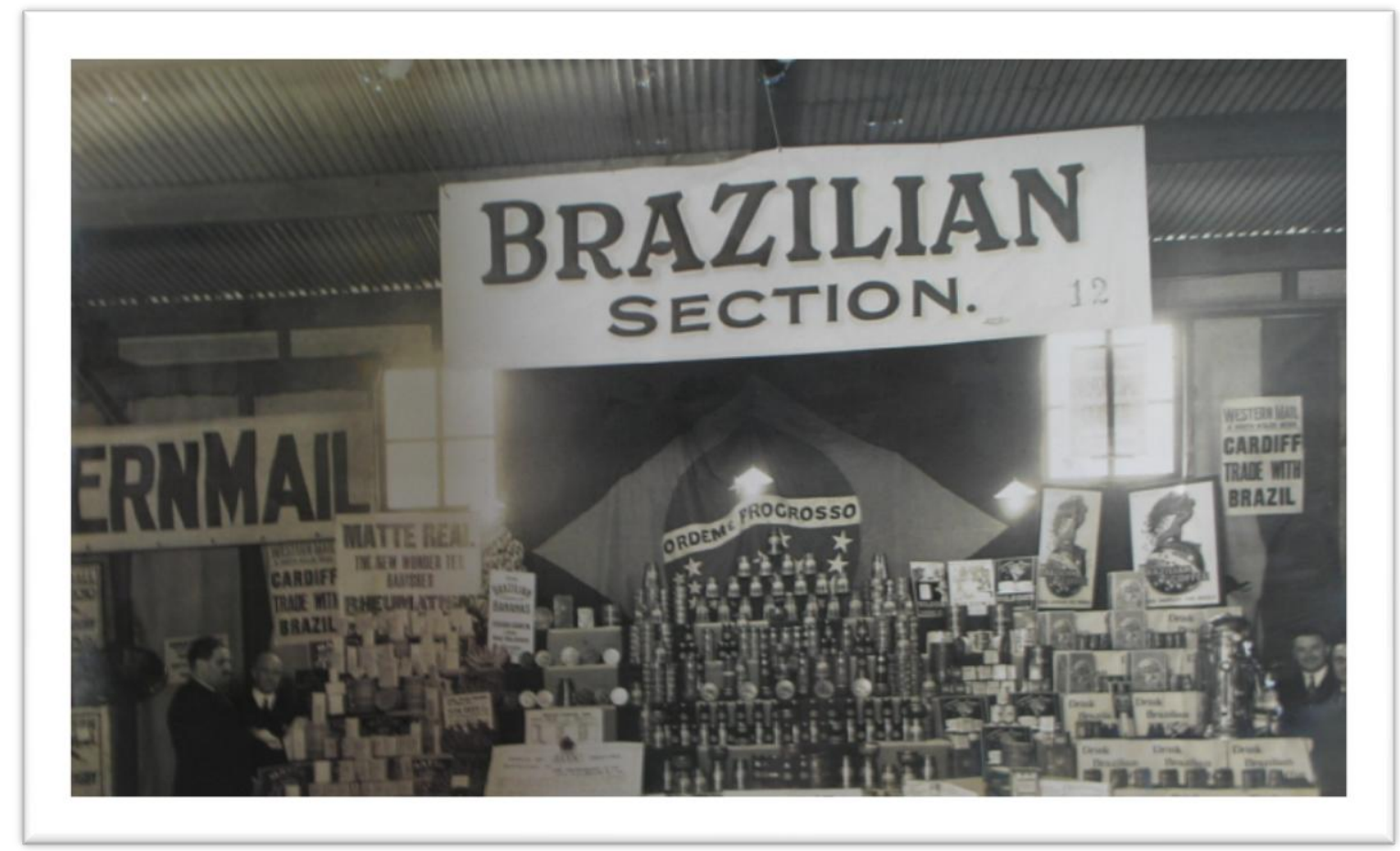

9 - "Brazilian Section" em uma das exposições de produtos brasileiros em Cardiff, País de Galles. Fotografia (s.d., fotógrafo não identificado) inserida nas "razões de defesa" de Eduardo Porto Osorio Bordini. Anexo ao relatório de (ass. ileg.) para Getúlio Vargas, Presidente da República do Brasil. Distrito Federal, 11 ago. 1942. Departamento Administrativo do Serviço Público. Maço 34502, lata 1587. AHI/RJ. 


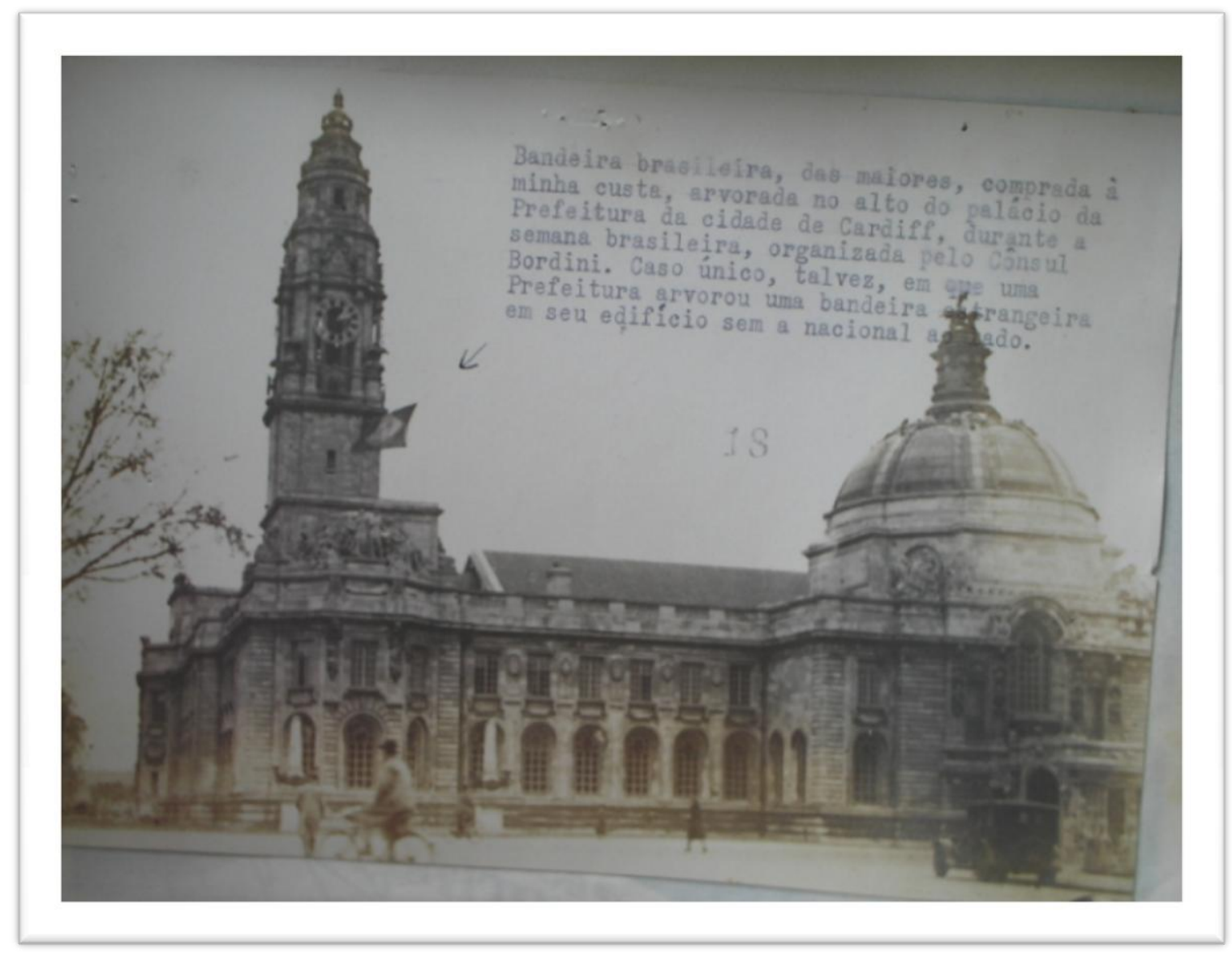

10 - Palácio da prefeitura de Cardiff com bandeira do Brasil hasteada durante a semana brasileira na cidade. Fotografia (s.d., fotógrafo não identificado) inserida nas "razões de defesa" de Eduardo Porto Osorio Bordini. Anexo ao Relatório de (ass. ileg) para Getúlio Vargas, Presidente da República do Brasil. Distrito Federal, 11 ago. 1942. Departamento Administrativo do Serviço Público. Maço 34502, lata 1587. AHI/RJ.

O conflito mundial trouxe à tona desconfianças de que pessoas ligadas às representações diplomáticas na Europa estariam dedicando-se à "venda" de vistos em passaportes. Não apenas na Península Ibérica, cujos portos apresentavam-se como rota de "fuga", mas em toda a Europa circulavam notícias sobre tais irregularidades.

Em Missão no Reich, Roberto Lopes analisa a atuação da diplomacia latino-americana na Alemanha à época do nazismo, e demonstra que muitos diplomatas de países considerados de "segunda ordem", envolveram-se em vergonhosos casos de comércio de passaportes e vistos consulares. Menciona, por exemplo, que uma fração considerável dos judeus que emigraram em 1937 para a América do Sul, passou pelo Consulado Geral da Bolívia, onde o cônsul Carlos Virreira Paccieri distribuía "confirmaciones" de 
vistos em troca de "contribuiciones", "que variavam entre dez mil e vinte mil francos por pessoa." 340

Em 1940, Carlos da Silveira Martins Ramos concedeu uma entrevista ao jornal $A$ Notícia, denunciando a venda de passaportes brasileiros falsos em Paris. llustra o artigo uma foto em que Martins Ramos aparece junto a outros diplomatas que retornavam ao Brasil em decorrência da expansão nazista nos territórios europeus. O diplomata, que após a Guerra Civil Espanhola atuara como conselheiro da Embaixada na França fazia uma grave acusação, mas não parecia sensibilizar-se com a situação daqueles tentavam fugir do horror nazi-fascista.

A pesquisa do jornalista Roberto Lopes revelou que Martins Ramos foi um dos muitos diplomatas fascinados com a ascensão do nazismo e as primeiras medidas contra os judeus na Alemanha. Em 1933, quando servia como secretário da Legação do Brasil em Budapeste, Ramos, considerado "um dos elementos mais cultos entre os mais jovens", afirmou que não havia maustratos contra os israelitas e que Hitler estava somente procurando "defender o cristianismo contra o seu inimigo tradicional e o povo contra o seu explorador habitual". ${ }^{341}$ Seduzido pela Alemanha de Hitler, Martins Ramos parecia, tanto em 1933, quanto em pleno desenrolar do Holocausto, não perceber a verdadeira dimensão da tragédia efetivada a partir daquelas idéias hitleristas.

Em sua entrevista ao jornal $A$ Notícia, Martins Ramos comentou sobre a "indústria de passaportes falsos", tema abordado por Tucci Carneiro em $O$ anti-semitismo na Era Vargas ${ }^{342}$ :

Creou-se com a guerra uma verdadeira indústria de passaportes falsos". Por 55 francos, qualquer família composta de três pessoas, consegue obter o "viato" para vir ao nosso paiz". Até passaportes diplomáticos estão sendo concedidos criminosamente. ${ }^{343}$

\footnotetext{
${ }^{340}$ Roberto Lopes. Missão no Reich: glória e covardia dos diplomatas latino-americanos na Alemanha de Hitler. Rio de Janeiro: Lexikon Editora digital, 2008, p.444.

341 "Os interesses comerciais húngaro-brasileiros". Folha da Manhã, edição de 3 de junho de 1933. São Paulo. Apud Roberto Lopes, op. cit., p.139.

${ }^{342}$ Maria Luiza Tucci Carneiro. O anti-semitismo na Era Vargas, op. cit.

343 "Na Europa estão vendendo passaportes falsos para o Brasil à razão de 55 francos cada um. Graves declarações do Sr. Carlos da Silveira Martins Ramos, ex-conselheiro da nossa embaixada em Paris." Recorte do jornal A Notícia de 04 nov. 1940. Serviço de Imprensa do Ministério das Relações Exteriores. Lata 1096, maço 20778. AHI/RJ.
} 
O artigo informava que Martins Ramos iria relatar a referida situação ao Ministério das Relações Exteriores o que, provavelmente, não foi necessário, já que as repercussões negativas de tais declarações chegaram antes ao Itamaraty. Dois dias após a publicação do artigo, Ramos foi à imprensa retificar as suas declarações que, a seu ver, foram mal-interpretadas:

Não declarei que vistos e passaportes brasileiros estavam sendo falsificados. As representações diplomáticas e consular brasileiras estão, aliás acima de qualquer suspeitas e, neste momento, em circunstâncias dificílimas, estão prestando ao Brasil relevantes serviços. Disse que tanto em Paris como em Lisboa havia "intermediários que, sob o falso pretexto de iniciarem gestões no Rio de Janeiro para a obtenção de visto, estavam extorquindo aos interessados somas vultuosas e que tivera mesmo conhecimento de um caso em que a uma família israelita, composta de 3 pessoas, tinha sido pedida a soma de 55 libras para a obtenção daquela autorização. Aliás acrescentei, esses fatos são do conhecimento das nossas autoridades.

Afim de que não paire nenhuma suspeita sobre a conduta dos nossos agentes no estrangeiro, é de justiça que se dê a esse esclarecimento e maior divulgação possível Com o que Sr. redator, vossa senhoria obsequiará seu patrício e servidor. (a.) Carlos da Silveira Martins Ramos. $^{344}$

Como político de larga experiência, Martins Ramos sabia da gravidade de levantar suspeitas quanto à idoneidade do corpo diplomático, do qual ele fazia parte. Provavelmente, com suas declarações teria pretendido manifestar a sua "honestidade" e a sua adesão às circulares secretas que restringiam a entrada de judeus em território brasileiro. A compreensão da situação pelo Itamaraty, no entanto, foi outra. Como em outros episódios já mencionados, a postura de Martins Ramos desagradou profundamente o MRE, que via naquelas declarações uma afirmação indireta de que a diplomacia brasileira pudesse estar envolvida naquelas irregularidades.

\footnotetext{
344 "Exploração em torno de passaportes brasileiros - retificação necessária". Recorte do Jornal do Brasil. Rio de Janeiro, 06 nov. 1940. Serviço de Imprensa do Ministério das Relações Exteriores. Lata 1096, maço 20778. AHI/RJ.
} 


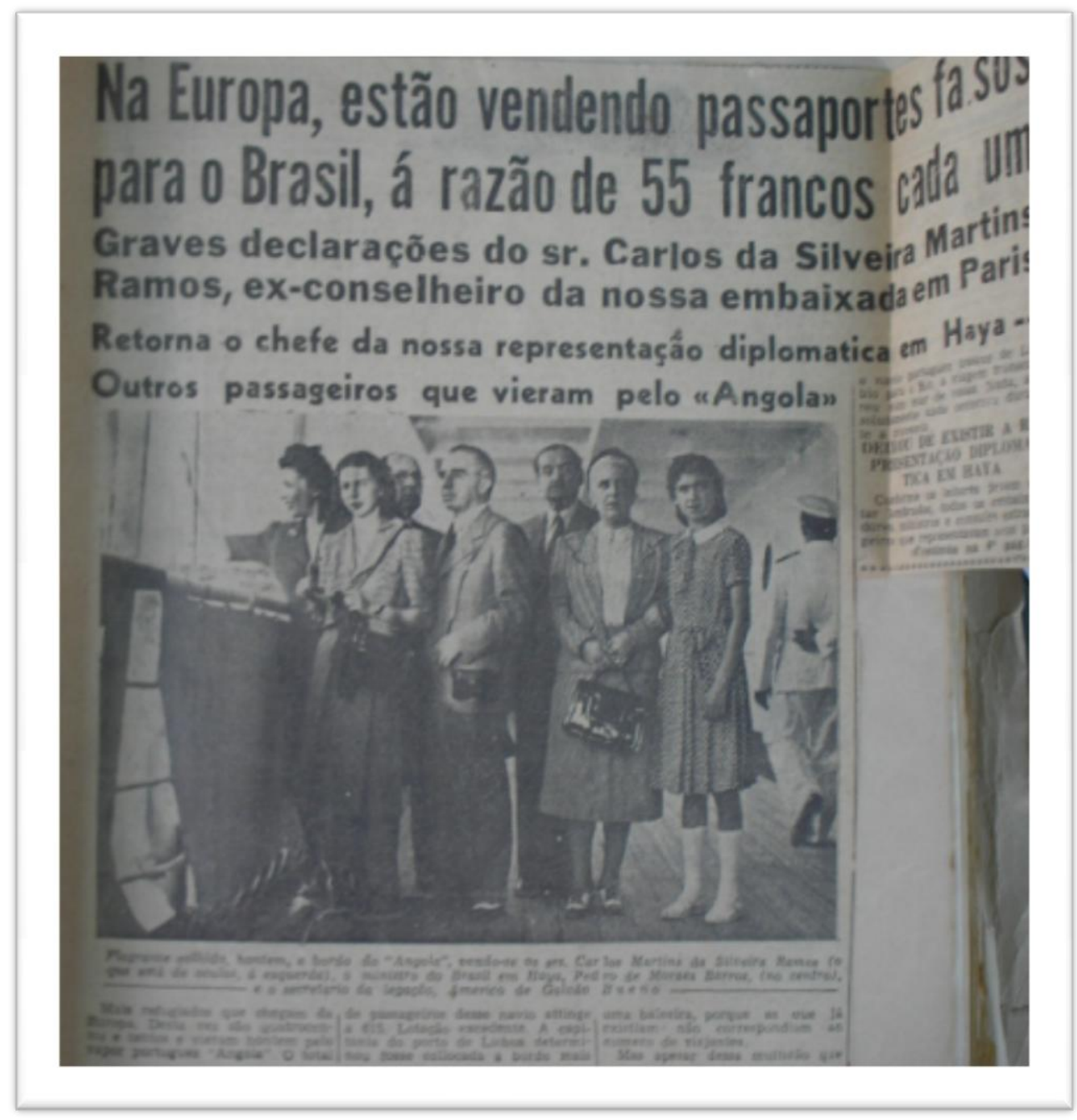

11 - Artigo que divulgou as polêmicas declarações de Carlos da Silveira Martins Ramos sobre a venda de passaportes falsos na Europa. Fotografia reproduzida no jornal $A$ Notícia. Rio de Janeiro, 04 de novembro de 1940. Serviço de Imprensa do Ministério das Relações Exteriores. Lata 1096, maço 20778. AHI/RJ. 
Em março de 1944, com a aposentadoria compulsória de Abelardo Roças, Mario de Pimentel Brandão assumiu a Embaixada brasileira em Madri. ${ }^{345}$ Se comparada à atuação de Roças, sua gestão foi marcada por uma ação mais enérgica na defesa de uma aproximação cultural e econômica entre Brasil e Espanha.

A situação da Embaixada, na visão de Pimentel Brandão, era de desordem. Em ofício ao Itamaraty, o novo embaixador relatou que muito havia por fazer quanto à organização da documentação e do espaço da sede diplomática. Mencionou também a necessidade de promover uma mudança do clima tenso que encontrou entre os funcionários, lembrando as desavenças entre seu antecessor e o encarregado de negócios Roberto Mendes Gonçalves. Assim era a sua compreensão da situação da representação brasileira em Madri:

Esse Ministério não ignora como se desenrolaram, nos últimos anos, os acontecimentos nesta Embaixada. O inquérito, levado a efeito a mando dessa Secretaria de Estado revelou muitos aspectos da falta de ordem, da indisciplina, tudo enfim que contribuiu para fazer desta Repartição diplomática um modelo pernicioso aos trabalhos públicos.(...)

(...) E a Península Ibérica, Senhor Ministro, não só pela sua situação atlântica e mediterrânea, mas também pela afinidade de raças e métodos de comércio, poderia ser um interessante mercado e empório para o Brasil. O que se tem feito aqui é fruto da iniciativa particular. A esta cabe abrir as pequenas rotas, mas é ao Estado que incumbe a grande política e o momento aparece azado para tal. Também qualquer iniciativa oficial seria agora a maneira de assegurar a distribuição dos mercados, após a guerra, certo privilégio em vista dos antecedentes que criaríamos. Devemos agir. Mas tudo que for teoria, ação retardada, deve ser afastada. A Embaixada do Brasil em Madrid não deve ser uma repartição de índole meramente informativa, e sim parte de um conjunto vivo político-econômico que já é a política internacional do Brasil. ${ }^{346}$

Medidas enérgicas para incrementar o comércio com a Espanha eram vistas como necessárias para gerar divisas e garantir uma posição de

\footnotetext{
${ }^{345}$ Ofício n. 44 de Mario de Pimentel Brandão, embaixador do Brasil na Espanha para Oswaldo Aranha, ministro das Relações Exteriores do Brasil. Madri, 24 mar. 1944. Missões Diplomáticas Brasileiras. Ofícios recebidos de Madri (janeiro a julho de 1944). AHI/RJ.

${ }_{346}$ Ofício n.139 (confidencial) de Mario de Pimentel Brandão, embaixador do Brasil na Espanha para ministro das Relações Exteriores do Brasil. Madri, 02 set. 1944. Missões Diplomáticas Brasileiras. Ofícios recebidos de Madri (agosto a outubro de 1944). AHI/RJ.
} 
destaque do Brasil no comércio internacional do pós-guerra. A "afinidade de raças", provavelmente era uma menção à herança ibérica na história brasileira, referência encontrada no discurso de vários dos diplomatas brasileiros em missão naquele país. É possível que a detalhada exposição, cujo fragmento transcrevemos acima, tenha sensibilizado o Itamaraty para a necessidade de, ao menos, oferecer os recursos materiais solicitados pelo embaixador.

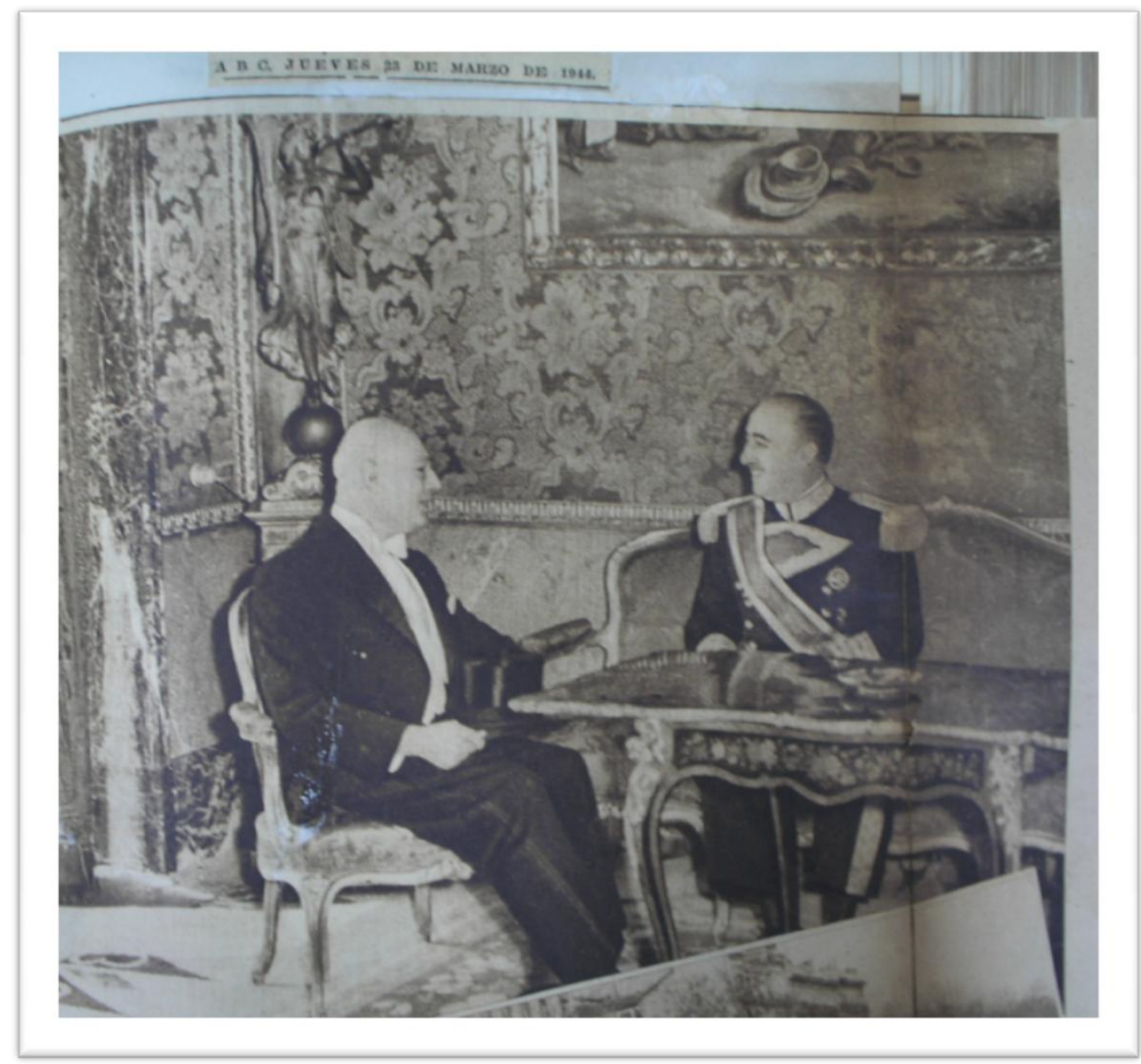

12 - Entrega de credenciais de Mario de Pimentel Brandão a Francisco Franco. Foto reproduzida no jornal $A B C$. Madri, 23 de março de 1944. Recorte anexado ao ofício n. 47 de Mario de Pimentel Brandão, embaixador do Brasil na Espanha para Oswaldo Aranha, ministro das Relações Exteriores do Brasil. Madri, 24 mar. 1944. Missões Diplomáticas Brasileiras. Ofícios recebidos de Madri (janeiro a julho de 1944). AHI/RJ.

Sendo assim, uma antiga demanda dos representantes nesse país foi atendida: a compra de um imóvel para a sede da Embaixada, cuja 
verba utilizada foi disponibilizada pelo Departamento Nacional do Café. ${ }^{347} \mathrm{~A}$ autorização da compra está relacionada à situação econômica daquele país, que favorecia a venda de imóveis por um valor convidativo. Solicitações semelhantes por parte dos representantes do Brasil em outros países europeus também foram realizadas nesse período, dadas as oportunidades decorrentes da situação européia, de adquirir bens para o Itamaraty a preços mais acessíveis ${ }^{348}$. A necessidade de reformar a sede da representação brasileira parece não ter se convertido em subsídios para realizá-la. Em 1950, o embaixador Rubens Ferreira de Mello também atentou para a necessidade de reformas estruturais do prédio. ${ }^{349}$

Pimentel Brandão, que já havia chefiado o Ministério das Relações Exteriores entre 1937 e 1938, elegeu como prioridade de seu trabalho fomentar uma imagem positiva do Brasil junto à imprensa e ao governo espanhol. A preocupação estava respaldada em dois objetivos: incentivar o crescimento das exportações brasileiras e promover "correções" nas alegadas distorções que a imprensa da Espanha cometia acerca do papel do Brasil no conflito mundial. No que tange ao primeiro objetivo, nenhum outro diplomata escreveu tanto sobre os ganhos efetivos que o incremento do comércio com a Espanha poderia trazer ao Brasil. Pimentel Brandão alertou o Itamaraty para as possibilidades de acordos econômicos que poderiam ser realizados no pós-guerra, tendo em vista a situação caótica da economia espanhola.

No intercâmbio comercial com a Espanha, o Brasil sempre havia sido favorecido. Entre 1943 e 1944, por exemplo, foram importadas do Brasil quinze milhões de pesetas, não tendo as exportações espanholas ultrapassado os três milhões de pesetas. ${ }^{350}$

\footnotetext{
347 Telegrama da Secretaria de Estado das Relações Exteriores para a Embaixada em Madri. Rio de Janeiro, 16 ago. 1944. Missões Diplomáticas Brasileiras. Telegramas enviados (19431944). AHI/RJ.

${ }^{348}$ Segundo Raul Bopp em suas memórias, o imóvel de "maior categoria artística, que o Brasil conta no seu patrimônio" é o Palácio de Piazza Navona em Roma. Bopp tece inúmeros elogios ao embaixador brasileiro Hugo Gouthier, que tomou iniciativas para a aquisição do imponente imóvel. (Raul Bopp. Memórias de um embaixador, op. cit., p.246).

${ }^{349}$ Ofício n. 368 de Rubens Ferreira de Mello, embaixador do Brasil para Raul Fernandes, ministro das Relações Exteriores do Brasil. Madri, 17 dez. 1950. Missões Diplomáticas Brasileiras. Ofícios recebidos de Madri (outubro a dezembro de 1950). AHI/RJ.

350 Ofício n. 18 de Roberto Mendes Gonçalves, adido comercial à Embaixada do Brasil na Espanha para Oswaldo Aranha, ministro das Relações Exteriores do Brasil. Madri, 18 jan.
} 
Ao contrário dos anos anteriores, durante 1944 procurou-se incentivar a propaganda da cultura brasileira. Em setembro desse ano, a Embaixada do Brasil solicitou ao Itamaraty o envio de material de propaganda, como fotografias e jornais, afirmando que o momento era propício para realizar a propaganda da cultura brasileira na Espanha:

O momento, Sr. Ministro, é excelente para iniciarmos uma campanha de propaganda brasileira em um país que, desconhecendo tudo na vida das demais nações, sente necessidade de enquadrar-se no concerto internacional e sair desse isolamento egoísta e orgulhoso para a luz do progresso. ${ }^{351}$

$\mathrm{O}$ isolamento a que se referia, prenunciava a necessidade que 0 governo franquista teria de desfazer-se de uma imagem de país adepto ao nazifascismo. Durante o ano de 1944, o embaixador brasileiro alertou diversas vezes o Itamaraty para a necessidade de intensificar a propaganda brasileira lamentando, por exemplo, que as músicas nacionais fossem conhecidas na Espanha graças à tournée de uma Orquestra da Argentina. ${ }^{352} \mathrm{Da}$ mesma forma, lastimava o fato do Brasil não ter sido citado no decreto espanhol que distribuía créditos para a propaganda cultural da Espanha nos países da América. Em carta pessoal a Jose Felix de Lequerica, ministro de Assuntos Exteriores da Espanha, Mario de Pimentel Brandão afirmou sentir necessidade de apelar para a "diplomacia sentimental", mencionando sua decepção ao constatar que o Brasil, assim como outros países, não havia sequer sido mencionado em tal decreto. ${ }^{353}$

Em julho de 1944 a Embaixada brasileira informou ao MRE que Pimentel Brandão visitou a Hemeroteca de Madri, negociando com o prefeito da capital espanhola a intensificação do intercâmbio de periódicos entre Brasil

1944. Missões Diplomáticas Brasileiras. Ofícios recebidos de Madri (janeiro a julho de 1944). AHI/RJ.

${ }^{351}$ Ofício n. 149 (reservado) de Mario de Pimentel Brandão, embaixador do Brasil na Espanha para Oswaldo Aranha, ministro das Relações Exteriores do Brasil. Madri, 13 set. 1944. Missões Diplomáticas Brasileiras. Ofícios recebidos de Madri. (agosto a outubro de 1944). AHI/RJ.

${ }_{352}$ Ofício n. 194 de Mario de Pimentel Brandão, embaixador do Brasil na Espanha para Oswaldo Aranha, ministro das Relações Exteriores do Brasil. Madri, 18 out. 1944. Missões Diplomáticas Brasileiras. Ofícios recebidos de Madri. (agosto a outubro de 1944). AHI/RJ.

${ }^{353}$ Carta de Mario de Pimentel Brandão, embaixador do Brasil na Espanha para José Felix de Lequerica, ministro de Assuntos Exteriores da Espanha. Madri, s/d. Missões Diplomáticas Brasileiras. Ofícios recebidos de Madri (setembro a dezembro de 1945). AHI/RJ. 
e Espanha. ${ }^{354}$ Além das questões de ordem comercial e política, cruciais nas relações hispano-brasileiras, a representação brasileira informava a Secretaria de Estado das Relações Exteriores sobre a política exterior espanhola. Em novembro de 1944 o Itamaraty foi comunicado da criação da Escola Diplomática, cuja meta era preparar profissionalmente o quadro de espanhóis atuantes no exterior. A fundação da referida escola, decretada ainda em 1942, introduziu mudanças substanciais no sistema de seleção de novos diplomatas. ${ }^{355}$

Mario de Pimentel Brandão teceu, por diversas vezes, críticas ao que considerava extremismos do regime de Francisco Franco. Essas podem ser atestadas no relato sobre o insucesso nas negociações para impedir a morte do brasileiro Antonio Fernandez Cuenca, acusado de "subversão política". ${ }^{356} \mathrm{O}$ embaixador brasileiro resolveu agir depois que a Representation in Spain of American Relief Organizations entregou à missão diplomática brasileira os documentos comprobatórios da nacionalidade do referido acusado: certidão de nascimento e passaporte.

A intercessão da Embaixada do Brasil em defesa da comutação de pena ou da libertação do prisioneiro Antonio Fernandez Cuenca, não impediu o seu fuzilamento em 1944. Em ofício confidencial ao ministro das Relações Exteriores, Brandão descreveu minuciosamente toda a trajetória que realizou para tentar salvar a vida do brasileiro, alegando que nem mesmo sua amizade com o ministro da Justiça Eduardo Aunós fora suficiente para que o caso tivesse outro desfecho. Expondo a situação de milhares de presos espanhóis que estavam sendo executados sem nenhuma condenação formal, Pimentel Brandão teceu críticas ao caráter arbitrário do governo franquista. ${ }^{357}$

\footnotetext{
${ }^{354}$ Ofício n. 87 de Mario de Pimentel Brandão, embaixador do Brasil na Espanha para Oswaldo Aranha, ministro das Relações Exteriores do Brasil. Madri, 13 jul. 1944. Missões Diplomáticas Brasileiras. Ofícios recebidos de Madri. (janeiro a julho de 1944). AHI/RJ.

${ }^{355}$ Rocío Valdivielso del Real. La Carrera Diplomática en España (1939-1940). Madri: Ministério de Asuntos Exteriores, 1996, p.33. Biblioteca Diplomática Española, Sección estúdios, 15.

356 Ofício n. 295 (confidencial) de Mario de Pimentel Brandão, embaixador do Brasil na Espanha para Oswaldo Aranha, ministro das Relações Exteriores do Brasil. Madri, 05 dez. 1944. Missões Diplomáticas Brasileiras. Ofícios recebidos de Madri (novembro a dezembro de 1944). AHI/RJ.

357 Ofício n. 295 (confidencial) de Mario de Pimentel Brandão, embaixador do Brasil na Espanha para Oswaldo Aranha, ministro das Relações Exteriores do Brasil. Madri, 05 dez. 1944. Missões Diplomáticas Brasileiras. Ofícios recebidos de Madri (novembro a dezembro de 1944). AHI/RJ.
} 
Brandão ofereceu um panorama da situação de extremismo político e das vinganças proporcionadas pelo lado vitorioso do conflito civil espanhol. Denunciou que na Espanha, apesar da propaganda que divulgava que o Caudilho indultaria os condenados à pena máxima, continuavam as execuções "sistematicamente, num afã de resolver um problema que na visão dos espanhóis falangistas só poderá ter fim com a eliminação total dos seus desafetos". Num tom de crítica aos extremismos o embaixador concluía, tecendo uma reflexão contundente acerca das dimensões do terror e da paixão política imperantes naquele país:

Entretanto, numa terra onde a compaixão não existe e a vida humana, apesar do individualismo exagerado do espanhol - não conta, apenas devemos anotar, como exemplo para os tempos vindoiros, o que espera a todo estrangeiro que busque este país em épocas de terror e de paixão política. ${ }^{358}$

Além de efetivar ações para aumentar o comércio com a Espanha, Pimentel Brandão deparou-se com outra missão: defender o posicionamento do Brasil no conflito europeu. O embaixador costumava dar entrevistas à imprensa espanhola, discursando especialmente sobre 0 alinhamento brasileiro à política pan-americana. É perceptível que sua preocupação era defender a autonomia política brasileira, rebatendo as diversas referências que a imprensa hispânica fazia ao Brasil como um país "controlado" pelos EUA.

Segundo o embaixador brasileiro, as notícias acerca do conflito europeu na Espanha, ao estarem sob o rígido controle da censura governamental, procuravam omitir do público as vitórias aliadas. ${ }^{359} \mathrm{Em}$ alguns momentos Pimentel Brandão procurou intervir diretamente nas notícias veiculadas sobre o Brasil. Comentários considerados desfavoráveis sobre a chegada da FEB à Itália publicadas pelo jornal $A B C$ levaram o embaixador a convidar o responsável pelas matérias de política internacional a prestar declarações. Diante das considerações de Brandão, o jornalista desculpou-se e

\footnotetext{
${ }^{358}$ Idem.

359 Ofício n. 130 (reservado) de Mario de Pimentel Brandão, embaixador do Brasil na Espanha para Pedro Leão Velloso, ministro interino das Relações Exteriores do Brasil. Madri, 25 ago. 1944. Lata 1373, maço 31856. AHI/RJ.
} 
alegou que não era sua intenção tecer críticas ao governo brasileiro, comprometendo-se a não mais cometer "equívocos" nas notícias sobre a presença do Brasil no teatro de operações de guerra. ${ }^{360}$

No início de 1945, com a derrota quase definitiva do Eixo, a ditadura franquista passou a "reescrever" a história da participação espanhola no conflito. Negando que a Espanha pudesse ter entrado na guerra, Franco procurou realçar junto ao exterior o caráter católico e monárquico da Espanha. Procurava assim, afastar os elementos "fascistas" de seu governo, apresentando-o como um "producto exclusivamente español". 361

O receio de Franco estava respaldado na promessa assumida pelas lideranças Aliadas de promover eleições livres a todos os povos satélites do Eixo, um propósito que poderia afetar a Espanha. ${ }^{362}$ Essa situação tornavase evidente na imprensa hispânica, que divulgava a necessidade de defender a não ingerência exterior nos assuntos próprios do país.

Em um artigo do jornal madrilenho El Alcázar, o Brasil foi utilizado como exemplo de país que não sofria a intervenção das demais nações aliadas, no que tange a seu regime político. Essa era uma referência direta ao fato dos Aliados não verem contradição na aliança com um país cujo regime era autoritário. O autor estabelecia uma comparação com o caso espanhol, afirmando não considerar excessiva a pretensão de que fosse dado a Espanha o "mesmo direito" de escolher seu regime de governo. Argumento esse que reforçava, na visão de Franco, a "injustiça" que os Aliados cometiam ao criticálo. ${ }^{363}$

\footnotetext{
360 Ofício n. 104 (reservado) de Mario de Pimentel Brandão, embaixador do Brasil na Espanha para Ministro das Relações Exteriores do Brasil. Madri, 30 jul. 1944. Missões Diplomáticas Brasileiras. Ofícios recebidos de Madri (janeiro a julho de 1944). AHI/RJ.

361 Paul Preston. Franco, Caudillo de España, op. cit., p.665.

${ }^{362}$ Idem, p.667.

${ }^{363}$ Recorte do jornal El Alcazar de 03 fev. 1945. Anexo ao ofício n. 64 de Mario de Pimentel Brandão, embaixador do Brasil na Espanha para Pedro Leão Velloso, ministro interino das Relações Exteriores do Brasil. Madri, 09 fev. 1945. Missões Diplomáticas Brasileiras. Ofícios recebidos de Madri (janeiro e fevereiro de 1945). AHI/RJ.
} 


\section{2 - A "euforia democrática": O Brasil e a questão espanhola na ONU (1945-1950)}

O término do conflito mundial em 1945, e a eleição do General Dutra para a presidência da República, inauguraram uma nova fase na política interna e externa do Brasil, na qual se tornou evidente a influência norteamericana. Internamente, as facilidades criadas para a penetração econômica dos EUA colocaram em cheque a possibilidade de um desenvolvimento autônomo brasileiro. ${ }^{364}$ No plano externo, o Brasil do pós-guerra apresentavase como potência intermediária que, junto à $\mathrm{ONU}$, esteve sob constante pressão dos EUA. Havia, por parte das elites brasileiras, a esperança de que a participação no conflito mundial e as credenciais do Brasil como um país de grandes extensões territoriais se revertessem numa posição de destaque na nova ordem mundial. O Brasil almejava ocupar um posto permanente no Conselho de Segurança, assunto esse que adquiriu relevância nas reuniões preparatórias e nas primeiras Assembléias Gerais da ONU. A diplomacia se apegava ao fato do Brasil ter participado ativamente da guerra, contribuindo militarmente para o combate ao nazifascismo. As ilusões, no entanto, iriam se desvanecer. Como afirma Clodoaldo Bueno, o Brasil possuía "uma concepção distante daquela que the era atribuída pelas potências européias" a respeito da sua importância no cenário mundial. ${ }^{365}$

O tímido apoio dos EUA a esse desejo foi substituído por uma atitude ambígua, sendo a presença brasileira neste fórum caracterizada por uma "fuerte inclusión institucional y una gran exclusión decisória". ${ }^{366} \mathrm{Na}$ primeira Assembléia Geral, o Brasil foi eleito para um mandato de dois anos para o primeiro lugar não permanente no referido Conselho. Sua eleição

\footnotetext{
${ }^{364}$ Amado Luiz Cervo (org.). O desafio internacional: a política exterior do Brasil de 1930 a nossos dias. Brasília: Editora UNB, 1994, p.34.

${ }_{365}$ Amado Luis Cervo; Clodoaldo Bueno. História da política exterior do Brasil, op. cit., p.205.

${ }^{366}$ Bruno Ayllón Pino. Las relaciones entre Brasil y España ponderadas desde la perspectiva de la politica exterior brasileña (1970-2000), op. cit., p.200.
} 
também pode ser entendida como a retribuição norte-americana à orientação brasileira de seguir a "potência hegemônica" nas votações. ${ }^{367}$

A postura do governo Dutra e do Ministério das Relações Exteriores, nesse aspecto, foi motivo de queixas dos representantes brasileiros na ONU, que alegavam ao Itamaraty que o voto brasileiro significava "uma mera duplicação do voto norte-americano". 368 Segundo Paulo Vizentini, Oswaldo Aranha, então chefe da delegação do Brasil e presidente da II Assembléia Geral da ONU, entrou em inúmeros atritos com o ministro Raul Fernandes, defendendo uma postura mais independente. ${ }^{369}$

As orientações do Itamaraty aos representantes brasileiros atuantes na referida Organização se faziam no sentido de defender as opiniões específicas do governo brasileiro, desde que as mesmas não entrassem em choque com a posição americana. Em setembro de 1945, o Itamaraty opinou que considerava que a melhor escolha para a sede da ONU seria uma cidade européia, mas que o Brasil deveria votar com os EUA. ${ }^{370} \mathrm{Em}$ outubro do mesmo ano, a orientação era para dialogar com o chefe da delegação britânica sobre a possibilidade da escolha da cidade francesa de Nice como sede da ONU. Na opinião do chanceler Raul Fernandes, havia as vantagens financeiras de ter uma sede na América do Norte, mas o Brasil deveria curvar-se à vantagem moral de se escolher a Europa. ${ }^{371}$

Embora a diplomacia brasileira vislumbrasse as dificuldades em adquirir as vantagens e privilégios almejados pelo Brasil, a tendência era de enfatizar a contribuição do país nos esforços para a construção da paz mundial. Em fevereiro de 1946, a delegação brasileira comunicou com entusiasmo que sua atuação junto à ONU recebia elogios dos representantes das grandes potências, e que os representantes brasileiros mantinham excelentes relações pessoais e de amizade com os delegados de outros

\footnotetext{
${ }^{367}$ Amado Luis Cervo. O desafio internacional, op. cit., p.66.

${ }^{368}$ Gerson Moura. Sucessos e ilusões. Relações Internacionais do Brasil durante e após a Segunda Guerra Mundial. Rio de Janeiro: Editora FGV, 1991.

369 Paulo Fagundes Vizentini. Relações Exteriores do Brasil (1945-64). O Nacionalismo e a política externa independente. Petrópolis: Vozes, 2004, p.21.

370 Telegrama do Ministério das Relações Exteriores para a Delegação do Brasil junto a ONU. Rio de Janeiro, 11 set. 1945. Diversos no Exterior. Telegramas e minutas (1945-1946). AHI/RJ.

${ }_{371}$ Telegrama do Ministério das Relações Exteriores para a Delegação do Brasil junto a ONU. Rio de Janeiro, 08 out. 1945. Diversos no Exterior .Telegramas e minutas (1945-1946). AHI/RJ.
} 
países. O Brasil, ao ser eleito o primeiro membro não permanente do Conselho de Segurança, se deparava com responsabilidades e deveres nunca antes enfrentados. ${ }^{372}$

Alguns expoentes da diplomacia brasileira, no entanto, passaram a demonstrar decepção com a real posição do Brasil na ONU. O anticomunismo e a defesa de uma concepção cristã de Estado marcaram os discursos de Hildebrando Accioly, diplomata de carreira e por vezes ministro interino das Relações Exteriores. Em uma conferência realizada na Faculdade de Direito, o diplomata criticou o modelo do Conselho de Segurança, numa demonstração de pesar pelo fracasso das reivindicações do Brasil quanto ao posto permanente. Também defendeu o papel da Igreja e do cristianismo nos "esforços pacificadores e na paz mundial". ${ }^{373}$

Nos anos que se seguiram ao término da guerra, o Brasil foi se distanciando da perspectiva inicial de estabelecer alguma "preeminência" na América Latina. Como afirma Gerson Moura, apesar do país emergir da guerra como a maior força armada da América Latina, "não logrou desempenhar nas conferências internacionais para a reorganização do pós-guerra o papel que imaginara para si. A política externa brasileira chegara aos limites possíveis do alinhamento". ${ }^{374}$

Nesse mesmo momento, a Espanha de Franco também se via obrigada a rever sua imagem. Franco deu uma guinada nas diretrizes de seu governo: era necessário mostrar ao mundo que a Espanha não era um país fascista. Para tanto, promoveu ações para apagar as lembranças que remetiam a seu apoio indireto a Hitler e Mussolini. Caberia, no novo contexto internacional, reforçar o mérito da Espanha em ter se mantido "neutra" durante toda a guerra mundial, o que nos primeiros momentos do conflito constituiu-se como benéfico, especialmente para a Inglaterra.

\footnotetext{
372 Ofício n. 26 da delegação do Brasil na ONU a João Neves da Fontoura, ministro das Relações Exteriores. Londres, 21 fev. 1946. Delegação do Brasil na ONU. Ofícios recebidos. (jan/fev. 1946). AHI/RJ.

373 Hildebrando Accioly. A Paz mundial e a Organização das Nações Unidas. São Paulo: Faculdade Paulista de Direito, 1946, p.10.

${ }^{374}$ Gerson Moura. A Revolução de 1930, op. cit., p.589.
} 
$\mathrm{Na}$ tentativa de amenizar a condenação internacional, em outubro de 1945 , foi promulgada uma lei que estabelecia que, quando determinados assuntos fossem de interesse público, haveria referendum para submeter à opinião pública os projetos elaborados pelas Cortes. ${ }^{375} \mathrm{Em} \mathrm{1947,} \mathrm{na} \mathrm{tentativa}$ de encerrar as disputas internas entre monarquistas e falangistas, foi sancionada a Lei de Sucessão, que delegava a Franco o poder de escolher o príncipe Juan Carlos de Bourbon como seu sucessor.

A Falange passou a ter menos poder e voz de comando, dando lugar a proeminência dos setores católicos na composição das elites dirigentes. Alberto Martin Artajo, dirigente da Acción Catolica assumiu, a partir de julho de 1945, a pasta de Assuntos Exteriores, buscando o apoio da Igreja Católica junto aos organismos internacionais. ${ }^{376}$ Uma das primeiras medidas de Martin Artajo foi aglutinar esforços da diplomacia em torno da necessidade de se cooptar o apoio dos países americanos. O ministro acreditava que esses poderiam defender junto à $\mathrm{ONU}$, a idéia de que a recriminação do regime franquista significava a ingerência em assuntos internos da Espanha. A estratégia do $M A E$, nesse momento, era reforçar o sentimento de hispanidade, e a necessidade de preservá-lo das diferenças políticas consideradas "circunstanciais". Na tentativa de recuperar a credibilidade da ditadura, o ministro convidou publicamente os governantes e personalidades das nações latino-americanas a visitarem a Espanha e comprovarem "la falsedad de la campaña de descrédito forjada contra la Madre Pátria." ${ }^{377}$

\footnotetext{
${ }^{375}$ Ramón Tamames. La República, La Era de Franco. Madrid: Alianza Editorial, Alfaguarra, 1977, p. 450.

${ }^{376}$ Jose Luis Rubio Cordon. El oficialismo institucional: El Instituto de Cultura Hispánica. In: Jose Luis Abellán; Antonio Monclus (Coord.), op. cit., p.131.

377 Lorenzo Delgado Gomez-Escalonilla. Imperio de Papel, op. cit., p. 437.
} 


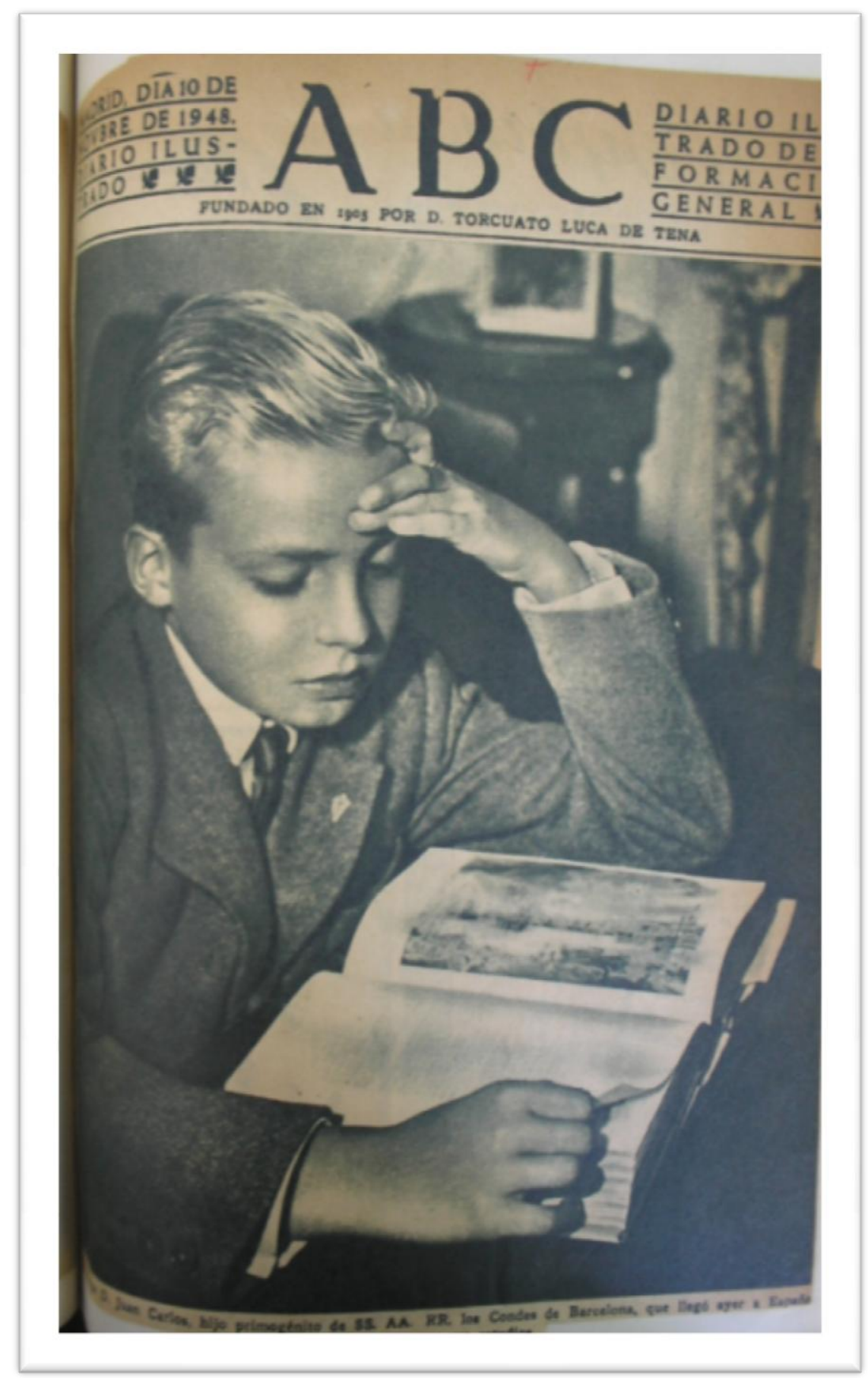

13 - Príncipe Juan Carlos de Bourbon que, em 1948, retornou a Espanha para dedicar-se aos estudos. Capa do jornal $A B C$. Madri (s.d). Anexo ao ofício n. 412 (reservado) de Vasco Leitão da Cunha, encarregado de negócios do Brasil na Espanha para Hildebrando Accioly, ministro interino das Relações Exteriores do Brasil. Madri, 18 nov. 1948. Missões Diplomáticas Brasileiras. Ofícios recebidos de Madri (nov. a dez. de 1948). AHI/RJ. 
Interessante observar que a política externa do franquismo muito se diferenciava daquela praticada no contexto do conflito mundial. $O$ resgate de um projeto imperialista, verificado na presença da Falange na América, foi deixado de lado. A necessidade de apoio promoveu uma valorização da Hispanidade como um sentido de comunidade espiritual entre todos os descendentes dos mesmos "heróes y santos". ${ }^{378}$ Embora o governo franquista se esforçasse por transmitir para a comunidade internacional uma imagem positiva do regime, no plano interno persistia a política de excluir os adversários do regime. O extermínio de presos políticos pela ditadura do general Franco ainda hoje é alvo de investigações e debates. ${ }^{379}$

Sob a mira da repressão, as associações socialistas viam na denúncia às representações estrangeiras em Madri uma forma de tentar acabar com a eliminação sistemática dos "inimigos políticos" de Franco. Em junho de 1945, a Embaixada do Brasil recebeu uma correspondência da Comisión Nacional de las Juventudes Socialistas de España, expondo a ocorrência do fuzilamento sistemático dos presos da cadeia de Alcalá de Henares ${ }^{380}$. Duvidando da veracidade dessa informação, Mario de Pimentel Brandão limitou-se a encaminhar a denúncia ao Itamaraty como "testemunho da agitação política que ainda persiste neste país" ${ }^{381}$

Os relatórios da diplomacia brasileira acerca da situação política e econômica da Espanha nos oferecem uma visão abrangente das principais dificuldades enfrentadas pela ditadura franquista entre 1945 e 1947. Nesse período, as atenções da imprensa hispânica estavam voltadas a cuestion española na ONU, além das conturbadas relações com a França. Em 1946, acatando as pressões internas, o governo francês decidiu fechar a fronteira com a Espanha, interrompendo as trocas comerciais. Esse fechamento tinha um valor simbólico, pois colocava em evidência, no cenário internacional, a força dos partidos franceses antifranquistas. Tal política, no entanto, foi 378 Idem.
379 A dimensão de tais atrocidades vem sendo revista por grupos que trabalham para mapear
valas coletivas, onde milhares de vítimas da ditadura espanhola foram enterradas e
"esquecidas" da história oficial. Sobre essa questão ver o artigo "Espanha livre optou por
silêncio sobre mortos na ditadura". Folha de S. Paulo, 21 set. 2008, p.19.
${ }^{380}$ Alcalá de Henares é uma cidade próxima a Madri conhecida por ser o berço de Miguel de
Cervantes.
${ }_{381}$ Ofício n. 191 (reservado) de Mario de Pimentel Brandão, embaixador do Brasil na Espanha
para Jose Roberto de Macedo Soares, secretário das Relações Exteriores. Missões
Diplomáticas Brasileiras. Ofícios recebidos de Madri (maio a agosto de 1945). AHI/RJ. 
temporária. Em 1948, a França mudou a sua política de retaliação ao vizinho com o propósito de corresponder mais à realidade do que à ideologia. As fronteiras foram reabertas em 10 de fevereiro de $1948 \mathrm{com}$ a intermediação dos EUA. Não houve, no entanto, completa normalização das relações bilaterais, pois a França não renunciaria à sua política de combate ao regime espanhol na ONU. ${ }^{382}$

Outro aspecto que dificultou ainda mais a precária situação da economia hispânica foi a sua exclusão do Plano Marshall. Os países europeus se articularam para impedir que a Espanha conseguisse obter, a partir do Plano, recursos financeiros. França e Inglaterra recusaram a entrada deste país, receando que os recursos para seus respectivos países fossem desviados para o território espanhol. Além disso, a opinião pública reagia diante dessa possibilidade e continuava a argumentar sobre o caráter fascista do regime espanhol. ${ }^{383}$

A ditadura franquista reconhecia o quanto era importante a inserção da Espanha no programa de recuperação européia, fazendo todo o possível para angariar o apoio dos países capazes de respaldar a sua entrada. No entanto, seguindo uma política de orgulho, não realizou nenhuma declaração pública manifestando seu interesse em tomar parte no Plano Marshall. ${ }^{384} \mathrm{O}$ resultado prático da ausência de ajuda financeira foi um largo período de miséria e privações para grande parte da população. Para o historiador espanhol Ramón Tamames, a raiz dessa situação residia na escassez de importações, que poderiam repor os equipamentos industriais necessários para retomar a economia espanhola. ${ }^{385}$

A atitude do General Franco diante da condenação internacional de seu governo foi a de manter uma postura auto denominada "digna", insistindo no caráter anticomunista do regime. Em 1947, o governo espanhol passou a transmitir à opinião pública sua insatisfação com a política norteamericana para a Espanha. A argumentação fazia-se sempre na mesma

\footnotetext{
382 Pedro Martínez Lillo. La diplomacia española y el Plano Marshall en el marco de las relaciones hispano-francesas (junio 1947 - abril 1948). Cuadernos de Historia Contemporanea. Madri, Universidad Complutense, n. 18, 1996, p. 161.

${ }^{383}$ Idem, p.171.

${ }^{384}$ Francisco Portero. Franco aislado. La cuestión española (1945-1950). Madrid: Aguilar, 1989, p.317.

${ }^{385}$ Ramón Tamames, op. cit., p. 424.
} 
direção: atestar o anticomunismo espanhol e a sua neutralidade durante o conflito mundial como uma considerável contribuição para a vitória dos Aliados. Assim era o título do artigo que anunciava a entrevista de Franco a um jornalista norte-americano:

Es una desgracia que una nación como la norte-americana, siempre respectuosa com la soberanía de otras naciones, ceda ante países interesados en provocar situaciones violentas para nuestra Patria. Se comprende que el comunismo no nos quiera, pero es incomprensible el recelo en el pueblo norteamericano, cuando nuestra neutralidad ayudó a su victoria. ${ }^{386}$

Franco aproveitava-se das dissidências entre EUA e URSS, especialmente no âmbito da defesa de interesses nos organismos internacionais, para demonstrar que a Espanha franquista deveria ser aceita por todos aqueles que temiam a expansão soviética.

A resistência antifranquista no Brasil

A resistência ao franquismo na década de 1940 ocorreu, com maior ou menor ênfase, em diversos países europeus e da América Latina. A opinião pública francesa contribuiu para que o governo da França mantivesse uma postura de combate ao regime espanhol. Para os franceses a Espanha continuou sendo motivo de discórdia suficiente para manter as dissidências internas. $^{387}$

Albert Cammus, um dos maiores escritores do século $X X$, foi porta-voz da luta antifranquista no imediato pós-guerra. Nos diversos artigos que escreveu sobre a Espanha, Cammus procurou demonstrar que a

\footnotetext{
386 Jornal Arriba. Madri, 16 fev. 1947. Recorte anexado ao ofício n. 85 (reservado) de Vasco Leitão da Cunha, encarregado de negócios do Brasil na Espanha para Raul Fernandes, ministro das Relações Exteriores. Madri, 20 fev. 1947. Missões Diplomáticas Brasileiras. Ofícios recebidos de Madri (jan. a fev. de 1947). AHI/RJ.

${ }^{387}$ Francisco Portero, op. cit., p.23.
} 
derrocada do regime franquista e a restituição da República espanhola eram de inteira responsabilidade dos Aliados. Em sua opinião, os Aliados deveriam agir com coerência, sendo fiéis aos princípios de liberdade. ${ }^{388}$ Cammus afirmava que a guerra européia havia começado na Espanha e não poderia terminar sem ela, ou seja, era chegada a hora de lutar pela restauração da República naquele país.

$\mathrm{Na}$ América Latina, o México foi o único país a prestar solidariedade oficial ao regime republicano durante o conflito civil. Nos anos subseqüentes, o antifranquismo permaneceu vivo, uma vez que, ao final da Segunda Guerra Mundial, este país acolheu o governo republicano espanhol no exílio. Ali também se estabeleceram milhares de espanhóis na condição de asilados, dentre os quais eminentes políticos como Manuel Azaña e Diego Martínez Barrio. O antifranquismo no México acabou por concentrar a hispanofobia de esquerda. ${ }^{389}$

No Brasil a mobilização contra o regime autoritário na Espanha, apesar de enfrentar os percalços da repressão policial, sobreviveu ao término do conflito civil. O movimento de caráter antifranquista de maior amplitude ocorrido no Brasil foi a greve que paralisou por alguns dias as atividades do porto de Santos, o maior do país. Em 1946 os trabalhadores do porto interromperam as atividades nos navios que tinham a Espanha como destino ou procedência, em sinal de protesto contra a ditadura de Franco. $O$ movimento, considerado um marco na história do movimento sindical brasileiro, foi imortalizado por Jorge Amado em Os subterrâneos da liberdade, obra na qual o autor cruzou ficção e realidade, na tentativa de criar uma visão mitológica da experiência dos trabalhadores portuários. ${ }^{390} \mathrm{~A}$ dimensão até então alcançada pelo movimento passou a preocupar o governo brasileiro,

\footnotetext{
388 Albert Cammus. "Nuestros hermanos de España" (Combat, 7 de septiembre 1944). In: España Libre. Gijón: Júcar, 1978, p.19. Cronica General de España.

${ }^{389} \mathrm{Cf}$. Abdon Mateos em resenha do livro de Clara E. Lida (Coord). México y España durante el primer franquismo, 1939-1950. Rupturas formales, relaciones oficiosas. Mexico: El Colegio de Mexico, 2001. In: Historia Mexicana. El Colegio de Mexico, n. 02, v. III, p.572-577, octubredeciembre, 2002.

390 Jorge Amado. Os subterrâneos da liberdade (II - A agonia da noite). São Paulo: Martins Fontes, 1970.
} 
tendo a repressão policial contribuído para o desfecho da greve, que durou quase quatro meses. ${ }^{391}$

A greve no porto de Santos causou a indignação do embaixador espanhol Jose de Rojas y Moreno, que recorreu ao Itamaraty para solicitar que as "agressões" contra Franco nas notícias veiculadas pela imprensa brasileira acerca da greve fossem censuradas. ${ }^{392} \mathrm{~A}$ resposta do Itamaraty, poucos dias depois, prenunciava outras de igual teor: em nome do governo brasileiro lamentava as referidas ofensas, mas alegava que não dispunha de meios legais para censurar os órgãos de imprensa. ${ }^{393}$

Logo após o conflito mundial foi criada a ABAPE (Associação Brasileira dos Amigos do Povo Espanhol), que aglutinou centenas de pessoas comprometidas com 0 antifascismo. Os estatutos da referida entidade declaravam que seu objetivo era congregar brasileiros e estrangeiros em defesa dos princípios de fraternidade, e da democracia espanhola em particular. Declaravam também o respeito às leis vigentes do país em todas as atividades, como nos atos públicos e festivais promovidos pela associação. ${ }^{394}$

A Embaixada da Espanha no Rio de Janeiro acompanhava com atenção as atividades da referida entidade, relatando ao MAE a sua repercussão em várias cidades do Brasil. Dentre os documentos um se destaca por trazer à tona o envolvimento da Embaixada da Espanha com um caso de espionagem.

Em um despacho reservado, o embaixador espanhol relatou ao ministro de Assuntos Exteriores da Espanha ter recebido no Rio de Janeiro o cidadão espanhol Claudio Díez Millas. Como prêmio aos serviços prestados ao seu país e pelo fato de ter sido jurado de morte por setores de esquerda da Espanha, Díez Millas teria obtido das autoridades espanholas a indicação para

\footnotetext{
391 Sobre a greve no porto de Santos em 1946 e a participação de espanhóis na mesma ver: Ismara Izepe de Souza. Solidariedade Internacional, op. cit., p.233. Ver também Rodrigo Rodrigues Tavares. O porto vermelho: a maré revolucionária (1930-1951). São Paulo: Arquivo do Estado/Imprensa Oficial, 2001, p.66-74. Inventário DEOPS, módulo VI - Comunistas.

${ }_{392}$ Nota n. 29 de Jose Rojas y Moreno, embaixador da Espanha no Brasil para João Neves da Fontoura, ministro das Relações Exteriores do Brasil. Rio de Janeiro, 03 jun. 1946. Representações Estrangeiras. Notas recebidas da Espanha (1946-1948). AHI/RJ.

${ }_{393}$ Nota n. 16 de Samuel de Leão Gracie, secretário-geral das Relações Exteriores do Brasil para Jose Gallostra Coelho, encarregado de negócios da Espanha no Brasil. Rio de Janeiro, 12 jun. 1946. Notas expedidas a Espanha (1946-1951). AHI/RJ.

${ }^{394}$ Estatutos da Associação Brasileira dos Amigos do Povo Espanhol. Rio de Janeiro, 05 jun. 1945. Prontuário 10503 - Associação dos Amigos do Povo Espanhol. DEOPS-SP/AESP.
} 
trabalhar junto àquela Embaixada. Tais serviços estavam relacionados ao seu trabalho como "confidente" para o governo espanhol. O embaixador informou ao Ministério que havia proposto a Díez Millas infitrar-se na ABAPE para conhecer detalhes das atividades antifranquistas no Brasil. Informava ainda que havia acertado que, por essa função, ele receberia uma remuneração de dois mil cruzeiros mensais. As considerações finais do documento revelam detalhes sobre as atividades da ABAPE que, certamente, foram obtidas a partir da ação de Díez Millas. Fazendo-se passar por um antifascista, o "confidente" conseguiu ser aceito como membro da entidade, tendo assistido às solenidades de uma dessas reuniões na tribuna de honra. ${ }^{395}$

Este caso revela o envolvimento direto da missão diplomática da Espanha com atividades como a espionagem, além de nos oferecer indícios sobre o funcionamento interno do MAE. A despeito das mudanças ocorridas em 1942, após a criação da escola diplomática, as representações da Espanha pelo mundo provavelmente passaram a empregar pessoas alheias à carreira diplomática. O governo franquista incentivava, ou pelo menos consentia esse tipo de ação. Ao admitirem a censura e a repressão aos dissidentes como instrumentos legítimos de ação política, os diplomatas espanhóis não interpretavam esse "tipo de serviço" como contrário aos princípios éticos que deveriam nortear as ações de um Estado. Ao financiar tal atividade, o embaixador acreditava estar cumprindo seu papel de zelar pelo regime político vigente no país que representava.

O referido "confidente" manteve a Embaixada espanhola informada sobre as atividades realizadas pela ABAPE. Em abril de 1947, diversos despachos foram enviados ao MAE sobre a atuação da entidade que, em prol dos refugiados espanhóis, enviou à França caixas contendo alimentos, vestuário e medicamento. ${ }^{396}$ Neste mesmo ano, Luiz Hildebrando de Horta Barbosa, presidente da ABAPE, escreveu a Oswaldo Aranha, então presidente da II Assembléia Geral da ONU, manifestando seu desejo de solucionar o "caso espanhol". Afirmava que os antifascistas brasileiros desejavam que 0

\footnotetext{
395 Despacho n. 112 (reservado) de Jose Rojas y Moreno, embaixador da Espanha no Brasil para ministro de Assuntos Exteriores. Rio de Janeiro, 11 mar. 1947. R1940, expt. 48. AMAE. ${ }^{396}$ Despacho n. 285 (confidencial) de Jose Rojas y Moreno, embaixador da Espanha no Brasil para ministro de Assuntos Exteriores. Rio de Janeiro, 29 abr. 1947. R 1940, expt. 48. AMAE.
} 
povo espanhol fosse "livrado do jugo que the foi imposto pela invasão nazifascista", sendo restaurada a República. ${ }^{397}$

Mesmo com o fortalecimento interno e externo da ditadura franquista nos anos 50, a ABAPE manteve suas atividades pelo menos até 1963. ${ }^{398}$ Vale observar que expoentes da cultura e da intelectualidade brasileira figuravam na lista do conselho deliberativo dessa entidade. Dentre os quais cabe citar Apparício Torelly, Alceu Amoroso Lima, Di Cavalcanti, Werneck de Castro, Oscar Niemeyer, Paulo Francis, Dias Gomes e Otto Maria Carpeaux.

As atividades antifranquistas no Brasil não ficaram circunscritas à direção da ABAPE. Há referências de que, nos anos 50, grupos brasileiros se dirigiram à Embaixada espanhola protestando contra a ditadura de Franco. Em 1950, o embaixador Jose Rojas y Moreno informou o ministro de Estado espanhol sobre uma manifestação "comunista" realizada por estudantes em frente à Embaixada, enfatizando que muitos deles eram fichados pela Polícia Política do Brasil. ${ }^{399}$

O repúdio à ditadura espanhola também foi realizado em Fortaleza, Ceará. A chegada de mais de quarenta espanhóis que, em condição clandestina, ali aportaram, serviu para iniciar um movimento de repúdio ao governo espanhol, além de incitar um embate com os padres espanhóis da Ordem dos Maristas residentes naquela capital.

O grupo de espanhóis havia aportado na capital cearense após cruzar o Atlântico na intenção de chegar até a Venezuela. Todos os espanhóis se declaravam clandestinos, sem assumir, no entanto, a condição de refugiados políticos, alegando que haviam deixado a Espanha em busca de uma vida melhor. A mobilização de um padre espanhol marista para enviar o grupo novamente à Espanha teve grande repercussão na imprensa. $O$ jornal Diário do Povo assim noticiava a questão:

Sórdida traição. O irmão Tomaz, da Ordem dos Maristas quer entregar a Franco os fugitivos espanhóis (...). Manobra para repatriar 47 vítimas

\footnotetext{
397 Carta de Luiz Hildebrando de Horta Barbosa, presidente da ABAPE para Oswaldo Aranha, presidente da Assembléia Geral da ONU. Rio de Janeiro, 19 set. 1947. Arquivo Oswaldo Aranha. CPDOC/FGV.

${ }^{398}$ Carta de Luiz Hildebrando de Horta Barbosa, presidente da ABAPE para Anísio Teixeira. Rio de Janeiro, 30 out. 1963. Arquivo pessoal de Anísio Teixeira. CPDOC/FGV.

399 Despacho n. 199 de Jose Rojas y Moreno, embaixador da Espanha no Brasil para ministro de Assuntos Exteriores da Espanha. Rio de Janeiro, 19 abr. 1950. R2409, expt. 58. AMAE.
} 
do terror franquista, entre as quais se encontram mulheres e crianças. Um falangista de batina que gosta de fuzilamentos. ${ }^{400}$

A imprensa conhecia os esforços que o padre empreendia para trazer à tona o "verdadeiro" perfil dos espanhóis que chegaram ao Brasil naquelas condições. O padre acreditava poder auxiliar o Consulado espanhol na Bahia, enviando informações sobre o deslocamento dos "fugitivos" espanhóis. Numa carta a Gregório Izaga, cônsul espanhol na Bahia, o padre Tomás manifestou seu desejo de vingança contra o referido jornal. Porém afirmou que "esa lección" deveria ser oficial, esperando assim que o cônsul tomasse providências para que o jornal "comunista" fosse punido. ${ }^{401}$

\section{A gestão de Vasco Leitão da Cunha}

Entre 1946 e 1949, a Embaixada do Brasil na Espanha esteve sob a responsabilidade de Vasco Leitão da Cunha, que se manteve em Madri na qualidade de encarregado de negócios. A retirada de Pimentel Brandão e o envio de um diplomata em condição hierárquica inferior a de um embaixador, foi a saída encontrada pelo governo Dutra, que aguardava o desenrolar das discussões sobre o caso espanhol junto à ONU. O Itamaraty decidiu desconsiderar a possibilidade de nomear Cyro de Freitas Valle para o posto. Em janeiro de 1946, através de um telegrama particular, Pedro Leão Velloso comunicou Freitas Valle que Raul Fernandes pretendia dar a ele um "posto de maior responsabilidade do que Madri". ${ }^{402}$ Dois dias depois, Leitão da Cunha foi informado que o futuro chefe do Itamaraty desejava que ele assumisse a Embaixada em Madri. ${ }^{403}$

\footnotetext{
400 "Sordida traição", (autor não identificado), jornal Diário do Povo de 26 nov. de 1949. Recorte anexado ao ofício n. 51 de Gregorio Izaga, cônsul espanhol na Bahia para Embaixador da Espanha no Brasil. Bahia, 02 dez. 1949. R5672, expt. 44. AMAE.

${ }^{401}$ Carta (cópia) de Tomás Llorente Buiza para cônsul espanhol na Bahia Gregorio Izaga. Fortaleza, 29 nov. 1949. Anexo 1 ao ofício n. 51 de Gregorio Izaga, cônsul espanhol na Bahia para Embaixador da Espanha no Brasil. Bahia, 02 dez. 1949. R5672, expt. 44. AMAE.

402 Telegrama (particular) de Pedro Leão Velloso para Cyro de Freitas Valle, embaixador junto a ONU. Rio de Janeiro, 23 jan. 1946. Diversos no Exterior. Telegramas e minutas expedidos a Delegação do Brasil junto à ONU (1945-1946). AHI/RJ.

${ }^{403}$ Telegrama (particular) de Pedro Leão Velloso para Vasco Leitão da Cunha. Rio de Janeiro, 25 jan. 1946. Diversos no Exterior. Telegramas e minutas expedidos a Delegação do Brasil junto à ONU (1945-1946). AHI/RJ.
} 
Ao contrário do Itamaraty, que não tinha interesse em nomear um de seus mais proeminentes diplomatas para Madri, a Espanha desejava que Eduardo Aunós se estabelecesse no Rio de Janeiro na qualidade de embaixador. A importância que a Espanha passava a dar ao Brasil, nomeando uma figura de grande prestígio internacional, chegou a surpreender Mario de Pimentel Brandão que teceu elogios a Aunós, afirmando que o Brasil nunca havia tido um representante espanhol de tanta importância "moral, política e intelectual". ${ }^{404}$

Provavelmente, a estratégia do governo espanhol era de cooptar, junto ao governo brasileiro, o apoio necessário para amenizar a situação internacional da Espanha. Para isso, à frente da Embaixada no Brasil deveria estar um político experiente e renomado. Um fato, no entanto, iria prejudicar os planos espanhóis: a polêmica que ficou conhecida como o "caso Aunós", e que obteve grande projeção na imprensa brasileira.

Em janeiro de 1946 veio a público no Brasil o Livro Azul, um conjunto de documentos reunidos pelo governo norte-americano que, divulgados pela imprensa internacional, demonstravam as intensas ligações da Argentina com o nazismo durante a Segunda Guerra Mundial. Para a historiadora Sandra Lubisco Brancato, que analisou a repercussão do "caso Aunós" na imprensa brasileira, a publicação evidenciava o protagonismo de Aunós no acordo triangular entre Argentina, Espanha e Alemanha sobre o comércio de armamentos. ${ }^{405}$

Diante de tais evidências Aunós, que havia conseguido o agrèement do governo Dutra, passava a ser considerado um suposto inimigo. Brancato resume a questão: "Como aceitar ter no Brasil um representante estrangeiro sobre o qual recaíam acusações tão comprometedoras?". ${ }^{406}$ Os principais jornais brasileiros deixavam evidente a indesejabilidade de Aunós no Brasil, uma vez que a aversão e críticas ao fascismo transformaram-se em referências no pós-guerra. O Itamaraty ficou numa situação difícil, já que o

\footnotetext{
404 Ofício n. 15 (confidencial) de Mario de Pimentel Brandão, embaixador do Brasil na Espanha para Pedro Leão Velloso, ministro das Relações Exteriores do Brasil. Madri, 15 jan. 1946. Missões Diplomáticas Brasileiras. Ofícios recebidos de Madri (janeiro de 1946). AHI/RJ.

${ }^{405}$ Sandra Maria Lubisco Brancato. O caso Aunós na versão da grande imprensa carioca e do Itamaraty. Revista de Estudos Ibero-Americanos. Porto Alegre: PUCRS, v. XXXII, n. 2, dez. de 2007, p. 139.

${ }^{406}$ Idem, p. 140.
} 
diplomata, nesse ínterim, estava a caminho do Rio de Janeiro. O MRE tentou sob todas as formas evitar que Aunós desembarcasse no Brasil, tendo Dutra o declarado persona non grata. ${ }^{407}$

A resolução da questão, que deveria corresponder a uma política liderada pelos EUA, reforçava o discurso da "presença democrática" no Brasil, marcando as relações hispano-brasileiras. Apesar de todas as tentativas do MAE para convencer o Itamaraty de que Aunós não tivera ligação com os nazistas, a solução possível foi o embaixador renunciar ao cargo e regressar à Espanha. Jose Rojas y Moreno, uma figura de menor destaque na diplomacia hispânica, assumiu o posto.

Ao contrário do que se poderia supor, o governo espanhol não reagiu à atitude brasileira de rejeitar uma figura de grande projeção no cenário político espanhol. O governo franquista não desejava envolver-se numa querela diplomática, que poderia culminar com a ruptura de relações com o Brasil. Madri não podia apelar para o princípio da reciprocidade, pois já contava com um escasso número de embaixadores.

A atuação de Vasco Leitão da Cunha à frente da representação brasileira parece não ter sofrido a influência da tensão desencadeada pelo retorno de Eduardo Aunós a Espanha. No que tange ao intercâmbio comercial, Leitão da Cunha e os outros diplomatas em missão na Espanha tinham como objetivo promover o aumento do comércio de algodão e de café com esse país. Mas dados os entraves da política cambial do governo franquista, as exportações brasileiras não puderam ser otimizadas. ${ }^{408} \mathrm{~A}$ venda de algodão brasileiro a Espanha, segundo o encarregado de negócios, estaria ameaçada pelas intenções do governo espanhol em negociar com os EUA a compra de excedentes desse produto. Em um balanço da situação econômica espanhola em 1949, Leitão da Cunha mencionou a necessidade de se negociar um acordo comercial hispano-brasileiro, uma vez que supunha que ao governo

\footnotetext{
${ }^{407}$ Idem, p.147.

408 Segundo Vasco Leitão da Cunha a Câmara de Comércio Hispano-Brasileira era uma entidade composta por industriais e comerciantes espanhóis que a mantinham sem auxílio de outras entidades e órgãos governamentais. Ofício n. 92 de Osório Dutra, cônsul do Brasil em Barcelona para Raul Fernandes, ministro das Relações Exteriores do Brasil. Barcelona, 22 abr. 1947. Consulados Brasileiros. Ofícios recebidos de Barcelona (1947). AHI/RJ.
} 
espanhol interessava ter outro parceiro na América para fazer um contraponto com o monopólio do comércio com a Argentina. ${ }^{409}$

Apesar do aumento das exportações brasileiras para a Espanha não se efetivar, o saldo de comércio com esse país continuou positivo. De acordo com os boletins da Câmara de Comércio e Navegação HispanoBrasileira, o Brasil havia exportado a Espanha mais de 62 milhões de pesetas de ouro enquanto que esse país havia conseguido vender ao Brasil pouco mais de 2, 6 milhões. ${ }^{410}$

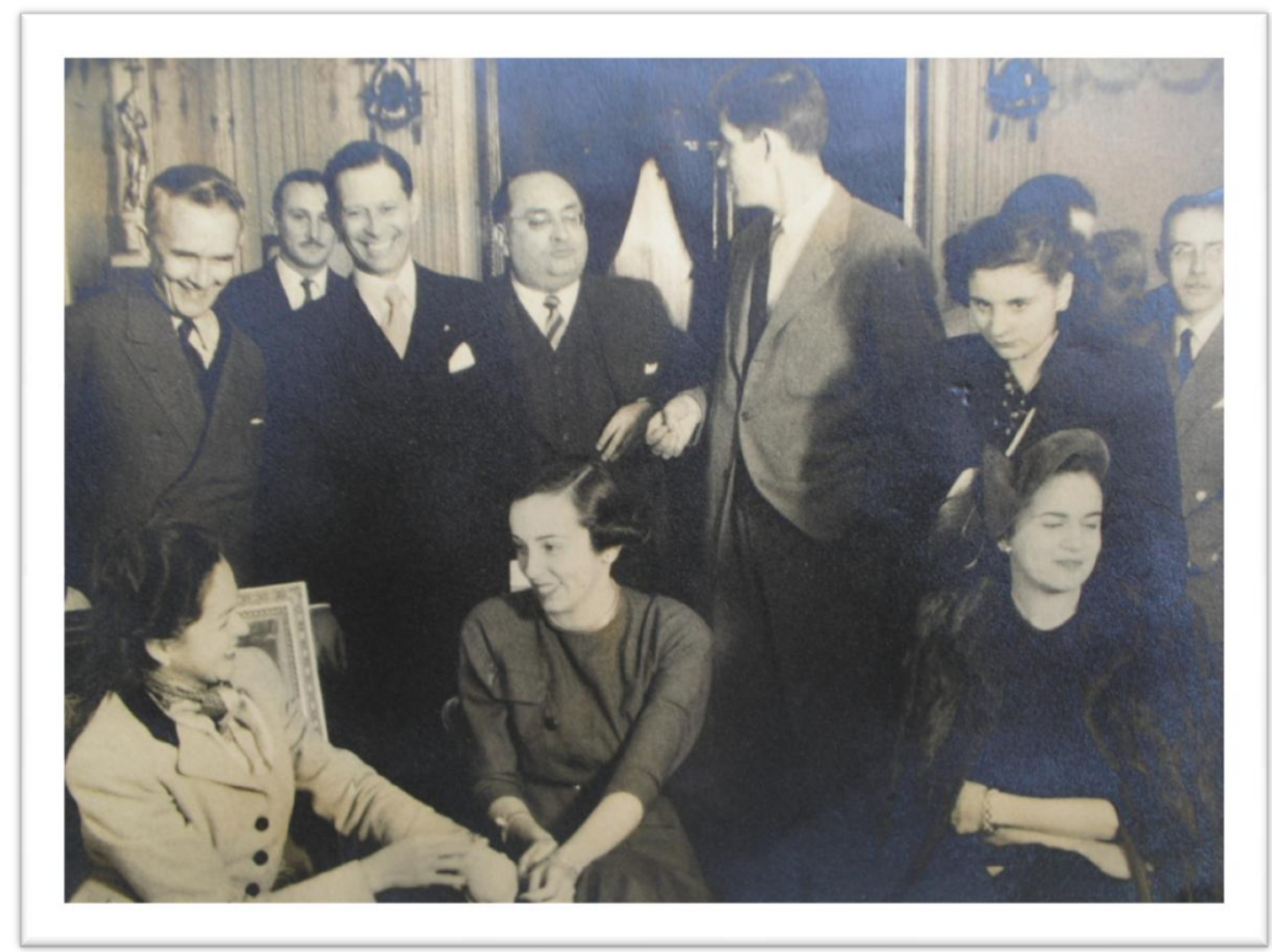

14 - Recepção na Embaixada do Brasil (Vasco Leitão da Cunha está sorrindo sendo o terceiro em pé, da esquerda para a direita). Madri, sem data, fotógrafo não identificado. Madri/389/948/anexo n. 5. Mapoteca Histórica do Itamaraty/RJ.

\footnotetext{
409 Relatório do mês político (dezembro de 1948) de Vasco Leitão da Cunha, encarregado de negócios do Brasil na Espanha para Raul Fernandes, ministro das Relações Exteriores do Brasil. Madri, 12 jan. 1949. Missões Diplomáticas Brasileiras. Ofícios recebidos de Madri (janeiro a março de 1949). AHI/RJ.

410 Ofício n. 115 do cônsul do Brasil em Barcelona (ass. ileg.) para a Secretaria de Estado das Relações Exteriores. Barcelona, 16 ago. 1949. Consulados Brasileiros. Ofícios recebidos de Barcelona (1949). AHI/RJ.
} 
Entre os meses de julho e setembro, durante o verão em Madri, o governo espanhol costumava se trasladar para San Sebastián, ao norte do país. Grande parte das missões diplomáticas dos países estrangeiros também se transferia. Leitão da Cunha argumentava que a missão brasileira precisava trasladar-se durante esses meses, pois não via sentido em realizar uma viagem de mais de mil kilômetros (percurso de ida e volta) para encontrar-se com 0 ministro espanhol por cerca de $1 / 4$ de hora. ${ }^{411}$

A solicitação não foi atendida pelo Itamaraty, e nos parece que nem a requisição de mais verbas para o traslado dos representantes teve uma resposta satisfatória, pois em 1950, novamente as mesmas reivindicações foram realizadas pelo embaixador Rubens Ferreira de Mello. A argumentação era praticamente a mesma: a necessidade de verba para que ao menos 0 embaixador e seus secretários pudessem apresentar-se ao Ministério de Assuntos Exteriores da Espanha. Ferreira de Mello descrevia o procedimento de outras missões que, se não se fixavam temporariamente em San Sebástian, ao menos forneciam recursos para que seus representantes pudessem fazêlo. ${ }^{412}$

Cumpre mencionar que Leitão da Cunha reportava ao Itamaraty sua presença em muitos eventos e comemorações políticas, mesmo àquelas que ocorriam à contra gosto do Caudilho. Em um documento confidencial, Leitão da Cunha comunicou ao chanceler Raul Fernandes que havia se divertido em um episódio pilhérico: a audiência diplomática em homenagem à Eva Duarte Perón. Explicava que, mesmo sem a iniciativa do Caudilho em promover uma recepção do corpo diplomático à sua anfitriã, a Embaixada da Argentina havia preparado um encontro entre a primeira-dama de seu país e os diplomatas atuantes na Espanha. ${ }^{413}$

O encarregado de negócios informou a Raul Fernandes que fora o único a ser chamado pela senhora Perón para a troca de palavras. A recepção

\footnotetext{
${ }^{411}$ Ofício n. 321 de Vasco Leitão da Cunha, encarregado de negócios na Espanha para Samuel de Souza Leão Gracie, ministro interino das Relações Exteriores. Madri, 26 jul. 1946. Missões Diplomáticas Brasileiras. Ofícios recebidos de Madri (junho e julho de 1946). AHI/RJ.

${ }_{412}$ Ofício n. 209 de Rubens Ferreira de Mello, embaixador do Brasil para Raul Fernandes, ministro das Relações Exteriores do Brasil. Madri, 17 jul. 1950. Missões Diplomáticas Brasileiras. Ofícios recebidos de Madri (julho a setembro de 1950). AHI/RJ.

${ }^{413}$ Ofício n. 225 (confidencial) de Vasco Leitão da Cunha, encarregado de negócios do Brasil na Espanha para Raul Fernandes, ministro das Relações Exteriores do Brasil. Madri, 16 jun. 1947. Missões Diplomáticas Brasileiras. Ofícios recebidos de Madri (1947-1949). Arquivo de Correspondência Especial. CDO/MRE.
} 
havia sido um fracasso, evidenciando a falta de habilidade daquela dama em coordenar a recepção. Relatando questões que extrapolavam aspectos formais da diplomacia, Leitão da Cunha informava que todos os representantes diplomáticos haviam caído na gargalhada após a retirada de Eva Perón do recinto. ${ }^{414} \mathrm{~A}$ visita da primeira-dama argentina à Espanha ofereceu a oportunidade para Franco demonstrar que seu governo contava com o apoio de um país próspero como a Argentina. Grandes aliados, Franco e Perón estavam sujeitos ao intervencionismo norte-americano e sabiam aproveitar a conjuntura para consolidar suas respectivas lideranças. ${ }^{415}$ Segundo 0 historiador Amado Cervo, "a pretexto de uma aproximação entre a Espanha e os Estados Unidos, a cordialidade cedeu e o clima das relações bilaterais tornou-se hostil". ${ }^{416}$

Os relatos de Vasco Leitão da Cunha se faziam carregados de projeções pessoais, expressivas do cotidiano diplomático alimentado por comentários irônicos e "intrigas de bastidores". A situação política e econômica da Espanha era analisada a partir de suas opiniões pessoais. Afirmava, por exemplo, que a tática da ONU em romper com a Espanha constituía-se num "erro de psicologia". Sua impressão era de que as Nações Unidas deveriam esclarecer o tipo de regime que desejavam para a Espanha, para que a oposição nesse país pudesse se organizar. ${ }^{417}$

O processo de mudança cautelosa da política dos países europeus frente à ditadura na Espanha foi sempre acompanhado pelo encarregado de negócios do Brasil. Em 1947, seus ofícios e relatórios versavam sobre as dificuldades econômicas da Espanha e sua necessidade de receber auxílio do Plano Marshall. A situação de miséria e as dificuldades de reconstrução após a guerra civil impressionavam Leitão da Cunha, que possuía larga experiência como diplomata.

$\mathrm{Na}$ trama das relações hispano-brasileiras a persistência do anticomunismo nos chama a atenção. A imprensa hispânica procurava reforçar,

\footnotetext{
${ }^{414}$ Idem.

${ }^{415}$ Florentino Portero, op. cit., p.196.

${ }^{416}$ Amado Cervo. Relações Internacionais da América Latina. Brasília: IBRI: 2001, p.116.

417 Ofício n. 235 (confidencial) de Vasco Leitão da Cunha, encarregado de negócios do Brasil na Espanha para João Neves da Fontoura, ministro das Relações Exteriores do Brasil. Madri, 03 jun. 1946. Missões Diplomáticas Brasileiras. Ofícios recebidos de Madri (janeiro a julho de 1946). AHI/RJ.
} 
sempre que ensejava a oportunidade, a idéia de que o Brasil coadunava com a Espanha na luta contra o comunismo. A notícia do fechamento do Partido Comunista no Brasil, em 1947, nas palavras de Leitão da Cunha, despertou "vivo interesse na imprensa local" sendo os jornais "unânimes em elogiar a decisão da Justiça brasileira e a ação do Governo em determinar o fechamento das sedes do referido Partido." 418

Tal postura não era aleatória: havia a disposição em estreitar os laços que pudessem contribuir no combate a essa ideologia. Leitão da Cunha chegou a enviar a Raul Fernandes cópias dos documentos trocados entre a Embaixada brasileira e a Dirección General de Seguridad acerca da atuação de comunistas "brasileiros" na Espanha. ${ }^{419}$ Nesta correspondência havia uma lista na qual figuravam os nomes de alguns dos espanhóis expulsos em 1937, entre eles Julia Garcia e o ex-cônsul republicano Andres Rodrigues Barbeito. ${ }^{420}$.

A ausência de iniciativas que favorecessem o aprofundamento das relações culturais entre os dois países, por parte da Embaixada do Brasil, é outro aspecto marcante do período entre 1946 e 1950. Por outro lado, para o governo espanhol era importante se aproximar do Brasil, não apenas com a intenção de incentivar o sentimento de hispanidade dentre os imigrantes espanhóis, mas como uma maneira de mostrar ao mundo que a Espanha tinha aliados. Sendo assim, as parcas iniciativas para estreitar os laços culturais hispano-brasileiros, nesse período, foram tomadas pelo governo espanhol.

$\mathrm{O}$ incentivo à presença da cultura hispânica em território brasileiro não era um projeto disperso e individual, inserindo-se num contexto geral de apoio às ações na América. Martin Artajo, ministro de Assuntos Exteriores da Espanha, estava convencido de que os laços históricos e a língua facilitariam um maior apoio das nações latino-americanas à causa espanhola. O Ministério de Asuntos Exteriores havia criado a Dirección General de Relaciones Culturales para incentivar a expansão da cultura hispânica no mundo. Em abril

\footnotetext{
418 Ofício n. 197 de Vasco Leitão da Cunha, encarregado de negócios do Brasil na Espanha para Hildebrando P. Accioly, ministro interino das Relações Exteriores do Brasil. Madri, 24 mai. 1947. Missões Diplomáticas Brasileiras. Ofícios recebidos de Madri (maio a junho de 1946). AHI/RJ.

${ }^{419}$ Ofício n. 117 (reservado) de Vasco Leitão da Cunha, encarregado de negócios do Brasil na Espanha para Raul Fernandes, ministro das Relações Exteriores do Brasil. Madri, 22 abr. 1949. Missões Diplomáticas Brasileiras. Ofícios recebidos de Madri (abril a junho de 1949). AHI/RJ.

${ }^{420}$ O histórico político desses espanhóis no Brasil foi analisado em nossa dissertação de mestrado, publicada em 2005 (Solidariedade Internacional, op. cit.).
} 
de 1947, o Conselho de Hispanidade transformou-se no Instituto de Cultura Hispânica (ICH), cujo objetivo era manter "los vínculos espirituales com los pueblos hermanos de América". ${ }^{421}$

$\mathrm{O} \mathrm{ICH}$, presente em muitos países da América, transformou-se em uma importante estratégia de propaganda cultural e política sustentada pelo franquismo. Nos discursos oficiais, a propalada presença hispânica em solo americano não visava mais terras e riquezas, mas sim "devolver a la Hispanidad su conciência unitaria y estar presente em América, com viva presencia de inteligência y amor (...).,A22

A falta de disposição em reconhecer as especificidades do Brasil, e a insistência em inseri-lo na comunidade de países do "mundo hispânico", gerou um incidente envolvendo o governo espanhol e a Embaixada de Portugal. Na revista Mundo Hispânico - órgão do Instituto de Cultura Hispânica - Brasil e Portugal foram inseridos no rol de 23 países "hispânicos". Indignado com tais referências, o embaixador de Portugal teria protestado. De acordo com Vasco Leitão da Cunha, Renato de Mendonça, secretário da Embaixada brasileira, conseguiu com Sánchez Bella, seu amigo e diretor da Instituição, a promessa de que nas próximas referências ao Brasil fosse utilizada a expressão "hispano-brasileiro". ${ }^{423}$

O episódio relatado acima, embora não tivesse conseqüências para as relações entre os dois países, exemplifica a forma pela qual a Espanha franquista desejava pautar suas relações culturais com 0 Brasil. Os investimentos espanhóis para a ação cultural na América, a despeito da grave situação econômica do país, foram generosos. Em uma tabela sobre o crédito concedido para a ação cultural no estrangeiro, vemos que ao Brasil seriam repassados "500 mil" - que presumimos estar calculado em pesos. O mesmo valor foi destinado à Argentina, sendo que os demais países receberiam somas

\footnotetext{
${ }^{421}$ Florentino Portero, op. cit., p.191.

422 Preâmbulo da Lei que criou o Conselho de Hispanidade em 02 de novembro de 1940. Citado por José Luis Abellán (Coord.), op. cit., p.132.

${ }^{423}$ Ofício n. 326 (reservado) de Vasco Leitão da Cunha, encarregado de negócios do Brasil na Espanha para Raul Fernandes, ministro das Relações Exteriores do Brasil. Madri, 03 dez. 1949. Missões Diplomáticas Brasileiras. Ofícios recebidos de Madri (novembro e dezembro de 1949). AHI/RJ.
} 
bem menores. A ação cultural e religiosa na América Latina responderia por $32,5 \%$ do total de recursos para essa finalidade em todo o mundo. ${ }^{424}$

$O$ interesse em estreitar a permuta de livros e o intercâmbio de estudantes e professores levou o MAE a solicitar que seu embaixador no Rio de Janeiro, Conde de Casa Rojas, insistisse com o Itamaraty na necessidade de firmar um acordo cultural entre o Brasil e a Espanha. No início de 1948, Rojas manifestou a Hildebrando Accioly a intenção de seu governo em assinar um convênio cultural com o Brasil, nos moldes daquele que a Espanha tinha com as Filipinas, enviando o modelo do mesmo em anexo. Para reforçar a idéia de que o Brasil poderia assinar o referido convênio, sem que isso interferisse em sua postura junto à ONU, o embaixador lembrava que a resolução de 1946 não havia sido confirmada pela Assembléia Geral em 1947. ${ }^{425}$ Accioly, na qualidade de secretário geral do Itamaraty, não respondeu ao apelo do embaixador espanhol. Em julho de 1949, Casa Rojas fez novamente a proposta de convênio cultural ao Itamaraty. ${ }^{426}$ Sua correspondência ao Ministério brasileiro lembrava cuidadosamente que sua nota, datada de mais de um ano, havia ficado sem resposta. ${ }^{427} \mathrm{~A}$ indiferença do MRE frente a essa sugestão exemplifica a política brasileira para a Espanha naquela conjuntura: os interesses comerciais deveriam ser preservados, mas qualquer atitude que proporcionasse uma efetiva aproximação entre os dois países deveria ser evitada ou, pelo menos, adiada até o momento internacional apresentar-se mais propício.

O Brasil não se preocupava em implementar uma política cultural para a Espanha. As preocupações mais próximas, nesse sentido, foram a de observar e, por vezes, manifestar junto ao governo do Caudillo descontentamento para com as notícias da imprensa consideradas "desabonadoras ao Brasil". O encarregado de negócios do Brasil reportava ao MRE os casos considerados de maior importância, explicando que muitos dos

\footnotetext{
424 Tabela 5: "Desglose del crédito extraordinario concedido al Ministério de Asuntos Exteriores para la acción cultural en el extranjero (Ley de 15-V-1945). In: Lorenzo Delgado Gomez Escalonilla. Imperio de papel, op. cit., p. 466.

${ }^{425}$ Carta de Jose Rojas y Moreno, embaixador da Espanha no Brasil para Hildebrando Accioly, secretário-geral de Estado das Relações Exteriores. Rio de Janeiro, 15 jan. 1948. R2316, expt. 21. AMAE.

${ }^{426}$ Ofício n. 370 de Jose Rojas y Moreno, embaixador da Espanha no Brasil para ministro de Assuntos Exteriores da Espanha. Rio de Janeiro, 30 jul. 1949. R2316, expt. 21. AMAE.

${ }_{427}$ Nota n. 69 da Embaixada da Espanha para Raul Fernandes, ministro das Relações Exteriores do Brasil. Rio de Janeiro, 30 jul.1949. R2316, expt. 21. AMAE.
} 
jornais davam preferência aos assuntos que versavam sobre a presença de negros, índios e "selvas" na constituição brasileira. ${ }^{428}$ Analisando alguns desses artigos publicados pelo jornal $A B C$, percebemos que não houve referências pejorativas ou preconceituosas ao Brasil. $O$ artigo $E l$ mundo através de nuestros corresponsales, $A B C$ en Rio de Janeiro, publicado pelo jornal $A B C$ em 17 de abril de 1947, por exemplo, traça um histórico da escravidão no nordeste, mencionando a chegada de negros nessa região e apresentando as festas folclóricas do Recife como expressões da cultura africana. ${ }^{429}$ Constatamos, mais uma vez, uma tentativa por parte da diplomacia de encobrir a importância da herança negra na cultura brasileira.

Outro artigo considerado ofensivo à imagem do Brasil foi o que se intitulava El hambre en el Brasil, publicado pelo jornal Unidad em 12 de fevereiro de $1947^{430} \mathrm{Em}$ seu texto, o autor afirmava que a fome ainda assolava os rincões mais afastados do país, tendo sua causa ligada aos latifúndios. Colocava em evidência o fato de que no Brasil - uma grande potência agrícola - persistia uma vergonhosa realidade de miséria. Os diplomatas sabiam que a relação entre fome e latifúndio estava respaldada no histórico do país, mas tinham vergonha de admitir. Leitão da Cunha justificou não ter tomado providências somente porque sabia que o jornalista era um "desqualificado" e o jornal, um veículo sem expressão no cenário daquele país.

Apesar dos pedidos de reconsideração das notícias consideradas tendenciosas sobre o Brasil não percebemos, pelo menos até os anos 50, a intenção, por parte dos diplomatas, de consolidar estratégias para promover uma imagem positiva do Brasil. Ao atender aos pedidos de censura do governo brasileiro, o governo franquista também se sentia à vontade para fazer solicitações semelhantes. Nos anos 50 tornaram-se freqüentes as manifestações de indignação dos diplomatas espanhóis que, dirigindo-se ao

\footnotetext{
${ }^{428}$ Ofício n. 151 (reservado) de Vasco Leitão da Cunha, encarregado de negócios na Espanha para Raul Fernandes, ministro das Relações Exteriores. Madri, 28 abr. 1947. Missões Diplomáticas Brasileiras. Ofícios recebidos de Madri (março a abril de 1947). AHI/RJ.

429 "El mundo através de nuestros corresponsales. ABC em Rio de Janeiro", jornal ABC. Madri, 17 abr. 1947. Anexo ao ofício mencionado na nota anterior.

430 "El hambre en el Brasil", jornal Unidad de 12 fev. 1947. Recorte anexado ao ofício n. 105 (reservado) de Vasco Leitão da Cunha, encarregado de negócios na Espanha para Raul Fernandes, ministro das Relações Exteriores. Madri, 04 março 1947. Missões Diplomáticas Brasileiras. Ofícios enviados de Madri (março a abril de 1947). AHI/RJ.
} 
Itamaraty, cobravam medidas efetivas para proibir e punir as reportagens que faziam críticas ao regime político espanhol e ao Caudilho.

Durante o governo Dutra, e especialmente nos anos 50, as respostas do Ministério das Relações Exteriores do Brasil se faziam sempre no sentido de lamentar os fatos. O Itamaraty deixava evidente que não era possível censurar ou punir os meios de comunicação, uma vez que esses detinham liberdade de expressão e, portanto, estavam livres do controle governamental. Em abril de 1948, a SERE informou à Embaixada espanhola no Rio de Janeiro que não poderia atender aos seus pedidos de censura ao jornal Correio da Manhã. O embaixador foi informado que as penalidades solicitadas, dadas as "injúrias" proferidas contra Franco, só poderiam ser aplicadas por órgãos jurídicos. Hildebrando Accioly comunicou que, de acordo com a nova Constituição brasileira, cada cidadão responderia pelos excessos que viesse a cometer. Sugeria, no entanto, os caminhos que o encarregado de negócios espanhol poderia percorrer para ver reparada a difamação sofrida pelo chefe de Estado espanhol: o caso poderia ser levado ao Ministério Público. ${ }^{431}$

Caberia mencionar outro assunto que ganhou destaque durante a gestão de Vasco Leitão da Cunha: suas desavenças com o conselheiro comercial Osvaldo Orico, que era escritor e não pertencia à carreira diplomática. O mencionado conselheiro recebeu de Leitão da Cunha uma repreensão e, não conformado com a mesma, solicitou do Itamaraty abertura de inquérito. O conflito, que possivelmente representava o ápice de uma situação de antipatia mútua, teria sido deflagrado quando o conselheiro deu uma entrevista à imprensa espanhola sem a anuência do chefe da missão diplomática. Segundo Leitão da Cunha, Orico teria sido irresponsável ao afirmar aos jornais madrilenhos que o Brasil pretendia enviar um embaixador a Espanha, passando por cima da determinação do Itamaraty de manter coerência com o compromisso assumido junto à ONU. ${ }^{432}$

Em ofício confidencial ao ministro de Estado, Cunha expôs suas impressões acerca de Orico, demonstrando que não havia a mínima

\footnotetext{
431 Nota de Hildebrando Accioly, secretário das Relações Exteriores para Jose Cárcer Lassance, encarregado de negócios da Espanha no Brasil. Rio de Janeiro, 10 mai 1948. Representações Estrangeiras. Notas expedidas a Espanha (1946-1951). AHI/RJ.

432 Ofício n. 378 (reservado) de Vasco Leitão da Cunha, encarregado de negócios na Espanha para Hildebrando Accioly, ministro interino das Relações Exteriores. Madri, 20 out. 1948. Missões Diplomáticas Brasileiras. Ofícios recebidos de Madri (outubro de 1948). AHI/RJ.
} 
possibilidade de entendimento e convivência pacífica entre os dois. Demonstrando indignação, Cunha afirmou que sabia que a nomeação de seu desafeto tinha um significado de "premiação política", e que nos três anos e meio em que esteve em Madri, o referido conselheiro havia se ocupado exclusivamente da propaganda de sua literatura, realizando relatórios parciais feitos à base de "tesoura e cola". ${ }^{433}$ Esta última referência ressalta que cabia ao adido comercial realizar os relatórios mensais sobre a situação econômica espanhola, evidenciando especialmente as relações com o Brasil. Cunha acusava Osvaldo Orico de limitar-se a copiar e transcrever as notícias da imprensa espanhola sobre a questão. Também tecia críticas ao fato do conselheiro nunca ter se curvado à disciplina da Embaixada: "Era natural, aliás, num elemento estranho à carreira, "paraquedista" prestigioso e prestigiado pelos poderes públicos, ignorante voluntários das Leis e regulamentos que regem o nosso trabalho." 434

Vale lembrar que em depoimento ao CPDOC, Vasco Leitão da Cunha manifestou sua reprovação à nomeação de pessoas de fora da carreira diplomática para postos no Exterior, referindo-se também ao episódio relatado acima. ${ }^{435} \mathrm{Em}$ ofício confidencial de 4 de dezembro de 1947, Cunha acusou Orico de ser o autor de um artigo, mantido no anonimato, no qual o primeiro secretário da Embaixada Antonio Mendes Viana era moralmente atacado. Lamentava também não ter provas dessa autoria, não podendo assim submetê-lo ao processo administrativo que julgava adequado. Em sua opinião pessoal, Orico era:

Vaidoso, indiscreto, não se contentava com o título e funções que lhe cabiam, fazendo-se constantemente passar por Ministro e até por Embaixador do Brasil"; julgava humilhante ter que submeter-se, em assuntos de serviço, á disciplina da Chancelaria, cujo chefe é o Primeiro Secretário Antonio Mendes Viana. ${ }^{436}$

\footnotetext{
433 Ofício n. 437 (confidencial) de Vasco Leitão da Cunha, encarregado de negócios na Espanha para Hildebrando Accioly, ministro interino das Relações Exteriores. Madri, 04 dez. 1948. Missões Diplomáticas Brasileiras. Ofícios recebidos de Madri. (1947/1959). Arquivo de Correspondência Especial. CDO/MRE.

434 Idem.

${ }^{435}$ Vasco Leitão da Cunha, op. cit. p. 150.

436 Ofício n. 437 (confidencial) de Vasco Leitão da Cunha, encarregado de negócios na Espanha para Hildebrando Accioly, ministro interino das Relações Exteriores. Madri, 04 dez. 1948. Missões Diplomáticas Brasileiras. Ofícios recebidos de Madri. (1947/1959). Arquivo de Correspondência Especial. CDO/MRE.
} 
Leitão da Cunha, indagado sobre o episódio após cinqüenta anos, confirmou que o conflito teria sido motivado pelo artigo que trazia acusações a Mendes Viana. ${ }^{437}$ As denúncias contra 0 primeiro-secretário estariam relacionadas às possíveis irregularidades na venda de seu automóvel particular. Tal questão extrapolou as dimensões de um "caso particular", pois certamente esbarrava nos privilégios usufruídos pelos agentes diplomáticos. A isenção de taxas aduaneiras para a importação de veículos é um assunto recorrente na documentação oficial. Os diplomatas brasileiros lotados no exterior podiam vender os automóveis pelo preço de mercado, obtendo assim vantagens financeiras. A freqüência desses casos motivou o Itamaraty a estabelecer novas regras para a venda de carros do corpo diplomático. ${ }^{438}$

\section{O Brasil diante da questão espanhola na ONU}

Entre 1945 e 1951, a situação política da Espanha foi alvo de intensos debates na ONU, passando a denominar-se na referida organização como "cuestión española". A pressão dos países do bloco comunista para aprovar uma medida que contribuísse para a queda do regime de Franco, gerou grande polêmica, servindo ao mesmo tempo para Franco reforçar o seu poder interno. Na Conferência de São Francisco realizada entre abril e junho de 1945, o delegado do México, Luis Quintanilla, conseguiu que fosse aprovada a primeira manifestação oficial de condenação ao franquismo. Em fevereiro de 1946, o Panamá apresentou junto às Nações Unidas, reunidas em Londres, uma proposta que reforçava esse manifesto

Em 1946, o Itamaraty orientou a delegação brasileira a acompanhar os EUA nas votações sobre a Espanha. O MRE apostava na aprovação da condenação franquista, tendo pedido a suspensão da vinda do

\footnotetext{
${ }^{437}$ Vasco Leitão da Cunha, op. cit., p. 150.

${ }^{438}$ Despacho n. 16 da Secretaria de Estado das Relações Exteriores para Embaixada do Brasil em Madri. Missões Diplomáticas Brasileiras. Rio de Janeiro, 21 abr. 1949. Despachos a Madri (1946 a 1953). AHI/RJ.
} 
novo embaixador espanhol ao Brasil. ${ }^{439}$ Em março de 1946 uma "Nota tripartite" dos EUA, Inglaterra e França condenou o regime político espanhol, pedindo a retirada pacífica de Franco, a abolição da Falange e o estabelecimento de um governo provisório que restituísse a soberania popular.

Este debate ganhou espaço na imprensa espanhola, sendo alvo das atenções da Embaixada brasileira em Madri. Segundo o diplomata Antonio Mendes Viana, a declaração conjunta dos três países era apresentada como uma atitude de influência comunista e de ingerência nos assuntos espanhóis. Observava ainda que, em alguns jornais, o teor da "Nota tripartite" apresentada ao leitor não coincidia com o original que tinha em mãos. ${ }^{440}$

Mendes Viana mencionava uma prática bastante comum não apenas no regime espanhol, mas expressiva dos regimes autoritários: a deturpação das notícias que, antes de virem a público, passavam pelo crivo da censura governamental. Nesse caso específico, as alterações na tradução do documento foram realizadas com o intuito de reforçar junto ao povo espanhol a injustiça que os países membros da ONU cometiam contra a Espanha. Martin Artajo, ministro dos Assuntos Exteriores, refutava os argumentos levantados pela ONU, insistindo na defesa da neutralidade espanhola durante o conflito mundial. ${ }^{441}$ Procurava também demonstrar que os países comunistas desenvolviam uma propaganda internacional com vistas a estereotipar a imagem do país.

A estratégia de aproveitar os embates sobre a questão na ONU, para convencer o povo espanhol de que a Espanha era vítima de uma injustiça internacional, obteve resultados. Paradoxalmente, enquanto a ONU denunciava a falta de representatividade de seu governo, Franco aproveitava tais discussões para levar o povo espanhol "ferido em seu orgulho" a se unir em torno de sua figura. ${ }^{442}$

\footnotetext{
439 Telegrama n. 11 (confidencial) do Ministério das Relações Exteriores para Delegação brasileira junto a ONU. Rio de Janeiro, 16 fev. 1946. Diversos no Exterior. Delegação do Brasil junto a ONU. Telegramas e minutas expedidos (1945-1946). AHI/RJ.

${ }_{440}$ Ofício n. 120 (reservado) de Antonio Mendes Vianna, encarregado de negócios do Brasil na Espanha para João Neves da Fontoura, ministro das Relações Exteriores do Brasil. Madri, 12 mar. 1946. Missões Diplomáticas Brasileiras. Ofícios recebidos de Madri (março 1946). AHI/RJ. ${ }^{441}$ Antonio Fernández Garcia; Juan Carlos Pereira Castanares. La percepción española de la ONU (1945-1962). Cuadernos de Historia Contemporanea. Madri: Universidad Complutense, n. 17, 1995, p.124.

${ }^{442}$ Florentino Portero, op. cit., p.217.
} 
O Brasil teve um importante papel diante da questão espanhola a partir do momento em que, juntamente com Austrália, Países Baixos, México e Polônia, passou a integrar, em abril de 1946, o subcomitê criado para investigar a situação da Espanha. A Polônia, como porta-voz dos interesses soviéticos, defendia que a Espanha constituía-se numa ameaça internacional. Argumentava que esse país dava guarida a refugiados nazistas e que agentes da Gestapo estavam infiltrados e incorporados a Dirección General de Seguridad. ${ }^{443} \mathrm{~A}$ carta da ONU estabelecia que ameaças à paz e à segurança internacional deveriam ser tratadas pelo Conselho de Segurança. Como a definição no que consistia "ameaça" não era clara, o Conselho tinha amplo poder discricionário sobre a questão. ${ }^{44}$

A argumentação polaca sofria a oposição do Brasil e dos Países Baixos. As orientações do Itamaraty com relação ao posicionamento brasileiro nesse subcomitê deixam evidente que havia uma preocupação em manter uma postura que fosse entendida como autônoma, mas sem desagradar os norteamericanos e britânicos. Os EUA e Grã-Bretanha desejavam que o assunto saísse da alçada do Conselho de Segurança e fosse submetido à Assembléia Geral.

Em junho de 1946, o MRE orientou os membros brasileiros do subcomitê a proporem "discretamente e sem relevo público" uma fórmula conciliatória. ${ }^{445}$ Sugeria também que os delegados brasileiros indicassem 0 envio do assunto à Assembléia Geral sem recomendações específicas, o que era desejado pelos EUA naquele momento.

As discordâncias entre os membros do comitê impossibilitaram o êxito da proposta polonesa. A confirmação pelo Conselho de Segurança de que a Espanha se constituía em uma ameaça tornou-se inviável, dados os interesses de cada país na questão. Após meses de muita discussão, a posição britânica triunfou e a União Soviética sentiu dificuldades em condenar a Espanha a partir do referido Conselho.

\footnotetext{
${ }^{443}$ Idem, p.163.

${ }^{444}$ Monica Herz; Hoffmman, Andrea Ribeiro. Organizações Internacionais: história e práticas. Rio de Janeiro: Elsevier, 2004, p. 105.

445 Telegrama (confidencial) do Ministério das Relações Exteriores para Delegação brasileira junto a ONU. Rio de Janeiro, 05 jun. 1946. Diversos no Exterior. Delegação do Brasil junto à ONU. Telegramas e minutas expedidos (1945-1946). AHI/RJ.
} 
No ano de 1946, a diplomacia espanhola procurou demonstrar que uma Espanha anticomunista era de interesse da Europa Ocidental e que o regime franquista representava a segurança e a barreira contra o comunismo. Os diplomatas espanhóis acusavam a campanha empreendida pelos países antifranquistas, dos quais os mais fervorosos eram a Polônia e a França, de quererem desestabilizar o governo espanhol. Assim, "todo era una operación orquestrada por el comunismo que utilizaba a sus satélites - Francia y Polonia - para reiniciar la Guerra Civil."446

Dos países do subcomitê somente o Brasil e os Países Baixos mantinham relações diplomáticas com a Espanha. ${ }^{447}$ Dessa forma, a diplomacia espanhola esperava que 0 Brasil pudesse the oferecer o apoio necessário junto à Organização das Nações Unidas. Por não ter interesses estratégicos e ideológicos na condenação da Espanha, o Brasil poderia, na concepção franquista, ser o porta-voz das idéias do MAE. O embaixador espanhol no Rio de Janeiro escreveu ao MRE fazendo uma análise da política européia, lembrando que os "grupos marxistas" estavam adquirindo, através das eleições, uma força que tirava a segurança de todo o continente europeu. Assim, pedia que o governo brasileiro levasse em consideração não apenas a situação espanhola, mas a segurança do mundo todo. Apelando para o slogan "em nome da paz mundial", pedia reconsideração:

Por todas estas consideraciones muy claras y contundentes que el gobierno español ha expuesto en su Nota, me atrevo a esperar que Vuestra Excelencia, reexaminando la cuestión, curse nuevas instrucciones a su Delegado en El Consejo de Seguridad en un sentido favorable a la causa española. Al hacerlo así no pienso solo en un interes exclusivamente nacional. Fijo mi mirada en los días sombrios que se avecinan en los que todos tenemos el deber de afrontar nuestras propias responsabilidades y cooperar con nuestros esfuerzos para que no prevalezca la única amenaza seria existente contra la paz del mundo. ${ }^{448}$

Demonstrando com números que os partidos de esquerda cresciam na França e na Itália, o diplomata espanhol procurava convencer o

\footnotetext{
${ }^{446}$ Florentino Portero, op. cit., p.183.

${ }^{447}$ Idem, p. 169 .

${ }^{448}$ Nota n. 36 (confidencial) da Embaixada da Espanha no Brasil para Ministério das Relações Exteriores do Brasil. Rio de Janeiro, 07 jun. 1946. Representações Estrangeiras. Notas recebidas da Espanha (1946-1948). AHI/RJ.
} 
governo brasileiro de que a Espanha era um modelo de ordem e tranqüilidade, e que não merecia receber lição de países que se encontravam - como era o caso da França - em situação de instabilidade política e "ameaça revolucionária". O diplomata espanhol mencionava também que compreendia a explicação da diplomacia brasileira que, para esse caso, se declarava "escrava da lógica". Aliás, esta afirmação traz à luz um dos argumentos clássicos dos burocratas identificados com o jogo do poder. Ao alegar que não tinha motivos para se posicionar contra a Espanha, o Brasil evidenciava seu dever de "ser coerente" com a política de alinhamento aos EUA.

Convém mencionar que para o governo norte-americano, a Espanha era um assunto difícil de ser tratado: não queriam intervir diretamente na condenação espanhola, visto que essa era uma intenção dos soviéticos, mas também sofriam a pressão da opinião pública interna, que desejava uma postura de repúdio a Franco.

O alinhamento brasileiro à política norte-americana para o caso espanhol, fica explícito no debate sobre a inserção da Espanha em órgãos como a Organização Internacional da Saúde. Em julho de 1946, o MRE ordenou que a delegação brasileira junto à ONU votasse favoravelmente à proposta norte-americana de entrada da Espanha na entidade. ${ }^{449}$ Acompanhar as decisões norte-americanas não era exclusividade de países latinoamericanos, como o Brasil. Até 1955, os EUA mantiveram controle sobre o processo decisório da Assembléia através do bloco formado por europeus ocidentais, latino-americanos e britânicos. ${ }^{450}$

Após inúmeras discussões no subcomitê, o relatório sobre a questão espanhola foi encaminhado ao Conselho de Segurança, que decidiu manter a vigilância, colocando a questão em seus assuntos pendentes. ${ }^{451}$. Uma medida efetiva só seria tomada ao final de 1946 pela Assembléia Geral. Em novembro, o MRE orientou sua delegação junto à ONU a manter uma postura neutra no caso espanhol, coerente com a tradição brasileira de isentarse de responsabilidades que comprometessem o jogo do poder instituído. A

\footnotetext{
${ }^{449}$ Telegrama n. 112 do Ministério das Relações Exteriores para a Delegação do Brasil junto a ONU. Rio de Janeiro, 10 jul. 1946. Diversos no Exterior. Delegação do Brasil junto a ONU. Telegramas e minutas (1945-1946). AHI/RJ.

${ }^{450}$ Monica Herz; Andrea Ribeiro Hoffmann, op. cit., p 99-100.

${ }^{451}$ Florentino Portero, op. cit., p.181.
} 
orientação dada à delegação brasileira era de que o Brasil poderia rever sua posição caso ficasse provado que a Espanha constituía uma ameaça à paz internacional. ${ }^{452}$ Ao seguir os EUA nas votações sobre a Espanha, o Brasil pode ser incluído na categoria de países latino-americanos que, segundo Florentino Portero, aceitavam a condenação do regime franquista, mas estavam pouco dispostos a tomar medidas efetivas contra ele. ${ }^{453}$

O "caso espanhol" só foi parcialmente definido quando, em dezembro de 1946, foi incluído na lista de temas a serem debatidos pela Assembléia Geral. A questão saía do âmbito do Conselho de Segurança, uma vez que o subcomitê havia concluído que a Espanha não constituía um perigo internacional. Os intensos debates ao longo desse ano demonstraram não apenas o fracasso de todas as tendências extremas contra o regime franquista, mas também a necessidade de que se chegasse a uma solução que satisfizesse a opinião pública dos países envolvidos no debate. Em 12 de dezembro, por 34 votos a favor, 6 contra e 13 abstenções foi aprovada a resolução que excluiu a Espanha de todos os organismos internacionais, recomendando aos Estados membros que retirassem imediatamente de Madri seus embaixadores. ${ }^{454} \mathrm{O}$ Brasil votou com a maioria pela aprovação da medida. O governo Dutra limitou-se a acatar a recomendação, abortando o envio de um embaixador e deixando um encarregado de negócios à frente da representação brasileira.

Em 1947, a delegação brasileira na ONU foi orientada a não votar qualquer sanção que prejudicasse esse país, mas evitar tomar qualquer iniciativa neste sentido. ${ }^{455}$ Tais orientações estavam relacionadas ao voto brasileiro na Assembléia Geral, que não conseguiu reafirmar a condenação de 1946.

Podemos considerar que as relações entre o Brasil e a Espanha não sofreram significativas alterações diante da resolução da ONU. Como exemplo, citamos a tentativa do MRE em intermediar junto ao MAE da

452 Telegrama (confidencial) do Ministério das Relações Exteriores para a Delegação do Brasil junto a ONU. Rio de Janeiro, 06 nov. 1946. Diversos no Exterior. Delegação do Brasil junto à ONU. Telegramas e minutas (1945-1946). AHI/RJ.

${ }^{453}$ Florentino Portero, op. cit., p. 128.

${ }^{454}$ Idem, p.214.

${ }^{455}$ Telegrama (confidencial) da Secretaria de Relações Exteriores para a Embaixada do Brasil em Madri. Rio de Janeiro, 06 out. 1947. Missões Diplomáticas Brasileiras. Telegramas expedidos a Madri (1947-1959). Arquivo de Correspondência Especial. CDO/MRE. 
Espanha, a vinda de Ortega y Gasset ao Brasil. Segundo Maria Helena Capelato, houve grande repercussão das idéias de Gasset entre os intelectuais latino-americanos. Inspirados nas idéias orteguianas, esses intelectuais suscitaram debates sobre o problema da inautenticidade do pensamento latinoamericano e da identidade nacional. ${ }^{456}$

O ilustre filósofo manteve uma postura neutra diante da Guerra Civil Espanhola. Nos anos 40, sua presença como conferencista em vários países apresentava-se, aos olhos do governo de Franco, como um poderoso instrumento de propaganda do regime. Podemos observar a intenção do governo espanhol em utilizar o prestígio de Gasset para transmitir, internacionalmente, uma imagem positiva da Espanha como um país que prezava a liberdade de pensamento.

Em dezembro de 1947, o embaixador espanhol no Brasil informou ao $M A E$ que o ministro da Educação brasileiro desejava convidar Ortega y Gasset para realizar uma série de conferências no Brasil. Para o embaixador, a presença do filósofo no Brasil teria grande ressonância internacional e seria "altamente provechoso para nuestro prestigio nacional" ${ }^{457}$ Gasset alegou estar enfermo e através do MAE agradeceu profundamente a iniciativa, afirmando que assim que recobrasse a saúde aceitaria o convite. ${ }^{458}$

Com a não ratificação da recomendação de 1946 pela Assembléia Geral no ano seguinte, a situação internacional da Espanha sofreu uma significativa melhora. Durante o ano de 1948, a maioria dos países integrantes da ONU reconheceu o fracasso da política adotada para a Espanha. Os países europeus desejavam melhorar suas relações comerciais com a Espanha, mas estavam conscientes de que a aproximação política não seria facilmente aceita pela comunidade internacional, enquanto Franco estivesse no poder. ${ }^{459}$

O convite feito a Ortega y Gasset para visitar o Brasil, assim como a presença de intelectuais e artistas brasileiros na Espanha, levou a imprensa

\footnotetext{
456 Considerações realizadas por Maria Helena Rolim Capelato na Conferência intitulada "Intelectuais orteguianos na América Latina". São Paulo, 15 out. 2008. Simpósio Internacional Intercâmbios políticos e mediações culturais nas Américas.

${ }^{457}$ Despacho n. 718 de Jose Rojas y Moreno, embaixador da Espanha no Brasil para ministro de Assuntos Exteriores da Espanha. Rio de Janeiro, 15 de dez. 1947. R2896, expt. 117. AMAE. 458 Transcrição da resposta de Jose Ortega y Gasset. In: Despacho n. 39 de (ass. ileg.), embaixador da Espanha em Portugal para ministro de Assuntos Exteriores da Espanha. Lisboa, 26 jan. 1948. R2896, expt. 117. AMAE.

${ }^{459}$ Florentino Portero, op. cit., p. 303.
} 
espanhola a especular sobre a nomeação de um embaixador brasileiro para Madri. O Itamaraty, como sempre, optou por uma postura cautelosa. Desmentindo tais rumores, a SERE avisou a Embaixada em Madri que não havia intenção de nomear embaixador para a Espanha enquanto não ficasse esclarecido se na ONU subsistia a resolução de 12 de dezembro de $1946 .{ }^{460}$

Em 1949 a situação internacional já vislumbrava a derrocada da referida resolução. Os países ocidentais, especialmente Inglaterra e EUA, percebiam que a medida da ONU não fora suficiente para enfraquecer o regime franquista. Pelo contrário, tinha contribuído para despertar a indignação da maioria do povo espanhol. O encarregado de negócios do Brasil na Espanha, Vasco Leitão da Cunha, em 12 de março de 1949, relatou ao MRE que a situação política da Espanha não era passível de mudança. Informava também que a imprensa hispânica noticiava com otimismo o movimento no Congresso norte-americano em torno da idéia de realizar uma maior aproximação com o governo espanhol. ${ }^{461}$

O anúncio de uma mudança de postura dos EUA deve ter contribuído para a decisão do Itamaraty em orientar sua delegação na ONU para, juntamente com outros países latino-americanos, preparar uma moção que pedia a revogação da resolução de 1946. Esta deveria ser apresentada na próxima Assembléia Geral, a ser realizada em maio de 1949.

A preparação da proposta liderada pelo Brasil despertou interesse na Espanha. Os principais jornais espanhóis depositavam na iniciativa brasileira, esperanças de que o país sairia do ostracismo internacional. A proposta não defendia o regime franquista, mas sugeria que os Estados membros da ONU tivessem liberdade de ação para decidir sobre as suas representações naquele país. O jornal $A B C$, um dos mais importantes de Madri, publicou em 17 de março de 1949 um artigo intitulado "Libertad en las relaciones diplomáticas com España. Esto pide para los paises de la ONU el

\footnotetext{
460 Telegrama (confidencial) da Secretaria de Relações Exteriores para Embaixada do Brasil em Madri. Rio de Janeiro, 04 jun. 1948. Missões Diplomáticas Brasileiras. Telegramas expedidos a Madri (1947/1959). Arquivo de Correspondência Especial. CDO/MRE.

${ }^{461}$ Ofício n. 79 de Vasco Leitão da Cunha, encarregado de negócios do Brasil na Espanha para Raul Fernandes, ministro das Relações Exteriores do Brasil. Madri, 12 mar. 1949. Missões Diplomáticas Brasileiras. Ofícios recebidos de Madri (jan. a março de 1949). AHI/RJ.
} 
delegado del Brasil., ${ }^{, 462} \mathrm{O}$ artigo reproduzia fragmentos do discurso de João Carlos Muniz, delegado brasileiro junto ao Conselho de Segurança da ONU.

Durante os dias que precederam a apresentação da proposta, a Embaixada do Brasil em Madri manteve o MRE informado sobre a movimentação da imprensa espanhola, que já dava por derrocada da Resolução de 1946. Os elogios à proposta brasileira eram inúmeros, elevando junto ao povo espanhol a imagem do Brasil. O Itamaraty informou Leitão da Cunha, a título de "conhecimento pessoal", que iria propor que os Estados membros pudessem ter liberdade para enviar ou não embaixadores a Madri. ${ }^{463}$

Segundo Florentino Portero, que analisou a "cuestión española" na ONU, Raul Fernandes, ministro das Relações Exteriores do Brasil, escolheu um dos textos da proposta para apresentá-lo como próprio. O texto lembrava que nas últimas sessões da Assembléia Geral, o projeto que confirmava a recomendação condenatória de 1946 não havia sido aprovado. Afirmava que aquela resolução havia prejudicado muitos países, que se encontravam em situação de desigualdade com outros que mantinham vantagens nas relações comerciais com a Espanha. Propunha assim "dejar a .las naciones miembros de las Naciones Unidas en entera liberdad de acción en lo que se refiere a sus relaciones diplomáticas con España. ${ }^{464}$

Além do apoio da maioria dos países latino-americanos e do bloco árabe, o projeto contava com o voto norte-americano, o que tinha grande influência sobre o comportamento de outras delegações. Colocado em votação, o projeto conseguiu 26 votos a favor, 15 contra e 16 abstenções, faltando apenas um voto para a necessária maioria de dois terços. ${ }^{465}$ Apesar de não ter conseguido a maioria necessária para alterar a recomendação condenatória, a evolução dos votos ao longo das Assembléias de 1946 a 1949, demonstrou que a alteração da postura dos países ocidentais com relação à Espanha era uma questão de tempo. O governo brasileiro, a partir desse momento, passou

\footnotetext{
462 "Libertad en las relaciones diplomáticas com España. Esto pide para los países de la ONU el delegado del Brasil.", jornal ABC. Madri, 17 mar. 1949. Recorte anexado ao ofício n. 94 de Vasco Leitão da Cunha, encarregado de negócios do Brasil na Espanha para Raul Fernandes, ministro das Relações Exteriores do Brasil. Madri, 31 mar. 1949. Missões Diplomáticas Brasileiras. Ofícios recebidos de Madri (jan. a março de 1949). AHI/RJ.

${ }_{463}$ Telegrama (confidencial) da Secretaria de Estado das Relações Exteriores para Embaixada do Brasil na Espanha. Rio de Janeiro, 02 abr. 1949. Missões Diplomáticas Brasileiras. Telegramas expedidos a Madri (1947/1959). Arquivo de Correspondência Especial. CDO/MRE. ${ }^{464}$ Florentino Portero, op. cit., p.328.

${ }^{465}$ Idem, p. 336.
} 
a considerar que a não confirmação da resolução de 1946 pela Assembléia Geral em 1947, constituía-se em sua derrocada "virtual". Assim, o MAE passou a ter grande expectativa na nomeação de um embaixador brasileiro para Madri.

Em maio de 1949, Vasco Leitão da Cunha encaminhou ao Itamaraty várias mensagens oficiais de agradecimentos do governo espanhol à iniciativa brasileira. $\mathrm{O}$ jornal $A B C$ manteve durante algum tempo às referências positivas ao Brasil, chegando a publicar uma fotografia de Raul Fernandes, ministro das Relações Exteriores, intitulado de "paladino da causa espanhola". ${ }^{466}$

Embora praticasse uma ferrenha repressão aos grupos de esquerda que atuavam na clandestinidade, o governo espanhol não conseguiu evitar as manifestações dos mesmos em repúdio às representações dos países que, na ONU, haviam se posicionado a favor da proposta brasileira. No final da década de 1940, o General Franco ainda lutava contra grupos de resistência. 467

O governo espanhol enviou reforços para a sede da missão brasileira, oferecendo também agentes para garantir a segurança pessoal de Vasco Leitão da Cunha. Tais medidas respondiam às notícias de que "grupos terroristas" estariam planejando ataques às representações de diversos países e ao lançamento de uma bomba sobre o Consulado do Brasil em Barcelona. ${ }^{468}$ O cônsul-geral brasileiro nessa cidade comunicou ao Itamaraty, que havia concedido uma gratificação para Jose Cano Perez, porteiro que arriscou a sua própria vida ao desarmar a bomba. ${ }^{469}$

\footnotetext{
${ }^{466}$ Fotografia de Raul Fernandes publicada no jornal $A B C$. Madri, 13 maio 1949. Recorte anexado ao ofício n. 145 de Vasco Leitão da Cunha, encarregado de negócios do Brasil na Espanha para Cyro de Freitas Valle, ministro interino das Relações Exteriores do Brasil. Madri, 18 mai. 1949. Missões Diplomáticas Brasileiras. Ofícios recebidos de Madri (abril a junho de 1949). AHI/RJ.

${ }^{467}$ Isso nos remete à história do espanhol Victor Garcia, irmão de Julia Garcia, cuja trajetória de vida foi alvo de nosso interesse em estudos anteriores. Tendo sido expulso do Brasil na década de 1930, Victor passou a integrar um grupo guerrilheiro de resistência ao franquismo, que nos anos 40 atuou nas montanhas da Galícia. Cf Bernardo Maiz Vázquez. Galicia na Segunda Republica e baixo o franquismo (1930-1976). Vigo: Edicións Xerais de Galicia, 1988, p.173.

468 Ofício n. 230 (confidencial) de Vasco Leitão da Cunha, encarregado de negócios do Brasil na Espanha para Raul Fernandes, ministro das Relações Exteriores do Brasil. Madri, 26 set. 1949. Missões Diplomáticas Brasileiras. Ofícios recebidos de Madri (1947/1959). Arquivo de Correspondência Especial. CDO/MRE.

${ }^{469}$ Ofício n. 84 do cônsul do Brasil em Barcelona (ass. ileg.) para Secretaria de Estado das Relações Exteriores. Barcelona, 15 jun. 1949. Consulados Brasileiros. Ofícios recebidos de Barcelona (1949). AHI/RJ.
} 
Em setembro de 1949, Leitão da Cunha anunciava à imprensa hispânica a nomeação de um novo embaixador brasileiro. ${ }^{470} \mathrm{~A}$ chegada de Ferreira de Mello a Madri, em janeiro de 1950, foi noticiada por vários jornais que manifestaram vivo interesse em divulgar a projeção espanhola no contexto internacional. Apesar dessa nomeação, o governo Dutra não pretendia alterar a postura discreta que o Brasil sempre mantivera junto a ONU. No entendimento do governo brasileiro, sob a sua postura diante da questão espanhola não deveria pairar qualquer denúncia de incoerência.

Em outubro de 1949, vinte e dois embaixadores norte-americanos assinaram conjuntamente uma solicitação encaminhada ao governo de seu país, pedindo a nomeação de um embaixador para a Espanha. ${ }^{471}$ Isso indicava ao governo franquista que sua "política de dignidade" deveria continuar, ainda mais porque havia indícios de que as pressões do Senado norte-americano para efetivar uma aproximação com a Espanha teriam sucesso.

Em janeiro de 1950, a Espanha contava com embaixadores provenientes do Vaticano, Portugal, Argentina, Peru, República Dominicana, Bolívia, Egito e Brasil. ${ }^{472}$ Neste mesmo ano, a cuestion española foi retomada pela ONU. Por 38 votos a favor, 10 contra e 12 abstenções, o exílio internacional do regime franquista chegava a seu fim. ${ }^{473} \mathrm{~A}$ resolução $386 \mathrm{~V}$ de 4 de novembro de 1950 não deixava de rechaçar moralmente o regime político instaurado na Espanha, mas reconhecia o fracasso das medidas anteriores.

O processo de discussão da questão espanhola na ONU, ao longo desses anos, serviu para assegurar o poder do Caudillo, que teve a habilidade de canalizar as pressões externas para um sentimento popular de humilhação e orgulho. A Espanha teria ainda que esperar até 1955 para efetivar seu ingresso como membro das Nações Unidas. Segundo Lleonart Amselém, a entrada de 16 países deu a ONU uma nova perspectiva,

\footnotetext{
470 Ofício n. 240 de Vasco Leitão da Cunha, encarregado de negócios do Brasil na Espanha para Raul Fernandes, ministro das Relações Exteriores do Brasil. Madri, 30 set. 1949. Missões Diplomáticas Brasileiras. Ofícios recebidos de Madri (julho a out. 1949). AHI/RJ.

${ }^{471}$ Relatório do mês político (outubro) de Vasco Leitão da Cunha para Ministério das Relações Exteriores. Madri, 09 nov. 1949. Missões Diplomáticas Brasileiras. Ofícios recebidos de Madri (nov. a dez. de 1949). AHI/RJ.

${ }^{472}$ Florentino Portero, op. cit., p. 360.

${ }^{473}$ Idem, p.401.
} 
constituindo-se numa vocação reafirmada pela necessidade política e lógica histórica. ${ }^{474}$

${ }^{474}$ Alberto Jose Lleonart Amselém. El ingreso de España en la ONU: obstáculos e impulsos. Cuadernos de Historia Contemporanea. Madri: Universidade Complutense, n. 17, 1995, p.117. Disponível em: http://www.ucm.es/BUCM/revistas/ghi/0214400x/articulos/CHC09595110101A.PDF. Acesso em jul. de 2007. 
III - Rumo à parceria: os anos dourados 


\section{1 - 0 discurso da cordialidade}

No início da década de 1950 houve a retomada de um discurso de cordialidade recíproca entre a diplomacia brasileira e a espanhola. A vitória de Vargas em 1950 contentava o MAE e o ditador espanhol que, durante a Guerra Civil Espanhola, havia contado com a ajuda, ainda que discreta, de seu "amigo" brasileiro. No início de 1951, no discurso de agradecimento à atitude brasileira em the oferecer a mais alta condecoração brasileira, Franco assim se referia a Vargas e às relações entre os dois países:

La mision especial que vuestro presidente os encomendo de entregarme las insígnias del Gran Collar de la Cruz del Sur viene a colmarme de honores y de afecto.

Desde hoy, el nombre, evocador de tantas gloriosas gestas entre los navegantes hispânicos, se unirá em su corazón al cálido recuerdo de la nación brasileña y de sus amaneceres imperiales.

Quiso el Presidente Dutra que una de las últimas disposiciones de su mandato fuese la de destacar com esta alta distinción el aprecio por la obra de estrechamiento de las relaciones entre nuestros pueblos, tan íntimas, estrechas y cordiales, em estos últimos años, tan dificiles para la vida del mundo y em que se pusieron a prueba los amigos de nuestra nación. España no olvida jamás a los que en las horas difíciles o confusas siguieron siendo sus amigos, entre los cuales los Estados Unidos del Brasil ocuparon puesto de honor desde los primeros tiempos de nuestra Cruzada.

Si por imperativos reglamentarios un mandato presidencial termina com tan hermosos frutos outro se abre em mil halagueñas esperanzas. $\mathrm{Si}$ um excelente amigo e ilustre soldado termina su tarea, outro glorioso soldado y querido camarada le sustituye. Heraldo de que nuestras relaciones serán cada dia más estrechas y cordiales. Yo espero y mucho me complacería el que los tratados en preparación abran cauce amplio para que los sentimientos de nuestros pueblos y su comunión espiritual e intelectual sigan las corrientes cavez más intensas de nuestras relaciones comerciales y que los aviones que por nuestros acuerdos aéreos hoy cruzan nuestros cielos estiendan nuestros brazos en un cordial abrazo a los buenos hermanos de América. ${ }^{475}$

\footnotetext{
475 "Discurso pronunciado por sua excelência o General Francisco Franco na entrega do Grande Colar da Ordem Nacional do Cruzeiro do Sul por sua excelência o senhor embaixador do Brasil." Anexo ao ofício n. 71 de Rubens Ferreira de Mello, embaixador do Brasil na Espanha para João Neves da Fontoura, ministro das Relações Exteriores do Brasil. Madri, 13 fev. 1951. Missões Diplomáticas Brasileiras. Ofícios recebidos de Madri (jan. a março de 1951). $\mathrm{AHI} / \mathrm{RJ}$
} 
O discurso de Franco reforçava o elemento principal de unidade de pensamento entre os dois chefes de estado: o anticomunismo. Se ao final dos anos 30, Vargas e Franco tinham em comum o autoritarismo, dessa vez a situação era distinta. Getúlio Vargas voltava ao Palácio do Catete eleito e "nos braços do povo", como demagogicamente gostava de afirmar. A essa diferença, e às eleições livres, tão distantes da realidade espanhola, Franco se referia como "imperativos reglamentarios". O ditador espanhol mencionava também o acordo aéreo hispano-brasileiro que, assinado no Rio de Janeiro em 1949, estabeleceu regras para que as companhias aéreas pudessem ter linhas regulares entre Madri e Rio de Janeiro. ${ }^{476}$

A entrega de condecorações continuou a ser recorrente ao longo dos anos 50. ${ }^{477}$ Meses depois de Franco ter sido agraciado com o Grã-Colar, era a vez de Martin Artajo, ministro de Assuntos Exteriores, receber a Grande Cruz do Cruzeiro do Sul. ${ }^{478}$ Proeminentes políticos e personalidades brasileiras receberam a condecoração espanhola da Ordem de Isabel, la católica. Como já escreveu o historiador Amado Cervo, as condecorações outorgadas eram um instrumento para refletir e produzir a imagem. As medalhas oferecidas a "homens políticos, cientistas, literatos e professores de ambos os lados serviam

\footnotetext{
$476 \mathrm{O}$ acordo aéreo Brasil x Espanha foi assinado em 28 de novembro de 1949. Despacho da Secretaria de Estado das Relações Exteriores para Embaixada do Brasil em Madri. Rio de Janeiro, 20 jan. 1949. Missões Diplomáticas Brasileiras. Despachos para Madri (1946-1956). AHI/RJ.

477 Muitos diplomatas brasileiros foram condecorados pela Espanha, assim como muitos espanhóis foram agraciados pela Ordem Nacional do Cruzeiro do Sul, em suas várias modalidades. Mesmo nos momentos em que as relações diplomáticas com a Espanha tornaram-se tensas, como é o caso dos anos que correspondem à participação brasileira no conflito mundial, as condecorações continuaram a ser oferecidas com generosidade. Em 1944, por exemplo, Abelardo Roças foi condecorado com a Grã-Cruz de Isabel, la católica. (Ofício n. 46 de Mario de Pimentel Brandão, embaixador do Brasil na Espanha para ministro das Relações Exteriores do Brasil. Madri, 20 mar. 1944. Missões Diplomáticas Brasileiras. Ofícios recebidos de Madri (janeiro a julho de 1944). AHI/RJ). Tais homenagens, muitas vezes, eram realizadas levando-se em conta o princípio da reciprocidade. Em 1942, no auge das preocupações do governo Vargas com as atividades realizadas pela Embaixada da Espanha no Brasil, o Brasil recebeu do Ministério de Assuntos Exteriores da Espanha o pedido para que o diplomata Miguel Cordomí fosse condecorado. Cordomí havia prestado serviços entre 1934 e 1942 como segundo secretário na Embaixada espanhola no Rio de Janeiro. (Ofício n. 66 de Abelardo Roças, embaixador do Brasil na Espanha para ministro das Relações Exteriores do Brasil. Madri, 27 abr. 1942. Missões Diplomáticas Brasileiras. Ofícios recebidos de Madri (janeiro a junho de 1942). AHI/RJ).

478 Despacho da Secretaria de Estado das Relações Exteriores para Embaixada do Brasil em Madri. Rio de Janeiro, 13 abr. 1951. Missões Diplomáticas Brasileiras. Despachos para Madri (1946-1956). AHI/RJ.
} 
mais ainda para favorecer a simpatia das relações e as imagens de ambos os lados". 479

Além das condecorações, outro dado nos demonstra que a Embaixada do Brasil em Madri gozava de prestígio dentre os meios sociais e políticos espanhóis. Em um relatório sobre os eventos sociais, consta que em 1954 a representação brasileira ofereceu quarenta e dois almoços e duas recepções, sendo duas com mais de mil convidados. ${ }^{480}$

As simpatias mútuas entre os dois estadistas também podem ser verificadas nas referências elogiosas ao Caudillo realizadas por Vargas. Procurando demonstrar ao povo espanhol que a Espanha ganhava a cada dia prestígio internacional, os jornais desse país noticiaram com atenção tais referências. O jornal El Pueblo de Madri anunciava em letras garrafais: El Presidente Vargas elogia al Generalísimo Franco. ${ }^{481}$

O futuro das relações comerciais e culturais entre Brasil e Espanha parecia ser ainda mais promissor com a Embaixada brasileira sob a liderança de Rubens Ferreira de Mello, que chegou a Madri em março de 1950, parecendo nutrir forte admiração pelo regime espanhol. Logo após assumir como embaixador, Ferreira de Mello deu uma entrevista, publicada por diversos jornais espanhóis, mencionando que o Brasil nunca havia considerado a Espanha uma ameaça à paz internacional, afirmando que a resolução de 1946 havia sido "injusta e infeliz". Por suas declarações, consideradas "exageradas", o embaixador foi advertido pelo Itamaraty. O telegrama confidencial expedido pela Secretaria de Estado das Relações Exteriores em 29 de março de 1950 pedia para que, em posteriores declarações, o embaixador se ativesse somente à atitude do governo brasileiro fundada na exposição de motivos do ministro de Estado ao presidente da República. ${ }^{482}$

\footnotetext{
${ }^{479}$ Amado Cervo. As relações históricas entre Brasil e Itália, op. cit., p.140.

${ }^{480}$ Relatório social n. 04 da Embaixada do Brasil na Espanha para Ministério das Relações Exteriores do Brasil (4ำ trimestre de 1954). Madri, 03 jan. 1955. Missões Diplomáticas Brasileiras. Ofícios recebidos de Madri (janeiro a março de 1955). AHI/RJ.

481 "El Presidente Vargas elogia al Generalísimo Franco", jornal El Pueblo de 19 maio 1954. Recorte anexado ao ofício n. 224 da Embaixada do Brasil na Espanha para a Secretaria de Estado das Relações Exteriores do Brasil Madri, 31 maio 1954. Missões Diplomáticas Brasileiras. Ofícios recebidos de Madri (maio a julho de 1954). AHI/RJ.

482 Carta-telegrama n. 29 (confidencial) da Secretaria de Estado das Relações Exteriores para a Embaixada do Brasil na Espanha. Rio de Janeiro, 29 mar. 1950. Missões Diplomáticas Brasileiras. Telegramas expedidos a Madri (1947/1959). Arquivo de Correspondência Especial. CDO/MRE.
} 
As declarações de Ferreira de Mello colocavam a diplomacia brasileira numa situação desconfortável ao evidenciar, para a Espanha, que a postura brasileira na ONU estava estreitamente, e quase que incondicionalmente, dependente das diretrizes norte-americanas.

Indignado com a advertência, Ferreira de Mello solicitou que o MRE ponderasse a questão, pois a ele não constava que $\circ$ Brasil tivesse considerado a Espanha como uma ameaça internacional. Lembrava ainda, que suas considerações eram semelhantes àquelas realizadas por outros embaixadores, e que suas atitudes serviam ao propósito de facilitar a resolução de algumas pendências nas relações com aquele país. ${ }^{483}$

Os assuntos pendentes mencionados pelo embaixador brasileiro, possivelmente eram os mesmos que o embaixador espanhol Jose Rojas y Moreno apontara ao Ministério de Asuntos Exteriores da Espanha: a necessidade de estabelecer acordos nas áreas de comércio, cultura e imigração. O embaixador espanhol, no Brasil desde os tempos difíceis do embargo espanhol na ONU, mostrava-se entusiasmado com a possibilidade de estabelecer acordos e tratados nessas áreas. ${ }^{484}$ No entanto, o processo para a efetivação de acordos nas áreas de cultura e imigração se estenderia até a década de 1960.

\footnotetext{
${ }^{483}$ Carta-telegrama n. 32 (confidencial) de Rubens Ferreira de Mello, embaixador do Brasil na Espanha para a Secretaria de Estado das Relações Exteriores. Madri, 05 abr. 1950. Missões Diplomáticas Brasileiras. Telegramas recebidos de Madri (1947/1959). Arquivo de Correspondência Especial. CDO/MRE.

${ }^{484}$ Despacho n. 346 de Jose Rojas y Moreno, embaixador da Espanha no Brasil para ministro de Assuntos Exteriores da Espanha. Rio de Janeiro, 25 maio de 1951. R2829, expt. 74. AMAE.
} 


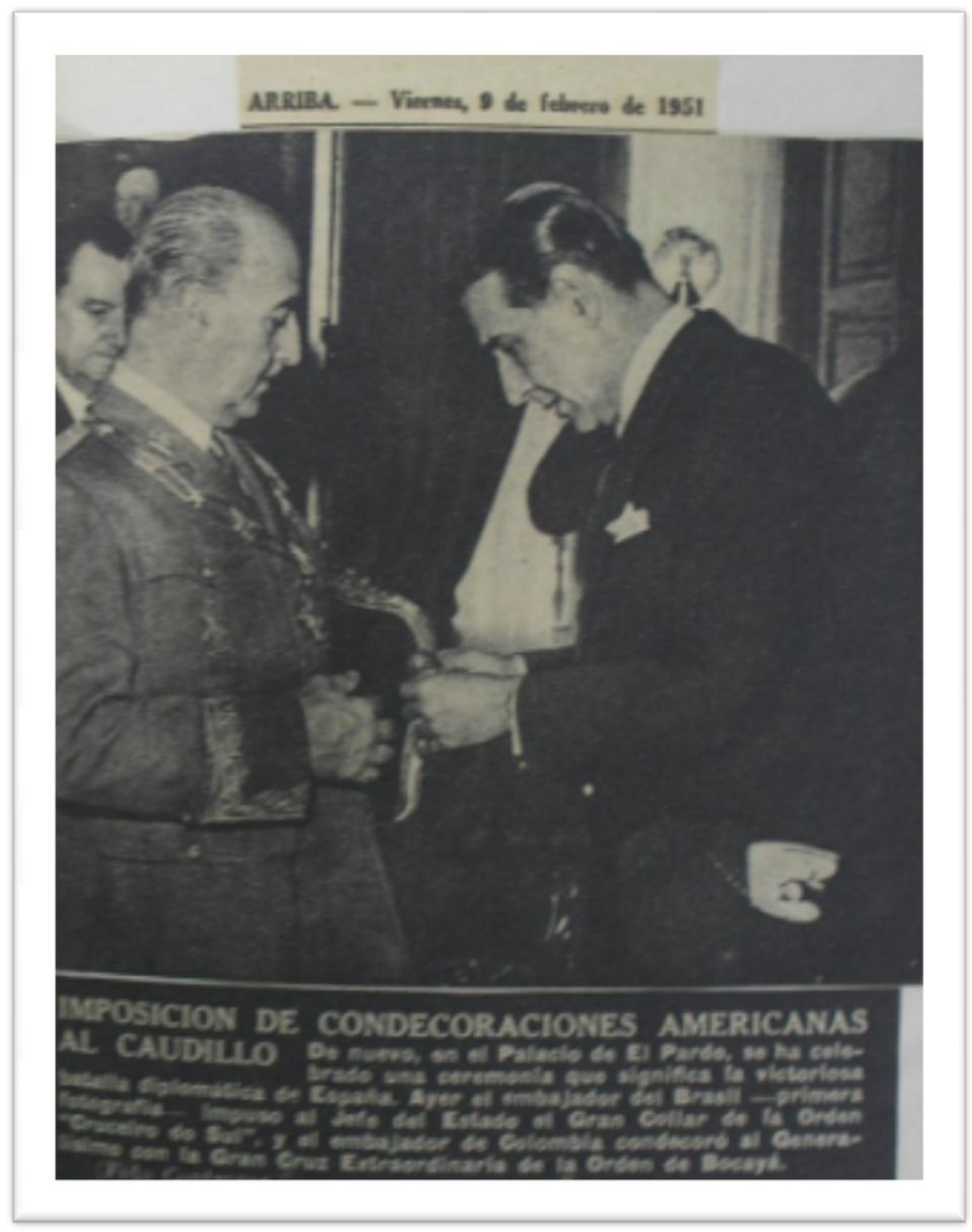

15 - Rubens Ferreira de Mello entrega o Grande Colar do Cruzeiro do Sul a Francisco Franco. Foto reproduzida no jornal Arriba. Madri, 09 de fevereiro de 1951. Recorte anexado ao ofício n. 71 de Rubens Ferreira de Mello, embaixador do Brasil na Espanha para João Neves da Fontoura, ministro das Relações Exteriores do Brasil. Madri, 13 fev. 1951. Missões Diplomáticas Brasileiras. Ofícios recebidos de Madri (jan. a março de 1951). AHI/RJ.

Rojas y Moreno, que assinava com o título nobiliário de Conde de Casa Rojas, demonstrou otimismo na descrição de sua audiência com Getúlio Vargas. Tecendo elogios à figura do presidente recém empossado, Casa Rojas informava que tal recepção significava uma grande deferência para com a Espanha, uma vez que Vargas só havia recebido o Núncio e os embaixadores 
de Portugal e EUA, nações com as quais o Brasil tinha laços estreitos. Os temas abordados, pelo que demonstra o relato de Rojas, não chegaram a incluir as questões mais pertinentes e de maior interesse para as relações comerciais e culturais. Falaram das características do povo brasileiro e da origem espanhola do presidente Vargas. ${ }^{485}$

Quanto a esse último aspecto, convém observar que em vários documentos produzidos pela diplomacia espanhola radicada no Brasil, é perceptível uma tentativa de enfatizar e exagerar a influência hispânica na formação cultural e no histórico familiar de brasileiros influentes. A "origem hispânica" de Vargas, na verdade, era longínqua. Em suas biografias, podem ser encontradas referências dispersas sobre a possível origem espanhola da avó paterna de Getúlio, de quem herdara o sobrenome Vargas. ${ }^{486}$

A gestão de Conde de Casa Rojas à frente da Embaixada espanhola no Rio de Janeiro terminou em 1952. A imprensa madrilenha noticiou a partida de Casa Rojas do Rio de Janeiro, evidenciando as inúmeras homenagens recebidas por setores da comunidade espanhola e da sociedade brasileira. ${ }^{487}$ Recepção essa, vale observar, muito diferente daquela recebida em 1946, quando chegou ao Brasil numa posição desconfortável por ter que assumir o lugar de Eduardo Aunós, preterido pelo governo brasileiro devido às denúncias já mencionadas.

Apesar dos acordos na esfera comercial e cultural não terem sido concluídos rapidamente, a aproximação entre o Brasil e a Espanha na primeira metade dos anos 50 extrapolou o âmbito do discurso, efetivando-se nas relações multilaterais. Os dois países estabeleceram apoio mútuo, visando o fortalecimento de suas posições junto à ONU.

Após 1950, a Espanha foi autorizada a integrar alguns órgãos secundários da ONU, como a FAO. Era muito importante para a Espanha sua aceitação como membro do Conselho da Organização das Nações Unidas para Agricultura e Alimentação. A situação precária da produção de alimentos e de

\footnotetext{
${ }^{485}$ Despacho n. 66 de Jose Rojas y Moreno, embaixador da Espanha no Brasil para Ministro de Assuntos Exteriores espanhol. Rio de Janeiro, 31 jan. de 1951. R2829, expt. 74. AMAE.

${ }^{486}$ Cf. Álvaro Rocha Vargas. História e genealogia dos Vargas. Disponível em http://www.losvargas.org/historia/1999 historia alvaro vargas.html. Acesso em 03 dez. 2008.

${ }^{487}$ Ofício n. 237 de Rubens Ferreira de Mello, embaixador do Brasil na Espanha para João Neves da Fontoura, Ministro de Estado das Relações Exteriores do Brasil. Madri, 20 jun. 1952. Missões Diplomáticas Brasileiras. Ofícios recebidos de Madri (abril a junho de 1952). AHI/RJ.
} 
abastecimento de grande parte do território espanhol tornava a eleição espanhola para o cargo uma causa de primeira ordem para a política externa de Franco. Sendo assim, em 1951, o Ministério de Asuntos Exteriores espanhol iniciou sua movimentação para angariar apoio para que a Espanha assumisse uma das dezoito vagas para o referido conselho. O governo franquista apostava no apoio brasileiro à candidatura da Espanha, o que parece ter sido efetivado. Em novembro de 1951, em nome do ministro João Neves da Fontoura, Heitor Lyra assentiu ao pedido do embaixador espanhol, informando a esse que a delegação brasileira junto à ONU seria orientada a apoiar a candidatura espanhola. ${ }^{488}$

Em novembro de 1952, a Espanha foi aceita na UNESCO, o que teve um significado importante, diante do esforço do povo espanhol para superar a penúria econômica. Este ano ficaria também marcado internamente por ser aquele em que foi suprimida a cartilla de racionamiento, um modelo de distribuição de alimentos básicos, que representava a dura situação de privação da maior parte da população espanhola. ${ }^{489}$

Em setembro de 1953, o governo franquista fechou vários acordos com os Estados Unidos, determinantes para agilizar o processo de recuperação da economia espanhola. Tais pactos, na área de defesa estratégica, deram aos EUA a oportunidade de estabelecer bases militares na Espanha. Segundo Jose Luis Abellán, o projeto supranacional da Comunidade Ibero-americana foi abandonado para incorporar a Espanha num outro projeto subordinado ao chamado "Mundo Ocidental", sob a liderança dos EUA. 490

Os relatórios encaminhados ao Itamaraty escritos mensalmente por Rubens Ferreira de Mello demonstram que era grande a expectativa espanhola pela efetivação dos referidos acordos. Em abril de 1953, Mello informou que os jornais procuravam demonstrar que a assinatura dos acordos era, para os EUA, mais urgente do que para a Espanha, tendo o Export-Import

\footnotetext{
${ }^{488}$ Nota n. 89 de Heitor Lyra, em nome do ministro de Estado para Conde de Casa Rojas, embaixador espanhol no Brasil. Rio de Janeiro, 12 nov. 1951. Representações Estrangeiras. Notas expedidas (1946-1951). AHI/RJ.

${ }^{489}$ Jose Luis Abellán, op. cit., p.140.

490 Idem, p. 141.
} 
Bank fornecido subsídios às empresas catalãs. ${ }^{491}$ Mais uma vez, o orgulho das elites dirigentes produzia um discurso de indiferença, que pouco refletia as reais necessidades de auxílio.

Qualquer opinião contrária à efetivação dos acordos, por parte de segmentos políticos norte-americanos, era interpretada pela imprensa espanhola como uma tendência "comunista". Segundo Mello, muitos senadores contrários aos acordos estavam sendo acusados de comunismo. ${ }^{492}$ Os EUA presenciavam, naquele momento, 0 auge da perseguição aos comunistas, movimento que ficou conhecido como "Macarthismo". O medo coletivo da espionagem soviética, e as ações anticomunistas exacerbadas, serviam como um ótimo instrumento de propaganda para o governo franquista, que também coadunava com a obsessão em combater aqueles que eram considerados os "inimigos número um" do regime.

A partir dos acordos com os EUA, O MAE passou a pleitear o apoio de diversos países, no sentido de defender a entrada de seu país na ONU. Também solicitou junto à referida Organização, a aceitação de um observador permanente, que não tinha direito a voz e voto, mas que já se colocava em contatos oficiais com outros membros. Em outubro de 1953, foi criada a Comissão de Bons Ofícios para a admissão de novos membros. ${ }^{493}$ Durante este ano, especialmente nos meses de novembro e dezembro, o Itamaraty e a representação da Espanha no Rio de Janeiro trocaram correspondências sobre a possível entrada de novos membros na referida Organização.

Prat y Nantouillet, embaixador espanhol no Rio de Janeiro, enviou a Vasco Leitão da Cunha - que naquela época chefiava a Secretaria de Estado das Relações Exteriores - uma extensa nota na qual demonstrava sua "crença" no apoio brasileiro à possível moção que os países hispano-americanos iriam propor na próxima Assembléia. Nantouillet argumentava que não podia se falar em universalidade da Organização excluindo países como Alemanha, Itália e

491 Ofício n. 141 de Rubens Ferreira de Mello, embaixador do Brasil na Espanha para João Neves da Fontoura, ministro de Estado das Relações Exteriores do Brasil. Madri, 27 abr. 1953. Missões Diplomáticas Brasileiras. Ofícios recebidos de Madri (abril a maio de 1953). AHI/RJ.

492 Ofício n. 36 de Rubens Ferreira de Mello, embaixador do Brasil na Espanha para João Neves da Fontoura, Ministro de Estado das Relações Exteriores do Brasil. Madri, 21 jan. 1953. Missões Diplomáticas Brasileiras. Ofícios recebidos de Madri (janeiro a março de 1953). AHI/RJ.

${ }^{493}$ Amselém, op. cit., p. 112-113. 
Japão. Tentando demonstrar sua preocupação com a paz mundial, o diplomata espanhol reforçava a afirmação de que não havia indícios de que a Espanha pediria o seu ingresso. ${ }^{494}$

A dificuldade em admitir o interesse espanhol na questão é perceptível em vários documentos diplomáticos e nos meios de comunicação da Espanha. A política de "dignidade" praticada por Franco e seu orgulho impediam o diplomata espanhol de reconhecer que todo aquele interesse na futura posição brasileira diante da ONU, tinha sim um objetivo: analisar as possíveis chances de sucesso de uma futura candidatura espanhola.

Leitão da Cunha respondeu a Nantouillet que desejava ver nações como Itália e Espanha inseridas na ONU, mas que neste aspecto pouco se tinha a fazer, uma vez que o problema do ingresso estava diretamente ligado ao Conselho de Segurança. Também afirmava que somente uma reforma da Carta possibilitaria, por exemplo, o fim do abuso do veto por parte da URSS. ${ }^{495} \mathrm{~A}$ estratégia de não externar o desejo espanhol de se integrar à ONU, mas ao mesmo tempo procurar conhecer, através de seus possíveis aliados, as condições para que isso se efetivasse, parece ter surtido o efeito esperado por Franco. Em dezembro de 1955 o Conselho de Segurança aprovou a candidatura espanhola, e a Assembléia Geral votou a proposta do Conselho sobre a admissão de quinze novos membros. A Espanha teve 55 votos a favor, nenhum contra e a abstenção da Bélgica e do México. ${ }^{496}$

A entrada da Espanha na ONU teve um importante significado para a sua política externa, no sentido de confirmar a legitimidade do governo do Generalíssimo que, mesmo assim, continuou a demonstrar pouco caso e indiferença diante dessa inserção. ${ }^{497}$ Os meios de comunicação franquistas noticiavam o fato como uma tardia reparação às injustiças cometidas contra a Espanha.

O governo espanhol, em 1954, decidiu substituir Prat y Nantouillet, que deixou a Embaixada da Espanha no Rio de Janeiro por ter se

\footnotetext{
${ }^{494}$ Nota de Marquês de Prat y Nantouillet, embaixador da Espanha no Brasil para Vasco Leitão da Cunha, secretário de Estado das Relações Exteriores. Rio de Janeiro, 14 nov. 1953. Representações Estrangeiras. Notas recebidas da Espanha (1952-1954). AHI/RJ.

${ }^{495}$ Nota de Vasco Leitão da Cunha, secretário de Estado das Relações Exteriores para Marquês de Prat y Nantouillet, embaixador da Espanha no Brasil. Rio de Janeiro, 8 dez. 1953. Representações Estrangeiras. Notas expedidas à Espanha (1952-1954). AHI/RJ.

${ }^{496}$ Antonio Fernandez Garcia et alii, op.cit., p.138.

497 Idem, p. 144.
} 
envolvido num escandaloso caso de corrupção. Um telegrama confidencial trouxe à tona um lado indecoroso, e não oficial da trajetória profissional desse diplomata.O Itamaraty foi informado por Rubens Ferreira de Mello que Prat y Nantouillet era acusado de beneficiar-se com a importação de acordeons para a "Fundação do Generalíssimo", além de ser acusado de envolver-se amorosamente com a esposa de um funcionário da Embaixada. ${ }^{498}$ Segundo Ferreira de Mello, o acusado estaria preparando a sua defesa em Madri. Para assumir o posto, o governo franquista enviou Tomás Suñer y Ferrer, que ficaria no Rio de Janeiro até 1960.

Em 1955, André Gourdon Shaw, espanhol que atuava como auxiliar contratado da Embaixada do Brasil foi preso por "delito monetário". Segundo o brasileiro Paulo Braz Pinto, primeiro-secretário em Madri, o referido auxiliar estaria sendo acusado de cometer acordos ilícitos com empresas espanholas, além de realizar transações financeiras na Suíça. Braz Pinto informava que, pelas leis espanholas, os auxiliares contratados de representações estrangeiras não gozavam de qualquer tipo de imunidade. ${ }^{499}$ Em que medida Gourdon Shaw teria se beneficiado das informações e contatos possibilitados pela sua função na representação brasileira, é uma questão a ser investigada. Outro funcionário da representação brasileira, Ramon lbañez, foi acusado de estar envolvido com irregularidades na emissão de vistos em passaportes. Casos como esses parecem ter sido recorrentes na Embaixada brasileira em Madri.

O suicídio de Getúlio Vargas, em 24 de agosto de 1954, alcançou grande repercussão na imprensa espanhola. O embaixador brasileiro, no início de setembro daquele ano, conseguiu reunir um montante de mais de 50 recortes de jornais hispânicos que noticiaram o falecimento do presidente brasileiro. Segundo Ferreira de Mello, a maioria dos jornais mantinha-se neutro nas considerações sobre as causas da morte de Vargas, mas alguns deles como o matutino Pueblo chegara a atribuir a atitude trágica do presidente à

${ }^{498}$ Carta-telegrama n. 16 (confidencial) de Rubens Ferreira de Melo, embaixador do Brasil na Espanha para Ministério das Relações Exteriores do Brasil. Missões Diplomáticas Brasileiras. Telegramas recebidos de Madri (1947/1959). Arquivo de Correspondência Especial. CDO/MRE.

499 Telegramas confidenciais de Paulo Braz Pinto, secretário da Embaixada do Brasil na Espanha para a Secretaria de Estado das Relações Exteriores. Madri, 02 e 13 de abril de 1955. Missões Diplomáticas Brasileiras. Telegramas recebidos de Madri (1947/1959). Arquivo de Correspondência Especial. CDO/MRE. 
imprensa, especialmente a do Rio de Janeiro, que de acordo com a transcrição do embaixador seria "... la más agresiva, irresponsable y libelesca del mundo. No goza de estatuto de libertad, sino de libertinaje. ${ }^{, 500}$

Mais uma vez as notícias sobre o Brasil ensejavam a oportunidade para criticar o que o governo franquista considerada um defeito da democracia: o excesso de liberdade dos meios de comunicação que, em sua visão, transformavam-se fatalmente em libertinagem. Aqueles que forneciam considerações particulares sobre o perfil de Vargas, não se furtavam em evidenciar a herança espanhola do presidente, citado mais uma vez, como neto de espanhóis. ${ }^{501}$

\section{A visita de JK à Espanha}

No início de seu mandato como presidente do Brasil, Juscelino Kubitschek procurou manter as alianças com os EUA, com o objetivo de colocar em prática seu projeto desenvolvimentista. Seu discurso político enfatizava a necessidade de "um diálogo construtivo com os Estados Unidos" ${ }^{502}$ Com a intenção de buscar parcerias econômicas, antes mesmo de sua posse, Kubitschek empreendeu, em janeiro de 1956, uma viagem aos Estados Unidos e a alguns países da Europa. A inclusão da Espanha na agenda de visitas e as preparações para a recepção do novo presidente pelo governo de Franco foram um dos pontos altos nas relações bilaterais entre Brasil e Espanha nos anos 50.

Na segunda metade da década de 1950 começaram a se delinear novas perspectivas para as relações hispano-brasileiras, especialmente por conta de alguns pontos em comum nas suas relações com os Estados Unidos, ou seja: a busca do apoio desta grande potência como um elemento essencial

500 Ofício n. 356 de Rubens Ferreira de Mello, embaixador do Brasil na Espanha para Raul Fernandes, ministro de Estado das Relações Exteriores do Brasil. Madri, 09 set. 1954. Missões Diplomáticas Brasileiras. Ofícios recebidos de Madri (agosto a setembro de 1954). AHI/RJ. ${ }_{501}$ Idem.

${ }^{502}$ Amado Cervo. Relações Internacionais na América Latina, op. cit., p.106. 
ao desenvolvimento. Brasil e Espanha também compartilhavam o otimismo no futuro. Este sentimento, no Brasil, estava consubstanciado no projeto desenvolvimentista e na crença de que o país estava designado a entrar na modernidade. Na Espanha, os acordos com os EUA e a sua inserção como membro da ONU geravam grandes expectativas.

O anticomunismo continuava a motivar os discursos cordiais dos diplomatas brasileiros e espanhóis, uma vez que se constituía em peça fundamental do projeto político de ambos os países. O argumento de que um programa de acelerado desenvolvimento era um poderoso instrumento de combate ao comunismo foi muito utilizado por Juscelino, especialmente em sua visita aos EUA. Esse discurso seria retomado com maior ênfase quando do lançamento da Operação Pan-Americana em 1958.

Kubitschek chegou à Espanha em 20 de janeiro de 1956, após ter cumprido uma agenda de compromissos em Portugal. Nos dois dias em que permaneceu em território espanhol, teve acalorada recepção de expoentes da política espanhola. A cobertura da imprensa revestiu-se de ampla cordialidade, tendo os jornais evidenciado o perfil anticomunista do presidente brasileiro.

A preparação para a recepção de JK pode ser acompanhada pela correspondência trocada entre a diplomacia brasileira e o Ministério de Asuntos Exteriores espanhol. A Espanha, segundo o embaixador Rubens Ferreira de Melo, foi o único país no qual Juscelino foi recepcionado com todas as honras de um Chefe de Estado. Francisco Franco o recebeu no aeroporto de Barajas. $^{503}$

A estadia foi curta, porém, intensa em compromissos. No primeiro dia, Juscelino passeou por Madri, almoçou com o ditador espanhol no Palácio El Pardo, além de visitar o Instituto de Cultura Hispânica e o campus da Cidade Universitária. No dia seguinte, após uma breve visita à cidade medieval de Toledo, participou de um almoço no Palácio Moncloa. ${ }^{504}$ A lista com o nome

\footnotetext{
503 Ofício n. 32 de Rubens Ferreira de Melo, embaixador do Brasil na Espanha para João Carlos de Macedo Soares, ministro das Relações Exteriores do Brasil. Madri, 25 jan. 1956. Missões Diplomáticas Brasileiras. Ofícios recebidos de Madri (janeiro a março de 1956). AHI/RJ.

${ }^{504}$ Conrad Wrzos, polonês radicado no Brasil, fez a cobertura jornalística da viagem realizando uma descrição pormenorizada das atividades desenvolvidas por $\mathrm{JK}$ em cada um dos países visitados. Em seu livro constam fragmentos de alguns discursos oficiais proferidos pelo
} 
dos convidados registra a presença de Francisco Franco e do chanceler espanhol, além de personalidades importantes da política espanhola. ${ }^{505}$

Ao anoitecer, Juscelino concedeu entrevista coletiva, tecendo considerações sobre o incremento do comércio com a Espanha nos últimos anos e o desejo de ver esses números duplicados em sua gestão. Mencionou também a intenção de criar bolsas de estudos para brasileiros. A visita encerrou-se com a recepção oferecida na sede da Embaixada do Brasil, na qual estiveram presentes autoridades e membros do corpo diplomático. ${ }^{506}$

Na Real Academia Española de Medicina, JK recebeu o título de Doutor Honoris Causa, discursando sobre as afinidades culturais e religiosas entre o Brasil e a Espanha:

Esta homenagem cordial e carinhosa autoriza-me a falar em nome do Brasil da simpatia e afeto que ali se sente pela Espanha, e a afirmar que nos dois povos existe um ideal comum, já que temos a mesma filosofia e o mesmo sentido cristão das cousas, seguros de que assim nos salvaremos todos. A realidade é que o Brasil e a Espanha se encontraram no caminho com os mesmos vínculos, a mesma cultura e porque nossas tarefas, em definitivo, são presididas pela cruz. ${ }^{507}$

O cristianismo enquanto herança cultural do povo brasileiro e espanhol foi citado por Juscelino para evidenciar mais um ponto de convergência entre os dois países. Importante lembrar que na Espanha, a influência da Igreja Católica fazia-se muito mais presente no âmbito político, estando estreitamente vinculada ao regime franquista desde 1939. Franco permitiu a institucionalização do poder eclesiástico e a sua efetiva participação em órgãos estatais, tal como o Conselho de Estado. A Igreja detinha grande influência na estrutura social através da educação, possuindo mais de cinqüenta por cento do ensino médio em suas mãos. ${ }^{508}$

presidente eleito. Conrad Wrzos. Juscelino Kubitschek: Estados Unidos, Europa (Diário de Viagem). Rio de Janeiro: J. Olympio, 1960.

505 Lista de precedência para o almoço oferecido por Juscelino Kubitschek e convite de honra do mesmo ao Ministro Alberto Martin Artajo. R5847, expt. 30. AMAE.

${ }^{506}$ Conrad Wrzos, op. cit., p. 128.

507 Relatório do Mês cultural (janeiro de 1956). Madri, 01 fev. 1956. Missões Diplomáticas Brasileiras. Ofícios recebidos de Madri (janeiro a março de 1956). AHI/RJ.

${ }^{508}$ Ramon Tamames, op. cit., p. 343. 


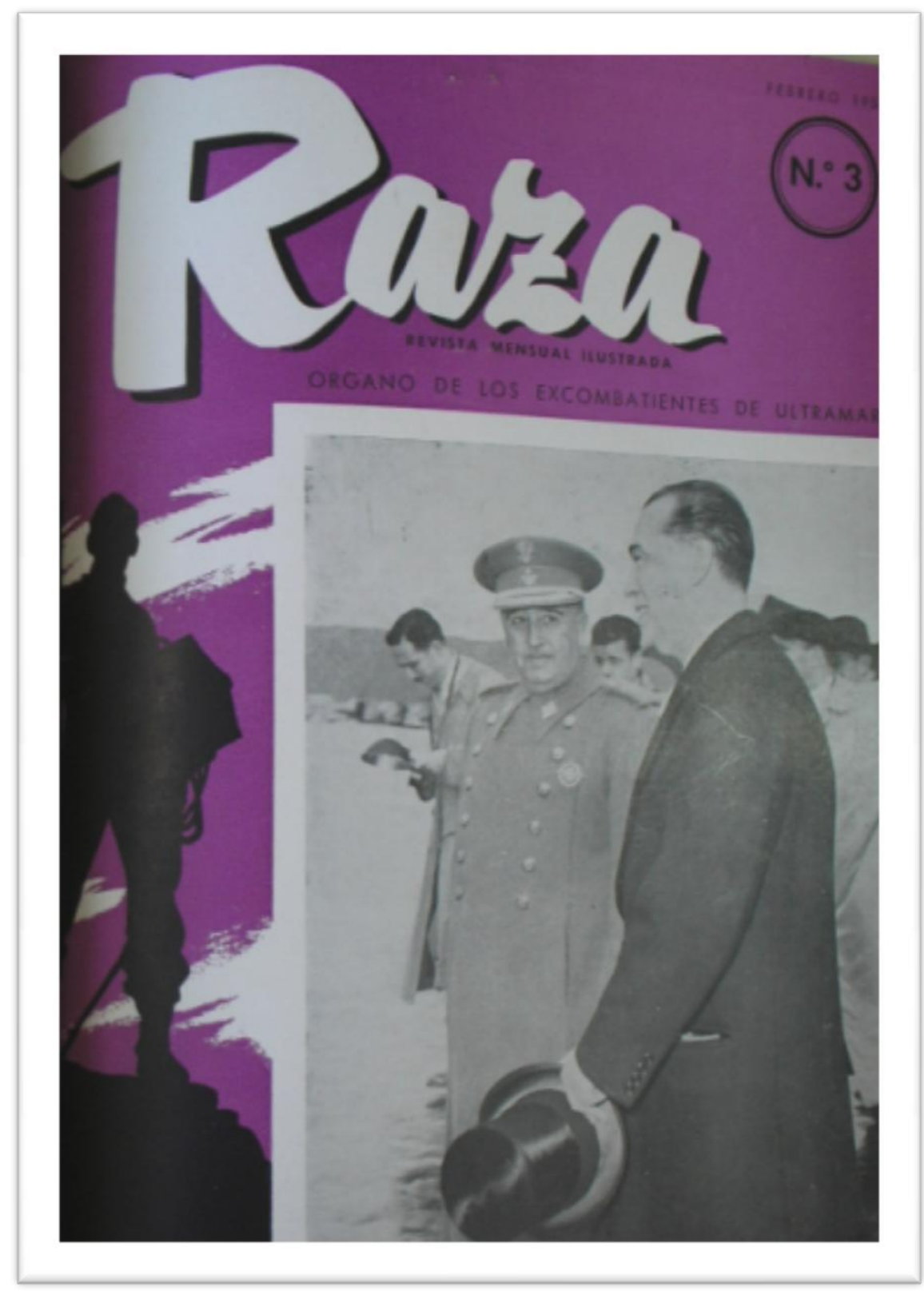

16 - Encontro entre Juscelino Kubistchek e Francisco Franco no aeroporto de Barajas. Fotografia reproduzida na capa do jornal Raza (s.d), anexado ao ofício n. 115 da Embaixada do Brasil na Espanha para a Secretaria de Estado das Relações Exteriores. Madri, 22 mar. 1956. Missões Diplomáticas Brasileiras. Ofícios recebidos de Madri (jan. a março de 1956). AHI/RJ. 
O otimismo demonstrado durante a visita de JK à Espanha parecia refletir também as simpatias pessoais e a amizade entre os dois chefes de Estado. Segundo a historiadora Elena Pájaro Peres, Franco preservou em destaque no salão do Palácio El Pardo, um retrato de JK com a faixa presidencial, mesmo após o término do seu mandato. ${ }^{509}$ Vale observar que anos depois, com o golpe militar de 1964, Juscelino encontrou no governo espanhol uma rápida receptividade, embarcando para Madri na qualidade de asilado político. A Espanha, mesmo não tendo acordo de asilo político com o Brasil, deu anuência para que o embaixador espanhol Jaime Alba Delibes acolhesse 0 então ex-presidente, perseguido pelos militares brasileiros no poder. ${ }^{510}$

A visita do presidente eleito à Europa sinalizava a tendência do Brasil em valorizar as relações internacionais com essa parte do mundo, uma vez que, desde o segundo governo Vargas, já havia a constatação de que o apoio irrestrito aos EUA não estava revertendo ao Brasil benefícios econômicos efetivos. Em meados da década de 1950, segundo Monica Hirst, a ilusão de um alinhamento automático com os EUA "perde sentido como premissa orientadora da política internacional do país" ${ }^{511}$

Durante o governo de $\mathrm{JK}$, as relações com os EUA esbarraram em impasses difíceis de resolução, contribuindo para que a política externa brasileira ampliasse suas relações com a Europa Ocidental. ${ }^{512} \mathrm{~A}$ visita de JK e os discursos cordiais de ambos os lados expressavam os interesses comuns de estreitamento dos laços comerciais e culturais.

${ }^{509}$ Faro de Vigo, 01/06/1961, anexado ao ofício de Consulado do Brasil em Vigo à Secretaria de Estado das Relações Exteriores, 02/06/1961, AHI-B Apud Elena Pájaro Peres. A inexistência da terra firme, op. cit., p.63.

510 Cf Biografia de Juscelino Kubistchek, texto Asilo no Rio. Disponível em: http://www.projetomemoria.art.br/JK/biografia/5 asilo.html. Acesso em 21 dez. 2008.

511 Monica Hirst, op. cit., p.229.

${ }^{512}$ Segundo Paulo Vizentini, a aproximação com a Europa representava mera retórica para barganhar com os EUA. (Paulo Fagundes Vizentini. Relações Exteriores do Brasil, op. cit., p. 79). 


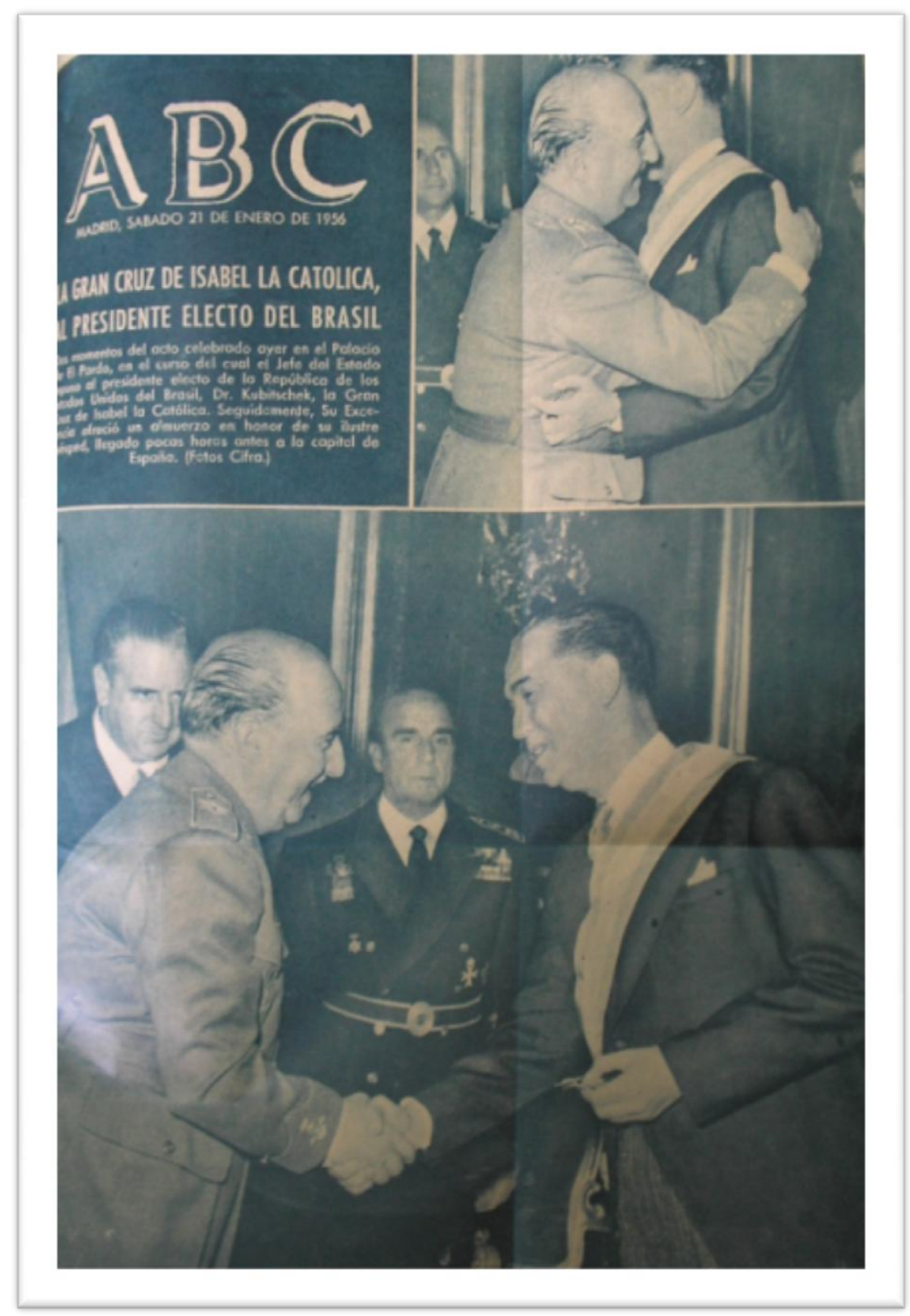

17 - Franco condecora Juscelino Kubitschek com a Gran Cruz de Isabel, la Católica. Fotografia reproduzida na capa do jornal $A B C$. Madri, 21 de janeiro de 1956. Anexo ao ofício n. 32 de Rubens Ferreira de Mello, embaixador do Brasil na Espanha para José Carlos de Macedo Soares, ministro das Relações Exteriores do Brasil. Madri, 25 jan. 1956. Missões Diplomáticas Brasileiras. Ofícios recebidos de Madri (jan. a março de 1956). AHI/RJ. 
Em retribuição à visita de Juscelino à Espanha, o governo franquista enviou ao Rio de Janeiro o falangista Raimundo Fernandez Cuesta, que liderou a missão espanhola presente na posse de Kubitschek. Segundo Ferreira de Mello, o envio de Cuesta, que havia sido embaixador no Brasil no conturbado início dos anos 40, poderia ser encarado como um "entierro de primera clase". As desavenças entre monarquistas e falangistas teriam influenciado Franco a decidir pela demissão de Cuesta do cargo de primeirosecretário da Falange, logo após seu retorno do Brasil. ${ }^{513}$

Em agosto de 1956, Ferreira de Mello foi substituído em Madri pelo embaixador João Pizarro Gabizo Coelho Lisboa, que permaneceu à frente deste posto até 1964. Durante a entrega de suas credenciais, o ditador espanhol agradeceu, mais uma vez, o apoio que o Brasil ofereceu à Espanha em épocas difíceis, além de reafirmar o interesse de seu país em participar "com capitais e técnica" do projeto de industrialização brasileiro.

Junto aos diplomatas estrangeiros em missão em Madri, Franco fazia questão de ressaltar que os avanços econômicos da Espanha deviam-se muito mais à competência de seu governo do que ao auxílio econômico recebido dos EUA. Havia, na imprensa hispânica, uma evidente intenção de convencer a população de que a situação econômica espanhola melhorava graças à capacidade administrativa do Estado. Os jornais, porta-vozes das determinações franquistas, tornavam-se elementos centrais da propaganda oficial do regime. Cabe lembrar que nos governos autoritários, a propaganda política atua no sentido de bloquear e suprimir qualquer versão do passado e do presente que seja distinta daquela enunciada pelo regime..$^{514}$

Franco aproveitou a audiência com o novo embaixador brasileiro para demonstrar que a Espanha estava rumo ao desenvolvimento. ${ }^{515} \mathrm{~A}$ retórica, no entanto, estava muito aquém das reais possibilidades da economia

${ }^{513}$ Relatório do "mês político" (janeiro de 1956) de Rubens Ferreira de Melo, embaixador do Brasil na Espanha para José Carlos de Macedo Soares, ministro das Relações Exteriores do Brasil. Missões Diplomáticas Brasileiras. Ofícios recebidos de Madri (jan. a março de 1956). $\mathrm{AHI} / \mathrm{RJ}$.

514 Sobre a importância da propaganda política nos regimes autoritários ver: Maria Helena Capelato. Multidões em cena: propaganda política no varguismo e no peronismo. Campinas: Papirus, 1998. Coleção Textos do Tempo.

${ }^{515}$ Carta-telegrama (confidencial) de João P. G. Coelho Lisboa, embaixador do Brasil na Espanha para Secretaria de Estado das Relações Exteriores do Brasil. Madri, 02 ago. 1956. Missões Diplomáticas Brasileiras. Telegramas recebidos de Madri (1947/ 1959) Arquivo de Correspondência Especial, cx 250. CDO/MRE. 
de seu país. Embora já estivesse colhendo os frutos do auxílio norteamericano, a situação da Espanha não permitia ainda "exportar capitais" como fazia supor o chefe espanhol.

Em outubro de 1956, a imprensa noticiou com ênfase a entrega da Grã -Cruz da Ordem Nacional do Mérito ao ditador espanhol, que agradeceu com as seguintes palavras: "O povo espanhol e eu nos recordamos sempre com carinho da visita que nos fez o presidente Juscelino Kubistchek, a quem muito admiramos". 516

A quebra desse discurso de afabilidades entre a diplomacia brasileira e a espanhola foi registrada em junho de 1956, durante uma partida de futebol entre o time brasileiro do Botafogo e o do Barcelona. De acordo com Lauro de Andrade Müller, vice-cônsul brasileiro nesta cidade, os brasileiros foram atacados e agredidos por "torcedores fanáticos e policiais exaltados". Como os brasileiros reagiram, o arqueiro Amauri foi preso por ordem irrevogável do governador civil. O episódio foi descrito por Andrade Muller, como humilhante para os jogadores - uma vez que tiveram que comparecer à Chefatura de Polícia - e para ele, que se viu desmerecido em sua função de representante dos interesses brasileiros. ${ }^{517}$

Por falha na comunicação ou por indiferença, o Consulado em Barcelona não pode contar com o auxílio da Embaixada do Brasil que, dias depois, recebeu da SERE a chamada para explicar com urgência quais as medidas tomadas quando do incidente. ${ }^{518}$ Pelo tom da correspondência, é possível identificar um descontentamento por parte do Itamaraty, provavelmente informado pelo Consulado em Barcelona, da inoperância do embaixador diante daquela situação.

\footnotetext{
${ }^{516}$ Ofício n. 455 de João P. G. Coelho Lisboa, embaixador do Brasil na Espanha para José Carlos de Macedo Soares, ministro das Relações Exteriores. Madri, 30 out. 1956. Missões Diplomáticas Brasileiras. Ofícios recebidos de Madri (agosto a outubro de 1956). AHI/RJ.

${ }^{517}$ Telegrama (confidencial) de Lauro de Andrade Muller, cônsul do Brasil em Barcelona para Ministério das Relações Exteriores do Brasil. Barcelona, 27 jun. 1956. Consulados Brasileiros. Telegramas e cartas recebidas (1947/1957). Arquivo de Correspondência Especial. CDO/MRE.

${ }^{518}$ Telegrama da Secretaria de Estado das Relações Exteriores para Embaixada do Brasil em Madri. Rio de Janeiro, 31 jun. 1956. Missões Diplomáticas Brasileiras. Telegramas expedidos a Madri (1947-1959). AHI/RJ.
} 


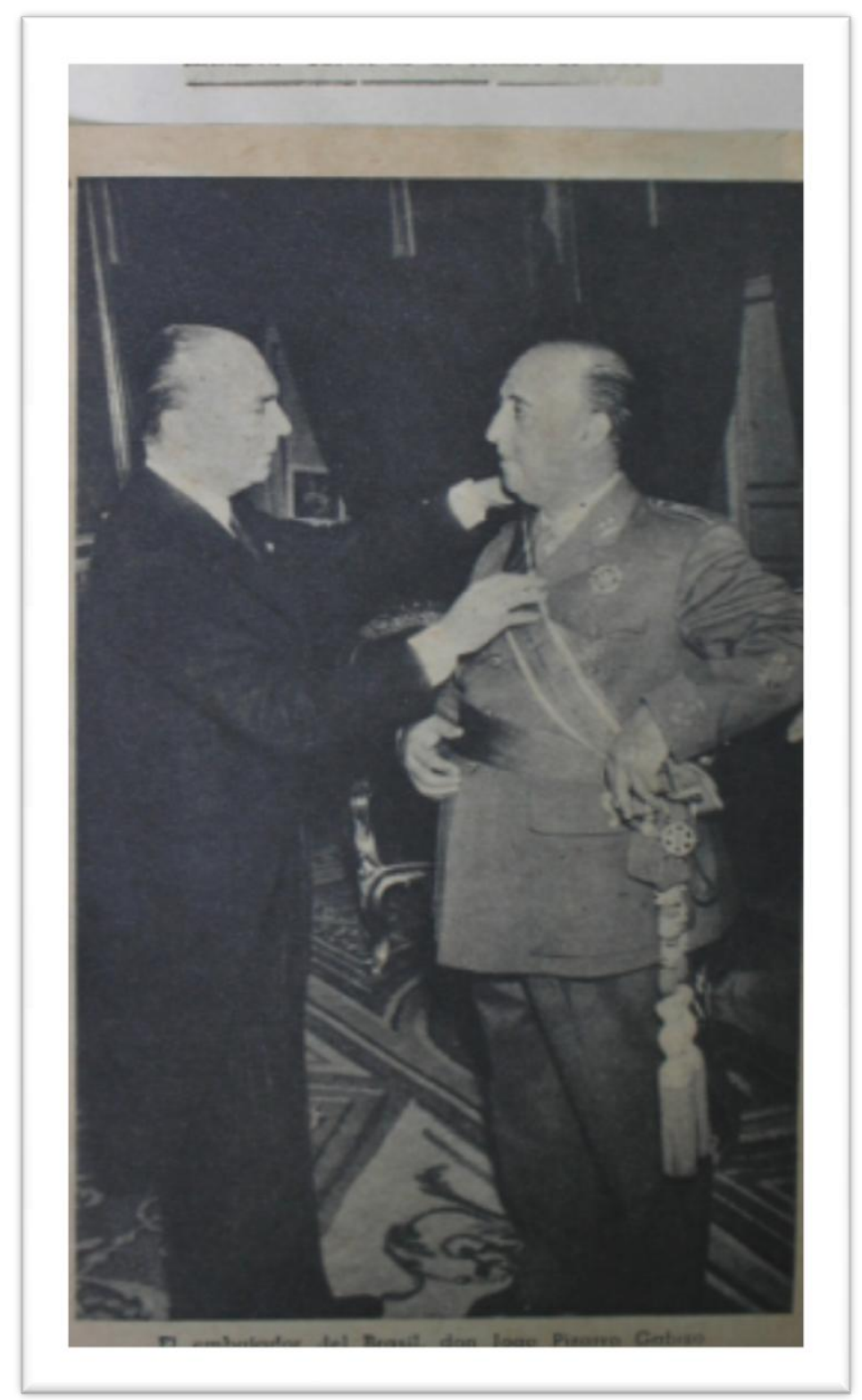

18 - Entrega de condecoração a Francisco Franco pelo embaixador brasileiro. Foto reproduzida em jornal (sem identificação), anexado ao ofício n. 455 de João P. G. Coelho Lisboa, embaixador do Brasil na Espanha para José Carlos de Macedo Soares, Ministro das Relações Exteriores. Madri, 30 out. 1956. Missões Diplomáticas Brasileiras. Ofícios recebidos de Madri (agosto a outubro de 1956). AHI/RJ.

A rivalidade desportiva entre clubes de futebol brasileiros e espanhóis parece ter motivado outros conflitos envolvendo jogadores. Em 1957, durante um jogo em Paris, foi a vez do Clube Vasco da Gama envolverse em desavenças com o Real Madrid. Os brasileiros saíram vitoriosos, mas foram acusados de incitar brigas, principiando uma nova confusão. A imprensa hispânica não se furtou em tecer comentários preconceituosos. Tomando 
partido de seus nacionais, José Maria Lorente, autor de um artigo publicado no jornal Arriba, se referia aos jogadores brasileiros como "negritos" ou "negrazcos del Vasco da Gama", reproduzindo, certamente, as expressões proferidas pelos torcedores espanhóis em campo, inconformados com a vitória dos brasileiros. ${ }^{519}$

Durante o ano de 1958, um novo fato motivou discursos de cordialidade entre a diplomacia de ambos os países: a visita da primeira-dama Sarah Kubitschek à Espanha. O Caudilho, segundo o embaixador Coelho Lisboa, cancelou sua reunião com o Conselho de Estado para participar da recepção à Sra. Kubitschek, homenageada com um jantar de gala. ${ }^{520}$

A estratégia do Brasil em cooptar o apoio espanhol para a Operação Pan-Americana efetivou-se em 1960, com a visita de Augusto Frederico Schmidt à Espanha e sua audiência com Fernando Maria Castiella, ministro de Assuntos Exteriores. Neste encontro, os discursos estiveram pautados por argumentos próprios do contexto da Guerra Fria. O ministro espanhol demonstrou simpatias ao afirmar que a Espanha não poderia ficar indiferente àquela proposta, interpretada como um plano em defesa do Ocidente. Schmidt respondeu elogiando a atuação da Espanha no combate ao comunismo. ${ }^{521}$ Vale lembrar que um dos argumentos centrais da OPA era o de que o desenvolvimento latino-americano era a forma mais eficiente de afastar o "perigo vermelho" do Continente. A política externa de Juscelino, a partir de 1958, procurava evidenciar que a ameaça da expansão soviética na América Latina poderia ser dissipada com o apoio financeiro da grande potência. ${ }^{522}$

\footnotetext{
519 "El escândalo de Paris" por Jose Maria Lorente. Jornal Arriba. Madri, 16 jun. 1957. Anexo ao ofício da Embaixada do Brasil na Espanha para a Secretaria de Estado das Relações Exteriores. Madri, 01 jul. 1957. Missões Diplomáticas Brasileiras. Ofícios recebidos de Madri (junho a julho de 1957). AHI/RJ.

520 Ofício n. 599 de João P. G. Coelho Lisboa, embaixador do Brasil na Espanha para Horácio Lafer, ministro das Relações Exteriores. Madri, 26 ago. 1959. Missões Diplomáticas Brasileiras. Ofícios recebidos de Madri (julho e agosto de 1959). AHI/RJ.

${ }^{521}$ Ofício n. 374 de João P. G. Coelho Lisboa, embaixador do Brasil na Espanha para Horácio Lafer, ministro das Relações Exteriores do Brasil. Madri, 17 mai 1960. Missões Diplomáticas Brasileiras. Ofícios recebidos de Madri (1960-1963). Arquivo de Correspondência Especial. $\mathrm{CDO} / \mathrm{MRE}$.

${ }^{522}$ A relação entre a OPA e a multilateralização da política externa brasileira é analisada por Paulo Fagundes Vizentini. (Paulo Fagundes Vizentini. A política externa do governo JK (19561961). In: José Augusto Guilhon Albuquerque (Org.). 60 anos de política externa brasileira (1930-1990). São Paulo: Cultura Editores; Núcleo de Pesquisa em Relações Internacionais da USP, 1996, p. 248-249).
} 


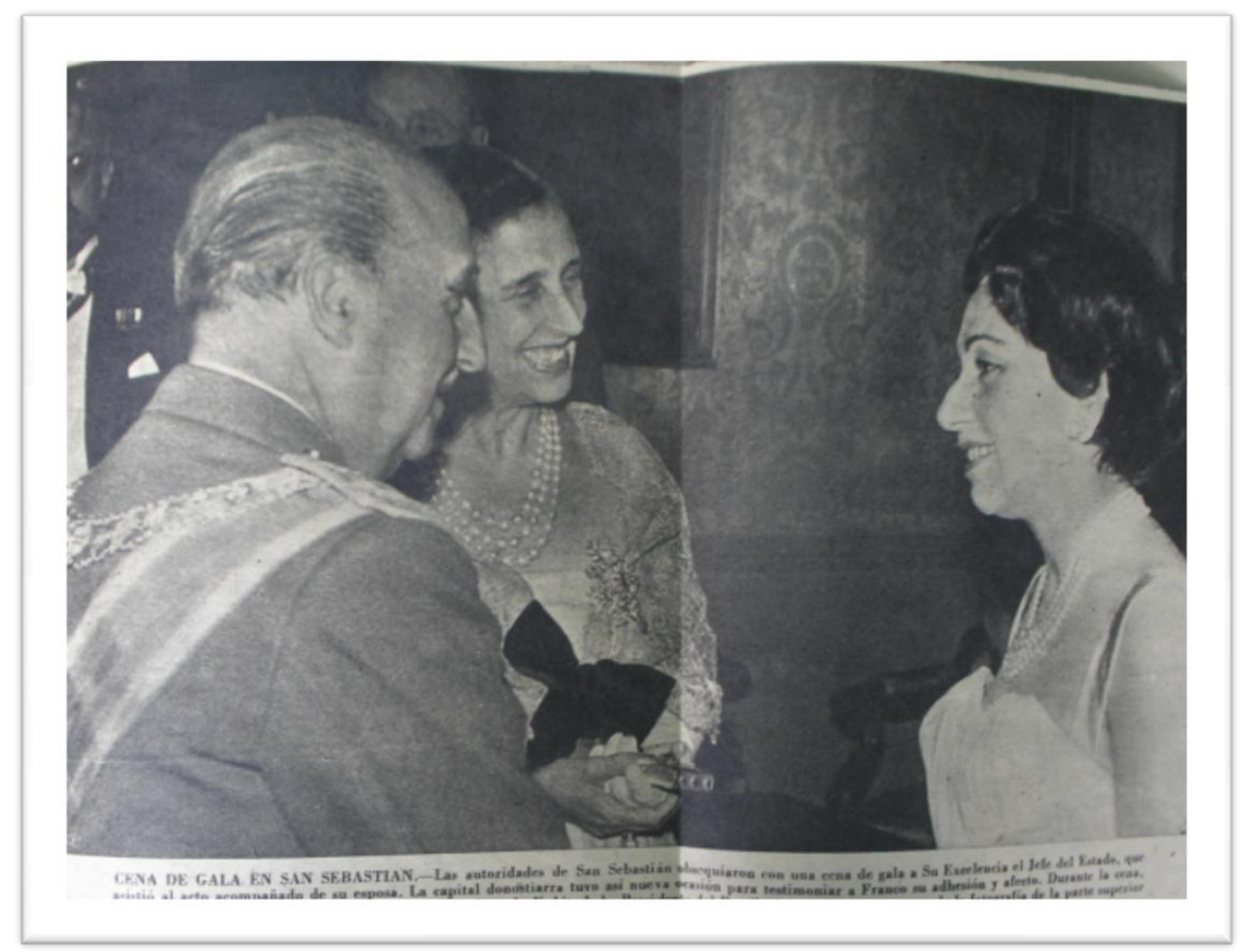

19 - Franco e sua esposa, D. Carmem, em recepção à Sarah Kubitschek, primeira-dama do Brasil. Foto reproduzida no jornal Arriba. Madri, 25 de agosto de 1959. Recorte anexado ao ofício n. 599 de João P. G. Coelho Lisboa, embaixador do Brasil na Espanha para Horácio Lafer, ministro das Relações Exteriores. Madri, 26 ago. 1959. Missões Diplomáticas Brasileiras. Ofícios recebidos de Madri (julho e agosto de 1959). AHI/RJ. 


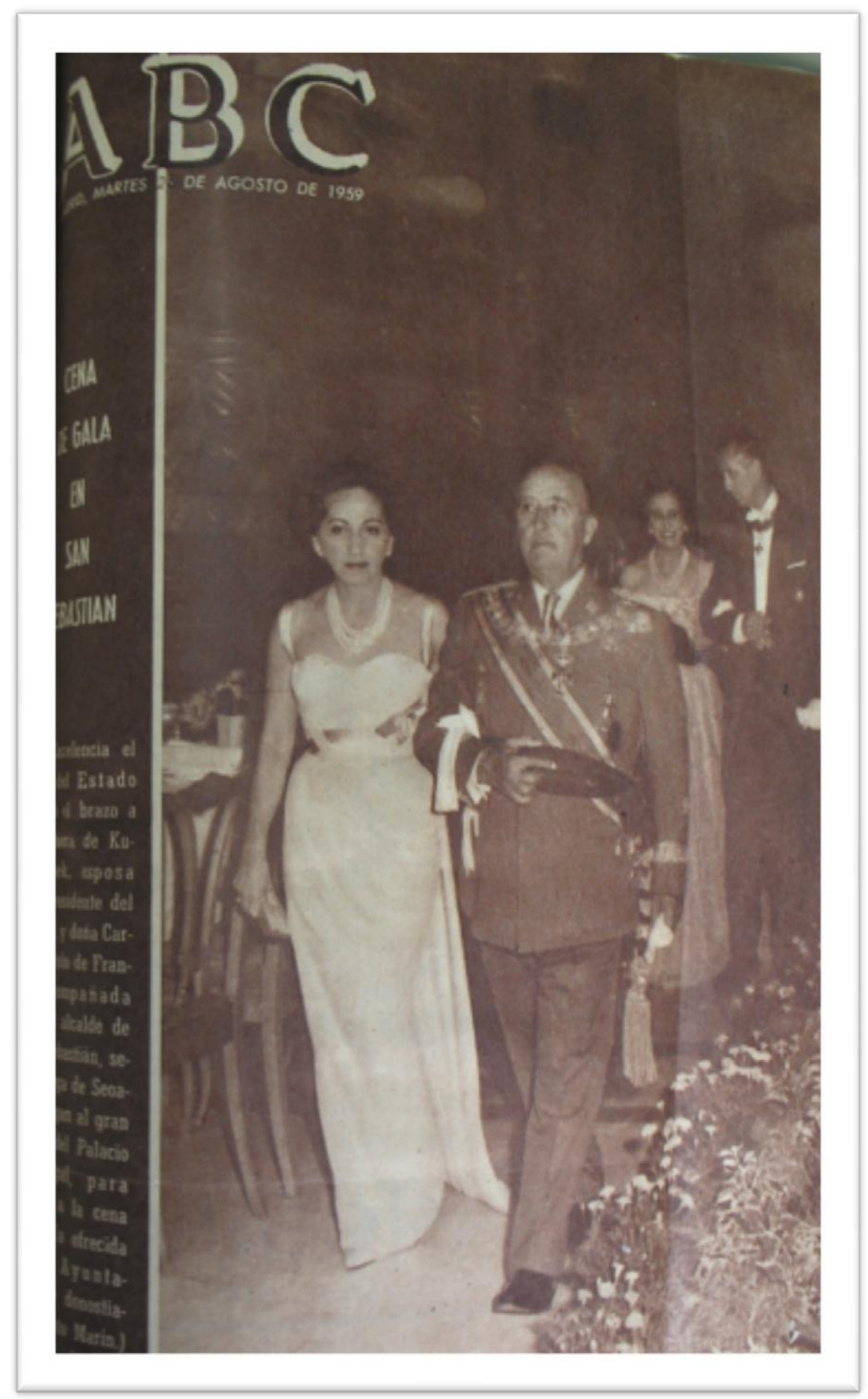

20 - Sarah Kubitschek e Francisco Franco no jantar de gala oferecido pelo governo espanhol à primeira dama brasileira. Foto reproduzida na capa do jornal $A B C$. Madri, (s/data). Anexo ao ofício n. 599 de João Pizarro Gabizo Coelho Lisboa, embaixador do Brasil na Espanha para Horácio Lafer, Ministro das Relações Exteriores do Brasil. Madri, 26 ago. 1959. Missões Diplomáticas Brasileiras. Ofícios recebidos de Madri (julho a agosto de 1959). AHI/RJ. 


\section{As relações comerciais}

Pode-se afirmar que mais de $10 \%$ da documentação destinada ao Itamaraty pela Embaixada do Brasil na Espanha aborda questões concernentes ao comércio bilateral entre os dois países. Essa porcentagem eleva-se, como é de se esperar, quando se analisa a documentação produzida pelos consulados brasileiros nas cidades portuárias de Barcelona e Vigo, a primeira seguramente o mais importante centro comercial da Espanha, por onde adentrava a maior parte dos produtos brasileiros.

Entre 1930 e 1960, o Brasil exportou para a Espanha, tanto em toneladas quanto em cifras, muito mais que o inverso, sendo o café o principal produto brasileiro a chegar aos portos espanhóis. Talvez pelo fato do Brasil estar em situação de vantagem na balança com esse país, não é perceptível, salvo em momentos específicos, uma atuação dinâmica dos representantes brasileiros neste aspecto.

$\mathrm{Na}$ década de 30 a venda de café sofreu as conseqüências do conflito civil que desestabilizou a economia espanhola. Mesmo antes de 1936, a diversificação das exportações brasileiras tornou-se uma tarefa difícil, uma vez que os acordos espanhóis com suas ex-colônias davam a essas a vantagem da "clausula de nação mais favorecida". ${ }^{523}$ No início dos anos 40 o embaixador Mario de Pimentel Brandão esforçou-se no sentido de promover acordos para estabelecer a preferência do algodão brasileiro no mercado espanhol.

Assim como no aspecto cultural e político, as relações comerciais com a Espanha transformaram-se em alvo mais definido para a diplomacia brasileira a partir da década de 1950. Em abril de 1952, o Itamaraty enviou à Europa Ocidental uma missão econômica, com o intuito de estabelecer contatos com vários países. ${ }^{524} \mathrm{~A}$ maioria apresentava sinais de recuperação da

\footnotetext{
${ }^{523}$ Em um livro sobre a política comercial brasileira escrito em 1934, o capítulo dedicado à Espanha traz informações sobre tarifas e a tentativa de efetivar um acordo para facilitar 0 escoamento de café. $O$ autor demonstra preocupação com as tarifas espanholas e com a concorrência dos países hispânico-americanos: Affonso de Toledo Bandeira de Mello. Política commercial do Brasil. Rio de Janeiro: Tip. do Departamento Nacional de Estatística, 1933, p. 235.

${ }^{524}$ Paulo Fagundes Vizentini. Relações Exteriores do Brasil, op. cit., p.55.
} 
guerra podendo, na visão brasileira, se constituir como parceiros efetivos do ponto de vista econômico. Expressivos deste momento são os relatórios mensais produzidos pelos adidos comerciais junto à Embaixada em Madri. No relatório do Mês econômico de fevereiro de 1950, Álvaro Trindade Cruz, ofereceu ao MRE condições de planejar uma estratégia mais adequada à Espanha, a partir de uma análise pormenorizada das possibilidades de comércio desse país com outros parceiros. Segundo o adido, o consumo de fumo, café e algodão - produtos advindos especialmente do Brasil - vinha crescendo no país. ${ }^{525}$

No relatório referente ao mês de março, Trindade Cruz sintetizou o panorama econômico espanhol e as possibilidades oferecidas para as exportações brasileiras. O algodão, nesse contexto, apresentava-se como a principal preocupação da diplomacia brasileira. $\mathrm{O}$ adido comercial explicava que, a partir da segunda metade da década de 1940, as exportações de algodão dos EUA para a Espanha haviam decaído, favorecendo a venda deste produto brasileiro às indústrias têxteis espanholas. Naquele momento, o Brasil respondia por cerca de 55\% do algodão importado pela Espanha, o segundo maior comprador deste produto. Trindade Cruz afirmou que a permanência dessa porcentagem estava sendo ameaçada pelas vantajosas propostas de financiamento apresentadas pelos EUA, que tentavam recuperar o mercado. ${ }^{526}$

Tais vantagens resultavam das negociações entre o governo norte-americano e o espanhol. Interessava aos EUA oferecer empréstimos e vantagens comerciais em troca da permissão espanhola para 0 estabelecimento de bases militares em seu território. Desse processo de negociações surgiram os acordos hispano-norte-americanos assinados em setembro de 1953: Convênio de Defesa, com o estabelecimento de bases de "utilização conjunta"; Convênio sobre ajuda para a Defesa Mútua, ou seja, um auxílio de armamentos e o Convênio de ajuda econômica. ${ }^{527}$

\footnotetext{
${ }^{525}$ Relatório do "Mês econômico" de Álvaro Trindade Cruz, adido comercial à Embaixada do Brasil na Espanha para Ministério das Relações Exteriores. Madri, 15 mar. 1950. Missões Diplomáticas Brasileiras. Ofícios recebidos de Madri (janeiro a março de 1950). AHI/RJ.

${ }^{526}$ Relatório "A Espanha como país exportador de algodão" de Álvaro Trindade Cruz, adido comercial da Embaixada do Brasil na Espanha para Ministério das Relações Exteriores. Anexo ao ofício n. 111 da Embaixada do Brasil na Espanha para a Secretaria de Estado das Relações Exteriores. Madri, 25 abr. 1950. Missões Diplomáticas Brasileiras. Ofícios recebidos de Madri (abril a junho de 1950). AHI/RJ.

527 Jose Luis Abellán, op.cit., p.140.
} 
Os relatórios políticos mensais elaborados pelo embaixador Rubens Ferreira de Melo entre 1951 e 1953, ofereciam ao Itamaraty uma descrição detalhada dos avanços e recuos nas negociações espanholas com os EUA. Tais documentos constituem-se como fontes privilegiadas, uma vez que nos oferecem a visão de quem acompanhava de perto as contradições entre as intenções do governo franquista e o que era divulgado pela imprensa ao povo espanhol.

Diante das investidas norte-americanas, o Brasil empreendeu esforços para a assinatura de um novo acordo de comércio e pagamentos, efetivado em 24 de julho de 1952. Como lembra Bruno Ayllón Pino, apesar do referido acordo, "el tema siguió figurando entre los principales puntos de la agenda conflictiva hispano-brasileña como consecuencia del permanente desequilibrio de la balanza comercial a favor del Brasil".

As relações comerciais hispano-brasileiras foram também o tema principal da visita oficial que Adhemar de Barros realizou à Espanha em 1952. Recepcionado por Franco e pelo ministro de Assuntos Exteriores Martin Artajo, o político brasileiro afirmou que o Brasil se interessava muito pelo intercâmbio comercial, sugerindo que em troca de café e algodão, nosso país poderia se beneficiar com a construção naval espanhola, tendo em vista as dimensões da costa brasileira. A imprensa madrilenha, por sua vez, demonstrou falta de conhecimento sobre o visitante referindo-se a Barros como um dos "más inquietos e enterados economistas del mundo. ${ }^{, 529}$

Caberia observar que, na primeira metade da década de 1950, Brasil e Espanha procuraram junto aos EUA, auxílio financeiro para seus respectivos projetos de desenvolvimento. Amado Cervo afirma que para a Europa prevaleceram os empréstimos de governo a governo, enquanto que para a América Latina, o afluxo de capitais se fazia "pela via dos investimentos em empresas privadas. ${ }^{530}$

\footnotetext{
${ }^{528}$ Bruno Ayllón Pino. Las relaciones entre Brasil y España, op.cit., p. 289.

529 "Serán incrementados los intercambios comerciales entre Brasil y España", jornal (s/ident.) de 03 out. 1952. Recorte anexado ao ofício n. 354 de Rubens Ferreira de Mello, embaixador do Brasil na Espanha para João Neves da Fontoura, ministro das Relações Exteriores do Brasil. Madri, 06 out. 1952. Missões Diplomáticas Brasileiras. Ofícios recebidos de Madri (outubro a dezembro de 1952). AHI/RJ.

${ }^{530}$ Amado Cervo. Relações Internacionais, op. cit., p.100.
} 
$\mathrm{Na}$ Espanha, contudo, os empréstimos destinaram-se majoritariamente ao setor privado. O ditador espanhol, partidário de uma política econômica centralizadora, preferia que o capital norte-americano fosse direcionado ao Estado, que controlaria os investimentos, tendo autonomia para decidir sobre sua aplicação. As necessidades da economia espanhola forçaram Franco a ceder e aceitar ainda em 1950, que os recursos financeiros dos EUA fossem destinados especialmente às empresas privadas. ${ }^{531}$ Esse seria um primeiro passo para a liberalização da economia espanhola. Comparando a figura pessoal de Salazar e Francisco Franco, João Medina afirma que o último era muito pragmático, sabendo livrar-se dos dogmas corporativistas para lançar-se ao desenvolvimento a partir dos anos $60 . .^{532}$

Apesar do Itamaraty demonstrar empenho nas negociações para manter ou aumentar as exportações brasileiras de algodão para a Espanha, o fato é que o Brasil acabou perdendo o mercado para os EUA, após os acordos assinados em 1953. Em outubro de 1954, o embaixador Ferreira de Mello confirmou ao Itamaraty os prejuízos sofridos naquele ano. Informou que a Espanha havia empregado cerca de 15 milhões de dólares na importação de algodão norte-americano, medida que atingiu profundamente o Brasil. ${ }^{533}$

Um dos objetivos da visita de Juscelino Kubitschek à Espanha em 1956 era impulsionar os contatos com setores importantes da economia desse país. Seu governo, no que se refere ás imbricações da política externa com o comércio, passou a dar maior importância às relações com a Europa, mostrando disposição em obter a cooperação desse continente ao seu Plano de Metas. ${ }^{534}$ Dentre os membros da comitiva brasileira que se reuniu com 0 ministro do Comércio e outras autoridades espanholas, a fim de tratar do comércio hispano-brasileiro, estava Roberto Campos, que viria a ser um dos economistas mais conhecidos do Brasil.

\footnotetext{
${ }^{531}$ Relatório do "Mês econômico" da Embaixada do Brasil na Espanha para Ministério das Relações Exteriores. Madri, 07 dez. 1950. Missões Diplomáticas Brasileiras. Ofícios recebidos de Madri (outubro a dezembro de 1950). AHI/RJ.

532 João Medina. Salazar e Franco: dois ditadores, duas ditaduras. In: Coggiola, Osvaldo (Org.). Espanha e Portugal: o fim das ditaduras. São Paulo: Xamã, 1995, p.30.

${ }^{533}$ Ofício n. 382 de Rubens Ferreira de Melo, embaixador do Brasil na Espanha para Raul Fernandes, ministro das Relações Exteriores. Madri, 02 out. 1954. Missões Diplomáticas Brasileiras. Ofícios recebidos de Madri (outubro a dezembro de 1954). AHI/RJ.

${ }^{534}$ Amado Cervo. As relações históricas entre Brasil e Itália, op. cit., p.208.
} 
De acordo com o embaixador Rubens Ferreira de Mello, as considerações iniciais feitas por ambos os lados foram cordiais, lembrando que o comércio hispano-brasileiro havia tido um aumento de 200\% no ano de 1955. Mesmo assim, a delegação brasileira mostrou pesar pela preferência ao algodão norte-americano. Visando manter um comércio permanente e não ocasional, ambas as partes concordaram que os produtos brasileiros deveriam ser pagos com mercadorias espanholas, tendo o ministro do Comércio Manuel Arburúa prometido que a Espanha daria preferência aos produtos brasileiros quando se apresentasse igualdade de condições com produtos de outros países. $^{535}$ As mercadorias espanholas importadas pelo Brasil eram diversificadas. Em meados de 1956, nosso país constituía-se no maior mercado externo para o livro espanhol.

Em julho de 1957, Manuel Arburúa, mesmo após ter deixado a pasta do Comércio, recebeu das mãos do embaixador brasileiro as insígnias da Ordem Nacional do Cruzeiro do Sul. O ato solene contou com a presença de Carrero Blanco, que gozava de status de Primeiro Ministro. ${ }^{536}$ Também foram condecorados, na mesma ocasião, alguns dos responsáveis pela política econômica da Espanha. Em seu discurso de agradecimento, Arburúa afirmou ter grande admiração pelo presidente Kubitschek e pela equipe de economistas que o acompanharam em sua visita à Espanha.

No ano de 1958, o governo espanhol propôs ao ministro da Fazenda Jose Maria Alkmin trocar café brasileiro por navios espanhóis. A solicitação parece ter sido acolhida com entusiasmo e, segundo notícias da imprensa madrilenha, o ministro brasileiro só estaria aguardando o parecer favorável do Ministério dos Transportes para efetivar as negociações. ${ }^{537}$

\footnotetext{
${ }^{535}$ Ofício n. 34 de Rubens Ferreira de Melo, embaixador do Brasil na Espanha para Josão Carlos de Macedo Soares, ministro das Relações Exteriores. Madri, 28 jan. 1956. Missões Diplomáticas Brasileiras. Ofícios recebidos de Madri (janeiro a março de 1956). AHI/RJ.

${ }^{536}$ Luis Carrero Blanco foi, por muitos anos, "braço direito" de Francisco Franco. Ocupou o cargo de Presidente do governo da Espanha durante a fase final da Ditadura franquista, sendo assassinado pelo grupo separatista ETA, em 1973. Segundo Paul Preston, as relações entre Franco e Carrero Blanco eram estreitas e o assassinato do último arruinou os planos do ditador de retirar-se das responsabilidades políticas. (Paul Preston. Franco, caudillo, op. cit., p.942).

537 "Buques españoles por café brasileño", jornal Madrid. Madri, 13 mai 1958. Recorte anexado ao ofício n. 565 de João P. G. Coelho Lisboa, embaixador do Brasil na Espanha para José Carlos de Macedo Soares, ministro das Relações Exteriores. Missões Diplomáticas Brasileiras. Ofícios recebidos de Madri (maio a junho de 1958). AHI/RJ.
} 
O comércio hispano-brasileiro não foi afetado pela criação do Mercado Comum Europeu em 1957. Este é um fator que pode ter contribuído para a aproximação comercial hispano-brasileira. Segundo o historiador Amado Cervo: "O ano de 1957 registrou uma movimentação febril das diplomacias latino-americanas, que expressavam enormes preocupações diante da criação do Mercado Comum Europeu. Imaginavam prejuízos ao comércio e aos investimentos". ${ }^{538}$

No final da década de 1950, as exportações brasileiras para a Espanha haviam crescido significativamente, permanecendo o café como 0 "carro chefe". Da participação do Brasil na Feira de Amostras de Barcelona surgiu, novamente, um episódio de rivalidades e desentendimentos envolvendo a Embaixada do Brasil e o Consulado em Barcelona. João P. Gabizo Coelho Lisboa, embaixador e Altamir de Moura, cônsul em Barcelona, trocaram acusações em diversos documentos enviados ao Itamaraty. Este indignou-se com o fato de não ter sido comunicado oficialmente pela Embaixada da participação brasileira naquela Feira. Em ofício ao embaixador brasileiro, Altamir de Moura afirmou que o stand brasileiro, que contava com a participação do Instituto Nacional do Café era de uma "mediocridade que não dignifica a projeção econômica e política do Brasil moderno".

A Embaixada e o Consulado Geral do Brasil, sediado em Barcelona, presenciaram, por diversas vezes, as divergências entre seus dirigentes. A dificuldade em definir os papéis de cada uma dessas instâncias do serviço diplomático nas questões comerciais estava no cerne do problema. A participação do Brasil em uma importante feira internacional não contou com a soma de esforços da diplomacia brasileira atuante na Espanha.

Especialmente após os acordos com os EUA, a Espanha passou por transformações que forçaram uma maior abertura de sua economia. Coelho Lisboa, ao analisar os mecanismos das licenças para a importação e exportação nesse país, teceu considerações que demonstram um crescente processo de multilateralização do comércio exterior espanhol. $O$ embaixador afirmava que o comércio bilateral nunca havia sido vantajoso para a Espanha,

\footnotetext{
${ }^{538}$ Amado Cervo. As relações históricas entre Brasil e Itália, op. cit., p.209.

${ }^{539}$ Ofício n. 38 de Altair de Moura, cônsul do Brasil em Barcelona para João P. G. Coelho Lisboa, embaixador do Brasil na Espanha. Barcelona, 17 jun. 1958. Missões Diplomáticas Brasileiras. Ofícios recebidos de Madri (maio a junho de 1958). AHI/RJ.
} 
pois este país nunca tinha tido força para impor suas condições comerciais para outros países. ${ }^{540}$

O Brasil também passou por um processo efetivo de multilateralismo nas relações comerciais. Em 1958, à margem do Itamaraty, foi lançada a Operação Pan-Americana (OPA), que alterou a política externa brasileira, levantando a bandeira da necessidade de ajuda norte-americana aos países da América Latina. ${ }^{541}$ Um discurso diplomático de contornos nacionalistas se tornou recorrente a partir deste ano, quando as novas medidas de política externa foram aprofundadas com a substituição de Macedo Soares por Francisco Negrão de Lima na pasta das Relações Exteriores. O novo chanceler ficaria incumbido de "impulsionar a retomada da política de barganha face aos EUA" ${ }^{542}$ Tais transformações trouxeram novas perspectivas para o comércio hispano-brasileiro.

\footnotetext{
${ }^{540}$ Relatório do "Mês econômico" (outubro de 1958), da Embaixada do Brasil na Espanha para Ministério das Relações Exteriores do Brasil. Missões Diplomáticas Brasileiras. Ofícios recebidos de Madri (setembro a outubro de 1958). AHI/RJ.

${ }^{541}$ Segundo Amado Cervo "A contribuição estratégica à política exterior do Brasil que adveio com a OPA correspondeu à introdução definitiva do multilateralismo, associado, em sua primeira expressão, à emergência da prioridade latino-americana e à vinculação entre o americanismo brasileiro e o neutralismo em voga na América Latina e no $3^{\circ}$ Mundo. Embora sejam perceptíveis certas ambigüidades da iniciativa, pode-se concluir que Kubitschek fez melhor o que Vargas pensava." (Amado Cervo. O desafio internacional, op. cit., p.39).

${ }_{542}$ Paulo Fagundes Vizentini. A política externa do governo JK (1956-1961), op.cit., p.236.
} 


\title{
3.2 - Momento de confluências: A política cultural entre Brasil e Espanha
}

\author{
A política cultural brasileira para a Espanha
}

Não restam dúvidas de que uma das formas de tornar influentes as relações internacionais de um país é a realização de uma boa política de relações culturais. Eduardo Vázquez, que analisou a política cultural da Segunda República espanhola, tece considerações que nos permitem refletir sobre o papel da diplomacia, tendo em vista a exportação de valores literários, artísticos e científicos:

Esta política tiene, en principio dos vertientes. La primera consiste en allanar caminos para que las manifestaciones culturales extranjeras puedan penetrar en un país sin obstáculos, sino en óptimas condiciones. Se trata en este caso de una política de recepción. La segunda vertiente sería aquella que posibilitaría, por medio de una buena organización y de recursos suficientes, la muestra en países extranjeros de los más sólidos valores literários, artísticos y científicos nacionales. En este segundo caso, se trata de una política activa, de impulsión de relaciones culturales por exportación de dichos valores.

Sin embargo, la segunda vertiente, la política activa de exportación de cultura, tiene una mayor transcendencia y puede constituir una forma de propaganda conformadora de una opinión pública internacional. Los instrumentos de política activa, de que se valen generalmente los países, son los siguientes: El establecimiento en El extranjero, de instituciones docentes e instituciones culturales, la organización de conferencias, cursos, exposiciones, conciertos, representaciones dramáticas e cinematográficas y la difusión de libros y revistas." 543

Tais considerações nos oferecem subsídios para pensar a política cultural empreendida pelo governo brasileiro em solo espanhol. Até a década de 1930, as ações da diplomacia brasileira nesse aspecto foram quase nulas e se limitavam a acompanhar as notícias sobre o Brasil divulgadas pela imprensa espanhola. No entanto, a disposição em promover uma maior aproximação entre Brasil e Espanha sempre foi evidenciada nos atos oficiais pela diplomacia

${ }^{543}$ Eduardo Vázquez, op. cit., p.171. 
de ambos os países. Discursos sobre os laços históricos e as semelhanças políticas eram comuns, mas nem sempre se reverteram em ações efetivas.

$\mathrm{Na}$ década de 1950, algumas ações e propostas da diplomacia brasileira reafirmaram a intenção de promover a aproximação cultural com a Espanha. Alguns fatores mencionados por Vázquez, tais como o incentivo às exposições, conferências e à difusão de livros e revistas receberam a atenção do Itamaraty. Caberia observar que, na maioria das vezes, a diplomacia brasileira aproveitava-se das iniciativas de setores privados, conectando-se e dando a elas algum apoio oficial. Isso ocorreu com algumas exposições sobre a cultura brasileira e na divulgação dos livros de autores nacionais na Espanha.

De acordo com Paulo Fagundes Vizentini

O Itamaraty desenvolveu, a partir de 1951, uma campanha cultural e propagandística visando a divulgar informações sobre o Brasil no exterior. $O$ instrumento prioritário dessa política foi o estabelecimento de adidos culturais nas embaixadas. ${ }^{544}$

Através de seus relatórios mensais, os adidos culturais colocavam - Itamaraty a par das ações culturais empreendidas. Tal preocupação acompanhava uma tendência interna brasileira. Nos anos 50 aumentou 0 interesse do governo brasileiro em formular uma política cultural, com o objetivo de instruir a população brasileira para que essa pudesse contribuir com o projeto modernizador do país. Elena Pájaro Peres, em seu trabalho sobre as populações moventes e a cultura na cidade de São Paulo demonstra, através de diversas fontes, que a elite dirigente do país imaginava haver uma carência cultural que

...seria suprida mediante a execução de uma série de projetos que visavam colocar a população em contato com uma fração da arte e do pensamento moderno, em particular aquela que mais interessava enquanto elemento disciplinador. ${ }^{545}$

Na década de 1950, o MRE parecia acreditar que as relações culturais poderiam favorecer os objetivos políticos e econômicos. Estabelecer

\footnotetext{
${ }^{544}$ Paulo Fagundes Vizentini. Relações Exteriores do Brasil, op.cit., p.37.

${ }^{545}$ Elena Pájaro Peres. Exuberância e Invisibilidade: populações moventes e cultura em São Paulo, 1942 ao início dos anos 70. São Paulo, 2006. Tese (Doutorado em História Social) FFLCH, USP, p.44.
} 
uma diplomacia cultural passou a ser o foco dos adidos culturais nas diversas embaixadas do Brasil no exterior. ${ }^{546}$ Nesse contexto, os diplomatas brasileiros atuantes na Espanha foram instruídos a incentivar, junto ao governo espanhol, a efetivação de um acordo cultural entre o Brasil e a Espanha. Embora o interesse maior tenha sido por parte da Espanha, é perceptível o envolvimento dos diplomatas brasileiros na elaboração da minuta deste acordo. Em 1951, o texto provisório foi aceito por ambos os governos, sendo composto de 14 artigos que incidiam sobre: incentivo ao intercâmbio de profissionais, divulgação da língua, criação de bolsas de estudo, exposições, trocas de filmes cinematográficos, incremento da radiodifusão, entre outros. O governo espanhol, no entanto, propôs algumas modificações, tendo Rubens Ferreira de Mello solicitado ao Itamaraty instruções sobre a aceitação das mesmas. Segundo o embaixador, as modificações incidiam

... essencialmente no compromisso de aceitar a equivalência de estudos e diplomas concedidos pelos estabelecimentos de ensino nos dois países, na revisão de textos de ensino afim de expurgá-los de erros históricos e de ataques aos regime e governantes dos dois países, e finalmente na posterior troca de notas para efetivação das disposições do convênio. ${ }^{547}$

Essa questão implicava na redefinição de certos conceitos como o da "liberdade de expressão" que, como era de se esperar, não correspondia aos ideais de um regime ditatorial como o de Franco. A ditadura franquista, além de manter um controle ferrenho dos meios de comunicação e do conteúdo ensinado nas escolas espanholas, desejava também interferir nos livros e publicações brasileiras que viessem a mencionar a Espanha. ${ }^{548}$ Como em outros regimes autoritários, havia a proibição de qualquer informação ou

\footnotetext{
${ }^{546}$ Edgar Ribeiro assim define Diplomacia Cultural: “....seria a utilização específica da relação cultural para a consecução de objetivos nacionais de natureza não somente cultural, mas também política, comercial ou econômica." (Diplomacia cultural: seu papel na política externa brasileira. Brasília: Fundação Alexandre de Gusmão; Instituto de Pesquisa de Relações Internacionais, 1989, p. 23).

547 Oficio n. 43 de Rubens Ferreira de Melo, embaixador do Brasil na Espanha para João Neves da Fontoura, ministro das Relações Exteriores do Brasil. Madri, 26 jan. 1951. Missões Diplomáticas Brasileiras. Ofícios recebidos de Madri (janeiro a março de 1951). AHI/RJ. Grifo nosso.

${ }^{548}$ Segundo Maria Helena Rolim Capelato os manuais escolares veiculados durante o regime franquista na Espanha "se destinavam à formação de uma identidade nacional inspirada nos valores do regime, com ênfase no catolicismo integrista." Resumo da comunicação "Pedagogia da Intolerância: o ideário franquista nos livros didáticos." Dossiê Comunicações e Currículos. Congresso Internacional Intolerância em tempos de fascismo. Proin, novembro de 2006.
} 
interpretação que significasse uma crítica direta ou indireta ao regime. A "verdade histórica" era aquela que legitimava Franco, promovendo sua imagem como o único responsável por salvar seu país da anarquia. Essa questão nos remete às reflexões de Michel Foucault sobre a "vontade de verdade" nos sistemas de exclusão. Foucault afirma que tal vontade apóia-se num suporte institucional como, por exemplo, as escolas. ${ }^{549}$

Controlar o que se veiculava sobre a Espanha na América era uma preocupação vital da política externa franquista, que enfrentava com desgosto as várias manifestações de repúdio ao governo espanhol realizadas pela imprensa brasileira. A não aceitação das alterações pelo governo brasileiro paralisou a negociação. Em telegrama reservado, a SERE informou à Embaixada em Madri que a aprovação do texto do acordo pelo Senado brasileiro era impossível, especialmente por conta do artigo 10ํ․ Esse estabelecia que os dois governos empreenderiam a revisão de textos escolares e publicações com o objetivo de adaptá-los para que "no se falsee la verdad histórica. ${ }^{550}$ Caso o governo espanhol concordasse em suprimi-lo, a SERE dava por certa a aprovação do texto. ${ }^{551}$ A polêmica envolvendo este acordo demonstra que, no Senado brasileiro, havia um grupo consciente de que a ditadura na Espanha visava aproveitar-se dos livros escolares brasileiros para impor uma imagem positiva de si. Numa casa representativa da democracia, como é o Senado, era natural que o artigo fosse recusado.

Em julho de 1954 a SERE afirmou que o Senado brasileiro considerada que o referido texto feria a liberdade de expressão e de pensamento. Trazia também um dado inovador: contribuíra para esse ponto de vista, a decisão arbitrária do Executivo espanhol com relação ao professor

\footnotetext{
${ }^{549}$ Michel Foucault. A Ordem do Discurso. São Paulo: Loyola Edições, 1996, p. 18.

${ }^{550} \mathrm{O}$ artigo 10 mencionava que: "Cada una de las Altas Partes Contratantes empreenderá la revisión de textos, libros y publicaciones utilizados en sus establecimientos de enseñanza, adáptandolos a los fines correspondientes, para evitar que, de ninguna forma, se falsee la verdad histórica." Texto do acordo cultural Brasil x Espanha para ratificação das Cortes Españolas. Anexo ao ofício n. 417 de Rubens Ferreira de Melo, embaixador do Brasil na Espanha para Mario de Pimentel Brandão, ministro interino das Relações Exteriores do Brasil. Madri, 18 nov. 1952. Missões Diplomáticas Brasileiras. Ofícios recebidos de Madri (outubro a dezembro de 1952).

${ }^{551}$ Carta-telegrama n. 59 (reservado) da Secretaria de Estado das Relações Exteriores para a Embaixada do Brasil na Espanha. Rio de Janeiro, 20 mai 1954. Missões Diplomáticas Brasileiras. Cartas-telegramas expedidas a Madri (1954-1956). AHI/RJ.
} 
brasileiro Murilo Mendes. ${ }^{552}$ Tal episódio foi tratado pela diplomacia brasileira e o Itamaraty em nível confidencial. Mendes, proeminente poeta brasileiro, era conhecido como um dos expoentes do modernismo. Em julho de 1953, Rubens Ferreira de Melo recebeu do MAE um pedido para que o governo brasileiro destituísse o referido professor da cadeira de Estudos Brasileiros da Universidade de Madri. O descontentamento teria surgido devido à recusa de Mendes em participar de um ciclo de conferências na Embaixada espanhola no Rio de Janeiro. De sua atitude decorreu um artigo denominado "comunista" por Ferreira de Melo intitulado "Murilo Mendes desmascara a Embaixada da Espanha". ${ }^{553}$

Ferreira de Melo, em longa exposição ao MRE sobre o desenrolar dos acontecimentos, afirmou que procurou por figuras influentes da política espanhola para tentar reverter o referido pedido:

Conhecedor, com efeito, da particular agressividade de certos órgãos da nossa imprensa quando tratam da Espanha, e não ignorando a marcada idiosincrasía de alguns dos nossos congressistas pelo regime franquista, era dever meu de lealdade para com êste país, mostrar aos seus dirigentes as graves consequências que poderiam decorrer do pedido de demissão do Senhor Murilo Mendes, formulado pelo Subsecretário de Asuntos Exteriores, Senhor Emílio de Navásques. ${ }^{554}$

O embaixador defendeu diante do ministro Martin Artajo, que a destituição poderia ser prejudicial para a imagem da Espanha, servindo de desculpas para a imprensa "radical" do Brasil atacar o regime espanhol. Martin Artajo, segundo Ferreira de Melo, compartilhou do seu ponto de vista lamentando a postura de seu subalterno com relação a Murilo Mendes. Para o embaixador brasileiro a reprovação do Acordo pelo Senado brasileiro era um exagero, e, a seu ver, tudo aquilo não passava de "tempestade em copo d'água". ${ }^{555}$

\footnotetext{
552 Telegrama da Secretaria de Estado das Relações Exteriores para a Embaixada do Brasil na Espanha. Missões Diplomáticas Brasileiras. Rio de Janeiro, 26 jul. 1954. Telegramas expedidos a Madri (1950-1956). AHI/RJ.

${ }_{553}$ Ofício n. 267 (confidencial) de Rubens Ferreira de Melo, embaixador do Brasil na Espanha para Vicente Rao, ministro das Relações Exteriores. San Sebástian, 28 jul. 1953. Missões Diplomáticas Brasileiras. Ofícios recebidos de Madri (1947-1959). Arquivo de Correspondência Especial. CDO/MRE.

554 Idem.

555 Idem.
} 
Não podendo ignorar o pedido oficial espanhol, o governo brasileiro destituiu Murilo Mendes, contratando para seu lugar Paulo Assis Silveira. ${ }^{556}$ Um acordo que assegurasse o comprometimento de ambos os países com ações para a estreita aproximação cultural e artística, no entanto, só seria assinado em $1960 .^{557}$

Assim como Murilo Mendes, outras personalidades da cultura brasileira residiram na Espanha nos anos 50. João Cabral de Melo Neto e Raul Bopp atuaram como diplomatas na cidade de Barcelona. De todos os países em que atuou como diplomata, o que mais exerceu influência sobre a obra de João Cabral de Melo Neto foi a Espanha. Impressionado e apaixonado pela cidade de Sevilha, Cabral "passou a tecer constantes paralelos entre o universo dos engenhos, do mar e do sertão nordestino com a também seca e quente, cigana e exoticamente árabe região da Andaluzia”. ${ }^{558}$ Em 1956, como cônsul adjunto em Barcelona, Cabral conseguiu autorização para realizar suas pesquisas no Arquivo das Índias em Sevilha. ${ }^{559} \mathrm{O}$ poeta e diplomata também contribuiu para a divulgação da poesia de Carlos Drummond de Andrade em solo espanhol, colocando-o em contato com autores naquele país. ${ }^{560}$

No ano de 1956, Gilberto Freyre também esteve na Espanha, sendo muito elogiado pela imprensa madrilenha, que o saudara como um dos mais influentes intelectuais do mundo. A revista Mundo Hispânico aproveitou a

\footnotetext{
${ }^{556}$ Telegrama confidencial da Secretaria de Estado das Relações Exteriores para a Embaixada do Brasil em Madri. Rio de Janeiro, 02 jul. 1953. Missões Diplomáticas Brasileiras. Telegramas expedidos a Madri (1947-1959). Arquivo de Correspondência Especial. CDO/MRE.

${ }_{557}$ O acordo foi firmado em Madri, em 25 de junho de 1960, e aprovado pelo Decreto Legislativo n. 20 de 17 de julho de 1964. Os artigos do referido acordo na íntegra estão em: Acordo Cultural Brasil - Espanha. Coleção de atos internacionais n. 498. Ministério das Relações Exteriores. Seção de publicações, 1966. Biblioteca do Arquivo Histórico e Diplomático do Itamaraty/RJ.

558 João Cabral de Melo Neto. O poeta diplomata. Disponível em: http://www.tvcultura.com.br/aloescola/literatura/joaocabral/joaocabral4.html Acesso em 09 jan. 2009.

${ }_{559}^{5}$ Idem.

${ }^{560}$ A obra de Carlos Drummond de Andrade encontrou importantes tradutores na Espanha por intermédio de João Cabral de Melo Neto. Cf Ricardo Souza de Carvalho. Drummond e a Espanha: apontamentos para duas recepções. O eixo e a roda, revista de literatura brasileira. Belo Horizonte: UFMG, v. 14, p.183-193, 2007. Do mesmo autor ver também: Terra e verso de Espanha em Murilo Mendes e João Cabral de Melo Neto. Congresso Brasileiro de Hispanistas, 2, 2002. São Paulo. Associação Brasileira de Hispanistas. Disponível em: http://www.proceedings.scielo.br/scielo.php?script=sci_arttext\&pid=MSC000000001200200020 0034\&lng=en\&nrm=abn>. Acesso em 09 Jan. 2009.
} 
oportunidade para cobrar de Gilberto Freyre um livro sobre a Espanha, produção que o tornaria um escritor completo. ${ }^{561}$

O governo de Juscelino Kubitschek demonstrou grande interesse pela divulgação da literatura brasileira em solo espanhol, sendo várias as medidas para ampliar a presença do livro brasileiro nas bibliotecas espanholas. A I Exposição do livro brasileiro contemporâneo em Madri, segundo o embaixador, atendia à proposta do presidente Juscelino, interessado em "favorecer o mútuo conhecimento dos dois povos e das duas culturas" ${ }^{562} \mathrm{O}$ então diretor da Biblioteca Nacional no Rio de Janeiro, Celso Ferreira da Cunha, foi à capital espanhola com o intuito de organizar a referida exposição e realizar a doação de mais de onze mil livros às bibliotecas hispânicas. Ao trascrever a entrevista com Ferreira da Cunha, o jornal Ya anunciava com otimismo: "España tiene desde hoy la mejor biblioteca brasileña en Europa". 563

A partir da década de 1950, tornou-se recorrente a concessão de bolsas de estudos, oferecidas pelos governos do Brasil e da Espanha, aos jovens que desejavam complementar seus estudos nesses países. O número de brasileiros beneficiados com essas bolsas foi grande, se compararmos com outros países latino-americanos. Segundo Bruno Ayllón Pino, na visão do Itamaraty era somente no campo das humanidades que se ofereciam boas oportunidades aos brasileiros na Espanha. Entre 1954 e 1970, a direção de intercâmbio do Instituto de Cultura Hispânica concedeu 379 bolsas de estudos a brasileiros, número que só era ultrapassado por aquelas oferecidas aos argentinos. $^{564}$

O Instituto de Cultura Hispânica tinha na concessão de bolsas de estudos, um dos instrumentos mais eficazes de propaganda do regime,

\footnotetext{
561 "Gilberto Freyre no se estimara escritor completo hasta que no haya hecho el libro sobre España", revista Mundo Hispânico de agosto de 1956. Recorte anexado ao ofício n.351 da Secretaria de Estado das Relações Exteriores para Embaixada do Brasil em Madri. 24 agosto 1956. Missões Diplomáticas Brasileiras. Ofícios recebidos de Madri (agosto a outubro de 1956). AHI/RJ.

562 Ofício n. 308 de João P. G. Coelho Lisboa, embaixador do Brasil na Espanha para Francisco Negrão de Lima, ministro das Relações Exteriores. Madri, 27 abr. 1959. Missões Diplomáticas Brasileiras. Ofícios recebidos de Madri (março a abril de 1959). AHI/RJ.

563 "España tiene desde hoy la mejor biblioteca brasileña en Europa", jornal Ya. Madri, 23 abr. 1959. Recorte anexado ao ofício n. 327 da Embaixada do Brasil na Espanha para Secretaria de Estado das Relações Exteriores. Madri, 02 maio. 1959. Missões Diplomáticas Brasileiras. Ofícios recebidos de Madri (maio a junho de 1959). AHI/RJ.

${ }^{564}$ Bruno Ayllón Pino. Las relaciones Brasil y España ponderadas, op. cit., p.290-291.
} 
constituindo-se em um "recurso que se valdría el régimen para ampliar su capacidad de maniobra exterior." 565 Alguns brasileiros, conhecidos por sua produção cultural e intelectual nas décadas posteriores, foram bolsistas em Madri. Evaldo José Cabral de Melo - que viria a se tornar um importante historiador - e Antonio Abujamra - ator e diretor de teatro - foram alguns dos beneficiários das bolsas oferecidas pelo governo espanhol. ${ }^{566}$

Em agosto de 1956, a Embaixada do Brasil enviou ao Itamaraty um extenso relatório através do qual Evaldo Cabral de Melo expôs sua trajetória acadêmica junto à Faculdade de Filosofia e Letras de Madri. Nesta exposição, Cabral de Melo aproveitava para tecer algumas críticas à "desorganização radical do ensino superior espanhol." Outro aspecto negativo, em sua opinião, residia nos cursos que careciam de um pensamento filosófico inovador. Apesar de mencionar Ortega Y Gasset como exemplo do que a Espanha tinha a oferecer, considerava que o ensino nesse país estava reduzido "a proporcionar aos alunos de filosofia nada mais do que corretas lições de metafísica". 567

Tais relatórios constituíam-se numa das exigências do departamento cultural do Itamaraty, para a liberação do subsídio mensal de 50 dólares aos estudantes que contavam com bolsas na Espanha. A Embaixada do Brasil também era responsável por intermediar a solicitação das referidas bolsas junto ao governo franquista. ${ }^{568}$

Iniciativa semelhante, por parte do governo brasileiro, foi registrada pelo jornal $A B C$, que informou sobre o processo de seleção para as cinco bolsas de estudos oferecidas pelo Brasil. A concessão seria realizada

\footnotetext{
565 Lorenzo Delgado Gomez-Escalonilla. Diplomacia franquista y política cultural hacia iberoamerica (1939-1953). Madri: Consejo Superior de Investigaciones Científicas, 1988, p.10.

${ }^{566}$ Em 1959 Antonio Abujamra solicitou junto à Embaixada do Brasil na Espanha a renovação por um ano do auxílio concedido pela Divisão Cultural do Itamaraty. Cf Ofício n. 462 da Embaixada do Brasil na Espanha para Secretaria de Estado das Relações Exteriores. Madri, 23 jun. 1959. Missões Diplomáticas Brasileiras. Ofícios recebidos de Madri (maio a junho de 1956). AHI/RJ.

${ }^{567}$ Relatório de Evaldo Jose Cabral de Mello para João P. G. Coelho Lisboa. Anexo ao ofício n. 350 da Embaixada do Brasil na Espanha para Secretaria de Estado das Relações Exteriores. Madri, 23 ago. 1956. Missões Diplomáticas Brasileiras. Ofícios recebidos de Madri (agosto a outubro de 1956). AHI/RJ.

${ }^{568}$ Despacho de Odette de Carvalho e Souza, chefe do Depto. Cultural do Itamaraty para João P. G. Coelho Lisboa, embaixador do Brasil na Espanha. Rio de Janeiro, 07 ago. 1956. Missões Diplomáticas Brasileiras. Despachos para Madri (1954 a 1959). AHI/RJ.
} 
para doutores e licenciados preferencialmente em Medicina, Letras, Direito e para engenheiros agrônomos. ${ }^{569}$

Em 1958, o presidente Juscelino passou a receber novos elogios do governo espanhol ao propor ao Congresso a elaboração de uma lei que tornasse obrigatório o ensino do espanhol nas escolas secundárias. Para o governo espanhol, tal medida estreitaria os laços culturais entre o Brasil e os países hispano-americanos, além de indiretamente fortalecer a imagem da Espanha como a "Madre de Naciones". Segundo Dr. Negri, presidente da Associação Cultural Italo-Hispânica, a medida expressava sobretudo "um profundo amor a España". 570

O fomento da língua oficial da Espanha no Brasil, no entanto, não tinha como objetivo central a aproximação com a Espanha, mas sim com os países vizinhos na América. A política pan-americanista do governo brasileiro tinha na expansão do conhecimento da língua espanhola, um dos instrumentos para alcançar o efetivo estreitamento dos laços não apenas políticos, mas culturais com a América Latina.

Durante o governo de JK foram iniciadas as obras de construção da Casa do Brasil em Madri, um projeto discutido pelos dois países desde o ano de 1952. A criação de um Instituto brasileiro de cultura na Espanha foi proposta pelo embaixador Rubens Ferreira de Melo ao governo espanhol, que sugeriu sua integração ao Instituto de Cultura Hispânica. Alfredo Sánchez Bella, diretor do $\mathrm{ICH}$, colocou à disposição do futuro Instituto brasileiro o salão de atos para eventos e conferências, e um espaço para a criação de uma biblioteca. ${ }^{571}$

Em carta, Sanchez Bella mencionou a segunda etapa mais ambiciosa desse projeto: a construção de um Colegio Mayor brasileiro,

569 "Becas a licenciados y doctores para estudios en el Brasil", jornal ABC. Madri, 22 dez. 1950. Recorte anexado ao ofício n. 374 da Embaixada do Brasil na Espanha para Secretaria de Estado das Relações Exteriores. Madri, 27 dez. 1950. Missões Diplomáticas Brasileiras. Ofícios recebidos de Madri (outubro a dezembro de 1950). AHI/RJ.

570 "Felicitación al presidente Kubitschek por su defensa del idioma español", jornal ABC. Madri, 8 out. 1958. Recorte anexado ao ofício n. 986 de Câmara Canto, encarregado de negócios do Brasil na Espanha para Francisco Negrão de Lima, ministro das Relações Exteriores. Madri, 15 out. 1958. Missões Diplomáticas Brasileiras. Ofícios recebidos de Madri (setembro a outubro de 1958). AHI/RJ.

${ }^{571}$ Carta de Alfredo Sánchez Bella para Rubens Ferreira de Melo. Madri, 28 fev. 1952. Anexo ao ofício n. 100 da Embaixada do Brasil na Espanha para Secretaria de Estado das Relações Exteriores. Madri, 7 mar. 1952. Missões Diplomáticas Brasileiras. Ofícios recebidos de Madri (janeiro a março de 1952). AHI/RJ. 
confirmando a disposição do governo espanhol em doar um terreno junto à Cidade Universitária. Sugeriu que o Colégio abrigasse estudantes brasileiros, uma biblioteca e um salão de atos solenes. Propunha inclusive a criação de um espaço destinado à degustação de café ou outros produtos tipicamente brasileiros. ${ }^{572}$

As sugestões acima mereceram a atenção do embaixador Ferreira de Melo, que as encaminhou ao ministro Neves da Fontoura, afirmando serem de interesse para o país. A partir desse momento, foram se tornando cada vez mais recorrentes as referências à criação de uma Casa do Brasil na Espanha, cuja construção foi iniciada somente em 1959. Leônidas Sobrinho Porto e Luis D'escragnolli Filho, funcionários do Ministério da Educação e Cultura, foram os responsáveis por negociar junto ao governo espanhol os aspectos técnicos e administrativos da referida construção. ${ }^{573}$

A finalização da instalação da Casa do Brasil na Cidade Universitária de Madri estava prevista para o ano de 1961. O governo brasileiro deu à obra um estilo moderno, seguindo o conceito da arquitetura idealizada por Oscar Niemeyer. $O$ arquiteto brasileiro Luis D'escragnolli Filho, foi o responsável por aquela que era, nas palavras do embaixador, uma "moderna e ampla obra arquitetônica". 574

Coelho Lisboa, ao informar sobre as etapas finais da construção, expôs em caráter confidencial as suas opiniões sobre o regulamento que considerava mais pertinente para a referida Instituição. $O$ embaixador sugeria que a nomeação do diretor fosse fruto da indicação do Ministério da Educação e Cultura em conjunto com o Ministério das Relações Exteriores. A preocupação do diplomata era garantir que a Casa do Brasil não ficasse inteiramente independente da Embaixada e que as normas fossem diferentes daquelas ditadas para a Casa do Brasil em Paris, subordinada somente ao Ministério da Educação e Cultura.

\footnotetext{
572 Idem.

573 Ofício n. 874 de João P. G. Coelho Lisboa, embaixador do Brasil na Espanha para Horácio Lafer, ministro das Relações Exteriores. Madri, 18 nov. 1959. Missões Diplomáticas Brasileiras. Ofícios recebidos de Madri (novembro a dezembro de 1959). AHI/RJ.

${ }^{574}$ Ofício n. 855 (confidencial) de João P. G. Coelho Lisboa, embaixador do Brasil na Espanha para Francisco C. San Thiago Dantas, ministro das Relações Exteriores. Madri, 10 out. 1961. Missões Diplomáticas Brasileiras. Ofícios recebidos de Madri (1960-1963). Arquivo de Correspondência Especial. CDO/MRE.
} 
As sugestões de Coelho Lisboa demonstravam uma tentativa de fazer daquela instituição um instrumento da diplomacia brasileira para promover o fortalecimento das relações culturais entre Brasil e Espanha. $\mathrm{O}$ Estatuto da Casa do Brasil foi estabelecido no ano de 1962. Segundo Ayllón Pino o interesse do governo por aquela Instituição diminuiu, ao verificar que ela não cumpria com a finalidade de difundir a cultura brasileira em território espanhol. O governo brasileiro pensou em várias ocasiões em extingui-la, não efetivando este desejo somente por causa do impacto que tal atitude teria sobre as relações hispano-brasileiras. ${ }^{575}$

A Casa do Brasil na Espanha permanece aberta e é, ainda hoje, um dos quatro Colegios Mayores adscritos à Universidade Complutense de Madri. Não abriga somente estudantes brasileiros, como a princípio se pretendia, mas também estudantes de outras nacionalidades que podem pagar por seus confortáveis apartamentos. ${ }^{576}$

Do paraíso tropical à selva de pedras: o Brasil na imprensa espanhola

Uma das missões da diplomacia brasileira era acompanhar de perto as notícias sobre o Brasil veiculadas pela imprensa local. Muitos dos ofícios enviados pela Embaixada e pelos consulados brasileiros para 0 Itamaraty eram acompanhados de recortes de jornais, que versavam sobre aspectos diversos da realidade brasileira. Tais notícias contribuíram para estabelecer na sociedade espanhola opiniões que, certamente influenciavam a natureza de nossas relações internacionais com a Espanha. Amado Cervo, em seu trabalho sobre as relações entre o Brasil e a Itália, afirma que as imagens influem "sobre a natureza das relações internacionais, criando condições tanto para iniciativas de cooperação quanto de conflito. Incidem diretamente sobre o desenvolvimento ou a estagnação dos negócios". ${ }^{577}$

Apesar de o Itamaraty reconhecer e desejar que o Brasil fosse bem visto externamente, a política para a Espanha menosprezou o papel que

\footnotetext{
${ }^{575}$ Bruno Ayllón Pino. Las relaciones Brasil y España ponderadas, op. cit., p.290.

576 Para maiores informações sobre a Casa do Brasil na Espanha consultar o site http://www.casadobrasil.org

577 Amado Cervo. As relações Históricas entre Brasil e Itália, op. cit., p. 95.
} 
as notícias poderiam ter na construção de uma imagem positiva do país e de seu povo. Nos anos 50 essa situação se alterou, sendo perceptível a tomada de ações dos adidos culturais à Embaixada em Madri com o intuito de promover uma imagem do Brasil como um país do futuro. Ao Itamaraty coube promover medidas que reforçassem, no exterior, o perfil de um Brasil moderno que se estabelecia internamente.

Em dezembro de 1950, Ferreira de Melo acusou o recebimento de 20 fotografias de "aspectos modernos de São Paulo e Rio de Janeiro", destinadas à imprensa espanhola. ${ }^{578}$ Ao longo dos anos 50 a cidade de São Paulo ganhou destaque na imprensa enquanto metrópole representativa de um Brasil de progresso e modernidade. A cidade de prédios descomunais, com grandes índices de crescimento econômico e populacional, tornou-se referência freqüente nos artigos da imprensa hispânica. A fotografia cumpria com a sua função de alimentar o imaginário coletivo espanhol, interessado em conhecer o Brasil.

A cidade do Rio de Janeiro, na maioria das vezes, alvo de atenções por conta de suas exuberantes paisagens naturais, passou a ser retratada como uma cidade que também seguia rumo à modernidade. Tais matérias atendiam, provavelmente, aos pedidos dos adidos culturais da representação brasileira em Madri.

578 Ofício n. 380 de Rubens Ferreira de Melo, embaixador do Brasil na Espanha para Raul Fernandes, ministro das Relações Exteriores. Madri, 30 dez. 1950. Missões Diplomáticas Brasileiras. Ofícios recebidos de Madri (outubro a dezembro de 1950). AHI/RJ. 


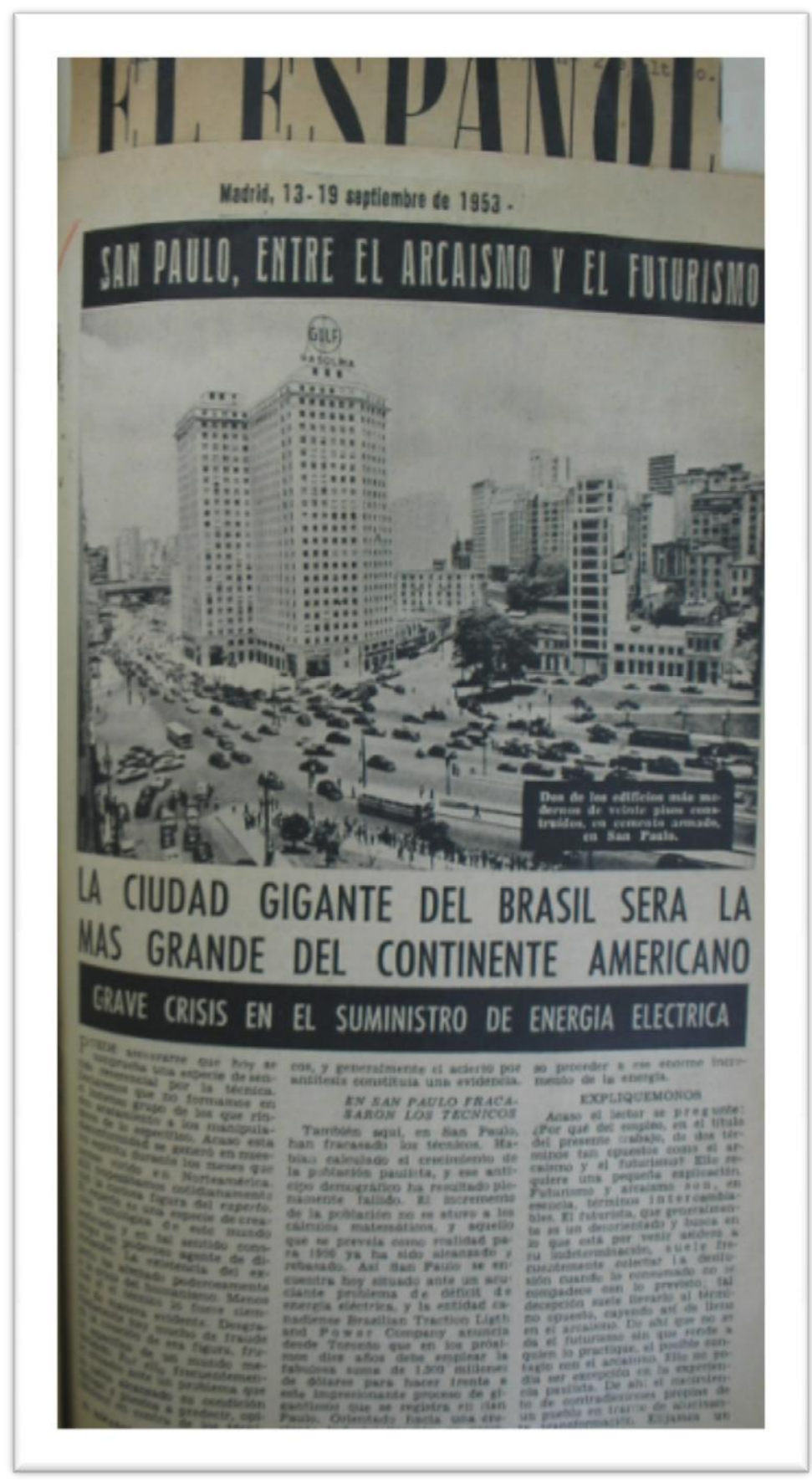

21 - "São Paulo, entre el arcaísmo y el futurismo". Matéria publicada na revista El Español de setembro de 1953. Anexo ao ofício n. 65 de Rubens Ferreira de Melo, embaixador do Brasil na Espanha para Vicente Rao, ministro das Relações Exteriores. Madri, 06 fev. 1954. Missões Diplomáticas Brasileiras. Ofícios recebidos de Madri (janeiro a fevereiro de 1954). AHI/RJ. 


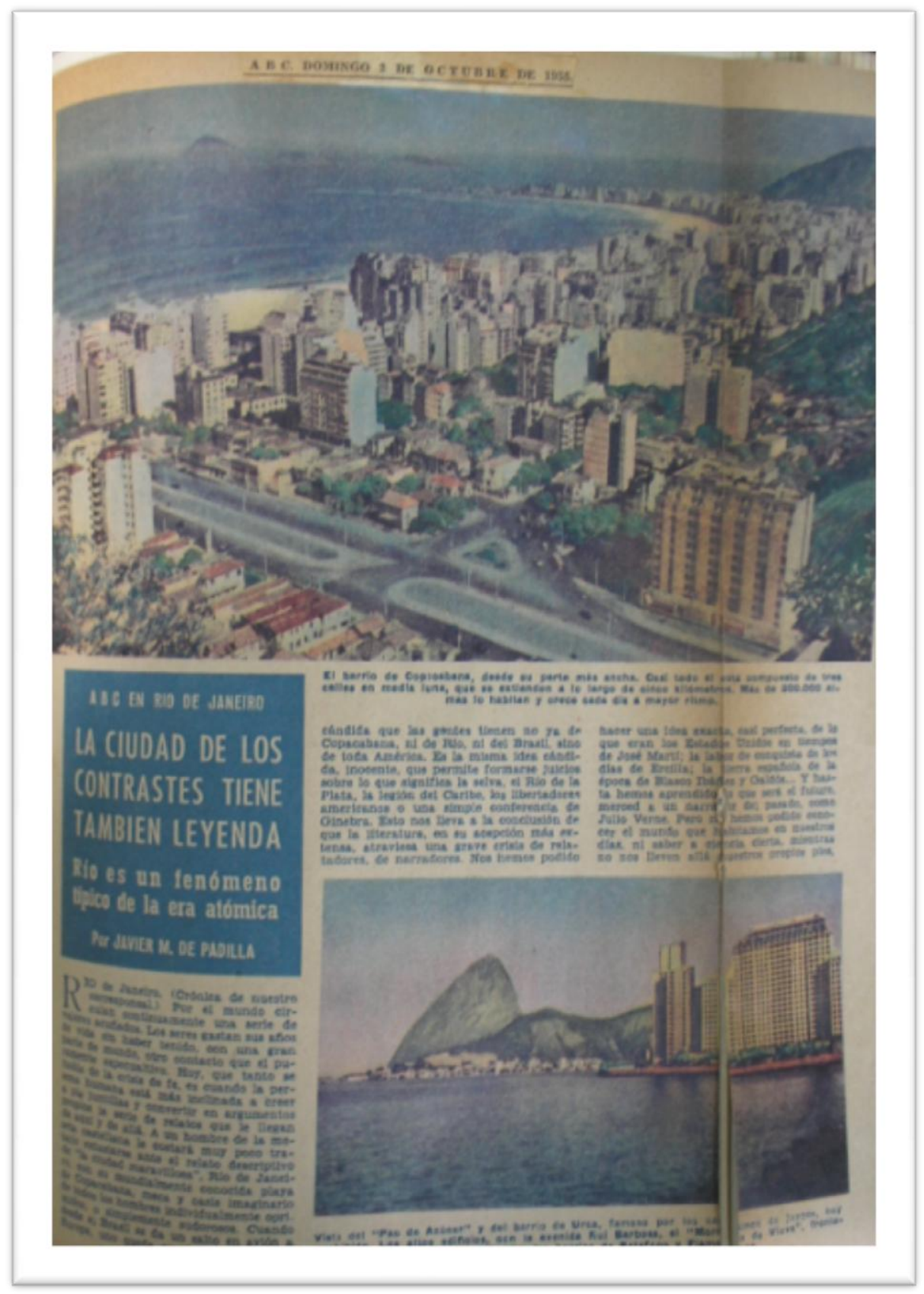

22 - A cidade do Rio de Janeiro evidenciada na imprensa hispânica. $A B C$. Madri, 2 de outubro de 1955. Recorte anexado ao ofício n. 356 da Embaixada do Brasil em Madri para Secretaria de Estado das Relações Exteriores. Madri, 31 out. 1955. Missões Diplomáticas Brasileiras. Ofícios recebidos de Madri (outubro a dezembro de 1955). AHI/RJ. 
Tais imagens atendiam aos interesses do governo espanhol, preocupado em incentivar a emigração para o Brasil, um movimento em franca expansão desde o final da década de 1940. Muitas das informações sobre o Brasil que chegavam até os jornais e revistas da Espanha eram transmitidas por espanhóis que, residindo no Rio de Janeiro, acumulavam os cargos de "correspondentes" de determinados periódicos e adidos culturais na Embaixada espanhola. Ramon Escohotado, por exemplo, ocupou simultaneamente as funções de funcionário diplomático e correspondente no Brasil do jornal $A B C$. Num país onde não havia liberdade de expressão, tais funções só poderiam ser assumidas por aqueles que se comprometessem em defender entusiasticamente o regime político espanhol.

A despeito das diferenças de regime político que separavam os dois países, uma característica manteve-se nas notícias sobre o Brasil nos anos 50: os elogios ao anticomunismo. Ramon Escohotado, no artigo "Brasil, en contra de la propaganda roja", evidenciava a disposição do Brasil em apoiar a batalha espanhola contra os "inimigos de Moscou". ${ }^{579}$

\footnotetext{
579 "Brasil, en contra de la propaganda roja", Ya. Madri, 22 dez. 1950. Recorte anexado ao ofício n. 373 de Rubens Ferreira de Melo, embaixador do Brasil na Espanha para Raul Fernandes, Ministro das Relações Exteriores. Madri, 22 dez. 1950. Missões Diplomáticas Brasileiras. Ofícios recebidos de Madri (outubro a dezembro de 1950). AHI/RJ.
} 


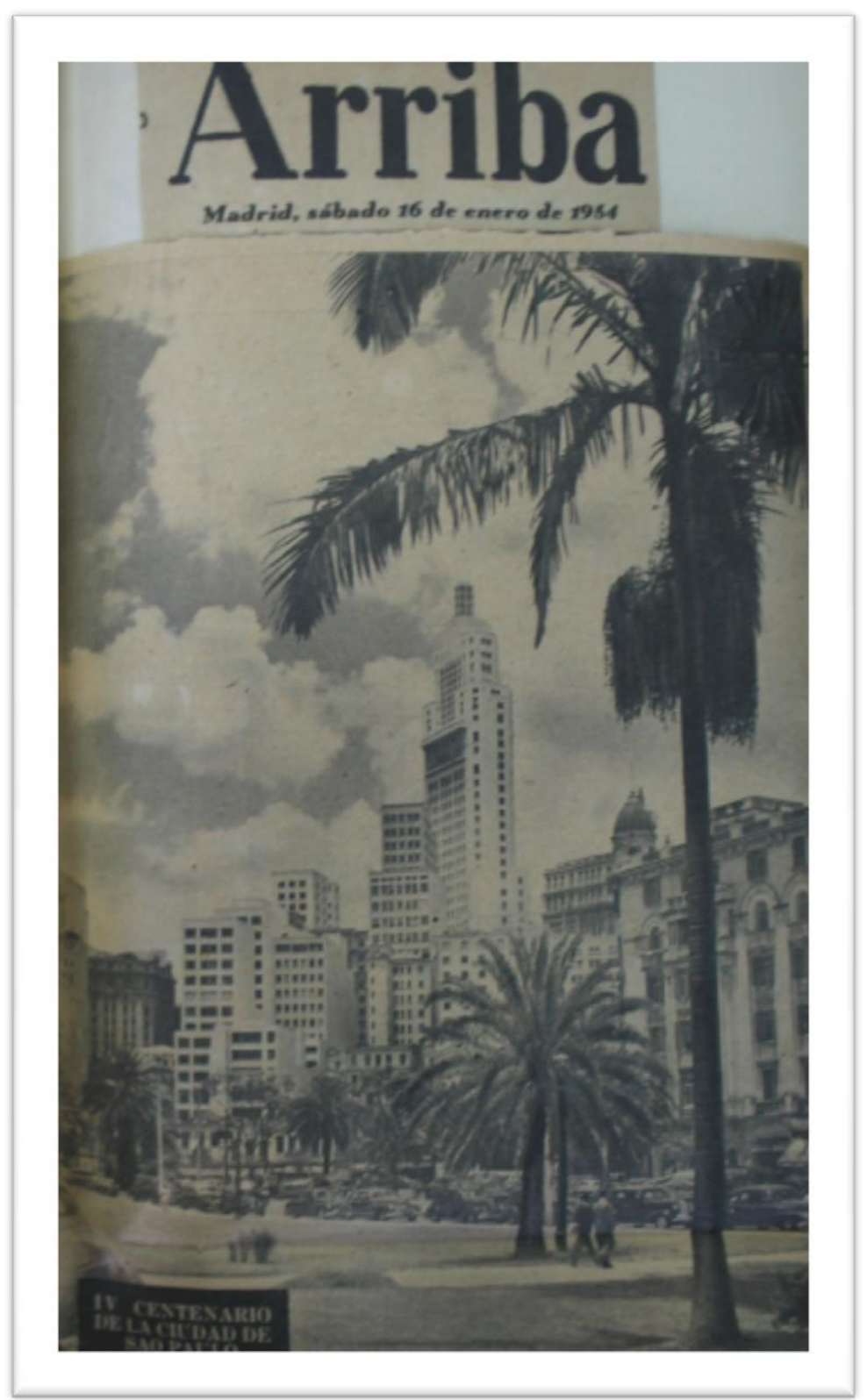

23 - Imagens da cidade de São Paulo em artigo sobre o seu IV Centenário. Jornal Arriba. Madri, 16 de janeiro de 1954. Recorte anexado ao ofício n. 86 da Embaixada do Brasil na Espanha para a Secretaria de Estado das Relações Exteriores. Madri, 26 fev. 1954. Missões Diplomáticas Brasileiras. Ofícios recebidos de Madri (janeiro a fevereiro de 1954). AHI/RJ. 
As notícias sobre as agitações políticas ocorridas durante 0 governo de Juscelino foram amplamente divulgadas na Espanha. Logo no início de seu mandato, o novo presidente enfrentou, além de revoltas nas Forças Armadas, manifestações de diferentes setores da sociedade brasileira descontentes com o aumento do custo de vida. ${ }^{580} \mathrm{O}$ enfrentamento da polícia do Rio de Janeiro à manifestação de estudantes contra o aumento das tarifas de transporte assim era divulgado pelo jornal Arriba: "Kubitschek da ordenes severas para atajar los desordenes estudantiles". O subtítulo anunciava ainda "La participación comunista en los distúrbios ha obligado al Presidente brasileño a adoptar uma enérgica postura". ${ }^{581}$

Caberia observar que tais notícias exageravam no peso que a repressão do governo brasileiro tinha sobre os movimentos dessa natureza. Segundo Célia Maria Leite Costa, o presidente mineiro era hábil nas negociações com os segmentos políticos e sociais, tendo concedido a anistia para os militares envolvidos com a Revolta de Jacareacanga, ocorrida em fevereiro de 1956. Quando possível, preferia conciliar o interesse dos grupos em questão a tomar medidas de repressão, caras à sua imagem de defensor da democracia. ${ }^{582}$

Após a viagem de Juscelino à Espanha, a imprensa hispânica passou a the dedicar mostras de admiração e simpatia. As notícias sobre as agitações sociais no Rio de Janeiro procuravam demonstrar ao povo espanhol que mesmo um presidente eleito democraticamente tinha que tomar medidas enérgicas para coibir as atividades subversivas que ameaçavam a ordem. A referência à infiltração comunista em tais manifestações, condizente ou não com a realidade, era uma regra nesses artigos.

\footnotetext{
${ }^{580}$ Sobre a revolta de Jacareacanga e a anistia concedida aos revoltosos pelo Congresso Nacional à pedido do Presidente da República ver: Celia Maria Leite Costa. Revolta de Jacareacanga. Os anos JK. Disponível em: http://www.cpdoc.fgv.br/nav jk/htm/O Brasil de JK/A politica como a arte de conciliar.asp. Acesso em 16 jan. 2008.

581 "Kubitschek da ordenes severas para atajar los desordenes estudantiles", jornal Arriba. Madri, 01 jun. 1956. Recorte anexado ao ofício n. 274 da Embaixada do Brasil na Espanha para Secretaria de Estado das Relações Exteriores. Madri, 30 jun. 1956. Missões Diplomáticas Brasileiras. Ofícios recebidos de Madri (junho a julho de 1956). AHI/RJ.

${ }^{582}$ Sobre a postura de JK diante das revoltas nas Forças Armadas e dos movimentos sociais ver Marly Motta. "A política como arte de conciliar", In: Os anos JK. Disponível em http://www.cpdoc.fgv.br/nav $\mathrm{jk} / \mathrm{htm} / \mathrm{O}$ Brasil de JK/A politica como a arte de conciliar.asp. Acesso em 16 jan. 2008.
} 
Divulgar as simpatias mútuas entre Franco e Juscelino foi uma das estratégias utilizadas pelo governo espanhol para demonstrar 0 fortalecimento das relações da Espanha com os países ocidentais. Assim, quando da visita a América do Sul, o presidente do Conselho de Ministros espanhol, Ibañez Martin, fez questão de ressaltar que o presidente brasileiro considerava Franco "como primer servidor de la civilización occidental." 583

Uma série de considerações sobre o Brasil foram realizadas por por Pedro Gómez Aparício, diretor da agência de notícias EFE, e contestadas pelo jornalista brasileiro Edilberto Coutinho. $O$ fato constituiu-se num verdadeiro imbróglio, sendo tratado como assunto diplomático de importância para ambos os países. O referido jornalista brasileiro, que residia na Espanha para estudar junto à Escola diplomática em Madri, teceu diversas acusações à maneira preconceituosa com que o Brasil era abordado nos artigos de Gómez Aparicio. ${ }^{584}$ Desejando esclarecer o assunto, o jornalista espanhol escreveu uma extensa carta ao embaixador Coelho Lisboa, anexando seus escritos como prova de que só havia feito menções elogiosas ao país. ${ }^{585}$

Um desses artigos nos permite entender a insatisfação de

Coutinho:

En Brasil no existe nada que se parezca a una discriminación racial: desde que el emperador Pedro II abolió la esclavitud, los negros, nietos de los antiguos esclavos africanos, son ciudadanos como los demás, y disfrutan de sus mismas posibilidades. Lo que pasa es que, por las razones que sean, esas posibilidades suelen ser esquivadas por los negros. Aunque de cada mil brasileños son negros puros alrededor de ciento diez, no hay uno solo que figure en los cuadros del Parlamento, de la Magistratura o de la Cátedra. Tienen abiertas todas las puertas de par en par, pero no las franquean: prefieren los servicios serviles y poco agotadores, y les sería difícil habituarse vivir fuera de las "favelas". La "favela" es un mal hoy por hoy inevitable. Como es inevitable el contraste que ofrecen sus apretados barrios cuando sirven de fondo a los túneles del aristocrático distrito de Flamengo, que vuelcan sobre

\footnotetext{
583 "Kubitschek considera a Franco como primer servidor de la civilización occidental", jornal Madrid. Madri, 17 ago. 1956. Recorte anexado ao ofício n. 353 da Embaixada do Brasil na Espanha para Secretaria de Estado das Relações Exteriores. Madri, 27 ago. 1956. Missões Diplomáticas Brasileiras. Ofícios recebidos de Madri (agosto a outubro de 1956). AHI/RJ.

${ }_{584}$ Ofício n. 887 (reservado) de Câmara Canto, encarregado de negócios do Brasil na Espanha para Décio Moura, ministro interino das Relações Exteriores. Madri, 04 dez. 1957. Missões Diplomáticas Brasileiras. Ofícios recebidos de Madri (dezembro de 1957). AHI/RJ.

${ }^{585}$ Carta de Pedro Gómez Aparicio, director da agência EFE para João P. G. Coelho Lisboa, embaixador do Brasil na Espanha. Madri, 03 dez. 1957. Anexo ao ofício n. 887 (reservado).. (citado em nota anterior).
} 
Copacabana la oleada interminable de los más ostentosos coches americanos. ${ }^{586}$

Demonstrando não compreender os motivos que levavam à exclusão dos negros da sociedade brasileira, Gomez Aparício reforçava uma visão que, de certa forma, se acomodava aos interesses da elite brasileira. Através dos artigos enviados à Embaixada do Brasil, procurava provar que seus escritos em nada poderiam desmerecer o povo brasileiro. O papel desempenhado pelos negros, e a miséria em que grande parte deles vivia, era explicado por sua vontade ou sua "falta de disposição" ao trabalho.

Câmara Canto, na qualidade de encarregado de negócios, resumiu ao Itamaraty o diálogo estabelecido com o jovem jornalista brasileiro, concluindo que o mesmo, por não dominar o idioma espanhol, poderia ter se equivocado nas interpretações realizadas. Supunha assim que ele não havia compreendido o verdadeiro sentido e o alcance das referidas declarações do jornalista espanhol, que em suas matérias sempre manifestava "sentimentos amistosos" ao Brasil. ${ }^{587}$

Em 1956, Carmen Dolores Barbosa, senhora da alta sociedade paulistana que havia patrocinado vários concursos de literatura, ofereceu um prêmio - que levava seu nome - no valor de 25 mil pesetas ao autor do conjunto de quatro melhores artigos sobre o Brasil na imprensa espanhola. ${ }^{588} \mathrm{Um}$ ano antes, intermediou também a doação de cerca de três mil livros de autores brasileiros realizados pelo Instituto Nacional do Livro ao Instituto de Cultura Hispânica. ${ }^{589}$

O júri do concurso para a escolha dos melhores artigos sobre o Brasil foi composto de personalidades dos círculos jornalísticos e literários, como o presidente do $\mathrm{ICH}$, Alfredo Sánchez Bella. O vencedor foi Ramon

\footnotetext{
586 “La Nación que se está haciendo" por Pedro Gomez Aparício (mimeo). Anexo ao ofício n. 887 (reservado) de Câmara Canto, encarregado de negócios do Brasil na Espanha para Décio Moura, ministro interino das Relações Exteriores. Madri, 04 dez. 1957. Missões Diplomáticas Brasileiras. Ofícios recebidos de Madri (dezembro de 1957). AHI/RJ.

${ }^{587}$ Ofício n. 887 (reservado) de Câmara Canto, encarregado de negócios do Brasil na Espanha para Décio Moura, ministro interino das Relações Exteriores. Madri, 04 dez. 1957. Missões Diplomáticas Brasileiras. Ofícios recebidos de Madri (dezembro de 1957). AHI/RJ.

588 Ofício n. 198 de Rubens Ferreira de Melo, embaixador do Brasil na Espanha para José Carlos de Macedo Soares, ministro das Relações Exteriores. Madri, 21 maio 1956. Missões Diplomáticas Brasileiras. Ofícios recebidos de Madri (abril a maio de 1956). AHI/RJ.

589 Ofício n. 193 de Rubens Ferreira de Melo, embaixador do Brasil na Espanha para Raul Fernandes, ministro das Relações Exteriores. Madri, 03 maio 1955. Missões Diplomáticas Brasileiras. Ofícios recebidos de Madri (abril a junho de 1955). AHI/RJ.
} 
Escohotado que, no discurso de agradecimento, mencionou seu amor ao país no qual servira como funcionário diplomático. ${ }^{590}$

A partir de 1958, somaram-se às imagens sobre o crescimento urbano das cidades de São Paulo e Rio de Janeiro, várias referências à construção de Brasília. A nova capital simbolizava os ideais de rápido desenvolvimento divulgados pelo governo de JK. Sua construção era sempre apresentada, tanto interna quanto externamente, como exemplo de esforço e superação, um empreendimento coletivo que materializava o nascimento de uma nova era.

Todos os comentários à moderna capital brasileira divulgados na Espanha eram reportados pela diplomacia brasileira ao Itamaraty. Os títulos dos artigos evidenciavam a grandiosidade e os esforços para criar uma cidade no meio da floresta. Em "Brasilia, capital de um gran futuro", Pedro Gomez Aparicio reproduzia o discurso do governo brasileiro, ao mencionar a necessidade de levar desenvolvimento às regiões remotas do país. A cidade parecia acontecer pelo desejo único do presidente brasileiro: "Brasilia, empresa audaz de um hombre - Juscelino Kubitschek - está dejando de ser uma promesa". 591

A revista Mundo Hispânico, publicada em Buenos Aires, México e Madri e auto-denominada "la revista de veintitres países", constituiu-se numa importante fonte de propaganda do regime franquista junto aos países hispanoamericanos. Esse periódico lançou diversos artigos sobre Brasília, e em junho de 1960, dedicou diversas páginas á inauguração da "capital do futuro". ${ }^{592}$. A transferência da capital também era apresentada como possuidora de intenções sociais, como demonstra o artigo "Brasilia, trabajo para todos". Brasília se constituiria, na tradução realizada pela Embaixada brasileira "... num

\footnotetext{
${ }^{590}$ Relatório do mês cultural (maio 56). Madri, 04 jun. 1956. Missões Diplomáticas Brasileiras. Ofícios recebidos de Madri (junho a julho de 1956). AHI/RJ.

591 "Brasilia, capital de um gran futuro", jornal Arriba. Madri, 14 de junho de 1958. Recorte anexado ao ofício n. 711 da Embaixada do Brasil na Espanha para a Secretaria de estado das Relações Exteriores. Madri, 02 jul. 1958. Missões Diplomáticas Brasileiras. Ofícios recebidos de Madri (julho a agosto de 1958). AHI/RJ.

${ }_{592}$ Consultamos alguns dos exemplares da revista Mundo Hispânico, que se apresentava como um instrumento de propaganda da Ditadura franquista. As referências ao Brasil começaram a se tornar mais freqüentes após 1955, com artigos em que predominavam informações sobre o desenvolvimento de São Paulo e sobre a construção de Brasília. (Fotocópias de fragmentos das revistas gentilmente cedidas por Elena Pájaro Peres. Números consultados: 87 (1955); 100 (1956); 107 (1957); 132 (1959); 147 (1960).
} 
grito de esperança, que em breve se estenderá até os mais remotos lugares da terra, por que ali haverá trabalho para todos, por que estamos na alvorada da solução de um problema social imenso". 593

Atendendo ao desejo de Juscelino em tornar internacionalmente conhecida a grande obra de seu governo, foi realizada em Madri a Exposição Brasília. Inaugurado na Feira Internacional do Campo, o stand brasileiro contou com a visita dos principais ministros do governo espanhol além da visita de Francisco Franco e sua esposa. Segundo o relatório diplomático do "Mês cultural", o Generalísimo visitou demoradamente a exposição, "demonstrando grande interesse em conhecer pormenores de vários dos principais edifícios de Brasília." Coelho Lisboa afirmou também que Franco teria observado que, assim como Brasília, Madri era uma das raras, senão a única capital que ocupava o centro geográfico do país. ${ }^{594}$ A alegação oficial de que a nova capital promoveria a integração do país certamente chamou a atenção do Caudillo, que via na posição geográfica de Madri um símbolo do que almejava em termos culturais e políticos: unidade e centralismo.

\footnotetext{
${ }^{593}$ Ofício n. 895 da Embaixada do Brasil na Espanha para a Secretaria de Estado das Relações Exteriores. Madri, 25 nov. 1959. Missões Diplomáticas Brasileiras. Ofícios recebidos de Madri (novembro a dezembro de 1959). AHI/RJ.

594 Relatório do mês cultural (maio de 1959) da Embaixada do Brasil na Espanha para Ministério das Relações Exteriores. Missões Diplomáticas Brasileiras. Ofícios recebidos de Madri (maio a unho de 1959). AHI/RJ.
} 


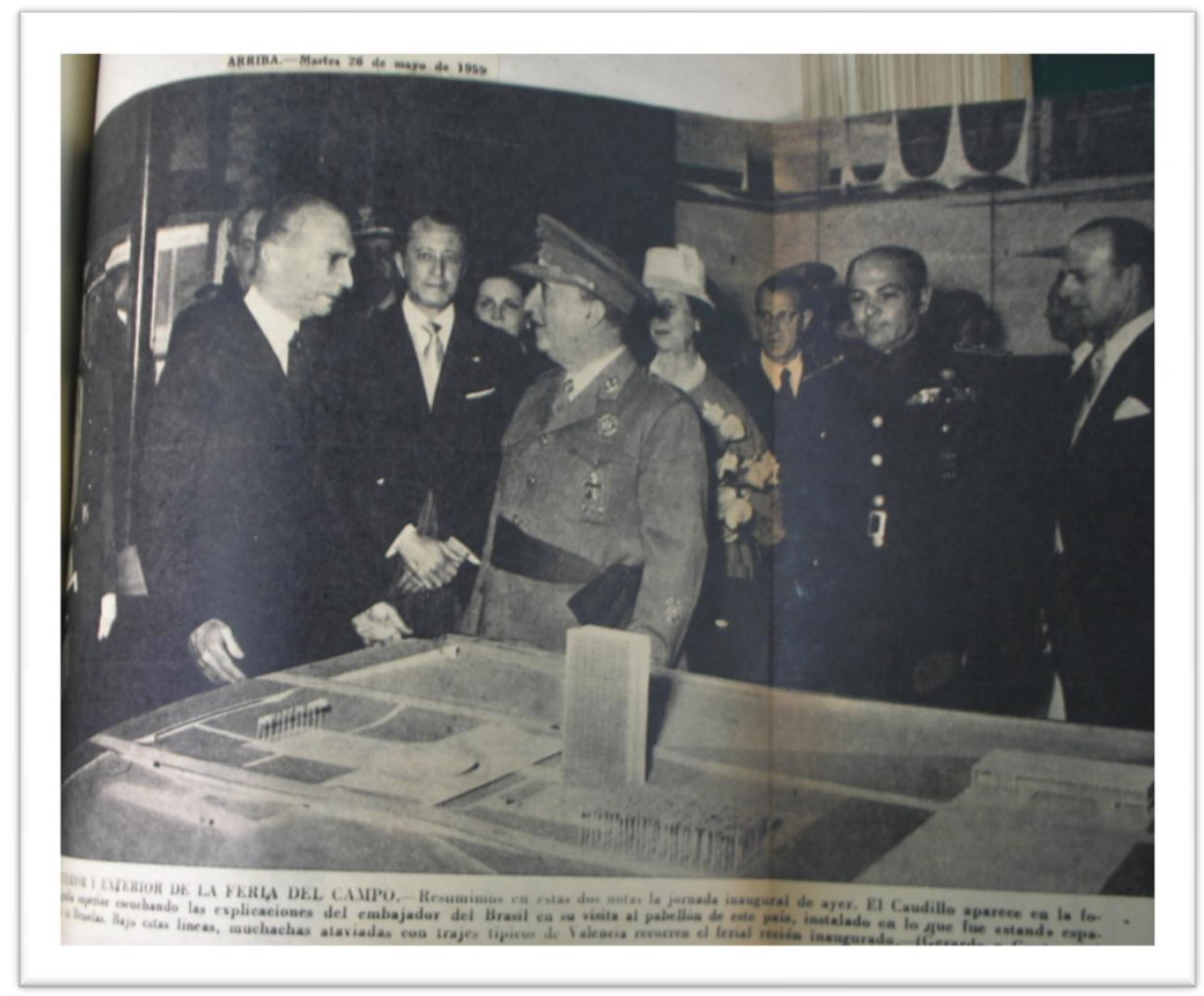

24 - Francisco Franco e o embaixador brasileiro João Gabizo Pizarro Coelho Lisboa na Exposição Brasília. Jornal Arriba. Madri, 26 de maio de 1959. Recorte anexado ao ofício n. 385 da Embaixada do Brasil na Espanha para Secretaria de Estado das Relações Exteriores. Madri, 26 maio 1959. Missões Diplomáticas Brasileiras. Ofícios recebidos de Madri (maio a unho de 1959). AHI/RJ.

\section{A política cultural da Espanha para o Brasil}

O período proposto neste estudo abrange momentos distintos da vida política espanhola, passando pela instauração da Segunda República, a Guerra Civil Espanhola e a partir de 1939, a ditadura franquista. A República Espanhola - especialmente nos momentos em que a maioria dos partidos de esquerda esteve no poder - preocupou-se em priorizar ações culturais internas e externas com base em uma concepção de "Estado educador". Segundo Eduardo Vázquez, a concepção de cultura que predominou neste período estava atrelada a uma visão burguesa, já que a maioria dos homens que ocuparam cargos de poder provinha da pequena burguesia como professores, 
artistas e intelectuais. A concepção de um Estado capaz de ampliar o acesso da população às manifestações culturais, não se confundia, porém, com a noção de um "Estado monopolizador da cultura", valor que acompanharia a política cultural do governo franquista. ${ }^{595}$

Durante o regime franquista, a política cultural para o exterior centrou-se no objetivo de atrair os países latino-americanos para a causa da Hispanidade. A política de Franco, a partir dos anos 50, passou a promover ações para atrair o Brasil para a mesma causa. Sabendo dos receios e protestos da diplomacia brasileira frente a tais tentativas, o Palácio Santa $\mathrm{Cruz}^{596}$, reconhecia que os meios para essa integração deveriam ser distintos, de forma a não interferir nas relações com Portugal.

O governo português via com receio o empenho espanhol em inserir o Brasil no rol de países que guardavam heranças hispânicas. Ayllón Pino afirma que apesar de desejar essa inserção, a política externa de Franco evitava entrar em discórdia com o país vizinho, que se constituía num parceiro importante na luta anticomunista e na defesa ocidental. ${ }^{597}$

Através de seus periódicos, a Espanha utilizava como elemento de reforço dessa pretensa aproximação, as referências à herança hispânica na formação política e cultural do Brasil. Um artigo do jornal Arriba intitulado "España intensifica su acción política y cultural en Brasil", além de anunciar a criação da "Casa de Cervantes" em São Paulo e do Centro Brasileiro de Estudos Hispânicos na Faculdade de Filosofia do Rio de Janeiro, enfatizava que nomes espanhóis já haviam figurado entre as personalidades históricas desse país. Carlota Joaquina, filha de Carlos IV; o quase aclamado rei de São Paulo no século XVI, Amador Bueno (paulista, mas filho do sevilhano Bartolomeu Bueno), e o aventureiro Luis Galvez, participante ativo na independência do Acre, são citados como exemplos dessa proximidade.

\footnotetext{
595 Ao analisar a política cultural de países cujos regimes são democráticos e autoritários, Martin Cesar Feijó chama a atenção para o fato de que "uma política cultural nunca está dissociada de uma política, e será reflexo desta. Onde esta não for democrática, aquela também não o será". Martin Cesar Feijó. O que é política cultural. São Paulo: Brasiliense, 1983, p.75.

596 O Palácio Santa Cruz em Madri é a sede do Ministério de Asuntos Exteriores, atualmente denominado Ministério de Asuntos Exteriores y Cooperación.

${ }^{597}$ Bruno Ayllón Pino. Las relaciones entre Brasil y España ponderadas, op. cit., p.260. Sobre as relações diplomáticas Brasil - Portugal ver: José Calvet Magalhães. Breve história das relações diplomáticas entre Brasil e Portugal. São Paulo: Paz e Terra; Fundação Alexandre de Gusmão, 1999.
} 
Nesses artigos a menção ao padre das Ilhas Canárias, José de Anchieta, era quase uma regra. ${ }^{598}$

A preservação da imagem do espanhol José de Anchieta como o "verdadeiro" fundador da maior cidade brasileira, figurou entre as principais preocupações da política cultural da Espanha para o Brasil. A preparação para as comemorações que ocorreriam por ocasião do IV Centenário de São Paulo, em 1954, foi alvo das atenções do embaixador espanhol no Brasil, Marqués de Prat y Nantouillet. Esse alertou o ministro Martin Artajo, da necessidade de impedir as intenções da colônia portuguesa em retirar a figura de Anchieta da memória da cidade, substituindo-o pelo Padre Manoel da Nóbrega. ${ }^{599}$ Cabe observar que a projeção da imagem do herói se constitui numa estratégia comumente empregada pela propaganda política dos regimes autoritários, que apelam para os ícones do passado com o objetivo de reforçar uma determinada visão histórica. ${ }^{600}$

Em despacho reservado, Nantouillet informou ao MAE que havia conseguido do governador de São Paulo, Lucas Nogueira y Garcez, a promessa de homenagear os espanhóis como "verdadeiros" fundadores da cidade. Também sugeria ao ministro espanhol que a Espanha enviasse, em sigilo, uma unidade naval em homenagem ao aniversário da cidade de São Paulo. O silêncio acerca do ato deveria se dar para que os portugueses não copiassem tal gesto. Nesse documento, o embaixador espanhol teceu considerações sobre suas rivalidades com o embaixador português lotado no Rio de Janeiro, que teria declarado tirar férias no mesmo período que ele, para não deixá-lo sozinho no Brasil. ${ }^{601}$

O governo espanhol mostrou-se interessado em marcar presença na II Bienal de Artes de São Paulo, uma amostra internacional grandiosa, que

\footnotetext{
598 "España intensifica su acción política y cultural en Brasil”, jornal Arriba. Madri, 29 dez. 1950. Recorte anexado ao ofício n. 02 da Embaixada do Brasil na Espanha para Secretaria de Estado das Relações Exteriores. Madri, 03 jan. 1951. Missões Diplomáticas Brasileiras. Ofícios recebidos de Madri (janeiro a março de 1951). AHI/RJ.

599 Despacho n. 951 de Marquês de Prat y Nantouillet, embaixador da Espanha no Brasil para ministro de Assuntos Exteriores da Espanha. Rio de Janeiro, 14 nov. 1952. R3579, expt.16. AMAE.

${ }^{600}$ Sobre o mito do herói e sua relação com o poder ver: Georges Balandier. O poder em cena. Brasília: UNB, 1982 , p.7.

${ }^{601}$ Despacho n. 1164 (reservado) de Marquês de Prat y Nantouillet, embaixador da Espanha no Brasil para ministro de Assuntos Exteriores da Espanha. Rio de Janeiro, 13 dez. 1953. R3579, expt.16. AMAE.
} 
dava início às comemorações do IV Centenário da cidade. No entanto, a presença de Guernica na Bienal impediu ou inibiu qualquer participação mais ativa da Espanha. Afinal a atração principal daquele evento era um quadro que remetia às lembranças trágicas da Guerra Civil, constituindo-se como um símbolo da resistência republicana. A obra, considerada uma das mais importantes do século $X X$, retrata na visão do pintor espanhol as atrocidades cometidas pelo bando rebelde durante a Guerra Civil Espanhola.

Guernica foi uma das grandes atrações daquela Bienal, marcando presença graças à influência de Cícero Dias, um dos representantes do modernismo e amigo do pintor espanhol. Uma das salas especiais foi dedicada a Picasso, reunindo cerca de 75 peças suas. Segundo o historiador Francisco Alambert, Cícero Dias usou de seu prestígio, obtendo a autorização do espanhol para que essa e outras obras fossem enviadas ao evento. Picasso não queria que seu mural saísse dos EUA enquanto durasse a ditadura franquista, mas cedeu diante da argumentação de que o Brasil era um país em processo de desenvolvimento, e que a Bienal celebrava acima de tudo a consolidação da democracia. Assim, Guernica juntamente com obras de autores do porte de Marcel Duchamp, George Braque e Paul Klee, chegaram ao Parque do lbirapuera. ${ }^{602}$

A vinda ao Brasil de renomados intelectuais espanhóis à convite do governo brasileiro forneceu ao Ministério de Asuntos Exteriores espanhol a possibilidade de realizar, através deles, uma intensa propaganda do regime franquista. Em 1952, o Itamaraty autorizou a Embaixada em Madri a convidar os intelectuais Gregorio Marañon, Ortega $Y$ Gasset e Jimenez Diaz para passarem dois meses do inverno de 1953 no Brasil, com os custos pagos pelo governo brasileiro. ${ }^{603}$

Ortega y Gasset, assim como nos anos 40, declinou o convite. Possivelmente os problemas de saúde impossibilitaram sua viagem, tendo 0

\footnotetext{
${ }^{602}$ Francisco Alambert. Guernica, um milagre no Brasil. Revista de História da Biblioteca Nacional. Rio de Janeiro, ano 3, n. 30, mar. 2008, p.63. Sobre as Bienais ver também do mesmo autor: As Bienais de São Paulo: da era do museu à era dos curadores (1951-2001). São Paulo: Boitempo, 2004.

${ }^{603}$ Carta-telegrama n. 93 da Secretaria de Estado das Relações Exteriores para Embaixada do Brasil. Rio de Janeiro, 23 jul. 1952. Missões Diplomáticas Brasileiras. Cartas-Telegramas expedidas a Madri (1951-1953). AHI/RJ.
} 
Itamaraty lamentado a "triste ocorrência" com o filósofo. ${ }^{604} \mathrm{O}$ ilustre médico Gregorio Marañon, no entanto, esteve no Brasil, sendo recebido por vários setores do governo e da sociedade brasileira. ${ }^{605}$ Segundo o Serviço de Informações do Ministério de Assuntos Exteriores da Espanha, foi grande a receptividade, especialmente da classe médica, tendo sua visita se transformado num meio eficaz de propaganda do regime no exterior.

Conhecido pela defesa dos princípios liberais, Marañon fez declarações que iam ao encontro do que o franquismo desejava divulgar: que na Espanha as ciências e a cultura passavam por um grande desenvolvimento, tendo muito mais liberdade do que o exterior supunha. ${ }^{606} \mathrm{Em}$ agradecimento às atenções recebidas, o médico escreveu ao embaixador brasileiro lotado na Espanha, tecendo muitos elogios ao "hermoso y generoso país" e mostrandose "deslumbrado de la punjanza, del brío, de la fé, de la gran nación..." 607

Em 1954, ocorreu a "semana brasileira" em Madri, evento organizado pela associação de estudantes brasileiros na Espanha, juntamente com o Instituto de Cultura Hispânica. Além de uma exposição de livros brasileiros, o evento contou com a palestra de Marañon, que teceu elogios ao desenvolvimento da medicina no Brasil, lembrando que a Santa Casa de Misericórdia no Rio de Janeiro e o "Hospital Clínico" de São Paulo (referência provável ao Hospital das Clínicas) representavam a transição da medicina clássica para a moderna. ${ }^{608}$

Uma das maneiras mais eficazes de realizar a propaganda do regime espanhol no Brasil, na visão do embaixador José Rojas Y Moreno, era incentivar a difusão de filmes hispânicos, especialmente junto aos colégios

\footnotetext{
${ }^{604}$ Carta-telegrama n. 83 da Secretaria de Estado das Relações Exteriores para Embaixada do Brasil. Rio de Janeiro, 17 jul. 1953. Missões Diplomáticas Brasileiras. Cartas-Telegramas expedidas a Madri (1951-1953). AHI/RJ.

${ }^{605}$ Gregorio Marañon foi um renomado cientista e médico espanhol que, no início do conflito civil da Espanha, se colocou a favor da Segunda República, mas pouco depois se manifestou contra o comunismo. Atualmente, o Hospital Universitário de Madri leva seu nome.

${ }^{606}$ Informe especial do "Servicio de Informaciones de temas españoles" (tomado do despacho do agregado de informações da Embaixada da Espanha no Brasil de 01 set. 1953. Madri, 16 set. 1953). R3191, expt. 77. AMAE.

${ }^{607}$ Carta (cópia) de Gregorio Marañon para Rubens Ferreira de Melo. San Sebastián, 13 set. 1953. Anexo ao ofício n. 313 de Rubens Ferreira de Melo, embaixador do Brasil na Espanha para Vicente Rao, ministro das Relações Exteriores. Madri,17 set. 1953. Missões Diplomáticas Brasileiras. Ofícios recebidos de Madri (setembro a outubro de 1953). AHI/RJ.

608 Ofício n. 71 de Rubens Ferreira de Melo, embaixador do Brasil na Espanha para Vicente Rao, ministro das Relações Exteriores. Madri, 10 fev. 1954. Missões Diplomáticas Brasileiras. Ofícios recebidos de Madri (janeiro a fevereiro de 1954). AHI/RJ.
} 
religiosos liderados por padres espanhóis. ${ }^{609}$ Rojas y Moreno repassou ao ministro espanhol um pedido dos referidos padres, que desejavam projetar para os alunos filmes como Raza, cujo roteiro fora escrito por Francisco Franco. Apresentado para os padrões da época como uma "grande produção espanhola", esse filme foi lançado em 1941 com o objetivo de sintetizar o ideário do regime franquista, e mostrar o espírito valoroso dos espanhóis que haviam lutado ao lado dos nacionalistas. ${ }^{610}$

O embaixador espanhol entrou em contato com os diretores da indústria cinematográfica Vera Cruz, que sugeriram a troca de filmes brasileiros e espanhóis "sem a equiparação de benefícios". O embaixador opinava que: “Quizá comercialmente ellos sacarían más provecho que nosotros, pero en cambio, en el aspecto de propaganda nosotros seríamos los favorecidos". 611

Com a intenção de promover os valores franquistas, o governo espanhol procurou estabelecer vários Institutos de Cultura Hispânica no Brasil. O primeiro deles foi inaugurado junto à cátedra Isabel, la Católica, na Universidade do Rio de Janeiro. O deputado brasileiro Luis Gama Filho foi à Espanha conhecer $\mathrm{o}$ Instituto espanhol, tendo recebido comendas $\mathrm{e}$ homenagens das autoridades espanholas. Como organizador e fundador da cátedra Isabel, la Católica, Gama Filho concedeu entrevistas aos jornais hispânicos e introduziu, junto aos ministros da Educação e dos Exteriores, a proposta de criação da Casa do Brasil na Espanha. ${ }^{612}$

Os vários centros de Cultura Hispânica espalhados pela América Latina visavam transmitir uma imagem idealizada da Espanha enquanto Nação. Em 1956, o embaixador Coelho Lisboa informou ao Itamaraty a importância desses Institutos, que contavam com quarenta e cinco sucursais na América,

${ }^{609}$ Consultando as listas de desembarque dos navios chegados ao porto de Santos na década de 1950, pode-se observar a grande quantidade de espanhóis que se declaravam religiosos. A maioria destinava-se aos conventos e Igrejas do Estado de São Paulo. Tais listas, que obedecem a uma ordem cronológica, encontram-se no Memorial do Imigrante em São Paulo.

610 Segundo Wagner Pinheiro Pereira, o cineasta José Luiz Sáenz de Heredia, primo do fundador da Falange José Antonio Primo de Rivera, ficou encarregado de realizar o filme "que deveria servir de modelo para as próximas produções cinematográficas dos franquistas." (Wagner Pinheiro Pereira. O império das imagens de Hitler: o projeto de expansão internacional do modelo de cinema nazista na Europa e na América Latina (1933-1955). São Paulo, 2008. Tese (Doutorado em História Social) - FFLCH, USP, p. 150).

${ }^{611}$ Despacho n. 82 de Jose Rojas y Moreno, embaixador da Espanha no Brasil para ministro de Assuntos Exteriores da Espanha. Rio de Janeiro, 19 mar. 1951. R3529, expt. 97. AMAE.

612 Ofício n. 39 de Rubens Ferreira de Melo, embaixador do Brasil na Espanha para João neves da Fontoura, ministro das Relações Exteriores. Madri, 24 jan. 1952. Missões Diplomáticas Brasileiras. Ofícios recebidos de Madri (janeiro a março de 1952). AHI/RJ. 
sendo seis delas no Brasil: São Paulo, Rio de Janeiro, Recife, Salvador, Porto Alegre e Natal. ${ }^{613}$

Grande contentamento causou ao governo espanhol o sucesso do filme Marcelino, pan y vino no Brasil que, lançado em 1955, constituiu-se numa eficiente propaganda da Espanha católica. A película, uma co-produção espanhola e italiana, emocionou multidões pelo roteiro que apresentava a história de um órfão criado por padres franciscanos. ${ }^{614} \mathrm{O}$ astro mirim do filme e ator principal, Pablito Calvo, visitou o Brasil em 1958, sendo recebido por Juscelino Kubitschek no Palácio das Laranjeiras. Os principais periódicos do país deram grande destaque à estadia do menino no Rio de Janeiro, tendo sua fotografia ilustrado a capa de Manchete na edição n. 315 , de maio de $1958 .{ }^{615}$

Outro fator de tensão nas relações culturais hispano-brasileiras foram as críticas que a ditadura espanhola recebeu da imprensa no Brasil. Através de intensa correspondência, a diplomacia espanhola solicitou providências do governo brasileiro para coibir e punir tais manifestações. A forma pela qual o Itamaraty respondeu a essas solicitações alterou-se entre as décadas de 1930 e 1950. Se durante o governo Vargas houve uma disposição no comprometimento de censura a tais notícias, nos anos 50 as respostas se deram no sentido de lastimar tais referências, além de afirmar que devido à liberdade de imprensa, esse era um assunto que fugia da competência do MRE.

${ }^{613}$ Ofício n. 472 de João P. G. Coelho Lisboa, embaixador do Brasil na Espanha para João Carlos de Macedo Soares, ministro das Relações Exteriores. Madri, 05 nov. 1956. Missões Diplomáticas Brasileiras. Ofícios recebidos de Madri (novembro a dezembro de 1956). AHI/RJ.

${ }_{614}$ Marcelino, Pan y Vino. Direção de Ladislao Vajda, 1955, Espanha, Itália. No Brasil, uma versão remasteurizada foi apresentada pela distribuidora Versátil Home Video.

615 "Marcelino, mais dois anos de vida", revista Manchete n. 315 de 03 mai. 1958. A revista $O$ Cruzeiro também divulgou fotos de Pablito Calvo quando de sua visita ao Rio de Janeiro: "No Rio de Janeiro Pablito Calvo foi Rei", revista O Cruzeiro n. 29 de 26 abr. 1958, p. 124-129. Biblioteca Nacional. 


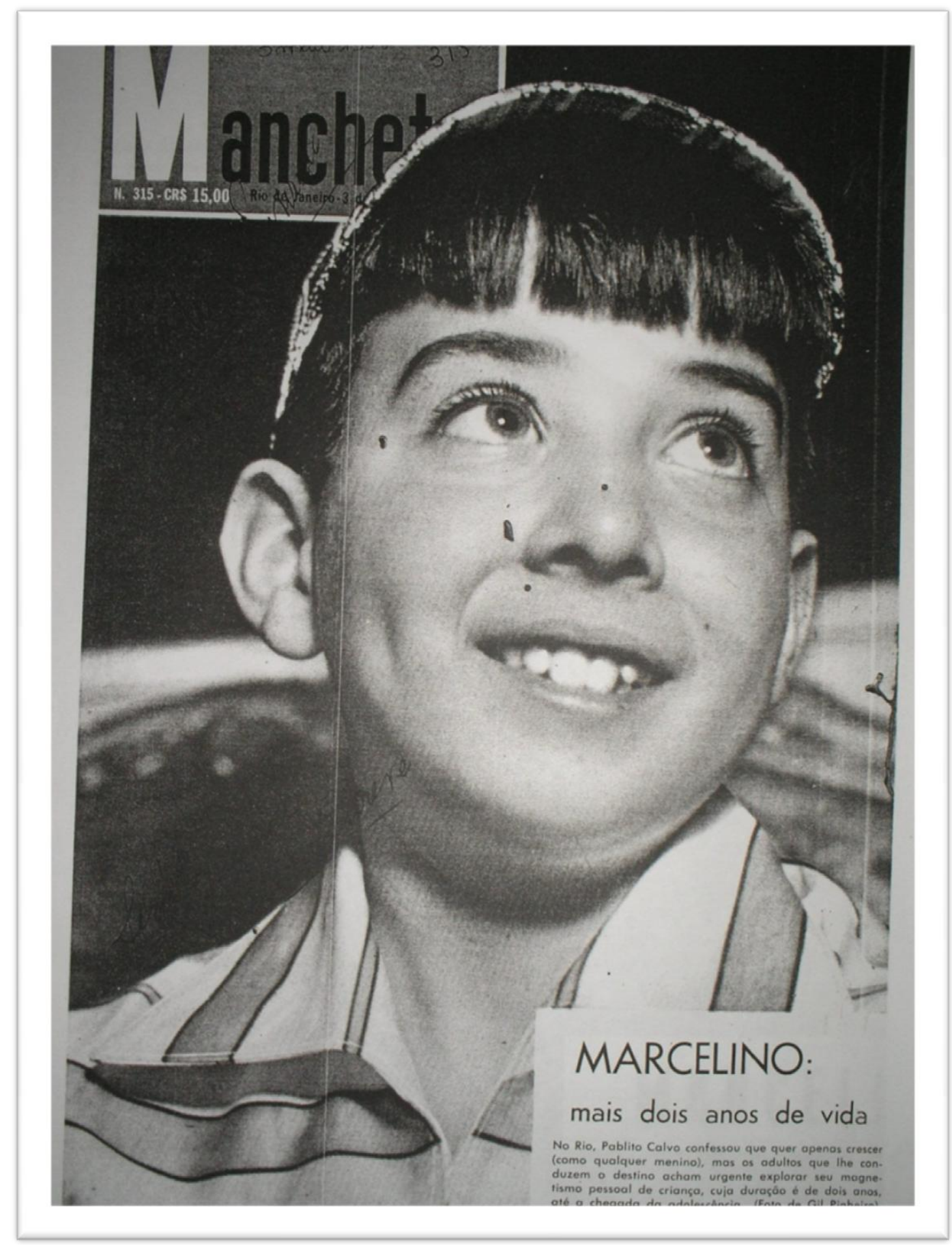

25 - Pablito Calvo, astro mirim do filme espanhol Marcelino, pan y vino, por ocasião de sua visita ao Brasil. Revista Manchete n. 315 de 03 de maio de 1958. Acervo da Associação Brasileira de Imprensa/ RJ. 
Em 1951, um voto de louvor aos fundadores da República espanhola e em repúdio à ditadura franquista foi realizado junto à Câmara municipal do Distrito Federal, fato que gerou protestos da representação espanhola ao Itamaraty. A Secretaria de Estado das Relações Exteriores respondeu que o referido voto em nada modificava a atitude e o sentimento do governo brasileiro diante da Espanha, com a qual desejava manter relações cordiais. Apesar do tom amistoso, Heitor Lyra, na qualidade de secretário interino, concluía que como se tratava de um órgão legislativo, não cabia ao governo brasileiro controlar-Ihe a opinião. ${ }^{616}$

Durante o governo de Juscelino Kubitschek, os órgãos de imprensa simpáticos aos princípios democráticos não pouparam críticas ao regime franquista. Representando esse posicionamento, a revista Manchete, que duas semanas antes havia agradado a representação espanhola no Brasil por dar destaque à presença do ator espanhol Pablito Calvo no Brasil, dedicou páginas a uma reportagem sobre a realidade econômica e social da Espanha de Franco. Evidenciando a influência do Exército no controle das liberdades de opinião, Manchete enriquecia suas considerações com fotografias que denunciavam a pompa dos desfiles militares e, ao mesmo tempo, o "atraso" e o sofrimento de grande parte da população espanhola. O título da reportagem já demonstra o teor das informações: "Baionetas caladas dão a palavra de ordem". Acompanhado de imagens do sofrimento das mulheres espanholas e da ausência de consumidores nas casas comerciais, um dos subtítulos enunciava: "Espanha de hoje: em cada face a marca (amarga) da opressão". 617

Acostumado a encarar o fenômeno censório como um dos elementos centrais da política interna e externa de seu país, o embaixador espanhol mostrou-se ofendido com a referida publicação. ${ }^{618}$ As mostras de

\footnotetext{
${ }^{616}$ Nota n. 42 de Heitor Lyra, secretário-geral interino das Relações Exteriores para Jose Rojas y Moreno, embaixador da Espanha no Brasil. Rio de Janeiro, 03 maio 1951. Representações Estrangeiras. Notas expedidas a Espanha (1946-1951). AHI/RJ.

617 "Baionetas caladas dão a palavra de ordem". Revista Manchete n. 317 de 17 mai 1958, p. 410. ABI/RJ.

${ }^{618}$ De acordo com Hans Jorg Neuschafer "Desde 1939 la censura estuvo tan omnipresente y sus dictámenes fueron tan inescrutables, que ni los autores... ni los periodistas pudieron sustraerse a su control. Es imposible apreciar em su justo término la producción cultural de esta época sin tener em cuenta lo que Abellán denomina El "fenômeno censorio"'. (Hans Jorg Neuschafer. Adiós a la España eterna: la dialectica de la censura: novela, teatro, y cine bajo el franquismo. Barcelona, Madrid: Anthropos; Ministerio de Asuntos Exteriores; Dirección General de Relaciones Culturales y Científicas, 1994, p. 44).
} 
indignação extrapolaram àquelas já manifestadas anteriormente, tendo o representante de Franco solicitado que o governo brasileiro encontrasse mecanismos jurídicos para impedir notícias como aquelas:

Puesto que em España no sería posible, con censura o sin ella, una publicación análoga atacando al Brasil, espera esta Embajada que ese Ministerio de Relaciones Exteriores comparta el deseo de la misma acerca de la conveniencia de encontrar un procedimiento legal que impida estas situaciones o que, producidas, la sancione debidamente. El prestígio español en Brasil estaría así amparado, según lo está el brasileño en España, contra ilícitas agresiones, como la de "Manchete". 619

Certamente as preocupações do embaixador eram maiores naquele momento, porque se tratava da segunda maior revista de circulação no país, portanto, uma das principais formadoras da opinião nacional. Manchete, cujo fundador Adolpho Bloch era amigo de JK, se identificava e apoiava o projeto desenvolvimentista do governo brasileiro. ${ }^{620}$ Assim, a resposta do MRE para o caso provavelmente deu-se nos mesmos parâmetros que as anteriores, sem garantias ou comprometimento de censura.

${ }^{619}$ Nota verbal n. 51 da Embaixada da Espanha no Brasil para Ministério das Relações Exteriores. Rio de Janeiro, 12 maio 1958. Representações Estrangeiras. Notas recebidas da Espanha (1957-1958). AHI/RJ.

${ }^{620}$ Cf Ana Mario Ribeiro de Andrade; José Leandro Rocha Cardoso. Aconteceu, virou manchete. Revista Brasileira de História, vol. 21, n. 41, 2001. Disponível em http://www.scielo.br/scielo.php?pid=S0102 01882001000200013\&script=sci_arttext Acesso em 26 jan. 2009. 


\section{3 - O Itamaraty diante da imigração}

Grande parte da historiografia brasileira convencionou denominar a década de 1950 como "os anos dourados", evidenciando os aspectos positivos que renovaram as esperanças e a crença da população brasileira no desenvolvimento do país. A aparente estabilidade democrática e a efervescência cultural do período pareciam prometer a efetivação do projeto desenvolvimentista consubstanciado no slogan " 50 anos em 5". ${ }^{621}$

Nesse contexto de otimismo se inseria a idéia de que o país deveria receber os estrangeiros que pudessem auxiliar o governo em sua missão. No final dos anos 40 , as elites brasileiras, que nunca haviam abandonado suas preocupações com o tipo de estrangeiro ideal para o país, voltariam a dar mais ênfase nas discussões sobre o fluxo de imigrantes que se dirigiam ao "país do futuro".

O Brasil recebeu entre o final dos anos 40 e final dos anos 50, uma segunda leva de imigrantes espanhóis que se direcionaram especialmente para o Estado de São Paulo. Vale lembrar que os espanhóis e seus descendentes já marcavam presença no Brasil desde o início do século XX, quando se deu o auge da imigração dessa nacionalidade. Nesse primeiro momento, egressos de várias regiões da Espanha se direcionaram ao Brasil, fugindo de uma situação de miséria e desemprego. ${ }^{622}$

A imigração espanhola para o Brasil constituiu-se num fator importante para as relações hispano-brasileiras, despertando maiores atenções dos diplomatas no pós-guerra. A partir de 1945 tornaram-se freqüentes os ofícios enviados pela representação brasileira em Madri ao Itamaraty, cujo

\footnotetext{
${ }^{621}$ Outros aspectos desse período, no entanto, não devem ser menosprezados. Essa também foi a época de "... racionamentos, demolições de casarões populares, surgimento das primeiras favelas paulistas, inflação implacável, greves, quebra-quebras, alta especulação imobiliária levando ao espalhamento e à aglomeração populacional, redirecionamento político do país, voltando-se para os Estados Unidos, inchaço populacional dos grandes centros, aprimoramento da publicidade e da cultura de consumo, incremento da sucata, que as populações moventes souberam reaproveitar como ninguém." Elena Pájaro Peres. Exuberância e invisibilidade, op. cit., p.63.

622 Sobre o primeiro surto imigratório de hispânicos para o Brasil ver: Ismara Izepe de Souza. Espanhóis: história e engajamento, op. cit.; Marília Dalva Klaumann Cánovas, op. cit.
} 
tema era a questão emigratória e a necessidade de estabelecer um acordo com a Espanha nessa área. O Brasil deveria atrair um imigrante cujo perfil fosse condizente com o projeto étnico e político defendido pelo governo Vargas durante o Estado Novo. ${ }^{623}$

Em 1945, Pimentel Brandão alertava para a importância de uma seleção criteriosa dos cidadãos desejosos de virem ao país, opinando que a melhor imigração seria a dos espanhóis do campo "menos corrompidos" e "mais adaptáveis à vida brasileira". Completava ainda que os espanhóis do norte eram os ideais e que o Consulado de Vigo, na Galícia, deveria se responsabilizar pelo processo seletivo. ${ }^{624}$

O governo brasileiro desejava atrair especialmente dois tipos de imigrantes: o agricultor e o técnico. O primeiro deveria contribuir para o crescimento demográfico, visto como necessário para o enaltecimento do país e o segundo perfil deveria auxiliar no projeto de industrialização brasileiro. $\mathrm{Na}$ mentalidade dos que pensavam a política imigratória, os espanhóis apresentavam-se como um grupo ideal para se fixarem em território nacional, especialmente por suas características étnicas e culturais: eram brancos e católicos.

O Brasil, ao final dos anos 40, ganhou destaque nas discussões sobre o direcionamento dos refugiados de guerra, sendo visto pela ONU como um dos países que ofereciam condições ideais para receber esse contingente. Para o Itamaraty um novo desafio se colocava: não desejava frustrar as expectativas dos países ocidentais junto àquele fórum internacional, mas também pretendia manter coerência com a política imigratória brasileira, que não intencionava receber deslocados de guerra. Importante lembrar que parte desse contingente era constituída por sobreviventes do Holocausto estigmatizados pela diplomacia brasileira.

Voz dissonante entre a diplomacia, Hélio Lobo foi um dos raros diplomatas a defender com ênfase a vinda de refugiados de guerra para o Brasil. Como membro da delegação brasileira junto a OIR (Organização

\footnotetext{
${ }^{623}$ Sobre o perfil do imigrante indesejável ver: Maria Luiza Tucci Carneiro. A imagem do imigrante indesejável. Revista Seminários. São Paulo, v. 3, n. dez., p.21-42, 2003.

${ }^{624}$ Ofício n. 211 de Mario de Pimentel Brandão, embaixador do Brasil na Espanha para ministro das Relações Exteriores. Madri, 25 jun. 1945. Missões Diplomáticas Brasileiras. Ofícios recebidos de Madri (maio a agosto de 1945). AHI/RJ.
} 
Internacional para os Refugiados), esse diplomata apontou ao Itamaraty os aspectos positivos de se receber esses grupos, entre eles o fato da maioria compor-se de pessoas cultas e de ideologia anticomunista. ${ }^{625} \mathrm{Em}$ sua tese de Livre-Docência, a historiadora Maria Luiza Tucci Carneiro demonstra que mesmo antes do conflito mundial, Lobo mostrara-se chocado com os fatos que afligiam a Europa. Este diplomata procurava "sensibilizar o governo brasileiro a tornar-se um "país de acolhimento" assumindo uma posição de solidariedade orgânica, forma específica de relacionamento nas sociedades modernas."

Parte da diplomacia considerava o imigrante espanhol desejável do ponto de vista racial, mas não via com bons olhos a emigração "espontânea". Pimenta Bueno e Osório Dutra, enquanto cônsules em Barcelona sustentaram a necessidade de tomar as rédeas do fluxo emigratório. Pimenta Bueno defendia entusiasticamente a imigração coletiva a partir de contratos de trabalho e Dutra, por sua vez, considerava que só a emigração dirigida, fruto de um acordo entre os dois governos, poderia contribuir para 0 desenvolvimento da agricultura e da indústria no Brasil. ${ }^{627}$

O controle da emigração tinha também como objetivo impedir que cidadãos que tivessem algum histórico de militância política adentrassem em território nacional. O espanhol enquanto "agitador político" dos grandes centros urbanos, compunha o imaginário das elites políticas brasileiras. Convém lembrar, que as lideranças sindicais e o movimento anarquista contaram com estrangeiros, destacando-se entre eles muitos espanhóis. ${ }^{628}$

Para agilizar o processo de concessão de vistos permanentes aos candidatos à emigração, a Secretaria de Estado das Relações Exteriores orientou a Embaixada em Madri e os Consulados a simplificar a documentação

${ }^{625}$ Ofício n. 29 de Hélio Lobo, da Delegação brasileira à Comissão Preparatória da OIR para Raul Fernandes, ministro das Relações Exteriores. Genebra, 30 jun. 1948. Diversos no Exterior. Ofícios recebidos da Delegação Brasileira na OIR (agosto de 1947 a 1948). AHI/RJ.

${ }_{626}$ Maria Luiza Tucci Carneiro. Cidadão do mundo, op. cit., p.149.

627 Ofício n. 125 de Pimenta Bueno, cônsul adjunto em Barcelona para Samuel de Souza Leao Gracie, ministro interino das Relações Exteriores. Barcelona, 30 set. 1946. Consulados Brasileiros. Ofícios recebidos de Barcelona (1946). Ofício n. 64 de Osório Dutra, cônsul brasileiro em Barcelona para Vasco Leitão da Cunha, encarregado de negócios do Brasil na Espanha. Barcelona, 13 ago. 1948. Consulados Brasileiros. Ofícios recebidos de Barcelona (1948). AHI/RJ.

${ }^{628}$ Entre os líderes anarquistas da greve que paralisou a capital paulista em 1917, estavam alguns espanhóis. Sobre esse assunto ver: Christina Roquette Lopreato. $O$ espírito da revolta: a greve geral anarquista de 1917. São Paulo: Annablume; Fapesp, 2000. 
exigida. Entretanto, alertava para não abrir mão, quando julgasse necessário, dos documentos comprobatórios de antecedentes políticos. ${ }^{629}$

Como resultado do interesse de ambos os governos pela imigração espanhola, a Embaixada do Brasil em Madri enviou ao Itamaraty, em 1953, um projeto de acordo de emigração que reconhecia a prevalência da emigração voluntária, mas tentava dar-lhe uma direção. Proposto pelo governo franquista, o projeto previa que somente os agricultores ficariam livres de algumas formalidades, como a apresentação de carta de chamada ou de contrato de trabalho. Os custos das passagens ficariam por conta do governo brasileiro somente quando se tratasse da emigração dirigida. ${ }^{630}$

A preferência brasileira pelo emigrante do campo fez com que milhares de espanhóis se declarassem agricultores mesmo sem o serem de fato. Apesar da disposição do Brasil em ditar normas, a emigração voluntária e espontânea acabou prevalecendo. $\mathrm{O}$ acordo de migração entre a Espanha e 0 Brasil somente seria assinado em 1960, momento em que o fluxo de espanhóis para o Brasil já havia diminuído consideravelmente. ${ }^{631}$

Com o objetivo de coordenar o movimento migratório na Europa após o conflito mundial, foi criado o CIME - Comité Intergovernamental para as Emigrações Européias - do qual o Brasil fazia parte, desde a sua criação em 1952. Através do referido comitê, o governo brasileiro recebeu milhares de europeus, incluindo os espanhóis, a partir de 1957. Durante 1956, o MAE fez várias consultas à Embaixada do Brasil pedindo auxílio para o ingresso espanhol no CIME. O Itamaraty respondeu afirmativamente autorizando a Embaixada a declarar o apoio brasileiro. ${ }^{632}$

A situação econômica e social da Espanha possibilitou o incentivo à emigração em massa pelo governo franquista. Apesar de o país acelerar seu

\footnotetext{
${ }^{629}$ Carta-Telegrama da Secretaria de Estado das Relações Exteriores para a Embaixada do Brasil na Espanha. Rio de Janeiro, 12 set. 1951. Missões Diplomáticas Brasileiras. CartasTelegramas expedidas a Madri (1949-1950). AHI/RJ.

630 "Proyecto de acuerdo de emigración entre España y Brasil". Anexo ao ofício n. 15 de Rubens Ferreira de Melo, embaixador do Brasil na Espanha para João Neves da Fontoura, ministro das Relações Exteriores. Madri, 09 jan. 1953. Missões Diplomáticas Brasileiras. Ofícios recebidos de Madri (janeiro a março de 1953). AHI/RJ.

631 Telegrama da Secretaria de Estado das Relações Exteriores para Embaixada do Brasil em Madri. Rio de Janeiro, 19 dez. 1960. Missões Diplomáticas Brasileiras. Telegramas expedidos à Madri (1957-1960). Seção Arquivo Histórico. CDO/MRE.

632 Telegrama da Secretaria de Estado das Relações Exteriores para Embaixada do Brasil na Espanha. Rio de Janeiro, 10 fev. 1956. Missões Diplomáticas Brasileiras. Telegramas expedidos à Madri (1950 -1956). AHI/RJ.
} 
processo de recuperação da guerra civil, e paulatinamente aceitar a necessidade de incorporar a economia espanhola à internacional, os níveis sociais ainda eram insatisfatórios no início dos anos 50 . Outro fator que deve ser considerado quando se analisa as motivações da emigração é o desejo e a ânsia pela mobilidade social, e pela aquisição de um estilo de vida de consumo. $^{633}$

Interessados na emigração como elemento de alívio das tensões sociais, as autoridades franquistas tinham dificuldades em reconhecer que aquele movimento tinha suas raízes na pobreza e na profunda desigualdade social que imperava no país. A emigração, oficialmente, era entendida como uma contribuição da Espanha para outros povos, transformando-se "em generosidade e missão hispânica" ${ }^{634}$

Em 1959, o jornal Arriba explicava o movimento emigratório como fruto da liberdade de escolha individual. Ao noticiar o II Congresso de Emigração Espanhola a Ultramar, este periódico propalava um "novo conceito de emigração": "o emigrante é um homem que usa a sua liberdade de decisão para escolher um cenário para sua existência e melhor possibilidade de bemestar". ${ }^{635}$ Tais considerações evidenciavam a recusa do governo espanhol em aceitar o caráter emergencial daquele movimento.

A imagem positiva de um país próspero e em pleno crescimento não apenas servia ao projeto brasileiro de política externa, como também ao governo espanhol. Assim, as notícias sobre o Brasil sempre procuravam mostrar que os espanhóis se adaptariam perfeitamente ao seu estilo de vida. As possibilidades de ascensão social também eram destacadas. O jornal $A B C$ informava que muitos “...ocupan destacadas posiciones em el comercio, en la industria y en la agricultura”. ${ }^{636}$

\footnotetext{
${ }^{633}$ Sobre essa questão Elena Pájaro Peres afirma que: “... a dispersão foi a saída encontrada por milhares de homens e mulheres na tentativa de superar o amortecimento e a desigualdade presentes na Espanha do pós-guerra. Também era a forma mais rápida de os camponeses espanhóis entrarem em contato com o horizonte de conforto e abundância prometido pela modernidade." ( $A$ inexistência da terra firme, op. cit., p.146).

${ }^{634}$ Idem, p.335.

635 Ofício n. 709 da Embaixada do Brasil na Espanha para a Secretaria de Estado das Relações Exteriores. Madri, 06 out. 1959. Missões Diplomáticas Brasileiras. Ofícios recebidos de Madri (outubro de 1959). AHI/RJ.

636 "La emigración española a Brasil", jornal ABC. Madri, 20 mar. 1958. Anexo ao ofício n.372 da Embaixada do Brasil na Espanha para a Secretaria de Estado das Relações Exteriores. Madri, 01 abr. 1958. Missões Diplomáticas Brasileiras. Ofícios recebidos de Madri (abril de 1958). AHI/RJ.
} 
Rojas y Moreno mencionou, em setembro de 1949, as contribuições positivas dos espanhóis à "qualidade" étnica da população brasileira:

Es indubidable que el Brasil, independientemente del problema de "brazos para la agricultura", y teniendo en cuenta solamente el aspecto demográfico de la cuestión, - tiene vital interés en aumentar su población de raza blanca, porque la negra, muy prolífica como es sabido, va cresciendo de dia en dia y existe un verdadero peligro de que, dentro de dos generaciones, sea esta, indiscutiblemente, - la más numerosa. ${ }^{637}$

Tais considerações eram reforçadas pela maioria dos diplomatas pertencentes aos quadros do Itamaraty que, como vimos, coadunavam com as preocupações acerca da preponderância do elemento negro na sociedade brasileira.

Com o recrudescimento da emigração espanhola para o Brasil, o Consulado na cidade de Vigo ganhou maior importância, sendo elevado, em 1953, à categoria de Consulado-Geral. ${ }^{638} \mathrm{O}$ novo status possibilitava que os vistos nos passaportes fossem realizados naquela repartição, o que poupava os emigrantes galegos de arcar com os custos da viagem até Barcelona.

Em 1958, o prefeito da cidade galega de La Coruña solicitou à Embaixada brasileira que o Consulado honorário naquela cidade também fosse autorizado a visar os passaportes dos emigrantes. ${ }^{639}$ Pela reincidência da solicitação, pode-se afirmar que o governo brasileiro não respondeu positivamente. Não havia interesse por parte do Itamaraty em aumentar a categoria de tais repartições devido aos custos financeiros que isso acarretaria. Com a diminuição significativa de candidatos à emigração, o Consulado em Vigo seria novamente rebaixado em $1962 .{ }^{640}$

\footnotetext{
${ }^{637}$ Despacho n. 433 de Jose Rojas y Moreno, embaixador da Espanha no Brasil para ministro de Assuntos Exteriores da Espanha. Rio de Janeiro, 03 set. 1949. R5672, expt. 43. AMAE.

${ }^{638}$ Carta-telegrama n. 83 da Secretaria de Estado das Relações Exteriores para Embaixada do Brasil na Espanha. Rio de Janeiro, 28 out. 1953. Missões Diplomáticas Brasileiras. Cartastelegramas expedidas a Madri (1951-1953). AHI/RJ.

639 Ofício n. 751 de João P. G. Coelho Lisboa para Francisco Negrão de Lima, ministro das Relações Exteriores. Madri, 15 jul. 1958. Missões Diplomáticas Brasileiras. Ofícios recebidos de Madri (julho a agosto de 1958). AHI/RJ.

640 Segundo Elena Pájaro Peres o Consulado de Vigo seria novamente elevado à categoria de "Consulado Geral" em 1964. (A inexistência da terra firme, op. cit., p.111).
} 
Os trâmites burocráticos para a concessão de visto permanente nem sempre ocorriam no tempo esperado pelo candidato à emigração. A falta de perspectiva numa Espanha autoritária e de imensas desigualdades sociais, aliada às dificuldades em se conseguir um visto pelos meios legais, levou alguns espanhóis a envolverem-se com uma rede que, em troca de dinheiro, agilizava a documentação necessária à emigração. Grande parte dos candidatos à emigração não possuíam recursos financeiros para aventarem tal possibilidade, mas é possível que a situação enunciada acima tenha levado muitos a oferecer o pouco que tinham para terem a entrada no Brasil garantida.

Dois espanhóis, funcionários do Consulado de Barcelona, envolveram-se com irregularidades. Em suas memórias, Raul Bopp cita a atuação de uma agência clandestina, cuja atividade centrava-se na "venda de vistos" em passaportes. ${ }^{641}$ Bopp, na qualidade de cônsul brasileiro em Barcelona realizou, em caráter confidencial, graves acusações a Ramon Ibañez, que coordenava a referida organização. Num extenso telegrama, o cônsul explicava que tinha provas de que outras pessoas participavam do esquema. Ibañez, que atuava como cônsul interino em Valencia, obteve a nacionalidade brasileira, o que explica as considerações indignadas de Bopp sobre a solução branda dada pelo Itamaraty ao caso.

Em 1935, Ibañez escreveu diretamente a Getúlio Vargas solicitando que the fosse concedida a nacionalidade brasileira uma vez que, segundo as leis espanholas, perderia a cidadania do seu país por prestar serviços por mais de dez anos consecutivos como auxiliar no Consulado do Brasil em Barcelona. ${ }^{642}$ Raul Bopp defendia a cassação da nacionalidade brasileira, dada a gravidade daquela denúncia. ${ }^{643}$

A organização clandestina atuava, não somente cobrando para a aquisição dos vistos permanentes, como também facilitava negócios

641 Em suas memórias, Raul Bopp relata questões concernentes à carreira diplomática. Ao mencionar a sua experiência como cônsul em Barcelona, dedica algumas páginas ao relato da descoberta de irregularidades praticadas por auxiliares contratados. Esses, segundo o autor, faziam parte de uma organização privada que vendia vistos permanentes para espanhóis emigrarem para o Brasil. (Raul Bopp. Memórias de um embaixador, op. cit., p.138).

642 Carta de Ramon Ibañez para Presidente da República dos Estados Unidos do Brasil. Barcelona, 21 out. 1935. Consulados Brasileiros. Ofícios recebidos de Barcelona (1935 a abril de 1936). AHI/RJ.

643 Telegrama confidencial de Raul Bopp para Ministério das Relações Exteriores. Barcelona, 26 nov. 1952. Consulados Diversos. Telegramas e cartas recebidas (1947-1957). Arquivo de Correspondência Especial. CDO/MRE. 
comerciais com empresas brasileiras. Eis alguns fragmentos da descrição do cônsul:

Ainda com relação ao caso dos irmãos lbañez e para que não subsistam dúvidas sobre a culpabilidade dos mesmos, trago alguns dados complementares sobre o modo como se processavam os negócios de vistos para o Brasil, na zona de Valência, em cuja organização Miguel Mas Santa Creu, associado a Ramon Ibañez, era a principal figura. $O$ interessado em emigrar para o nosso país, procurava naturalmente o Consulado honorário do Brasil em Valência, onde era atendido por Valero. O candidato era, em seguida encaminhado a Miguel Mas Santa Creu, em Barcelona, que providenciava a obtenção do visto junto ao seu sogro e sócio, o vice-cônsul interino (!) Ramon Ibañez. O candidato da citada zona, que não viesse com as senhas dessa Organização, encontrava uma série de dificuldades para a obtenção do visto, com risco de perda das passagens pagas. Tenho de outros gestores que, por experiência própria, conheciam a fundo a organização Santa Creu e lbañez alguns dados sôbre o funcionamento dessa máquina, cuja peça principal estava instalada dentro do próprio Consulado Geral do Brasil. (... $)^{644}$

Após expor minuciosamente os casos de cidadãos que esperaram

por mais de um ano pelo visto e que o conseguiram imediatamente após recorrer à intermediação do referido esquema, Bopp concluía que:

Não tenho dados para informar qual a quota que cabia a Ramon Ibañez nessas negociatas com coisas do Consulado. A organização em apreço, com Miguel Mas Santa Creu na chefia das atividades externas, era complexa. Não somente a concessão do visto para o Brasil era objeto de negócio, como também as reservas das passagens, numa articulação com a Companhia Juan Salvador. Também as oportunidades comerciais para o Brasil, quando tratava-se de negócios de vulto, estavam sendo canalizados a um terceiro membro dessa organização. (...) Com toda essa soma de irregularidades a ponto de provocarem uma denúncia do próprio Ministério, na sua CT n. 27, deste ano,e abusando de sua posição de Vice-Cônsul interino para pôr o Consulado Geral a serviço de uma camarilha sem escrúpulos, Ramon Ibañez apressou-se em seguir para o Rio, dramatizar a "injustiça" de que foi vítima. Tenho informações de que 0 mesmo pleiteia presentemente a sua reintegração como auxiliar, alegando a sua condição de brasileiro, naturalizado há 4 anos, quando a sua participação evidente nessa indústria de exploração de incautos, envolvendo o bom nome dêste Consulado Geral, constitue já base suficiente para a cassação do seu título de nacionalidade."645

644 Idem. 
Munido de depoimentos de diversos espanhóis que denunciaram as dificuldades para se obter os vistos sem a intermediação dos referidos funcionários, o cônsul mostrava-se disposto a dissipar as irregularidades na concessão dos vistos. Contava para isso com o auxílio da cônsul-adjunto Marina Moscoso, que passou a receber pessoalmente todos os candidatos à concessão de vistos. Bopp e a referida cônsul conseguiram aglutinar provas suficientes da atuação dessa agência clandestina que facilitava a emigração para o Brasil. ${ }^{646}$

Diante das "provas" do envolvimento dos irmãos Ibañez com a venda de vistos, o Itamaraty autorizou o Consulado de Barcelona a afastá-los de seus respectivos cargos. ${ }^{647}$ Ramon Ibañez viajou ao Rio de Janeiro para alegar sua inocência. As memórias de Bopp, escritas anos depois, indicam a concretização do que ele temia ao final de 1952: o Itamaraty não cassou a cidadania, tampouco efetivou a punição dos acusados. ${ }^{648}$

A existência de irregularidades desse porte chamou a atenção do Conde de Casa Rojas, embaixador espanhol no Brasil, que sugeriu ao MAE que fossem tomadas providências para que, sem impedir a saída de espanhóis que buscavam trabalho no Brasil, se evitasse a exploração dos mesmos pelas referidas agências clandestinas. ${ }^{649} \mathrm{~A}$ necessidade de um acordo de emigração que impedisse a exploração dos espanhóis era alardeada constantemente por Conde de Casa Rojas. O próprio ministro Martin Artajo, chegou a pedir que 0 embaixador insistisse junto ao Itamaraty na importância de se chegar a um acordo formal sobre emigração. ${ }^{650}$

Outra medida tomada pelo governo franquista para controlar a emigração e evitar a atuação das referidas organizações foi a criação, em 1956, do Instituto Espanhol de Emigração. Esse tinha por objetivo tutelar e

${ }^{646}$ Telegrama (confidencial) de Raul Bopp, cônsul brasileiro em Barcelona para Ministério das Relações Exteriores do Brasil. Barcelona, 22 jul. 1952. Consulados Diversos. Telegramas expedidos (1947-1957). Arquivo de Correspondência Especial. CDO/MRE.

647 Telegrama (confidencial) da Secretaria de Estado das Relações Exteriores para o Consulado do Brasil em Barcelona. Rio de Janeiro, 30 jul. 1952. Consulados Diversos. Telegramas expedidos (1947-1957). Arquivo de Correspondência Especial. CDO/MRE.

648 Bopp critica a atitude do Itamaraty de não punir com severidade os irmãos lbañez, afirmando que os mesmos foram reintegrados a outros consulados brasileiros depois de um inquérito presidido no Rio de Janeiro. (Raul Bopp. Memórias de um embaixador, op. cit., p.138).

649 Despacho n. 206 de Jose Rojas y Moreno, embaixador da Espanha no Brasil para ministro de Assuntos Exteriores da Espanha. Rio de Janeiro, 30 mar.1951. R5672, expt. 41. AMAE.

650 Telegrama de Alberto Martin Artajo, ministro de Assuntos Exteriores para embaixador do Brasil na Espanha. Madri, 12 abr. 1951. R5672, expt. 41. AMAE. 
fiscalizar os contratos de trabalho, assim como orientar os interessados na emigração sobre as condições de vida e de trabalho dos locais onde pretendiam dirigir-se. ${ }^{651} \mathrm{~A}$ tentativa do governo espanhol de evitar a exploração de seus súditos em terras brasileiras continha, a nosso ver, um componente de propaganda política. Nas entrelinhas desta iniciativa, persistia a preocupação do governo franquista em impedir que o movimento migratório servisse para reproduzir externamente uma imagem negativa da Espanha.

\section{O Instituto Nacional de Imigração e Colonização}

Durante o século XX persistiu, por parte de alguns intelectuais e políticos brasileiros, um discurso de cunho racista, que valorizava a promoção do branqueamento da população brasileira. Expoentes da intelectualidade foram partidários da idéia de que a emigração deveria contribuir para minimizar a influência negra no Brasil. Dessa forma, imigrantes portugueses, italianos e espanhóis constituíam-se no perfil desejável, uma vez que eram brancos e por sua cultura, considerados mais assimiláveis à vida brasileira.

Vale lembrar que, desde o início do século XX, alguns grupos de estrangeiros, como os japoneses, foram considerados refratários aos costumes e à cultura nacionais, havendo resistência de intelectuais e políticos ao incentivo a esse tipo de emigração. Durante o Estado Novo, especialmente a partir de 1938, o discurso contra alemães e japoneses com ênfase na tese do enquistamento recrudesceu, servindo aos interesses daqueles que entendiam todos os estrangeiros como inimigos em potencial. ${ }^{652}$

Essa corrente de pensamento que influenciou as ações do Brasil frente aos estrangeiros, conviveu com aquela que reconhecia e reforçava a importância da mestiçagem e do caráter multiétnico da população brasileira. No entanto, a tese do branqueamento racial não foi totalmente abandonada

651 Ofício n. 130 de Rubens Ferreira de Mello, embaixador do Brasil na Espanha para José Carlos de Macedo Soares, ministro das Relações Exteriores. Madri, 02 abr. 1956. Missões Diplomáticas Brasileiras. Ofícios recebidos de Madri (abril a maio de 1956). AHI/RJ.

${ }_{652}$ De acordo com Márcia Yumi Takeuchi, os meios intelectuais e políticos, apesar de considerarem os nipônicos como "bons trabalhadores", o estigmatizaram como estrangeiros inassimiláveis, perigosos à segurança nacional. (Marcia Yumi Takeuchi. O perigo amarelo. Imagens do mito, realidade do preconceito (1920-1945). São Paulo: Humanitas; FAPESP, 2008). 
durante a Era Vargas. Considerando-se que a maior parte da diplomacia brasileira compactuava com a idéia de que o caráter mestiço do povo brasileiro apresentava-se como um "problema" a ser resolvido, entendemos que a emigração de grupos europeus se apresentava como uma "solução possível".

Os espanhóis possuíam um perfil condizente com o projeto étnico defendido por parte da elite brasileira, mas isso não os excluiu de um rigoroso processo seletivo. Efetivaram-se, inclusive na "democrática" década de 1950, medidas extremamente restritivas à entrada de determinados imigrantes. Os indesejáveis não eram somente os "subversivos políticos" e os grupos considerados inassimiláveis, mas qualquer um que portasse características consideradas anômalas. A seleção deveria permitir que somente os "aptos" física e psicologicamente adentrassem no Brasil.

Com o intuito de controlar rigorosamente a entrada dos imigrantes foi criado, durante o segundo governo de Vargas, o Instituto Nacional de Imigração e Colonização (INIC), herdeiro do Conselho de Imigração e Colonização (CIC), em franca atividade desde 1938. O INIC contava com a participação de representantes de todos os ministérios, dentre os quais o MRE e o Ministério da Justiça. Este Instituto manteve, durante vários anos, a Revista de Imigração e Colonização, cujos colaboradores deveriam ajudar a pensar uma política migratória para o Brasil que favorecesse a entrada de cidadãos "ideais". Diplomatas, psiquiatras, juristas, educadores, entre outros, colaboravam assiduamente com a revista, sustentando o pensamento preconceituoso das elites brasileiras sobre o imigrante desejável. ${ }^{653}$

Centenas, senão milhares de espanhóis foram impedidos de entrar no Brasil por serem portadores de algum problema de saúde. O discurso dos membros do Conselho de Imigração e Colonização, e posteriormente do INIC, deixa evidente o cumprimento de uma política imigratória extremamente restritiva e intolerante. ${ }^{64}$ A concessão de vistos aos trabalhadores que

\footnotetext{
653 Sobre a revista de Imigração e Colonização ver: Osvaldo Nunes de Siqueira. Biotipologia do Imigrante no discurso da Revista de Imigração e Colonização (1940-1955). São Paulo, 2006. Dissertação (Mestrado em História Social) - FFLCH, USP.

${ }^{654}$ Elena Pájaro Peres analisou os discursos presentes na Revista de Imigração e Colonização acerca do imigrante espanhol (Proverbial hospitalidade? A Revista de Imigração e Colonização e o discurso oficial sobre o imigrante (1945-1955). Acervo, revista do Arquivo Nacional. Rio de Janeiro, Arquivo Nacional, v.10, n² 2, p. 53-70, jul/dez.1997, 1998).
} 
pudessem contribuir para o progresso do país obedecia a uma legislação específica, que não permitia a entrada de portadores de lesões que implicassem na redução da capacidade de trabalho. A avaliação dessa capacidade se fazia a partir de critérios que se pretendiam objetivos, mas que na maioria das vezes, se mesclavam a critérios subjetivos, dando margem para arbitrariedades.

O presidente do CIC, em correspondência com Mario de Pimentel Brandão, então Secretário-Geral do Itamaraty, sustentava, em dezembro de 1952, uma política migratória que permitisse somente a entrada de cidadãos saudáveis e fisicamente dispostos a servir à nação. Propunha a implementação de cotas diminutas que restringissem a entrada de familiares de trabalhadores que possuíssem alguma deficiência. Fazendo valer a "ideologia do trabalho", enfatizava que estes representavam um "peso morto na economia da Nação":

É de se esclarecer ainda que o cônsul deverá dispensar a maior atenção na concessão dos vistos a famílias com elementos deficientes fisicamente, porque, representando estes um peso morto na economia da nação, o seu número deve ser restrito as possibilidades dos elementos ativos, a fim de não os onerar demasiado e destarte criar um desajustamento. ${ }^{655}$

Tratando 0 assunto dessa forma, o referido Conselho desconsiderava os laços de afetividade das famílias que emigravam. 0 Itamaraty obedecia fielmente às orientações do INIC para os casos que dependiam de sua permissão. Como afirmava a SERE à Embaixada: "A atual orientação do INIC é no sentido de evitar a entrada de imigrantes que, de futuro, apelando para a feição humana da reintegração de família, venham a promover a admissão no país, de parentes enfermos e inúteis". 656

Observações como essas eram recorrentes na correspondência enviada pelo Itamaraty à Embaixada e aos diversos Consulados brasileiros na Espanha. Todo candidato à emigração tinha que apresentar aos consulados brasileiros um laudo médico que era remetido ao Itamaraty que, por sua vez, o

655 Ofício n. 5595 de Fernando Nilo de Alvarenga, presidente do Conselho de Imigração e Colonização para Mario de Pimentel Brandão, secretário do Ministério das Relações Exteriores. Rio de Janeiro, $31 \mathrm{dez}$. 1952. Diversos no Exterior. Ofícios recebidos do Conselho de Imigração e Colonização (dezembro de 1952). AHI/RJ.

${ }^{656}$ Carta-Telegrama n. 116 da Secretaria de Estado das Relações Exteriores para Embaixada do Brasil em Madri. Rio de Janeiro, 25 set. 1954. Missões Diplomáticas Brasileiras. Ofícios expedidos a Madri (1954-1956). AHI/RJ. 
encaminhava ao INIC. Junto aos ofícios enviados pelos consulados brasileiros ao MRE encontram-se fichas intituladas "Consulta sobre visto dependente de aprovação pelo INIC". O parecer do referido Instituto era transmitido aos consulados pelo Itamaraty, o que em muitos casos demorava meses ou mais de um ano. Muitos casos são dramáticos, por envolverem o destino de famílias inteiras, que poderiam ter recebido um tratamento mais humano e menos burocrático por parte das autoridades brasileiras.

Dentre os inúmeros pedidos de vistos que dependiam do parecer do INIC, chamou-nos a atenção o do menor Narciso Cruz Gabriel, cuja documentação e laudo médico foram enviados pela Embaixada em Madri à SERE, em abril de 1957. Oficialmente, a Embaixada pedia maior rapidez na resposta do INIC por tratar-se de um menor de cinco anos de idade, cuja família estava em precárias condições financeiras, tendo se desfeito da casa em que moravam por terem a viagem marcada para o final daquele mês. $O$ ofício acrescentava ainda que a família não esperava que o defeito físico do menor impediria a viagem de todos. O pai de Cruz Gabriel já residia em São Paulo e a emigração do restante da família estaria recomendada pelo CIME. ${ }^{657}$ Os conselheiros do INIC parecem não ter se sensibilizado com a situação descrita, uma vez que o parecer demorou o mesmo tempo que de outros casos para ser entregue ao Itamaraty: cerca de quatro meses. Em agosto daquele ano, o presidente do INIC informou o MRE sobre o indeferimento do pedido de visto para Narciso Cruz Gabriel, tendo em vista o "pronunciamento desfavorável do setor de saúde desse órgão". 658

A orientação para que pessoas consideradas "inúteis" do ponto de vista da capacidade produtiva não adentrassem em território nacional, parece ter impedido que os conselheiros do INIC levassem em consideração as especificidades de cada situação. Por vezes, havia também a desarticulação entre as representações consulares na Espanha e o referido Instituto. Em muitos casos, o parecer do consulado era favorável à concessão do visto, o que entrava em desacordo com o indeferimento do mencionado Instituto.

657 Ofício n. 171 da Embaixada do Brasil na Espanha para Secretaria de Estado das Relações Exteriores. Madri, 09 abr. 1957. Missões Diplomáticas Brasileiras. Ofícios recebidos de Madri (abril a maio de 1957). AHI/RJ.

658 Ofício (cópia) do presidente do Instituto Nacional de Imigração e Colonização (s/ass.) para a Secretaria de Estado das Relações Exteriores. Rio de Janeiro, 06 ago. 1957. Ofícios recebidos do INIC (julho a dezembro de 1957). AHI/RJ. 
Em 1958, o agricultor Eusébio Peguero Tena foi impedido de desembarcar em Santos pelo Serviço de Saúde dos Portos, que constatou a amputação de dois dedos da mão direita. O presidente do INIC, em resposta a SERE, mostrava urgência em identificar os motivos que teriam levado o Consulado de Barcelona a emitir aquele visto sem a sua consulta prévia. ${ }^{659}$

Os membros do INIC, responsáveis pelo parecer sobre a conveniência ou não da emigração dos que possuíam algum tipo de deficiência, costumavam alegar que o Brasil não deveria correr o risco de ser onerado por indivíduos "inúteis". Assim, conclui-se que o imigrante, mesmo aquele considerado mais propenso à assimilação, foi desumanizado por essas esferas do governo brasileiro, e tratado como um objeto que correspondia ou não aos interesses do Brasil.

659 Ofício de Walter Cechella, presidente do Instituto Nacional de Imigração e Colonização para a Secretaria de Estado das Relações Exteriores. Rio de Janeiro, 19 fev. 1958. Ofícios recebidos do INIC (janeiro a março de 1958). AHI/RJ. 


\section{Considerações Finais}

Com o presente trabalho procuramos demonstrar que as relações hispano-brasileiras - apesar de não se apresentarem como prioritárias para a política externa brasileira entre 1936 e 1960 - se constituíram em alvo de expectativas e preocupações do Itamaraty.

Durante a Guerra Civil Espanhola, as relações entre Brasil e Espanha foram marcadas pela dubiedade, uma vez que o governo Vargas procurou praticar nos assuntos europeus, uma política afinada com os interesses norte-americanos. Oficialmente, mantinham-se as relações diplomáticas com o governo legalmente constituído, mas através de ações oficiosas o governo brasileiro procurou favorecer o lado rebelde, o que se comprovou com o envio sigiloso de café aos franquistas. Este ato não deve ser interpretado como desprovido de ideologia. O "secretismo" da doação combinava com uma série de outras iniciativas do Estado Novo que, sem ser dúbio nos bastidores do poder, atendia as preferências das elites políticas brasileiras pelos nacionalistas espanhóis. As ações da Polícia Política brasileira, e em especial a de São Paulo - principal centro acolhedor dos espanhóis radicados no Brasil - em repressão às manifestações de apoio ao governo espanhol demonstram que a República espanhola era considerada um modelo a ser evitado.

O comprometimento do Brasil com os Aliados, durante a Segunda Guerra Mundial, fez com que o Itamaraty alterasse sua postura frente à Espanha. Surgiram assim, tensões nas relações hispano-brasileiras, uma vez que havia fortes indícios de que a Embaixada da Espanha no Rio de Janeiro encobria e auxiliava as atividades de espionagem nazista na América. Com o término do conflito mundial, os compromissos assumidos junto à ONU levaram o Brasil a acatar as determinações de rompimento diplomático em mais alto nível com a Espanha de Franco. Nos momentos em que o governo brasileiro precisou assumir uma postura oficial frente à situação política espanhola, o Itamaraty optou por seguir as diretrizes norte-americanas. Durante a Guerra Civil Espanhola e frente à cuestion española na ONU, tal política tornou-se evidente. 
A rejeição do Itamaraty a Eduardo Aunós, em 1946, nomeado para assumir a Embaixada espanhola no Rio de Janeiro, nos demonstra que 0 MRE não se importou em ameaçar as relações com a Espanha para manter a coerência com a atuação brasileira junto à ONU. O episódio confirma que, ao final do conflito mundial, a Espanha não era tão importante para a política externa brasileira quanto o Brasil o era para a política de reafirmação do governo franquista.

Avaliando as relações hispano-brasileiras no período imediato ao pós-guerra, consideramos que o jogo de poderes se fez pautado na construção de uma imagem positiva de ambos os países no panorama internacional. Tanto o governo brasileiro como o espanhol procuravam desvincular sua imagem dos atos de violência física e simbólica que identificavam Franco e Vargas com o fascismo.

Na década de 1950, a aproximação entre o Brasil e a Espanha extrapolou o âmbito do discurso, efetivando-se nas relações multilaterais, favorecidas pelo apoio mútuo junto aos órgãos ligados à ONU. A partir de 1956 começaram a se delinear novas perspectivas para as relações entre os dois países, devido as suas respectivas situações internas. Ambos compartilhavam do otimismo proporcionado pelas políticas desenvolvimentistas, sustentando 0 discurso de que estavam rumo ao progresso e à modernidade. As relações comerciais com a Espanha passaram a ser um alvo mais objetivo para a diplomacia brasileira, que se dedicava a fortalecer as relações com a Europa, medida que pode ser entendida como um instrumento de barganha com os EUA.

No que tange às relações culturais, cumpre mencionar que a visita que Juscelino Kubitschek fez à Espanha contribuiu para promover uma imagem positiva do Brasil, efetivando assim uma aproximação cultural. As exposições sobre a construção de Brasília e as notícias sobre o ritmo intenso de crescimento urbano de cidades como São Paulo, serviam ao propósito de criar externamente a imagem de "país do futuro". O governo franquista também se beneficiou desta propaganda, pois tinha interesse em promover a emigração de grandes contingentes de sua população, o que contribuía para aliviar as tensões sociais. 
O fato dos imigrantes espanhóis possuírem um perfil condizente com o projeto étnico defendido por parte da elite brasileira, não os excluiu de um rigoroso processo seletivo sustentado pelo Instituto Nacional de Imigração e Colonização. Os registros diplomáticos demonstram que as medidas extremamente restritivas à entrada dos imigrantes obedeciam a uma política intolerante, expressiva de um ideário elitista e nacionalista, cujas raízes antecedem a 1930.

Os diplomatas brasileiros possuíam uma visão do Brasil e da sociedade brasileira, que dificultava a compreensão e a identificação dos principais problemas nacionais. A tentativa de evitar que notícias sobre a composição étnica e a realidade sócio-econômica do povo brasileiro fossem veiculadas na Espanha demonstra que parte da "elite Rio Branco" desejava transmitir uma imagem idealizada do Brasil. Cabe ressaltar que a práxis diplomática brasileira na Espanha nem sempre foi condizente com os interesses reais da política externa brasileira, pautando-se, em algumas ocasiões, por interesses pessoais.

Em busca da identificação dos momentos de ruptura $e$ permanência nas relações entre Brasil e Espanha, constatamos que o projeto de relações internacionais de ambos os países esteve pautado por valores e diretrizes semelhantes. Na década de 1950, o projeto desenvolvimentista e a necessidade de buscar recursos externos apresentaram-se como pontos de congruência. $O$ mais forte elemento de identificação política, no entanto, foi o anticomunismo. Em todo o período que este estudo abrange, a diplomacia brasileira e a espanhola demonstraram grande preocupação em unir esforços e ressaltar a similaridade no objetivo de identificar e combater o "perigo vermelho". 


\section{Acervos e fontes}

\section{Acervos consultados}

- Arquivo Histórico do Itamaraty - Rio de Janeiro

- Arquivo do Ministério de Asuntos Exteriores y Cooperación - Madri/Espanha

- Associação Brasileira de Imprensa - Rio de Janeiro

- Arquivo Nacional - Fundo do Ministério da Justiça - Rio de Janeiro

- Arquivo do Estado de São Paulo - Fundo DEOPS

- Arquivo Público do Estado do Rio de Janeiro - Fundo DOPS

- Biblioteca Nacional - Rio de Janeiro

- Centro de Documentação do MRE - Brasília

- Centro de Pesquisa e Documentação de História Contemporânea do Brasil da Fundação Getúlio Vargas 


\section{Fontes}

\section{Diplomáticas (AHI; CDO; AMAE)}

\section{Cartas-telegramas}

n. 16 (confidencial) de Rubens Ferreira de Melo, embaixador do Brasil na Espanha para Ministério das Relações Exteriores do Brasil. Missões Diplomáticas Brasileiras. Telegramas recebidos de Madri (1947/1959). Arquivo de Correspondência Especial. CDO/MRE.

n. 29 (confidencial) da Secretaria de Estado das Relações Exteriores para a Embaixada do Brasil na Espanha. Rio de Janeiro, 29 mar. 1950. Missões Diplomáticas Brasileiras. Telegramas expedidos a Madri (1947/1959). Arquivo de Correspondência Especial. CDO/MRE.

n. 32 (confidencial) de Rubens Ferreira de Mello, embaixador do Brasil na Espanha para a Secretaria de Estado das Relações Exteriores. Madri, 05 abr. 1950. Missões Diplomáticas Brasileiras. Telegramas recebidos de Madri (1947/1959). Arquivo de Correspondência Especial. CDO/MRE.

da Secretaria de Estado das Relações Exteriores para a Embaixada do Brasil na Espanha. Rio de Janeiro, 12 set. 1951. Missões Diplomáticas Brasileiras. Cartas-Telegramas expedidas a Madri (1949-1950). AHI/RJ.

n. 93 da Secretaria de Estado das Relações Exteriores para Embaixada do Brasil. Rio de Janeiro, 23 jul. 1952. Missões Diplomáticas Brasileiras. Cartas-Telegramas expedidas a Madri (1951-1953). AHI/RJ.

n. 83 da Secretaria de Estado das Relações Exteriores para Embaixada do Brasil. Rio de Janeiro, 17 jul. 1953. Missões Diplomáticas Brasileiras. Cartas-Telegramas expedidas a Madri (1951-1953). AHI/RJ.

n. 83 da Secretaria de Estado das Relações Exteriores para Embaixada do Brasil na Espanha. Rio de Janeiro, 28 out. 1953. Missões Diplomáticas Brasileiras. Cartas-telegramas expedidas a Madri (1951-1953). AHI/RJ.

n. 59 (reservado) da Secretaria de Estado das Relações Exteriores para a Embaixada do Brasil na Espanha. Rio de Janeiro, 20 mai 1954. Missões Diplomáticas Brasileiras. Cartastelegramas expedidas a Madri (1954-1956). AHI/RJ.

n. 116 da Secretaria de Estado das Relações Exteriores para Embaixada do Brasil em Madri. Rio de Janeiro, 25 set. 1954. Missões Diplomáticas Brasileiras. Ofícios expedidos à Madri (1954-1956). AHI/RJ.

(confidencial) de João P. G. Coelho Lisboa, embaixador do Brasil na Espanha para Secretaria de Estado das Relações Exteriores do Brasil. Madri, 02 ago. 1956. Missões Diplomáticas Brasileiras. Telegramas recebidos de Madri (1947/ 1959) Arquivo de Correspondência Especial, cx 250. CDO/MRE.

\section{Cartas}

credencial de José de Cárcer y Lassance. Burgos, 09 nov. 1936. Notas de governo a governo recebidas (1931-1950). AHI/RJ.

de Abelardo Roças para Pedro Leão Velloso, secretário-geral das Relações Exteriores. Madri, 19 jul. 1943. Missões Diplomáticas Brasileiras. Ofícios recebidos de Madri (1943). $\mathrm{AHI} / \mathrm{RJ}$.

de Mario de Pimentel Brandão, embaixador do Brasil na Espanha para José Felix de Lequerica, ministro de Assuntos Exteriores da Espanha. Madri, s/d. Missões Diplomáticas Brasileiras. Ofícios recebidos de Madri (setembro a dezembro de 1945). AHI/RJ.

\section{Despachos}

n. 08 da Secretaria de Estado das Relações Exteriores do Brasil para Luis Guimarães Filho, ministro plenipotenciário do Brasil na Espanha. Madri, 08 mar. 1933. Missões Diplomáticas Brasileiras. Despachos expedidos a Madri (1931 - 1945). AHI/RJ. 
n. 92 de Fernando Morales Llamas, encarregado de negócios da Espanha no Brasil para ministro de Assuntos Exteriores da Espanha. Rio de Janeiro, 29 out. 1936. R999, expt. 12. AMAE.

n. 115 do encarregado de negócios da Espanha no Brasil para ministro de Assuntos Exteriores. Rio de Janeiro, 20 nov. 1937. R999, expt. 13. AMAE.

n. 121 do encarregado de negócios da Espanha no Brasil para Ministro de Assuntos Exteriores. Rio de Janeiro, 27 nov. 1937. R999, expt. 13. AMAE.

n. 223 (confidencial e reservado) de Manuel Garcia Miranda, encarregado de negócios da Espanha no Brasil para ministro de Assuntos Exteriores da Espanha. Rio de Janeiro, 23 jun. 1938. R999, expt. 12. AMAE.

n. 375 de (ass. ileg.), encarregado de negócios da Espanha no Brasil para Ministro de Estado. Rio de Janeiro, 22 out. 1938. R999, expt. 12. AMAE.

n. 438 de Jose Prieto del Rio, encarregado de negócios para ministro de Assuntos Exteriores da Espanha. RJ, 02 dez. 1938. R999 Expt. 12. AMAE.

de C. de Ouro Preto em nome do ministro de Estado para Carlos da Silveira Martins

Ramos, encarregado de negócios do Brasil na Espanha. Rio de Janeiro, 05 jan. 1939. Missões

Diplomáticas Brasileiras. Despachos enviados a Madri (1935-1941). AHI/RJ.

de Cyro de Freitas Valle em nome do ministro de Estado para Argeu Guimarães, encarregado de negócios em Madri. Rio de Janeiro, 01 abr. 1939. Missões Diplomáticas Brasileiras. Despachos expedidos a Madri (1935-1941). AHI/RJ.

de Oswaldo Aranha, ministro de Estado para Abelardo Roças, embaixador do Brasil na

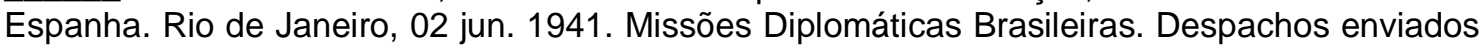
a Madri (1935-1941). AHI/RJ.

n. 112 (reservado) de Jose Rojas y Moreno, embaixador da Espanha no Brasil para ministro de Assuntos Exteriores. Rio de Janeiro, 11 mar. 1947. R1940, expt. 48. AMAE. n. 285 (confidencial) de Jose Rojas y Moreno, embaixador da Espanha no Brasil para

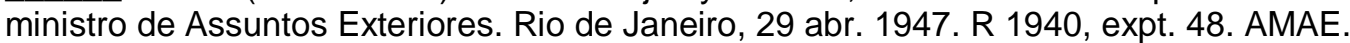
n. 718 de Jose Rojas y Moreno, embaixador da Espanha no Brasil para ministro de Assuntos Exteriores da Espanha. Rio de Janeiro, 15 de dez. 1947. R2896, expt. 117. AMAE. n. 39 de (ass. ileg.), embaixador da Espanha em Portugal para ministro de Assuntos Exteriores da Espanha. Lisboa, 26 jan. 1948. R2896, expt. 117. AMAE.

de Jose Rojas y Moreno, embaixador da Espanha no Brasil para Hildebrando Accioly, secretário-geral de Estado das Relações Exteriores. Rio de Janeiro, 15 jan. 1948. R2316, expt. 21. AMAE.

da Secretaria de Estado das Relações Exteriores para Embaixada do Brasil em Madri. Rio de Janeiro, 20 jan. 1949. Missões Diplomáticas Brasileiras. Despachos para Madri (19461956). AHI/RJ.

n. 16 da Secretaria de Estado das Relações Exteriores para Embaixada do Brasil em Madri. Missões Diplomáticas Brasileiras. Rio de Janeiro, 21 abr. 1949. Despachos a Madri (1946 a 1953). AHI/RJ.

n. 433 de Jose Rojas y Moreno, embaixador da Espanha no Brasil para ministro de Assuntos Exteriores da Espanha. Rio de Janeiro, 03 set. 1949. R5672, expt. 43. AMAE. n. 199 de Jose Rojas y Moreno, embaixador da Espanha no Brasil para ministro de

Assuntos Exteriores da Espanha. Rio de Janeiro, 19 abr. 1950. R2409, expt. 58. AMAE. n. 66 de Jose Rojas y Moreno, embaixador da Espanha no Brasil para Ministro de Assuntos Exteriores espanhol. Rio de Janeiro, 31 jan. de 1951. R2829, expt. 74. AMAE. n. 82 de Jose Rojas y Moreno, embaixador da Espanha no Brasil para ministro de Assuntos Exteriores da Espanha. Rio de Janeiro, 19 mar. 1951. R3529, expt. 97. AMAE. n. 206 de Jose Rojas y Moreno, embaixador da Espanha no Brasil para ministro de Assuntos Exteriores da Espanha. Rio de Janeiro, 30 mar.1951. R5672, expt. 41. AMAE. da Secretaria de Estado das Relações Exteriores para Embaixada do Brasil em Madri. Rio de Janeiro, 13 abr. 1951. Missões Diplomáticas Brasileiras. Despachos para Madri (19461956). AHI/RJ.

n. 346 de Jose Rojas y Moreno, embaixador da Espanha no Brasil para ministro de Assuntos Exteriores da Espanha. Rio de Janeiro, 25 maio de 1951. R2829, expt. 74. AMAE.

n. 951 de Marquês de Prat y Nantouillet, embaixador da Espanha no Brasil para ministro de Assuntos Exteriores da Espanha. Rio de Janeiro, 14 nov. 1952. R3579, expt.16. AMAE.

do agregado de informações da Embaixada da Espanha no Brasil de 01 set. 1953. Madri, 16 set. 1953. R3191, expt. 77. AMAE. 
n. 1164 (reservado) de Marquês de Prat y Nantouillet, embaixador da Espanha no Brasil para ministro de Assuntos Exteriores da Espanha. Rio de Janeiro, 13 dez. 1953. R3579, expt.16. AMAE.

da Secretaria de Estado das Relações Exteriores para Embaixada do Brasil na Espanha. Rio de Janeiro, 14 jan. 1956. Missões Diplomáticas Brasileiras. Despachos para Madri (1954-1959). AHI/RJ.

de Odette de Carvalho e Souza, chefe do Depto. Cultural do Itamaraty para João P. G.

Coelho Lisboa, embaixador do Brasil na Espanha. Rio de Janeiro, 07 ago. 1956. Missões Diplomáticas Brasileiras. Despachos para Madri (1954 a 1959). AHI/RJ.

\section{Discurso}

"Discurso pronunciado por sua excelência o General Francisco Franco na entrega do Grande Colar da Ordem Nacional do Cruzeiro do Sul por sua excelência o senhor embaixador do Brasil." Anexo ao ofício n. 71 de Rubens Ferreira de Mello, embaixador do Brasil na Espanha para João Neves da Fontoura, ministro das Relações Exteriores do Brasil. Madri, 13 fev. 1951. Missões Diplomáticas Brasileiras. Ofícios recebidos de Madri (jan. a março de 1951). AHI/RJ.

\section{Memoranduns}

(ass. llegível) para o chefe da divisão política e diplomática. Ministério das Relações Exteriores. Rio de Janeiro, 16 jan. 1939. Lata 716, maço 10364. AHI/RJ. do chefe da divisão consular (ass. ileg.) para secretário-geral das Relações Exteriores. Rio de Janeiro, 06 abr. 1940. Lata 1756, maço 35635. AHI/RJ.

\section{Notas}

de José Carlos de Macedo Soares, ministro das Relações Exteriores do Brasil para Vicente Rao, ministro da Justiça. Rio de Janeiro, 11 nov. 1935. Lata 1030 maço 17657. AHI/RJ. de Mario de Pimentel Brandão, em nome do Ministro de Estado para Vicente Sales, embaixador da Espanha no Brasil. Rio de Janeiro, 11 nov. 1935. Lata 1030 maço 17657. $\mathrm{AHI} / \mathrm{RJ}$

(cópia) de Alcebíades Peçanha, embaixador do Brasil na Espanha para governo espanhol (documento sem identificação de destinatário), Madri, 17 abr. 1936. Missões Diplomáticas Brasileiras. Ofícios recebidos de Madri (1936 a junho de 1937). AHI/RJ.

n. 46 da Embaixada do Brasil na Espanha para o governo republicano espanhol (cópia). Madri,1º set. 1936. Missões Diplomáticas Brasileiras. Ofícios recebidos de Madri (1936 a junho de 1937). AHI/RJ.

(cópia) do governador civil de Almeria para Embaixada do Brasil na Espanha. Madri, 16 out. 1936. Missões Diplomáticas Brasileiras. Ofícios recebidos de Madri (janeiro de 1936 a julho de 1937). AHI/RJ.

da Embaixada da Espanha no Brasil para Ministério de Assuntos Exteriores da Espanha. Rio de Janeiro, 27 fev. 1938. R1070, exp.57. AMAE.

(cópia) de Juan Beigbeder, ministro de Assuntos Exteriores da Espanha para Abelardo Roças, embaixador do Brasil na Espanha. Ministério de Asuntos Exteriores da Espanha. Madri, 16 jul. 1940. Missões Diplomáticas Brasileiras. Ofícios recebidos de Madri (1940 a março de 1941). AHI/RJ.

confidencial (cópia) de Abelardo Roças, embaixador do Brasil na Espanha para Juan Beigbeder, ministro de Assuntos Exteriores da Espanha. Madri, 16 set. 1940. Missões Diplomáticas Brasileiras. Ofícios recebidos de Madri. (1940 a março de 1941). AHI/RJ.

(cópia) da Embaixada do Brasil na Espanha para Conde Jordana, ministro de Assuntos

Exteriores da Espanha. Madri, 01 jun. 1943. Missões Diplomáticas Brasileiras. Ofícios recebidos de Madri (1943). AHI/RJ.

n. 29 de Jose Rojas y Moreno, embaixador da Espanha no Brasil para João Neves da Fontoura, ministro das Relações Exteriores do Brasil. Rio de Janeiro, 03 jun. 1946. Representações Estrangeiras. Notas recebidas da Espanha (1946-1948). AHI/RJ.

n. 36 (confidencial) da Embaixada da Espanha no Brasil para Ministério das Relações Exteriores do Brasil. Rio de Janeiro, 07 jun. 1946. Representações Estrangeiras. Notas recebidas da Espanha (1946-1948). AHI/RJ. 
n. 16 de Samuel de Leão Gracie, secretário-geral das Relações Exteriores do Brasil para Jose Gallostra Coelho, encarregado de negócios da Espanha no Brasil. Rio de Janeiro, 12 jun. 1946. Notas expedidas a Espanha (1946-1951). AHI/RJ.

de Hildebrando Accioly, secretário das Relações Exteriores para Jose Cárcer Lassance, encarregado de negócios da Espanha no Brasil. Rio de Janeiro, 10 mai 1948. Representações Estrangeiras. Notas expedidas a Espanha (1946-1951). AHI/RJ.

n. 69 da Embaixada da Espanha para Raul Fernandes, ministro das Relações Exteriores do Brasil. Rio de Janeiro, 30 jul.1949. R2316, expt. 21. AMAE.

(cópia) da Embaixada do Brasil na Espanha para Ministério de Assuntos Exteriores da

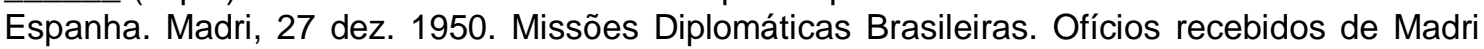
(janeiro a março de 1951). AHI/RJ.

n. 42 de Heitor Lyra, secretário-geral interino das Relações Exteriores para Jose Rojas y Moreno, embaixador da Espanha no Brasil. Rio de Janeiro, 03 maio 1951. Representações Estrangeiras. Notas expedidas a Espanha (1946-1951). AHI/RJ.

n. 74 da Secretaria de Estado das Relações Exteriores para Embaixada da Espanha no Brasil. Rio de Janeiro, 12 set. 1951. Representações Estrangeiras. Notas expedidas (19461951). AHI/RJ.

n. 89 de Heitor Lyra, em nome do ministro de Estado para Conde de Casa Rojas, embaixador espanhol no Brasil. Rio de Janeiro, 12 nov. 1951. Representações Estrangeiras. Notas expedidas (1946-1951). AHI/RJ.

de Marquês de Prat y Nantouillet, embaixador da Espanha no Brasil para Vasco Leitão da Cunha, secretário de Estado das Relações Exteriores. Rio de Janeiro, 14 nov. 1953. Representações Estrangeiras. Notas recebidas da Espanha (1952-1954). AHI/RJ.

de Vasco Leitão da Cunha, secretário de Estado das Relações Exteriores para Marquês de Prat y Nantouillet, embaixador da Espanha no Brasil. Rio de Janeiro, 8 dez. 1953. Representações Estrangeiras. Notas expedidas à Espanha (1952-1954). AHI/RJ.

verbal n. 51 da Embaixada da Espanha no Brasil para Ministério das Relações

Exteriores. Rio de Janeiro, 12 maio 1958. Representações Estrangeiras. Notas recebidas da Espanha (1957-1958). AHI/RJ.

\section{Ofícios}

n. 38 de Moniz Gordilho para Afrânio de Mello Franco, ministro das Relações Exteriores do Brasil. Madri, 28 mar. 1931. Missões Diplomáticas Brasileiras. Ofícios recebidos de Madri (1931 a março de 1932). AHI/RJ.

n. 48 de Luis Guimarães Filho, chefe da Legação brasileira na Espanha para Afrânio de Mello Franco, ministro das Relações Exteriores do Brasil. Madri, 21 abr. 1931. Missões Diplomáticas Brasileiras. Ofícios recebidos de Madri (1931 a março de 1932). AHI/RJ.

n. 16 de Luis Guimarães Filho, ministro plenipotenciário do Brasil na Espanha para

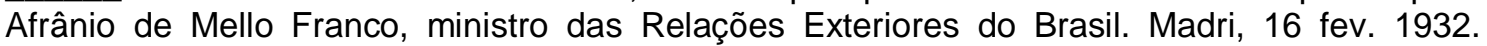
Missões Diplomáticas Brasileiras. Ofícios recebidos de Madri (1931 a março de 1932). AHI/RJ.

n. 32 de Luis Guimarães Filho, ministro plenipotenciário do Brasil na Espanha para

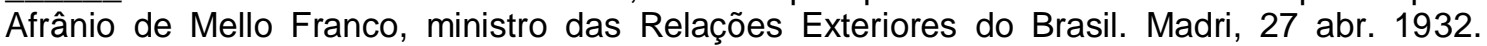
Missões Diplomáticas Brasileiras. Ofícios recebidos de Madri (1931 a março de 1932). AHI/RJ. de Luis Guimarães Filho, ministro plenipotenciário do Brasil na Espanha para Afrânio de Mello Franco, ministro das Relações Exteriores do Brasil. Madri, 30 jul. 1932. Missões Diplomáticas Brasileiras. Ofícios recebidos de Madri (abril de 1932 a janeiro de 1933). AHI/RJ. n. 07 de Luis Guimarães Filho, ministro plenipotenciário do Brasil na Espanha para

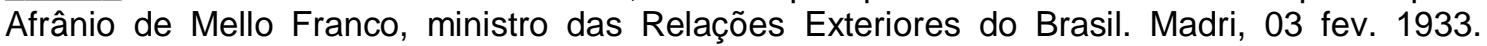
Missões Diplomáticas Brasileiras. Ofícios recebidos de Madri (abril de 1932 a junho de 1933). AHI/RJ.

n. 17 de Luis Guimarães Filho, encarregado de negócios na Espanha para Afrânio de Mello Franco, ministro das Relações Exteriores do Brasil. Madri, 13 fev. 1933. Missões Diplomáticas Brasileiras. Ofícios recebidos de Madri (abril de 1932 a junho de 1933). AHI/RJ.

n. 65 de Luis Guimarães Filho, ministro plenipotenciário do Brasil na Espanha para

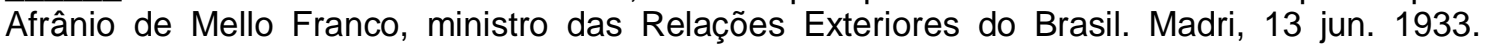
Missões Diplomáticas Brasileiras. Ofícios recebidos de Madri (abril de 1932 a junho de 1933). AHI/RJ.

n. 11 de Luis Guimarães Filho, ministro plenipotenciário do Brasil na Espanha para F. de B. Cavalcante de Lacerda, secretário geral do Ministério das Relações Exteriores do Brasil. 
Madri, 09 jan. 1934. Missões Diplomáticas Brasileiras. Ofícios recebidos de Madri (julho de 1933 a março de 1934). AHI/RJ.

n. 52 da Embaixada do Brasil na Espanha para Secretaria de Estado das Relações Exteriores do Brasil. Madri, 20 abr. 1934. Missões Diplomáticas Brasileiras. Ofícios recebidos de Madri (abril de 1934 a fevereiro de 1935). AHI/RJ.

n. 191 (reservado) de Alcebíades Peçanha, embaixador do Brasil na Espanha para José Carlos de Macedo Soares, ministro das Relações Exteriores do Brasil. Madri, 26 dez. 1935. Missões Diplomáticas Brasileiras. Ofícios recebidos de Madri (março a dezembro de 1935). AHI/RJ.

n. 10 de Alcebíades Peçanha, embaixador do Brasil na Espanha para José Carlos de Macedo Soares, ministro das Relações Exteriores do Brasil. Madri, 19 jan. 1936. Missões Diplomáticas Brasileiras. Ofícios recebidos de Madri (1936 a junho de 1937). AHI/RJ.

n. 36 de Alcebíades Peçanha, embaixador do Brasil na Espanha para José Carlos de Macedo Soares, ministro das Relações Exteriores do Brasil. Madri, 25 mar. 1936. Missões Diplomáticas Brasileiras. Ofícios recebidos de Madri (1936 a junho de 1937). AHI/RJ.

n. 55 de Alcebíades Peçanha, embaixador do Brasil na Espanha para José Carlos de Macedo Soares, ministro das Relações Exteriores do Brasil. Madri, 06 maio 1936. Missões Diplomáticas Brasileiras. Ofícios recebidos de Madri (1936 a junho de 1937). AHI/RJ.

n. 65 de Alcebíades Peçanha, embaixador do Brasil na Espanha para José Carlos de

Macedo Soares, ministro das Relações Exteriores do Brasil. Madri, 25 maio 1936. Missões Diplomáticas Brasileiras. Ofícios recebidos de Madri (1936 a junho de 1937). AHI/RJ.

n. 75 de Alcebíades Peçanha, embaixador do Brasil na Espanha para José Carlos de Macedo Soares, ministro das Relações Exteriores do Brasil. Madri, 15 jun. 1936. Missões Diplomáticas Brasileiras. Ofícios recebidos de Madri (1936 a junho de 1937). AHI/RJ.

n. 48 do cônsul (ass. ileg.) em Barcelona para José Carlos de Macedo Soares, ministro das Relações Exteriores do Brasil. Barcelona, 19 jun. 1936. Consulados Brasileiros. Ofícios recebidos de Barcelona (maio de 1936 a setembro de 1938). AHI/RJ.

(reservado) do cônsul em Barcelona (ass. ilegível) para José Carlos de Macedo

Soares, ministro das Relações Exteriores do Brasil. Marselha, 22 ago. 1936. Consulados Brasileiros. Ofícios recebidos de Barcelona (maio de 1936 a setembro de 1938). AHI/RJ.

n. 112 de Alcebíades Peçanha, embaixador do Brasil na Espanha para Mario de

Pimentel Brandão, ministro interino das Relações Exteriores do Brasil. Madri, 31 dez. 1936.

Missões Diplomáticas Brasileiras. Ofícios recebidos de Madri (1936 a junho de 1937). AHI/RJ.

n. 5 (cópia) de Octaviano Machado para Mario de Pimentel Brandão, ministro Interino das Relações Exteriores. Antuérpia, 11 fev. 1937. Lata 630, maço 9696. AHI/RJ.

de Alcebíades Peçanha, embaixador do Brasil em Madri para José F. de Barros

Pimentel, ministro interino das Relações Exteriores do Brasil. Madri, 28 abr. 1937. Missões

Diplomáticas Brasileiras. Ofícios recebidos de Madri (1936 a julho de 1937). AHI/RJ.

de Alcebíades Peçanha, embaixador do Brasil na Espanha para Mario de Pimentel

Brandão, ministro das Relações Exteriores do Brasil. Madri, 10 maio 1937. Missões

Diplomáticas Brasileiras. Ofícios recebidos de Madri (1936 a junho de 1937). AHI/RJ.

de Alcebíades Peçanha, embaixador do Brasil na Espanha para José Carlos de

Macedo Soares, ministro das Relações Exteriores. Madri, 03 jul. 1937. Missões Diplomáticas Brasileiras. Ofícios recebidos de Madri (julho de 1937 a 1938). AHI/RJ.

n. 48 de Alcebíades Peçanha, embaixador do Brasil na Espanha para José Carlos de

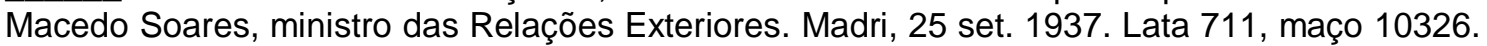
AHI/RJ.

n. 64 de Alcebíades Peçanha, embaixador do Brasil na Espanha para Mario de Pimentel Brandão, ministro das Relações Exteriores do Brasil. Madri, 11 dez. 1937. Missões Diplomáticas Brasileiras. Ofícios recebidos de Madri (julho de 1937 a 1938). AHI/RJ.

de Alcebíades Peçanha, embaixador do Brasil na Espanha para Mario de Pimentel Brandão, ministro das Relações Exteriores do Brasil. Madri, 10 fev. 1938. Missões Diplomáticas Brasileiras. Ofícios recebidos de Madri (julho de 1937 a 1938). AHI/RJ.

n. 08 (secreto) de Alcebíades Peçanha, embaixador do Brasil na Espanha para Mario de Pimentel Brandão, ministro das Relações Exteriores do Brasil. Madri, 11 fev. 1938. Missões Diplomáticas Brasileiras. Ofícios recebidos de Madri (julho de 1937 a 1938). AHI/RJ.

n. 17 de Aluízio de Magalhães, cônsul adjunto em Barcelona para Oswaldo Aranha, ministro das Relações Exteriores do Brasil. Barcelona, 24 mar. 1938. Consulados Brasileiros. Ofícios recebidos de Barcelona (maio de 1936 a setembro de 1938). AHI/RJ. 
de Carlos da Silveira Martins Ramos, encarregado de negócios em Barcelona para Oswaldo Aranha, ministro das Relações Exteriores do Brasil. Barcelona, 25 mar. 1938. Lata 711, maço 10326. AHI/RJ.

n. 20 de Aluisio de Magalhães, cônsul do Brasil em Barcelona para Oswaldo Aranha, ministro das Relações Exteriores do Brasil. Barcelona, 28 mar. 1938. Consulados Brasileiros. Ofícios recebidos de Barcelona (maio de 1936 a setembro de 1938). AHI/RJ.

(cópia) do Ministério de Estado Español para Carlos da Silveira Martins Ramos, encarregado de negócios na Espanha. Barcelona, 30 mar. 1938. Lata 711, maço 10326. AHI/RJ.

n. 12 do encarregado de negócios na Espanha, Carlos da Silveira Martins Ramos, para Oswaldo Aranha, ministro das Relações Exteriores do Brasil. Barcelona, 23 abr. 1938. Missões Diplomáticas Brasileiras. Ofícios recebidos de Madri (julho de 1937 a 1938). AHI/RJ.

de Carlos da Silveira Martins Ramos, encarregado de negócios em Barcelona para Oswaldo Aranha, ministro das Relações Exteriores do Brasil. Barcelona, 05 mai. 1938. Lata 711, maço 10326. AHI/RJ.

(cópia) de Andres Rodriguez Barbeito, secretário do ministro de Estado Julio Alvarez del Vayo para Carlos da Silveira Martins Ramos, encarregado de negócios do Brasil na Espanha. Barcelona, 20 jun. 1938.

n. 30 do encarregado de negócios na Espanha, Carlos da Silveira Martins Ramos para Oswaldo Aranha, ministro das Relações Exteriores do Brasil. Barcelona, 22 jun. 1938. Missões Diplomáticas Brasileiras. Ofícios recebidos de Madri (julho de 1937 a 1938). AHI/RJ.

n. 33 da Embaixada do Brasil na Espanha para o Ministério das Relações Exteriores do Brasil. Barcelona, 27 jun. 1938. Missões Diplomáticas Brasileiras. Ofícios recebidos de Madri (julho de 1937 a 1938). AHI/RJ.

n.54 de Carlos da Silveira Martins Ramos, encarregado de negócios em Barcelona para Oswaldo Aranha, ministro das Relações Exteriores do Brasil. Barcelona, 16 jul. 1938. Missões Diplomáticas Brasileiras. Ofícios recebidos de Madri (julho de 1937 a 1938). AHI/RJ.

n. 56 (reservado) de Carlos da Silveira Martins Ramos, encarregado de negócios em Barcelona para Oswaldo Aranha, ministro das Relações Exteriores do Brasil. Barcelona, 24 jul. 1938. Lata 630, maço 9696. AHI/RJ.

de Luis de Soroa Garcia Goyena para Carlos da Silveira Martins Ramos, encarregado de negócios do Brasil em Barcelona. Madri, 22 ago. 1938. Lata 711, maço 10326. AHI/RJ. de Carlos da Silveira Martins Ramos, encarregado de negócios do Brasil na Espanha para Oswaldo Aranha, ministro das Relações Exteriores do Brasil. Barcelona, 23 ago. 1938. Lata 711, maço 10326. AHI/RJ.

n. 73 (reservado) de Carlos da Silveira Martins Ramos, encarregado de negócios do Brasil na Espanha para Oswaldo Aranha, ministro das Relações Exteriores do Brasil. Barcelona, 30 ago. 1938. Lata 713, maço 10343. AHI/RJ.

n. 91 de Carlos da Silveira Martins Ramos, encarregado de negócios do Brasil em Barcelona para Osvaldo Aranha, ministro das Relações Exteriores do Brasil. Barcelona, 23 set. 1938. Missões Diplomáticas Brasileiras. Ofícios recebidos de Madri (julho de 1937 a 1938). AHI/RJ.

n. 85 de Aluízio de Magalhães, cônsul do Brasil em Barcelona para Oswaldo Aranha, ministro das Relações Exteriores do Brasil. Barcelona, 26 out. 1938. Consulados Brasileiros. Ofícios recebidos de Barcelona (outubro de 1938 a junho de 1939). AHI/RJ.

n. 100 (reservado) de Carlos da Silveira Martins Ramos, encarregado de negócios na Espanha para Oswaldo Aranha, ministro das Relações Exteriores. 14 out. 1938. Lata 710, maço 10325. AHI/RJ

n. 87 de Aluisio de Magalhães, cônsul do Brasil em Barcelona para Oswaldo Aranha, $\overline{\text { ministro }}$ das Relações Exteriores do Brasil. Barcelona, 28 out. 1938. Consulados Brasileiros. Ofícios recebidos de Barcelona (outubro de 1938 a junho de 1939). AHI/RJ.

n. 110 de Carlos da Silveira Martins Ramos, encarregado de negócios do Brasil na Espanha para Oswaldo Aranha, Ministro das Relações Exteriores. Barcelona, 01 nov. 1938. Lata 716, maço 10364. AHI/RJ.

n. 118 do encarregado de negócios na Espanha, Carlos da Silveira Martins Ramos, para Oswaldo Aranha, ministro das Relações Exteriores do Brasil. Barcelona, 08 nov. 1938. Missões Diplomáticas Brasileiras. Ofícios recebidos de Madri (julho de 1937 a 1938). AHI/RJ.

de Carlos da Silveira Martins Ramos, encarregado de negócios em Barcelona para Oswaldo Aranha, ministro das Relações Exteriores do Brasil. Barcelona, 28 nov. 1938. Missões Diplomáticas Brasileiras. Ofícios recebidos de Madri (julho de 1937 a 1938). AHI/RJ. 
de Carlos da Silveira Martins Ramos, encarregado de negócios do Brasil na Espanha para Oswaldo Aranha, ministro das Relações Exteriores do Brasil. Barcelona, 29 nov. 1938. Lata 711, maço 10326. AHI/RJ.

n. 138 de Carlos da Silveira Martins Ramos, encarregado de negócios do Brasil na Espanha para Osvaldo Aranha, ministro das Relações Exteriores do Brasil. Barcelona, 27 dez. 1938. Missões Diplomáticas Brasileiras. Ofícios recebidos de Madri (julho de 1937 a 1938). AHI/RJ.

de Carlos da Silveira Martins Ramos, encarregado de negócios do Brasil na Espanha para Oswaldo Aranha, ministro das Relações Exteriores do Brasil. Barcelona, 29 dez. 1938. Missões Diplomáticas Brasileiras. Ofícios recebidos de Madri (julho de 1937 a 1938). AHI/RJ.

n. 3 de Aluisio de Magalhães, cônsul do Brasil em Barcelona para Oswaldo Aranha, ministro das Relações Exteriores do Brasil. Barcelona, 07 jan. 1939. Lata 630, maço 9696. AHI/RJ.

n. 14 de Aluísio de Magalhães, cônsul do Brasil em Barcelona para Oswaldo Aranha, ministro das Relações Exteriores do Brasil. Barcelona, 04 mar. 1939. Consulados Brasileiros. Ofícios recebidos de Barcelona (outubro de 1938 a junho de 1939). AHI/RJ.

n.25 de Aluísio de Magalhães, cônsul em Barcelona para Oswaldo Aranha, ministro das Relações Exteriores do Brasil. Barcelona, 25 mar. 1939. Consulados Brasileiros. Ofícios recebidos de Barcelona (outubro de 1938 a junho de 1939). AHI/RJ.

n. 26 (reservado) de Argeu Guimarães, embaixador do Brasil na Espanha para Oswaldo Aranha, ministro das Relações Exteriores do Brasil. Burgos, 10 abr. 1939. Missões Diplomáticas Brasileiras. Ofícios recebidos de Madri (abril a dezembro de 1939). AHI/RJ.

n. 48 de Matheus de Albuquerque, do Consulado Geral de Barcelona para Oswaldo Aranha, ministro das Relações Exteriores do Brasil. Barcelona, 27 mai. 1939. Consulados Brasileiros. Ofícios recebidos de Barcelona (outubro de 1938 a junho de 1939). AHI/RJ.

n. 69 (confidencial) de Argeu Guimarães Filho, encarregado de negócios do Brasil na Espanha para Oswaldo Aranha, ministro das Relações Exteriores do Brasil San Sebastián, 10 jun. 1939. Missões Diplomáticas Brasileiras. Ofícios recebidos de Madri. (abril a dezembro de 1939). AHI/RJ.

n. 57 de Matheus de Albuquerque, cônsul brasileiro para Oswaldo Aranha, ministro das Relações Exteriores do Brasil. Barcelona, 15 jun. 1939. Consulados brasileiros. Ofícios recebidos de Barcelona (outubro de 1938 a junho de 1939). AHI/RJ. Grifo nosso.

n. 71 de Argeu Guimarães, embaixador do Brasil na Espanha para Oswaldo Aranha,

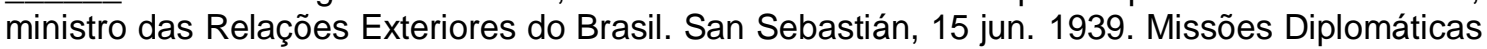
Brasileiras. Ofícios recebidos de Madri (abril a dezembro de 1939). AHI/RJ.

n. 65 de Matheus de Albuquerque, cônsul em Barcelona para Oswaldo Aranha, ministro das Relações Exteriores do Brasil. Barcelona, 06 jul. 1939. Lata 713, maço 10343. AHI/RJ.

de Argeu Guimarães, embaixador do Brasil na Espanha para Oswaldo Aranha, ministro das Relações Exteriores do Brasil. San Sebastián, 10 jul. 1939. Missões Diplomáticas Brasileiras. Ofícios recebidos de Madri (abril a dezembro de 1939). AHI/RJ.

n. 84 (confidencial) de Argeu Guimarães, encarregado de negócios do Brasil na Espanha para Oswaldo Aranha, ministro das Relações Exteriores do Brasil. San Sebastián, 10 jul. 1939. Missões Diplomáticas Brasileiras. Ofícios recebidos de Madri (abril a dezembro de 1939). AHI/RJ.

n. 87 de Argeu Guimarães, encarregado dos negócios do Brasil na Espanha para Oswaldo Aranha, ministro das Relações Exteriores do Brasil. San Sebastián, 12 jul. 1939. Missões Diplomáticas Brasileiras. Ofícios recebidos de Madri (abril a dezembro de 1939). $\mathrm{AHI} / \mathrm{RJ}$.

n. 115 de Abelardo Roças, embaixador do Brasil na Espanha para Oswaldo Aranha, $\overline{\text { ministro }}$ das Relações Exteriores do Brasil. San Sebastián, 9 ago. 1939. Missões Diplomáticas Brasileiras. Ofícios recebidos de Madri (abril a dezembro de 1939). AHI/RJ.

n.72 de Matheus de Albuquerque, cônsul do Brasil em Barcelona para Oswaldo Aranha, ministro das Relações Exteriores do Brasil. Barcelona, 30 ago.1939. Consulados Brasileiros. Ofícios recebidos de Barcelona (julho de 1939 a abril de 1940). AHI/RJ.

(cópia) do Ministério da Justiça para Adhemar de Barros, interventor federal do Estado

de São Paulo. Rio de Janeiro, 12 out. 1939. Ministério da Justiça, Subsérie Repatriamento, Processo n. 9774/39. Arquivo Nacional/RJ. 
n. 168 de Abelardo Roças, embaixador do Brasil na Espanha para Oswaldo Aranha, ministro das Relações Exteriores do Brasil. Madri, 01 dez. 1939. Missões Diplomáticas Brasileiras. Ofícios recebidos de Madri (abril a dezembro de 1939). AHI/RJ.

n. 41 (reservado) de Abelardo Roças, embaixador do Brasil na Espanha para Oswaldo Aranha, ministro das Relações Exteriores do Brasil. Madri, 12 fev. 1940. Missões Diplomáticas Brasileiras. Ofícios recebidos de Madri. (1940 a março de 1941). AHI/RJ.

n. 48 de Abelardo Roças, embaixador do Brasil na Espanha para Oswaldo Aranha, ministro das Relações Exteriores do Brasil. Madri, 24 fev. 1940. Missões Diplomáticas Brasileiras. Ofícios recebidos de Madri (1940 a março de 1941). AHI/RJ.

n. 81 de Abelardo Roças, embaixador do Brasil na Espanha para Oswaldo Aranha, $\overline{\text { ministro }}$ das Relações Exteriores do Brasil. Madri, 04 abr. 1940. Missões Diplomáticas Brasileiras. Ofícios recebidos de Madri. (1940 a março de 1941). AHI/RJ.

confidencial (cópia) de Luis Martins de Sousa Dantas para Ministério das Relações Exteriores. Paris, 05 abr. 1940. Lata 1756, maço 35635. AHI/RJ.

n. 40 de Matheus de Albuquerque, cônsul em Barcelona para Oswaldo Aranha, ministro das Relações Exteriores do Brasil. Barcelona, 18 mai. 1940. Consulados Brasileiros. Ofícios recebidos de Barcelona (maio de 1940 a dezembro de 1941). AHI/RJ.

n. 52 de Matheus de Albuquerque, cônsul do Brasil em Barcelona para Oswaldo Aranha, ministro das Relações Exteriores do Brasil. Barcelona, 22 jul. 1940. Consulados Brasileiros. Ofícios recebidos de Barcelona (maio de 1940 a dezembro de 1941). AHI/RJ.

n. 227 de Abelardo Roças, embaixador do Brasil na Espanha para Oswaldo Aranha, ministro das Relações Exteriores do Brasil. Madri, 08 dez. 1941. Missões Diplomáticas Brasileiras. Ofícios recebidos de Madri (abril a dezembro de 1941). AHI/RJ.

n.60 (reservado) de Abelardo Roças, embaixador do Brasil na Espanha para Oswaldo Aranha, ministro das Relações Exteriores do Brasil. Madri, 22 abr. 1942. Missões Diplomáticas Brasileiras. Ofícios recebidos de Madri (janeiro a junho de 1942). AHI/RJ.

n. 66 de Abelardo Roças, embaixador do Brasil na Espanha para ministro das Relações Exteriores do Brasil. Madri, 27 abr. 1942. Missões Diplomáticas Brasileiras. Ofícios recebidos de Madri (janeiro a junho de 1942). AHI/RJ).

n. 153 de Abelardo Roças, embaixador do Brasil na Espanha para Oswaldo Aranha, ministro das Relações Exteriores do Brasil. Madri, 09 set. 1943. Missões Diplomáticas Brasileiras. Ofícios recebidos de Madri. (julho a dezembro de 1943). AHI/RJ.

n. 18 de Roberto Mendes Gonçalves, adido comercial à Embaixada do Brasil na Espanha para Oswaldo Aranha, ministro das Relações Exteriores do Brasil. Madri, 18 jan. 1944. Missões Diplomáticas Brasileiras. Ofícios recebidos de Madri (janeiro a julho de 1944). AHI/RJ.

n. 46 de Mario de Pimentel Brandão, embaixador do Brasil na Espanha para ministro das Relações Exteriores do Brasil. Madri, 20 mar. 1944. Missões Diplomáticas Brasileiras. Ofícios recebidos de Madri (janeiro a julho de 1944). AHI/RJ.

n. 44 de Mario de Pimentel Brandão, embaixador do Brasil na Espanha para Oswaldo Aranha, ministro das Relações Exteriores do Brasil. Madri, 24 mar. 1944. Missões Diplomáticas Brasileiras. Ofícios recebidos de Madri (janeiro a julho de 1944). AHI/RJ.

n. 87 de Mario de Pimentel Brandão, embaixador do Brasil na Espanha para Oswaldo Aranha, ministro das Relações Exteriores do Brasil. Madri, 13 jul. 1944. Missões Diplomáticas Brasileiras. Ofícios recebidos de Madri. (janeiro a julho de 1944). AHI/RJ.

n. 104 (reservado) de Mario de Pimentel Brandão, embaixador do Brasil na Espanha para Ministro das Relações Exteriores do Brasil. Madri, 30 jul. 1944. Missões Diplomáticas Brasileiras. Ofícios recebidos de Madri (janeiro a julho de 1944). AHI/RJ.

n. 130 (reservado) de Mario de Pimentel Brandão, embaixador do Brasil na Espanha para Pedro Leão Velloso, ministro interino das Relações Exteriores do Brasil. Madri, 25 ago. 1944. Lata 1373, maço 31856 . AHI/RJ.

n.139 (confidencial) de Mario de Pimentel Brandão, embaixador do Brasil na Espanha para ministro das Relações Exteriores do Brasil. Madri, 02 set. 1944. Missões Diplomáticas Brasileiras. Ofícios recebidos de Madri (agosto a outubro de 1944). AHI/RJ.

n. 149 (reservado) de Mario de Pimentel Brandão, embaixador do Brasil na Espanha para Oswaldo Aranha, ministro das Relações Exteriores do Brasil. Madri, 13 set. 1944. Missões Diplomáticas Brasileiras. Ofícios recebidos de Madri. (agosto a outubro de 1944). AHI/RJ.

n. 194 de Mario de Pimentel Brandão, embaixador do Brasil na Espanha para Oswaldo Aranha, ministro das Relações Exteriores do Brasil. Madri, 18 out. 1944. Missões Diplomáticas Brasileiras. Ofícios recebidos de Madri. (agosto a outubro de 1944). AHI/RJ. 
n. 295 (confidencial) de Mario de Pimentel Brandão, embaixador do Brasil na Espanha para Oswaldo Aranha, ministro das Relações Exteriores do Brasil. Madri, 05 dez. 1944. Missões Diplomáticas Brasileiras. Ofícios recebidos de Madri (novembro a dezembro de 1944). $\mathrm{AHI} / \mathrm{RJ}$.

n. 191 (reservado) de Mario de Pimentel Brandão, embaixador do Brasil na Espanha para Jose Roberto de Macedo Soares, secretário das Relações Exteriores. Missões Diplomáticas Brasileiras. Ofícios recebidos de Madri (maio a agosto de 1945). AHI/RJ.

n. 211 de Mario de Pimentel Brandão, embaixador do Brasil na Espanha para ministro das Relações Exteriores. Madri, 25 jun. 1945. Missões Diplomáticas Brasileiras. Ofícios recebidos de Madri (maio a agosto de 1945). AHI/RJ.

n. 153 de Roberto Mendes Gonçalves, cônsul do Brasil em Barcelona para Pedro Leão Velloso, ministro das Relações Exteriores do Brasil. Barcelona, 06 dez. 1945. Consulados Brasileiros. Ofícios recebidos de Barcelona (1944). AHI/RJ.

n. 15 (confidencial) de Mario de Pimentel Brandão, embaixador do Brasil na Espanha para Pedro Leão Velloso, ministro das Relações Exteriores do Brasil. Madri, 15 jan. 1946. Missões Diplomáticas Brasileiras. Ofícios recebidos de Madri (janeiro de 1946). AHI/RJ.

n. 26 da delegação do Brasil na ONU a João Neves da Fontoura, ministro das Relações Exteriores. Londres, 21 fev. 1946. Delegação do Brasil na ONU. Ofícios recebidos. (jan/fev. 1946). AHI/RJ.

n. 120 (reservado) de Antonio Mendes Vianna, encarregado de negócios do Brasil na Espanha para João Neves da Fontoura, ministro das Relações Exteriores do Brasil. Madri, 12 mar. 1946. Missões Diplomáticas Brasileiras. Ofícios recebidos de Madri (março 1946). AHI/RJ.

n. 235 (confidencial) de Vasco Leitão da Cunha, encarregado de negócios do Brasil na Espanha para João Neves da Fontoura, ministro das Relações Exteriores do Brasil. Madri, 03 jun. 1946. Missões Diplomáticas Brasileiras. Ofícios recebidos de Madri (janeiro a julho de 1946). AHI/RJ.

n. 321 de Vasco Leitão da Cunha, encarregado de negócios na Espanha para Samuel de Souza Leão Gracie, ministro interino das Relações Exteriores. Madri, 26 jul. 1946. Missões Diplomáticas Brasileiras. Ofícios recebidos de Madri (junho e julho de 1946). AHI/RJ.

n. 125 de Pimenta Bueno, cônsul adjunto em Barcelona para Samuel de Souza Leao Gracie, ministro interino das Relações Exteriores. Barcelona, 30 set. 1946. Consulados Brasileiros. Ofícios recebidos de Barcelona (1946). Ofício n. 64 de Osório Dutra, cônsul brasileiro em Barcelona para Vasco Leitão da Cunha, encarregado de negócios do Brasil na Espanha. Barcelona, 13 ago. 1948. Consulados Brasileiros. Ofícios recebidos de Barcelona (1948). AHI/RJ.

n. 105 (reservado) de Vasco Leitão da Cunha, encarregado de negócios na Espanha para Raul Fernandes, ministro das Relações Exteriores. Madri, 04 março 1947. Missões Diplomáticas Brasileiras. Ofícios enviados de Madri (março a abril de 1947). AHI/RJ.

n. 151 (reservado) de Vasco Leitão da Cunha, encarregado de negócios na Espanha

para Raul Fernandes, ministro das Relações Exteriores. Madri, 28 abr. 1947. Missões Diplomáticas Brasileiras. Ofícios recebidos de Madri (março a abril de 1947). AHI/RJ.

n. 197 de Vasco Leitão da Cunha, encarregado de negócios do Brasil na Espanha para Hildebrando P. Accioly, ministro interino das Relações Exteriores do Brasil. Madri, 24 mai. 1947. Missões Diplomáticas Brasileiras. Ofícios recebidos de Madri (maio a junho de 1946). $\mathrm{AHI} / \mathrm{RJ}$

n. 225 (confidencial) de Vasco Leitão da Cunha, encarregado de negócios do Brasil na

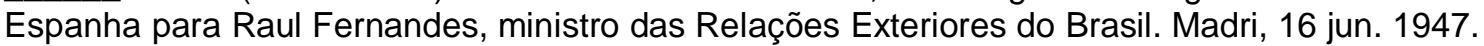
Missões Diplomáticas Brasileiras. Ofícios recebidos de Madri (1947-1949). Arquivo de Correspondência Especial. CDO/MRE.

n. 29 de Hélio Lobo, da Delegação brasileira à Comissão Preparatória da OIR para Raul Fernandes, ministro das Relações Exteriores. Genebra, 30 jun. 1948. Diversos no Exterior. Ofícios recebidos da Delegação Brasileira na OIR (agosto de 1947 a 1948). AHI/RJ.

n. 378 (reservado) de Vasco Leitão da Cunha, encarregado de negócios na Espanha para Hildebrando Accioly, ministro interino das Relações Exteriores. Madri, 20 out. 1948. Missões Diplomáticas Brasileiras. Ofícios recebidos de Madri (outubro de 1948). AHI/RJ.

n. 437 (confidencial) de Vasco Leitão da Cunha, encarregado de negócios na Espanha para Hildebrando Accioly, ministro interino das Relações Exteriores. Madri, 04 dez. 1948. Missões Diplomáticas Brasileiras. Ofícios recebidos de Madri. (1947/1959). Arquivo de Correspondência Especial. CDO/MRE. 
n. 79 de Vasco Leitão da Cunha, encarregado de negócios do Brasil na Espanha para Raul Fernandes, ministro das Relações Exteriores do Brasil. Madri, 12 mar. 1949. Missões Diplomáticas Brasileiras. Ofícios recebidos de Madri (jan. a março de 1949). AHI/RJ.

n. 94 de Vasco Leitão da Cunha, encarregado de negócios do Brasil na Espanha para Raul Fernandes, ministro das Relações Exteriores do Brasil. Madri, 31 mar. 1949. Missões Diplomáticas Brasileiras. Ofícios recebidos de Madri (jan. a março de 1949). AHI/RJ.

n. 117 (reservado) de Vasco Leitão da Cunha, encarregado de negócios do Brasil na Espanha para Raul Fernandes, ministro das Relações Exteriores do Brasil. Madri, 22 abr. 1949. Missões Diplomáticas Brasileiras. Ofícios recebidos de Madri (abril a junho de 1949). AHI/RJ.

n. 84 do cônsul do Brasil em Barcelona (ass. ileg.) para Secretaria de Estado das Relações Exteriores. Barcelona, 15 jun. 1949. Consulados Brasileiros. Ofícios recebidos de Barcelona (1949). AHI/RJ.

n. 370 de Jose Rojas y Moreno, embaixador da Espanha no Brasil para ministro de Assuntos Exteriores da Espanha. Rio de Janeiro, 30 jul. 1949. R2316, expt. 21. AMAE.

n. 115 do cônsul do Brasil em Barcelona (ass. ileg.) para a Secretaria de Estado das

Relações Exteriores. Barcelona, 16 ago. 1949. Consulados Brasileiros. Ofícios recebidos de Barcelona (1949). AHI/RJ.

n. 230 (confidencial) de Vasco Leitão da Cunha, encarregado de negócios do Brasil na

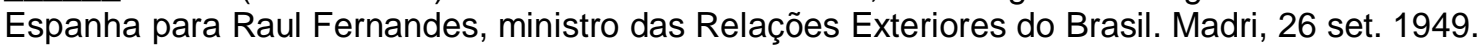
Missões Diplomáticas Brasileiras. Ofícios recebidos de Madri (1947/1959). Arquivo de Correspondência Especial. CDO/MRE.

n. 240 de Vasco Leitão da Cunha, encarregado de negócios do Brasil na Espanha para Raul Fernandes, ministro das Relações Exteriores do Brasil. Madri, 30 set. 1949. Missões Diplomáticas Brasileiras. Ofícios recebidos de Madri (julho a out. 1949). AHI/RJ.

n. 51 de Gregorio Izaga, cônsul espanhol na Bahia para Embaixador da Espanha no Brasil. Bahia, 02 dez. 1949. R5672, expt. 44. AMAE.

n. 326 (reservado) de Vasco Leitão da Cunha, encarregado de negócios do Brasil na Espanha para Raul Fernandes, ministro das Relações Exteriores do Brasil. Madri, 03 dez. 1949. Missões Diplomáticas Brasileiras. Ofícios recebidos de Madri (novembro e dezembro de 1949). AHI/RJ.

n. 209 de Rubens Ferreira de Mello, embaixador do Brasil para Raul Fernandes, ministro das Relações Exteriores do Brasil. Madri, 17 jul. 1950. Missões Diplomáticas Brasileiras. Ofícios recebidos de Madri (julho a setembro de 1950). AHI/RJ.

n. 368 de Rubens Ferreira de Mello, embaixador do Brasil para Raul Fernandes, ministro das Relações Exteriores do Brasil. Madri, 17 dez. 1950. Missões Diplomáticas Brasileiras. Ofícios recebidos de Madri (outubro a dezembro de 1950). AHI/RJ.

n. 373 de Rubens Ferreira de Melo, embaixador do Brasil na Espanha para Raul Fernandes, Ministro das Relações Exteriores. Madri, 22 dez. 1950. Missões Diplomáticas Brasileiras. Ofícios recebidos de Madri (outubro a dezembro de 1950). AHI/RJ.

n. 374 da Embaixada do Brasil na Espanha para Secretaria de Estado das Relações Exteriores. Madri, 27 dez. 1950. Missões Diplomáticas Brasileiras. Ofícios recebidos de Madri (outubro a dezembro de 1950). AHI/RJ.

n. 380 de Rubens Ferreira de Melo, embaixador do Brasil na Espanha para Raul Fernandes, ministro das Relações Exteriores. Madri, 30 dez. 1950. Missões Diplomáticas Brasileiras. Ofícios recebidos de Madri (outubro a dezembro de 1950). AHI/RJ.

n. 02 da Embaixada do Brasil na Espanha para Secretaria de Estado das Relações Exteriores. Madri, 03 jan. 1951. Missões Diplomáticas Brasileiras. Ofícios recebidos de Madri (janeiro a março de 1951). AHI/RJ.

n. 43 de Rubens Ferreira de Melo, embaixador do Brasil na Espanha para João Neves da Fontoura, ministro das Relações Exteriores do Brasil. Madri, 26 jan. 1951. Missões Diplomáticas Brasileiras. Ofícios recebidos de Madri (janeiro a março de 1951). AHI/RJ.

n. 39 de de Rubens Ferreira de Melo, embaixador do Brasil na Espanha para João

neves da Fontoura, ministro das Relações Exteriores. Madri, 24 jan. 1952. Missões Diplomáticas Brasileiras. Ofícios recebidos de Madri (janeiro a março de 1952). AHI/RJ.

n. 237 de Rubens Ferreira de Mello, embaixador do Brasil na Espanha para João

Neves da Fontoura, Ministro de Estado das Relações Exteriores do Brasil. Madri, 20 jun. 1952. Missões Diplomáticas Brasileiras. Ofícios recebidos de Madri (abril a junho de 1952). AHI/RJ.

n. 354 de Rubens Ferreira de Mello, embaixador do Brasil na Espanha para João

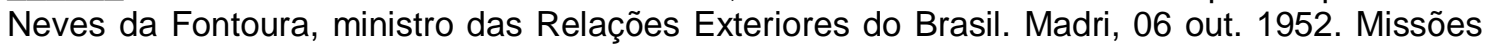
Diplomáticas Brasileiras. Ofícios recebidos de Madri (outubro a dezembro de 1952). AHI/RJ. 
n. 417 de Rubens Ferreira de Melo, embaixador do Brasil na Espanha para Mario de Pimentel Brandão, ministro interino das Relações Exteriores do Brasil. Madri, 18 nov. 1952. Missões Diplomáticas Brasileiras. Ofícios recebidos de Madri (outubro a dezembro de 1952).

n. 5595 de Fernando Nilo de Alvarenga, presidente do Conselho de Imigração e Colonização para Mario de Pimentel Brandão, secretário do Ministério das Relações Exteriores. Rio de Janeiro, $31 \mathrm{dez}$. 1952. Diversos no Exterior. Ofícios recebidos do Conselho de Imigração e Colonização (dezembro de 1952). AHI/RJ.

n. 15 de Rubens Ferreira de Melo, embaixador do Brasil na Espanha para João Neves da Fontoura, ministro das Relações Exteriores. Madri, 09 jan. 1953. Missões Diplomáticas Brasileiras. Ofícios recebidos de Madri (janeiro a março de 1953). AHI/RJ.

n. 36 de Rubens Ferreira de Mello, embaixador do Brasil na Espanha para João Neves da Fontoura, Ministro de Estado das Relações Exteriores do Brasil. Madri, 21 jan. 1953. Missões Diplomáticas Brasileiras. Ofícios recebidos de Madri (janeiro a março de 1953). AHI/RJ.

n. 141 de Rubens Ferreira de Mello, embaixador do Brasil na Espanha para João Neves da Fontoura, ministro de Estado das Relações Exteriores do Brasil. Madri, 27 abr. 1953. Missões Diplomáticas Brasileiras. Ofícios recebidos de Madri (abril a maio de 1953). AHI/RJ.

n. 267 (confidencial) de Rubens Ferreira de Melo, embaixador do Brasil na Espanha para Vicente Ráo, ministro das Relações Exteriores. San Sebastián, 28 jul. 1953. Missões Diplomáticas Brasileiras. Ofícios recebidos de Madri (1947-1959). Arquivo de Correspondência Especial. CDO/MRE.

n. 71 de Rubens Ferreira de Melo, embaixador do Brasil na Espanha para Vicente Rao, ministro das Relações Exteriores. Madri, 10 fev. 1954. Missões Diplomáticas Brasileiras. Ofícios recebidos de Madri (janeiro a fevereiro de 1954). AHI/RJ.

n. 224 da Embaixada do Brasil na Espanha para a Secretaria de Estado das Relações Exteriores do Brasil Madri, 31 maio 1954. Missões Diplomáticas Brasileiras. Ofícios recebidos de Madri (maio a julho de 1954). AHI/RJ.

n. 356 de Rubens Ferreira de Mello, embaixador do Brasil na Espanha para Raul Fernandes, ministro de Estado das Relações Exteriores do Brasil. Madri, 09 set. 1954. Missões Diplomáticas Brasileiras. Ofícios recebidos de Madri (agosto a setembro de 1954). AHI/RJ.

n. 382 de Rubens Ferreira de Melo, embaixador do Brasil na Espanha para Raul Fernandes, ministro das Relações Exteriores. Madri, 02 out. 1954. Missões Diplomáticas Brasileiras. Ofícios recebidos de Madri (outubro a dezembro de 1954). AHI/RJ.

n. 193 de Rubens Ferreira de Melo, embaixador do Brasil na Espanha para Raul Fernandes, ministro das Relações Exteriores. Madri, 03 maio 1955. Missões Diplomáticas Brasileiras. Ofícios recebidos de Madri (abril a junho de 1955). AHI/RJ.

n. 32 de Rubens Ferreira de Melo, embaixador do Brasil na Espanha para João Carlos de Macedo Soares, ministro das Relações Exteriores do Brasil. Madri, 25 jan. 1956. Missões Diplomáticas Brasileiras. Ofícios recebidos de Madri (janeiro a março de 1956). AHI/RJ.

n. 34 de Rubens Ferreira de Melo, embaixador do Brasil na Espanha para Josão Carlos de Macedo Soares, ministro das Relações Exteriores. Madri, 28 jan. 1956. Missões Diplomáticas Brasileiras. Ofícios recebidos de Madri (janeiro a março de 1956). AHI/RJ.

n. 130 de Rubens Ferreira de Mello, embaixador do Brasil na Espanha para José

Carlos de Macedo Soares, ministro das Relações Exteriores. Madri, 02 abr. 1956. Missões Diplomáticas Brasileiras. Ofícios recebidos de Madri (abril a maio de 1956). AHI/RJ.

n. 198 de Rubens Ferreira de Melo, embaixador do Brasil na Espanha para José $\overline{\text { Carlos }}$ de Macedo Soares, ministro das Relações Exteriores. Madri, 21 maio 1956. Missões Diplomáticas Brasileiras. Ofícios recebidos de Madri (abril a maio de 1956). AHI/RJ.

n. 274 da Embaixada do Brasil na Espanha para Secretaria de Estado das Relações Exteriores. Madri, 30 jun. 1956. Missões Diplomáticas Brasileiras. Ofícios recebidos de Madri (junho a julho de 1956). AHI/RJ.

n.351 da Secretaria de Estado das Relações Exteriores para Embaixada do Brasil em Madri. 24 agosto 1956. Missões Diplomáticas Brasileiras. Ofícios recebidos de Madri (agosto a outubro de 1956). AHI/RJ.

n. 455 de João P. G. Coelho Lisboa, embaixador do Brasil na Espanha para José Carlos de Macedo Soares, ministro das Relações Exteriores. Madri, 30 out. 1956. Missões Diplomáticas Brasileiras. Ofícios recebidos de Madri (agosto a outubro de 1956). AHI/RJ.

n. 472 de João P. G. Coelho Lisboa, embaixador do Brasil na Espanha para João $\overline{\text { Carlos }}$ de Macedo Soares, ministro das Relações Exteriores. Madri, 05 nov. 1956. Missões Diplomáticas Brasileiras. Ofícios recebidos de Madri (novembro a dezembro de 1956). AHI/RJ. 
n. 171 da Embaixada do Brasil na Espanha para Secretaria de Estado das Relações Exteriores. Madri, 09 abr. 1957. Missões Diplomáticas Brasileiras. Ofícios recebidos de Madri (abril a maio de 1957). AHI/RJ.

da Embaixada do Brasil na Espanha para a Secretaria de Estado das Relações Exteriores. Madri, 01 jul. 1957. Missões Diplomáticas Brasileiras. Ofícios recebidos de Madri (junho a julho de 1957). AHI/RJ.

(cópia) do presidente do Instituto Nacional de Imigração e Colonização (s/ass.) para a Secretaria de Estado das Relações Exteriores. Rio de Janeiro, 06 ago. 1957. Ofícios recebidos do INIC (julho a dezembro de 1957). AHI/RJ.

n. 887 (reservado) de Câmara Canto, encarregado de negócios do Brasil na Espanha para Décio Moura, ministro interino das Relações Exteriores. Madri, 04 dez. 1957. Missões Diplomáticas Brasileiras. Ofícios recebidos de Madri (dezembro de 1957). AHI/RJ.

de Walter Cechella, presidente do Instituto Nacional de Imigração e Colonização para a Secretaria de Estado das Relações Exteriores. Rio de Janeiro, 19 fev. 1958. Ofícios recebidos do INIC (janeiro a março de 1958). AHI/RJ.

n.372 da Embaixada do Brasil na Espanha para a Secretaria de Estado das Relações Exteriores. Madri, 01 abr. 1958. Missões Diplomáticas Brasileiras. Ofícios recebidos de Madri (abril de 1958). AHI/RJ.

n. 565 de João P. G. Coelho Lisboa, embaixador do Brasil na Espanha para José Carlos de Macedo Soares, ministro das Relações Exteriores. Missões Diplomáticas Brasileiras. Ofícios recebidos de Madri (maio a junho de 1958). AHI/RJ.

n. 38 de Altair de Moura, cônsul do Brasil em Barcelona para João P. G. Coelho Lisboa, embaixador do Brasil na Espanha. Barcelona, 17 jun. 1958. Missões Diplomáticas Brasileiras. Ofícios recebidos de Madri (maio a junho de 1958). AHI/RJ.

n. 711 da Embaixada do Brasil na Espanha para a Secretaria de estado das Relações Exteriores. Madri, 02 jul. 1958. Missões Diplomáticas Brasileiras. Ofícios recebidos de Madri (julho a agosto de 1958). AHI/RJ.

n. 751 de João P. G. Coelho Lisboa para Francisco Negrão de Lima, ministro das Relações Exteriores. Madri, 15 jul. 1958. Missões Diplomáticas Brasileiras. Ofícios recebidos de Madri (julho a agosto de 1958). AHI/RJ.

n. 913 da Embaixada do Brasil na Espanha para SERE. Madri, 09 set. 1958. Missões Diplomáticas Brasileiras. Ofícios recebidos de Madri (setembro a outubro de 1958). AHI/RJ.

n. 986 de Câmara Canto, encarregado de negócios do Brasil na Espanha para

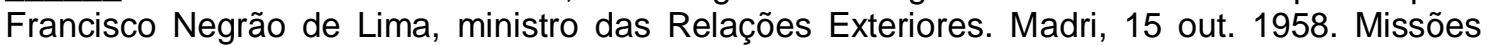
Diplomáticas Brasileiras. Ofícios recebidos de Madri (setembro a outubro de 1958). AHI/RJ.

(reservado) n.1078 da Embaixada do Brasil na Espanha (s/assin.) para Francisco

Negrão de Lima, ministro das Relações Exteriores. Madri, 09 dez. 1958. Missões Diplomáticas Brasileiras. Ofícios recebidos de Madri (novembro a dezembro de 1958). AHI/RJ.

n. 308 de João P. G. Coelho Lisboa, embaixador do Brasil na Espanha para Francisco

Negrão de Lima, ministro das Relações Exteriores. Madri, 27 abr. 1959. Missões Diplomáticas Brasileiras. Ofícios recebidos de Madri (março a abril de 1959). AHI/RJ.

n. 327 da Embaixada do Brasil na Espanha para Secretaria de Estado das Relações Exteriores. Madri, 02 maio. 1959. Missões Diplomáticas Brasileiras. Ofícios recebidos de Madri (maio a junho de 1959). AHI/RJ.

n. 462 da Embaixada do Brasil na Espanha para Secretaria de Estado das Relações Exteriores. Madri, 23 jun. 1959. Missões Diplomáticas Brasileiras. Ofícios recebidos de Madri (maio a junho de 1956). AHI/RJ.

n. 599 de João P. G. Coelho Lisboa, embaixador do Brasil na Espanha para Horácio Lafer, ministro das Relações Exteriores. Madri, 26 ago. 1959. Missões Diplomáticas Brasileiras. Ofícios recebidos de Madri (julho e agosto de 1959). AHI/RJ.

n. 709 da Embaixada do Brasil na Espanha para a Secretaria de Estado das Relações

Exteriores. Madri, 06 out. 1959. Missões Diplomáticas Brasileiras. Ofícios recebidos de Madri (outubro de 1959). AHI/RJ.

n. 874 de João P. G. Coelho Lisboa, embaixador do Brasil na Espanha para Horácio Lafer, ministro das Relações Exteriores. Madri, 18 nov. 1959. Missões Diplomáticas Brasileiras. Ofícios recebidos de Madri (janeiro a março de 1952). AHI/RJ.

n. 895 da Embaixada do Brasil na Espanha para a Secretaria de Estado das Relações Exteriores. Madri, 25 nov. 1959. Missões Diplomáticas Brasileiras. Ofícios recebidos de Madri (novembro a dezembro de 1959). AHI/RJ. 
n. 374 de João P. G. Coelho Lisboa, embaixador do Brasil na Espanha para Horácio Lafer, ministro das Relações Exteriores do Brasil. Madri, 17 mai 1960. Missões Diplomáticas Brasileiras. Ofícios recebidos de Madri (1960-1963). Arquivo de Correspondência Especial. CDO/MRE.

n. 855 (confidencial) de João P. G. Coelho Lisboa, embaixador do Brasil na Espanha para Francisco C. San Thiago Dantas, ministro das Relações Exteriores. Madri, 10 out. 1961. Missões Diplomáticas Brasileiras. Ofícios recebidos de Madri (1960-1963). Arquivo de Correspondência Especial. CDO/MRE.

\section{Portaria}

assinada por Abelardo Roças, embaixador do Brasil na Espanha. Madri, 05 out. 1942. Missões Diplomáticas Brasileiras. Ofícios recebidos de Madri (julho a dezembro de 1942). AHI/RJ.

\section{Relatórios}

(reservado) do "mês político" de Abelardo Roças, embaixador do Brasil na Espanha para Oswaldo Aranha, ministro das Relações Exteriores do Brasil. Madri, 30 abr. 1941. Missões Diplomáticas Brasileiras. Ofícios recebidos de Madri (abril a dezembro de 1941). AHI/RJ. do mês político (confidencial) de julho de 1941, de Abelardo Roças, embaixador do

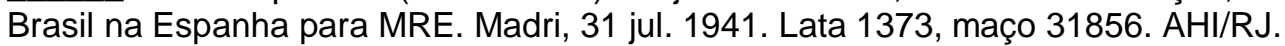
"mês econômico" de Abelardo Roças, embaixador do Brasil na Espanha para Oswaldo

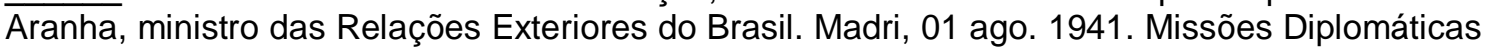
Brasileiras. Ofícios recebidos de Madri (abril a dezembro de 1941). AHI/RJ. de Maurício de Nabuco, presidente da Comissão de Inquérito para Getúlio Vargas, Presidente da República. Rio de Janeiro, 25 fev. 1942. Maço 20778, lata 1096. AHI/RJ. de (ass. ileg.) para Getúlio Vargas, Presidente da República do Brasil. Distrito Federal, 11 ago. 1942. Departamento Administrativo do Serviço Público. Maço 34502, lata 1587. AHI/RJ.

(reservado) do mês político de Abelardo Roças, embaixador do Brasil na Espanha para Oswaldo Aranha, ministro das Relações Exteriores do Brasil. Madri, 28 fev. 1943. Missões Diplomáticas Brasileiras. Ofícios recebidos de Madri (janeiro a junho de 1942). AHI/RJ. do mês político (dezembro de 1948) de Vasco Leitão da Cunha, encarregado de negócios do Brasil na Espanha para Raul Fernandes, ministro das Relações Exteriores do Brasil. Madri, 12 jan. 1949. Missões Diplomáticas Brasileiras. Ofícios recebidos de Madri (janeiro a março de 1949). AHI/RJ.

do mês político (outubro) de Vasco Leitão da Cunha para Ministério das Relações Exteriores. Madri, 09 nov. 1949. Missões Diplomáticas Brasileiras. Ofícios recebidos de Madri (nov. a dez. de 1949). AHI/RJ.

do "Mês econômico" de Álvaro Trindade Cruz, adido comercial à Embaixada do Brasil na Espanha para Ministério das Relações Exteriores. Madri, 15 mar. 1950. Missões Diplomáticas Brasileiras. Ofícios recebidos de Madri (janeiro a março de 1950). AHI/RJ.

"A Espanha como país exportador de algodão" de Álvaro Trindade Cruz, adido comercial da Embaixada do Brasil na Espanha para Ministério das Relações Exteriores. Anexo ao ofício n. 111 da Embaixada do Brasil na Espanha para a Secretaria de Estado das Relações Exteriores. Madri, 25 abr. 1950. Missões Diplomáticas Brasileiras. Ofícios recebidos de Madri (abril a junho de 1950). AHI/RJ.

do "Mês econômico" da Embaixada do Brasil na Espanha para Ministério das Relações Exteriores. Madri, 07 dez. 1950. Missões Diplomáticas Brasileiras. Ofícios recebidos de Madri (outubro a dezembro de 1950). AHI/RJ.

social n. 04 da Embaixada do Brasil na Espanha para Ministério das Relações

Exteriores do Brasil (4ำ trimestre de 1954). Madri, 03 jan. 1955. Missões Diplomáticas Brasileiras. Ofícios recebidos de Madri (janeiro a março de 1955). AHI/RJ.

do "mês político" (janeiro de 1956) de Rubens Ferreira de Melo, embaixador do Brasil

na Espanha para José Carlos de Macedo Soares, ministro das Relações Exteriores do Brasil. Missões Diplomáticas Brasileiras. Ofícios recebidos de Madri (jan. a março de 1956). AHI/RJ.

do Mês cultural (janeiro de 1956). Madri, 01 fev. 1956. Missões Diplomáticas Brasileiras. Ofícios recebidos de Madri (janeiro a março de 1956). AHI/RJ. 
do mês cultural (maio 56). Madri, 04 jun. 1956. Missões Diplomáticas Brasileiras. Ofícios recebidos de Madri (junho a julho de 1956). AHI/RJ.

de Evaldo Jose Cabral de Mello para João P. G. Coelho Lisboa. Anexo ao ofício n. 350

da Embaixada do Brasil na Espanha para Secretaria de Estado das Relações Exteriores. Madri, 23 ago. 1956. Missões Diplomáticas Brasileiras. Ofícios recebidos de Madri (agosto a outubro de 1956). AHI/RJ.

do "Mês econômico" (outubro de 1958), da Embaixada do Brasil na Espanha para Ministério das Relações Exteriores do Brasil. Missões Diplomáticas Brasileiras. Ofícios recebidos de Madri (setembro a outubro de 1958). AHI/RJ.

do mês cultural (maio de 1959) da Embaixada do Brasil na Espanha para Ministério das Relações Exteriores. Missões Diplomáticas Brasileiras. Ofícios recebidos de Madri (maio a junho de 1959). AHI/RJ.

\section{Telegramas}

de Oswaldo Aranha para Getúlio Vargas (s/d). Arquivo Getúlio Vargas (GVc, $\overline{1936.05 .00 ~ / ~ X X I I ~-~ 54) . ~ C P D O C / F G V . ~}$

da Secretaria de Estado das Relações Exteriores para Embaixada do Brasil em Madri.

Rio de Janeiro, 14 ago. 1936. Missões Diplomáticas Brasileiras. Telegramas expedidos a Madri (1931-1937). AHI/RJ.

(confidencial) da Secretaria de Estado das Relações Exteriores do Brasil para Embaixada do Brasil em Buenos Aires. Rio de Janeiro, 31 out. 1936. Lata 711, maço 10326. AHI/RJ.

de Oswaldo Aranha para Getúlio Vargas. Washington, 12 jul. 1937. Arquivo Getúlio Vargas (GVc 1937.07.12). CPDOC/FGV.

do Ministério das Relações Exteriores para Consulado do Brasil em Barcelona. Rio de Janeiro, 05 fev. 1938. Lata 998, maço 16237. AHI/RJ.

de Luiza Prado Lisboa para Getúlio Vargas remetido através de Telegrama das Relações Exteriores para Luis Vergara, secretário da Presidência da República. 19 mar. 1938. Lata 711, maço 10326. AHI/RJ.

da Secretaria de Relações Exteriores do Brasil para Embaixada do Brasil em Barcelona. Rio de Janeiro, 25 mar. 1938. Missões Diplomáticas Brasileiras. Telegramas expedidos a Madri (1938-1942). AHI/RJ.

de Carlos da Silveira Martins Ramos, encarregado de negócios em Barcelona para Oswaldo Aranha, ministro das Relações Exteriores do Brasil. Barcelona, 29 mar. 1938. Lata 711, maço 10326. AHI/RJ.

(cópia) traduzido do secretário de Estado norte-americano Cordell Hull para a Embaixada dos EUA no Rio de Janeiro. Washington, 21 set. 1938. Lata 713, maço 10343. AHI/RJ.

da Secretaria de Estado das Relações Exteriores para a Embaixada do Brasil em Barcelona. Rio de Janeiro, 10 dez. 1938. Missões Diplomáticas Brasileiras. Telegramas expedidos a Madri (1938-1942). AHI/RJ.

de Carlos da Silveira Martins Ramos, encarregado de negócios do Brasil na Espanha para Ministério das Relações Exteriores. Perpignan, 03 mar. 1939. Lata 293, maço 10326. AHI/RJ.

da Secretaria das Relações Exteriores para Legação do Brasil em Berna. Rio de Janeiro, 06 mar. 1939. Lata 293, maço 10326. AHI/RJ.

da Secretaria de Relações Exteriores para Embaixada do Brasil na Espanha. Rio de Janeiro, 01 jul. 1939. Missões Diplomáticas Brasileiras. Telegramas expedidos a Madri (19381942). AHI/RJ.

(cópia) da Secretaria de Estado das Relações Exteriores à Embaixada do Brasil na Espanha. Rio de Janeiro, 16 nov. 1939. Missões Diplomáticas Brasileiras. Telegramas expedidos a Madri (1938-1942). AHI/RJ.

da Secretaria de Relações Exteriores para Embaixada do Brasil em Madri. Rio de Janeiro, 20 dez. 1939. Missões Diplomáticas Brasileiras. Telegramas expedidos a Madri (19381942). AHI/RJ.

(cópia) da Secretaria de Estado das Relações Exteriores para a Embaixada do Brasil na Espanha. Rio de Janeiro, 27 fev. 1940. Missões Diplomáticas Brasileiras. Telegramas expedidos a Madri (1938-1942). AHI/RJ. 
(confidencial) do Ministério das Relações Exteriores para a Embaixada do Brasil na Espanha. Rio de Janeiro, 29 out. 1940. Missões Diplomáticas Brasileiras. Telegramas expedidos a Madri (1938/1942). AHI/RJ.

confidencial n. 93 da Secretaria de Estado das Relações Exteriores para Embaixada em Madri. Rio de Janeiro, 07 out. 1942. Missões Diplomáticas Brasileiras. Telegramas expedidos a Madri (1938 a 1942). AHI/RJ.

n. 95 da Secretaria de Estado das Relações Exteriores para Embaixada em Madri. Rio de Janeiro, 09 out. 1942. Missões Diplomáticas Brasileiras. Telegramas expedidos a Madri (1938 a 1942). AHI/RJ.

da Secretaria de Estado das Relações Exteriores para a Embaixada em Madri. Rio de Janeiro, 16 ago. 1944. Missões Diplomáticas Brasileiras. Telegramas enviados (1943-1944). $\mathrm{AHI} / \mathrm{RJ}$.

do Ministério das Relações Exteriores para a Delegação do Brasil junto a ONU. Rio de Janeiro, 11 set. 1945. Diversos no Exterior. Telegramas e minutas (1945-1946). AHI/RJ. do Ministério das Relações Exteriores para a Delegação do Brasil junto a ONU. Rio de

Janeiro, 08 out. 1945. Diversos no Exterior .Telegramas e minutas (1945-1946). AHI/RJ. (particular) de Pedro Leão Velloso para Cyro de Freitas Valle, embaixador junto a ONU. Rio de Janeiro, 23 jan. 1946. Diversos no Exterior. Telegramas e minutas expedidos a Delegação do Brasil junto à ONU (1945-1946). AHI/RJ.

(particular) de Pedro Leão Velloso para Vasco Leitão da Cunha. Rio de Janeiro, 25 jan. 1946. Diversos no Exterior. Telegramas e minutas expedidos a Delegação do Brasil junto à ONU (1945-1946). AHI/RJ.

n. 11 (confidencial) do Ministério das Relações Exteriores para Delegação brasileira junto a ONU. Rio de Janeiro, 16 fev. 1946. Diversos no Exterior. Delegação do Brasil junto à ONU. Telegramas e minutas expedidos (1945-1946). AHI/RJ.

(confidencial) do Ministério das Relações Exteriores para Delegação brasileira junto a ONU. Rio de Janeiro, 05 jun. 1946. Diversos no Exterior. Delegação do Brasil junto à ONU. Telegramas e minutas expedidos (1945-1946). AHI/RJ.

n. 112 do Ministério das Relações Exteriores para a Delegação do Brasil junto a ONU.

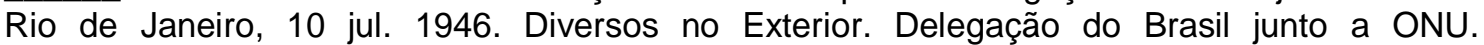
Telegramas e minutas (1945-1946). AHI/RJ.

(confidencial) do Ministério das Relações Exteriores para a Delegação do Brasil junto a ONU. Rio de Janeiro, 06 nov. 1946. Diversos no Exterior. Delegação do Brasil junto à ONU. Telegramas e minutas (1945-1946). AHI/RJ. (confidencial) da Secretaria de Relações Exteriores para a Embaixada do Brasil em Madri. Rio de Janeiro, 06 out. 1947. Missões Diplomáticas Brasileiras. Telegramas expedidos a Madri (1947-1959). Arquivo de Correspondência Especial. CDO/MRE.

(confidencial) da Secretaria de Relações Exteriores para Embaixada do Brasil em Madri. Rio de Janeiro, 04 jun. 1948. Missões Diplomáticas Brasileiras. Telegramas expedidos a Madri (1947/1959). Arquivo de Correspondência Especial. CDO/MRE.

(confidencial) da Secretaria de Estado das Relações Exteriores para Embaixada do Brasil na Espanha. Rio de Janeiro, 02 abr. 1949. Missões Diplomáticas Brasileiras. Telegramas expedidos a Madri (1947/1959). Arquivo de Correspondência Especial. CDO/MRE.

de Alberto Martin Artajo, ministro de Assuntos Exteriores para embaixador do Brasil na

Espanha. Madri, 12 abr. 1951. R5672, expt. 41. AMAE.

(confidencial) de Raul Bopp, cônsul brasileiro em Barcelona para Ministério das

Relações Exteriores do Brasil. Barcelona, 22 jul. 1952. Consulados Diversos. Telegramas expedidos (1947-1957). Arquivo de Correspondência Especial. CDO/MRE. (confidencial) da Secretaria de Estado das Relações Exteriores para o Consulado do Brasil em Barcelona. Rio de Janeiro, 30 jul. 1952. Consulados Diversos. Telegramas expedidos (1947-1957). Arquivo de Correspondência Especial. CDO/MRE. confidencial de Raul Bopp para Ministério das Relações Exteriores. Barcelona, 26 nov.

1952. Consulados Diversos. Telegramas e cartas recebidas (1947-1957). Arquivo de Correspondência Especial. CDO/MRE. confidencial da Secretaria de Estado das Relações Exteriores para a Embaixada do Brasil em Madri. Rio de Janeiro, 02 jul. 1953. Missões Diplomáticas Brasileiras. Telegramas expedidos a Madri (1947-1959). Arquivo de Correspondência Especial. CDO/MRE.

da Secretaria de Estado das Relações Exteriores para a Embaixada do Brasil na Espanha. Missões Diplomáticas Brasileiras. Rio de Janeiro, 26 jul. 1954. Telegramas expedidos a Madri (1950-1956). AHI/RJ. 
s confidenciais de Paulo Braz Pinto, secretário da Embaixada do Brasil na Espanha para a Secretaria de Estado das Relações Exteriores. Madri, 02 e 13 de abril de 1955. Missões Diplomáticas Brasileiras. Telegramas recebidos de Madri (1947/1959). Arquivo de Correspondência Especial. CDO/MRE.

da Secretaria de Estado das Relações Exteriores para Embaixada do Brasil na

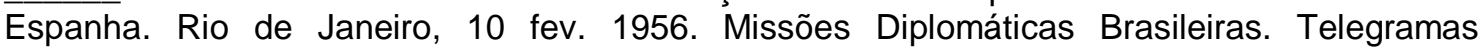
expedidos a Madri (1950 -1956). AHI/RJ.

(confidencial) de Lauro de Andrade Muller, cônsul do Brasil em Barcelona para

Ministério das Relações Exteriores do Brasil. Barcelona, 27 jun. 1956. Consulados Brasileiros. Telegramas e cartas recebidas (1947/1957). Arquivo de Correspondência Especial. CDO/MRE. da Secretaria de Estado das Relações Exteriores para Embaixada do Brasil em Madri.

Rio de Janeiro, 31 jun. 1956. Missões Diplomáticas Brasileiras. Telegramas expedidos a Madri (1947-1959). AHI/RJ.

da Secretaria de Estado das Relações Exteriores para Embaixada do Brasil em Madri. Rio de Janeiro, 19 dez. 1960. Missões Diplomáticas Brasileiras. Telegramas expedidos a Madri (1957-1960). Seção Arquivo Histórico. CDO/MRE.

\section{Correspondência Particular (AHI; CPDOC; AMAE)}

\section{Cartas}

(assinada por diversos comerciantes) para ministro do Brasil na Espanha. San Sebastián, 09 ago 1932. Missões Diplomáticas Brasileiras. Ofícios recebidos de Madri (abril de 1932 a janeiro de 1933). AHI/RJ.

de Ramon Ibañez para Presidente da República dos Estados Unidos do Brasil. Barcelona, 21 out. 1935. Consulados Brasileiros. Ofícios recebidos de Barcelona (1935 a abril de 1936). AHI/RJ.

de Getúlio Vargas para Oswaldo Aranha. Rio de Janeiro, 17 ago. 1936. Arquivo

Oswaldo Aranha (OA cp 1936.08.17/1). CPDOC/FGV.

de Oswaldo Aranha para Getúlio Vargas. Washington, 26 ago. 1936. Arquivo Getúlio

Vargas (GV c, 1936.08.26). CPDOC/FGV.

de Francisco Franco, "El jefe del Estado y general em jefe del Ejercito Nacional" para

Getúlio Vargas. Salamanca, 29 out. 1936. Arquivo Getúlio Vargas (GV 36.10/1 XXIV - 44). CPDOC/FGV.

(cópia) de Alcebíades Peçanha para Carlos da Silveira Martins Ramos. Villa la

Pommerais, 22 jul. 1938. Anexo n. 1 ao ofício n. 60 (reservado) de Carlos da Silveira Martins

Ramos, encarregado de negócios em Barcelona para Oswaldo Aranha, ministro das Relações

Exteriores do Brasil. Barcelona, 02 ago. 1938. Lata 630, maço 9696. AHI/RJ.

(cópia) de Ameletto Branda para Julio Alvarez del Vayo, ministro de Estado. Valencia,

11 jun. 1938. AHI/RJ.

(cópia) de Carlos da Silveira Martins Ramos para Hildebrando Accioly. Barcelona, 14

out. 1938. Lata 710, maço 10325. AHI/RJ.

(cópia) de Carlos da Silveira Martins Ramos para "Cyro". Perpignan, 10 fev. 1939. Lata

716, maço 10364. AHI/RJ.

(cópia) de Howard E. Kerahner (em nome da International Comission for the Assistance of Child Refugees in Spain) para Oswaldo Aranha. Paris, 07 abr. 1939. Lata 713, maço 10343. AHI/RJ.

(cópia) de Andres Rodriguez Marin para Oswaldo Aranha. São Paulo, 27 jun. 1939.

Anexo ao ofício (cópia) de Oswaldo Aranha, ministro das Relações Exteriores para Francisco

Campos, ministro da Justiça. Rio de Janeiro, 02 set. 1939. Lata 630, maço 9696. AHI/RJ. (cópia) de Getúlio Vargas e Oswaldo Aranha para Francisco Franco. Palácio da

Presidência. Rio de Janeiro, 17 out. 1939. Lata 998, maço 16237. AHI/RJ.

de Dolores de Burgos para Oswaldo Aranha, ministro das Relações Exteriores. Cádiz,

21 nov. 1939. Lata 1756, maço 35635. AHI/RJ.

(cópia) de Agustina Romo y Mayo para o presidente Getúlio Vargas. Havana, 24 nov.

1939. Lata 630, maço 9696. AHI/RJ.

(particular) de Juan Beigbeder para Abelardo Roças. Madrid, 31 ago. 1940. Missões

Diplomáticas Brasileiras. Ofícios recebidos de Madri (1940 a março de 1941). AHI/RJ. 
de Oswaldo Aranha para Antonio Hermosilla. Rio de Janeiro, 05 set. 1940. Em anexo carta (manuscrita) de Luis Hermosilla para Oswaldo Aranha. Santiago do Chile, 19 ago. 1940. Arquivo Oswaldo Aranha. CPDOC/FGV.

de Luiz Hildebrando de Horta Barbosa, presidente da ABAPE para Oswaldo Aranha, presidente da Assembléia Geral da ONU. Rio de Janeiro, 19 set. 1947. Arquivo Oswaldo Aranha. CPDOC/FGV.

(cópia) de Tomás Llorente Buiza para cônsul espanhol na Bahia Gregorio Izaga. Fortaleza, 29 nov. 1949. Anexo 1 ao ofício n. 51 de Gregorio Izaga, cônsul espanhol na Bahia para Embaixador da Espanha no Brasil. Bahia, 02 dez. 1949. R5672, expt. 44. AMAE.

de Alfredo Sánchez Bella para Rubens Ferreira de Melo. Madri, 28 fev. 1952. Anexo ao

ofício n. 100 da Embaixada do Brasil na Espanha para Secretaria de Estado das Relações Exteriores. Madri, 7 mar. 1952. Missões Diplomáticas Brasileiras. Ofícios recebidos de Madri (janeiro a março de 1952). AHI/RJ.

(cópia) de Gregorio Marañon para Rubens Ferreira de Melo. San Sebastián, 13 set. 1953. Anexo ao ofício n. 313 de Rubens Ferreira de Melo, embaixador do Brasil na Espanha para Vicente Rao, ministro das Relações Exteriores. Madri, 17 set. 1953. Missões Diplomáticas Brasileiras. Ofícios recebidos de Madri (setembro a outubro de 1953). AHI/RJ.

de Pedro Gómez Aparicio, director da agência EFE para João P. G. Coelho Lisboa, embaixador do Brasil na Espanha. Madri, 03 dez. 1957. Anexo ao ofício n. 887 (reservado)... (citado em nota anterior).

de Luiz Hildebrando de Horta Barbosa, presidente da ABAPE para Anísio Teixeira. Rio de Janeiro, 30 out. 1963. Arquivo pessoal de Anísio Teixeira. CPDOC/FGV.

\section{Policiais (DEOPS/AESP; DOPS/APERJ)}

Prontuários consultados (DEOPS/SP):

- 4.872 - Emilio Castrillo Rodrigues

- 3.817 - Andres Rodrigues Barbeito

- 5.290 - Carlos da Costa Leite

- 80.136 - Comité Central de Propaganda de España Republicana

- 10.503 - Associação dos Amigos do Povo Espanhol

\section{Termo de Declarações}

de Andres Rodriguez Barbeito a Guilherme Pires de Albuquerque. Delegacia de Ordem Social. São Paulo, 23 nov. 1937. Prontuário 80136 - Comité Central de Propaganda de España Republicana. DEOPS-SP/AESP.

\section{Parecer}

de Venâncio Ayres, delegado de Ordem Social. Delegacia de Ordem Social. São Paulo, 9 nov. 1937. Prontuário 4872 - Emilio Castrilho Rodrigues. DEOPS/AESP.

\section{Informes}

(cópia) de José Gomes para delegado adido à Seção de Investigações. São Paulo, 06 dez. 1937, doc. 18, fl 26. Prontuário 3817 - Andres Rodriguez Barbeito. DEOPS-SP/AESP. reservado (cópia) de Osvaldo Aranha para Francisco Campos, ministro de Estado da $\overline{J u s t i c ̧ a ~ e ~ N e g o ́ c i o s ~ I n t e r i o r e s . ~ M i n i s t e ́ r i o ~ d a s ~ R e l a c ̧ o ̃ e s ~ E x t e r i o r e s . ~ R i o ~ d e ~ J a n e i r o, ~} 7$ jun. 1940. Prontuário 3817 - Andres Rodrigues Barbeito. DEOPS-SP/AESP. reservado (cópia) de Francisco Campos para Adhemar de Barros, interventor federal de São Paulo em 03 jul. 1940, fl 58-593817 - Andres Rodrigues Barbeito. DEOPS-SP/AESP. RJ/APERJ. em 03 jul. 1942. Dossiê Embaixada da Espanha. Setor espanhol, pasta 1. DOPS-

\section{Outros}

- Relação dos Brigadistas Brasileiros", (s/d); Ofício do delegado especial de Segurança Política e Social, Batista Teixeira ao delegado de Segurança Política e Social de São Paulo, Carneiro da Fonte. Delegacia Especializada de Segurança Política e Social. Rio de Janeiro, 17 mar. 1939. Prontuário 5290 - Carlos da Costa Leite. DEOPS-SP/AESP. 
- Estatutos da Associação Brasileira dos Amigos do Povo Espanhol. Rio de Janeiro, 05 jun. 1945. Prontuário 10503 - Associação dos Amigos do Povo Espanhol. DEOPS-SP/AESP.

\section{Iconográficas}

\section{Fotografias}

s anexadas às "Conclusões do processo administrativo sobre concessão de vistos em passaportes". Do chefe do Departamento Administrativo do Serviço Público (ass. ileg.) para Presidente da República. Rio de Janeiro, 11 ago. 1942. Lata 1587, maço 34502. AHI/RJ. de grupo de crianças espanholas auxiliadas por Carlos da Silveira Martins Ramos. Fotografia anexada ao ofício n.110 de Carlos da Silveira Martins Ramos, encarregado de negócios do Brasil para Oswaldo Aranha, Ministro das Relações Exteriores. Barcelona, 01 nov. 1936. Lata 716, maço 10364. AHI/RJ. de recepção na Embaixada do Brasil. Madri, (s.d.; fotógrafo não identificado). Madri/389/948/anexo n. 5. Mapoteca Histórica do Itamaraty/RJ.

\section{Periódicos}

"O Peru rompeu as relações diplomáticas com o governo de Barcelona". Jornal Acção. São Paulo, 22 mar. 1938, n 439, p. 1. AESP.

"Presentación de credenciales del embajador del Brasil.". Jornal (s/ ident. e s.d). Recorte anexado ao ofício n. 23 de Luis Guimarães Filho para F. de Cavalcanti de Lacerda, ministro interino das Relações Exteriores do Brasil. Madri, 8 fev. 1934. Missões Diplomáticas Brasileiras. Ofícios recebidos de Madri (julho de 1933 a março de 1934). AHI/RJ.

"Comida al embajador del Brasil.", jornal (s. ident.; s.d.). Recorte anexado ao ofício n. 106 de Luis Guimarães Filho para José Carlos de Macedo Soares. Madri, 24 set. 1934. MDB. Ofícios recebidos de Madri (abril de 1934 a fevereiro de 1935). AHI/RJ.

"La madre y la hermana de Carlos Prestes visitan nuestra redacción", jornal Heraldo de Madrid. Madri, 13 de maio de 1936. Recorte anexado ao ofício n. 61 de Alcebíades Peçanha, embaixador do Brasil na Espanha para José Carlos de Macedo Soares, ministro das Relações Exteriores do Brasil. Madri, 25 maio 1936. Missões Diplomáticas Brasileiras. Ofícios recebidos de Madri (1936 a junho de 1937). AHI/RJ.

"IBasta ya de complascencias peligrosas" (autor desconhecido), jornal Castilla Libre, de 16 ago. 1938. Anexo ao ofício de Luis de Soroa Garcia Goyena para encarregado de negócios, Carlos da Silveira Martins Ramos. Madri, 22 ago. 1938. Lata 711, maço 10326. AHI/RJ.

"Transigir com os communistas é nos condemnarmos ao suicídio" (autor não identificado), jornal A Pátria de 21 out. 1938. Recorte anexado ao despacho n. 375 de (ass. ileg.), encarregado de negócios da Espanha no Brasil para Ministro de Estado. Rio de Janeiro, 22 out. 1938. R999, expt. 12. AMAE.

"El Brasil regala al Generalísimo 240.000 Kilos de café", jornal La Vanguardia Española. Pontevedra, de 06 jul. 1939. Recorte anexado ao ofício n. 65 de Matheus de Albuquerque, cônsul em Barcelona para Oswaldo Aranha, ministro das Relações Exteriores do Brasil. Barcelona, 06 jul. 1939. Lata 713, maço 10343. AHI/RJ.

"Na Europa estão vendendo passaportes falsos para o Brasil à razão de 55 francos cada um. Graves declarações do Sr. Carlos da Silveira Martins Ramos, ex-conselheiro da nossa embaixada em Paris.", jornal A Notícia de 04 nov. 1940. Serviço de Imprensa do Ministério das Relações Exteriores. Lata 1096, maço 20778. AHI/RJ.

"Exploração em torno de passaportes brasileiros - retificação necessária", jornal do Brasil de 06 nov. 1940. Serviço de Imprensa do Ministério das Relações Exteriores. Lata 1096, maço 20778. AHI/RJ.

"El hambre en el Brasil", jornal Unidad de 12 fev. 1947. Recorte anexado ao ofício n. 105 (reservado) de Vasco Leitão da Cunha, encarregado de negócios na Espanha para Raul Fernandes, ministro das Relações Exteriores. Madri, 04 março 1947. Missões Diplomáticas Brasileiras. Ofícios enviados de Madri (março a abril de 1947). AHI/RJ. 
"El mundo através de nuestros corresponsales. $A B C$ em Rio de Janeiro", jornal $A B C$. Madri, $\overline{1} 7$ abr. 1947. Recorte anexado ao ofício n. 151 (reservado) de Vasco Leitão da Cunha, encarregado de negócios na Espanha para Raul Fernandes, ministro das Relações Exteriores. Madri, 28 abr. 1947. Missões Diplomáticas Brasileiras. Ofícios recebidos de Madri (março a abril de 1947). AHI/RJ.

"Libertad en las relaciones diplomáticas con España. Esto pide para los países de la ONU el delegado del Brasil.", jornal ABC. Madri, 17 mar. 1949. Recorte anexado ao ofício n. 94 de Vasco Leitão da Cunha, encarregado de negócios do Brasil na Espanha para Raul Fernandes, ministro das Relações Exteriores do Brasil. Madri, 31 mar. 1949. Missões Diplomáticas Brasileiras. Ofícios recebidos de Madri (jan. a março de 1949). AHI/RJ.

"Sordida traição", (autor não identificado), jornal Diário do Povo de 26 nov. de 1949. Recorte anexado ao ofício n. 51 de Gregorio Izaga, cônsul espanhol na Bahia para Embaixador da Espanha no Brasil. Bahia, 02 dez. 1949. R5672, expt. 44. AMAE.

"Brasil, en contra de la propaganda roja", jornal Ya. Madri, 22 dez. 1950. Recorte anexado ao ofício n. 373 de Rubens Ferreira de Melo, embaixador do Brasil na Espanha para Raul Fernandes, Ministro das Relações Exteriores. Madri, 22 dez. 1950. Missões Diplomáticas Brasileiras. Ofícios recebidos de Madri (outubro a dezembro de 1950). AHI/RJ.

"Becas a licenciados y doctores para estudios en el Brasil", jornal ABC. Madri, 22 dez. 1950. Recorte anexado ao ofício n. 374 da Embaixada do Brasil na Espanha para Secretaria de Estado das Relações Exteriores. Madri, 27 dez. 1950. Missões Diplomáticas Brasileiras. Ofícios recebidos de Madri (outubro a dezembro de 1950). AHI/RJ.

"España intensifica su acción política y cultural en Brasil", jornal Arriba. Madri, 29 dez. 1950. Recorte anexado ao ofício n. 02 da Embaixada do Brasil na Espanha para Secretaria de Estado das Relações Exteriores. Madri, 03 jan. 1951. Missões Diplomáticas Brasileiras. Ofícios recebidos de Madri (janeiro a março de 1951). AHI/RJ.

"Serán incrementados los intercambios comerciales entre Brasil y España", jornal (s/ident.) de 03 out. 1952. Recorte anexado ao ofício n. 354 de Rubens Ferreira de Mello, embaixador do Brasil na Espanha para João Neves da Fontoura, ministro das Relações Exteriores do Brasil. Madri, 06 out. 1952. Missões Diplomáticas Brasileiras. Ofícios recebidos de Madri (outubro a dezembro de 1952). AHI/RJ.

"El Presidente Vargas elogia al Generalísimo Franco", jornal El Pueblo de 19 de maio de 1954. Recorte anexado ao ofício n. 224 da Embaixada do Brasil na Espanha para a Secretaria de Estado das Relações Exteriores do Brasil Madri, 31 maio 1954. Missões Diplomáticas Brasileiras. Ofícios recebidos de Madri (maio a julho de 1954). AHI/RJ.

"Kubitschek da ordenes severas para atajar los desordenes estudantiles", jornal Arriba. Madri, 01 jun. 1956. Recorte anexado ao ofício n. 274 da Embaixada do Brasil na Espanha para Secretaria de Estado das Relações Exteriores. Madri, 30 jun. 1956. Missões Diplomáticas Brasileiras. Ofícios recebidos de Madri (junho a julho de 1956). AHI/RJ.

"Gilberto Freyre no se estimara escritor completo hasta que no haya hecho el libro sobre España", revista Mundo Hispânico de agosto de 1956. Recorte anexado ao ofício n.351 da Secretaria de Estado das Relações Exteriores para Embaixada do Brasil em Madri. 24 agosto 1956. Missões Diplomáticas Brasileiras. Ofícios recebidos de Madri (agosto a outubro de 1956). $\mathrm{AHI} / \mathrm{RJ}$.

"El escândalo de Paris" por Jose Maria Lorente, jornal Arriba. Madri, 16 jun. 1957. Anexo ao ofício da Embaixada do Brasil na Espanha para a Secretaria de Estado das Relações Exteriores. Madri, 01 jul. 1957. Missões Diplomáticas Brasileiras. Ofícios recebidos de Madri (junho a julho de 1957). AHI/RJ.

"La Nación que se está haciendo" por Pedro Gomez Aparício (mimeo). Anexo ao ofício n. 887 (reservado) de Câmara Canto, encarregado de negócios do Brasil na Espanha para Décio Moura, ministro interino das Relações Exteriores. Madri, 04 dez. 1957. Missões Diplomáticas Brasileiras. Ofícios recebidos de Madri (dezembro de 1957). AHI/RJ.

"La emigración española a Brasil", jornal ABC. Madri, 20 mar. 1958. Anexo ao ofício n.372 da Embaixada do Brasil na Espanha para a Secretaria de Estado das Relações Exteriores. Madri, 01 abr. 1958. Missões Diplomáticas Brasileiras. Ofícios recebidos de Madri (abril de 1958). AHI/RJ.

"Buques españoles por café brasileño", jornal Madrid. Madri, 13 mai 1958. Recorte anexado ào ofício n. 565 de João P. G. Coelho Lisboa, embaixador do Brasil na Espanha para José Carlos de Macedo Soares, ministro das Relações Exteriores. Missões Diplomáticas Brasileiras. Ofícios recebidos de Madri (maio a junho de 1958). AHI/RJ. 
"Brasilia, capital de um gran futuro", jornal Arriba. Madri, 14 de jun. 1958. Recorte anexado ao ofício n. 711 da Embaixada do Brasil na Espanha para a Secretaria de estado das Relações Exteriores. Madri, 02 jul. 1958. Missões Diplomáticas Brasileiras. Ofícios recebidos de Madri (julho a agosto de 1958). AHI/RJ.

"Felicitación al presidente Kubitschek por su defensa del idioma español", jornal ABC. Madri, 8 out. 1958. Recorte anexado ao ofício n. 986 de Câmara Canto, encarregado de negócios do Brasil na Espanha para Francisco Negrão de Lima, ministro das Relações Exteriores. Madri, 15 out. 1958. Missões Diplomáticas Brasileiras. Ofícios recebidos de Madri (setembro a outubro de 1958). AHI/RJ.

"España tiene desde hoy la mejor biblioteca brasileña en Europa", jornal Ya de 23 abr. 1959. Recorte anexado ao ofício n. 327 da Embaixada do Brasil na Espanha para Secretaria de Estado das Relações Exteriores. Madri, 02 maio. 1959. Missões Diplomáticas Brasileiras. Ofícios recebidos de Madri (maio a junho de 1959). AHI/RJ.

"Baionetas caladas dão a palavra de ordem", revista Manchete n. 317 de 17 mai 1958, p. 410. $\mathrm{ABI} / \mathrm{RJ}$.

"Marcelino, mais dois anos de vida", revista Manchete n. 315 de 03 mai. 1958. ABI

- "No Rio de Janeiro Pablito Calvo foi Rei", revista O Cruzeiro n. 29 de 26 abr. 1958, p. 124129. BN.

\section{Recortes de jornal (sem identificação do artigo)}

Recorte do jornal El Alcázar de 03 fev. 1945. Anexo ao ofício n. 64 de Mario de Pimentel Brandão, embaixador do Brasil na Espanha para Pedro Leão Velloso, ministro interino das Relações Exteriores do Brasil. Madri, 09 fev. 1945. Missões Diplomáticas Brasileiras. Ofícios recebidos de Madri (janeiro e fevereiro de 1945). AHI/RJ.

Recorte do jornal Madri de 17 ago. 1956. Anexo ao ofício n. 353 da Embaixada do Brasil na Espanha para Secretaria de Estado das Relações Exteriores. Madri, 27 ago. 1956. Missões Diplomáticas Brasileiras. Ofícios recebidos de Madri (agosto a outubro de 1956). AHI/RJ.

Recorte do jornal Arriba de 16 fev. 1947. Anexo ao ofício n. 85 (reservado) de Vasco Leitão da Cunha, encarregado de negócios do Brasil na Espanha para Raul Fernandes, ministro das Relações Exteriores. Madri, 20 fev. 1947. Missões Diplomáticas Brasileiras. Ofícios recebidos de Madri (jan. a fev. de 1947). AHI/RJ.

\section{Revistas}

Mundo Hispânico Números consultados: 87 (1955); 100 (1956); 107 (1957); 132 (1959); 147 (1960). Manchete, n. 317 de 17 mai 1958, p. 4-10. ABI/RJ. O Cruzeiro n. 29 de 26 abr. 1958, p. 124-129. BN.

\section{Ministério da Justiça}

Parecer de Luis Bordini, diretor de Seção interna. Rio de Janeiro, 19 set. 1939. Ministério da Justiça, Subsérie Repatriamento, Processo n. 9774/39. Arquivo Nacional/RJ.

Obs: A imagem utilizada na abertura deste trabalho foi retirada da fotografia reproduzida na capa do jornal $A B C$ de 21 de janeiro de 1956. Anexo ao ofício n. 32 de Rubens Ferreira de Mello, embaixador do Brasil na Espanha para José Carlos de Macedo Soares, ministro das Relações Exteriores do Brasil. Madri, 25 jan. 1956. Missões Diplomáticas Brasileiras. Ofícios recebidos de Madri (jan. a março de 1956). AHI/RJ. 


\section{Bibliografia}

ABELLÁN, Jose Luis; MONCLÚS, Antonio (Coord.). El pensamiento en España desde 1939. Barcelona: Anthropos, 1989. Colección El pensamiento español contemporâneo y la Idea de America.

ABREU, Alzira Alves de. (Coord.). Dicionário histórico-biográfico brasileiro (pós 1930). 2a Ed. Rio de Janeiro: FGV Editora, 2001.

ACCIOLY, Hildebrando. A paz mundial e a Organização das Nações Unidas. São Paulo: Faculdade Paulista de Direito, 1946.

ALAMBERT, Francisco. Guernica, um milagre no Brasil. Revista de História da Biblioteca Nacional. Rio de Janeiro, ano 3, n. 30, p.62-67, mar. 2008.

As Bienais de São Paulo: da era do museu à era dos curadores (19512001). São Paulo: Boitempo, 2004.

ALBUQUERQUE, José Augusto Guilhon (Org.) 60 anos de política externa brasileira (1930-1990). São Paulo: Cultura Editores; Núcleo de Pesquisa em Relações Internacionais da USP, 1996.

ALMEIDA, Paulo Roberto. O estudo das relações internacionais do Brasil. São Paulo: Unimarco, 1999.

O Brasil e a Guerra Civil Espanhola: participação de brasileiros no conflito. Disponível em: http://www.hispanista.com.br/revista/artigo37esp.htm. Acesso em outubro de 2007.

AMADO, Jorge. Os subterrâneos da liberdade (II - A agonia da noite). São Paulo: Martins Fontes, 1970.

AMSELÉM, Alberto Jose Lleonart. El ingreso de España en la ONU: obstáculos e impulsos. Cuadernos de Historia Contemporanea. Madri, Universidade Complutense, n. 17, p.102-119, 1995.

ANDERSON, Benedict. Nação e Consciência Nacional. São Paulo: Ática, 1989.

ANDRADE, Ana Mario Ribeiro de; CARDOSO, José Leandro Rocha. Aconteceu, virou manchete. Revista Brasileira de História, vol. 21, n. 41, 2001. Disponível em: $\quad$ http://www.scielo.br/scielo.php?pid=S0102 $01882001000200013 \&$ script=sci_arttext Acesso em 26 jan. 2009.

ARENDT, Hannah. Origens do totalitarismo. São Paulo: Companhia das Letras, 1998. 
AYLLÓN PINO, Bruno. Las relaciones entre Brasil y España ponderadas desde la perspectiva de la politica exterior brasileña (1970-2000). Madri, 2004. Tese (Doutorado) - Universidad Complutense de Madrid.

Las relaciones culturales en la agenda bilateral hispano-brasileña: un poco de historia. Revista de Cultura Brasileña. Madrid, Embajada de Brasil en Madrid, n. 3, 2005.

As relações Brasil - Espanha na perspectiva da política externa brasileira (1945-2005). São Paulo: Emblema, 2006.

BAHIANA, Paulo Henrique. A Espanha e o mundo. Rio de Janeiro: Tupy, 1966.

BALANDIER, Georges. O poder em cena. Brasília: UNB, 1982.

BANDEIRA, Luiz Alberto Moniz. Presença dos Estados Unidos no Brasil: dois séculos de História. Rio de Janeiro: Civilização Brasileira, 1978.

BARBALHO, Alexandre. Relações entre Estado e cultura no Brasil. ljuí: UNIJUÍ, 1998.

BARRETO, Luiz Paulo Teles. Das diferenças entre os institutos jurídicos do asilo e do refúgio. Disponível em: http://www.mj.gov.br/snj/artigo refugio.htm. Acesso em 31 mar. 2007.

BATTIBUGLI, Thaís. A militância antifascista: comunistas espanhóis na Guerra Civil Espanhola (1936-1939). São Paulo, 2000. Dissertação (Mestrado em História Social) - FFLCH, USP.

BOBBIO, Norberto; MATTEUCCI, Nicola e PASQUINO, Gianfranco (Orgs.) Dicionário de Política. Brasília: Universidade de Brasília, 1999.

BOPP, Raul. Memórias de um embaixador. Rio de Janeiro: Record Editora, 1968.

BRANCATO, Sandra Maria Lubisco. As relações Brasil/Espanha na transição para o Estado Novo. Revista de Estudos Ibero-Americanos. Porto Alegre, Pontifícia Universidade Católica, vol. XIII, n² 2, p.151-160,dez. 1987.

O caso Aunós na versão da grande imprensa carioca e do Itamaraty. Revista de Estudos Ibero-Americanos. Porto Alegre, Pontifícia Universidade Católica, v. XXXII, n. 2, p. 134-155, dez. 2007.

BROUÉ, Pierre. A Revolução Espanhola (1931-1939). São Paulo: Perspectiva, 1992. Kronos, 17.

BURON, Thierry; GAUCHON, Pascal. Los Fascismos. México: Fondo de Cultura Económica, 1983. 
BUSSALLEU, Jacint Aixer; TORRES, Estanislau. La guerra civil a Arenys del Mar. Publicacions de L'abadia de Montserrat, 1999.

CAMMUS, Albert. España Libre. Trad. Juan M. Molina. Madri: Jucar, 1978.

CANCELLI, Elisabeth. O mundo da violência: A polícia da Era Vargas. Brasília: UNB Editora, 1993.

CÁNOVAS, Marília Dalva Klaumann. Imigrantes espanhóis na Paulicéia: trabalho e sociabilidade urbana, 1890-1922. São Paulo, 2007. Tese (Doutorado em História) - FFLCH, USP.

CAPELATO, Maria Helena Rolim. Multidões em cena: propaganda política no varguismo e no peronismo. Campinas: Papirus, 1998. Coleção Textos do Tempo.

CARNEIRO, Maria Luiza Tucci. O antisemitismo na Era Vargas: fantasmas de uma geração (1930-1945). $2^{3}$ ed. São Paulo: Brasiliense, 1995

Livros Proibidos, Idéias malditas: O DEOPS e as minorias silenciadas. São Paulo: Estação Liberdade, 1997.

La Guerra Civil Espanõla através de las revistas ilustradas brasileñas: imagenes y simbolismos. Estudios Interdisciplinares da América Latina y el Caribe. Jerusalém, Universidade Hebraica de Jerusalém, v.2, $n^{\circ} 2$, p. 3950,1990 . Fapesp, 2002.

Minorias silenciadas. História da Censura no Brasil. São Paulo: Edusp;

Cidadão do mundo. Brasil e a questão dos refugiados judeus (19331948). São Paulo, 2001. Tese (Livre-docência) - FFLCH, USP.

A imagem do imigrante indesejável. Revista Seminários. São Paulo, v. 3, n. dez., p.21-42, 2003.

CARVALHO, Apolônio de. Vale a Pena Sonhar. Rio de Janeiro: Rocco, 1997.

CARVALHO, Ricardo Souza de. Drummond e a Espanha: apontamentos para duas recepções. O eixo e a roda, revista de literatura brasileira. Belo Horizonte, UFMG, v. 14, p.183-193, 2007.

Terra e verso de Espanha em Murilo Mendes e João Cabral de Melo Neto.Congresso Brasileiro de Hispanistas, 2. São Paulo, Associação Brasileira de Hispanistas, 2002. Disponível em: http://www.proceedings.scielo.br/scielo.php?script=sci_arttext\&pid=MSC000000 $0012002000200034 \&$ Ing=en\&nrm=abn>. Acesso em 09 Jan. 2009. 
CASANOVAS, Marina. La diplomacia española durante la Guerra Civil.. Madrid: Ministerio de Asuntos Exteriores, 1996. Biblioteca diplomática española, estudios 13.

CASTRO, Flávio Mendes de Oliveira. História da Organização do Ministério das Relações Exteriores. Brasília: Editora UNB, 1983. Coleção Temas Brasileiros.

CAVLAK, luri. A política externa brasileira e a argentina peronista (1946/1955). Assis, 2005. Dissertação (Mestrado em História) - Unesp.

CERVO, Amado Luiz; BUENO, Clodoaldo. A política externa brasileira: 18221985. São Paulo: Ática, 1986.

Ática, 1992.

; BUENO, Clodoaldo. História da política exterior do Brasil. São Paulo:

CERVO, Amado Luis. Relações Internacionais da América Latina. Brasília: IBRI, 2001.

O desafio internacional: a política exterior do Brasil de 1930 a nossos dias. Brasília: Editora UNB, 1994

CHASE, Allan. Falange: o Exército Secreto do Eixo na América. Rio de Janeiro: Vitória Editorial, 1944.

COGGIOLA, Osvaldo (Org). Segunda Guerra Mundial: Um balanço Histórico. São Paulo: Xamã, 1995.

(Org.). O fim das ditaduras (Portugal e Espanha). São Paulo: Xamã, 1995. Série Eventos.

CONTIER, Arnaldo D. Passarinhada do Brasil: canto orfeônico, educação e getulismo. Bauru, SP: EDUSC, 1998.

COSTA, Célia Maria Leite. Revolta de Jacareacanga. Os anos JK. Disponível em:http://www.cpdoc.fgv.br/nav jk/htm/O Brasil de JK/A politica como a art e de conciliar.asp. Acesso em 16 jan. 2008.

CUNHA, José Gay. Um brasileiro na Guerra Civil Espanhola. São Paulo: AlfaÔmega, 1986.

CUNHA, Vasco Leitão da Cunha. Diplomacia em alto-mar (depoimento ao CPDOC). Rio de Janeiro: Fundação Getúlio Vargas, 1994.

DELGADO, Lorenzo Gomez-Escalonilla. Imperio de Papel. Acción cultural y política exterior durante el primer franquismo. Madrid: Consejo Superior de Investigaciones Científicas, 1992. 
Diplomacia franquista y política cultural hacia lberoamerica (19331953). Madri: Consejo Superior de Investigaciones Científicas, 1988. Colleción Monografias del Centro de Estudios Históricos, 6.

DUMA, Jean. Sobre as elites: abordagem historiográfica. Revista História Unisinos. São Leopoldo, UNISINOS, Vol. 7º (8), p. 89-103, 2003.

DUROSELLE, Jean Baptiste. Todo Império perecerá. Trad. Ane Lize Spaltemberg Seiqueira Magalhães. Brasília: UNB; São Paulo: Imprensa Oficial, 2000.

DUTRA, Eliane de Freitas. O ardil totalitário: Imaginário político no Brasil dos anos 30. Rio de Janeiro: Editora UFRJ; Belo Horizonte:Editora UFMG, 1997.

FILHO, Gisálio Cerqueira; NEDER, Gizlene. Ecos da Segunda República e da Guerra Civil Espanhola no Brasil. Disponível em: www.gladiator.historia.uff.br/tempo/textos/art8-5.pdf Acesso em 15 jan. 2007

FOUCAULT, Michel. A ordem do discurso. São Paulo: Loyola, 1998.

GALINA, Lucia Rivero. Centro Español y Repatriación de Santos: 1895-1919.

Santos, 1990. Monografia (Curso de História) - Universidade Católica de Santos.

GALLEGO, Avelina Martinez. Os espanhóis em São Paulo: presença e invisibilidade. São Paulo, 1993. Dissertação (Mestrado em Ciências Sociais) PUC.

GALT, Thomas Franklin. Nações Unidas: história, organização, funcionamento. Rio de Janeiro: Bloch, 1966.

GAMBINI, Roberto. O duplo jogo de Getúlio Vargas: influência americana e alemã no Estado Novo. São Paulo: Símbolo, 1977.

GARCIA, Eugênio Vargas. Cronologia das relações internacionais. São Paulo: Editora Alfa-Ômega, 2000.

GARCIA, Antonio Fernández; CASTANARES, Juan Carlos Pereira. La percepción española de la ONU (1945-1962). Cuadernos de Historia Contemporanea. Madri, Universidade Complutense, n. 17, p.121-146, 1995.

GATTAZ, André Castanheira. Braços da resistência: Uma história oral da imigração espanhola. São Paulo: Xamã, 1996.

GIMÉNEZ, Esther Gambi. La guerra en la distancia. Los inmigrantes españoles en el Brasil de los anos 30. Salamanca, 2005. Dissertação (Mestrado) Centro de Estudos Brasileiros, Universidade de Salamanca.

GIRARDET, Raoul. Mitos e Mitologias políticas. São Paulo: Companhia das Letras, 1987. 
GOLDAR, Ernesto. Los argentinos y la Guerra Civil Española. Buenos Aires: Plus Ultra, 1996.

GUIBERNEAU, Montserrat. Nacionalismos: O Estado Nacional e o nacionalismo no século XX. Rio de Janeiro: Jorge Zahar, 1997.

GUIMARÃES, Argeu. Dicionário Bio- Bibliographico Brasileiro de Diplomacia, Política Externa e Direito Internacional. Rio de Janeiro: Ed. do autor, 1938.

HEMINGWAY, Ernest. Por quem os sinos dobram. São Paulo: Companhia Editora Nacional, 1996.

HERZ, Monica; HOFFMANN, Andrea Ribeiro. Organizações Internacionais: história e práticas. Rio de Janeiro: Elsevier, 2004.

HOBSBAWN, Eric. A Era dos Extremos (o breve século XX 1914-1991). São Paulo: Companhia das Letras, 1995.

1990

Nações e Nacionalismos desde 1780. Rio de Janeiro: Paz e Terra, ; RANGER, Terence. A Invenção das Tradições. Trad. Celina Cardim Cavalcante. Rio de Janeiro: Paz e Terra, 1984.

HUERTAS VÁZQUEZ, Eduardo. La política cultural de la Segunda República Española. Madrid: Ministerio de Cultura; Dirección General de Bellas Artes y Archivos, 1988.

KLEIN, Herbert S. Imigração Espanhola no Brasil. São Paulo: Sumaré; FAPESP, 1994. Série Imigração.

KOIFMAN, Fabio. Quixote nas trevas: o embaixador Souza Dantas e os refugiados do nazismo. Rio de Janeiro: Record, 2002.

LENHARO, Alcir. Sacralização da Política. Campinas: Papirus, 1986.

LEVINE, Robert. O regime de Vargas: os anos críticos (1934-1938). Rio de Janeiro: Nova Fronteira, 1980.

LIDA, Clara E. (Org.) México y España durante el primer franquismo, 19391950. Rupturas formales, relaciones oficiosas. Mexico: El Colegio de Mexico, 2001.

LILLO, Pedro Martínez. La diplomacia española y el Plano Marshall en el marco de las relaciones hispano-francesas (junio 1947 - abril 1948). Cuadernos de Historia Contemporanea. Madri, Universidade Complutense, n. 18, p.155-174, 1996. 
LOPES, Roberto. Missão no Reich. Glória e covardia dos diplomatas latinoamericanos na Alemanha de Hitler. Rio de Janeiro: Lexicon Editora digital, 2008.

LOPREATO, Christina Roquette. O espírito da revolta: a greve geral anarquista de 1917. São Paulo: Annablume;Fapesp, 2000.

LYRA, Heitor. Minha vida diplomática. Brasília: Editora UNB, 1972.

MACIEL, Laura Antunes ; ANTONACCI, Maria Antonieta Martinez. Espanhóis em São Paulo: modos de vida e experiências de associação. Revista do programa de estudos pós-graduados em História. São Paulo, PUC, $n^{\circ} 12$, p.173-192, 1995.

MAGALHÃES, José Calvet de. Breve história das relações diplomáticas entre Brasil e Portugal. São Paulo: Paz e Terra, 1999.

MARTINS CASAS, Julio. El exílio español, 1936-1978. 5a ed. Barcelona: Planeta, 2002.

MARTINS, José de Souza. A imigração espanhola no Brasil e a formação da força de trabalho na economia cafeeira: 1880-1930. Revista de História. São Paulo: n. 21, p. 5-21, ago-dez, 1989.

MATTHEWS, Herbert. Metade da Espanha Morreu: Uma reavaliação da Guerra Civil Espanhola. Rio de Janeiro: Civilização Brasileira, 1975.

MEIHY, José Carlos Sebe Bom; BERTOLLI, Claudio. A Guerra Civil Espanhola. São Paulo: Ática, 1996. Coleção História em movimento.

Espanha: pigmaleão da $2^{\mathrm{a}}$ Guerra Mundial? In: COGGIOLA, Osvaldo (Org.) Segunda Guerra Mundial: Um balanço Histórico. São Paulo: Xamã, 1995, p. 155-171.

MELLO, Affonso de Toledo Bandeira de. Política commercial do Brasil. Rio de Janeiro: Tip. do Departamento Nacional de Estatística, 1933.

MILZA, Pierre. As relações internacionais de 1918 a 1939. Lisboa: Edições 70, 1998.

MORAES, Maria Candelária Volponi. Centro Democrático Espanhol: um pedaço da Espanha no coração de São Paulo. Centro de Cultura e Resistência ao Franquismo 1957-1975 . São Paulo: 1997. Dissertação (Mestrado em História) - PUC.

MORAIS, Fernando. Chatô: o rei do Brasil. São Paulo: Companhia das Letras, 1994. 
MOTTA, Marly. A política como arte de conciliar.Os anos JK. Disponível em http://www.cpdoc.fgv.br/nav jk/htm/O Brasil de JK/A politica como a arte d e conciliar.asp. Acesso em 16 jan. 2008.

MOURA, Gerson. Autonomia na dependência: a política externa brasileira de 1935 a 1942. Rio de Janeiro: Nova Fronteira, 1980.

A Revolução de 1930 e a política externa brasileira: ruptura ou continuidade? Seminário Internacional. Brasília: Editora da UNB, 1983, p.574596.

Avanços e recuos: a política exterior de JK. In: GOMES, Ângela de Castro (Org.). O Brasil de JK. Rio de Janeiro: Editora FGV, 2002.

Sucessos e ilusões. Relações Internacionais do Brasil durante e após a 2믈 Guerra Mundial. Rio de Janeiro: Editora FGV, 1991.

NAÇÕES UNIDAS. Naciones Unidas al alcance de todos: la estructura, funciones y obra de la organizacion. $2^{\underline{a}}$ Ed. Nova York: Naciones Unidas, 1960.

NAÇÕES UNIDAS. ABC das Nações Unidas. Rio de Janeiro: Centro de Informações; Nações Unidas, 1982.

NEGRÃO, João Henrique Botteri. Selvagens e Incendiários: o discurso anticomunista e as notícias da Guerra Civil Espanhola. São Paulo: Humanitas/ Fapesp, 2005.

NERUDA, Pablo. Confesso que vivi: memórias. Rio de Janeiro: Difel, 1977.

NEUSCHAFER, Hans Jorg. Adiós a la España eterna: la dialectica de la censura: novela, teatro, y cine bajo el franquismo. Barcelona, Madrid: Anthropos, Ministerio de Asuntos Exteriores, Dirección General de Relaciones Culturales y Científicas, 1994.

ORWELL, George. Lutando na Espanha e o ensaio: recordando a guerra civil. Rio de Janeiro: Civilização Brasileira, 1967.

PANDOLFI, Dulce (Org). Repensando o Estado Novo. Rio de Janeiro: Editora FGV,1999.

PAYNE, Stanley G. El fascismo. Madrid: Alianza Editorial, 2005.

LA PEÑA, Pablo Sapag Muñoz. Propaganda republicana y franquista en Chile durante la Guerra Civil Española. Madri, 1996. Tese (Doutorado) - Universidad Complutense de Madrid.

PECAUT, Daniel. Os intelectuais e a política no Brasil: entre o povo e a nação. São Paulo: Ática, 1990. 
PERAZZO, Priscila Ferreira. O perigo alemão e a repressão policial no Estado Novo. São Paulo: Arquivo do Estado; Imprensa Oficial, 1999.

Prisioneiros de guerra: os cidadãos do Eixo nos campos de concentração brasileiros (1942-1945). São Paulo, 2002. Tese (Doutorado em História Social) - FFLCH, USP.

PEREIRA, Wagner Pinheiro. O império das imagens de Hitler: o projeto de expansão internacional do modelo de cinema nazista na Europa e na América Latina (1933-1955). São Paulo, 2008. Tese (Doutorado em História Social) FFLCH, USP.

PERES, Elena Pájaro. A inexistência da terra firme: a imigração galega em São Paulo (1946 - 1964). São Paulo: Edusp; Fapesp; Imprensa Oficial, 2003.

Proverbial hospitalidade? A Revista de Imigração e Colonização e o discurso oficial sobre o imigrante (1945-1955). Acervo, revista do Arquivo Nacional. Rio de Janeiro, Arquivo Nacional, v.10, n² 2, p. 53-70, jul/dez.1997, 1998.

Exuberância e Invisibilidade: populações moventes e cultura em São Paulo, 1942 ao início dos anos 70. São Paulo, 2006. Tese (Doutorado em História Social) - FFLCH, USP.

PORTERO, Francisco. Franco aislado. La cuestión española (1945-1950). Madrid: Aguilar, 1989.

PRESTON, Paul. Franco: Caudillo de España. Barcelona: Grijalbo Mandadori, 1999. Colección Mitos Bolsillo.

Las três Españas del 36. Barcelona: Debolsillo, 2005.

2005.

A Guerra Civil de Espanha. Trad. Antonio Belo. Lisboa: Edições 70,

La Guerra Civil, las fotos que hicieron historia. (S.I.): La esfera de los libros, 2005.

REIN, Raanan. La salvación de una dictadura: Alianza Franco-Perón 19461955. Madrid: Consejo Superior de Investigaciones Científicas; Instituto de Cooperación para el Desarrollo, 1995.

RENOUVIN, Pierre; DUROSELLE, Jean Baptiste. Introdução à História das Relações Internacionais. São Paulo: Difusão Européia do Livro, 1967.

REZEK, José Francisco. Direito Internacional público: curso elementar. São Paulo: Saraiva, 1995. 
RIBEIRO, Mariana Cardoso dos Santos. Venha o decreto de expulsão. A legitimação da ordem autoritária no Governo Vargas (1930-1945). São Paulo, 2003. Dissertação (Mestrado em História Social) - FFLCH, USP.

Expulsão de estrangeiros: o mito da nocividade no Brasil (1937-1945). São Paulo, 2008. Tese (Doutorado em História Social) - FFLCH,USP.

RIBEIRO, Edgard Telles. Diplomacia cultural: seu papel na política externa brasileira. Brasília: Fundação Alexandre de Gusmão; Instituto de Pesquisa de Relações Internacionais, 1989.

RUBIO, Javier. Asilos y canjes durante la guerra civil española: aspectos humanitários de una contienda fratricida. Barcelona: Editorial Planeta, 1979.

SANDOICA, Elena Hernández. Los Fascismos Europeos. Ediciones Istmo, 1992. Colección La Historia en sus textos.

SEITENFUS, Ricardo. O Brasil de Getúlio Vargas e a formação dos blocos (1930-1942). São Paulo: Editora Nacional, 1985.

SEGUí Gonzalez, Luis. Politica migratória e infiltración totalitária em America. Montevidéo: Editorial Alfa y Omega, 1947.

SILVA, José Luis Werneck (Org.). O Feixe: o autoritarismo como questão teórica e historiográfica. Rio de Janeiro: Zahar, 1989.

SILVA, Alberto da Costa (Org.). O Itamaraty na cultura brasileira. Brasília: Instituto Rio Branco, 2001.

SILVEIRA, Eliana Ávila. A Guerra Civil Espanhola e as elites políticas brasileiras: 1936-1939. Porto Alegre, 1991. Dissertação (Mestrado em História Ibero-Americana) - PUC.

SKIDMORE, Thomas. Brasil: De Getúlio a Castelo (1930-1964). 12 ed. Trad. Ismênia Tunes Dantas. Rio de Janeiro: Paz e Terra, 1982.

SOUZA, Ismara Izepe de. Solidariedade Internacional. A comunidade espanhola do Estado de São Paulo e a polícia política diante da Guerra Civil da Espanha (1936-1946). São Paulo: Humanitas;FAPESP, 2005. Coleção Histórias da Intolerância, 5.

Espanhóis: história e engajamento. São Paulo: Lazuli;Cia Editora Nacional, 2006. Coleção Imigrantes no Brasil.

República Espanhola: um modelo a ser evitado. São Paulo: Arquivo do Estado; Imprensa Oficial, 2001. Inventário DEOPS: Módulo IV - Espanhóis.

Adiós Compañeros: os espanhóis expulsos na Era Vargas. Revista Histórica. São Paulo: Arquivo do Estado;Imprensa Oficial, ano 3, n 4, p.35-39, 2001. 
TABANERA, Nuria. Las dotaciones presupuestarias de la Segunda República española para el servicio diplomático en Hispanoamerica, 1931-1936: embajadas, legaciones y consulados. Disponível em: www.ucm.es/BUCM/revistas/ghi/02116111/articulos Acesso em 20 set. 2007.

TAMAMES, Ramón. La República, La Era de Franco. $7^{\text {a }}$ ed. Madrid: Alianza Editorial, Alfaguarra, 1977.

TAKEUCHI, Marcia Yumi. O perigo amarelo em tempos de guerra (1939-1945). São Paulo: Imprensa Oficial; Arquivo do Estado, 2002. Inventário DEOPS: Módulo III - Japoneses.

O perigo amarelo: imagens do mito, realidade do preconceito (19201945). São Paulo: Humanitas; Fapesp, 2008. Coleção Histórias da repressão e da resistência.

THOMAS, Hugh. Guerra Civil Espanhola. Rio de Janeiro: Civilização Brasileira, 1964.

TOTA, Antonio Pedro. O Imperialismo Sedutor: a americanização do Brasil na época da $2^{a}$ Guerra Mundial. São Paulo: Companhia das Letras, 2000.

WRZOS, Conrad. Juscelino Kubitschek. Estados Unidos, Europa. Rio de Janeiro: José Olympio, (s.d.).

VALDIVIELSO DEL REAL, Rocío. La Carrera diplomática en España (19391940). Madrid: Ministério de Asuntos Exteriores, 1996. Biblioteca Diplomática Española, Sección Estudios, 15.

VARGAS, Getúlio. Diário. São Paulo: Siciliano; Rio de Janeiro: FGV, 1995.

VAZQUEZ, Bernardo Maiz. Galicia na Segunda Republica e baixo o franquismo (1930-1976). Vigo: Edicións Xerais de Galicia, 1988

VIANNA, Hermano. O Mistério do Samba. Rio de Janeiro: Jorge Zahar/UFRJ, 1995.

VIZENTINI, Paulo Fagundes. Relações Exteriores do Brasil (1945-64). O Nacionalismo e a política externa independente. Petrópolis: Vozes, 2004.

Do nacional-desenvolvimentismo à Política Externa Independente (1945-1964). In: FERREIRA, Jorge; DELGADO, Lucília de Almeida Neves (Orgs.). O Brasil Republicano. Rio de Janeiro: Civilização Brasileira, 2003, vol. 3, p.195-216.

A política externa do governo JK (1956-1961). In: ALBUQUERQUE, José Augusto Guilhon (Org.). 60 anos de política externa brasileira (19301990). São Paulo: Cultura Editores; Núcleo de Pesquisa em Relações Internacionais da USP, 1996, p. 231-251. 
VILAR, Pierre. A Guerra da Espanha. São Paulo: Paz e Terra, 1989. História de España. Barcelona: Critica, 1980. 


\title{
Notas biográficas ${ }^{660}$
}

\section{Adrian de Burgos}

Atuava como vice-cônsul do Brasil em Almeria quando iniciou a Guerra Civil Espanhola, tendo sido preso pelas autoridades republicanas. Morreu em decorrência do referido conflito.

\begin{abstract}
Abelardo Roças (1881-1950)
Diplomata de carreira atuou como embaixador do Brasil no México entre 1931 e 1939 e na Espanha entre 1939 e 1943, ano em que teve decretada a sua aposentadoria compulsória. Escreveu Civilização e Democracia: questões contemporâneas, livro publicado em 1920.
\end{abstract}

\section{Afrânio de Melo Franco (1870-1943)}

Político e diplomata nascido em Paracatu, Rio de Janeiro. Foi deputado estadual e federal por Minas Gerais, atuando em diversas comissões de assuntos internacionais. Em 1919 comandou a delegação do Brasil à primeira Conferência Internacional do Trabalho, realizada em Washington. Foi partidário da Revolução de 1930 e chefiou o Ministério das Relações Exteriores entre 1930 e 1934.

\section{Alberto Martín Artajo (1905-1957)}

Espanhol, ativo participante do movimento católico na Espanha. Por representar essa aproximação com o catolicismo e certo distanciamento com as idéias nazi-fascistas, foi escolhido por Franco para chefiar o Ministério de Assuntos Exteriores em 1945, cargo que ocupou até 1957.

\section{Alcebíades Peçanha (1869/?)}

Irmão do ex - presidente Nilo Peçanha. A partir de 1910 passou a dedicar-se à carreira diplomática, tendo servido em diversos postos. Foi embaixador na Itália entre 1930 e 1934 e representante diplomático na Espanha em três momentos distintos (1916-1917; 1919/1923; 1935/1938). Durante a Guerra Civil Espanhola envolveu-se em diversos incidentes. Teve seus bens apreendidos pelos republicanos espanhóis e foi decano do corpo diplomático em 1936. Foi vitimado por um bombardeio durante àquele conflito e aposentado em 1938.

\section{Álvaro Trindade Cruz}

Em 1945 foi nomeado para chefiar o escritório comercial brasileiro em Madri. Em 1953, o Ministério do Trabalho, Indústria e Comércio o designou para chefiar a inspeção permanente dos escritórios de propaganda e expansão comercial do Brasil na Europa.

\footnotetext{
${ }^{660}$ As notas biográficas que se seguem foram elaboradas a partir de informações de fontes diversas. Muitas delas foram formuladas a partir de centenas de documentos diplomáticos (AHI/RJ e AMAE/Espanha). Outras, especialmente de diplomatas brasileiros que alcançaram altos postos no Brasil e no exterior, contam com dados fornecidos por sites da Internet e pelas seguintes obras de referência: - Argeu de Segadas Guimarães. Dicionário Bio-Bibliográfico Brasileiros de Diplomacia, Política Exterior e Direito Internacional. Rio de Janeiro: Ed. do autor, 1938. - Alzira Alves de Abreu (Coord.). Dicionário histórico-biográfico brasileiro (pós 1930). $2^{\underline{a}}$ Ed. Rio de Janeiro: Editora FGV, 2001.
} 


\section{Antonio Cândido da Câmara Canto (1910-1977)}

Nascido em Montevidéu (Uruguai), adquiriu a nacionalidade brasileira por dispositivos constitucionais. Ingressou na carreira diplomática em 1938, atuando em diversos postos. Entre 1958 e 1960, assumiu interinamente a Embaixada do Brasil na Espanha, como encarregado de negócios. Foi nomeado embaixador na Espanha em 1963 e no Chile em 1968.

\section{Antonio Francisco Azeredo da Silveira (1917/1990)}

Nasceu no Rio de Janeiro. Diplomata de carreira, em 1954 foi transferido para a Embaixada do Brasil em Madri, onde atuou como primeiro secretário até 1956. Foi embaixador na Argentina, EUA e Portugal e Ministro das Relações Exteriores durante o governo de Ernesto Geisel (1974-1979).

\section{Antonio Mendes Viana (1908/?)}

Nascido em São Luis, bacharelou-se em Direito, ingressando em seguida na carreira diplomática. Em 1944 foi removido para Madri como primeiro secretário, onde permaneceu até 1949 exercendo, em muitos momentos, a função de encarregado de negócios. Cumulativamente, neste período, foi membro da delegação do Brasil junto à reunião preparatória da ONU e junto à 1 Assembléia Geral da referida Organização em Londres (1946). Foi embaixador brasileiro na Grécia (1959), em Paris (1964-1965) e no Chile (1966-1967).

\section{Aluisio de Magalhães}

Foi cônsul do Brasil em Barcelona durante a Guerra Civil Espanhola.

\section{Argeu de Segadas Guimarães (1892 - ?)}

Foi advogado, biógrafo e membro do Instituto Histórico do Rio de Janeiro. Serviu como diplomata em diversos postos e foi fundador da Divisão Cultural do Itamaraty. E autor do único dicionário biográfico da diplomacia brasileira com o qual tivemos contato. Foi encarregado de negócios em Madri (1939). Em 1949 foi nomeado cônsul-geral em Barcelona.

\section{Carlos Alberto Muniz Gordilho (1887 - ?)}

Nasceu em Salvador (BA) e bacharelou-se em Ciências Jurídicas e Sociais. Ingressou na carreira diplomática em 1912, e ao longo de sua vida atuou em vários postos. Foi encarregado de negócios em Madri entre 1929 e 1931 e nomeado embaixador em Roma em janeiro de 1942, atuando até outubro daquele ano. Em 1949, assumiu a Embaixada da Colômbia em Bogotá.

\section{Carlos da Silveira Martins Ramos (1894 - ?)}

Nascido em Paris, formou-se bacharel em Ciências Jurídicas e Sociais. Como diplomata, serviu em diversos postos. Entre 1938 e 1939 foi encarregado de negócios na Espanha, envolvendo-se em conturbadas questões decorrentes da postura do Brasil frente à Guerra Civil Espanhola. Atuou na questão dos asilados, manifestando a Oswaldo Aranha suas críticas à condução da política externa do Brasil para a Espanha naquele momento. Foi o único diplomata brasileiro a manifestar simpatias aos republicanos espanhóis. Foi conselheiro em Paris no início da Segunda Guerra Mundial e embaixador no Equador entre 1953 e 1955. 


\section{Cyro de Freitas Valle (1896-1969)}

Nascido na cidade de São Paulo era filho de um senador da República Velha e primo de Oswaldo Aranha. Na carreira diplomática, alcançou postos de destaque, sendo embaixador na Alemanha (1939-1942), na Argentina (19471948) e no Chile (1952-1955). Foi secretário geral do Itamaraty por diversas vezes e ministro Interino das Relações Exteriores entre janeiro e março de 1939 e entre maio e junho de 1949. Foi nomeado embaixador na Espanha em 1946, mas não chegou a assumir o posto. Foi delegado do Brasil junto a ONU e chefiou a delegação do Brasil junto as Assembléias da referida Organização em 1955 e 1956.

\section{Eduardo Porto Osorio Bordini}

Diplomata de carreira. Na década de 1930 atuou como cônsul brasileiro em Cardiff, País de Gales. Entre 1940 e 1941 atuava como cônsul na cidade espanhola de Cádiz. Devido às acusações de envolvimento na concessão ilegal de vistos em passaportes de judeus, sofreu processo administrativo, 0 mesmo no qual figura o nome de Luis Martins de Sousa Dantas. Foi absolvido das acusações, mas não encontramos referências à sua permanência na carreira diplomática.

\section{Eduardo Aunós}

Político, intelectual e diplomata espanhol. Foi nomeado embaixador da Espanha no Brasil, mas não chegou a assumir por ser declarado persona non grata pelo governo brasileiro. Durante sua viagem rumo ao Rio de Janeiro para assumir o cargo, vieram à público informações sobre o seu envolvimento com um acordo entre Argentina-Espanha-Alemanha durante a Segunda Guerra Mundial.

\section{Francisco Negrão de Lima (1901-1981)}

Nascido em São João Nepomuceno (MG), foi advogado e jornalista antes de ingressar na política. Na década de 1930 foi deputado federal e chefe do gabinete do Ministério da Justiça. Assumiu esta pasta no segundo governo Vargas (1951-1953) e o Ministério das Relações Exteriores entre 1958 e 1959. Foi embaixador na Venezuela, Paraguai e Portugal. Em 1965 elegeu-se governador do Estado da Guanabara pelo PSB.

\section{Fernando Maria Castiella (1907-1976)}

Político e diplomata espanhol. Durante a Guerra Civil Espanhola foi oficial das tropas do General Franco. Atuou como voluntário da División Azul e como professor catedrático de Direito Internacional. Foi ministro de Assuntos Exteriores entre 1956 e 1969. Sua gestão foi marcada por esforços para negociar com o Reino Unido a questão de Gibraltar, e por manter uma postura mais crítica com relação aos EUA.

\section{Gregorio Maranõn (1887-1960)}

Médico, cientista e escritor espanhol. Publicou diversas obras sobre medicina, especialmente na área de endocrinologia, sua especialidade. Politicamente colocou-se a favor da Segunda República Espanhola, mas pouco depois se manifestou contra o comunismo. Retornou a Espanha em 1942, 
reincorporando-se ao Hospital Provincial de Madri, que atualmente leva seu nome. Esteve no Brasil pelo menos duas vezes: em 1937 e em 1953, nessa última recebendo todas as honras e atenções do governo brasileiro.

\section{Hildebrando Pompeu Pinto Accióli (1888-1962)}

Nascido em Fortaleza (Ceará), formou-se em Direito e ingressou na carreira diplomática em 1914. Representou o Brasil em diversas conferências internacionais e foi secretário geral do MRE entre 1937 e 1939 e 1946. Assumiu interinamente a direção do Itamaraty em diferentes momentos entre 1947 e 1948. Integrou a Corte Permanente de arbitragem em Haia em 1957, e teve considerável atividade no magistério.

\section{Horácio Lafer (1900-1965)}

Nascido em São Paulo, formou-se em Direito. Foi deputado federal, mas com o advento do Estado Novo voltou a dedicar-se aos negócios da família, especialmente ao grupo Klabin-Lafer. Foi ministro da Fazenda em 1951 e chanceler durante o governo de Juscelino Kubitschek, desenvolvendo uma política de prioridade às questões de economia internacional. Era favorável à participação do capital estrangeiro no país. Foi presidente da FIESP (Federação das Indústrias do Estado de São Paulo).

\section{João Cabral de Melo Neto (1920-1999)}

Poeta, escritor e diplomata nascido no Recife. Publicou diversas obras literárias e foi por mais de trinta anos, membro da Academia Brasileira de Letras. Em 1946 iniciou sua carreira diplomática. Atuou em diversos postos, e no Consulado Geral de Barcelona como vice-cônsul e cônsul nos seguintes períodos: 1947 a 1950; 1956 a 1958 e 1967. A Espanha teve grande influência em algumas de suas obras. Em 1952 foi acusado de subversão e afastado da carreira diplomática, se reintegrado dois anos depois.

\section{Jose Carlos de Macedo Soares (1883-1968)}

Advogado, industrial e diplomata. Formou-se em 1905 pela Faculdade de Direito de São Paulo. Em 1930 deu apoio à candidatura de Getúlio Vargas à presidência da República. Foi deputado federal e chefiou o Ministério das Relações Exteriores entre 1934 e janeiro de 1937. Foi em seguida para o Ministério da Justiça, anistiando mais de 400 presos políticos sem processo formado, gesto que ficou conhecido como a "macedada". Chefiou novamente o MRE entre 1955 e 1958.

\section{João Neves da Fontoura (1889-1963)}

Político nascido em Cachoeira do Sul (RS). Na década de 1920 foi promotor público, deputado estadual e vice-governador por seu Estado. Entre 1943 e 1945, assumiu a Embaixada do Brasil em Portugal. Foi ministro das Relações Exteriores em 1946, e entre 1951 e 1953, defendendo uma política de apoio irrestrito aos Estados Unidos.

\section{João Pizarrro Gabizo de Coelho Lisboa (1890-?)}

Embaixador do Brasil na Espanha entre 1956 e 1964. Era irmão de Rosalina Coelho Lisboa, adepta do Estado Novo e uma das poucas mulheres a alcançar projeção na política nacional nos anos 30 . 


\section{Jose de Cárcer y Lassance}

Espanhol, atuou por muitos anos como diplomata no Brasil. Em 1936 foi designado para atuar como representante oficioso do governo de Burgos no Rio de Janeiro. Em 1952 assumiu a Embaixada da Espanha na qualidade de encarregado de negócios.

\section{Jose Felix de Lequerica (1891-1963)}

Político e diplomata espanhol que apoiou o golpe contra a República Espanhola em 1936. Foi designado por Franco a assumir a Embaixada espanhola em Paris (1939-1944) e entre 1944 e 1946 foi Ministro de Assuntos Exteriores. Entre 1951 e 1954 foi embaixador nos EUA e a partir de 1956, representante permanente da Espanha na ONU.

\section{Jose Losada de la Torre ( $?$ - 1947)}

Jornalista espanhol, foi membro da Associación de la Prensa de Madri no início dos anos 40. Em 1946, o encarregado de negócios do Brasil na Espanha o acusou de escrever artigos considerados desabonadores ao Brasil. Faleceu em 1947, quando atuava como adido cultural à Embaixada da Espanha no Rio de Janeiro.

\section{Jose Ortega Y Gasset (1883-1955)}

Um dos mais importantes filósofos europeus do século XX. Espanhol, nascido em Madri, foi professor da Universidade Central desta capital. Manteve-se exilado na Argentina e em países europeus durante a Guerra Civil Espanhola, não manifestando apoio a nenhum dos campos em conflito. Regressou a Espanha em 1948, dedicando-se à carreira docente e de escritor. Em 1947, o governo brasileiro o convidou para vir ao Brasil proferir conferências, o que não se efetivou.

\section{Jose Rojas y Moreno (Conde de Casa Rojas)}

Foi embaixador da Espanha no Brasil entre 1946 e 1952. Consta que tenha atuado como diplomata na cidade de Bucareste (Romênia) e que em 1941, tenha ajudado muitos judeus, vítimas do nazismo nesta cidade.

\section{Juan Biegbeder (1890-1957)}

Militar espanhol que participou ativamente de ações na África. Apoiou os rebeldes espanhóis, sendo responsável pelo recrutamento e participação de marroquinos durante a Guerra Civil Espanhola. Foi, por influência de Serrano Suñer, nomeado ninistro de Assuntos Exteriores em 1939.

\section{Julio Alvarez Del Vayo (1895-1975)}

Jornalista espanhol e militante socialista. Em 1933 foi embaixador no México. Foi ministro de Estado nos governos de Largo Caballero e Juan Negrin, durante o conflito civil espanhol. Viveu exilado no México, EUA e Suiça. Nos últimos anos de vida, radicalizou suas opiniões políticas, sendo expulso do PSOE (Partido Socialista Obrero Español).

\section{Julio Morin}


Em 1936, atuava como agente no Consulado do Brasil em Barcelona. Foi preso pelos republicanos, acusado de ajudar os nacionalistas espanhóis durante a Guerra Civil da Espanha. Não encontramos documentos que elucidem o desfecho do caso. Segundo os documentos diplomáticos, não possuía o exeqüator do governo espanhol para atuar.

\section{Luis de Soroa Filho}

Funcionário contratado da Embaixada do Brasil na Espanha. Durante a Guerra Civil Espanhola, quando o encarregado de negócios trasladou-se para Barcelona (1938), ficou responsável pela sede da representação brasileira em Madri. Em 1952, ainda atuava como auxiliar da Embaixada do Brasil.

\section{Luis Guimarães Filho (1878-1940)}

Poeta, cronista e diplomata nascido no Rio de Janeiro. Estudou em Portugal, ingressando na carreira diplomática em 1901. Serviu em vários postos como Tóquio, Pequim, Havana e Berna. Foi encarregado de negócios e o primeiro embaixador do Brasil em Madri, quando a representação brasileira foi elevada à Embaixada em 1933. Dedicou-se às letras, publicando alguns livros. Foi membro de diversas associações culturais no Brasil e em Portugal.

\section{Marina Moscoso}

Segundo as fontes diplomáticas, em 1953 foi removida do Consulado de Barcelona para a Secretaria de Estado do MRE.

\section{Mario de Pimentel Brandão (1889 - 1956)}

Nascido no Rio de Janeiro, então capital do Império, bacharelou-se em Direito em 1911, ingressando em seguida na carreira diplomática. Atuou em diversos postos no exterior e em 1934, a convite de José Carlos de Macedo Soares assumiu a Secretaria de Estado das Relações Exteriores. Foi chanceler em 1937, apoiando o golpe do Estado-Novo. Foi embaixador nos EUA (1938), Espanha (1944-1946), URSS (1946-1947) e na Alemanha Ocidental (19501951). Em 1953 assumiu interinamente o MRE, até a posse de Vicente Rao.

\section{Mateus de Albuquerque}

Diplomata brasileiro que, nos anos 20, serviu como cônsul em Marselha. Escreveu, nas décadas de 1910 e 1920, diversas obras literárias. Em 1935 assumiu o cargo de conselheiro comercial junto á Embaixada do Brasil em Madri.

\section{Murilo Mendes (1901-1975)}

Nasceu em Juiz de Fora (MG), formando-se em medicina. É considerado um dos poetas expoentes do modernismo brasileiro. Entre 1953 e 1955 viajou pela Europa em missão cultural, divulgando a cultura brasileira. Em 1953, regeu a cátedra de Estudos Brasileiros na Universidade de Madri.

\section{Nicolas Fernandez Estevez}

Espanhol, atuante no Consulado espanhol de Santos desde a década de 1920. Aderiu ao franquismo, e em 1952 atuava como cônsul nessa cidade portuária.

\section{Odette de Carvalho e Souza}


Foi a primeira mulher a chefiar uma missão do Brasil como embaixadora. Foi, durante a maior parte dos anos 50, chefe do departamento político do Itamaraty. Foi chefe da missão brasileira junto à Comunidade Econômica Européia entre 1965 e 1969.

Osorio Dutra (1889-1968)

Diplomata e poeta. Foi, durante a Segunda Guerra Mundial, cônsul em Lyon, defendendo as leis brasileiras que restringiam a entrada de judeus em território brasileiro. Em 1948 atuava como cônsul em Barcelona. Escreveu diversos livros, a maioria de poesias.

\section{Oswaldo Aranha (1894-1960)}

Natural de Alegrete (RS) formou-se em Direito, tendo iniciado jovem sua carreira política. Amigo e aliado de Getúlio Vargas, foi um dos articuladores da revolução de 1930. Ocupou a pasta da Fazenda e da Justiça, sendo embaixador do Brasil nos EUA entre 1934 e 1937. Chefiou o Ministério das Relações Exteriores entre 1938 e 1945, sendo defensor do alinhamento brasileiro à política norte-americana. Atuou como embaixador brasileiro junto à ONU, sendo em 1947, benemérito no processo de criação do Estado de Israel. Voltou a chefiar o Ministério da Fazenda entre 1953 e 1954, afastando-se da vida pública após o suicídio de Vargas.

\section{Osvaldo Orico (1900-1981)}

Nascido em Belém (Pará), foi professor, escritor, jornalista e poeta. Publicou diversas obras literárias, sendo membro de vários institutos e academias. Foi deputado federal por seu Estado entre 1951 e 1954. Atuou como conselheiro comercial junto ás Embaixadas do Brasil nos seguintes países : Chile (1943); Espanha (1945-1948 e 1949) e Holanda (1948).

\section{Pedro Gomez Aparicio}

Jornalista espanhol, que em 1946 assumiu a direção da Agência de notícias EFE. Em 1957, visitou o Brasil. Na Espanha, envolveu-se em conflitos verbais com o brasileiro Edilberto Coutinho, que protestou junto à Embaixada do Brasil, contra as "supostas" inverdades sobre o Brasil presentes em seus artigos. Em 1961 assumiu a presidência da Asociación de la Prensa de Madri.

Pedro Garcia Conde y Menendez (1880-1982)

Diplomata espanhol. Foi embaixador na Itália (1937-?) e no Brasil entre 1942 e 1946.

\section{Pedro Leão Velloso (1887/1947)}

Nasceu em Pindamonhangaba, SP. Diplomou-se em Direito em 1907, ingressando na carreira diplomática. Foi embaixador do Brasil na Itália entre 1939 e 1941 e ministro das Relações Exteriores, interino e efetivo, entre 1944 e janeiro de 1946. Foi, em seguida, nomeado representante do Brasil no Conselho de Segurança, falecendo em Nova York em 16 de janeiro de 1947.

Pedro de Prat y Soutzo - Marqués de Prat de Nantouillet (1892-1969)

Nasceu na Grécia, e era descendente de uma família nobre vinculada ao Rei Alfonso XII da Espanha. Ingressou na carreira diplomática em 1912, servindo 
em vários postos como Grécia e Turquia. Após a Segunda Guerra Mundial, os Aliados confiscaram seu patrimônio sob a alegação de investigar suas ligações com o alemão Von Papen, julgado em Nuremberg. Em 1948, ocupou-se da política da América junto ao Ministério de Assuntos Exteriores da Espanha. Foi embaixador no Brasil entre 1952 e 1954.

\section{Ramon Serrano Suñer (1901-2003)}

Advogado e político espanhol, desempenhou cargos de destaque no governo do General Franco, de quem era cunhado. Foi o idealizador e organizador da División Azul, grupo militar espanhol que participou da invasão da URSS, durante a Segunda Guerra Mundial. Conhecido por suas posições "germanófilas" foi ministro de Assuntos Exteriores entre 1939 e 1942.

\section{Raimundo Fernandez Cuesta y Merello (1897-1992)}

Advogado nascido em Madri. Começou sua carreira política militando na Falange Espanhola. Foi preso pelas tropas republicanas durante a Guerra Civil Espanhola, sendo trocado por outro político republicano. Foi secretário geral da Falange e ministro da Agricultura de Francisco Franco. Foi embaixador no Rio de Janeiro entre 1940 e 1942, envolvendo-se com as atividades falangistas no Brasil. Foi embaixador na Itália (1942-1945), e presidente do Conselho de Estado e ministro da Justiça até 1951. Desempenhou diversos outros cargos políticos até a década de 1970.

\section{Raul Fernandes (1877-1968)}

Nascido em Valença (RJ), bacharelou-se em Ciências Jurídicas e Sociais. Começou a advogar em 1898, fazendo carreira política nos anos subseqüentes. Nas décadas de 1910 e 1920, foi deputado federal, e nos anos 30, consultor-geral da República. Em 1946, Dutra o convidou para ser ministro das Relações Exteriores, cargo que ocupou até 1951 e, posteriormente, entre 1954 e 1956.

\section{Raul Bopp (1898-1984)}

Nascido em Santa Maria (RS), bacharelou-se em Direito. Trabalhou como jornalista colaborando, em 1922, na divulgação da Semana de Arte Moderna de São Paulo. Publicou diversas obras literárias, ingressando na carreira diplomática em 1932. Serviu em vários postos, sendo cônsul-geral do Brasil em Barcelona entre 1951 e 1953. Em Memórias de um embaixador, expôs suas impressões sobre aspectos particulares e curiosos de proeminentes figuras do Itamaraty.

\section{Renato de Mendonça}

Escritor e diplomata brasileiro. Publicou diversos livros, entre eles História da Política Exterior do Brasil (1945) e Fronteira em Marcha (1956). Em 1945, foi primeiro secretário da Embaixada do Brasil na Espanha.

\section{Roberto Mendes Gonçalves (? - 1971)}

Escritor e diplomata que atuou como cônsul em Barcelona (1946). Foi eleito, pouco antes de sua morte, presidente do Instituto Cultural Brasil-Japão. Escreveu Quarenta anos de champanha 1920-1960, publicado em 1968. 


\section{Román Escohotado}

Espanhol, autor do livro La Bella Cabarrus, publicado em 1944. Foi crítico literário do jornal falangista Arriba atuando, nos anos 40, como correspondente de jornais espanhóis no Rio de Janeiro. Em fevereiro de 1948, assumiu como adido da imprensa à Embaixada da Espanha no Rio de Janeiro. Segundo Vasco Leitão da Cunha, escreveu notícias desabonadoras ao Brasil. Em 1956 venceu o Prêmio Carmen Dolores Barbosa, com o melhor artigo sobre o Brasil publicado na imprensa espanhola.

\section{Rubens Ferreira de Mello (1896-1975)}

Nascido no Rio de Janeiro (DF) bacharelou-se em Direito e ingressou na carreira diplomática em 1916. Serviu em vários postos no exterior, e chefiou alguns departamentos internos do Itamaraty. Foi embaixador na Espanha (1950-1956) e no Chile (1960-1961).

\section{Salvador de Madariaga (1886-1978)}

Espanhol nascido em La Coruña, foi diplomata, escritor e historiador. Durante a Segunda República espanhola, foi ministro da Instrução Pública (1934). Foi um dos co-fundadores do Colégio de Europa em 1949. Escreveu importantes obras literárias.

\section{Tomás Suñer y Ferrer (1895-1972)}

Diplomata espanhol, embaixador da Espanha no Brasil entre 1954 e 1960. Entre 1960 e 1964(?) foi embaixador no Chile.

\section{Vasco Leitão da Cunha (1903-1984)}

Natural do Rio de Janeiro, em 1927 iniciou a sua carreira diplomática. Em 1941, assumiu interinamente o Ministério da Justiça e Negócios Interiores. Atuou como encarregado de negócios em Madri entre 1946 e 1949, período no qual o governo de Franco sofreu as pressões e o exílio internacional. Foi embaixador na URSS (1962-1964), nos EUA (1966-1968), e ministro das Relações Exteriores durante o governo do General Castelo Branco (19651965).

\section{Vicente Rao (1892-1978)}

Político e jurista nascido em São Paulo. Foi ministro da Justiça (1934-1937), e responsável pela elaboração da Lei de Segurança Nacional em 1935. Participou da fundação da Universidade de São Paulo, sendo um dos autores de seu estatuto. Foi ministro das Relações Exteriores entre julho de 1953 e agosto de 1954, deixando o cargo após o suicídio de Vargas.

\section{Vicente Sales Musoles (1883-1958)}

Político e diplomata espanhol. Estudou Direito, Filosofia e Letras nas Universidades de Valência e Madri. Com a proclamação da Segunda República espanhola, foi eleito deputado pela província de Castellón. Foi embaixador da Espanha no Brasil entre 1933 e 1936. 


\section{Anexos}

\section{Ministros de Estado das Relações Exteriores/ Brasil}

\begin{tabular}{|c|c|}
\hline Octavio Mangabeira & $11 / 1926$ a $10 / 1930$ \\
\hline Afrânio de Mello Franco & $10 / 1930$ a $12 / 1933$ \\
\hline Felix de Barros Cavalcanti de Lacerda (interino) & $12 / 1933$ a $07 / 1934$ \\
\hline José Carlos de Macedo Soares & $07 / 1934$ a $05 / 1935$ \\
\hline Mario de Pimentel Brandão (interino) & 05/1935 a 06/1935 \\
\hline José Carlos de Macedo Soares & $06 / 1935$ a $11 / 1936$ \\
\hline Mario de Pimentel Brandão (interino) & $11 / 1936$ a $08 / 1937$ \\
\hline Mario de Pimentel Brandão & 08/1937 a 03/1938 \\
\hline Oswaldo Aranha & $03 / 1938$ a $01 / 1939$ \\
\hline Cyro de Freitas Valle (interino) & $01 / 1939$ a 03/1939 \\
\hline Oswaldo Aranha & $03 / 1939$ a $01 / 1940$ \\
\hline Maurício Nabuco (interino) & $01 / 1940$ a $02 / 1940$ \\
\hline Oswaldo Aranha & 02/1940 a 04/1941 \\
\hline Maurício Nabuco (interino) & 04/1941 a 05/1941 \\
\hline Oswaldo Aranha & 05/1941 a $11 / 1941$ \\
\hline Maurício Nabuco (interino) & 11/1941 a $11 / 1941$ \\
\hline Oswaldo Aranha & 11/1941 a 08/1944 \\
\hline Pedro Leão Velloso (interino) & 08/1944 a 02/1945 \\
\hline José Carlos de Macedo Soares (interino) & 02/1945 a 03/1945 \\
\hline Pedro Leão Velloso (interino) & 03/1945 a 04/1945 \\
\hline José Carlos de Macedo Soares (interino) & 04/1945 a 07/1945 \\
\hline Pedro Leão Velloso (interino) & 07/1945 a 11/1945 \\
\hline Pedro Leão Velloso & $11 / 1945$ a $01 / 1946$ \\
\hline João Neves da Fontoura & $01 / 1946$ a $07 / 1946$ \\
\hline Samuel de Souza Leão Gracie (interino) & $07 / 1946$ a $12 / 1946$ \\
\hline Raul Fernandes & $12 / 1945$ a $05 / 1947$ \\
\hline Hildebrando Pompeu Pinto Accioly (interino) & 05/1947 a 06/1947 \\
\hline Raul Fernandes & 06/1947 a 09/1948 \\
\hline Hildebrando Pompeu Pinto Accioly (interino) & 09/1948 a 12/1948 \\
\hline Raul Fernandes & $12 / 1948$ a $05 / 1949$ \\
\hline Cyro de Freitas Valle (interino) & 05/1949 a 06/1949 \\
\hline Raul Fernandes & 06/1949 a 02/1951 \\
\hline João Neves da Fontoura & 02/1951 a 03/1951 \\
\hline Heitor Lyra (interino) & 03/1951 a 05/1951 \\
\hline João Neves da Fontoura & 05/1951 a 11/1952 \\
\hline Mario de Pimentel Brandão (interino) & 11/1952 a 12/1952 \\
\hline João Neves da Fontoura & 12/1952 a 06/1953 \\
\hline Mario de Pimentel Brandão (interino) & 06/1953 a 07/1953 \\
\hline Vicente Ráo & 07/1953 a 01/1954 \\
\hline Vasco T. Leitão da Cunha (interino) & 01/1954 a 03/1954 \\
\hline Vicente Ráo & 03/1954 a 08/1954 \\
\hline Raul Fernandes & 08/1954 a 04/1955 \\
\hline Antonio Camillo de Oliveira (interino) & 04/1955 a 04/1955 \\
\hline Raul Fernandes & 04/1955 a 11/1955 \\
\hline
\end{tabular}




\begin{tabular}{|l|l|}
\hline José Carlos de Macedo Soares & $11 / 1955$ a 09/1957 \\
\hline Décio Honorato de Moura (interino) & $09 / 1957$ a $11 / 1957$ \\
\hline José Carlos de Macedo Soares & $11 / 1957$ a $07 / 1958$ \\
\hline Francisco Negrão de Lima & $07 / 1958$ a 08/1958 \\
\hline Antonio Mendes Viana (interino) & $08 / 1958$ a 08/1958 \\
\hline Francisco Negrão de Lima & $08 / 1958$ a 09/1958 \\
\hline Antonio Mendes Viana (interino) & $09 / 1958$ a 09/1958 \\
\hline Francisco Negrão de Lima & $09 / 1958$ a $11 / 1958$ \\
\hline Francisco Negrão de Lima & $11 / 1958$ a 08/1959 \\
\hline Horácio Lafer & $08 / 1959$ a 08/1959 \\
\hline Armando Falcão (interino) & $08 / 1959$ a 08/1959 \\
\hline Horácio Lafer & $08 / 1959$ a $11 / 1959$ \\
\hline Fernando Ramos de Alencar (interino) & $11 / 1959$ a $11 / 1959$ \\
\hline Horácio Lafer & $11 / 1959$ a 03/1960 \\
\hline Fernando Ramos de Alencar (interino) & $03 / 1960$ a 03/1960 \\
\hline Horácio Lafer & $03 / 1960$ a 05/1960 \\
\hline Fernando Ramos de Alencar (interino) & $05 / 1960$ a 05/1960 \\
\hline Horácio Lafer & $05 / 1960$ a 08/1960 \\
\hline Fernando Ramos de Alencar (interino) & $08 / 1960$ a 09/1960 \\
\hline Horácio Lafer & $09 / 1960$ a 09/1960 \\
\hline Fernando Ramos de Alencar (interino) & $09 / 1960$ a $10 / 1960$ \\
\hline Horácio Lafer & $10 / 1960$ a $12 / 1960$ \\
\hline Edmundo Penna Barbosa da Silva (interino) & $12 / 1960$ a $12 / 1960$ \\
\hline Horácio Lafer & $12 / 1960$ a $12 / 1960$ \\
\hline &
\end{tabular}

\section{Ministros de Assuntos Exteriores/ Espanha}

\begin{tabular}{|l|l|}
\hline Período da 2a República & \\
\hline Duque de Alba & $1930 / 1931$ \\
\hline Luis de Zulueta & $1931 / 1933$ \\
\hline Fernando de los Ríos & 1933 \\
\hline Claudio Sanchez Albornoz & 1933 \\
\hline Ricardo Samper Ibãnez & 1934 \\
\hline Alejandro Lerroux e Garcia & 1935 \\
\hline Jose Martínez de Velasco & 1935 \\
\hline Joaquín Urzáiz Cadaval & 1935 \\
\hline $\begin{array}{l}\text { Augusto Barcía Trelles (Augusto } \\
\text { Garcia Telels) }\end{array}$ & 1936 \\
\hline Justino Azcárate & 1936 \\
\hline Julio Alvarez Del Vayo & 1936 \\
\hline Jose Giral Pereira & 1937 \\
\hline Julio Alvarez Del Vayo & 1938 \\
\hline Ministros de Asuntos Exteriores & \\
\hline \begin{tabular}{l} 
(Período franquista) \\
\hline Juan Beigbeder
\end{tabular} & 1939 \\
\hline Ramón Serrano Suñer & $1939 / 1942$ \\
\hline $\begin{array}{l}\text { Francisco GómezJordana (Conde de } \\
\text { Jordana) }\end{array}$ & $1942 / 1944$ \\
\hline José Felix de Lequerica & $1944 / 1945$ \\
\hline & \\
\hline
\end{tabular}




\begin{tabular}{|l|l|}
\hline Alberto Martín Artajo & $1945 / 1957$ \\
\hline Fernando Maria de Castiella & $1957 / 1969$ \\
\hline
\end{tabular}

Chefes de missão brasileira na Espanha

\begin{tabular}{|c|c|c|}
\hline $\begin{array}{l}\text { Carlos Alberto Moniz } \\
\text { Gordilho }\end{array}$ & 1929 a $1931(?)$ & Encarregado de Negócios \\
\hline Luiz Guimarães Filho & $\begin{array}{l}\text { Abril de } 1931 \text { a } \\
\text { nov de } 1933\end{array}$ & E.E e P.M \\
\hline Luiz Guimarães Filho & $\begin{array}{l}\text { Nov. de } 1933 \text { a } \\
\text { dez. de } 1934\end{array}$ & Embaixador \\
\hline $\begin{array}{l}\text { Luis Guimarães } \\
\text { Fernandes Pinheiro }\end{array}$ & $\begin{array}{l}\text { Dez. de } 1934 \text { a } \\
\text { março de } 1935\end{array}$ & Encarregado de negócios \\
\hline Alcebíades Peçanha & $\begin{array}{l}\text { Março de } 1935 \text { a } \\
\text { fev. de } 1938\end{array}$ & Embaixador \\
\hline $\begin{array}{l}\text { Carlos da Silveira } \\
\text { Martins Ramos }\end{array}$ & $\begin{array}{l}\text { Fev de } 1938 \text { a } \\
\text { abril de } 1939\end{array}$ & Encarregado de negócios \\
\hline $\begin{array}{l}\text { Argeu de Segadas } \\
\text { Machado Guimarães }\end{array}$ & $\begin{array}{l}\text { Abril de } 1939 \text { a } \\
\text { out. de } 1939\end{array}$ & Encarregado de negócios \\
\hline Abelardo Roças & $\begin{array}{l}\text { Out. de } 1939 \text { a } \\
\text { dez. de } 1943\end{array}$ & Emba \\
\hline $\begin{array}{l}\text { Roberto Mendes } \\
\text { Gonçalves }\end{array}$ & $\begin{array}{l}\text { Dez de } 1943 \text { a } \\
\text { março de } 1944\end{array}$ & Encarregado de negócios \\
\hline $\begin{array}{l}\text { Mario de Pimentel } \\
\text { Brandão }\end{array}$ & $\begin{array}{l}\text { le } 1944 \text { a } \\
1945\end{array}$ & Embaixador \\
\hline Antonio Mendes Viana & $\begin{array}{l}\text { Fev de } 1945 \text { a } 04 \\
\text { de } 1946 \\
\text { (confirmar) }\end{array}$ & Encarregado de negócios \\
\hline $\begin{array}{l}\text { Vasco Tristão Leitão } \\
\text { da Cunha }\end{array}$ & $\begin{array}{l}\text { Abril de } 1946 \text { a } \\
\text { setembro de } 1947\end{array}$ & Encarregado de Negócios \\
\hline Antonio Mendes Viana & $\begin{array}{l}\text { Setembro e } \\
\text { outubro de } 1947\end{array}$ & Encarregado de Negócios \\
\hline $\begin{array}{l}\text { Vasco Tristão Leitão } \\
\text { da Cunha }\end{array}$ & $\begin{array}{l}\text { Out e novembro } \\
\text { de } 1947\end{array}$ & cios \\
\hline Antonio Mendes Viana & $\begin{array}{l}\text { Novembro de } \\
1947 \text { a julho de } \\
1948 \\
\end{array}$ & Encarregado de negócios \\
\hline $\begin{array}{l}\text { Vasco Tristão Leitão } \\
\text { da Cunha }\end{array}$ & $\begin{array}{l}\text { Julho de } 1948 \text { a } \\
\text { agosto de } 1949\end{array}$ & Encarregado de negócios \\
\hline $\begin{array}{l}\text { Renato de Firmino } \\
\text { Maia de Mendonça }\end{array}$ & $\begin{array}{l}\text { Agosto e } \\
\text { setembro de } 1949\end{array}$ & Encarregado de negócios \\
\hline $\begin{array}{l}\text { Vasco Tristão Leitão } \\
\text { da Cunha }\end{array}$ & $\begin{array}{l}\text { Setembro de } 1949 \\
\text { a março de } 1950\end{array}$ & Encarregado de $n$ \\
\hline $\begin{array}{l}\text { Rubens Ferreira de } \\
\text { Mello }\end{array}$ & $\begin{array}{l}\text { Março de } 1950 \text { a } \\
\text { junho de } 1954\end{array}$ & Embaixador \\
\hline $\begin{array}{l}\text { Paulo Bras Pinto da } \\
\text { Silva }\end{array}$ & $\begin{array}{l}\text { Junho de } 1954 \text { a } \\
\text { julho de } 1954\end{array}$ & Encarregado de negócios \\
\hline $\begin{array}{l}\text { Rubens Ferreira de } \\
\text { Mello }\end{array}$ & $\begin{array}{l}\text { Julho de } 1954 \text { a } \\
\text { abril de } 1955\end{array}$ & $E$ \\
\hline
\end{tabular}




\begin{tabular}{|l|l|l|}
\hline $\begin{array}{l}\text { aulo Bras Pinto da } \\
\text { Silva }\end{array}$ & $\begin{array}{l}\text { Abril a julho de } \\
1955\end{array}$ & Encarregado de negócios \\
\hline $\begin{array}{l}\text { Rubens Ferreira de } \\
\text { Mello }\end{array}$ & $\begin{array}{l}\text { Julho de 1955 a } \\
\text { junho de 1956 }\end{array}$ & Embaixador \\
\hline $\begin{array}{l}\text { Paulo Bras Pinto da } \\
\text { Silva }\end{array}$ & $\begin{array}{l}\text { Junho e julho de } \\
1956\end{array}$ & Encarregado de negócios \\
\hline $\begin{array}{l}\text { João Pizarro Gabizo } \\
\text { Coelho Lisboa }\end{array}$ & $\begin{array}{l}\text { Julho a dezembro } \\
\text { de 1956 }\end{array}$ & Embaixador \\
\hline $\begin{array}{l}\text { Modestino Deloy } \\
\text { Gibbon }\end{array}$ & $\begin{array}{l}\text { Dezembro de } \\
1956 \text { a janeiro de } \\
1957\end{array}$ & Encarregado de negócios \\
\hline $\begin{array}{l}\text { João Pizarro Gabizo } \\
\text { Coelho Lisboa }\end{array}$ & $\begin{array}{l}\text { Janeiro a } \\
\text { setembro de 1957 }\end{array}$ & Embaixador \\
\hline $\begin{array}{l}\text { Antonio Candido da } \\
\text { Câmara Canto }\end{array}$ & $\begin{array}{l}\text { Setembro a } \\
\text { outubro de 1957 }\end{array}$ & Encarregado de negócios \\
\hline $\begin{array}{l}\text { João Pizarro Gabizo } \\
\text { Coelho Lisboa }\end{array}$ & $\begin{array}{l}\text { Outubro a } \\
\text { novembro de } \\
1957\end{array}$ & Embaixador \\
\hline $\begin{array}{l}\text { Antonio Candido da } \\
\text { Câmara Canto }\end{array}$ & $\begin{array}{l}\text { Novembro de } \\
1957 \text { a janeiro de } \\
1958\end{array}$ & Encarregado de negócios \\
\hline $\begin{array}{l}\text { João Pizarro Gabizo } \\
\text { Coelho Lisboa }\end{array}$ & $\begin{array}{l}\text { Janeiro de 1958 a } \\
\text { dezembro de } \\
1959\end{array}$ & Embaixador \\
\hline $\begin{array}{l}\text { OBS: Até 1960 } \\
\text { alternância de João } \\
\text { Pizarro como } \\
\text { embaixador e Antonio } \\
\text { Candido como } \\
\text { encarregado de } \\
\text { negócios }\end{array}$ & & \\
\hline
\end{tabular}

Chefes de missão da Espanha no Brasil

\begin{tabular}{|l|l|l|}
\hline Alfredo Mariátegui y Carratalá & Ministro & 1929 \\
\hline Antonio Benítez y Fernandez & Ministro & $1930 / 1932$ \\
\hline Vicente Sales Musoles & & $1933 / 1936$ \\
\hline Teodomiro de Aguilar Salas & Embaixador & 1936 \\
\hline Luis Fernando Clérigo & Ministro & 1938 \\
\hline Manuel Garcia Miranda & $\begin{array}{l}\text { Min. Enc. de } \\
\text { negócios }\end{array}$ & $1938 / 1939$ \\
\hline Cárcel Lassance & $\begin{array}{l}\text { (Repres. do } \\
\text { governo de Burgos) }\end{array}$ & 1939 \\
\hline Raimundo Fernandez Cuesta & Embaixador & $194 ?-1942$ \\
\hline Pedro Garcia Conde y Menendez & Embaixador & $1942-1946$ \\
\hline Eduardo Aunós Perez & Embaixador & 1946 \\
\hline $\begin{array}{l}\text { Jose de Rojas y Moreno (Conde } \\
\text { de Casas Rojas) }\end{array}$ & Embaixador & $1946 / 1952$ \\
\hline
\end{tabular}




\begin{tabular}{|l|l|l|}
\hline $\begin{array}{l}\text { Pedro de Prat y Soutzo (Marqués } \\
\text { de Prat de Natouillet) }\end{array}$ & Embaixador & $1952 / 1954$ \\
\hline Tomás Suñer y Ferrer & Embaixador & $1954 / 1960$ \\
\hline Jose de Rojas y Moreno & Embaixador & $1960 / 1962$ \\
\hline
\end{tabular}

